\title{
land
}

\section{Livelihood and \\ Landscape \\ Change in Africa \\ Future Trajectories for \\ Improved Well-Being under \\ a Changing Climate}

\section{Sheona Shackleton, P. Hebinck, C. Ifejika Speranza,}

V. Masterson, D. Spear and M. Tengö

Printed Edition of the Special Issue Published in Land 
Livelihood and Landscape Change in Africa 



\section{Livelihood and Landscape Change in Africa}

\section{Future Trajectories for Improved Well-Being under a Changing Climate}

Special Issue Editors

Sheona Shackleton

Paul Hebinck

Chinwe Ifejika Speranza

Vanessa Masterson

Dian Spear

Maria Tengö 
Special Issue Editors

Sheona Shackleton

University of Cape Town

South Africa

Chinwe Ifejika Speranza

University of Bern

Switzerland

Dian Spear

University of Cape Town

South Africa

Editorial Office

MDPI

St. Alban-Anlage 664052

Basel, Switzerland
Paul Hebinck

Wageningen University

South Africa

Vanessa Masterson

Stockholm University

Sweden

Maria Tengö

Stockholm University

Sweden

This is a reprint of articles from the Special Issue published online in the open access journal Land (ISSN 2073-445X) from 2018 to 2019 (available at: https://www.mdpi.com/journal/land/special_ issues/africalivelihoods)

For citation purposes, cite each article independently as indicated on the article page online and as indicated below:

LastName, A.A.; LastName, B.B.; LastName, C.C. Article Title. Journal Name Year, Article Number, Page Range.

\section{ISBN 978-3-03921-469-3 (Pbk)}

ISBN 978-3-03921-470-9 (PDF)

Cover image courtesy of Ross T Shackleton.

(C) 2019 by the authors. Articles in this book are Open Access and distributed under the Creative Commons Attribution (CC BY) license, which allows users to download, copy and build upon published articles, as long as the author and publisher are properly credited, which ensures maximum dissemination and a wider impact of our publications.

The book as a whole is distributed by MDPI under the terms and conditions of the Creative Commons license CC BY-NC-ND. 


\section{Contents}

About the Special Issue Editors $\ldots \ldots \ldots \ldots \ldots \ldots \ldots$ vii

Preface to "Livelihood and Landscape Change in Africa" $\ldots \ldots \ldots \ldots \ldots \ldots$ ix

Sheona Shackleton, Vanessa Masterson, Paul Hebinck, Chinwe Ifejika Speranza, Dian Spear and Maria Tengö

Editorial for Special Issue: "Livelihood and Landscape Change in Africa: Future Trajectories for Improved Well-Being under a Changing Climate"

Reprinted from: Land 2019, 8, 114, doi:10.3390/land8080114 . . . . . . . . . . . . . . . . . .

\section{Andreas Scheba}

Market-Based Conservation for Better Livelihoods? The Promises and Fallacies of REDD+ in Tanzania

Reprinted from: Land 2018, 7, 119, doi:10.3390/land7040119 . . . . . . . . . . . . . . . . .

\section{Annemiek Pas}

Governing Grazing and Mobility in the Samburu Lowlands, Kenya

Reprinted from: Land 2018, 7, 41, doi:10.3390/land7020041 . . . . . . . . . . . . . . . . .

Rebecca Kariuki, Simon Willcock and Rob Marchant

Rangeland Livelihood Strategies under Varying Climate Regimes: Model Insights from Southern Kenya

Reprinted from: Land 2018, 7, 47, doi:10.3390/land7020047 . . . . . . . . . . . . . . . . 5

Sarah J. Findlay and Wayne C. Twine

Chiefs in a Democracy: A Case Study of the 'New' Systems of Regulating Firewood Harvesting in Post-Apartheid South Africa

Reprinted from: Land 2018, 7, 35, doi:10.3390/land7010035 . . . . . . . . . . . . . . . . 73

Felix Akrofi-Atitianti, Chinwe Ifejika Speranza, Louis Bockel and Richard Asare

Assessing Climate Smart Agriculture and Its Determinants of Practice in Ghana: A Case of the Cocoa Production System

Reprinted from: Land 2018, 7, 30, doi:10.3390/land7010030 . . . . . . . . . . . . . . . . . 94

\section{Nelson Mango, Clifton Makate, Lulseged Tamene, Powell Mponela and Gift Ndengu}

Adoption of Small-Scale Irrigation Farming as a Climate-Smart Agriculture Practice and Its Influence on Household Income in the Chinyanja Triangle, Southern Africa

Reprinted from: Land 2018, 7, 49, doi:10.3390/land7020049 . . . . . . . . . . . . . . . 115

Edward N. Mwavu, Vettes K. Kalema, Fred Bateganya, Patrick Byakagaba, Daniel Waiswa, Thomas Enuru and Michael S. Mbogga

Expansion of Commercial Sugarcane Cultivation among Smallholder Farmers in Uganda: Implications for Household Food Security

Reprinted from: Land 2018, 7, 73, doi:10.3390/land7020073 . . . . . . . . . . . . . . . . . 134

Dian Spear and Angela Chappel

Livelihoods on the Edge without a Safety Net: The Case of Smallholder Crop Farming in North-Central Namibia

Reprinted from: Land 2018, 7, 79, doi:10.3390/land7030079 . . . . . . . . . . . . . . . . 149 
Donna Hornby, Adrian Nel, Samuel Chademana and Nompilo Khanyile

A Slipping Hold? Farm Dweller Precarity in South Africa's Changing Agrarian Economy and Climate

Reprinted from: Land 2018, 7,40, doi:10.3390/land7020040 . . . . . . . . . . . . . . . . . 160

Wilhelm Östberg, Olivia Howland, Joseph Mduma and Dan Brockington

Tracing Improving Livelihoods in Rural Africa Using Local Measures of Wealth: A Case Study from Central Tanzania, 1991-2016

Reprinted from: Land 2018, 7,44, doi:10.3390/land7020044 . . . . . . . . . . . . . . . . . . . 185

Current Masunungure and Sheona E. Shackleton

Exploring Long-Term Livelihood and Landscape Change in Two Semi-Arid Sites in Southern Africa: Drivers and Consequences for Social-Ecological Vulnerability

Reprinted from: Land 2018, 7, 50, doi:10.3390/land7020050 


\section{About the Special Issue Editors}

Sheona Shackleton: African Climate and Development Initiative, University of Cape Town, Rondebosch, 7700, South Africa. Interest: vulnerability; climate change adaptation; ecosystem services; landscape and livelihood change; transdisciplinarity.

Paul Hebinck: Sociology of Development and Change, Wageningen University, 6706KN Wageningen, The Netherlands; Adjunct Professor, Faculty of Science and Agriculture, University of Fort Hare, South Africa. Interests: agrarian transformation processes in Africa with an emphasis on land reform; small scale farming and rural livelihoods.

Chinwe Ifejika Speranza: Group Head Integrative Geography, Institute of Geography, University of Bern, CH-3012 Bern, Switzerland. Interests: sustainable land management; land use and land cover analysis; climate variability and climate change adaptation and mitigation; ecosystem services/natural resources; agricultural landscapes/agro-ecology; social-ecological resilience; environmental performance; environmental justice; environmental stewardship; environmental policy; conceptual and methodological development.

Vanessa Masterson: Stockholm Resilience Centre, Stockholm University, S-106 91 Stockholm, Sweden. Interests: social-ecological systems; sense of place; stewardship; cultural connections to nature; urban-rural migration.

Dian Spear: African Climate and Development Initiative, University of Cape Town, Private Bag X3, Rondebosch 7701, South Africa. Interests: biodiversity conservation; biogeography; wildlife translocations; interdisciplinary research; climate change adaptation.

Maria Tengö: Stockholm Resilience Centre, Stockholm University, 106,91 Stockholm, Sweden. Interests: social-ecological resilience; biocultural systems; ecosystem services and human well-being; transformations towards sustainability. 



\section{Preface to "Livelihood and Landscape Change in Africa"}

This Special Issue was invited by LAND as a follow-up on the Special Issue on "Changing Land Uses, Changing Livelihoods,", published in 2016, but with a specific focus on Africa and on exploring the linkages between various aspects of human-environmental change and climate change. Given that Africa is one of the most vulnerable regions globally to climate change, we felt a focus on this region was timely and critical. Improved knowledge on the complex interactions between the multiple drivers of landscape and livelihood change and the impacts of and responses to these changes is required if we are to consider future pathways that are African-led, equitable, and just and that take account of local contexts, cultures, complexities, and realities. Too often development and landscape management interventions and adaptation options are imported from elsewhere and consequently de-contextualized and de-politicized, ignoring the legacies of colonialism, as well as important local sociocultural contexts. See Editorial for Special Issue: "Livelihood and Landscape Change in Africa: Future Trajectories for Improved Well-Being under a Changing Climate".

Sheona Shackleton, Paul Hebinck, Chinwe Ifejika Speranza, Vanessa Masterson, Dian Spear, Maria Tengö

Special Issue Editors 



\title{
Editorial for Special Issue: "Livelihood and Landscape Change in Africa: Future Trajectories for Improved Well-Being under a Changing Climate"
}

\author{
Sheona Shackleton ${ }^{1, *}$, Vanessa Masterson ${ }^{2}$, Paul Hebinck ${ }^{3,4}$, Chinwe Ifejika Speranza ${ }^{5}$, \\ Dian Spear ${ }^{1}$ and Maria Tengö ${ }^{2}$ \\ 1 African Climate and Development Initiative (ACDI), University of Cape Town, \\ Rondebosch 7700, South Africa \\ 2 Stockholm Resilience Centre, Stockholm University, S-106 91 Stockholm, Sweden \\ 3 Sociology of Development and Change, Wageningen University, 6706KN Wageningen, The Netherlands \\ 4 Department of Agriculture, University of Fort Hare, Alice 5700, South Africa \\ 5 Group Head Integrative Geography, Institute of Geography, University of Bern, CH-3012 Bern, Switzerland \\ * Correspondence: sheona.shackleton@uct.ac.za; Tel.: +27-46-603-7009
}

Received: 21 July 2019; Accepted: 22 July 2019; Published: 26 July 2019

\section{Introduction}

Rural people's livelihoods are intimately linked to the landscapes in which they live and are particularly vulnerable to changes in these landscapes (Suich et al. 2015 [1]). At the same time changes in livelihood activities may have negative feedbacks on landscapes and the ecosystem services they provide. In much of Africa, rural landscapes are subject to increasing pressures from environmental and socio-economic change. Ongoing and accelerated change in climate, populations, migration, land use and national and local economies often translate to increased vulnerability for both local natural resource-dependent communities and the biodiversity and ecosystem services they depend on (Reid and Vogel 2006 [2], Fraser et al. 2011 [3]). Considering climate change, Africa is one of the most vulnerable regions, globally, to climate change (Niang et al. 2014 [4]). Some of the expected impacts include, an increase in extreme weather events, increased exposure to water stress, a decrease in rain-fed agriculture in some countries, and the transformation of some $8 \%$ of the land surface towards greater aridity with multiple consequences for people, biodiversity, and landscapes. For example, there is emerging evidence of changes in species ranges and ecosystems, beyond the effects of land use change and other non-climate stressors. Water scarcity and water insecurity are highly likely to increase with serious consequences for agriculture and food security (Niang et al. 2014 [4]). Moreover, in the African context these climate driven changes are frequently superimposed and feedback on a wide range of cross-scale, socio-economic stressors that contribute to social vulnerability in the first place. These stressors include, high levels of poverty, food insecurity, health concerns, and associated shocks (such as disease epidemics), low levels of development, rapid urbanization, weak governance and natural resource management systems, ecosystem service degradation and land and green grabs (forms of nature commodification that effectively exclude local users) to name just a few (African Union 2014 [5]). Such pervasive changes can translate into increased risk and vulnerability at the local level, particularly for poor natural resource-dependent communities and small-holder farmers. Indeed, the continual onslaught of multiple stressors on poor rural communities can overwhelm their ability to cope and adapt, and potentially draw them into a poverty trap (e.g., Casale et al. 2010 [6], Shackleton and Luckert 2015 [7]).

To address these challenges and concerns, we argue that there is a need for improved knowledge on the complex interactions between the multiple drivers of landscape and livelihood change and the impacts of, and responses (both autonomous and facilitated), to these changes. Such knowledge 
development may range from a greater understanding of the social-ecological changes taking place and their consequences, to exploring the outcomes of different local responses, external interventions and policy actions, including new governance arrangements, that purport to enhance sustainable agriculture, land management and stewardship, and consequently rural livelihoods. While the need for transformations in how landscapes are used and managed for ecosystem services, livelihood production and human well-being is well-recognized as critical for more resilient future pathways, the question of how this can be achieved in ways that are equitable, take account of local cultures, complexities and realities, and contribute to long-term sustainability requires more in-depth investigation ((Folke et al. 2016 [8], Berbes-Blasquez et al. 2017 [9], Pascua et al. 2017 [10]). Often development and landscape management interventions and adaptation options are de-contextualized and de-politicized and ignore the legacies of colonialism, as well as the socio-cultural drivers of change or stagnation (and implications for transformation and stewardship) (see Pas [11] and Scheba [12]). Ignoring the political, cultural, and contextual aspects of these interventions and adaptation options may have dire consequences for both livelihoods and the ecosystems that underpin these livelihoods (e.g., Shackleton and Luckert 2015 [7], Murphy et al. 2016 [13]).

This special issue of LAND draws together a collection of 11 diverse articles at the nexus of climate change, landscapes and livelihoods in rural Africa; all explore the links between livelihood and landscape change, including shifts in farming practices and natural resource use. Articles were invited that link social-ecological drivers of change across scale to changes in livelihood strategies and human well-being, and landscape functioning and management. We were particularly interested in studies that could assist in answering some of the following questions: What are the changes we are observing in landscapes and livelihoods in rural Africa? What are the multiple, interacting socio-economic, political and environmental drivers of these changes? What are the responses to these changes and what do they mean for future livelihood trajectories? Where responses are potentially maladaptive, what transformations are needed to set livelihoods on more sustainable trajectories given the uncertainties associated with climate change? Where have there been success stories and what are the lessons from these?

We received a range of articles from research undertaken in nine different African countries that cover several, not necessarily mutually exclusive, thematic areas relevant to the special issue. Five articles center on smallholder farming and livelihoods under new climate risk, two address the long-term dynamics of livelihoods and landscape change and future trajectories; and four consider aspects of natural resource management and governance under a changing climate, spanning forests, woodlands and rangelands (Table 1). Across these categories the articles cover a wide range of methods: Some are based on purely qualitative data, while others are highly quantitative and apply different types of models, and a few use mixed methods. 


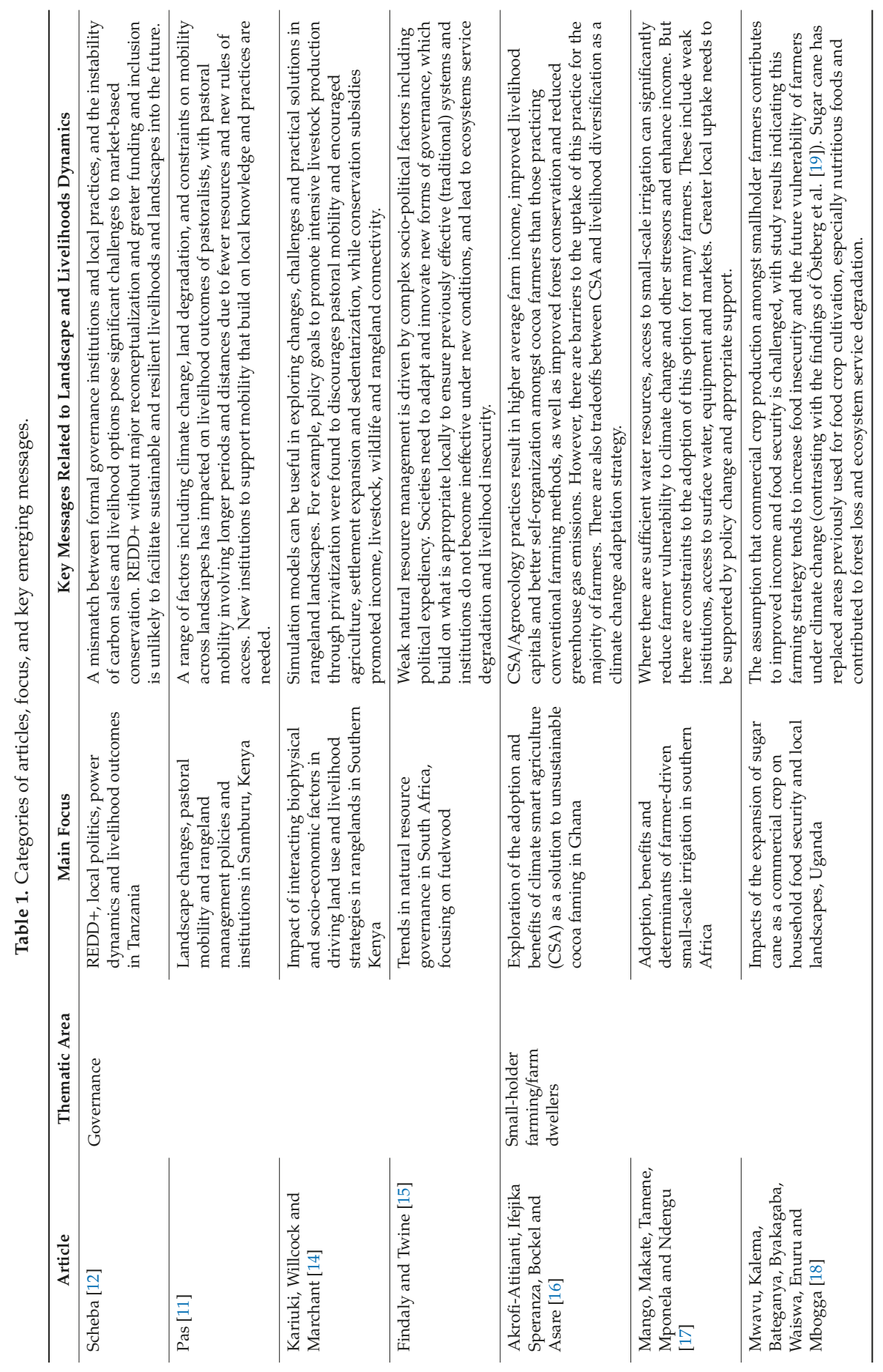




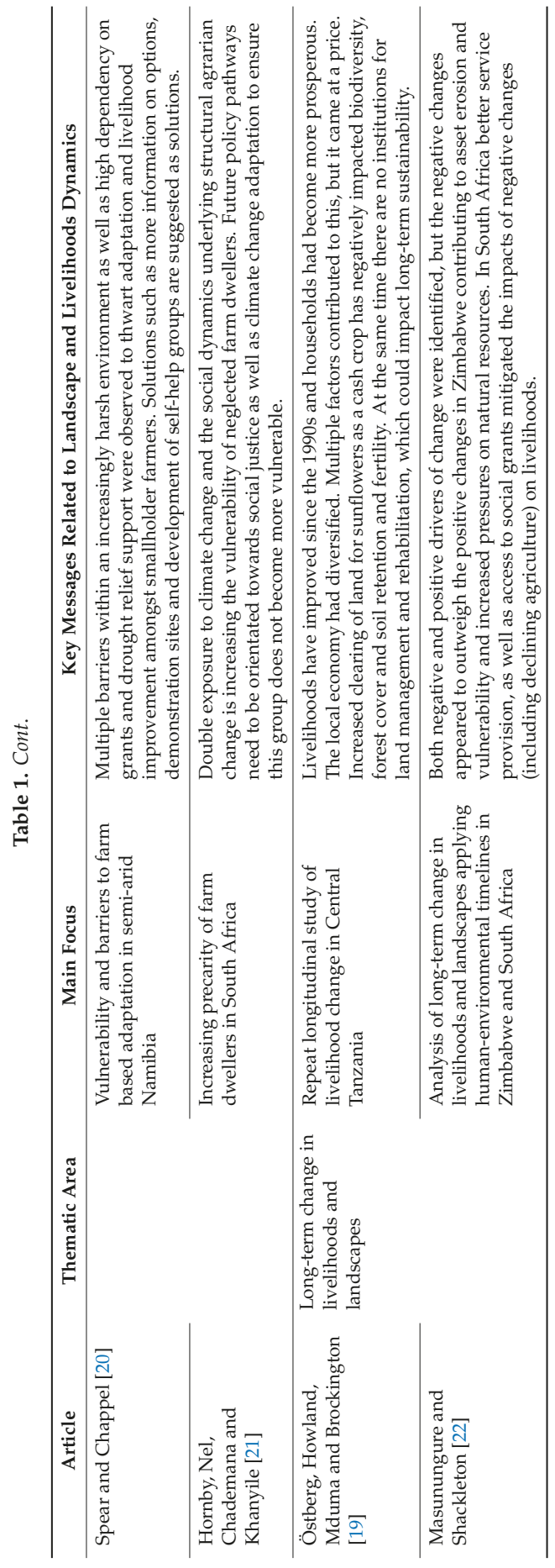




\section{Highlights and Emerging Commonalities and Issues}

Despite the varying focus of the articles published in this special issue, several common themes and messages emerge that relate to enhancing landscape and livelihood sustainability and resilience. We share these below under three sections that relate to drivers of change, responses and interventions/solutions, and future research.

\subsection{Complex Drivers of Change and Implications}

For all of the articles, the landscape and livelihood changes identified were the result of a combination of biophysical, socio-economic, and political drivers across both temporal and spatial scales, and which together created complex impacts and inspired different responses at the local level. While climate change was acknowledged as an important driver, several articles highlighted how it needs to be considered alongside other stressors on landscapes and livelihoods, especially since new climate risks can exacerbate these. Very few drivers or changes were viewed as has having a positive impact on livelihoods other than in the articles that consider long-term changes by Masunugure and Shackleton [22] and Östberg et al. [19]. In these two studies, improved road and communication infrastructure, enhanced water supply and other services, and new opportunities for entrepreneurship (e.g., through electrification and piped water access) were shown to have improved rural livelihoods. But in all cases, concerns were expressed by local people regarding the increasing impacts of their changing livelihood activities on ecosystems (e.g., rivers, woodlands, and forests) and the numerous services they provide. It was also highlighted that new and incipient risks and threats have the potential to outpace and supersede any positive changes that may have strengthened livelihoods in the past. Understanding the dynamic linkages and feedbacks between multiple drivers of change and how these impact both livelihoods and landscapes is essential to identifying avenues towards local sustainability.

Concerns for future generations (access to land, food security, social concerns) were expressed by participants in many of the studies presented in this special issue. The speed of the changes taking place and the negative impacts of many drivers, with no immediate solutions being evident, as well as limited existing opportunities, resulted in pessimism regarding how the younger generation is going to cope in the future. However, a few of the studies also showed how younger farmers were more likely to adopt new farming approaches and how youth, that have been working in towns and cities, may bring home new ideas with the potential for innovation (e.g., Akrofi-Atitianti et al. [16], Mango et al. [17], Östberg et al. [19]). The next generation, who are likely to face some of the greatest impacts of climate change, are rarely included in the type of research covered in this issue's articles. More work focusing on this societal group, particularly in the rural context, is required.

\subsection{Unpacking Responses and Uptake of 'Solutions'}

Local knowledge, practices, cultures, and realities often do not receive adequate attention before the implementation of external 'solutions' for improved landscape and farm management. At the same time local ways of life and institutions are under increasing pressure from the multiple changes taking place. There is a need to harmonize local responses with external support to build on what is appropriate and works locally. This was emphasized in several articles including Pas [13], Spear and Chappel [20], and Scheba [12].

Related to the above point, technical or policy solutions on their own are inadequate. For landscape management, agricultural, and governance interventions to be effective at a local level, equal attention needs to be given to the social and relational dimensions, including local politics, of these as is given to the technical or policy aspects. This requires working closely with affected people and communities and allowing space for local definitions of concepts such as poverty or wealth and local expressions of changes and their impacts. Good examples of this include the importance of farmer-to-farmer support and learning in the practice of Climate Smart/ Agroecology farming amongst Ghana cocoa producers 
(Akrofi-Atitianti et al. [16]) and the need to understand traditional forms of land access in Samburu, Kenya, which are based on values of reciprocity and trust (Pas [13]). Further, Östberg et al. [19] highlight the role of local entrepreneurs and community initiatives in creating the opportunity for 'change from within' as important factors in stimulating the local economy and improving opportunities for livelihood security in their study in Tanzania. Conversely, Spear and Chappel [20] argue that a lack of such enterprise and resourcefulness is hindering livelihood security and adaptation in communities in Northern Namibia. Östberg and colleagues [19] contend that there is a need for further research to distinguish between the role of exogenous factors (e.g., policy, infrastructure) and endogenous factors (e.g., attitudes to wealth and work) in contributing to transforming livelihoods. They also assert that such nuanced social relations are best identified through in-depth, qualitative place-based studies.

As a result of the multi-dimensional nature of landscape and livelihood challenges, most of the articles mentioned the need for multiple stakeholder and cross-sectoral engagement and the participation of local farmers and resource users in any proposed solutions. For example, in the article by Kariuki at al. [14] there is mention of the need for more effective collaboration between the Wildlife Conservation Authorities and those responsible for agriculture and rangeland management, as well as for the inputs of local actors, while the article by Akrofi-Atitianti et al. [16] argue for "extensive coordination and collaboration between key stakeholders, many of which have traditionally not collaborated, like the Cocoa Board and the Forestry Commission". Linked to this, and related to the point above, is the need for more holistic and multi-pronged approaches and cross-scale transformations from a policy level through to local institutions and community relations.

Interventions, such as climate smart agriculture (Akrofi-Atitianti et al. [16]), small-holder irrigation (Mango et al. [17]), and wildlife management alongside livestock production (Kariuki et al. [14]) were seen to improve the incomes of farmers and pastoralists, but the ability to take-up such new practices and livelihood strategies was conditional on a range of factors that prohibited some households from participating. The result is that the majority of farmers continue to employ conventional farming methods. For example, amongst cocoa farmers in Ghana, those with secure land tenure, who are settlers and who have good access to extension services are more likely to engage in CSA (Akrofi-Atitianti et al. [16]). Similarly, one of the factors influencing small-holder-driven irrigation adoption is access to off-farm income amongst household members (Mango et al. [17]). Issues of equity therefore require careful consideration if such initiatives are to be scaled-up and benefit the most vulnerable households. Moreover, despite good intentions, some interventions such as REDD+ in Tanzania (Scheba [12]) and the expansion of sugar cane cultivation amongst smallholders in Uganda (Mwavu et al. [18]) can have negative impacts and even undermine local livelihoods and well-being. Such aspects need more careful exploration and the on-going monitoring of livelihood and landscape outcomes is critical.

\subsection{Future Research: Needs and Opportunities}

The importance of longitudinal data for assessing the social and economic impacts of new risks and stresses, local responses and external interventions was highlighted in several of the articles. Only in this way can the dynamics of landscape and livelihood change be properly tracked. More studies of the nature of that by Östberg et al. [19], that undertake in depth and longitudinal research in a place over many years, are needed. This is also emphasized by Hoffman et al. [23] in a special issue on change in the arid Karoo region of South Africa. These authors argue that "long-term studies of shifting social dynamics in the Karoo in recent decades are missing. This reflects the relative paucity of such studies for significant issues, such as migration patterns, changing social identities, intra-community relationships, and social challenges such as poor educational outcomes and substance abuse" (Hoffman et al. 2018, p. 389 [23]).

The importance of understanding policy, governance processes, and institutions (and changes in these over time from the colonial period to present) was mentioned in all the articles as critical to finding approaches and governance systems to support improved landscape management and livelihoods into the future. Insufficient institutional capacity, linked to other obstacles such as finance, was seen as a 
major barrier to effective implementation of solutions, such as climate smart agriculture and improved natural resource management in several of the articles (e.g., see Mango et al. [17], Findlay and Twine [15], Kairiuki et al. [14]). Greater understanding of these barriers and the links amongst them is required.

Trade-offs between ecosystem services, different land uses and between socio-economic/livelihood and environmental benefits are often a feature of landscape and land use decision-making. It is argued that more research is required to find ways to minimize such trade-offs. Some of these trade-offs have emerged in more recent years as the demand for land for farming or alternative sources of natural resource income have increased. This is highlighted in Östberg et al. [19], Mwavu et al. [18], and Masunungure and Shackleton [22] amongst others.

Several of the articles highlight the role of different forms of government social protection (from unconditional grants to food for work, agricultural subsidies, and drought relief) in: a) improving livelihood sustainability; b) reducing pressures on ecosystem services (see Masunungure and Shackleton [22], Östberg et al. [19], Mwavu et al. [18] and Mango et al. [17]); but also in c) potentially undermining local agency (Spear and Chappel [20]). At the same time, there is mention of the benefits of, or the need for, local safety nets through collective efforts and systems of mutual support. This is an area where there appears to be a gap. There is very little research considering how different forms of social protection impact local livelihood and landscape dynamics and how they could be part of the solution moving forward.

Aspects of intersectionality, social equality and justice require more attention in studies similar to the ones in this special issue. This added level of complexity is only superficially dealt with in most of the articles in this issue, and mainly in those that explore the factors influencing the uptake of different land management options, where, for example, age was found to play are role alongside other factors (e.g., Mango et al. [17] and Akrofi-Atitianti et al. [16]). There is a need to unpack the differential impacts of changes on different social grouping (particularly with regards to gender and age) and critically interrogate who wins or who loses under different forms of intervention. We need to think about what is needed to ensure both social justice and environmental integrity.

Integrated research to understand the dynamics of landscape and livelihood change for greater sustainability and resilience, and which aims to have impact and effect transformation at a local level, requires more conscious engagement with transdisciplinary approaches. More effort is needed to ensure co-production of knowledge with local actors, e.g., landscape users, farmers, implementers of landscape management approaches and policy and decision makers. Ideally, for maximum impact, there needs to be opportunity for learning and the integration of different knowledge systems, throughout the research. Generally, there is a tendency to pay lip-service to the idea that we need to learn from farmers/local people. To avoid this requires process orientated projects that embed all actors in the research from start to finish, with ample time built-in for sharing, reflections, and communication. Furthermore, gaining insight into what works, or worked in the past, and why for local livelihoods and landscape management (see Pas [13]), without using the 'lenses of labels' such as CBNRM, CSA, or climate change adaptation, among others, could better capture the circumstances under which actors in rural areas make their choices around different livelihood options and landscape management practices.

Funding: The collation of this special issue received no external funding.

Acknowledgments: The co-editors would like to thank all authors of articles for their contributions, reviewers of these articles for their time, and the editorial team at LAND for their support.

Conflicts of Interest: The authors declare no conflict of interest.

\section{References}

1. Suich, H.; Howe, C.; Mac, G. Ecosystem Services and Poverty Alleviation: A Review of the Empirical Links. Ecosyst. Serv. 2015, 12, 137-147. [CrossRef]

2. Reid, P.; Vogel, C. Living and Responding to Multiple Stressors in South Africa-Glimpses from KwaZulu-Natal. Glob. Environ. Chang. 2006, 16, 195-206. [CrossRef] 
3. Fraser, E.D.G.; Dougill, A.J.; Hubacek, K.; Quinn, C.H.; Sendzimir, J.; Termansen, M. Assessing Vulnerability to Climate Change in Dryland Livelihood Systems: Conceptual Challenges and Interdisciplinary Solutions. Ecol. Soc. 2011, 16, 3. [CrossRef]

4. Niang, I.; Ruppel, O.C.; Abdrabo, M.A.; Essel, A.; Lennard, C.; Padgham, J.; Urquhart, P. Africa. In Climate Change: Impacts, Adaptation, and Vulnerability. Part B: Regional Aspects. Contribution of Working Group II to the Fifth Assessment Report of the Intergovernmental Panel on Climate Change; Cambridge University Press: Cambridge, UK; New York, NY, USA, 2014; pp. 1199-1265.

5. African Union. African Strategy on Climate Change. 2014. Available online: https://www.un.org/en/africa/ osaa/pdf/au/cap_draft_auclimatestrategy_2015.pdf (accessed on 27 June 2019).

6. Casale, M.; Drimie, S.; Quinlan, T.; Ziervogel, G. Understanding Vulnerability in Southern Africa: Comparative Findings Using a Multiple-Stressor Approach in South Africa and Malawi. Reg. Environ. Chang. 2010, 10, 157-168. [CrossRef]

7. Shackleton, S.E.; Luckert, M. Changing Livelihoods and Landscapes in the Rural Eastern Cape, South Africa: Past Influences and Future Trajectories. Land 2015, 4, 1060-1089. [CrossRef]

8. Folke, C.; Biggs, R.; Norström, A.V.; Reyers, B.; Rockström, J. Social-ecological Resilience and Biosphere-Based Sustainability Science. Ecol. Soc. 2016, 21, 41. [CrossRef]

9. Berbés-Blázquez, M.; González, J.A.; Pascual, U. Towards an Ecosystem Services Approach that Addresses Social Power Relations. Curr. Opin. Environ. Sustain. 2016, 19, 134-143. [CrossRef]

10. Pascua, P.; McMillen, H.; Ticktin, T.; Vaughan, M.; Winter, K.B. Beyond Services: A Process and Framework to Incorporate Cultural, Genealogical, Place-Based, and Indigenous Relationships in Ecosystem Service Assessments. Ecosyst. Serv. 2017, 26, 465-475. [CrossRef]

11. Pas, A. Governing Grazing and Mobility in the Samburu Lowlands, Kenya. Land 2018, 7, 41. [CrossRef]

12. Scheba, A. Market-Based Conservation for Better Livelihoods? The Promises and Fallacies of REDD+ in Tanzania. Land 2018, 7, 119. [CrossRef]

13. Murphy, C.; Tembo, M.; Phiri, A.; Yerokun, O.; Grummell, B. Adapting to climate Change in Shifting Landscapes of Belief. Clim. Chang. 2015, 134, 101-114.

14. Kariuki, R.; Willcock, S.; Marchant, R. Rangeland Livelihood Strategies under Varying Climate Regimes: Model Insights from Southern Kenya. Land 2018, 7, 47. [CrossRef]

15. Findlay, S.; Twine, W. Chiefs in a Democracy: A Case Study of the 'New' Systems of Regulating Firewood Harvesting in Post-Apartheid South Africa. Land 2018, 7, 35. [CrossRef]

16. Akrofi-Atitianti, F.; Ifejika Speranza, C.; Bockel, L.; Asare, R. Assessing Climate Smart Agriculture and Its Determinants of Practice in Ghana: A Case of the Cocoa Production System. Land 2018, 7, 30. [CrossRef]

17. Mango, N.; Makate, C.; Tamene, L.; Mponela, P.; Ndengu, G. Adoption of Small-Scale Irrigation Farming as a Climate-Smart Agriculture Practice and Its Influence on Household Income in the Chinyanja Triangle, Southern Africa. Land 2018, 7, 49. [CrossRef]

18. Mwavu, E.; Kalema, V.; Bateganya, F.; Byakagaba, P.; Waiswa, D.; Enuru, T.; Mbogga, M. Expansion of Commercial Sugarcane Cultivation among Smallholder Farmers in Uganda: Implications for Household Food Security. Land 2018, 7, 73. [CrossRef]

19. Östberg, W.; Howland, O.; Mduma, J.; Brockington, D. Tracing Improving Livelihoods in Rural Africa Using Local Measures of Wealth: A Case Study from Central Tanzania, 1991-2016. Land 2018, 7, 44. [CrossRef]

20. Spear, D.; Chappel, A. Livelihoods on the Edge without a Safety Net: The Case of Smallholder Crop Farming in North-Central Namibia. Land 2018, 7, 79. [CrossRef]

21. Hornby, D.; Nel, A.; Chademana, S.; Khanyile, N. A Slipping Hold? Farm Dweller Precarity in South Africa's Changing Agrarian Economy and Climate. Land 2018, 7, 40. [CrossRef]

22. Masunungure, C.; Shackleton, S. Exploring Long-Term Livelihood and Landscape Change in Two Semi-Arid Sites in Southern Africa: Drivers and Consequences for Social-Ecological Vulnerability. Land 2018, 7, 50. [CrossRef]

23. Hoffman, M.T.; Walker, C.; Henschel, J.R. Reflections on the Karoo Special Issue: Towards an Interdisciplinary Research Agenda for South Africa's Drylands. Afr. J. Range Forage Sci. 2018, 35, 3-4. [CrossRef]

(C) 2019 by the authors. Licensee MDPI, Basel, Switzerland. This article is an open access article distributed under the terms and conditions of the Creative Commons Attribution (CC BY) license (http://creativecommons.org/licenses/by/4.0/). 


\title{
Market-Based Conservation for Better Livelihoods? The Promises and Fallacies of REDD+ in Tanzania
}

\author{
Andreas Scheba \\ Economic Performance and Development, Human Sciences Research Council, 116-118 Buitengracht Street, \\ City of Cape Town 8001, South Africa; ascheba@hsrc.ac.za; Tel.: +27-21-466-7924
}

Received: 31 July 2018; Accepted: 12 October 2018; Published: 15 October 2018

\begin{abstract}
Governments, multilateral organisations, and international conservation NGOs increasingly frame nature conservation in terms that emphasise the importance of technically managing and economically valuing nature, and introducing markets for ecosystem services. New mechanisms, such as REDD+, have been incorporated in national-level policy reforms, and have been piloted and implemented in rural project settings across the Global South. By reflecting on my research on REDD+ implementation in two case study villages in Tanzania, the paper argues that the emergence and nature of market-based conservation are multi-faceted, complex, and more profoundly shaped by structural challenges than is commonly acknowledged. The paper identifies three particularly important challenges: the politics surrounding the establishment of community-based forest management; the mismatch between formal governance institutions and actual practices on the ground; and the fickleness of income from carbon sales and alternative livelihood opportunities. I argue that these challenges are not merely teething troubles, but they question fundamental assumptions of market-based conservation, more generally. I end with reference to better ideas for achieving sustainable development.
\end{abstract}

Keywords: neoliberal conservation; Africa; REDD+, market-based conservation; Tanzania

\section{Introduction}

Livelihoods and landscapes in rural Africa are changing in important new ways. Rural populations across the continent are adapting to unprecedented biophysical and political-economic transformations. Climate change, extreme weather events, such as droughts and floods, soil degradation, and deforestation, threaten livelihoods and increase vulnerabilities [1,2]. These biophysical changes are occurring in conjunction with important global political-economic transformations that are filtered through policy, at national and sub-national scales [3,4].

Under the banner of the green economy, governments, multilateral organisations, and international conservation organisations have introduced new ideas, technologies, and practices of managing landscapes in the Global South, with the proclaimed aim of promoting sustainable development $[5,6]$. These interventions depart from previous rural development initiatives in significant ways, as they emphasise the importance of economically valuing nature and introducing new markets (or market like instruments) for the management and protection of nature. Market-based approaches to nature conservation, and natural resource management, more broadly, include schemes such as REDD+ (reducing emissions from deforestation and forest degradation and the role of conservation, sustainable management of forests, and enhancement of forest carbon stocks in developing countries), payments for ecosystem services, and biodiversity offsetting.

While market-based instruments differ in their specific form, they all share a common objective of re-framing landscapes as providers of "ecosystem services" and rural communities as latent eco-entrepreneurs, who can cultivate and sell them as commodities for profit [7-9]. In the words 
of McAfee [10], "selling nature to save it" is promoted as the best means of achieving sustainable rural livelihoods in the face of mounting environmental crises and persistent poverty. The multiple win promises of market-based instruments are the decisive factors behind their immense political support and surge in popularity across the Global South [11,12]. They offer something to everyone: better landscapes, better livelihoods, better environment, and better economic growth.

Scholars have described the shift in global conservation policy and practice towards the increasing use of markets as neoliberal conservation [8,11]. Neoliberal conservation is, here, defined as initiatives which promote the idea (both in policy and practice) that "the value of ecosystems should be captured in monetary terms and conserved through market dynamics" [13]. The fundamental assumption behind neoliberal conservation is that nature needs to be made economically valuable (through pricing) and profit-making, in order for conservation to compete with alternative land uses (e.g., conversion of forests into agricultural land) $[6,8,11]$. Market-based conservation thus hinges on the process of commodifying ecosystem services, which means creating distinct tradeable commodities from complex ecosystems (e.g., carbon credits from carbon sequestration services). However, this is anything but a natural and easy process. Its success relies on the active restructuring of society-nature relations, and institutional arrangements by a capacitated state towards market exchange and private sector engagement (including businesses, non-governmental organisations, consultants, international organisations) [14]. Local communities are often drawn into this neoliberalisation process, on the premise that they will obtain significant socioeconomic benefits [15-17].

A growing number of studies have examined the effectiveness of REDD+ and other Payment for ecosystem services (PES) schemes on slowing deforestation and protecting ecosystem services. These studies have found mixed results, with some programs demonstrating conservation success and positive livelihood outcomes, while others have shown little or no impacts [18-21]. Many scholars have emphasized that market-based conservation is much more complex and, indeed, contested in practice, than is implied in dominant policy narratives, with outcomes being mixed and particularly dependent on the institutions, politics, and particularities of place [11,22-27]. Market-based conservation produces both benefits (e.g., nature protection, political inclusion, monetary income, economic opportunities) AND risks (e.g., physical displacement, loss of livelihoods, increased human-wildlife conflicts, unequal distribution of benefits) to local population groups [6,12,27-29]. Some scholars view the successful implementation of REDD+ and PES as dependent on decentralization and community empowerment [30,31]. West, for instance, examined a REDD+ pilot project in Amazonian Brazil, and emphasized the importance of engaging indigenous people through a properly designed institutional framework that fostered transparency, accountability, and good governance [32].

While recent quantitative studies have generated important knowledge on the environmental effectiveness and socioeconomic impacts of REDD+ and PES [18-21], they have neglected other important process-related aspects of REDD+ implementation, which qualitative studies are better able to reveal. In bringing an anthropological perspective to the literature, which is less common compared to quantitative impact assessments, the contribution of this article is to examine the process of implementation of two community-oriented REDD+ projects, and demonstrate the significant social challenges underlying it. As will be shown below, the challenges are intimately linked, and share much in common with previous community-based forest management schemes. The aim of this paper is to reflect on my research on REDD+ implementation in Tanzania, to answer often-neglected, yet important questions, such as who and what enable market-based conservation in this specific context?; how and why does it manifest itself in this particular time and place?; and what are its multiple and contradictory outcomes to the environment and people? Using a political ecology lens (Political ecology has been defined and practiced in numerous ways, thereby cutting across different disciplines and subject matters. However, it is fundamentally premised on the understanding "that politics are inevitably ecological and that ecology is inherently political" [33]. Political ecologists view processes of social and environmental change as mutually conditional and relational [33-35]. Key areas of interest in political ecology are how discourse, power, institutions and politics shape 
resource access, use, and the distribution of costs and benefits.) the paper draws on primarily qualitative data collected through various methods in two case study villages to synthesise key findings of my study. The qualitative nature of the evidence inevitably brings forth important limitations with regard to sample size and representativeness. This paper is not an impact evaluation of REDD+ in Tanzania, and no generalisations should be made. Instead, it provides new insights into the emergence and nature of REDD+ in a particular context, and argues that it is multi-faceted, complex, and more profoundly shaped by structural challenges than is commonly acknowledged. The paper proceeds as follows. In the next section, I discuss REDD+ in Tanzania, and describe the two pilot projects in the case study villages. In section three, I present my research approach and methods. In section four, I describe and discuss three major findings emanating from my research. In the final section, I offer conclusions and suggestions for alternatives.

\section{REDD+ Context in Tanzania}

\subsection{REDD+ in Tanzania}

Tanzania has been a popular REDD+ country, which received large amounts of donor funding to test community-based approaches to REDD+ [36,37]. The government of Tanzania embraced the REDD+ mechanism as early as 2008 , and began to establish the required institutional and policy framework to support conservation organisations and researchers in initiating REDD+ demonstration projects [38]. The government had high hopes in REDD+, to address the shortcomings of previous participatory forest management initiatives and to contribute to sustainable forest management and poverty alleviation [36]. Nine conservation organisations received official REDD+ funding to demonstrate how REDD+ can contribute to sustainable forest management and poverty reduction. In addition, researchers and other organisations used foreign donor money to initiate REDD+ in the country.

Most REDD+ initiatives in Tanzania aimed to reduce emissions from deforestation and degradation in the villages by linking community-based forest management with international carbon markets. The idea was to transfer formal ownership and management rights over the forests to the local village council, which is a recognised legal entity in Tanzania, and monetarily reward villagers for conservation efforts by selling carbon credits. REDD+ was to benefit from Tanzania's progressive forest governance legislation, that allows for forest decentralisation through the establishment of joint management or community-based forest management institutions (CBFM).

The Tanzanian National Forest Act of 2002 [39] provides a strong legal basis for communities to own and manage forest reserves, and it entails a clear pathway to the transfer of rights to the community (The nuts and bolts of "participatory forest management" (PFM) in Tanzania have been well documented and summarized by Blomley and Iddi (2008) [40]. Limited space prohibits me from elaborating on PFM here, but it is useful to explain the most important features of CBFM, which forms part of PFM. In order for a village to establish community-based forest management, it must have legal tenure over its land, which means it must be classified as "village land" and not "general land". Second, a village natural resource committee (VNRC) must be elected by the village assembly, which are all the adult residents in the village. Third, the boundaries of the village must be described, and plans for different land uses (including village land forest reserve) must be delineated in a village land use plan. Fourth, the village natural resource committee must develop a forest management plan, and bylaws describing how their forest is managed, used, and protected. The management plan and the bylaws must then be approved by the village assembly and the district council. Following all this, the village land forest reserve (VLFR) is declared and managed in accordance with the forest management plan, bylaws, and normal rules governing local governments [40].). Under CBFM, the village council (i.e., village government) obtains the formal rights to establish a village land forest reserve (VLFR) on its land, which is then being managed by the village natural resource committee (VNRC), based on legally binding forest management plan and by-laws. The forest management plan 
and by-laws contain, in detail, the responsibilities of the VNRC, the village council, and residents and, together, they set the rules in terms of accessing and managing the VLFR. The village is entitled to up to $100 \%$ of the benefits from the sale of products from the VLFR but, in practice, benefits are often shared with the local district office in return for support services.

\subsection{REDD+ Case Study Sites}

This paper draws on data collected in two REDD+ projects that were located in the Lindi region in Tanzania, albeit only one of them was an official REDD+ project that received Norwegian funding. The second project was mainly supported by Finnish funding, and part of an international research project. The two projects are called the TFCG/Mjumita "Making REDD work for communities and forest conservation in Tanzania" and the Angai Village Land Forest Reserve (AVLFR) REDD+ project.

\subsubsection{TFCG/Mjumita}

The TFCG/Mjumita "Making REDD work for communities and forest conservation in Tanzania" project was the first REDD+ pilot project in Tanzania. It was a partnership between two local conservation organisations: Tanzania Forest Conservation Group (TFCG) and Community Forest Conservation Network of Tanzania (Mjumita). The project received funding of USD $5.9 \mathrm{~m}$ from the Ministry of Foreign Affairs of the Government of Norway for a period of 5 years (2009 to 2014) [41]. The TFCG/Mjumita REDD+ initiative was internationally acclaimed for its pro-poor approach and multiple benefits, aiming to "reduce greenhouse gas emissions from deforestation and forest degradation in Tanzania in ways that provide direct and equitable incentives to communities to conserve and manage forest sustainably" [42]. It aimed "to demonstrate at local, national and international levels, a pro-poor approach to reducing deforestation and forest degradation by generating equitable financial incentives from carbon finance sources for communities that are sustainably managing or conserving Tanzanian forests at community level" (ibid.).

TFCG and Mjumita committed to good governance principles and social safeguards when introducing and implementing the REDD+ project [41,43]. Emphasis was placed on obtaining the free, prior, and informed consent from project participants before the interventions started. In-depth assessments of local livelihoods and drivers of deforestation preceded the design of crucial project elements, including the community governance framework and proposed alternative livelihood strategies. The project utilised participatory and bottom-up methods to introduce rural villagers to the REDD+ concept, and let the village community decide democratically whether they want the project or not. Information strategies (brochures, information sheets, meetings) were adapted to fit the specific local cultural context and language. From the outset, the project proponents promised that the REDD+ project would establish community-based forest management, which will transfer management, ownership, and beneficiary rights of the forests to the community. The protection of the forests would enable villagers to benefit from the sale of carbon credits. Biodiversity conservation and alternative livelihoods were another important co-benefits (ibid.).

By the end of the TFCG/Mjumita project period in December 2014, a total area of 151,867 hectares of forests across 27 villages were put under community-based forest management and trial cash payments of over USD 450,000 were made to over 44,000 people in the villages. In Ruhoma, the project set aside 2488 hectares of forest under protection, covering around $65 \%$ of the entire village land ( $3817 \mathrm{ha}$ ) and $88 \%$ of all forests in the village. Ruhoma was among several villages that have recently been successful in developing a Verified Carbon Standard/Climate, Community \& Biodiversity Standards Project Documents (The Climate, Community and Biodiversity Standards are a prominent certification mechanism for forestry-carbon and other land management projects. It was developed by the Climate, Community and Biodiversity Alliance, and is now managed by Verified Carbon Standard, which is the world's largest certification programme for voluntary carbon reduction projects. Certification from CCB/VCS supposedly guarantees that the carbon project genuinely reduces carbon emissions, contributes to biodiversity, supports community development and adheres 
to good governance principles. For more information, see http://verra.org/project/ccb-program/) in preparation of selling forest-carbon [41]. However, no carbon credits have been sold as of yet, which is a major concern to the sustainability of the project $[37,44]$.

\subsubsection{AVLFR REDD+}

In the AVLFR, an international participatory action research project titled "The role of Participatory Forest Management in Mitigation of and Adaptation to Climate Change: Opportunities and Constrains" aimed to demonstrate the benefits of REDD+. The aims of the project were "(a) to assess local communities' perception and willingness to be involved in the REDD+ initiative; (b) to assess local communities' capability and the costs to carry out participatory forest carbon assessment in three villages surrounding Angai Village Land Forest Reserve (AVLFR); (c) to determine forest carbon stock in three villages' forest area constituting AVLFR" [45]. The research was specifically concerned with the idea of linking village land forest reserves with REDD+ efforts, to promote sustainable and poverty alleviating forest management. The Clinton Climate Initiative (CCI) and local district council, among other stakeholders, supported the AVLFR REDD+ initiative, which built on many years of donor support for community-based forest management in Liwale district [46]. The Clinton Climate Initiative selected the Angai forest from a pool of 70 potential sites to support community-based forest management linked with REDD+ based carbon payments and FSC timber harvesting [47]. However, Clinton Climate Initiative's proposal, to include Liwale as an official site for REDD+ piloting, was not supported by the Norwegian government. In 2010, a new Finnish-led development programme started in Liwale titled LIMAS (Lindi and Mtwara Agribusiness Support). LIMAS was a five-year programme aimed at increasing agricultural productivity, business opportunities, and participatory forest management in selected districts in Lindi and Mtwara regions. Among the options to generate more income from forestry, the LIMAS project mentions the sale of forest carbon credits, but the focus of the programme was to establish village land forest reserves and empower communities to sell timber commercially on a sustainable basis [48,49].

By the end of the LIMAS project, 14 out of 24 villages completed land use plans. Mihumo/Darajani was one of the 14 villages. Only 6 out of the 14 plans that were approved by the Liwale district council, had been submitted to the National Land Use Planning Commission in order to be gazetted. Mihumo/Darajani is still waiting for its plan to be submitted. The village still does not have an approved forest management plan, which means that villagers continue to wait for their legal rights to harvest and sell timber, carbon, and other commodities commercially [49].

\section{Approach and Methods}

\subsection{Case Study Contexts}

The paper is based on data collected in two case study villages-Mihumo/Darajani (Around the Angai forest there were 13 villages in the past, but in the year 2008/2009, eight of them split into two or three villages, creating a new total of 24 villages. Mihumo/Darajani was Mihumo before, and split into Mihumo and Darajani. For reasons of simplicity, I refer to the two villages as one.) and Ruhoma-both located in the Lindi region, southeastern Tanzania. Lindi region is the fourth largest of Tanzania's 30 regions, and covers approximately $67,000 \mathrm{~km}^{2}$. Residents belong to the poorest people in the world, by most standards, and they are part of a geographical band of food insecurity in the country [50]. While livestock grazing and pastoralism is extensively practiced in other areas of Tanzania, residents in the Lindi region mainly practice crop production as their major agricultural activity, due to widespread existence of the tsetse fly (Tsetse fly are large biting flies, commonly found in East Africa, which transmit dangerous diseases, including human sleeping sickness and animal trypanosomiasis.) [51-53]. Major agricultural crops are maize, sorghum, and paddy, followed by oil seeds and oil nuts [53]. Small-scale agriculture is one of the main drivers of deforestation and associated carbon emissions in the region [54,55]. When REDD+ projects started in Tanzania, 
the national deforestation rate was estimated to be significant-1.1\% annually [54]. Besides using it for agricultural land, villagers derive important benefits from forests, including poles and timber for construction, mushrooms, fruits, wild meat, and honey for consumption, and firewood for cooking [55].

The first case study village is Mihumo/Darajani, which is located in the Liwale district in the Lindi region. The village was part of the AVLFR REDD+ project. In 2011, the village had more than 3000 inhabitants, and spanned across an area of 29,555 hectares. In the district are two forest reserves, one of which is Angai village land forest reserve (AVLFR), which covers a total area of 139,420 ha and is surrounded by 24 villages (previously 13 villages). The village of Mihumo/Darajani set aside 11,792 ha as forest reserve, which is equivalent to about $8.45 \%$ of the total AVLFR.

The second case study village is Ruhoma, which is situated in the Lindi rural district in the Lindi region. Ruhoma is part of the TFCG/Mjumita "Making REDD work for communities and forest conservation in Tanzania" project. Ruhoma is considerably smaller than Mihumo/Darajani, both in size and population. In 2011, it counted 475 residents, living in 169 households, in an area of 3817 hectares. Despite its smaller size, forests play an equally significant role in Ruhoma, covering a total area of 2830 hectares. About $88 \%$ of this area, which is equivalent to 2488 hectares, was set aside as forest reserve in the course of the REDD+ intervention by the two non-governmental organisations Tanzania Forest Conservation Group (TFCG) and Mjumita.

\subsection{Data Sources}

This paper synthesises findings from various sources of data, which were collected for my $\mathrm{PhD}$ study from August 2011 to July 2012 [56]. During my 11-month-long stay in Tanzania, 7 months of which I lived in the two case study villages, I employed a range of qualitative and quantitative methods, including participant observation, ethnographic interviewing, 116 recorded semi-structured interviews, 116 household surveys, one focus group discussion, and document analysis. In this paper, I predominantly reflect on the results from the qualitative research methods, in order to highlight three particularly important findings on REDD+ implementation in Tanzania. The qualitative data were collected through direct observations, informal conversations, and structured conversations in more formal interviews and focus group discussion. During my stay in the villages, I participated in the everyday life of villagers, and engaged in innumerable informal conversations with as many villagers as possible. For the 116 more formal, semi-structured recorded interviews, and for the participants of the focus group discussion in Ruhoma, I used purposive sampling to interview villagers with different characteristics and from a variety of backgrounds and positions in the village, to have a wide range of viewpoints in my analysis. I conducted 66 semi-structured interviews with stakeholders of Mihumo/Darajani village, and 50 semi-structured interviews with stakeholders in Ruhoma village. This was the maximum amount I was able to achieve in the time available. For a detailed list of all recorded interviews, see Appendix A. The majority of the data were collected in Swahili, and later translated into English for analysis.

The primary data has been complemented with an in-depth analysis of project documentation, which include project leaflets, internal reports, independent evaluation reports, and legal documents (e.g., by-laws, forest management plans, village land-use plans). An important source of more recent information on the TFCG/Mjumita project is an official final project evaluation report conducted by NIRAS for the Royal Norwegian Embassy in Dar es Salaam [44]. Similarly, a project completion report of the LIMAS project in Liwale provided updated information on the AVLFR project [49].

\section{Results and Discussion: Three Major Challenges of REDD+ Implementation}

From my research findings, it emerges that REDD+ projects encountered important challenges and unanticipated consequences in the two case study villages. Reflecting on my data, I identify three challenges that are particularly important to REDD+ implementation in Tanzania: the politics surrounding the establishment of community-based forest management; the mismatch between formal governance institutions and actual practices on the ground; and the fickleness of income from 
carbon sales and alternative livelihood opportunities. This section discusses these three identified key challenges, with less focus on the first one, because I have dealt with it extensively elsewhere $[15,46,57]$.

\subsection{The Politics of Establishing Community-Based Forest Management}

The establishment of community-based forest management in the two case study villages was technically complicated, resource intensive, and much more time-consuming than expected. Throughout the project period, villagers depended on the state and project proponents to take the process forward, requiring more resources, time, and investment than donors anticipated $[15,46,57]$. Structural issues regarding ownership of land and boundary demarcation became the most significant obstacles. The final review report of the LIMAS programme confirmed: "There have been continued delays to resolve boundaries between villages, and additional land use planning and forest management planning costs. In many instances the difficulties in resolving boundary disputes has delayed the opportunity for communities to enter into PFM, and boundary uncertainty has also been a factor in illegal logging" [49]. Although the establishment of community-based forest management was quicker in Ruhoma than in Mihumo/Darajani, the process still experienced delays due to inter- and intra-village conflicts over forest resources and village boundaries, and complex bureaucratic requirements [44,57].

The first key finding from my data questions the assumption that market-based conservation is a quick and win-win solution that benefits everyone. My data show that the establishment of community-based forest management and REDD+ is not a straightforward technical process, but requires active engagement with local politics, power struggles, and deep-seated structural challenges regarding land ownership and boundaries. This requires the availability of significant resources and capacitated actors outside the village, who could take the complex and contested decentralisation process forward. The seemingly technical activities were inherently political-they shaped who gets access to what-and required serious time and resource commitment to resolve land use conflicts. Project proponents needed access to substantial amounts of up-front capital to finance necessary activities, which the carbon market does not provide.

If followed through though, the study shows that community-based REDD+ activities can result in important positive changes, such as assisting villages to express their claims over the authority of village and forestland, helping to address boundary conflicts, organising village land use planning exercises, and establishing formal village institutions. However, it is also important to recognise that introducing formal community governance institutions shifts power away from customary arrangements with detrimental effects to some population groups in and outside the concerned villages [57]. In the Lindi region, forests were generally treated as de facto open-access and, thus, accessed freely by villagers. Residents from different villages could move between forests and access them for agriculture or other uses without major hindrances. With the introduction of REDD+ and community-based forest management, certain parts of the forests were put under formal protection, and villagers excluded from specific uses [58]. By excluding villagers from farming and logging in the forests, it was hoped that the forest carbon content would increase, and be turned into income from carbon sales. The expectation was that villagers would manage the forest reserve sustainably, i.e., follow the rules and institutions laid out in the forest management plans and by-laws. Unsurprisingly, villagers only partially adopted the new set of formal institutions, as will be described below.

\subsection{The Intricacies of Practicing Community-Based Forest Management}

Based on the newly established forest management plans and by-laws, a range of forest activities became prohibited, including farming in the forest, collecting fresh cut firewood, harvesting wild bee hives, trapping wildlife, herding livestock, setting fire, and producing charcoals, among others. Some activities were restricted to the availability of permits, which were given for free or after payment [15]. The VNRC became a powerful group in the village as it was tasked with the responsibility of managing and protecting the community forests from any prohibited activity. Furthermore, any income from permits, fines, and sales of forest products were to be managed transparently 
and transferred to the village council. While the different responsibilities, rules, and regulations were clearly outlined in the forest management plans and by-laws, the following text will discuss how they were actually practiced by residents.

\subsubsection{Practising CBFM in Mihumo/Darajani}

Although the forest management plan and by-laws formally permitted various activities in the village land forest reserve, many villagers in Mihumo/Darajani generally thought of it as a closed-off area. Ethnographic interviews with residents attested that entering the reserve would lead to arrest by the village natural resource committee. Exclusion from the village land forest reserve was tolerated by villagers because of the large forest areas outside of the reserve, which they used to meet their livelihood needs. One way the VNRC used to keep villagers out of the reserve, was to conduct patrols. According to the management plan of Mihumo/Darajani, the patrol team should go every two weeks to check the forest reserve. Yet, in reality, patrols were less frequent and not carried out as planned. Village and committee members explained that organised patrols into the forest reserve had become rare, and only took place if prompted by obvious intruders in the forest.

The people of the forest committee used to go every week. But these days they don't go. They have quit going. When they went in the past, they started there, walked and slept over. Then they made a mark that they passed here. If you catch somebody then it is necessary to pay a fine. (M Interview 5).

We started the system of going into the forest. We went twice this year. Last year the secretary quit and another one joined. Since then we haven't gone to do a survey in the forest. We do patrols in the open area. When we hear that they fell trees then we go. We hear people entered, then we go (M Interview 49).

The reasons given for the lack of regular patrolling into the forest reserve related to insufficient resources to cover the incurred expenses, which can be substantial, given the size of the forest reserve and time needed to complete a patrol.

We haven't gone there again because in our cash register there is no money. Because it is far. You need to carry food and medicine. We struggle because we don't have money (M Interview 50).

But we are asking: Who will facilitate us? There is no money. If they had given us money, we would stay the whole time there. But you stay to your own loss (M Interview 29).

In informal conversations, villagers told me that, when village committee members did go on patrols, they often went in the area outside of the reserve after they had heard about tree felling from villagers. It appeared to them that, in order to save costs, the VNRC focussed on issuing permits and conducting patrols for areas outside of the reserves. This would be a clear divergence from the formal rules, as there are no provisions to carry out patrols outside of the forest reserve. The allegation that committee members especially went on patrols after they had heard about "illegal" intruders, could suggest that patrols were primarily conducted for functional reasons, namely to catch and fine people for the committee's and/or individual committee members' benefit. Yet, according to the views of some villagers, despite patrols, the illegal harvesting of timber products continued to take place, and often remained unreported and without prosecution.

Some people who fell trees in the open area don't pay tax. They log timber and sell, but they claim to fell trees for construction. In the morning we see people who buy timber and go with it. If you ask him he says ah this is just to pay my debts with him. I rent from him and now he is taking my timber (M Interview 49).

For some people who live on their farms it is easy to enter the forest, fell trees and we don't know about it (M Interview 50). 
Around three people got fined. But because they are our brothers, you know. If they arrive their they say people we don't have 50,000. We did so because of poverty. So the 50,000 can be cancelled. He can pay 20,000 or 20 something. And others arrive there and say yes you caught me and my tools but I don't have anything. He can complain and maybe pays 15,000. We just put the 50,000 as a law. If somebody gets caught he pays 50,000. But nobody has ever paid 50,000. (M Interview 50).

The possibility of mismanagement and corruption was supported by the confusion that prevailed over the income and expenses from the village land forest reserve. Despite several attempts, I was not given access to records of income and expenses from the forest reserve by committee members. There was confusion over the amount of fines, stories about the handling of illegal forest users, and secrecy over the income and expenses. From interviews with village natural resource committee members, it also transpired that people had to pay different amounts of tax per plank. The tax on sawed planks seemed to be negotiated on an individual basis, where village natural resource committee members often tried to levy 500 TShs (0.3 USD) tax on each plank, in order to increase their own share of benefits.

So what happens is that the price is 250. But we from the village natural resource committee we don't have any salary. Maybe if there is somebody from there who comes here to get 10 planks for doors. If I meet him then I tell him 500 shillings. From the 500 shillings I take 250 shillings for soaps for the work I do and 250 I take to village (M Interview 54).

\subsubsection{Practicing CBFM in Ruhoma}

In Ruhoma, REDD+ interventions resulted in regular patrolling and more transparent forest management practices at the time of my fieldwork in 2011/2012. In conversations with ordinary villagers and village natural resource committee members, I was told that regular patrols had been conducted. In the beginning, it was done voluntarily but, once the REDD+ trial money arrived, the amount of 700,000 TShs (450 USD) was set aside to finance patrolling four times a month for a period of one year. Every week, six members of the village natural resource committee went into the forest reserve to assess the situation and check for any criminal offences. Because of the small size of the forest reserve, the patrolling took three to four hours, on average, and there were no particular challenges. At the end of the day, each member received an allowance of 2000 TShs (1.3 USD).

The money from REDD+ contributed to regular patrols, as payments were set aside for the activities of committee members. It seems that they felt less of a need to obtain money by fraud. The smaller forest size and fewer dangerous animals in Ruhoma made forest management activities much easier than in the vast dangerous landscape of Mihumo/Darajani.

In Ruhoma, permits for timber harvesting were issued for subsistence purposes only. Also, in this village, village natural resource committee members had a different understanding of the amount of money required to obtain a permit. One member explained to me that for 10,000 TShs (6.4 USD), you obtain a permit, which allows you to harvest 50 planks and 40 beams, where you pay 200 TShs (0.1 USD) tax on each plank. Another member spoke of 500 TShs tax per plank, and a third one told me that 20,000 TShs (10 USD) are required to obtain a permit for 100 planks and 300 TShs (0.2 USD) tax are levied on each plank. From the income statements that I received from the village natural resource committee secretary, I learnt that people were usually charged with 200 TShs (0.1 USD) tax per plank, but I also viewed a case where 300 TShs (0.2 USD) tax was charged. What I could not ascertain from the income records provided to me, was whether anything was charged for issuing the permits.

One issue that emerged from my conversations with villagers about the harvesting of timber related to follow-ups of permits. I was told that craftsmen could easily log more trees than they were permitted, in order to produce more planks. Village natural resource committee members seem to not rigorously follow-up on the amount of planks sawn. Craftsmen were, therefore, easily tempted to apply for small amounts of timber, and then log much more than permitted. 
Also in Ruhoma, I came across cases where timber was harvested without the permission of the village natural resource committee. Obtaining a permit for a few planks to produce stools, chairs, or similar things seemed, to many, to be an unnecessary obligation. This view appears to be shared by villagers, in general, and the responsible authorities, as non-compliance to the rules does not result in penalisation.

... I for myself I haven't been ready to get permits. If I get the timber illegally [michocholo] then the days continue as if nothing happened (siku zinakwenda). And if you go for permit, you are being robbed a lot ( $R$ Interview 32).

The second key finding from my data questions the assumption that formal governance institutions can be introduced relatively easily into villages to promote sustainable forest management. My data show that the formal community-based institutions, which were introduced to manage the village land forest reserve sustainably, were not entirely adopted by villagers at the local level. According to Dill, this is a lack of fit between domestic norms, which inhibit or constrain popular participation, and the imported institutional superstructure, which should facilitate it. He further argues that, by following a certain mode of institutionalisation, community-based organisations are reified and separated "in an unrealistic way from the dynamics of change in the community of which it is both part and reflection" [59]. In both case studies, project proponents displayed a rather static and homogenous notion of a "community" yet, in reality, communities are heterogeneous entities where diverse interests exist [60]. The discrepancy between formal institutions and actual practices was most striking in Mihumo/Darajani, but it was also present in the village of Ruhoma and other TFCG/Mjumita REDD+ villages. According to the final evaluation report of the REDD+ projects, there is "on-going agricultural expansion from residents within the village, encroachment from neighbouring villages, unregulated harvesting taking place between villages, clearance of forest land reserved for agriculture in the land use plan and lack of enforcement of bylaws. A weakness in local governance such as tension between the village natural resource committee and the village government in some villages has also contributed to the lack of effective enforcement" [44].

\subsection{Carbon Sales and Alternative Income Opportunities}

The fundamental premise of REDD+ is that the income from carbon sales incentivises villagers to protect the forests and contributes to economic development. By aiming to reward forest users with performance-based payments for the protection and enhancement of carbon, REDD+ initiatives represent a deliberate external intervention that aims to facilitate collective protection of the forest [26]. Carbon payments are the primary means of REDD+ to balance incurred livelihood losses from forest protection [61]. Like all other REDD+ pilot projects in the country, both initiatives failed to sell carbon credits in the global market. Although TFCG/Mjumita distributed trial payments to several villages including Ruhoma, the dispersed payments were only possible due to donor funding, which stopped in 2014 (A special committee was founded in Ruhoma to distribute carbon trial payments. A group of 12 people, $50 \%$ male and $50 \%$ female, were selected by sub-village chairmen and other village leaders to manage the distribution of forest-carbon payments among the villagers. Among the members are representatives from the village council, village natural resource committee, land use planning committee, and the wider village community.). The initial expectation was that, by this time, a carbon cooperative was to be established, through which income from the sale of carbon credits would be channelled directly to the communities and their village residents. The idea was that the carbon cooperative would aggregate and market the voluntary emission reductions from the various villages that take part in the TFCG/Mjumita REDD+ project. Each village resident would be a member of the cooperative, and entitled to its dividend. In addition to individual dividends, carbon sales would be uses to finance community development projects and the operation costs of the cooperative [41]. Because no carbon credits had been sold by the project (at least until 2015/2016), the carbon cooperative was not in operation $[37,44]$. 
In the beginning, the project planned to reward individual villagers based on their actual performance and contribution, but this was abandoned for the trial payments, which were distributed equally among villagers. The REDD+ trial money was put to use by villagers in different ways. Most of them spent the money on food, clothes, and miscellaneous items, such as consumer goods. Food was the most popular benefit from carbon payments for villagers in Ruhoma. One explanation for this is that the trial payments were dispersed in February, which is usually a month characterised by food insecurity. The final review report of the TFCG/Mjumita REDD+ project points out that

It seems unlikely that at present levels payments were sufficient to significantly impact poverty or vulnerability levels - although the review team was able to verify the very high level of popularity of REDD+ payments across all villages visited. Although the project has made a significant achievement developing the payment system and testing the value of payments it is worth noting that the funds for this were not coming from the carbon market and that funds for future carbon payments are still not secured [44].

Because the opportunity costs for protecting the forests range from USD 10 to 20 per ton of carbon [62,63], it could just be a matter of time until villagers go back to converting the forests to agriculture. The pressure on forest protection is exacerbated by the growing demand in agricultural land and increased prices for cash crops, such as sesame and cashew nuts [36]. Besides carbon payments, project proponents promised alternative livelihoods as compensation for forest protection. All REDD+ projects in Tanzania struggled to generate alternative livelihood strategies. Efforts to introduce alternative income generating activities, such as beekeeping, conservation agriculture, butterfly farming, vegetable farming, and development of woodlots, generally struggled to deliver the expected results [36]. In the final review report of the TFCG/Mjumita REDD+ project, it is stated that

A number of concerns were expressed by the visited communities on the relevance and quality of support provided for income generation activities (IGAs) as well as on the lack of market linkages. This included technical support and advisory services on beekeeping and poultry farming which had very limited success. Poultry keeping was discontinued by the project due to its poor performance and limited links to the broader deforestation objectives. Identifying private sector or non-governmental service providers during design and engaging them to deliver these outputs could have improved performance [44].

The third key finding from my data questions the most fundamental assumption behind market-based conservation, namely, that there is a market for conservation. In the words of the final evaluation report: "the sale of carbon credits remains a "killer assumption" that underpins long-term sustainability of measures that reduce deforestation" [44]. However, in both case studies, REDD+ projects have failed to sell carbon credits via market exchanges, while relying on government funding. The case studies demonstrated that initial hopes of generating long-term income from carbon markets proved to be illusive. There is much uncertainty over the future of the projects and, indeed, villager's willingness in performing conservation. Given the high opportunity costs of forest protection and serious extent of poverty in the villages, the likelihood that villagers go back to previous land use practices is high if the payments fail to materialise. In addition to failing to generate long-term security over performance-based payments, the projects have not succeeded in creating alternative income sources, due to long-standing structural constraints and other well-known barriers.

\section{Conclusions}

In this article, I synthesise findings from my research on REDD+ in Tanzania to discuss three key challenges of implementation: the politics surrounding the establishment of community-based forest management; the mismatch between formal governance institutions and actual practices on the ground; and the fickleness of income from carbon sales and alternative livelihood opportunities. I argue that these challenges are not merely teething troubles, but they question fundamental assumptions of 
market-based conservation, more generally. Market-based conservation promises win-win benefits and a relatively quick fix to complex socio-environmental problems. In practice, however, it encounters resistance, politics, and deep-seated structural inequalities that are prevalent in many rural African landscapes. Market-based conservation thus appears to be, in the words of Lund et al. (2017), a conservation fad that promises change but delivers continuity. Although, this notion of fad is being criticised by others who place the responsibility for its failures on implementation shortcomings. As there is urgent need for conservation that is both environmentally and socially sustainable [64-66], what is to be done?

To attain the objective of long-term sustainable development, we need to significantly transform the political economy of nature conservation. Community-based forest management holds promise to deliver environmental and social benefits, but its establishment is complex and politically contested. It requires political and financial commitment over a long period of time, during which, considerable losses may be incurred. Markets and profit-making mechanisms are ill-suited to carry those. As Fletcher et al. (2017) suggested, we need global commitment to sustainable sources of funding without a competitive process, which can assist local communities in obtaining the rights over resources, and assists them in covering the costs of establishing and implementing community-based forest management [65].

In addition, conservation initiatives need to acknowledge the complex and contentious process of strengthening democratic governance in rural villages [67]. Promoting good leadership, accountability, participation, and equal distribution of benefits requires the building of active citizenship among rural villagers. Simply developing good governance institutions on paper, even with local participation, does little to achieve actual good governance on the ground. Conservation initiatives will have to actively fund measures that strengthen citizenship and positively impact on democratic governance, even if they take years to bear fruit.

Lastly, as suggested by Turnhout et al. (2013), conservation initiatives should go beyond the techno-managerial and economic-centric focus of payments for ecosystem services, and learn about the variety and multiple ways of shaping society-nature relations, which have existed for millennia, and involved many different reasons for engaging with nature. We need to avoid singular measures to represent the myriad relationships with nature, and commit to inclusive processes of knowledge creation, to include alternative voices and perspectives [68]. Aside from appreciating the diversity of possible human-environment interactions, we need to build on existing alternative practices and examine how they can be replicated across diverse contexts.

Funding: This research received no external funding.

Acknowledgments: This article is based on my PhD studies at the University of Manchester, which I conducted under the guidance of Dan Brockington and Professor Phil Woodhouse. I am grateful to all the villagers, district officials, and project proponents for their participation in the research. I would also like to acknowledge the support provided by the University of Manchester and Irmeli Mustalahti for the fieldwork in Tanzania. The article benefitted from discussions with Amber Huff and comments by three anonymous reviewers and the editors.

Conflicts of Interest: The author declares no conflict of interest.

\section{Appendix A. List of Recorded Interviews}

Interviews recorded in Mihumo/Darajani 
No.

M 1

M 2

M 3

M 4

M 5

M 6

M 7

M 8

M 9

M 10

M 11

M 12

M 13

M 14

M 15

M 16

M 17

M 18

M 19

M 20

M 21

M 22

M 23

M 24

M 25

M 26

M 27

M 28

M 29

M 30

M 31

M 32

M 33

M 34

M 35

M 36

M 37

M 38

M 39

M 40

M 41

M 42

M 43

M 44

M 45

M 46

M 47

M 48

M 49

M 50

M 51

M 52

$$
\begin{gathered}
\text { Type of Interviewee } \\
\text { Researcher } \\
\text { Researcher } \\
\text { Livestock owner } \\
\text { Village leader } \\
\text { Young villager } \\
\text { Sub-village Chairman } \\
\text { Elder } \\
\text { Elder } \\
\text { Sub-village Chairman } \\
\text { Sub-village Chairman } \\
\text { Sub-village Chairman } \\
\text { Vicoba } \\
\text { Elder } \\
\text { VNRC } \\
\text { Village outsider } \\
\text { VNRC }
\end{gathered}
$$

CA (CA refers to Conservation Agriculture group) Darajani Young villager Elder

Sub-village Chairman

Young villagers

Female farmer

Male farmer

Single mother

CA Darajani

CA Mihumo

CA Darajani

CA Mihumo \& REDD REDD

Sub-village Chairman

CA Mihumo

CA Mihumo

CA Mihumo

CA Mihumo

CA Mihumo

CA Mihumo

Elder

CA Darajani

CA Darajani

CA Darajani

CA Darajani

CA Darajani

CA Darajani

CA Darajani REDD

Village council REDD

Elder

VNRC

VNRC

VNRC

Health/Dispensary
Sex

$\mathrm{M}$

F

M

$\mathrm{M}$

M

M

M

$\mathrm{M}$

M

M

M

M

M

M

M

M

M

$\mathrm{M}$

F

M

F

$\mathrm{M}$

F

M

F

M

F

$\mathrm{M}$

M

F

F

F

F

M

F

M

$\mathrm{F}$

M

F

M

F

M

M

M

M

F

F

M
Date

17.08.2011

21.08.2011

19.12.2011

19.12.2011

19.12.2011

24.12.2011

26.12.2011

29.12.2011

30.12.2011

30.12.2011

31.12.2011

02.01.2012

02.01.2012

04.01.2012

12.01.2012

14.01.2012

19.01.2012

26.01.2012

26.01.2012

27.01.2012

23.03.2012

23.03.2012

23.03.2012

24.03.2012

24.03.2012

26.03.2012

27.03.2012

27.03.2012

28.03.2012

28.03.2012

04.04.2012

04.04.2012

05.04.2012

07.04.2012

09.04.2012

09.04.2012

10.04.2012

10.04.2012

10.04.2012

11.04.2012

12.04.2012

12.04.2012

13.04.2012

13.04.2012

21.04.2012

22.04.2012

22.04.2012

23.04.2012

24.04.2012

25.04.2012

25.04.2012

26.04.2012 
No.

M 53

M 54

M 55

M 56

M 57

M 58

M 59

M 60

M 61

M 62

M 63

M 64

M 65

M 66
Type of Interviewee

VNRC

VNRC

VNRC

VNRC

VNRC

Teacher

Sub-village Chairman

District

District

Ward

Village council

VNRC

Village council

Village council

\section{Interviews recorded in Ruhoma}

\begin{tabular}{|c|c|}
\hline No. & Type of Interviewee \\
\hline $\mathrm{R} 1$ & VNRC \\
\hline R 2 & VNRC \\
\hline R 3 & VNRC \\
\hline R 4 & VNRC \\
\hline R 5 & CA \\
\hline R 6 & $\mathrm{CA}$ \\
\hline R 7 & Village outsider \\
\hline R 8 & REDD \\
\hline R 9 & Elder \\
\hline R 10 & LUP \\
\hline R 11 & LUP \\
\hline $\mathrm{R} 12$ & LUP \\
\hline R 13 & Village leader \\
\hline R 14 & CA \\
\hline R 15 & Ordinary villagers \\
\hline R 16 & Village outsider \\
\hline $\mathrm{R} 17$ & CA \\
\hline R 18 & LUP \\
\hline R 19 & LUP \\
\hline R 20 & Committees \\
\hline R 21 & Committees \\
\hline R 22 & Ordinary villagers \\
\hline R 23 & Ordinary villagers \\
\hline R 24 & $\mathrm{CA}$ \\
\hline R 25 & LUP \\
\hline R 26 & CA \\
\hline R 27 & Teacher \\
\hline R 28 & Village leader \\
\hline R 29 & Project staff \\
\hline R 30 & Ordinary villagers \\
\hline R 31 & CA \\
\hline R 32 & Ordinary villagers \\
\hline R 33 & Ordinary villagers \\
\hline R 34 & REDD \\
\hline
\end{tabular}

Sex

$\mathrm{F}$

M

$\mathrm{M}$

$\mathrm{F}$

$\mathrm{F}$

$\mathrm{M}$

M

F

$\mathrm{M}$

M

M

$\mathrm{F}$

$\mathrm{M}$

$\mathrm{F}$

F

M

M

F

F

F

M

$\mathrm{M}$

$\mathrm{M}$

F

M

F

F

M

M

$\mathrm{M}$

M

M

M

F
Place

Date

Darajani

Darajani

Darajani

Mihumo

Mihumo

Mihumo

Mihumo

Liwale

Liwale

Liwale

Mihumo

Mihumo

Darajani

Mihumo

Place

Ruhoma

Ruhoma

Ruhoma

Ruhoma

Ruhoma

Ruhoma

Ruhoma

Ruhoma

Ruhoma

Ruhoma

Ruhoma

Ruhoma

Ruhoma

Ruhoma

Ruhoma

Ruhoma

Ruhoma

Ruhoma

Ruhoma

Ruhoma

Ruhoma

Ruhoma

Ruhoma

Ruhoma

Ruhoma

Ruhoma

Ruhoma

Ruhoma

Ruhoma

Ruhoma

Ruhoma

Ruhoma

Ruhoma

Ruhoma
Date

26.04.2012

26.04.2012

26.04.2012

27.04.2012

27.04.2012

11.07.2012

11.07.2012

16.07.2012

16.07.2012

16.07.2012

20.07.2012

20.07.2012

20.07.2012

21.07.2012

09.03.2012

09.03.2012

09.03.2012

10.03.2012

10.03.2012

11.03.2012

11.03.2012

11.03.2012

12.03.2012

08.05.2012

09.05.2012

09.05.2012

10.05.2012

11.05.2012

11.05.2012

12.05.2012

13.05.2012

14.05.2012

14.05.2012

15.05.2012

15.05.2012

16.05.2012

16.05.2012

16.05.2012

17.05.2012

17.05.2012

20.05.2012

20.05.2012

21.05.2012

02.06.2012

02.06.2012

02.06.2012

03.06.2012

04.06.2012 
No.

R 35

R 36

R 37

R 38

R 39

R 40

R 41

R 42

R 43

R 44

R 45

R 46

R 47

R 48

R 49

R 50

R 51

$$
\begin{gathered}
\text { Type of Interviewee } \\
\text { Teacher } \\
\text { Ordinary villagers } \\
\text { Ordinary villagers } \\
\text { Ordinary villagers } \\
\text { District } \\
\text { District } \\
\text { District } \\
\text { District } \\
\text { Project staff } \\
\text { Ordinary villagers } \\
\text { Ordinary villagers } \\
\text { Ordinary villagers } \\
\text { Elder } \\
\text { Project staff } \\
\text { Ward } \\
\text { Ward }
\end{gathered}
$$

Focus Group Discussion

$\begin{array}{ccc}\text { Sex } & \text { Place } & \text { Date } \\ \text { M } & \text { Ruhoma } & 04.06 .2012 \\ & \text { Ruhoma } & 06.06 .2012 \\ \text { M } & \text { Ruhoma } & 06.06 .2012 \\ \text { M } & \text { Ruhoma } & 06.06 .2012 \\ \text { M } & \text { Lindi } & 13.06 .2012 \\ \text { M } & \text { Lindi } & 13.06 .2012 \\ \text { M } & \text { Lindi } & 14.06 .2012 \\ \text { M } & \text { Lindi } & 14.06 .2012 \\ \text { M } & \text { Lindi } & 14.06 .2012 \\ \text { F } & \text { Ruhoma } & 20.06 .2012 \\ \text { F } & \text { Ruhoma } & 20.06 .2012 \\ \text { F } & \text { Ruhoma } & 20.06 .2012 \\ \text { M } & \text { Ruhoma } & 21.06 .2012 \\ \text { M } & \text { Kinyope } & 22.06 .2012 \\ \text { M } & \text { Rutamba } & 22.06 .2012 \\ \text { M } & \text { Lindi } & 22.06 .2012 \\ & \text { Ruhoma } & 26.06 .2012\end{array}$

\section{References}

1. IPCC. Summary for Policymakers. In: Climate Change 2014: Impacts, Adaptation, and Vulnerability. Part A: Global and Sectoral Aspects. Contribution of Working Group II to the Fifth Assessment Report of the Intergovernmental Panel on Climate Change; Field, C.B., Barros, V.R., Dokken, D.J., Mach, K.J., Mastrandrea, M.D., Bilir, T.E., Chatterjee, M., Ebi, K.L., Estrada, Y.O., Genova, R.C., et al., Eds.; Cambridge University Press: Cambridge, UK; New York, NY, USA, 2014; pp. 1-32.

2. UNEP. GEO 5: Global Environment Outlook: Environment for the Future we Want; United Nations Environment Programme: Nairobi, Kenya, 2012; ISBN 978-92-807-3177-4.

3. UNEP. Towards a Green Economy: Pathways to Sustainable Development and Poverty Eradication; United Nations Environment Programme: Nairobi, Kenya, 2011.

4. UNDESSA. A guidebook to the Green Economy Issue 1: Green Economy, Green Growth, and Low-Carbon Development-History, Definitions and a Guide to Recent Publications. Available online: http://sustainabledevelopment.un.org $/$ index.php?page=view\&type $=400 \& n r=634 \&$ menu $=35 \quad$ (accessed on 3 March 2013).

5. Kettunen, M.; ten Brink, P. Nature, green economy and sustainable development: The outcomes of UN Rio+20 Conference on Sustainable Development. Nat. Conserv. 2012, 2, 1-6. [CrossRef]

6. Büscher, B.; Dressler, W.; Fletcher, R. Nature Inc.: Environmental Conservation in the Neoliberal Age; University of Arizona Press: Tucson, AZ, USA, 2014; ISBN 978-0-8165-9885-4.

7. Gómez-Baggethun, E.; de Groot, R.; Lomas, P.L.; Montes, C. The history of ecosystem services in economic theory and practice: From early notions to markets and payment schemes. Ecol. Econ. 2010, 69, 1209-1218. [CrossRef]

8. Büscher, B.; Sullivan, S.; Neves, K.; Igoe, J.; Brockington, D. Towards a Synthesized Critique of Neoliberal Biodiversity Conservation. Capital. Nat. Social. 2012, 23, 4-30. [CrossRef]

9. Muradian, R. Payments for Ecosystem Services as Incentives for Collective Action. Soc. Nat. Resour. 2013, 26, 1155-1169. [CrossRef]

10. McAfee, K. Selling nature to save it? Biodiversity and green developmentalism. Environ. Plan. D Soc. Space 1999, 17, 133-154. [CrossRef]

11. Igoe, J.; Brockington, D. Neoliberal Conservation: A Brief Introduction. Available online: http: / / www.conservationandsociety.org / article.asp?issn=0972-4923; year=2007; volume=5;issue=4; spage $=432$;epage $=449$; aulast $=$ Igoe (accessed on 28 May 2011).

12. McAfee, K. The Contradictory Logic of Global Ecosystem Services Markets. Dev. Chang. 2012, 43, $105-131$. [CrossRef]

13. Büscher, B. Payments for ecosystem services as neoliberal conservation: (Reinterpreting) evidence from the Maloti-Drakensberg, South Africa. Conserv. Soc. 2012, 10, 29-41. [CrossRef] 
14. Castree, N. Neoliberalising nature: The logics of deregulation and reregulation. Environ. Plan. A 2008, 40, 131-152. [CrossRef]

15. Scheba, A.; Scheba, S. REDD+ as 'inclusive' neoliberal conservation: The case of Lindi, Tanzania. J. East. Afr. Stud. 2017, 11, 526-548. [CrossRef]

16. Castree, N. Neoliberalising nature: Processes, effects, and evaluations. Environ. Plan. A 2008, 40, 153-173. [CrossRef]

17. Büscher, B.; Dressler, W. Commodity conservation: The restructuring of community conservation in South Africa and the Philippines. Geoforum 2012, 43, 367-376. [CrossRef]

18. Simonet, G.; Subervie, J.; Ezzine-de-Blas, D.; Cromberg, M.; Duchelle, A.E. Effectiveness of a REDD+ Project in Reducing Deforestation in the Brazilian Amazon. Am. J. Agric. Econ. 2018. [CrossRef]

19. Jayachandran, S.; de Laat, J.; Lambin, E.F.; Stanton, C.Y.; Audy, R.; Thomas, N.E. Cash for carbon: A randomized trial of payments for ecosystem services to reduce deforestation. Science 2017, 357, 267-273. [CrossRef] [PubMed]

20. Arriagada, R.A.; Sills, E.O.; Ferraro, P.J.; Pattanayak, S.K. Do Payments Pay Off? Evidence from Participation in Costa Rica's PES Program. PLoS ONE 2015, 10, e0131544. [CrossRef]

21. Costedoat, S.; Corbera, E.; Ezzine-de-Blas, D.; Honey-Rosés, J.; Baylis, K.; Castillo-Santiago, M.A. How Effective Are Biodiversity Conservation Payments in Mexico? PLoS ONE 2015, 10, e0119881. [CrossRef] [PubMed]

22. Milne, S.; Adams, B. Market Masquerades: Uncovering the Politics of Community-level Payments for Environmental Services in Cambodia. Dev. Chang. 2012, 43, 133-158. [CrossRef]

23. Dempsey, J.; Suarez, D.C. Arrested Development? The Promises and Paradoxes of "Selling Nature to Save It." Ann. Am. Assoc. Geogr. 2016, 106, 653-671.

24. Buscher, B. Transforming the Frontier: Peace Parks and the Politics of Neoliberal Conservation in Southern Africa; Duke University Press: Durham, UK, 2013; ISBN 978-0-8223-5420-8.

25. Fletcher, R. Neoliberal environmentality: Towards a poststructuralist political ecology of the conservation debate. Conserv. Soc. 2010, 8, 171-181. [CrossRef]

26. Corbera, E. Problematizing REDD+ as an experiment in payments for ecosystem services. Curr. Opin. Environ. Sustain. 2012, 4, 612-619. [CrossRef]

27. Roth, R.J.; Dressler, W. Market-oriented conservation governance: The particularities of place. Geoforum 2012, 43, 363-366. [CrossRef]

28. Leach, M.; Scoones, I. (Eds.) Carbon Conflicts and Forest Landscapes in Africa; Routledge: Abingdon, UK, 2015.

29. Fletcher, R. Using the Master's Tools? Neoliberal Conservation and the Evasion of Inequality. Dev. Chang. 2012, 43, 295-317. [CrossRef]

30. Agrawal, A.; Nelson, F.; Adams, W.M.; Sandbrook, C. Governance and REDD: A Reply to Wunder. Oryx 2010, 44, 337-338. [CrossRef]

31. Agrawal, A.; Angelsen, A. Using community forest management to achieve REDD+ goals. In Realising REDD+: National Strategy and Policy Options; CIFOR: Bogor, Indonesia, 2009; pp. 201-212.

32. West, T.A.P. Indigenous community benefits from a de-centralized approach to REDD+ in Brazil. Clim. Policy 2016, 16, 924-939. [CrossRef]

33. Robbins, P. Political Ecology: A Critical Introduction; John Wiley \& Sons: Hoboken, NJ, USA, 2012; ISBN 978-0-470-65732-4.

34. Bailey, S.; Bryant, R. Third World Political Ecology: An Introduction; Routledge: Abingdon, UK, 2005; ISBN 978-1-134-79804-9.

35. Forsyth, T. Critical Political Ecology: The Politics of Environmental Science; Routledge: London, UK.; New York, NY, USA, 2003; ISBN 978-0-415-18562-2.

36. Lund, J.F.; Sungusia, E.; Mabele, M.B.; Scheba, A. Promising Change, Delivering Continuity: REDD+ as Conservation Fad. World Dev. 2017, 89, 124-139. [CrossRef]

37. Blomley, T.; Edwards, K.; Kingazi, S.; Lukumbuzya, K.; Mäkelä, M.; Vesa, L. When community forestry meets REDD+: Has REDD+ helped address implementation barriers to participatory forest management in Tanzania? J. East. Afr. Stud. 2017, 11, 549-570. [CrossRef]

38. Norad Real-Time Evaluation of Norway's International Climate and Forest Initiative. Synthesising Report 2007-2013-norad.no. Available online: http:/ / www.norad.no/en/tools-and-publications/publications / evaluations / publication?key=415169 (accessed on 27 February 2015). 
39. URT. The Forest Act, No. 7 of 7th June 2002. Ministry of Natural Resources and Tourism, The United Republic of Tanzania; Government Printer: Dar es Salaam, Tanzania, 2002.

40. Blomley, T.; Iddi, S. Participatory Forest Management in Tanzania: 1993-2009: Lessons Learned and Experiences to Date; Ministry of Natural Resources and Tourism: Dodoma, Tanzania, 2009.

41. Mjumita. MJUMITA Community Forest Project Report Lindi CCB PDD.; Mjumita: Dar-es-Salaam, Tanzania, 2014.

42. TFCG. Making REDD Work for People and Forest Conservation in Tanzania; TFCG: Dar es Salaam, Tanzania, 2009.

43. Forrester-Kibuga, K.; Nguya, N.; Chikira, H.; Luwuge, B.; Doggart, N. Integrating the Principles of Free, Prior and Informed Consent in the Establishment of REDD: A Case Study from Tanzania; TFCG Technical Report 27; TFCG: Dar es Salaam, Tanzania, 2011.

44. NIRAS. Final Review of the Project: Making REDD+ and the Carbon Market Work for Communities and Forest Conservation in Tanzania. The Royal Norwegian Embassy in Dar es Salaam; NIRAS Finland, Oy: Vantaa, Finland, 2015.

45. Mukama, K.; Mustalahti, I.; Zahabu, E. Participatory Forest Carbon Assessment and REDD. Int. J. For. Res. 2011, 2012, e126454. [CrossRef]

46. Scheba, A.; Mustalahti, I. Rethinking 'expert' knowledge in community forest management in Tanzania. For. Policy Econ. 2015, 60, 7-18. [CrossRef]

47. CCI. Angai Village Forest Reserve: Tanzania, Forestry Project Overview; CCI: Agen, France, 2011.

48. LIMAS. Lindi \& Mtwara Agri-Business Support: Project Document; Government of Finland: Helsinki, Finland, 2010.

49. LIMAS. Project Completion Report 2010-2016: Presented to LIMAS Steering Committee and Supervisory Board in December 2016 for Final Endorsement; Government of Finland: Helsinki, Finland, 2017.

50. Research and Analysis Working Group. Poverty and Human Development Report 2011; Research and Analysis Working Group, United Republic of Tanzania: Dar es Salaam, Tanzania, 2011.

51. Covarrubias, K.; Nsiima, L.; Zezza, A. Livestock and Livelihoods in Rural Tanzania. A Descriptive Analysis of the 2009 National Panel Survey; LSMS-ISA: Washington, DC, USA, 2012.

52. URT. National Sample Census of Agriculture 2007/08. Small Holder Agriculture. Volume III Livestock Sector-National Report; National Bureau of Statistics, Ministry of Finance: Dar es Salaam, Tanzania, 2012.

53. URT. National Sample Census of Agriculture 2007/2008 Volume Vh Regional Report_Lindi Region; United Republic of Tanzania, Ministry of Agriculture, Food Security and Cooperatives, Ministry of Livestock Development and Fisheries, Ministry of Water and Irrigation, Ministry of Agriculture, Livestock and Environment, Zanzibar, Prime Minister's Office, Regional Administration and Local Governments, inistry of Industries, Trade and Marketing, The National Bureau of Statistics and the Office of the Chief Government Statistician: Zanzibar, Tanzania, 2012.

54. URT. National Strategy for Reduced Emissions from Deforestation and Forest Degradation (REDD+); Vice President's Office: Dar es Salaam, Tanzania, 2013.

55. Forrester-Kibuga, K.; Samweli, B. TFCG Technial Report 26: Analysis of the drivers of Deforestation and Stakeholders in the Lindi Project Site; TFCG: Dar es Salaam, Tanzania, 2010.

56. Scheba, A. Commodifying Forest Carbon: How Local Power, Politics and Livelihood Practices Shape REDD+ in Lindi Region, Tanzania. Ph.D. Dissertation, University of Manchester, Manchester, UK, 2014.

57. Scheba, A.; Rakotonarivo, O.S. Territorialising REDD+: Conflicts over market-based forest conservation in Lindi, Tanzania. Land Use Policy 2016, 57, 625-637. [CrossRef]

58. Dokken, T.; Dwi Putri, A.A.; Kweka, D. Making REDD Work for Communities and Forest Conservation in Tanzania. In REDD+ on the Ground: A Case Book of Subnational Initiatives across the Globe; CIFOR: Bogor, Indonesia, 2014.

59. Dill, B. Community-Based Organizations (CBOs) and Norms of Participation in Tanzania: Working against the Grain. Afr. Stud. Rev. 2010, 53, 23-48. [CrossRef]

60. Agrawal, A.; Gibson, C.C. Enchantment and Disenchantment: The Role of Community in Natural Resource Conservation. World Dev. 1999, 27, 629-649. [CrossRef]

61. Angelsen, A. (Ed.) Realising REDD+: National Strategy and Policy Options; CIFOR: Bogor, Indonesia, 2009.

62. Hofstad, O.; Araya, M.M. Optimal wood harvest in miombo woodland considering REDD+payments-A case study at Kitulangalo Forest Reserve, Tanzania. For. Policy Econ. 2015, 51, 9-16. [CrossRef]

63. Nuru, F.; Abdallah, J.M.; Ngaga, Y.M. Opportunity Costs of REDD. Available online: https:/ /www.hindawi. com/journals/ijfr/2014/697464/ (accessed on 31 March 2018). 
64. Angelsen, A.; Brockhaus, M.; Duchelle, A.E.; Larson, A.; Martius, C.; Sunderlin, W.D.; Verchot, L.; Wong, G.; Wunder, S. Learning from REDD+: A response to Fletcher et al.: Learning from REDD+. Conserv. Boil. 2017, 31, 718-720. [CrossRef] [PubMed]

65. Fletcher, R.; Dressler, W.; Büscher, B.; Anderson, Z.R. Debating REDD+ and its implications: Reply to Angelsen et al.: Debating REDD+. Conserv. Boil. 2017, 31, 721-723. [CrossRef] [PubMed]

66. Redford, K.H.; Padoch, C.; Sunderland, T. Fads, Funding, and Forgetting in Three Decades of Conservation: Editorial. Conserv. Boil. 2013, 27, 437-438. [CrossRef] [PubMed]

67. Brockington, D. Corruption, Taxation and Natural Resource Management in Tanzania. J. Dev. Stud. 2008, 44, 103-126. [CrossRef]

68. Turnhout, E.; Waterton, C.; Neves, K.; Buizer, M. Rethinking biodiversity: From goods and services to "living with." Conserv. Lett. 2013, 6, 154-161.

(C) 2018 by the author. Licensee MDPI, Basel, Switzerland. This article is an open access article distributed under the terms and conditions of the Creative Commons Attribution (CC BY) license (http:/ / creativecommons.org/licenses/by/4.0/). 


\title{
Article \\ Governing Grazing and Mobility in the Samburu Lowlands, Kenya
}

\author{
Annemiek Pas \\ Department of Human Geography, Stockholm University, Svante Arrhenius väg 8, \\ Se-106 91 Stockholm, Sweden; annemiek.schrijver@humangeo.su.se; Tel.: +46-700-128-959 \\ Received: 11 January 2018; Accepted: 29 March 2018; Published: 31 March 2018
}

\begin{abstract}
Pastoral mobility is seen as the most effective strategy to make use of constantly shifting resources. However, mobile pastoralism as a highly-valued strategy to manage grazing areas and exploit resource variability is becoming more complex, due to recurrent droughts, loss of forage, government-led settlement schemes, and enclosure of land for community conservation, among other reasons. Yet knowledge of how Samburu pastoralists perceive these changes, and govern and innovate in their mobility patterns and resource use, has received limited attention. This paper seeks to understand how Samburu pastoralists in the drylands of northern Kenya use and govern natural resources, how livestock grazing and mobility is planned for, and how boundaries and territory are constructed and performed both within and beyond the context of (non)governmental projects. Fieldwork for this paper was conducted in Sesia, Samburu East, and consisted of interviews, focus group discussions, and participatory observation. Findings show that livestock mobility involves longer periods and more complex distances due to a shrinking resource base and new rules of access. Although access was previously generated based on the value of reciprocity, the creation of new forms of resource management results in conditional processes of inclusion and exclusion. Policy and project implementation has historically been driven by the imperative to secure land tenure and improve pasture in bounded areas. Opportunities to support institutions that promote mobility have been given insufficient attention.
\end{abstract}

Keywords: communal grazing regulations; pastoral mobility; boundaries; Samburu pastoralists; Kenya

\section{Introduction}

African rangelands, also referred to as drylands or arid and semi-arid lands (ASALs), cover about two-thirds of sub-Saharan Africa [1] and are characterized by unpredictable rainfall and variations in vegetation growth leading to highly dynamic environments [2-4]. In these rangelands, pastoral mobility is seen as the most effective strategy to sustain both pastoralism as a livelihood and rangeland environments [5-7]. In northern Kenya, rangelands are mainly grass-growing savannah ecosystems which constantly co-evolve with mobile livestock herding, predominantly based on cattle, but increasingly also goats, sheep, and camels $[8,9]$. Pastoralists move around with livestock herds in search of water and pasture. Such pastoral mobility is carefully planned in order to make optimal use of the variation of resources in time and space. Rainfall and the ensuing quantity and distribution of grasses are important factors in determining how livestock mobility occurs. In addition to ecological factors, socio-political access to and control over territories are involved in the decision-making process. Hence, pastoralists optimize differing factors-the changing environment, the needs of different resource users, and social, cultural, and political constraints-to access pastures while managing conflict, a process which is supported by flexible and reciprocal social arrangements $[5,6,10,11]$.

However, the context of pastoral mobility in northern Kenya has changed radically over time, not least during the last two decades. Rangeland fragmentation, boundary formation, climate change, 
violent conflict, and rangeland degradation, as well as political marginalization and forced settlement schemes create resources and mobility constraints for pastoralists who are increasingly dependent on livestock mobility [12-19]. Rangeland-enclosing processes are becoming more common [20-24] while farmer-herder conflicts are increasing [25,26]. Additionally, conservation and large-scale infrastructural developments to modernize pastoral areas create significant obstacles for the continuation of mobile pastoralism while adding to the dynamic of further fragmentation, marginalization, and conflict [27-29].

In a growing number of African states, a recent shift in policy and legislation to formally recognize and support pastoral mobility has taken place, particularly in West Africa, but also in Kenya [30,31]. This 'mobility paradigm', importantly, breaks significantly with common views about pastoralists as destroyers of the environment who are responsible for widespread rangeland degradation through overstocking, overgrazing, and overpopulation [32-37]. Former policies aimed to settle pastoralists and to provide support for the improvement of rangelands [7], if there was any policy at all [38].

For Kenya, current policies for the improvement of pastoralist livelihoods in the ASALs mainly focus on the 'stabilization and development' of northern Kenya, where development is not only of benefit to the pastoralists, but also for Kenya as a state. More specifically, in the 'National Policy for the Sustainable Development of Northern Kenya and other Arid Lands', the ASALs are recognized for their specific characteristics regarding mobile livelihoods and hence the need to develop governance and services that target mobile populations [31]. At the same time, in the 'Vision 2030 Development Strategy for Northern Kenya and other Arid Lands', the ASALs are mainly seen for their importance to national policy and planning, in order to make use of their 'untapped potential' concerning trade, tourism, and energy [27]. Furthermore, Vision 2030 promotes the inclusion of pastoralists in national development as a way to curtail the continuous marginalization of pastoral areas and to make the ASALs 'equal to the rest of Kenya' [31,39]. Additionally, the new 2010 Constitution, and the Community Land Act (2016) — where pastoralists' livelihoods are perceived as valuable and in need of formalized and documented rights to their land-all mark a shift in thinking about pastoral land use and promote the use of customary institutions for managing resources and (cross-border) mobility [27,40].

Although pastoral mobility has gained recognition in policy and legislation, it has lacked support in its implementation [6,31], and hardships and struggles to access resources are still part of daily practice in the drylands within the context of rapidly changing socio-economical and climatic conditions shaping and negatively affecting livelihoods of pastoralists [12,14,41]. Therefore, it is important to recognize current patterns of constructing livelihoods by pastoralists and draw important lessons from local struggles and opportunities $[8,11,42-44]$.

This paper focuses on the Samburu management of grazing areas, pastoral mobility, and grazing access amid shifting socio-ecological conditions in the lowlands of Samburu County. In Samburu County, pasture availability is decreasing and the need for long-distance pastoral mobility is increasing. To date, however, limited research has been carried out on how Samburu pastoralists move with their livestock within this complex landscape. Research at the intersection of Samburu culture, ecology, and biology was carried out extensively in the 1970s and 1980s [45-48]. Later work comprehensively describes Samburu livelihoods and coping strategies during droughts [49,50], followed by extensive anthropological work on Samburu culture, gender, and sexuality, among other topics [51,52]. Furthermore, significant research on pastoralists in Samburu County has been directed towards pastoralist sedentarization, land privatization, and economic diversification with a strong focus on institutions of resource governance $[21,53,54]$, whereas little research has focused on pastoral mobility [55]. Southern Kenya, on the other hand, has been the subject of a number of studies on pastoral mobility $[5,56,57]$.

The aim of this paper was to examine shifting relations between Samburu pastoralists, the land, and the resources (which are variable over space and time) by looking closely at patterns of mobility and institutions governing resource access in a semi-nomadic setting [58]. To achieve this, I did fieldwork in Samburu, Isiolo, and Laikipia, Kenya, for a total period of 12 months conducting interviews, group 
discussions, and participatory observation. I explored how Samburu pastoralists gain and maintain access to natural resources through grazing management and access negotiations as part of governing mobility and grazing within a shrinking resource base. In addition to an understanding of how current pastoral mobility among Samburu pastoralists is governed using concepts of mobility, access, and institutions, this approach provides a deeper understanding of shifting engagements with space by focusing on new sets of relations that emerge in the processes of gaining and controlling access to resources [15,58-60]. This paper is organized as follows: Section 2 provides theoretical background of the study. In Section 3 I explain the methods used and introduce the research area. In Section 4 I present the results, focusing on shifting access relations and mobility patterns within the study area. The discussion and conclusions ensue in Sections 5 and 6, respectively.

\section{Mobility, Access, and Institutions}

In northern Kenya, pastoral systems are inherently flexible, enabling families and households to make effective use of constantly shifting resources. In this paper, livestock mobility, movement, and migration are used interchangeably to refer to the movement of (segments of) households with livestock, including cattle, goats, sheep, and camels—often with the assistance of donkeys-in search of water and pasture [61]. Mobile pastoralism can be ordered in various forms, from daily circular movements around a homestead, here referred to as short-distance mobility, to large-scale movements, and combinations of these $[6,46]$. The distance and frequency of such movements depend on multiple factors and are highly place-specific. In this paper I draw specific attention to long-distance cattle herding. Such livestock mobility is energy-costly for the livestock, as well as the herders, resulting in a declining ability to move for longer distances as a drought proceeds. At times, herds are split into separate herds to release the pressure on the herder, although this depends, among other things, on the availability of herding labour. Furthermore, in a pastoral society where resources are unpredictable and fluctuating, access consists of social relations constituted across the landscape. Mobility over long distances means that herders need to have a strong and wide social network of connections to share information and to access pastures and water points maintained by other communities [7].

Pastoral mobility, then, is not only an ecological endeavour, but social and relational as well $[7,15,62-64]$. In order to access these resources, social connections are formed to gain and maintain such access. Access to resources over a communally managed area must be negotiated and is managed according to certain regulations [5]. Here, access to resources is defined as "the ability to benefit from things" [60] (p. 153), mutually and continuously constituted out of processes and relations between people and nature. Within a socio-political landscape, access claims are subject to processes of, and relations to, power and authority, as well as rules and regulations, that, combined, govern access and control over specific resources $[5,59,64,65]$.

Objects of access for (semi)nomadic pastoralists can vary between paths and sites, which can be anywhere within a landscape [7,62]. More specifically, tenure rules and regulations exist around water points and specific vegetation as opposed to a grounded surface, or land:

Thus when it turns out [ ... ] that a clan holds a cluster of sites, we do not have to suppose that this follows from their inclusion within a bounded area, which for some strange reason is not recognized by the people themselves. On the contrary, the surrounding country is held by virtue of its inclusion, in some sense, within the sites themselves. Land does not contain sites; rather, the sites contain the land [62] (p. 156)

This distinction between access regulations existing around objects existing and/or growing on the land, and the land itself, is highly relevant for understanding the multiple ways in which access is gained, maintained, and controlled in semi-nomadic pastoral societies where resources are patchily distributed $[64,65]$. Access and control of resources, then, is managed through the formation of social boundaries, to which members of a specific (sub-)group or entire community belong [65]. Being part of that community does not imply that one has the right to exclude others; 
however, it gives one the right to take part in decisions on resource conservation, regulation, and allocation $[37,66]$. Hence, these home-areas and their boundaries are relationally produced. To secure access to localized resources, access relations are also produced 'on the road' $[10,62,63,65,67]$. This, then, makes pastoralists perform an 'open engagement with space' [15] mainly based on 'relations, movements, and flows' [24], articulated through institutions. These institutions become the mediator between people and resources, and play a major role in defining the distribution of, and access to, resources $[68,69]$. It is important to note that often one can speak of an ideology of reciprocity, meaning that conditional access to resources in a home-area to members of one's wider social group is rarely refused [5,7,70]. Furthermore, governing mobility is mutually constitutive of the governance of grazing [7]. In addition to rules and regulations, or institutions, to manage and control access 'on the road', pastoralists traditionally produce spaces for the management and control of resources 'at home' $[5,65]$. Hence, in order to understand the institutions at work for access 'on the road', one has to understand the institutions in the home-areas as well.

\section{Methods and Context}

\subsection{Approach}

Fieldwork for this study was conducted in 2015 and partly in 2016 and 2017 in Samburu, Isiolo, and Laikipia. I spent a total period of 12 months in six sites along the mobility route of Samburu pastoralists within the Ewaso Nyiro (north) river basin [71-73]. For this paper, I held semi-structured in-depth interviews with Samburu pastoralists, including 17 women, 31 men, and 22 lmurrani ${ }^{1}$. I interviewed elder men (from here referred to as 'elders', a category of local authority that consists of men above the age of 45) and women mainly at their homesteads ${ }^{2}$ to focus on narratives of change based on life-time memories, with a strong focus on the past 60 years of landscape changes and governmental interventions $[44,74,75]$. I also interviewed lmurrani who were moving with cattle herds in order to understand their movements across the landscape [76]. In total I conducted 70 interviews. Interviews were supported by four focus group discussions (FGD), one with women and one with elders in two sites, and participatory observation to obtain a detailed understanding of the landscape and daily interactions [44,77]. Furthermore, besides pastoralists, I also interviewed 20 key informants from governments and NGOs. Interviews in Samburu and Swahili were translated in situ by an experienced research assistant from the community, fluent in Samburu and English, of which a part were recorded with consent and transcribed at a later stage. Data was analysed, during and after fieldwork, through a manual coding system to categorize according to identified topics. This paper focuses on Sesia, although research did not confine itself to Sesia only, as I 'went along' with people and joined them on daily trips with their livestock, or met with them at places where they were setting up their temporary camps (lale), or at markets and meetings.

\subsection{Study Area}

The wider Ewaso ecosystem is part of the intersection between Samburu, Laikipia, and Isiolo Counties, connected by the Ewaso Nyiro (north) river flowing from south to northeast (Figure 1). This paper focuses on people from Samburu County, more specifically the area the Samburu refer to as the 'red lowlands', where Sesia is also located. Still, as the Samburu are semi-nomadic, mainly living within the arid and semi-arid area of Samburu, Isiolo, and Laikipia Counties in central-northern Kenya, they access resources at distant places within the wider region. Samburu County is administratively divided into three constituencies: Samburu East, North, and Central. Sesia is located in the Samburu

1 An lmurran [pl. Imurrani] is a circumcised and unmarried Samburu youth, of the age-grade between boyhood and junior elderhood, who is responsible for cattle herding and long distance migrations with livestock.

2 In Samburu, nkang' [pl. nkang'itie] refers to home, homestead or settlement. The $n k a n g^{\prime}$ often consists of various households. 
East constituency, and refers both to the Sesia sub-location and the Sesia group ranch. Sesia is part of the Meibae Conservancy.

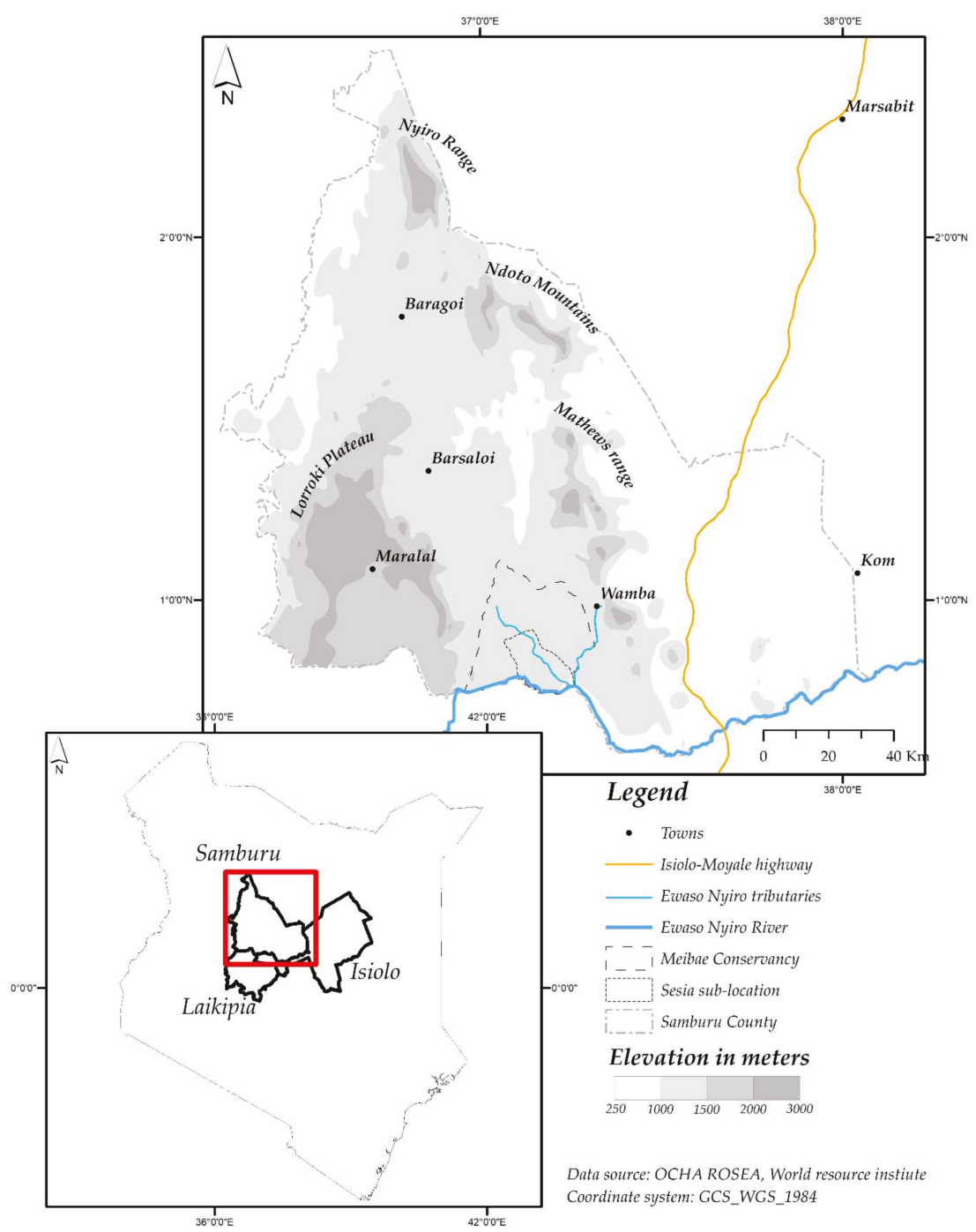

Figure 1. Sesia in Samburu, Kenya.

The Samburu population was approximately 223,947 in 2009, $12 \%$ up from 2006, with a population density of 11 inhabitants per $\mathrm{km}^{2}$ [78]. The Samburu communities are heterogeneous and diverse. Social distinctions among the Samburu are formed around gender, age, clan, sub-clan, location of residence (highlands or lowlands), level of education, and economic position, among other factors [51,79-81]. These social distinctions have different meanings over time and shape the way individuals and groups respond to socio-political and environmental changes and the way they use natural resources [82-84]. Pastoralism is the main economic activity, with cattle, sheep, goats, and camels being the most important livestock. Herding is increasingly diversified on the Lorroki Plateau, 
specifically into rain-fed maize cropping, petty trade, livestock marketing, and tourism. Samburu living outside of these counties are often engaged in livelihood activities other than pastoralism, while sending remittances back home $[21,82,85,86]$.

Samburu County is approximately $21,000 \mathrm{~km}^{2}$, and is part of Rift Valley Province [78]. Marsabit is to the north-east, Turkana to the north-west, Baringo to the west, and Isiolo to the east. The Ewaso Nyiro River comprises the main southern boundary of Samburu, with Laikipia County finalizing the boundary to the south-east. Samburu County can be roughly divided into the highlands (ldonyo), with a general altitude of $1500 \mathrm{~m}$, including the Lorroki Plateau, and the lowland plains (lpurkel), with an altitude ranging between $1140 \mathrm{~m}$ and $1500 \mathrm{~m}$. The lowlands can be characterized by four different zones: the escarpment zone to the western edge of Samburu County; the mountain ranges at the eastern parts of the district, including the Nyiro Range (2709 m), the Ndoto Mountains (2595 m), and the Mathews Range (2337 m); the central plains, including the Lbarta Plains (Baragoi), the Swari Plains (Barsaloi), and lpurkel onyieki (red lowlands, named after the red desert soils southwest of Wamba); and lpurkel oibor (white lowlands, named after the white stony soil to the east of the Mathews Range), where elevation drops to $900 \mathrm{~m}$. The soils all over the lowlands are very poor, and fertile soils are found on Lorroki and the mountain ranges [46].

Generally, the highlands are cold and wet, with an annual rainfall of $1200 \mathrm{~mm}$, while the lowlands are hot and dry with precipitation averaging between $600 \mathrm{~mm}$ and $200 \mathrm{~mm}$. The highlands generally receive more rainfall because of the long rains (Ln'ger erwa) and the short rains (Lorikine and Ltumurin), in addition to several showers (Table 1). The lowlands, however, do not receive Lorikine and the dry season (Lamei Odo, or 'long hunger') is longer than in the highlands. The rainfall pattern is typified as tri-modal.

Table 1. Rainfall peaks in the lowlands and highlands of Samburu.

\begin{tabular}{lccccc}
\hline Season & $\begin{array}{c}\text { Ln'ger Erwa } \\
\text { (Long Rains) }\end{array}$ & $\begin{array}{c}\text { Lorikine } \\
\text { (Short Rains) }\end{array}$ & $\begin{array}{c}\text { Lamei Lo'odo } \\
\text { (Dry Season) }\end{array}$ & $\begin{array}{c}\text { Ltumurin } \\
\text { (Short Rains) }\end{array}$ & $\begin{array}{c}\text { Lamei Ndorop } \\
\text { (Dry Season) }\end{array}$ \\
\hline $\begin{array}{c}\text { Lowlands } \\
\text { (lpurkel) }\end{array}$ & April-May & - & June-October & October-December & January-March \\
\hline $\begin{array}{c}\text { Highlands } \\
\text { (ldonyo) }\end{array}$ & April-May & July-August & September-October + Showers ${ }^{1}$ & October-December & January-March + Showers \\
\hline $\begin{array}{l}\text { 1 Occasional showers (Nkokwai (June) Rurume (January), Somson Oibor (February), and Somson Orok (March)) are } \\
\text { more likely to fall on ldonyo. }\end{array}$ & &
\end{tabular}

The highly-localized rainfall based on geographical and topographical locations results in micro-climates $[45,46]$. Furthermore, although erratic, a shift in rainfall has been observed over the past decade, with almost a complete loss of the short showers in the highlands and the lowlands ${ }^{3}$ [18].

Samburu living in the lowlands move within and beyond the area in order to profit from the topographically complex, but valuable, variation in climatic conditions and vegetation growth within this large area. Consecutive prolonged droughts in 1960, 1965, 1971 [46], and 1980, 1984, 1995, 2005, 2006, 2009, and 2011-2015 (a multiyear period of drought) ${ }^{4}$, impacted the amount of water and vegetation growth, and led to the loss of livestock. The droughts often last long, specifically in the lowlands, where rainfall is highly erratic and unreliable.

According to various studies and publications on historical vegetation in Samburu, the lowlands used to be a grass-dominated savannah with patches of woody vegetation, including dwarf bushes and shrubs, with the important Ltepes (Acacia tortilis) as dominant dryland tree mainly found along seasonal rivers $[16,46,48]$. In the hills and mountain ranges with higher rainfall within the lowlands, dense forests were-and still are-found, offering forage for livestock in times of drought ${ }^{5}$. Nowadays, the

\footnotetext{
Interview informant 3 and interview informant 13

FGD Sesia, 12-13 October 2017.

Interview informant 14 and interview informant 9
} 
lowlands are mainly covered with woody vegetation and annual grasses, suggesting land degradation. These woody trees and shrubs are green for longer periods of time compared to annual grasses, which only grow during the rainy seasons [87]. An increase in the Acacia reficiens has been detected, a species which is considered to curtail the regeneration of grasses and other valuable vegetation. Furthermore, after long periods of drought, surface runoff is common when rainfall on bare ground takes away fertile soil and stored seeds, leading to the formation of gullies, as well as the reduction of grasses and an increase in bushes and shrubs $[16,46]$.

There is only one permanent river in the County, the Ewaso $\mathrm{Nyiro}^{6}$, while many small rivers and streams carry surface flow for only a few weeks each year (if not less). Smaller streams carry water after flash floods. The waterbeds of these seasonal rivers and streams hold saline water, which provides important minerals for livestock, and are accessible through wells dug by hand in the sand in the riverbeds. The river and wells form the major source of water for the people in the lowlands. Additionally, sand dams fill up with rainfall water for short periods of time. Boreholes are another source of water, funded by the local government or missionaries ${ }^{7}$.

\section{Grazing in Samburu}

\subsection{Historical Grazing and Mobility: Reciprocal Relations, Communal Grazing, and Restrictions}

In the past, and for the most part to date, mobility has been central in the lives of Samburu. Before colonial intervention in Samburu, Samburu pastoralists would regulate pastoral resources under communal tenure among members of the wider Samburu community, allowing access to different areas depending on rainfall and vegetation within Samburu territory. Entire families would move with their herds in groups. As one woman remembered:

"The home was moving bit by bit, to Loroshi, then to Ndigirr, then to Ngorungoru, then Matakweni, then to Ndigirr again, back to Matakwani, then to Sordo, then to Sarara, then to Sordo again, to Seramiti, Ndigirr, Nuash, Ndigirr again. There I gave birth to the first born and back to Seramiti where I gave birth to the second born. Then to Ndigirr, to Nanguarak, then there was a conflict with the Somali so I left to Ngankare. From that mijoni [abandoned homestead where there are still some structures standing], to that mijoni to that mijoni up here where we are now. Move, move, move. We were almost all over this area!" (Interview informant 21)

Herd mobility took place on a regular but gradual basis; during the rainy season or in areas where pastures were abundant, the elders set certain areas aside for either settlement or grazing. Following a system called enata nkop (restricted land), a specific area was restricted during the wet season in order to be grazed upon when the drought had set in. Only after the pasture inside the restricted area was gone would families continue to move again. One elder recalled:

"People restricting grazing areas was originally there even before the colonial government. People used to set aside a portion of land for grazing during the dry season. This was happening before the introduction of schemes and after. ( . . . ) It was referred as enata nkop" (Interview informant 2)

In addition to enata nkop, through interviews I was also introduced to the system of lokere. Although later I will discuss the lokere as it is used currently, the lokere before colonial intervention was a communal institution where the sick, weak, and young animals from various families could be placed together. The difference between enata nkop and lokere was not always clear and the terms

6 Although lately showing signs of seasonality: in 2015, the river was observed dry for the first time in living memory.

7 Interview informant 17. 
were sometimes used interchangeably, though the lokere was more often identified as a fenced area. The lokere would be created at any place of settlement, as families were moving together. As an elder recounted:

"[T]he elders were cooperating; they were planning for grazing and settlement. In groups they would move on while grazing specific sites-moving step by step as they graze." (Interview informant 20)

Despite various forms of customary resource management, pastoralists were discursively construed as inferior and unable to manage and use such vast areas of land in an efficient and productive way [32,36], and colonial control over the Samburu people and their territory was mediated through grazing management and stock control to recover lands that were perceived by the colonial administration as 'devastated by over-grazing'. Strict destocking policies and grazing schemes were initiated $[21,45,46]$. The grazing schemes, initiated in 1936 in Lorroki and throughout the entire Samburu District in the 1950s, through various forms of grazing and stock control, became a highly contested and controversial issue between the colonial administrators and Samburu pastoralists. Areas with high-quality pasture and rainfall were demarcated within the bounded areas of the grazing schemes, which were subdivided into paddocks for rotational grazing, and where a quota of cattle was established to limit herd sizes. Other measures carried out by the colonial administration besides controlling grazing included fierce destocking policies and obligatory off-selling of livestock $[21,36,45,46]$. Each household was allowed a restricted number of animals, which had to graze within pre-defined areas at specific times of the year ${ }^{8}$. In 1960, 31.5\% of the entire Samburu District was under the control of grazing schemes, including the forest areas on the hillsides where grazing was forbidden. The general trend was an increase in livestock numbers outside of the schemes, in the more arid and uncontrolled areas. Dissatisfaction with the fierce destocking and grazing policies grew, and circumvention of the grazing regulations became a form of opposition. Resistance against grazing control became a strong disadvantage to the colonial administration, and after a serious drought, the grazing schemes were abandoned in $1961[36,45,88]$.

One elder, in describing the period after the abolition of the grazing schemes in Sesia, explained how the grazing schemes marked the separation between the lmurran and the family and, likewise, the start of sedentarization:

"When Lkishili was circumcised, schemes disappeared and we came to settle here. That was the time that the cattle started to move to mountains and other places, and children to stay with the women. This is how we slowly got into settlement; because if you were an elder before, you would go around with your animals, but now you would only let the lmurrani go. The schemes had made lmurrani to leave." [Interview informant 23]

In the years following independence, the new government did not interfere with grazing management and strategies in Samburu, neither in the lowlands nor the highlands. People could move freely over the landscape again and there were no restrictions on the number of livestock owned by individuals. Another elder informed me:

“Then we didn't follow any restrictions [regarding grazing]. It was time for Lkishili circumcision, so everybody went to his clan and didn't follow any plan. Just we settled with the clan. Immediately after the schemes ended, it rained El Niño and it was as if everywhere there was a [grazing scheme]. We had a lot of grass and rain so there was no need for restrictions or anything." (Interview informant 24)

This open engagement with space in which livestock movement occurred would still follow rules of sharing and reciprocity, though without significant restrictions for specified areas in the landscape.

8 Interview informant 15. 
After the rains stopped, however, mobility and Samburu grazing management institutions were quickly retained. Between 1961 and 1965, elders in Samburu lowlands decided to start managing settlement and grazing again through the customary communal regulation called nkwe ngishu ('head of a cow', keeping grass for cattle). One elder recounted:

"Then it was the plan of god to not give us rain. It is the plan of god to have the land the way it is now. Since then, we have started planning to settle in one area and leave another area for grazing, nkwe ngishu. So we can hold animals at home for some longer time." (Interview informant 24)

An nkwe ngishu area does not entail restricted grazing, as is the case with enata nkop, but restricted settlement; it is the area where one can bring their livestock (specifically cattle) for grazing, especially on the high-quality grazing sites. Hence, nkwe ngishu, as still in use at the time of writing, is mainly a strategy to control the construction of homesteads, since settlement is not permitted in an area designated as nkwe ngishu. The nkwe ngishu area can shift over time, hence, it is not static in space. Another elder also said:

"Before and up to now, when it rains, there is a line where behind people are not supposed to settle, and another side where they are not supposed to graze with livestock. Such a line can be a river between the settlement and the grazing area. And grazing and settlement is divided." (Interview informant 8)

Thus nkwe ngishu, as an arrangement, is a term used to designate an area for cattle grazing in any place one happens to be. Although nkwe ngishu is mainly based on customary rules of resource allocation, it was also mentioned to be motivated by the colonial grazing schemes where settlement and grazing were strictly divided.

An elder explained to me that with time, however, it became harder to restrict settlement, and restrictions increasingly focused on grazing again, instead of on settlements:

"So everyone now started to settle here and there and everywhere, and the land started to deteriorate." (Interview informant 9)

In order to deal with increased sedentarization and declining resources, the Samburu, during the Lkororo age-set (initiated in 1977-1978), started to initiate the $m p a k a^{9}$, as based on the previously existing enata nkop, implying an area restricted for grazing. The mpaka was meant to reduce conflict occurring during cattle movements by making it possible for the cattle to be kept at home for longer periods of time. The mpaka system, as opposed to nkwe ngishu, is less flexible in space and refers to a restricted designated area. The designated area is restricted during the wet season for grasses to grow, to be grazed by cattle after the rains. Settling is not permitted in the mpaka, and livestock are only allowed once the elders have opened the mpaka for the community. Hence, mpaka is associated with strict boundaries and boundary control. There are diverging understandings of how the mpaka came to be. Although the term mpaka is the Swahili word for 'border', according to various informants, mpaka is derived from the English 'park' and has been given that name by the Samburu to relate to the national parks ${ }^{10}$, as they are known to be restricted areas where livestock cannot enter. One elder clarified:

"It was referred as enata nkop, meaning restricted area of which nowadays we call mpaka. This name mpaka originates from the Samburu National Reserve which was a restricted park. After the skimi [grazing schemes] we decided also to restrict these areas following the idea of colonial government as we have seen it was a good management of land." (Interview informant 2)

9 FGD Lekiji elders, 13 October 2017

10 National parks are areas solely allocated by the government for wildlife conservation and management; human settlement is not allowed. 
As described, customary institutions from enata nkop —an area restricted in order to be grazed upon when the drought set in —and lokere—an area set aside especially for small and weak stock—gradually towards institutions as nkwe ngishu-restricting homestead formation in a specific area-and mpaka - a fixed, restricted area-that were more suitable to manage and deal with increasingly sedentary lifestyles.

\subsection{Post-Independence: Group Ranches and Conservancies}

At the same time the Samburu strengthened their customary institutions, the postcolonial government of Kenya introduced group ranches. The Kenyan government continued to view northern Kenya as an unproductive and particularly conflict-prone area over which the nation state had no control [89]. In 1972, under the Land (Group Representatives) Act of 1968, the Group Representative Officer started to demarcate land on Lorroki and in Baragoi Division for both individual and group ranches as a way to formalize land tenure. Group ranches are similar to grazing schemes in that they are a demarcated pasture area with the aim of controlling grazing, encouraging settlement, and commercializing livestock. Officially, group ranch management, control, and ownership are community-based instead of externally-owned and enforced. They were meant to link people to a specific area of land through the concept of membership, which would increase the sense of ownership and responsibility for the land. Similarly, through group ranches, land degradation could be controlled, decreasing the need for mobile pastoralism $[21,88,90,91]$.

The Sesia group ranch was initiated in 1976. I was repeatedly told that pastoralists initially did not like these boundary demarcations. As an elder told me:

"When the group ranch started, Lkishili [age-set] were lmurrani, only people from ldonyo [highlands] accepted them. We at lpurkel [lowlands] did not like it at all. We did not even like the introduction of the location [administrative boundaries]." (Interview informant 1)

Resistance against the introduction of group ranches took place by refusing to register as members. However, this did not lead to the rejection of this form of communal tenure, as a small group of elders did register, and so the Sesia group ranch came to exist. Two elders and one woman told me very clearly why they disliked the idea of a group ranch:

“When the group ranch started, many people really didn't like it because they thought land was to be taken away. Where would we graze the cow now? At the time, only five people were registered. Other people thought that one was signing for selling the land away." (Interview informant 24)

"It was believed that they participated in land division into group ranches after the white government left. During the introduction of Sesia group ranch, I remember people being called for membership registration but no one wanted to participate; luckily the secretaries and land officers managed to gather only ten people who represented Sesia group ranch." (Interview informant 2)

“In that time, people really refused. People didn't want even to know or hear about what this group ranch is. During that time we were not people who had gone to school, we didn't know people who had gone to school. So we did not know what is going on, so we didn't want it. We thought, this is the idea of the Kikuyu people who are coming to divide this land. Samburu people started to circulate the rumour that land will be divided, a portion to each individual, and only five cows were to be placed inside! Nobody wanted that." (Interview informant 22)

Hence, in 1976 only 37 people were registered as members of the Sesia group ranch, as they did not trust that the group ranch would be of benefit to them. Furthermore, as entire families were fully nomadic during the time of implementation, or have since migrated due to conflict, many Samburu 
pastoralists are registered in one group ranch while living in another. As a result, many residents of the Sesia group ranch are not members of the Sesia group ranch; they have moved over time towards these areas, but at the time of the group ranch introduction they were residing in Baragoi. One elder explained:

"We are members of Marti group ranch; it is our fathers' land because it is our fathers that are registered. Nobody lives there now because of the Turkana conflict, but we are still members there. We are not members here in Sesia and we are not sure if we will become members. ( ... ) Most people here are not registered as members but we have been in these areas for so long and we only wait for the registration to be announced and we go and register." (Interview informant 3)

Additionally, half a century later, after the establishment of group ranches in the Samburu lowlands, everyone is not yet a member of a group ranch and registration lists are incomplete. Since the initiation of the Sesia group ranch, the register only opened once more in 1994 when an additional 368 new members were registered. Since then, the registration book has stayed closed, even though more people want to become members. Over time, people gained more interest in it and saw benefits of being a member of a group ranch.

"We now understand about group ranches and we want everyone who is originally from this place to attain membership as we have known this is our own land and we have rights over it" (Interview informant 2)

In addition to the ability to claim ownership over land through group ranch membership, and the willingness to secure this ownership for future generations, other benefits of group ranches mentioned were the opportunity to gain a share in benefits when land within the group ranch is used for certain investments, such as a hotel, a lodge, or rented out for other projects, or to obtain compensation for construction works occurring within the group ranch. Some informants also mentioned how the acceptance of group ranches in the highlands made people in the lowlands also accept the group ranches.

In addition to local resistance against, and the process of delays in relation to, the instalment of certain group ranches, 17 of the 48 group ranches in Samburu have neither been approved nor received final adjudication by either the County Government or the District Government ${ }^{11}$, including Sesia. Partly as a result of this unfinished process, but also partly due to unfavourable weather conditions, among other factors, subdivision of group ranches has not taken place in the Samburu lowlands, as opposed to the developments that took place in the Samburu highlands [21] and in southern Kenya [92]. Although the process of final adjudication of group ranches will continue, the Community Land Act of 2016 might lift the process of finalization to the incomplete adjudication and registration of group ranches in Samburu [40]. This process, however, had not yet been set into motion during my stay.

Although, initially, the group ranches were not desired, their membership and boundary demarcation have gradually become of importance to the Samburu in the lowlands. However, it was not until the initiation of conservancies that the Sesia group ranch and its boundaries gained real importance in the lives of the people. Community conservancies are the newest form of natural resource governance in the region. A community conservancy is a demarcated area on community land introduced to stimulate nature and wildlife conservation with a key role for the local community. Conservancies are intended to improve local livelihoods, economic development, and peace through tourism and management and control of grazing in Samburu, among others, and are supported by the Northern Rangelands Trust (NRT) and Samburu County Government, who try to link the community with a private investor to assist with the start-up of a lodge, for example. These conservancies are

11 Interview informant 18. 
composed of one group ranch, or a conglomeration. Lekiji, for instance, which is located in the Sesia sub-location and is on the Sesia group ranch, and is part of the Meibae Conservancy, together with three other group ranches. As many women and elders told me, it was not until the demarcation of the conservancy boundaries that the exact location of the group ranch boundaries became clear. Hence, the conservancies brought the group ranch boundaries to life, bringing in a new form of spatial organization and related (promised) benefits, such as employment, profit sharing, bursaries, and improved grazing management.

\subsection{Current Grazing Institutions in Sesia: Enclosing Space}

Currently, in Sesia, land and grazing resources are managed and controlled following the rules and regulations of the customary institutions, the Sesia group ranch and the Meibae conservancy combined. Sesia consists of various small permanent towns, a gathering of various single and aggregated homesteads that, combined, form a neighbourhood, and in some cases with a school and a shop. One of these small towns is Lekiji. The communities within Lekiji decided over the use and management of resources together with another neighbourhood, Lkalkaloi. Samburu from Lekiji have a clear concept of their home-area. This home-area is not necessarily a fixed place, nor is it clearly defined by hard boundaries; it mainly relates to where one's family resides and where important ceremonies have taken place. These home-areas are made up of important points, specifically water, but also grazing points, which are tied to people living there and who have prior access and decision-making power over the area. As a woman told me:

"This is our place, nkop'ang [our land], you can go and graze together; it is open. I am from here, so here I don't have to negotiate [to access grazing]." (Interview informant 5)

Since the life of Samburu pastoralists in Sesia is organized in long-term settlements, the mpaka is effectively used in Lekiji. The community living in the wider Lekiji area is allowed to herd livestock in the mpaka once the elders have opened it. The mpaka is monitored by elders from the two villages, Lekiji and Lkalkaloi, and those caught grazing their cattle before the season has opened are chased out and have to pay a fine of three goats. Monitoring occurs to discourage livestock herding by members of the community, but also by other communities who cross the Ewaso Nyiro from Isiolo County when the water level is low or when the river is completely dry, as was the case in 2015. Members from other communities also have to pay a fine when they herd livestock in a closed mpaka. Currently, the term mpaka is also used to refer to the core conservation zone of the conservancy since, as in the case of the Meibae Conservancy, the same mpaka area has now become the core zone. In the Meibae Conservancy, where no tourism facility is constructed, the core conservation zone has the same function as the original mpaka: to restrict grazing in the area until the elders open it during the dry season.

Mpaka, nkwe ngishu, and the conservancy are institutions at a community level. Outsiders, then, will have to ask the authorities of Lekiji and Lkalkaloi for permission to set up a temporary livestock camp (lale) for livestock to graze and use water within that area. At the household level, there are two ways in which forage is managed: through the system of lokere, as introduced previously, and by the organization of the use of sagaram. The lokere is an area restricted through demarcation of branches by the thorny acacia bush. A lokere is nowadays constructed at the homestead level and only the livestock of that specific homestead are allowed to use the lokere, as opposed to prior to the grazing schemes, when the lokere was used communally. A lokere can be useful, specifically in the case of a shortage of herders to take care of the weaker animals, as its purpose is to enable the lkilepo (milking) herd, together with sick and young or old livestock (mostly cattle), to access grazing in the lokere. Therefore, the lokere is sometimes referred to as 'the hospital', as it is mainly for the young, old, and sick who cannot cross large distances to either recover or gain strength until the rains return. Previously, the lokere was also used for the maintenance of the weak stock. An elder remembered: 
"Lokere was also not preferred in the past since people believed that he who has a lokere must have a sick cow, a sick goat, or his cows would have broken limbs. It's like an open grave that desires something to be inside." (Interview informant 2)

However, conflicts tend to arise involving the lokere. I was told that when, for example, children herded goats and sheep, it often happened that these would enter a lokere and start grazing inside. This often created tensions between the owner of the lokere and the owner of the herd. Even more people started creating larger lokere, which restricted livestock movements and grazing patterns of other homesteads. Since 1996, in Lekiji and in wider Sesia, in order to avoid such conflicts, the lokere was abolished. There are places, however, where the use of a lokere is still allowed, for example, around towns where access to grazing is increasingly difficult. Even the lokere, just like mpaka and nkwe ngishu, is occasionally compared to the colonial grazing schemes. An elder told me:

"Are you seeing some green trees down there (pointing to near his homestead), on the 14 of March 1977, I started restricting that area. That is my lokere. Because I saw that during the schemes, this land was so good. And then I decided to preserve also this small side for my own benefit." (Interview informant 9)

Another way in which residents of Lekiji manage forage for their livestock is through controlling access to sagaram. Sagaram is a seed-pod from the Acacia tortilis, or Ltepes, a common and highly important tree in Samburu East. The acacia grows mainly along (seasonal) water streams and, hence cannot be found everywhere. The sagaram has always been an important kind of fodder-especially for goats and sheep-and, according to the informants, gained special protection and strict regulations in times of severe drought ${ }^{12}$. Nowadays, these regulations are year-round and include a strict sagaram season that is opened by the elders who also regulate the mpaka season; a ban on shaking the tree (to avoid the premature release of seedpods); and a clear demarcation of which tree can be used by which family or community. For example, if an acacia is located near a homestead, the members of this homestead are entitled to use the seedpods from this tree. Furthermore, in Sesia, where seasonal water streams perform the role of a boundary between two clans, the acacias on one side of the river are only used by the people living on that side of the river, and vice versa. Sagaram can be taken out of the trees with a stick, pushing the seedpods out. I was told that the restrictions on sagaram are highly valued, and they are considered the example to follow for pasture management, too.

During the dry season, or when necessary, the resources of the mpaka, and sagaram trees are allowed to be used. Access can be obtained upon request, hence, there are no exclusive rights; rather, there are prior access rights and the right to manage and control. Within a home-area, the members within that social network are allowed to use these resources if they follow the rules. The rules are enforced by local elders, who have the authority to announce restricted areas or resources as 'open' or 'closed'. Furthermore, outsiders have to request access from these elders if they wish to make use of the same pastures or resources as the local residents do.

However, prolonged droughts make it much harder to manage and restrict grazing areas. As one of the elders informed me:

"I also think this prolonged drought is disorganising people as elders plan their programs during wet seasons when everyone is at home. It is now one and half years that our cows are not at home, the rains have been failing all the time, Lorikine fails, Ltumurin fails, and Ln'ger erwa fails. All of them fail and getting people together at home is hard as everybody is working harder for his or her livestock to survive drought." (Interview informant 2)

As can be seen, the previously 'more open' form of managing pasture for cattle, the nkwe ngishu, has been substituted by a stricter and 'closed' form, the less flexible and negotiable mpaka, where

12 FGD Sesia, 12-13 October 2017. 
boundaries and their enforcement play a stricter, more important role. The conversion of the mpaka into core conservancy zones with institutionalized rules or membership and clear boundaries, as well as ranger patrols, further enforces these boundaries. The communal abolition of the lokere is an important example of how restrictions can be reduced by engaging in a more 'open' way with space on communal basis, instead of enclosures on individual basis. Other forms of regulations to plan for sufficient grazing and forage for livestock are shifting as well, e.g., the restrictions on the sagaram that has become an increasingly important resource to be distributed equally when other nutritious vegetation is not available. With recurrent droughts and people being away from home often and for long periods because of prolonged droughts, the management of grazing is particularly challenging. Samburu from Lekiji find it difficult to implement grazing rules and regulations in the absence of any grass or people. Hence, during interviews, it became clear that their effective implementation only occurs during periods of rainfall, when people gather and plan the restriction of certain areas. Lack of rains, loss of vegetation, and an increase in consecutive and prolonged droughts have made the management of pasture difficult since planning can, and will, only occur after rain.

\subsection{Current Mobility and Access: Complex Distances and Conditional Provision of Access}

While people settle, livestock continues to move seasonally only with a section of the household, the Imurran. When the dry period sets in, the homestead will split the herd according to productivity and forage requirements. A herd composed of milking cows, young cows, and sick cows, together with the goats, sheep, camels, and donkeys, will stay at the homestead with the elders, women, and children, while the 'surplus' cattle herds will move with lmurrani to greener pastures. Hence, cattle will follow different patterns of migration following the lmurrani, who join in small groups to form a shared lale and organize their temporary homestead. They group with at least two to six lmurrani in order to share responsibilities and food. These groups shift over time and vary per year and location of migration. Only in extreme situations of drought will the women and elders move with the goats and sheep to lale in order to find available forage. Although this is rare, goat-lale-as adaptation to drought-has occurred increasingly since 2015, which demonstrates that it is becoming harder to find forage for goats near the homesteads. As a woman told me:

"Goat lale is something new. Very, very recent. Twenty to fifteen years ago, people who would go for goat lale would not go so far. But now, goat lale is very far, up to Kom people will go with their goats. Before, 15-20 years ago, they would go to find sagaram with the goats." (Interview informant 34)

Previously, the elders, who in principle are the herd-owners, were the main decision-makers on the movements of the cattle. Elders still have a say in the whereabouts of cattle, e.g., they may decide upon the movements and length of stay in certain places in order to regenerate grasses elsewhere. However, with the lmurrani being out with the cattle for most of the time, this has changed as well. As an elder clarified:

"Also in the past elders were very powerful compared to now. These days elders are less powerful, Imurrani are the one in charge of where to go and when to move with the cattle, they are conversant with the grazing areas as most of the time they are outside homes with the cattle. Elders, nowadays, we have strong power on conservancies that usually provides us with little grass which is not enough. (.. ) Lmurrani are the one in control of the movement of livestock due to them being away from home for most of the time with cattle and they are given the authority to move with them as they have been moving across all this areas and they understand places that can sustain them for long time." (Interview informant 2)

Similarly, with the lmurrani moving a lot they spend most of their time in lale. This was not usual. As an elder remembered of the time he was an lmurran: 
"When I was an lmurran, it was an adventure to go for lale. You would choose to go for lale only to fatten cows, to activate the bull, to go on adventure, to get medicines from the forest, to get more milk for the lmurrani only-we would take many lactating cows ourselves and leave four or five cows behind. When the drought was severe, people move with cattle to the mountain and hillsides. But this was sometimes dangerous, and then only the lmurrani would go up with the cattle to set up lale, while the rest of the family would stay behind. But then a lot of changes happened in the past 20 to 30 years. With this shortage of grass, lale becomes a force." (Interview informant 25)

There is a significant shift in the role lale plays in daily life of the lmurrani, but also for the cattle and the people that are at home. People repeatedly informed me that nowadays, the cattle and the Imurrani were away from home all the time, and that the cattle have become used to going for lale. The woman and elders mentioned that they had missed two separate occasions of calf birthing. The movements with cattle are challenging for the lmurrani, having to spend long periods of time away from home and accessing grazing in particularly precarious places.

Still, the movement of livestock is carefully planned for, and deliberate choices and alterations between accessing water and accessing pastures are made on a daily basis. Besides available pastures, water, and knowledge of the area, it is the social connections that exist or are created ahead of moving the herd that are often of decisive importance. In case the chosen route leads to an area where a Samburu community resides, an lmurran will go scouting for pastures (saa), which includes making arrangements with the local communities about accessing grazing and water resources. Typically, the lmurran who went scouting will discuss with the elders of that specific community where to set up the lale, as well as the rules on grazing and water use that are to be followed according to the regulations of that community (e.g., not to graze in the local mpaka, in the core zone of the conservancy when applicable, or in the lokere, to respect seasonal rules of sagaram). These negotiations are of high importance to avoid future disputes. Grazing is in principle only provided based on understandings of reciprocity. An elder explained:

"We do allow them to graze here freely as long as they adhere to our rules and regulations. This is because they will also allow us to graze in their [group ranches] too when we do not have pasture in ours. We have no restriction on grazing across group ranches, we freely graze everywhere. We allow people to have grass in our group ranch whenever we have enough grass." (Interview informant 2)

Additionally, the moving herders are supposed to set up a lale in specific designated areas where they do not obstruct routes to water points nor reside near existing homesteads to avoid contamination and spread of diseases. Furthermore, water points are to be shared accordingly. Depending on the type of water point, the moving herders can either dig their own well in the river bed or use the permanent water point available. In the case of the latter, clear arrangements are made regarding which day the moving herd can go to the water point, and which day the local community will use it instead. Finally, the visiting herds are allowed to stay for as long as there is grazing available. However, if water is limited, the lmurrani are not supposed to stay long in that specific place, as the residing community has precedence over water usage. This occasionally leads to being driven away. As an lmurran told me:

"There are many places in between where people are not settled-so these are grazing areas for many different communities. However, also, such as the grazing area of Naisunyai, the neighbouring community of Naisunyai, they have their own wells for water, and they do not share that with visiting communities. So you can only stay there for two days because of lack of water and then you have to move on. The same in Sera, where you cannot graze because of the rhino sanctuary, and you are pushed away and have to move on. So, along the way there are some pushing places that make us move faster to the dry season grazing areas in Kom, Marti and Laikipia." (Interview informant 20) 
Another two lmurrani added:

"It is people who chase other people away because they live there. If there were no people, it is okay to be there." (Interview informant 19)

Likewise:

"They were pushing us away further for them to preserve grass for their cattle. Thinking that we will exhaust their grass and they will be left with nothing to graze their cattle" (Interview informant 29)

In addition to increased settlements which make it harder for lmurrani and their livestock to access grazing areas along the way, informants also mentioned that the conservancies and their related benefits and restrictions result in a form of access to grazing for members only. In relation to grazing, an elder told me:

"There is a small problem of the owners; when it is dry, there is an area that is called mpaka, which is grass only for the people from that area. The laleta are chased away from that place. So that the grass is for a few cows from Westgate only and not for the others." (Interview informant 23)

Furthermore, in relation to benefits accrued from conservancies, a woman explained ${ }^{13}$ :

"Yes it is free, you can go and graze on others peoples group ranch [conservancy]. There is no problem. Also people can come and graze also in Sesia if there is enough grass. But whenever there is an income for the group ranch, that is now where the problems start. They will say 'you do not belong here, so you should not benefit from this'. It is money that created the problem for grazing on other people's group ranch." (Interview informant 31)

Consequently, settlements, mpaka, the restrictions stemming from wildlife conservation areas, and membership-based benefits related to conservancies clearly make it harder for lmurrani and other herders to move on with their livestock over specific areas. As these places are increasing, there is also an increase in the driving away of lmurrani and other herders with their livestock to further places where there are no conservation areas or settlements. Moreover, grazing based on this principle of reciprocity is changing. There is a gradual change towards conditional provision of access. An elder informed me:

"Before we have been allowing people to graze freely and settle randomly where they would like to, but for now we have a policy that everybody should plan for their own grass as we are not going to share with them. We will not accommodate [other Samburu pastoralists] anymore so that at least our forage will last for a longer time. We are not going even to graze in their areas." (Interview informant 1)

Additionally, an lmurran told me that access should only be provided conditionally:

"It [mpaka] should be closed for a short time only, not for so long, because otherwise other people from other areas will come in and graze together with us and this is not good. We have conserved the grass for ourselves and then it will be finished in a very short period-and then we have to move." (Interview informant 19)

This conditional provision of access does not only count for pastures, as an elder added:

"We will not allow people to get our sagaram if they do not restrict it themselves." (Interview informant 32)

13 Note that 'group ranch' is used in order to refer to 'conservancy'. 
In other words, a clear understanding of boundaries and the people who belong with them has prompted this shift towards conditional provisioning of access. Only people from a particular community can use the nearby resources unconditionally, while people from other communities can only use those resources if they have restricted and managed their own resources as well. This new form of conditional provisioning of access to grazing is not always respected nor adhered to by lmurrani moving with cattle. Boundaries are crossed without consent and often by night. People also mention that this is a result of weakness and a lack of obedience to the elders. With the increase of boundaries and restricted areas, people are more likely to cross boundaries without consent and access sagaram before the season has opened, leading to an increase of fines, sanctions, and struggle.

In addition, instead of accessing pastures within Samburu County, which are either not available for outsiders or which have gone dry, lmurrani move with their herds to saatia: a place that has a large amount of grass. These areas are usually avoided, although they are considered 'sweet spots' and have some of the best forage available in large quantities. These border areas are unused due to diseases, conflict, or because there is no water available. As mentioned, the frontiers of Samburu County in Kom (bordering Isiolo County) and the Lbarta plains near Baragoi (bordering Turkana County) offer grazing sites where recurrent conflicts between other pastoral communities take place. People do not live here anymore due to hostile conflicts between the Samburu and the pastoral Borana and Turkana communities. These 'refuge' areas are grazed upon only during extreme drought when people have no other choice; they are dry-year places and are not considered to be part of the routinely-chosen spots for easy grazing. Mostly, an lmurran will only go to saatia if he has arms at his disposal. Laikipia is also considered a saatia with a large amount of pasture, although here the pastures are privately owned for ranching and/or conservation and tourism purposes. On private land, Imurrani bring their cattle to graze at night. In some cases, Imurrani are arrested and have to pay heavy fines for trespassing. An one lmurran informed me:

"We just go around these plains during the day and we graze at night in the ranches." (Interview informant 28)

It can be concluded that it came to a point where the herders with cattle, and increasingly with goats, have to be on the move all the time. The family wants their animals and lmurrani to be at home. The lmurrani themselves want to be at home to sing, to dance, and to drink milk together with the rest of the family. Instead of herding cows in distant places, many lmurrani prefer to stay home and take care of the goats and camels. As a number of lmurrani told me:

"It is getting hard, because the cattle takes you to a place where it is hot and fight with people. You go to Kom, you fight, you go to Baragoi, you fight, you go to Laikipia, it is a problem too. We do not know now what to do with the cows." (Interview informant 19)

In the same way:

"[W]ho wants to buy cows now? You better buy camels! Cows [sigh]... they can take you to Kom, to Baragoi ..." (Interview informant 12)

\section{Discussion}

\subsection{Reciprocal Relations and Enclosing Space}

Customary institutions to manage and access grazing still appear to play an important role in the governance of resources in the lowlands of Samburu. There is a general perception, however, that these institutions have changed significantly over time. Given the explanations of informants, changing weather conditions, permanent settlements, but also (post)colonial interventions have, combined, played a role in the shifting practices of grazing management and mobility. Whereas previously-restricted areas were rather flexible in space, such as the enata nkop and lokere, gradually these were exchanged for institutions that are more fixed in space, such as the nkwe ngishu and mpaka. 
Apparently, the shift towards less flexible institutions came along with increasing sedentarization and permanent settlements of the Samburu pastoralists. In addition, colonial and post-colonial interventions, which introduced spatial boundaries aimed at fixing spaces for grazing and settlement, may also have resulted in an increase of sedentary lifestyles and motivated, locally, a strict division of settlement and grazing as well. Initially, these boundaries did not withhold Samburu from practicing mobility based on rules of reciprocity. Based on reciprocal relations and the rule of elders, mobility and access to resources in areas where other members of the Samburu community were residing continued to take place. While settlement increased, and grazing areas were strictly controlled by the elders, weather conditions also marked changes and access to resources became more complex. Livestock mobility involved longer distances and it became more difficult for the elders to maintain strict rules over restricted grazing areas for two reasons. Firstly, as people and livestock were more often away from home it became more difficult to organize and regulate restricted areas. Secondly, the boundaries of restricted areas were more often crossed without permission of the elders. This suggests a general weakening of the control of elders over customary institutions. In contrast, however, the abolition by the elders of the individual lokere shows that the elders continue to have a say in matters related to the enclosing of space. It may also suggest that the lokere, as it is an enclosed space on individual basis, has relatively little support at community level as it does not benefit the community as a whole. The lokere, then, instead of providing grazing and other benefits to the entire community, such as those the mpaka is supposed to bring, is only to the benefit of those who are able to maintain a lokere. Additionally, as it brought a great deal of struggle and conflict among members of the community, the decision by the elders to abolish the lokere gained significant support from within the community. At the same time, this might explain why other enclosures, such as the mpaka and nkwe ngishu, are not abolished by the elders.

\subsection{New Rules of Access}

The findings suggest that, while livestock mobility involves longer periods and more complex distances due to a shrinking resource base, the value of reciprocity is eroding. With the introduction of group ranches, followed by conservancies, other layers of boundaries were introduced in the landscape. Although the current conservancy boundaries already existed prior to their introduction of conservancies, their meaning and interpretation changed: the boundaries became a marker to identify who is entitled to the benefits accruing from the conservancies, and who is not. Hence, reciprocity as a form of mutual access to resources has gradually been replaced by conditional provision of access. While reciprocity is eroding, there is a continuous trend towards a more rigid understanding of spatial boundaries demarcated on the land leading to a 'closed engagement with space' $[15,24,93]$. This closed engagement delineates a stronger connection to a certain place where clear spatial boundaries are drawn and bounded territories are formed. Where, previously, access was guaranteed based on social networks and relations of reciprocity, there are now processes of exclusion at play, implying a different approach to access resources. Instead of providing access to fluctuating resources, as was initially the case, processes of exclusion imply a stronger focus on the land itself [62]. Group ranches and their (externally-initiated) transformation into conservancies are currently of great importance for such processes of conditional access, fuelling struggle, and conflict. Despite the transformations, boundaries are crossed at times legitimately or illegitimately.

Furthermore, this case illustrated that changing socio-political and environmental circumstances affect natural resource governance and access, involving spatial reconfiguration. This shifting engagement with space, however, is not merely a result of (post)colonial policies and practices gradually changing Samburu resource governance and territories, but also the interpretation and implementation by Samburu pastoralists and their strategies to reach their own goals, as can also be seen in other examples where certain processes and interventions create openings on the ground for processes of boundary making and struggles over resource access, power, and space [24,66,93-95]. However, although the conditional provision of access might seem valid, conditionality might not 
be the most suitable way to control access in a landscape where rainfall is heavily fluctuating in time and space. Restoring and strengthening values, such as reciprocity, could overcome strict membership-based access, and seeing the separated conservancies and home-areas as part of a connected and integrated landscape instead of a grid of enclosures could bring back a more open engagement with space, which is of vital importance to pastoralists in the drylands. Even though mobility is evidently of major importance to pastoralists living in drylands, policy and project implementation has historically been driven by the imperative to secure land tenure and improve pasture in bounded areas. Although the Kenyan government has shown an interest in pastoral livelihoods, and suitable policies for the development of pastoral areas have followed, opportunities to support institutions that promote mobility have been given insufficient attention. Policies still reflect the need to 'improve the rangelands' through management of grazing, and the securitization of tenure through both land rights and ownership in an enclosed manner, as opposed to the management and support of mobility strategies and institutions $[7,15,41,45,46]$. Hence, the inherent paradox whereby policies for securing access to resources generally go hand-in-hand with an increase in spatial boundaries that limit mobility and tend to result in growing uncertainties in terms of access to grazing and water [96]. Therefore, State policy and legislation on how to secure tenure to mobile pastoralists should start to include support for livestock mobility within and between pastoralist communities in order to foster mutual sharing. This includes regulations among communities to enhance mobility as a way to overcome the boundaries that have come to exist. By-laws based on customary forms of mobility and grazing management, for example, could be formulated in a truly participatory way by the local government and the organization responsible for initiating the conservancies. In doing so, closer attention should be given to what factors actually support, and limit, livestock mobility. Furthermore, governing mobility is mutually constitutive of the governance of rangelands [7]. Hence, livestock mobility will enhance the regeneration of grazing resources. Additionally, the securitization of land at the regional and national scales should occur without the need to fix people to specific bounded spaces, and the violation of pastoralist land use and ownership should carry heavier penalties.

\section{Conclusions}

This paper has provided a deeper understanding of shifting engagements with space by focusing on new sets of relations that emerge in the processes of gaining and controlling access to resources. I conclude that livestock mobility for Samburu pastoralists in the lowlands involves longer periods and more complex distances due to a shrinking resource base and new rules of access. Communal grazing and pasture management institutions are (re)formed and (re)enacted in this increasingly enclosed landscape. Access to pastures and water has to be negotiated beyond social networks. Processes of inclusion and exclusion do not solely follow the pastoral logic of reciprocity, which is becoming less common. Instead, access is based on an increasingly complex set of interactions, relations, and boundaries, which makes it more difficult to maintain access to pastures and water. Furthermore, as recurrent droughts and livestock losses continue, herders are turning to crossing boundaries without permission to access pastures, leading to increased struggle and conflict.

As argued at the beginning of this article, livestock mobility is of vital importance to Samburu pastoralists. Due to related struggle and conflict occurring in the landscape, and the complexity of colonial legacies, State policy, biodiversity and wildlife conservation, and local interpretations and processes, it is urgent to identify appropriate strategies to support such livestock mobility. These strategies must operate locally while being connected with socio-environmental and political processes within the wider landscape. As a result of conducting this research, I propose that policy emphasis is given to locally-formulated by-laws which support reciprocal use and access of resources as a means to strengthen landscape-level interconnectivity integrating people, land, and resources. At regional and national scales, these by-laws will have to be incorporated into relevant social and environmental policy and planning documents. 
Acknowledgments: This paper benefited from constructive comments and support by Lowe Börjeson, Liz Watson, and William Gibbs, as well as three anonymous reviewers. I thank my research assistant and informants who were willing to share their time with me, and also Tomas Pickering and Kasmira Cockerill, among others, for their valuable discussions and constructive cooperation. This work was supported by the Marie Skłodowska-Curie Actions Resilience in East African Landscapes (REAL) Innovative Training Network funded by the European Commission [FP7-PEOPLE-2013-ITN project no. 606879].

Conflicts of Interest: The author declares no conflict of interest.

\section{References}

1. Homewood, K.M. Policy, environment and development in African rangelands. Environ. Sci. Policy 2004, 7, 125-143. [CrossRef]

2. Ellis, J.E.; Swift, D.M. Stability of African pastoral ecosystems: Alternate paradigms and implications for development. Rangel. Ecol. Manag. J. Range Manag. Arch. 1988, 41, 450-459. [CrossRef]

3. Behnke, R.H.; Scoones, I.; Kerven, C. Range Ecology at Disequilibrium: Newe Models of Natural Variability and Pastoral Adaptation in African Savannas; Overseas Development Institute for the Overseas Development Institute, the International Institute for Environment and Development and the Commonwealth Secretariat: London, UK, 1993; p. 259.

4. Zimmerer, K.S. The Reworking of Conservation Geographies: Nonequilibrium Landscapes and Nature-Society Hybrids. Ann. Assoc. Am. Geogr. 2000, 90, 356-369. [CrossRef]

5. Galaty, J. The indigenisation of pastoral modernity: Territoriality, mobility, and poverty in dryland Africa. In Pastoralism in Africa: Past, Present and Future; Bollig, M., Schnegg, M., Wotzka, H., Eds.; Berghahn Books: New York, NY, USA, 2013; pp. 473-510.

6. Butt, B. Ecology, mobility and labour: Dynamic pastoral herd management in an uncertain world. Rev. Sci. Tech. 2016, 35, 461-472. [CrossRef] [PubMed]

7. Turner, M.D. The New Pastoral Development Paradigm: Engaging the Realities of Property Institutions and Livestock Mobility in Dryland Africa. Soc. Nat. Resour. 2011, 24, 469-484. [CrossRef]

8. Watson, E.E.; Kochore, H.H.; Dabasso, B.H. Camels and Climate Resilience: Adaptation in Northern Kenya. Hum. Ecol. 2016, 44, 701-713. [CrossRef] [PubMed]

9. Vehrs, H.; Heller, G.R. Fauna, Fire, and Farming: Landscape Formation over the Past 200 years in Pastoral East Pokot, Kenya. Hum. Ecol. 2017, 45, 613-625. [CrossRef]

10. Scoones, I. Ecological dynamics and grazing-resource tenure: A case study from Zimbabwe. In Managing Mobility in African Rangelands. The Legitimization of Transhumance, 1st ed.; Niamir-Fuller, M., Ed.; Intermediate Technology Publications Ltd. (ITP): London, UK, 1999; pp. 217-235.

11. Sullivan, S.; Homewood, K. On Non-Equilibrium and Nomadism: Knowledge, Diversity and Global Modernity in Drylands (and Beyond ... ); Working Paper No. 122/03; CSGR: Coventry, UK, 2003.

12. Galvin, K.A.; Reid, R.S.; Behnke, R.; Hobbs, N.T. Fragmentation in Semi-Arid and Arid Landscapes. Consequences for Human and Natural Systems; Springer: Dordrecht, The Netherlands, 2008; p. 411.

13. Reid, R.S.; Fernández-Giménez, M.E.; Galvin, K.A. Dynamics and Resilience of Rangelands and Pastoral Peoples Around the Globe. Ann. Rev. Environ. Resour. 2014, 39, 217-242. [CrossRef]

14. Catley, A.; Lind, J.; Scoones, I. Pastoralism and Development in Africa: Dynamic Change at the Margins; Routledge: Abingdon, UK, 2013; p. 295.

15. Watson, E.E. A "hardening of lines": Landscape, religion and identity in northern Kenya. J. East. Afr. Stud. 2010, 4, 201-220. [CrossRef]

16. Kimiti, D.W.; Hodge, A.C.; Herrick, J.E.; Beh, A.W.; Abbott, L.E. Rehabilitation of community-owned, mixed-use rangelands: Lessons from the Ewaso ecosystem in Kenya. Plant Ecol. 2017, 218, 23-37. [CrossRef]

17. Lovett, J.C. Modelling the effects of climate change in Africa. Afr. J. Ecol. 2015, 53, 1-2. [CrossRef]

18. Pricope, N.G.; Husak, G.; Lopez-Carr, D.; Funk, C.; Michaelsen, J. The climate-population nexus in the East African Horn: Emerging degradation trends in rangeland and pastoral livelihood zones. Glob. Environ. Chang. 2013, 23, 1525-1541. [CrossRef]

19. Bottazzi, P.; Goguen, A.; Rist, S. Conflicts of customary land tenure in rural Africa: Is large-scale land acquisition a driver of 'institutional innovation'? J. Peasant Stud. 2016, 43, 971-988. [CrossRef]

20. Greiner, C.; Mwaka, I. Agricultural change at the margins: Adaptation and intensification in a Kenyan dryland. J. East. Afr. Stud. 2016, 10, 130-149. [CrossRef] 
21. Lesorogol, C.K. Contesting the Commons: Privatizing Pastoral Lands in Kenya; University of Michigan Press: Ann Arbor, MI, USA, 2008; p. 264.

22. Woodhouse, P.; Bernstein, H.; Hulme, D. African Enclosures? The Social Dynamics of Wetlands in Drylands; James Currey: Oxford, UK, 2000; p. 238.

23. Mwangi, E. The puzzle of group ranch subdivision in Kenya's Maasailand. Dev. Chang. 2007, 38, 889-910. [CrossRef]

24. Korf, B.; Hagmann, T.; Emmenegger, R. Re-spacing African drylands: Territorialization, sedentarization and indigenous commodification in the Ethiopian pastoral frontier. J. Peasant Stud. 2015, 42, 881-901. [CrossRef]

25. Brottem, L.V. Environmental Change and Farmer-Herder Conflict in Agro-Pastoral West Africa. Hum. Ecol. 2016, 44, 547-563. [CrossRef]

26. Turner, M.D. Political ecology and the moral dimensions of "resource conflicts": The case of farmer-herder conflicts in the Sahel. Political Geogr. 2004, 23, 863-889. [CrossRef]

27. Mosley, J.; Watson, E.E. Frontier transformations: Development visions, spaces and processes in Northern Kenya and Southern Ethiopia. J. East. Afr. Stud. 2016, 10, 452-475. [CrossRef]

28. Enns, C. Infrastructure projects and rural politics in northern Kenya: The use of divergent expertise to negotiate the terms of land deals for transport infrastructure. J. Peasant Stud. 2017, 1-19. [CrossRef]

29. Greiner, C. Pastoralism and Land-Tenure Change in Kenya: The Failure of Customary Institutions. Dev. Chang. 2017, 48, 78-97. [CrossRef]

30. African Union. Policy Framework for Pastoralism in Africa: Securing, Protecting and Improving the Lives, Livelihoods and Rights of Pastoralist Communities; African Union: Addis Ababa, Ethiopia, 2013.

31. Elmi, M.; Birch, I. Creating Policy Space for Pastoralism in Kenya; Future Agricultures Consortium: Brighton, UK, 2013; pp. 1-28.

32. Anderson, D.M. Cow power: Livestock and the pastoralist in Africa. Afr. Aff. 1993, 92, 121-133. [CrossRef]

33. Hardin, G. The Tragedy of the Commons. Science 1968, 162, 1243-1248. [CrossRef] [PubMed]

34. Herskovits, M.J. The cattle complex in East Africa. Am. Anthropol. 1926, 28, 230-272. [CrossRef]

35. Lamprey, H. Pastoralism yesterday and today: The over-grazing problem. Ecosyst. World 1983, 13, $643-666$.

36. Waweru, P. Continuity and Change in Samburu Pastoralism: Under Colonial Rule, C. 1909-1963; LAP, Lambert Academic Publishing: Saarbrücken, Germany, 2012; p. 292.

37. Niamir-Fuller, M.; Turner, M.D. A review of recent literature on pastoralism and transhumance in Africa. In Managing Mobility in African Rangelands: The Legitimization of Transhumance; Niamir-Fuller, M., Ed.; Intermediate Technology Publications Ltd. (ITP): London, UK, 1999; pp. 18-46.

38. Odhiambo, M.O. Moving beyond the Rhetoric: The Challenge of Reform in Kenya's Drylands; IIED Briefing: London, UK, 2013.

39. Odhiambo, M.O. The Unrelenting Persistence of Certain Narratives: An Analysis of Changing Policy Narratives about the ASALs in Kenya; A Position Paper Prepared for the New Perspectives on Climate Resilient Drylands Development Project; IIED: London, UK, 2013.

40. Republic of Kenya. The Community Land Act; Government Printer: Nairobi, Kenya, 2016.

41. Fratkin, E.; Roth, E.A. As Pastoralists Settle: Social, Health, and Economic Consequences of the Pastoral Sedentarization in Marsabit District, Kenya; Kluwer Academic Publishers: New York, NY, USA, 2005; p. 280.

42. Haller, T.; Van Dijk, H.; Bollig, M.; Greiner, C.; Schareika, N.; Gabbert, C. Conflicts, security and marginalisation: Institutional change of the pastoral commons in a 'glocal' world. Rev. Sci. Tech. 2016, 35, 405-416. [CrossRef] [PubMed]

43. Adger, W.N.; Huq, S.; Brown, K.; Conway, D.; Hulme, M. Adaptation to climate change in the developing world. Prog. Dev. Stud. 2003, 3, 179-195. [CrossRef]

44. Krätli, S. Discontinuity in pastoral development: Time to update the method. Rev. Sci. Tech. 2016, 35, $485-497$. [CrossRef] [PubMed]

45. Spencer, P. Nomads in Alliance. Symbiosis and Growth among the Rendille and Samburu of Kenya; Oxford University Press: Londen, UK, 1973; p. 230.

46. Fumagalli, C.T. A Diachronic Study of Change and Socio-Cultural Process among the Pastoral Nomadic Samburu of Kenya, 1900-1975; State University of New York: Buffalo, NY, USA, 1977.

47. Perlov, D.C. Trading for Influence: The Social and Cultural Economics of Livestock Marketing among the Highland Samburu of Northern Kenya. Ph.D. Thesis, University of California, Los Angeles, CA, USA, 1987. 
48. Barkham, J.; Rainy, M. The vegetation of the Samburu-Isiolo Game Reserve. Afr. J. Ecol. 1976, 14, $297-329$. [CrossRef]

49. Sperling, L. Food acquisition during the African drought of 1983-1984: A study of Kenyan herders. Disasters 1987, 11, 263-272. [CrossRef]

50. Sperling, L. The adoption of camels by Samburu cattle herders. Nomadic Peoples 1987, 23, 1-17.

51. Straight, B.S. Altered Landscapes, Shifting Strategies: The Politics of Location in the Constitution of Gender, Belief, and Identity Among the Samburu Pastoralists in Northern Kenya; University of Michigan: Ann Arbor, MI, USA, 1997.

52. Straight, B.; Lane, P.; Hilton, C.; Letua, M. "Dust people": Samburu perspectives on disaster, identity, and landscape. J. East. Afr. Stud. 2016, 10, 168-188. [CrossRef]

53. Fratkin, E. Pastoral Land Tenure in Kenya: Maasai, Samburu, Boran, and Rendille Experiences, 1950-1990. Nomadic Peoples 1994, 55-68.

54. Lesorogol, C.K. Transforming institutions among pastoralists: Inequality and land privatization. Am. Anthropol. 2003, 105, 531-541. [CrossRef]

55. Lengoiboni, M.; van der Molen, P.; Bregt, A. Pastoralism within the cadastral system: Seasonal interactions and access agreements between pastoralists and non-pastoralists in Northern Kenya. J. Arid Environ. 2011, 75, 477-486. [CrossRef]

56. Butt, B.; Shortridge, A.; WinklerPrins, A.M. Pastoral herd management, drought coping strategies, and cattle mobility in southern Kenya. Ann. Assoc. Am. Geogr. 2009, 99, 309-334. [CrossRef]

57. Homewood, K.; Trench, P.C.; Kristjanson, P. Staying Maasai? Livelihoods, Conservation, and Development in East African Rangelands; Springer: New York, NY, USA, 2009; p. 418.

58. Li, T.M. Land's end: Capitalist Relations on an Indigenous Frontier; Duke University Press: London, UK, 2014; p. 240.

59. Sikor, T.; Lund, C. Access and Property: A Question of Power and Authority. Dev. Chang. 2009, 40, 1-22. [CrossRef]

60. Ribot, J.C.; Peluso, N.L. A Theory of Access. Rural Sociol. 2003, 68, 153-181. [CrossRef]

61. Niamir-Fuller, M. Managing mobility in African rangelands. In Managing Mobility in African Rangelands: The Legitimization of Transhumance; Niamir-Fuller, M., Ed.; Intermediate Technology Publications Ltd. (ITP): London, UK, 1999; pp. 102-131.

62. Ingold, T. Territoriality and tenure: The appropriation of space in hunting and gathering societies. In The Appropriation of Nature: Essays on Human Ecology and Social Relations; Ingold, T., Ed.; University of Iowa Press: Iowa City, IA, USA, 1986; pp. 130-164.

63. Van Dijk, H. Land tenure, territoriality and ecological instability: A Sahelian case study. In The Role of Law in Natural Resource Management; Spiertz, J., Wiber, M.J., Eds.; VUGA: The Hague, The Netherlands, 1996; pp. 17-45.

64. Casimir, M.J. The Dimensions of Territoriality: An Introduction. In Mobility and Territoriality. Social and Spatial Boundaries among Foragers, Fishers, Pastoralists and Peripatetics; Casimir, M.J., Rao, A., Eds.; Berg Publishers: Oxford, UK, 1992; pp. 1-26.

65. Casimir, M.J. The Determinants of Rights to Pasture: Territorial Organisation and Ecological Constraints. In Mobility and Territoriality. Social and Spatial Boundaries among Foragers, Fishers, Pastoralists and Peripatetics; Casimir, M.J., Rao, A., Eds.; Berg Publishers: Oxford, UK, 1992; pp. 153-204.

66. Marin, A.; Bjørklund, I. A tragedy of errors? Institutional dynamics and land tenure in Finnmark, Norway. Int. J. Commons 2015, 9, 19-40. [CrossRef]

67. Karplus, Y.; Meir, A. The Production of Space: A Neglected Perspective in Pastoral Research. Environ. Plan. D Soc. Space 2013, 31, 23-42. [CrossRef]

68. Leach, M.; Mearns, R.; Scoones, I. Environmental Entitlements: Dynamics and Institutions in Community-Based Natural Resource Management. World Dev. 1999, 27, 225-247. [CrossRef]

69. Young, O.R. International Governance: Protecting the Environment in a Stateless Society; Cornell University Press: Ithaca, NY, USA, 1994; p. 221.

70. Moritz, M. Open property regimes. Int. J. Commons 2016, 10, 688-708. [CrossRef]

71. Yin, R.K. Case Study Research: Design and Methods; Sage Publications: Thousand Oaks, CA, USA, 1994; p. 171.

72. Gagnon, Y. The Case Study as Research method: A Practical Handbook; Presses de l'Université du Québec: Québec, QC, Canada, 2010; p. 130. 
73. Ericksen, P.; de Leeuw, J.; Said, M.; Silvestri, S.; Zaibet, L. Mapping ecosystem services in the Ewaso Ng'iro catchment. Int. J. Biodivers. Sci. Ecosyst. Serv. Manag. 2012, 8, 122-134. [CrossRef]

74. Dunn, K. Interviewing. In Qualitative Research Methods in Human Geography; Hay, I., Ed.; Oxford University Press: Melbourne, Australia, 2000; pp. 50-82.

75. Li, T.M. The Will to Improve: Governmentality, Development, and the Practice of Politics; Duke University Press: North Dakham, NC, USA, 2007; p. 374.

76. Evans, J.; Jones, P. The walking interview: Methodology, mobility and place. Appl. Geogr. 2011, 31, 849-858. [CrossRef]

77. Cameron, J. Focussing on the Focus Group. In Qualitative Research Methods in Human Geography, 2nd ed.; Hay, I., Ed.; Oxford University Press: Melbourne, Australia, 2005; pp. 116-132.

78. Kenya National Bureau of Statistics. Population and Housing Census of Kenya, 2009: Volume 1A Population Distribution by Administrative Units; Government Printer: Nairobi, Kenya, 2010.

79. Spencer, P. The Samburu: A Study of Gerontocracy in a Nomadic Tribe; Routledge: New York, NY, USA, 2004; p. 384.

80. Meiu, G.P. Ethno-Erotic Economies: Sexuality, Money, and Belonging in Kenya; University of Chicago Press: Chicago, IL, USA, 2017; p. 304.

81. Holtzman, J. Uncertain Tastes: Memory, Ambivalence, and the Politics of Eating in Samburu, Northern Kenya; University of California Press: Berkeley, CA, USA, 2009; p. 296.

82. Little, P.D.; Smith, K.; Cellarius, B.A.; Coppock, D.L.; Barrett, C. Avoiding Disaster: Diversification and Risk Management among East African Herders. Dev. Chang. 2001, 32, 401-433. [CrossRef]

83. Holtzman, J. Eating Time: Capitalist History and Pastoralist History among Samburu Herders in Northern Kenya. J. East. Afr. Stud. 2007, 1, 436-448. [CrossRef]

84. Ongoro, E.B.; Ogara, W. Impact of climate change and gender roles in community adaptation: A case study of pastoralists in Samburu East District, Kenya. Int. J. Biodivers. Conserv. 2012, 4, 78-89.

85. Karanja Ng'ang'a, S.; Bulte, E.H.; Giller, K.E.; McIntire, J.M.; Rufino, M.C. Migration and Self-Protection Against Climate Change: A Case Study of Samburu County, Kenya. World Dev. 2016, 84, 55-68. [CrossRef]

86. Meiu, G.P. 'Beach-Boy Elders' and 'Young Big-Men': Subverting the Temporalities of Ageing in Kenya's Ethno-Erotic Economies. Ethnos 2015, 80, 472-496. [CrossRef]

87. McCabe, J.T. Cattle Bring Us to Our Enemies: Turkana Ecology, Politics, and Raiding in a Disequilibrium System; University of Michigan Press: Ann Arbor, MI, USA, 2004; p. 301.

88. Fumagalli, C.T. An evaluation of development projects among East African pastoralists. Afr. Stud. Rev. 1978, 21, 49-63. [CrossRef]

89. Whittaker, H.A. The socioeconomic dynamics of the shifta conflict in Kenya, c. 1963-8*. J. Afr. Hist. 2012, 53, 391-408. [CrossRef]

90. Rutten, M. Selling Wealth to Buy Poverty: The Process of the Individualization of Landownership among the Maasai Pastoralists of Kajiado District, Kenya, 1890-1990; Breitenbach: Saarbrücken, Germany, 1992.

91. Letai, J.; Lind, J. Squeezed from all sides: Changing resource tenure and pastoralist innovation on the Laikipia Plateau, Kenya. In Pastoralism and Development in Africa. Dynamic Change at the Margins; Catley, A., Lind, J., Scoones, I., Eds.; Routledge: New York, NY, USA, 2013; pp. 164-176.

92. Mwangi, E. The Transformation of Property Rights in Kenya's Maasailand: Triggers and Motivations; CGIAR Systemwide Program on Collective Action and Property Rights, International Food Policy Research Institute: Washington, DC, USA, 2005.

93. Bollig, M.; Lesorogol, C. The "new pastoral commons" of Eastern and Southern Africa. Int. J. Commons 2016, 10, 665-687. [CrossRef]

94. Ichinkhorloo, B.; Yeh, E.T. Ephemeral 'communities': Spatiality and politics in rangeland interventions in Mongolia. J. Peasant Stud. 2016, 43, 1010-1034. [CrossRef] 
95. Gargallo, E. Conservation on contested lands: The case of Namibia's communal conservancies. J. Contemp. Afr. Stud. 2015, 33, 213-231. [CrossRef]

96. Fernandez-Gimenez, M.E. Spatial and Social Boundaries and the Paradox of Pastoral Land Tenure: A Case Study from Postsocialist Mongolia. Hum. Ecol. 2002, 30, 49-78. [CrossRef]

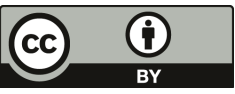

(C) 2018 by the author. Licensee MDPI, Basel, Switzerland. This article is an open access article distributed under the terms and conditions of the Creative Commons Attribution (CC BY) license (http:/ / creativecommons.org/licenses/by/4.0/). 
Article

\title{
Rangeland Livelihood Strategies under Varying Climate Regimes: Model Insights from Southern Kenya
}

\author{
Rebecca Kariuki $^{1,2, *}$, Simon Willcock ${ }^{3,4}$ and Rob Marchant ${ }^{1}$ \\ 1 York Institute for Tropical Ecosystems, Environment Department, University of York, Heslington, \\ York YO10 5NG, UK; robert.marchant@york.ac.uk \\ 2 School of Life Sciences and Bio-Engineering, The Nelson Mandela African Institution of Science and \\ Technology, P.O. Box 447 Arusha, Tanzania \\ 3 Centre for Biological Sciences, Faculty of Natural \& Environmental Sciences, University of Southampton, \\ Highfield Campus, Southampton SO17 1BJ, UK; s.willcock@bangor.ac.uk \\ 4 School of Environment, Natural Resources and Geography, Bangor University, Deiniol Road, Bangor, \\ Gwynedd LL57 2UW, UK \\ * Correspondence: rebecca.kariuki@york.ac.uk; Tel.: +255-764-254-751
}

Received: 31 January 2018; Accepted: 10 April 2018; Published: 12 April 2018

\begin{abstract}
Rangelands throughout sub-Saharan Africa are currently undergoing two major pressures: climate change (through altered rainfall and seasonality patterns) and habitat fragmentation (brought by land use change driven by land demand for agriculture and conservation). Here we explore these dimensions, investigating the impact of land use change decisions, by pastoralists in southern Kenya rangelands, on human well-being and animal densities using an agent-based model. The constructed agent-based model uses input biomass data simulated by the Lund-Potsdam-Jena General Ecosystem Simulator (LPJ-GUESS) dynamic vegetation model and parameterized with data from literature. Scenarios of land use change under different rainfall years, land tenure types and levels of wildlife conservation support were simulated. Reflecting reality, our results show livestock grazing as the predominant land use that changes with precipitation and land tenure leading to varying livelihood strategies. For example, agriculture is the most common livelihood in wet years and conservation levels increase with increasing support of wildlife conservation initiatives. Our model demonstrates the complex and multiple interactions between pastoralists, land management and the environment. We highlight the importance of understanding the conditions driving the sustainability of semi-arid rangelands and the communities they support, and the role of external actors, such as wildlife conservation investors, in East Africa.
\end{abstract}

Keywords: agent-based-model; climate change; conservation; grazing; pastoralists; precipitation; savannahs; social-ecological systems

\section{Introduction}

Rangelands occupy $45 \%$ of the earth's land surface and $61 \%$ of the African continent [1] with $35 \%$ of African rangelands under permanent pasture [2]. They include grasslands, shrublands and savannahs used largely for livestock production and wildlife conservation that are often characterized by low productivity, sparse human population and common land use [2,3]. About $60 \%$ of global rangelands are relatively dry [1] with water scarcity common during certain months of the year [4,5], leaving any local human populations who are dependent on their ecosystem services at risk that is often mitigated by migration.

In East Africa, ecosystems are shaped by long term interactions between changing climates and human activities [6,7]. Human impact, through land use change, is one of the strongest factors 
changing rangelands and is driven by the demand for ecosystem services [3,8]. However, rainfall is a major control of human land use options [9]. Rainfall seasonality affects pasture production independent of mean annual rainfall [10]. Rainfed agriculture is only viable in areas receiving at least $700 \mathrm{~mm}$ year $^{-1}$ of rainfall $[9,11]$; thus, pastoralism is the main livelihood strategy in areas of low and/or highly variable rainfall [12]. Wildlife and livestock utilize rangelands in complimentary ways [13-15] where livestock grazing maintains the rangelands for wildlife by keeping them open and as hotspots of biodiversity [16,17].

In arid and semi-arid areas of Kenya, the pastoral economy accounts for $90 \%$ of all employment opportunities and 95\% of household income [18]. Pastoralists in Kenyan rangelands were organized in group ranches to allow members to own land communally, to improve livestock production and encourage socio-economic development [19]. To reduce their vulnerability to unfavorable climates and socio-economic factors, pastoralists use various adaptation and coping mechanisms such as movement of livestock, changing livestock herd composition and selling stock to get money $[18,20,21]$. In the 1970s, the Kenyan Government deemed pastoralism as an inefficient land use type [22] and encouraged sedentarization and/or land subdivision, commercialization and privatization of communal group ranches [23,24]. Furthermore, leadership in the group ranches was ineffective and did not provide equitable distribution of resources to all group ranch members leading to their dissatisfaction and prompting further subdivision $[19,25]$. As a result, by the end of the twentieth century, the future of exclusive pastoralism in East African rangelands was uncertain $[10,26]$. With increasing sedentarization and subdivision; land tenure became an important driver of pastoralists land use change decisions, agriculture expanded in wet areas and near permanent water bodies $[22,27,28]$ and wildlife conservancies were formed in response to changing climatic, socio-economic and political factors [3,17,29].

The sustainability of pastoralism is primarily threatened by climate and land use change [30] and its success depends on rainfall patterns, land availability, forage availability and socio-economic changes. About $65 \%$ of the pastoral population living in arid and semi-arid areas in Kenya live below the poverty line [31]. With low income, decreasing livestock numbers and increasing climate variability, the number of pastoralists that can rely entirely on livestock reduces making livelihood diversification and/or intensification a necessity $[1,10,11]$. Pastoralists who can no longer sustain themselves by livestock grazing use their land for agropastoralism, agriculture or real estate. These land use transformations cause rangeland fragmentation through the loss of connectivity between landscapes [23].

In contrast to some other parts of Africa, diverse wildlife species still coexist with pastoralists and agropastoralists within East Africa [1,11]. The rapidly growing human population, multiple socio-economic and political factors and the interaction between pastoralist activities and wildlife pose a challenge on how best the sustainability of East African rangelands can be addressed. This unique interaction between humans and rangeland ecosystem services make them complex social-ecological systems where adaptations between the social and ecological components need to be understood. Additionally, it is by understanding the interactions between pastoralist livelihoods and the environment that more sustainable management of pastoral lands futures in East Africa can be developed. As the interactions between components in social-ecological systems are complex, nonlinear and adaptive, perspectives from social and natural environments have been used to understand them [32]. However, integrating these perspectives is challenged by the difficulty of understanding the interactions between multiple ecosystem services and trade-offs in human impact [33] making simulation modelling a potential tool to quantitatively address the response of pastoral activities to changing socio-economic and environmental factors [34]. As such, integrated modelling could contribute to answering important questions of interest to conservation researchers and practitioners, including: Which driver (biological, climatic, or anthropogenic) is more important in driving livelihood strategies in rangelands? How can payment for ecosystem services enhance conservation activities in rangelands? How can trade-offs between conservation and national development be addressed to 
promote sustainable development? Who are the likely "winners" and "losers" in rangelands under climate change scenarios?

Our study aims to understand grazing and sedentarization levels in southern Kenyan rangelands using an agent-based model to simulate pastoral land use decision making criteria and the impact it has on animal densities and pastoral livelihoods. Two objectives were used to address this research. First, we aim to show land use change across different rainfall years and land tenure scenarios. These land use change types are simulated over varying levels of wildlife conservation support in form of maximum annual income per land use type. Second, we aim to establish the impact of land use change on livestock densities, wildlife densities and pastoralist income. These impacts are simulated over nine different scenarios of rainfall and land tenure. We hypothesize that rainfall variability and socio-economic changes influence pastoral land use change decisions as pastoralists select the land use type that remains most profitable despite changing rainfall and socio-economic patterns. We also hypothesize that the land use selected by pastoralists drives their well-being and animal densities in rangelands.

\section{Study Areas}

The Amboseli and Mara ecosystems in southern Kenya were selected for study as their ecologies, historical land use types and conservation use have broadly been similar but have changed over the recent past due to varying pastoral sedentarization levels, social-economic development, and conservation initiatives. The Amboseli ecosystem consists of the Amboseli Basin, which is mainly the Amboseli National Park, and the group ranches surrounding the park (Figure 1). The park provides a dry season grazing reserve for wildlife while the group ranches surrounding the national park provide wildlife dispersal zones. For instance, the Kimana group ranch provides a migratory corridor for wildlife migrating between the Amboseli, Chyulu Hills and Tsavo National Parks/Reserves. The group ranches were formed under the Land Act of 1968 which aimed to incorporate landowners in collective management of pastoral land and resource use [35]. The group ranches were meant to encourage pastoralists to maintain a sizeable herd and to limit livestock grazing within their group ranch boundaries [36]. However, the group ranches were ineffectively managed and the pastoralists neither reduced their herds nor restricted grazing to their ranches leading to group ranch subdivision from the mid-1980s to present [1,36].

Rainfall in Amboseli is influenced by altitude [31] where higher rainfall areas occur along the northern foothills of Kilimanjaro (>800 $\mathrm{mm}_{\text {year }}{ }^{-1}$ ) and Chyulu Hills (500-600 $\mathrm{mm}_{\text {year }}{ }^{-1}$ ) [1] while lower points such as the Amboseli receive an average rainfall of $350 \mathrm{~mm}_{\text {year }}^{-1}[37,38]$. There are two annual rainfall seasons (November-January and March-May) and sometimes one or both of the rainfall seasons fail [1]. The ecosystem is characterized by a series of swamps, streams and rivers that are supported by the underground flows from Mt. Kilimanjaro [35,39]. Grasslands in Amboseli are dominated by Chloris rocksburghiana, Eragrostis tennuifolia and Sporobolus spp., woodlands are dominated by Commiphora and Acacia spp., swamps and flooded areas are dominated by Acacia xanthophloea, Cyperus immensus, Psilolemma jaegeri and Salvadora persica and the slopes of Kilimanjaro and Chyulu Hills are dominated by broad leaved dry tropical forests [38,40,41]. Our study was only interested in the drier parts of Amboseli and covered the Amboseli National Park and the surrounding pastoral group ranches (Figure 1).

The Mara ecosystem is north of the Serengeti ecosystem in Tanzania and provides dry season grazing reserve for wildebeests migrating from the Serengeti [42]. It consists of the Maasai Mara National Reserve and the surrounding group ranches which form wildlife dispersal zones (Figure 1). These group ranches also act as a buffer between the national reserve and the agricultural lands in the north of Narok County that are largely under mechanized agriculture [27,40,43]. The Mara is characterized by two rainfall seasons (November-December and March-May) with a gradient from the dry south eastern parts with an average rainfall of $500 \mathrm{~mm}$ year ${ }^{-1}$, to the wet north-western parts with an average rainfall of $1200 \mathrm{~mm}$ year $^{-1}$ [40,44]. The average temperature is $18^{\circ} \mathrm{C}$ [45]. 
There are several permanent and seasonal rivers and streams in the Mara and they all flow into the Mara River [46]. Vegetation in the Mara is characterized by open woodlands and forests along river and water courses [46]. Our study area in Mara covered the Maasai Mara National Reserve and the surrounding group ranches (Figure 1).

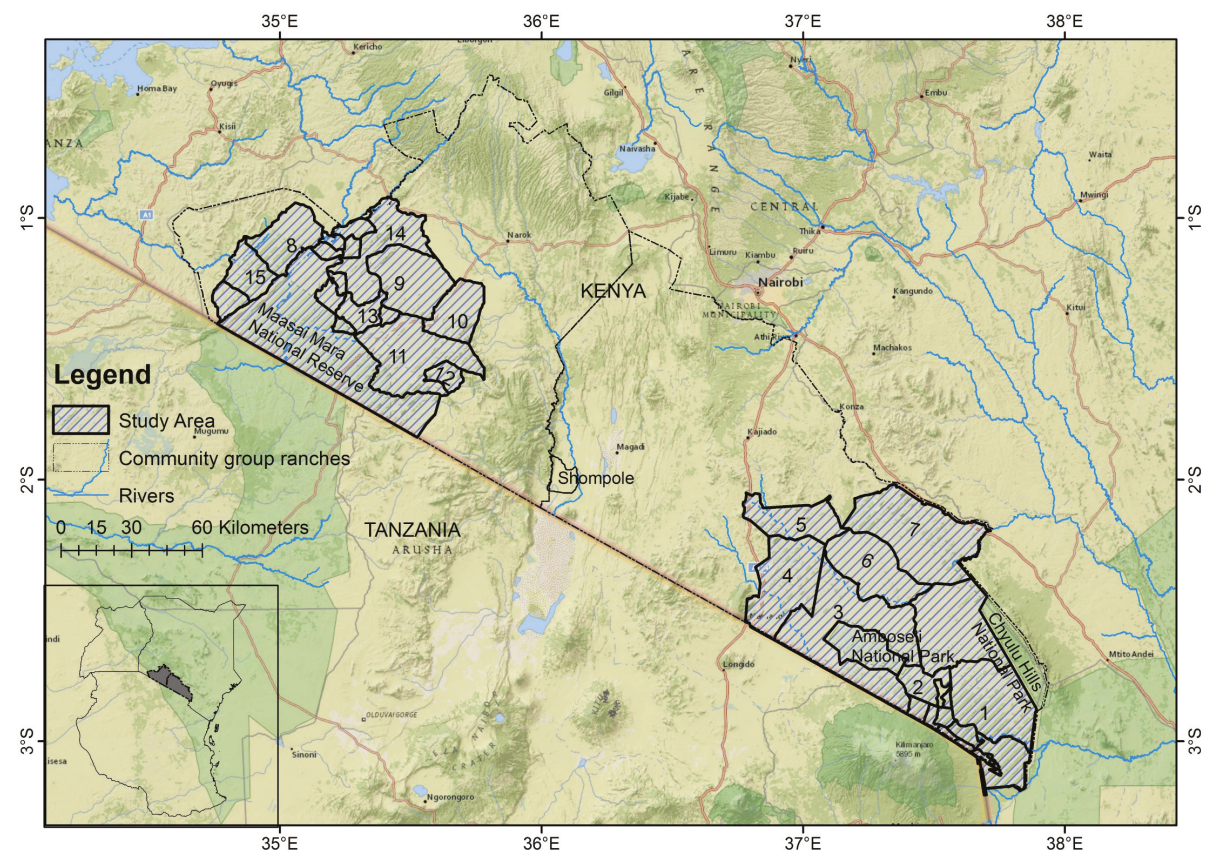

Figure 1. Amboseli and Mara ecosystems in southern Kenya and the surrounding group ranches (numbered 1-15). Group ranches 1 to 7 are in Amboseli while group ranches 8 to 15 are in the Mara. The name for the numbered group ranches are as follows: 1-Kuku, 2-Kimana, 3-Olgulului/Ololorashi, 4-Mailua, 5-Osilalei, 6-Lengesim, 7-Kaputei South, 8-Kimintet, 9-Ol Kinyei, 10-Maji Moto, 11-Siana, 12-Naikara, 13-Naboisho, 14-Lemek and 15-Oloirien. Those areas specifically modelled in this investigation are shaded. Group ranches in Amboseli were digitised by the International Livestock Research Institute (ILRI) while those in Mara were digitised by Benson Maina. Base layer Source: National Geographic.

\section{Methods}

Agent-based models (ABMs) are used to study complex adaptive systems made up of interactive, autonomous agents which give the system an ability to adapt, self-organize and show emerging patterns [47-50]. They simulate the behavior of agents from bottom-up to show the influence of individual agents in explaining the emergent patterns of a system [51-54]. ABMs can be used to link biophysical and socio-economic components of a system by incorporating outputs from biophysical process-based models as input data and linking them to other socio-economic factors simulated in the model $[34,51,55]$.

The Lund-Potsdam-Jena General Ecosystem Simulator (LPJ-GUESS) dynamic global vegetation model $[56,57]$ is a deterministic, process-based dynamic global vegetation model that simulates changes in vegetation dynamics and biogeochemical cycles as a function of changing climates [58-62]. LPJ-GUESS uses gridded time series climate data, atmospheric carbon dioxide $\left(\mathrm{CO}_{2}\right)$ concentrations and soil physical properties as input data [62]. Vegetation is described as plant functional types (PFT) 
distinguished by bioclimatic limits, morphological, phenological, life history traits and photosynthetic pathway [60]. Simulated vegetation dynamics arise from competition for light, space, and soil resources among plant functional types [57,63]. Validation of LPJ-GUESS has been done by measures of vegetation structure, composition and productivity [61], and with vegetation maps, remote sensed and pollen data $[64,65]$.

We apply an ABM to a social-ecological system [66] in Amboseli and Mara ecosystems in southern Kenya to understand the feedback between pastoral land use activities and natural resources. We link our custom-build ABM (details below) to LPJ-GUESS dynamic global vegetation model.

\subsection{Our Model Description and Dataset}

We developed a novel ABM in NetLogo (version 6.0.2) [67]. To the best of our knowledge, this is the first model that integrates a process-based dynamic global vegetation model and an ABM to assess the interaction between climates, livelihoods, and conservation in East African rangelands. The description of the model follows the ODD (Overview, Design concepts and Details) protocol (Appendix A) [68,69] formulated to make models complete, reproducible and easy to communicate [70]. The period for the ABM is from 1950 to present. To parameterize ecological and socio-economic variables used in the ABM, we used data on animal densities, grazing rates, income levels, household densities and irrigation probabilities from literature focused on pastoralists/agropastoralists in the study areas [39,71-73] and from the 2009 Kenya census [74] (Table 1).

Table 1. Model variables, their descriptions and data sources. Variables are divided into two types: fixed variables are constant throughout the model run, while updated variables are continually altered throughout the model based on other parameters.

\begin{tabular}{|c|c|c|c|}
\hline State Variables & Description/Units & $\begin{array}{l}\text { Variable } \\
\text { Type }\end{array}$ & Data Source \\
\hline Land tenure-type of land ownership & $\begin{array}{l}\text { Communal, government and } \\
\text { private }\end{array}$ & fixed & $\begin{array}{l}\text { Randomised (see } \\
\text { Appendix A) }\end{array}$ \\
\hline Land use-current land use in the land area & $\begin{array}{c}\text { Livestock grazing, irrigated } \\
\text { agropastoralism, agriculture, } \\
\text { livestock grazing with conservation } \\
\text { activities and built-up }\end{array}$ & updated & $\begin{array}{l}\text { Assigned via the } \\
\text { NetLogo model }\end{array}$ \\
\hline $\begin{array}{l}\text { Households - the density of homes found } \\
\text { in the land area }\end{array}$ & $\begin{array}{l}\text { Number per kilometre squared } \\
\qquad\left(\# / \mathrm{km}^{2}\right)\end{array}$ & fixed & {$[74]$} \\
\hline $\begin{array}{l}\text { Distance to the road-the closeness of a } \\
\text { grazing land to the nearest all-weather road }\end{array}$ & $\mathrm{km}$ & fixed & {$[73]$} \\
\hline $\begin{array}{l}\text { Irrigation-probability-the likelihood that a } \\
\text { pastoralist will irrigate his / her land based } \\
\text { on the overall likelihood of irrigation in the } \\
\text { study areas }\end{array}$ & Probability of $0-1$ & fixed & {$[75]$} \\
\hline $\begin{array}{l}\text { The annual income earned from specific } \\
\text { land uses practiced in } 1 \mathrm{~km}^{2} \text { land area }\end{array}$ & Dollars per year $\left(\$\right.$ year $\left.^{-1}\right)$ & updated & {$[40]$} \\
\hline $\begin{array}{l}\text { Income-the highest income from different } \\
\text { land uses practiced in } 1 \mathrm{~km}^{2} \text { land area }\end{array}$ & $\$$ year $^{-1}$ & updated & $\begin{array}{l}\text { Calculated by the } \\
\text { NetLogo model }\end{array}$ \\
\hline $\begin{array}{l}\text { Grass biomass - the amount of grass } \\
\text { available for livestock and wildlife grazing } \\
\text { in } 1 \mathrm{~km}^{2} \text { of land area }\end{array}$ & $\begin{array}{l}\text { Kilograms per kilometre squared } \\
\qquad\left(\mathrm{kg} / \mathrm{km}^{2}\right)\end{array}$ & Updated & LPJ-GUESS $[56,57]$ \\
\hline $\begin{array}{l}\text { Livestock density-the number of tropical } \\
\text { livestock units (TLU) in } 1 \mathrm{~km}^{2} \text { of land area }\end{array}$ & TLU & Updated & {$[40]$} \\
\hline $\begin{array}{l}\text { Wildlife density - the number of wildlife } \\
\text { found in } 1 \mathrm{~km}^{2} \text { of land area }\end{array}$ & $\# / \mathrm{km}^{2}$ & Updated & [39] \\
\hline
\end{tabular}

To represent the density of livestock in the ABM, we used tropical livestock units (TLU). TLU are a composite index used to standardize livestock species according to their body weight whereby one 
TLU is equivalent to $250 \mathrm{~kg}$ which is the weight of a female zebu cow [13,40,76,77]. TLU as a measure allows comparison of livestock species and wealth across pastoral households [78] whereby a cow is approximately $1 \mathrm{TLU}$ and one goat or sheep is $0.125 \mathrm{TLU}$ [13]. Other ABM studies that use TLU to understand the behavior of pastoral systems in Africa include [34] who simulates the decision making system of household heads with regard to ecosystem services and [49] who studied the role of herd numbers and stochastic events on the growth of herds. For each parameter we used the mean and standard deviation to incorporate stochasticity in the ABM. To capture multiple land use change behaviors observed in the ABM, we applied the principle of pattern oriented modelling [79] in the model design. We used insights from semi-structured interviews conducted with pastoralists in the study areas in January and February 2016. The interviews focused on questions on the history and drivers of land use patterns, land tenure, livelihood strategies and land management. In the model, the important role of government policy in advocating for land subdivision in the study areas is reflected through the land tenure variable that has three land tenure scenarios (communal, government and private).

Long term mean rainfall and temperature estimates from Climatic Research Unit TS 3.0 dataset, Climate Research Unit (CRU) University of East Anglia [80] were used in LPJ-GUESS to simulate vegetation biomass for the Amboseli and Mara ecosystems for the period between 1950 and 2005. As LPJ-GUESS simulations are run at both daily and annual time steps over a spatial resolution of 0.5 degrees [81], we simulated grass biomass annually and converted the output to $\mathrm{kg} / \mathrm{km}^{2}$. Grass biomass from three representative years in Amboseli (1990, 1993 and 2001) and Mara (1983, 1987 and 1994) were used to represent dry (low biomass), normal (medium biomass) and wet (high biomass) years respectively. Grass biomass was then used as input data for the ABM and used to simulate grass biomass that was available to wildlife and livestock based on their feeding rates and the land use practiced on a given cell. The model assumed an animal of $250 \mathrm{~kg}$ (equivalent of one tropical livestock unit) grazes on $2500 \mathrm{~kg}$ of dry matter per year [72]. It also assumed that all cells used for livestock grazing land use were grazed by livestock alone, half of the cells used for irrigated agropastoralism land use were grazed by livestock, one-third of the cells used for livestock grazing with conservation land use were grazed by livestock while two-thirds were used by wildlife and all the cells used for agriculture and urban land use types had no livestock or wildlife grazing.

From the grass available for grazing, wildlife and livestock densities were simulated for each cell. Animal densities, together with the likelihood of irrigation, type of land tenure, distance to road, household density and the price of livestock were then used to simulate the potential income a pastoralist can earn from different land uses in a given cell. From each cell, the land use type that had the highest income was then selected as the preferred land use type. In addition, the wildlife and livestock density in that cell were simulated as model outputs.

As our model was interested in understanding land use change types and their impacts on animal density and pastoralists' income, it was not spatially explicit. However, the patterns underlying the designing and implementation of our model are based on patterns observed and documented for Amboseli and Mara.

\subsection{Simulation Experiments}

\section{Scenarios}

We used repeated scenario experiments to explore a range of possible behaviours of the system from changing interactions between model variables. In the model, the variables used for computing different scenarios are the types of rainfall years (dry, normal and wet), and land tenure (communal, government and private), combined with modification on the amount of money available to support pastoralists who are willing to rent their land to be used for wildlife conservation (ranging 0-1000 $\$$ year $^{-1}$ ) (See Appendix A for full details). Simulation of each scenario was done independently from the start to the end and there was no alteration between scenarios when running the model. 


\section{Results}

Our main findings were: (1) with no conservation subsidies, livestock grazing remains the main land use type on dry, normal and wet years across all land tenure scenarios; (2) agriculture levels increase on subdivided and privatised land on all rainfall years; (3) provision of conservation subsidies heightens livestock grazing with conservation land use and; (4) livestock numbers, wildlife numbers and pastoralist income go up with higher conservation subsidies and decline with low conservation subsidies. Broadly, our findings were consistent across both Amboseli and Mara, and so we focus on Amboseli here, highlighting any differences with Mara throughout. For further details on the results for Mara please see the supplementary information.

\subsection{Land Use Change in Normal Rainfall Year}

Our model assumed the normal rainfall year formed the baseline conditions in the rangeland. The levels of irrigated agropastoralism land use under all the different scenarios was negligible while livestock grazing with conservation was not practiced when there were no conservation subsidies.

In a normal rainfall year, the three land tenure scenarios are dominated by livestock grazing when there is no budget to support conservation initiatives. When the conservation budget increases, livestock grazing with conservation becomes the predominant land use type followed by agriculture, livestock grazing and built-up land uses (Figure 2). Compared to communal and government land tenure scenarios, the private land tenure scenario had higher levels of agriculture.
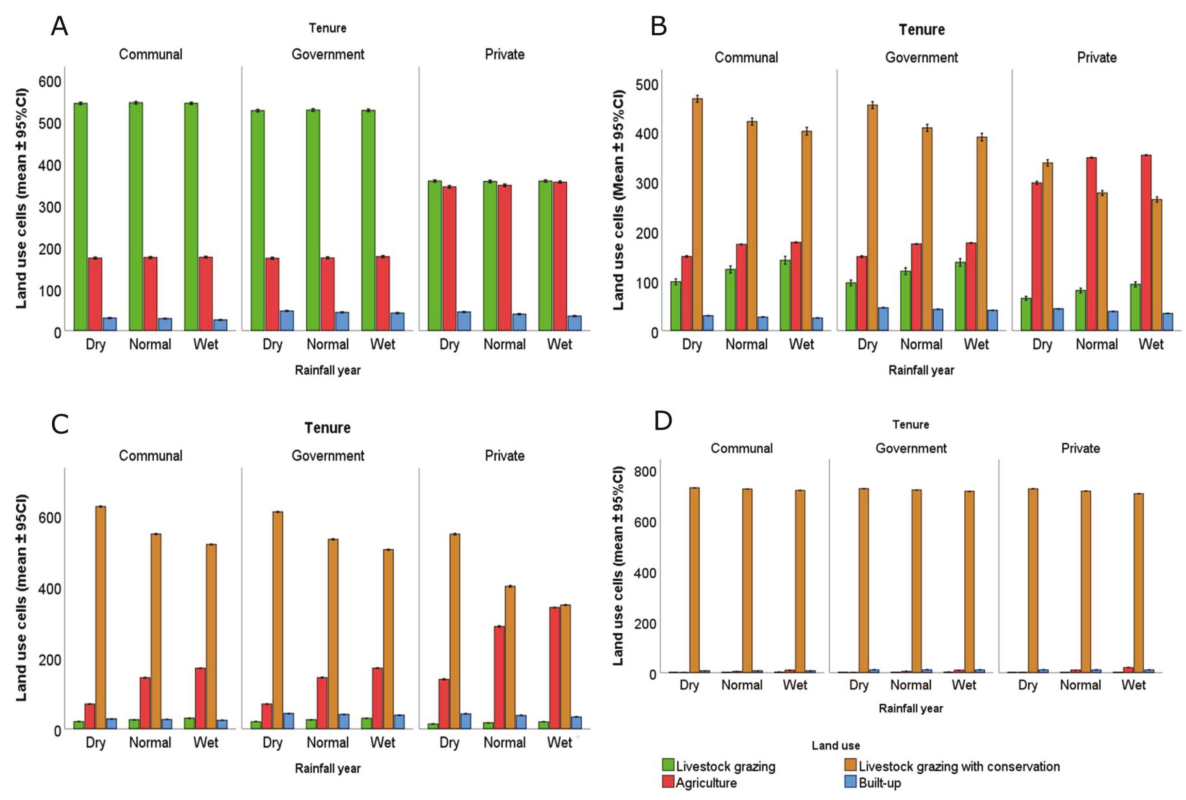

Figure 2. Comparison of land use types at different levels of conservation subsidies in Amboseli. In (A) there is no conservation subsidy, in (B) the conservation subsidy ranges from 10 to $100 \$$ year $^{-1}$ while $^{-1}$ in $(\mathbf{C}, \mathbf{D})$, the conservation subsidy ranges from 110 to $200 \$$ year $^{-1}$ and 210 to $1000 \$$ year $^{-1}$. In all the graphs, the three land tenure scenarios are labelled as 'Tenure'. The error bars represent $95 \%$ confidence interval. 


\subsection{Land Use Change in Dry and Wet Rainfall Years}

Land use trends during the dry rainfall year are mainly similar to the normal rainfall year apart from the private land tenure scenario where increase in agriculture levels is higher (Figure 2). One key difference between Amboseli and Mara in a dry rainfall year is that in Mara, under the private land tenure scenario, livestock grazing decreases as agriculture increases while in Amboseli livestock grazing does not decline as agriculture increases.

In a wet rainfall year, livestock grazing is the main land use type in communal and government land tenure scenarios. However, under the private land tenure scenario, both livestock grazing and agriculture levels are high.

\subsection{Land Use Change over Different Conservation Budgets}

In a normal rainfall year, as the conservation budget increases, livestock grazing with conservation dominates and all other land uses decline leading a wide margin between the levels of livestock grazing with conservation land use and other land use types. Under the private land tenure scenario, between 10 and $90 \$$ year $^{-1}$ of conservation budget, agriculture is the main land use type after which livestock grazing with conservation dominates as the conservation budget increases.

In a dry rainfall year, under communal and government land tenure scenarios, livestock grazing is the predominant land use type at conservation budget of $10 \$$ year $^{-1}$. However, when the budget increases to $20 \$$ year $^{-1}$, livestock grazing with conservation becomes the main land use type followed by agriculture, livestock grazing and built-up in that order with the built-up areas surpassing livestock grazing as the conservation budget continues to rise. Similar trends are observed in the Mara. However, unlike Amboseli, overall trends in the Mara show agriculture levels declining faster as conservation budget increases. During a wet year, under the communal land tenure scenario, a provision of 10-20 \$ year ${ }^{-1}$ of conservation budget raises the level of livestock grazing with conservation. Similar trends are observed under the government land tenure scenarios. However, land use trends differ between Amboseli and Mara under the private land tenure scenario. In Amboseli, below a conservation budget of $150 \$$ year $^{-1}$, the private land tenure scenario has high levels of agriculture and livestock grazing with conservation and low levels of the built-up and livestock grazing land use. At $160 \$$ year $^{-1}$, livestock grazing with conservation and agriculture are practiced in somewhat equal levels after which agriculture decreases as the conservation budget increases. In Mara, when a small budget $\left(<20 \$\right.$ year $\left.^{-1}\right)$ is available for conservation, agriculture increases as livestock grazing diminishes and at $30 \$$ year $^{-1}$ of conservation budget, livestock grazing with conservation land use overtakes agriculture and increases proportionally with increasing conservation budget.

Under all three land tenure scenarios, in a wet rainfall year, the level of livestock grazing with conservation in Mara is higher than in Amboseli while the levels of agriculture and built-up land are higher in Amboseli than in the Mara.

\subsection{Impact of Land Use Change on Wildlife, Livestock and Pastoralist Income}

Overall, wildlife density was higher in a wet rainfall year compared to normal and dry rainfall years (Table S1). It was also higher under communal and government land tenure scenarios than under the private land tenure scenario. In all rainfall and land tenure scenarios, as the conservation budget goes up, livestock grazing with conservation land use predominates leading to higher wildlife density (Figure 3 and Figure S2). The highest wildlife density was recorded in a wet rainfall year under the communal land tenure scenario while the lowest wildlife density was recorded in a dry rainfall year under the private land tenure scenario (Table S1). 

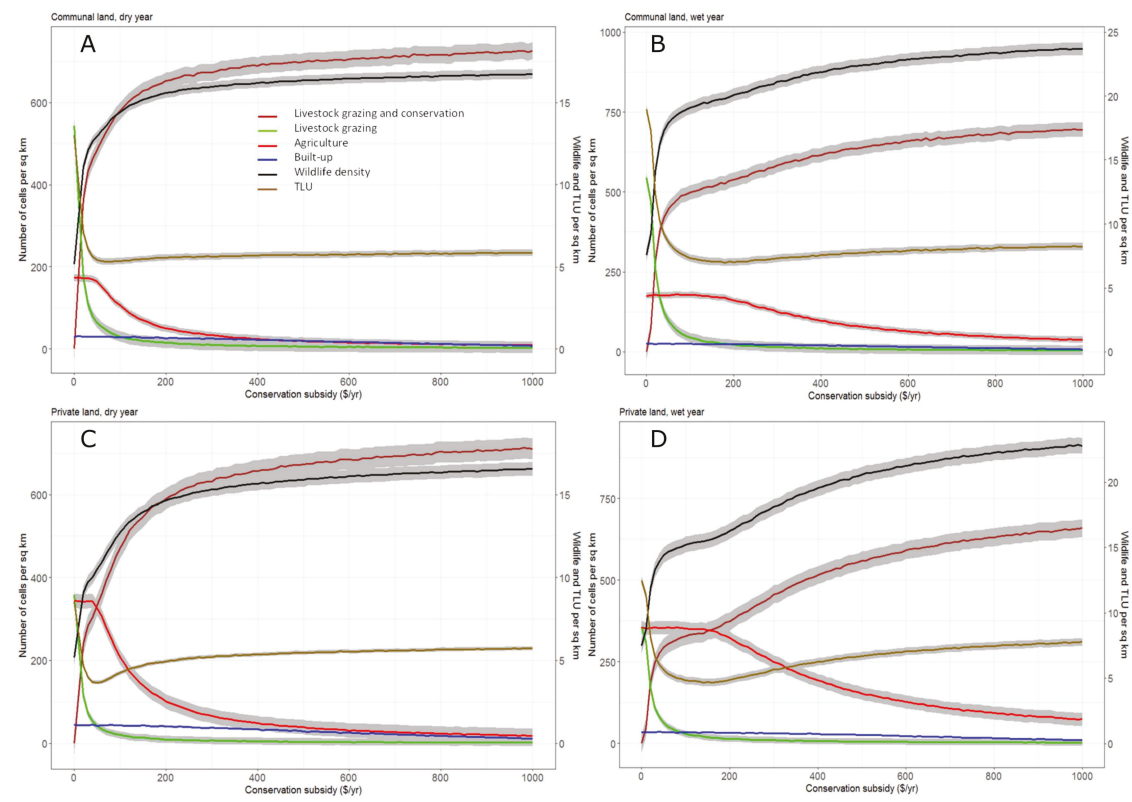

Figure 3. Trends in the relationship between land use types, wildlife and livestock density (TLU) in Amboseli. Figure (A,B) show dry and wet year trends under the communal land tenure scenario while figures (C,D) show dry and wet year trends under the private land tenure scenario. In all the figures, the grey zones represent the $95 \%$ confidence interval. From the figures, animal density increases with conservation subsidies though at different levels under different rainfall years and land tenure scenarios.

For all rainfall and land tenure scenarios, when there is no support for conservation, livestock grazing is the main land use type leading to higher livestock density relative to wildlife (Figure 3 and Figure S2). Livestock density follows similar trends to wildlife where livestock density is higher in the wet rainfall year compared to the normal and dry years and private land tenure scenarios have less livestock density when compared to communal and government land tenure scenarios.

Income earned by pastoralists from different land use types was higher during the wet year and under private land tenure scenario. Income increased as the conservation budget increased since land use types such as agriculture and livestock grazing with conservation earned pastoralists more income than livestock grazing or urbanization.

\section{Discussion}

By combining LPJ-GUESS with the land use change ABM, we aimed to integrate the impact of natural and social factors in pastoral land use decisions. Other studies in southern Kenyan rangelands that have integrated ABMs and biophysical models have been used to study: (1) the well-being of pastoralists in response to drought by simulating scenarios of lack of access to grazing resources and compensation for loss of grazing resource [34]; (2) to explore the possibility of payment for ecosystem services to pastoralists whose land use types are compatible with wildlife conservation [82] and; (3) to quantify the impact of land subdivision to livestock numbers and food security of households in Kajiado [83]. Our modelling work has shown the feedbacks between pastoral land use change decisions, their well-being and animal densities. With trends in land use, droughts and rainfall seasonality in East 
Africa expected to change in the future these land use change insights will improve our understanding of potential impacts of land use change on ecosystem services in East African rangelands.

The relative importance of livestock grazing, as the dominant land use type across southern Kenyan rangelands, change as rainfall, land tenure and conservation benefits change. Although land use changes have been attributed to multiple interactions between bio-physical and socio-economic factors, these interactions are complex, non-linear and difficult to include in land use analysis [84]. Livestock grazing is the most viable land use type in arid and semi-arid savannahs as it allows seasonal movement of livestock between dry and wet season grazing reserves $[39,85,86]$. It is also compatible to wildlife conservation [17], promotes cultural diversity [86] and supports many livelihoods thus making a significant contribution to the gross domestic product (GDP) of many East African countries [87]. However, climatic variability, manifested as delayed/failed rains, unreliable intensity of rainfall and increased frequency of droughts, drives rangeland conditions and impact on fodder available for livestock [88-90]. There is an increase in livestock grazing and agriculture during wet years in both Amboseli and Mara (Appendix B). This is because when adequate forage and water is available for livestock during wet years, pastoralists tend to maintain their livelihoods. Pastoralists also tend to practice agriculture where irrigated or rain-fed agriculture can be supported [88] leading to agricultural expansion in wet years and contraction in droughts or when there is intensified competition with wildlife [40].

Trends in the levels of irrigated agropastoralism, conservation and built-up land use are not different across the three rainfall years. This is probably because our model only considers three representative (dry, normal, and wet) rainfall years and not rarer extreme events. Also, despite rainfall being a key determinant of the main land use types in rangelands [35], and pastoralists using different adaptive strategies to droughts, it is extreme droughts that lead to rapid pastoral land use change and sedentarization [1]. This means that even the best land management techniques used to mitigate the effects of drought can fail under extreme droughts [91].

The influence of land fragmentation is modelled through land tenure scenarios in which the communal and government land tenures scenarios are largely un-subdivided and are used jointly by community members. On the other hand, the private land tenure scenario is largely divided into individual titled parcels of land and land use decisions are individual-based. Our model results show that the levels of livestock grazing land use were high under communal and government land tenure scenarios compared to private land tenure scenarios. In contrast, agriculture levels were higher under private land tenure scenarios compared to the other land tenures. These trends are synonymous to the increasing smallholder agriculture and sedentarization levels that have occurred in pastoral areas in southern Kenya following land subdivision [38,43,92,93]. Agriculture compartmentalizes rangelands components by introducing fences and water canals and utilizing dry season grazing lands as farms [88]. Changes in land tenure are driven by internal and external factors and lead to different land use change choices. Pastoralists, sometimes, encourage land subdivision when they are interested in controlling their land by keeping off agriculturalists and conservationists from gaining access to their lands [88]. Other times, when there is uncertainty over the leadership and effectiveness of communal land tenure, land privatization is encouraged, and pastoralists decide how to use their land. The outcome of land privatization is a decline in exclusive pastoralism, increased sedentarization and livelihood diversification [22].

Though our results show livestock grazing and agriculture levels increasing in the wet years, agricultural expansion during wet years under private land tenure scenarios is higher than the expansion of livestock grazing. As opposed to mechanized agriculture which is driven by land suitability and economic factors such as market accessibility; smallholder agriculture is driven by changes in demographic and socio-economic factors [27]. The goal of government policies that supported the privatization of communal lands was to promote intensive livestock production $[25,31,94]$. However, privatization promoted land fragmentation that discouraged pastoral mobility $[1,25,94]$ and encouraged agriculture and settlements expansion, land privatization and sedentarization $[1,42,95]$. 
Besides rainfall and land tenure, the impact of external drivers such as conservation investors and politics are equally important in shaping pastoral land use change decisions [96]. Our results show the potential impact of conservation subsidies. In our model, conservation land use is not practiced when there is no conservation budget but increases with the conservation support provided. This is because pastoralists view conservation as a livelihood that complements pastoralism, rather than as a main livelihood [17]. When they receive wildlife related economic benefits, their perception towards conservation is positive consequently leading to an increase in wildlife numbers [24,97]. Wildlife and livestock densities from the model are also correlated with conservation support. National parks and game reserves in Kenya cover $8 \%$ of the land surface and account for $35 \%$ of wildlife $[14,98]$. However, between $65 \%$ and $70 \%$ of wildlife is found in communal lands surrounding protected areas [14,99]. Thus, it is important that income from conservation is extended to pastoralists nearby protected areas to encourage a more permeable matrix outside of protected areas [82]. Such conservation-orientated income could provide an important safety-net for pastoralists, especially during dry years $[3,17,76]$. To help manage this matrix, fragmented rangelands across Kenya are being merged and managed together in form of wildlife conservancies $[3,100]$. Conservancies are lands set aside for wildlife and tourism with controlled livestock grazing to promote wildlife conservation and pastoral well-being through partnerships between tourism operators and landowners $[17,29,40,101]$. The tourism operators manage the conservancy and pay landowners fixed land lease payments (maximum of 50 dollars per hectare per year) to voluntary vacate their land and refrain from putting up settlements, overgrazing and practicing agriculture [17,102]. As the conservancies discourage agriculture, due to its unsustainability and the human wildlife conflicts it brings $[22,103]$, they encourage controlled livestock grazing which is seen to be compatible to wildlife conservation [82,103] leading to higher livestock grazing levels and no agriculture in conservancies. These community-based wildlife conservancies have been documented as successful in enhancing wildlife populations compared to other non-community-based wildlife zones [24]. For instance, formation of Nakuru Wildlife Conservancy, in central Kenya, is attributed to increasing the numbers of 32 wildlife species [99].

Our model results also highlight the impact of climate on wildlife and livestock, both of which show an increase in their densities during a wet year. Herbivore biomass has been associated with rainfall and food availability implying that it goes up in wet seasons and declines during droughts [99]. Simulation of wildlife and livestock densities across different land tenure scenarios showed both their densities were higher on communal and government land tenure scenarios compared to private land tenure scenario. This is because land subdivision and sedentarization disrupts the distribution and mobility of wildlife and livestock and may lead to their decline $[15,24,104]$. Over the late twentieth century and early twenty first century, wildlife densities in East African savannahs have declined [15]. Initial wildlife declines were recorded on wet pastoral areas where agriculture had expanded while drier pastoral areas where land was communally owned and not subdivided recorded relatively high wildlife density [24]. Similar wildlife trends have also been observed in southern Kenya where subdivided group ranches have lower wildlife densities compared to ecologically similar un-subdivided group ranches [24,104].

With increasing pastoral sedentarization, livestock density has also been declining in East African rangelands. To a great extent the wealth of Maasai pastoralists is associated with livestock and the number of TLU per person is used for estimating the wealth of households [78]. Per capita number of TLU needed by a pastoral family for subsistence and survival during droughts is six [77]. With per capita livestock numbers in East African rangelands having reduced from 10 in the 1960s to four in the 1980s [10], the ability of pastoral communities to depend entirely on livestock grazing for their subsistence is declining leading to diversification and intensification of pastoral livelihood strategies on and off the land $[40,92]$. However, our model shows that provision of conservation subsidies increases livestock density, particularly under the private land tenure scenario. It also shows that the influence of conservation subsidies in driving livestock density is key when subsidies are $<200 \$$ year $^{-1}$ and 
further increases in the subsidies maintains wildlife and livestock density levels. This means that average conservation subsidies of $200 \$$ year ${ }^{-1}$ for $1 \mathrm{~km}^{2}$ grazing land can allow pastoralists to practice livestock grazing, thus maintaining their cultural heritage, and promote wildlife conservation.

Though our model simulations provide useful trends on land use change, pastoral well-being, and animal densities, it has some limitations. Firstly, it was not spatially explicit and the location of pastoralists land, though randomly assigned, could not be linked to environmental and socio-economic conditions. A spatially explicit ABM would have enabled the agents to make decisions based on the prevailing environmental and socio-economic conditions [34]. Secondly, to reduce the complexity of interpreting the model output, our model did not use time series data of changing rainfall and biomass amounts. Instead, we used three representative rainfall years and biomass available for animals was related to these years. Utilizing time-series data would provide detailed information that is useful for predicting the behavior of the system $[105,106]$. Thirdly, our model is sensitive to conservation subsidies because pastoral land use change decisions are primarily driven by income. Thus, as the subsidies increase, more pastoralists change to livestock grazing with conservation land use because it gives them higher income. However, our model shows that pastoralists will rely on conservation income only when conservation subsidies supplement their livestock grazing income. Similar trends have been documented in southern Kenyan rangelands where conservancy payment is ranked second or third income earner and is an important source of cash that prevents pastoralists from selling their herds when they need cash [17]. With rainfall variability in Africa expected to increase [89,107], how pastoralists respond to harsh weather patterns and ecosystem changes will challenge the resilience of rangelands and their ability to adapt to fast, slow, broad scale or fine scaled drivers of change [11]. Previous studies [17,88,108] have demonstrated the resilience and adaptive capacity of pastoral social-ecological systems in East Africa, and insights from modelling studies complement and inform the potential behavior of pastoral systems under changing climates, development and political factors. These insights not only help in understanding the sustainable management of other rangelands across East Africa but can be used to inform appropriate policy and practice. Based on our model results, we recommend the use of stakeholders' perceptions in informing land use change modelling studies. The results from modelling studies can then be shared with the stakeholders who should also be involved in developing future scenarios of sustainable land use policy and practices. Furthermore, we recommend the development of policies that support and manage the provision of conservation subsides in rangelands as this provides adaptation strategies to climate change as well as prevents land fragmentation and consequently, land use change in rangelands.

\section{Conclusions}

In this study, we combine a process-based model to an agent-based model to understand the impact of interacting biophysical and socio-economic factors in driving land use patterns across two rangelands in southern Kenya. By using grass biomass estimates, simulated by LPJ-GUESS dynamic global vegetation model, as input to the agent-based model, we show how biophysical and agent-based models can be integrated. From the model outputs we discuss the implication of land use change on pastoral well-being, by simulating changes in pastoralist income and livestock density, and on rangeland ecology, by simulating changing trends in wildlife density. We show the role of conservation subsidies, in form of annual income, in enhancing livestock grazing and conservation land use type across the rangelands. Our model shows that this land use type not only increases pastoralists' income, livestock, and wildlife density, but also promotes rangeland connectivity across fragmented rangelands as it emerged the main land use type when conservation subsidies are provided under the private land tenure scenario. By simulating land use trends across two study areas, our model was able to simulate similarities and differences in land use trends across two ecological similar rangelands. It also showed changing landscapes and livelihoods patterns in Kenyan rangelands and the factors that drive these changes. These insights are useful in highlighting the impact of multiple, interacting climatic, socio-economic, and political factors in shaping livelihood strategies and ecological responses 
across semi-arid rangelands in East Africa. They can also be used to better understand the changes and the challenges faced by these social-ecological systems. Thus, providing ways of developing practical solutions that will enhance environmental sustainability and human well-being, particularly in addressing questions on the longevity of pastoralism and the trade-offs between land use types.

Supplementary Materials: The following are available online at http://www.mdpi.com/2073-445X/7/2/47/s1.

Acknowledgments: We are grateful to the local community experts we interviewed and whose views informed the designing of the agent based model. We thank Rebecca Muthoni, Francis Sopia, Daniel Letee and John Lembakuli for their help in conducting the interviews. We appreciate the support in model development granted by the SES-LINK project at the Stockholm Resilience Centre (SRC), Sweden. The research permit for this study was issued by the National Commission for Science, Technology and Innovation (NACOSTI) in Kenya. This research was supported by the European Commission Marie Curie Initial Training Network grant to RM for the Resilience in East African Landscapes (REAL) (FP7-PEOPLE-2013-ITN 606879) project. Finally, we would like to thank the anonymous reviewers, whose comments improved the manuscript.

Author Contributions: Rebecca Kariuki and Simon Willcock developed the model. Rebecca Kariuki led the writing of the manuscript with substantial feedback from Simon Willcock and Rob Marchant. All authors contributed to the development of ideas and drafts and gave their final approval for publication.

Conflicts of Interest: The authors declare they have no conflict of interest.

\section{Appendix A. ODD Protocol}

The ODD protocol used to simulate the model is described below.

\section{Appendix A.1. Overview}

Appendix A.1.1. Purpose

The ABM seeks to understand the feedback between pastoral land use change and the ecology of southern Kenya by exploring the role of rainfall, socio-economic and governance factors in driving land use types and the impact of adopted land use types on livestock densities, wildlife densities and pastoralists' annual income. Land use change by pastoralists means changes from livestock grazing to other land use types such as agricultural expansion and urbanization because of shifting livelihood strategies.

This model is developed for researchers and decision makers to improve understanding of the influence of climate change, government policy and socio-economic development on pastoral land use decisions and the impact of land use change on pastoral well-being and wildlife.

Appendix A.1.2. Entities, State Variables and Scales

The model has one agent; "cells", which represents areas of land that can be used. The state variables for cells are listed in Table 1. Climatic variability, social-economic and political factors are the main reasons pastoralists in semi-arid rangelands change to other land use types $[1,10,22,38,85,92,96,109]$.

From our field observations and literature, the main land use changes and livelihood diversification in the study areas are expansion of agriculture, urbanization and ecotourism $[40,93]$. Consequently, our model distinguished five land use types and for each $1 \mathrm{~km}^{2}$ "cell" more than one land use could be practiced. Our model only simulates small-holder agriculture that is dependent on rainfall and is practiced in wildlife dispersal communal grazing lands. We do not simulate mechanized agriculture as it was rare in our study areas.

The environment is composed of amount of rainfall per year (low, normal, and high) and budget available to pastoralists from investors and non-governmental conservation organizations to support wildlife conservation. The temporal setting for the model simulations is based on biophysical and socio-economic conditions from the 1950s and is simulated on an annual time step over 200 model runs. The spatial resolution for a single cell is $1 \mathrm{~km}^{2}$ and a single cell can have multiple households, land tenure and land ownership types. 
Appendix A.1.3. Process Overview and Scheduling

The processes in the model are simulated in five steps related to natural and social-economic events that influence land use change decisions by pastoralists. Changes in rainfall influence the grass biomass available for livestock and wildlife to graze on. The density of livestock and wildlife, together with other socio-economic factors, drives the income pastoralists can earn from different land use types. In turn, the land use types that pastoralists choose have implications on their income and the density of livestock and wildlife.

The five processes and the order they are modelled in are listed below. The state variables are updated in each process.

i. Grass is assigned to every cell. The grass biomass depends on the rainfall year. A wet year produces more grass and a dry year produces less grass.

ii. Animal grazing: The current land use type and grass biomass on each cell is checked and used to simulate the livestock and wildlife density that can graze that given cell.

iii. Income calculation: For each cell, the income earned for each land use type was calculated. This depends on: the number of households on that cell, the rainfall year, available grass biomass for animals, probability of irrigation, land tenure, household density and distance to the road.

iv. Land use change: In each cell, the land use type with the highest income is selected as the preferred land use type by pastoralists.

v. In each cell, the number of selected land use type, the income, the mean wildlife and livestock density is calculated and updated for every time step.

Appendix A.2. Design Concepts

Appendix A.2.1. Basic Concepts

The basic principles principles underlying the model design are based on real world patterns observed in the study area. Land use change choices by pastoralists are based on what is most rewarding financially at each time step. The potential income for each land use type in each cell is calculated and the land use that gives the highest income is selected.

Appendix A.2.2. Emergence

Feedback between social-economic and biophysical variables emerge from the interactions between grass biomass, animal density and land use types. Land use change to agriculture mainly occurs in wet rainfall years among pastoralists with private land ownership. Change to irrigated agropastoralism largely occurs near permanent water bodies while livestock grazing with conservation activities is preferred in areas where pastoralists derive monetary benefits, mainly through land rents, from investors or organizations supporting wildlife conservation initiatives.

Appendix A.2.3. Adaptation

The land use type with the highest income is adopted.

Appendix A.2.4. Objectives

In each cell, the objective is to select the land use type that maximizes profitability by using available natural resources and favorable weather and socio-economic patterns. If this is impossible, the land use and livelihood type that can easily be practiced based on existing infrastructure is selected.

Appendix A.2.5. Prediction

There is no foresight of rainfall or the trends in other socio-economic variables. In the cell, if livestock grazing is hampered by low water availability, low income and high human population, then it is likely that the land use will shift to a more profitable land use. 


\section{Appendix A.2.6. Sensing}

Before a different land use type is selected, the potential income of all land uses can be sensed and are used to inform land use change decisions.

Appendix A.2.7. Interaction

None.

Appendix A.2.8. Stochasticity

The state variables for each cell are randomly assigned when the model starts.

Appendix A.2.9. Observation

Observed variables per annual time steps are: land use types, annual income, average livestock (tropical livestock units) and wildlife density in each cell.

\section{Appendix A.3. Details}

Appendix A.3.1. Initialization

When the model begins, livestock grazing is the main land use type. The household density, distance to road, grass biomass, livestock and wildlife density have a normal distribution centered around the mean and standard deviation of each variable in Amboseli and Mara ecosystems (Table A1). The probability of irrigation is randomly allocated to the cells and range between zero and one. Income for each land use type is set to zero. For the land tenure scenarios:

- In the communal scenario, land tenure it is randomly allocated a 50\% chance of being communal, $25 \%$ of being government and $25 \%$ of being private.

- In the government scenario, land tenure is randomly given a chance of being $50 \%$ government, $25 \%$ communal and $25 \%$ private.

- In the private scenario, land tenure is randomly allocated a $50 \%$ chance of being private, $25 \%$ of being communal and $25 \%$ being government.

Table A1. Initialization state variable values.

\begin{tabular}{cccc}
\hline Variable & Amboseli & Mara & Source \\
\hline Mean household density & $13.18 / \mathrm{km}^{2}$ & $15.55 / \mathrm{km}^{2}$ & {$[74]$} \\
Mean distance to road & $9.4 \mathrm{~km}$ & $9.4 \mathrm{~km}$ & {$[73]$} \\
Mean grass biomass & $93,000 \mathrm{~kg} / \mathrm{km}^{2}$ & $2958 \mathrm{~kg} / \mathrm{km}^{2}$ & LPJGUESS DGVM \\
Mean TLU & $61.3 / \mathrm{km}$ & $71.06 / \mathrm{km}^{2}$ & {$[40]$} \\
Mean wildlife density & $33.33 / \mathrm{km}^{2}$ & $138.94 / \mathrm{km}^{2}$ & {$[39]$} \\
\hline
\end{tabular}

Appendix A.3.2. Submodels

\section{Animal Grazing}

The amount of grass grazed is a function of available grass biomass and the annual amount of dry matter $(\mathrm{kg})$ grazed by one TLU of livestock per year. The model assumes wildlife grazing habits are similar to those of livestock hence their annual grass offtake amounts are similar. One TLU feeds on $2500 \mathrm{~kg} / \mathrm{km}^{2}$ of dry matter per year [72] thus the formulas used for calculating livestock and wildlife density that can graze on a given cell in the three land use type are as follows: Note: agricultural and urban land use types have no livestock or wildlife grazing. 
i. Livestock grazing land use where all the land is exclusively used for livestock grazing

$$
T L U=\left(\frac{\text { Grass biomass }}{2500}\right)
$$

ii. Irrigated agro-pastoralism where half of the land is grazed by livestock and the other half is used for agriculture.

$$
T L U=\left(\frac{\text { Grass biomass } \times \frac{1}{2}}{2500}\right)
$$

iii. Livestock grazing with conservation activities where one third of the land is used for livestock grazing and two-thirds of the land is rented out for wildlife conservation.

$$
\begin{gathered}
\text { TLU }=\left(\frac{\text { Grass biomass } \times \frac{1}{3}}{2500}\right) \\
\text { Wildlife density }=\left(\frac{\text { Grass biomass } \times \frac{2}{3}}{2500}\right)
\end{gathered}
$$

Calculation of Income for Each Land use Type in Each Grazing Land

Income earned in each land use type differs. It depends on the interactions between social and the biophysical components of the system. Though each land tenure scenario has varying proportions of each land use type, livestock grazing is largely practiced in communal and government land while irrigated agropastoralism, agriculture and built-up areas are largely found on private land. The probability of irrigation is calculated as a ratio between irrigated area $[75,110]$ and the total area studied resulting in a probability of 0.013 and 0.1389 for Amboseli and Mara respectively.

In suitable areas, potential income for each land use type in each grazing land is calculated as follows:

i. $\quad$ Income from livestock grazing $=$

$$
\left(\frac{\text { Grass biomass }}{2500}\right) \times\left(\frac{\text { Cost }(\$) \text { of one TLU }}{\text { households }}\right)
$$

ii. Income from irrigated agropastoralism $=$

$$
\left(\left(\frac{\text { Mean household density }}{\text { households }}\right)+\left(\frac{\text { Grass biomass } \times \frac{1}{2}}{2500}\right) \times\left(\frac{\text { Cost }(\$) \text { of one TLU }}{\text { households }}\right)\right)
$$

iii. Income from irrigated agriculture $=$

$$
\text { (Agriculture income from literature } \times \frac{\text { Mean household density }}{\text { households }} \text { ) }
$$

iv. Income from livestock grazing and conservation =

$$
\text { (Amount of conservation subsidy }+\left(\frac{\text { Grass biomass } \times \frac{1}{3}}{2500}\right) \times\left(\frac{\text { Cost }(\$) \text { of one TLU }}{\text { households }}\right) \text { ) }
$$

v. The only built-up areas that earn pastoralists income are those $<2 \mathrm{~km}$ from all-weather roads with the income earned based on the mean income earned from urban areas in the study sites. 


\section{Appendix B. Comparison between Amboseli and Mara}

In Amboseli, although land use types are a result of long term changes in physical and cultural interactions, current trends of increasing sedentarization, agricultural expansion and development of conservation-based initiatives are more recent [38]. These land use trends are a result of infrastructure access, economic opportunities, land tenure changes and settlement patterns [40]. Access to physical infrastructure such as roads, schools, markets and health centers vary considerable across Amboseli and depend on the location of pastoral settlements [1]. Agriculture expanded on swamps and the slopes of Mt. Kilimanjaro which are dry season animal grazing zones [38,111].

In Mara, subdivided group ranches that receive adequate rainfall that can support agriculture have been converted to agriculture $[40,92]$ leaving only $25-35 \%$ livestock available to maintain a nomadic livelihood [45]. When pastoralists in Mara are selecting land use types, they consider trade-offs between increasing the size of livestock or maintaining income from wildlife conservation activities and between expanding land for small scale farming or leasing land for mechanized farming [92]. In areas close to the Maasai Mara National Reserve, residents are involved in wildlife related and tourism activities. The national reserve accounts for $25 \%$ of the total national wildlife population in Kenya [14]. This makes wildlife conservation initiatives an integral component of the land use systems in Mara and contribution from wildlife conservation to most households is higher than livestock and agriculture income $[40,45]$. However, livestock still supports many livelihoods as integrating pastoralism with conservation has been challenging [92].

Wildlife declines in the rangelands have been attributed to agriculture expansion that results to habitat loss and fragmented landscapes of wildlife dispersal areas [14]. From the model, general wildlife trends show lower wildlife density in private land tenure compared to communal and government land and higher wildlife density in wet years relative to dry years. In Amboseli, the consequence of agricultural expansion in swamps in Amboseli has been fragmentation of wildlife dispersal zones, decline in dry season pasture, loss of wildlife habitat and intense human-wildlife conflicts $[38,109]$. The Mara rangelands have shown huge resilience in supporting large biomass of resident and migratory herbivores for years [92]. However, conversion of large tracts of rangelands on the Loita plains (north of the national reserve) to large scale commercial farms has led to habitat loss for wildlife, and consequently their decline [27,44,92].

\section{References}

1. Galvin, K.A.; Reid, R.S.; Behnke, R.H., Jr.; Hobbs, N.T. Fragmentation in Semi-Arid and Arid Landscapes: Consequences for Human and Natural Systems; Springer: Dordrecht, The Netherlands, 2008.

2. Milne, E.; Williams, S.E. Grazing Lands, Livestock and Climate Resilient Mitigation in Sub-Saharan Africa: State of the Science. Report for USAID Project Contract No. AIDOAAL1000001. Available online: http:/ / www.vivo.colostate.edu/lccrsp/reports/GrazingLandsLivestockClimateMitigation_Paper1_ Final6Aug2015editedv4a.pdf (accessed on 22 January 2018).

3. Reid, R.S.; Fernández-Giménez, M.E.; Galvin, K.A. Dynamics and Resilience of Rangelands and Pastoral Peoples Around the Globe. Annu. Rev. Environ. Resour. 2014, 39, 217-242. [CrossRef]

4. Scholes, R.J.; Archer, S.R. Tree-Grass Interactions in Savannas. Annu. Rev. Ecol. Syst. 1997, 28, 517-544. [CrossRef]

5. Plisnier, P.D.; Serneels, S.; Lambin, E.F. Impact of ENSO on East African Ecosystems: A Multivariate Analysis Based on Climate and Remote Sensing Data. Glob. Ecol. Biogeogr. 2000, 9, 481-497. [CrossRef]

6. Marchant, R.; Lane, P. Past perspectives for the future: Foundations for sustainable development in East Africa. J. Archaeol. Sci. 2014, 51, 12-21. [CrossRef]

7. Willcock, S.; Phillips, O.L.; Platts, P.J.; Balmford, A.; Burgess, N.D.; Lovett, J.C.; Ahrends, A.; Bayliss, J.; Doggart, N.; Doody, K.; et al. Quantifying and understanding carbon storage and sequestration within the Eastern Arc Mountains of Tanzania, a tropical biodiversity hotspot. Carbon Balance Manag. 2014, 9, 2. [CrossRef] [PubMed] 
8. Willcock, S.; Phillips, O.L.; Platts, P.J.; Swetnam, R.D.; Balmford, A.; Burgess, N.D.; Ahrends, A.; Bayliss, J.; Doggart, N.; Doody, K.; et al. Land cover change and carbon emissions over 100 years in an African biodiversity hotspot. Glob. Chang. Biol. 2016, 22, 2787-2800. [CrossRef] [PubMed]

9. Ellis, J.; Galvin, K.A. Climate Patterns and Land-Use Practices in the Dry Zones of Africa. Bioscience 1994, 44, 340-349. [CrossRef]

10. Western, D.; Nightingale, D.L.M. Environmental Change and the Vulnerability of Pastoralists to Drought: A Case Study of the Maasai in Amboseli, Kenya; Cambridge University Press: New York, NY, USA, 2003.

11. Dong, S.; Kassam, K.-A.S.; Tourrand, J.F.; Boone, R.B. Building Resilience of Human-Natural Systems of Pastoralism in the Developing World; Springer: Basel, Switzerland, 2016; p. 295.

12. Ogutu, J.O.; Piepho, H.P.; Dublin, H.T.; Bhola, N.; Reid, R.S. El Niño-Southern Oscillation, rainfall, temperature and Normalized Difference Vegetation Index fluctuations in the Mara-Serengeti ecosystem. Afr. J. Ecol. 2008, 46, 132-143. [CrossRef]

13. Galvin, K.A.; Thornton, P.K.; de Pinho, J.R.; Sunderland, J.; Boone, R.B. Integrated Modeling and Its Potential for Resolving Conflicts between Conservation and People in the Rangelands of East Africa. Hum. Ecol. 2006, 34, 155-183. [CrossRef]

14. Western, D.; Russell, S.; Cuthill, I. The status of wildlife in protected areas compared to non-protected areas of Kenya. PLoS ONE 2009, 4, e6140. [CrossRef] [PubMed]

15. Kiffner, C.; Wenner, C.; LaViolet, A.; Yeh, K.; Kioko, J. From savannah to farmland: Effects of land-use on mammal communities in the Tarangire-Manyara ecosystem, Tanzania. Afr. J. Ecol. 2015, 53, 156-166. [CrossRef]

16. Western, D. Amboseli National Park: Enlisting landowners to conserve migratory wildlife. AMBIO 1982, 11, 302-308.

17. Bedelian, C.; Ogutu, J.O. Trade-offs for climate-resilient pastoral livelihoods in wildlife conservancies in the Mara ecosystem, Kenya. Pastoralism 2017, 7, 10. [CrossRef]

18. Opiyo, F.; Wasonga, O.; Nyangito, M.; Schilling, J.; Munang, R. Drought Adaptation and Coping Strategies Among the Turkana Pastoralists of Northern Kenya. Int. J. Disaster Risk Sci. 2015, 6, 295-309. [CrossRef]

19. Boone, R.B.; Burnsilver, S.B.; Thornton, P.K.; Worden, J.S.; Galvin, K.A. Quantifying Declines in Livestock Due to Land Subdivision. Rangel. Ecol. Manag. 2005, 58, 523-532. [CrossRef]

20. Campbell, D.J. Response to Drought Among Farmers and Herders in Southern Kajiado District, Kenya. Hum. Ecol. 1984, 12, 35-64. [CrossRef]

21. Riginos, C.; Porensky, L.M.; Veblen, K.E.; Odadi, W.O.; Sensenig, R.L.; Kimuyu, D.; Keesing, F.; Wilkerson, M.L.; Young, T.P. Lessons on the relationship between livestock husbandry and biodiversity from the Kenya Long-term Exclosure Experiment (KLEE). Pastor. Res. Policy Pract. 2012, 2. [CrossRef]

22. Campbell, D.J.; Gichohi, H.; Mwangi, A.; Chege, L. Land use conflict in Kajiado district, Kenya. Land Use Policy 2000, 17, 337-348. [CrossRef]

23. Hobbs, N.T.; Galvin, K.A.; Stokes, C.J.; Lackett, J.M.; Ash, A.J.; Boone, R.B.; Reid, R.S.; Thornton, P.K. Fragmentation of rangelands: Implications for humans, animals, and landscapes. Glob. Environ. Chang. 2008, 18, 776-785. [CrossRef]

24. Western, D.; Groom, R.; Worden, J. The impact of subdivision and sedentarization of pastoral lands on wildlife in an African savanna ecosystem. Biol. Conserv. 2009, 142, 2538-2546. [CrossRef]

25. Galaty, J.G. Reasserting the commons: Pastoral contestations of private and state lands in East Africa. Int. J. Commons 2016, 10, 709. [CrossRef]

26. Greiner, C.; Mwaka, I. Agricultural change at the margins: Adaptation and intensification in a Kenyan dryland. J. East. Afr. Stud. 2016, 10, 130-149. [CrossRef]

27. Serneels, S.; Lambin, F.E. Proximate causes of land-use change in Narok District, Kenya: A spatial statistical model. Agric. Ecosyst. Environ. 2001, 85, 65-84. [CrossRef]

28. Greiner, C.; Alvarez, M.; Becker, M. From Cattle to Corn: Attributes of Emerging Farming Systems of Former Pastoral Nomads in East Pokot, Kenya. Soc. Nat. Resour. 2013, 26, 1478-1490. [CrossRef]

29. Bhola, N.; Ogutu, J.O.; Said, M.Y.; Piepho, H.P.; Olff, H. The distribution of large herbivore hotspots in relation to environmental and anthropogenic correlates in the Mara region of Kenya. J. Anim. Ecol. 2012, 81, 1268-1287. [CrossRef] [PubMed] 
30. Franz, T.E.; Caylor, K.K.; Nordbotten, J.M.; Rodríguez-Iturbe, I.; Celia, M.A. An ecohydrological approach to predicting regional woody species distribution patterns in dryland ecosystems. Adv. Water Resour. 2010, 33, 215-230. [CrossRef]

31. Mwangi, E.; Ostrom, E. A Century of Institutions and Ecology in East Africa's Rangelands: Linking Institutional Robustness with the Ecological Resilience of Kenya's Maasailand. In Institutions and Sustainability: Political Economy of Agriculture and the Environment-Essays in Honour of Konrad Hagedorn; Beckmann, V., Padmanabhan, M., Eds.; Springer: Dordrecht, The Netherlands, 2009; pp. 195-222.

32. Orach, K.; Schlüter, M. Uncovering the political dimension of social-ecological systems: Contributions from policy process frameworks. Glob. Environ. Chang. 2016, 40, 13-25. [CrossRef]

33. Miyasaka, T.; Le, Q.B.; Okuro, T.; Zhao, X.; Takeuchi, K. Agent-based modeling of complex social-ecological feedback loops to assess multi-dimensional trade-offs in dryland ecosystem services. Landsc. Ecol. 2017, 32, 707-727. [CrossRef]

34. Boone, R.B.; Galvin, K.; BurnSilver, S.B.; Thornton, P.; Ojima, D.; Jawson, J. Using coupled simulation models to link pastoral decision making and ecosystem services. Ecol. Soc. 2011, 16. [CrossRef]

35. Ntiati, P. Land Use Change Impacts and Dynamics (LUCID) Project Working Paper 7; International Livestock Research Institute: Nairobi, Kenya, 2002.

36. Kimani, K.; Pickard, J. Recent trends and implications of group ranch sub-division and fragmentation in Kajiado District, Kenya. Geogr. J. 1998, 164, 202-213. [CrossRef]

37. Altmann, J.; Alberts, S.C.; Altmann, S.A.; Roy, S.B. Dramatic change in local climate patterns in the Amboseli basin, Kenya. Afr. J. Ecol. 2002, 40, 248-251. [CrossRef]

38. Worden, J.; Reid, R.S.; Gichohi, H. Land-Use Impacts on Large Wildlife and Livestock in the Swamps of the Greater Amboseli Ecosystem; Kajiado District, Kenya (LUCID) Project Working Paper 27; International Livestock Research Institute: Nairobi, Kenya, 2003.

39. Okello, M.M.; Kenana, L.; Maliti, H.; Kiringe, J.W.; Kanga, E.; Warinwa, F.; Bakari, S.; Ndambuki, S.; Massawe, E.; Sitati, N.; et al. Population density of elephants and other key large herbivores in the Amboseli ecosystem of Kenya in relation to droughts. J. Arid Environ. 2016, 135, 64-74. [CrossRef]

40. Homewood, K.; Kristjanson, P.; Trench, P. Staying Maasai? Livelihoods, Conservation and Development in East African Rangelands; Springer Science \& Business Media: Dordrecht, The Netherlands, 2009; Volume 5.

41. Rucina, S.M.; Muiruri, V.M.; Downton, L.; Marchant, R. Late-Holocene savanna dynamics in the Amboseli Basin, Kenya. Holocene 2010, 20, 667-677. [CrossRef]

42. Reid, R.S.; Nkedianye, D.; Said, M.Y.; Kaelo, D.; Neselle, M.; Makui, O.; Onetu, L.; Kiruswa, S.; Kamuaro, N.O.; Kristjanson, P.; et al. Evolution of models to support community and policy action with science: Balancing pastoral livelihoods and wildlife conservation in savannas of East Africa. Proc. Natl. Acad. Sci. USA 2016, 113, 4579-4584. [CrossRef] [PubMed]

43. Serneels, S.; Said, M.Y.; Lambin, E.F. Land cover changes around a major east African wildlife reserve: The Mara Ecosystem (Kenya). Int. J. Remote Sens. 2001, 22, 3397-3420. [CrossRef]

44. Homewood, K.; Lambin, E.F.; Coast, E.; Kariuki, A.; Kikula, I.; Kivelia, J.; Said, M.; Serneels, S.; Thompson, M. Long-term changes in Serengeti-Mara wildebeest and land cover: Pastoralism, population, or policies? Proc. Natl. Acad. Sci. USA 2001, 98, 12544-12549. [CrossRef] [PubMed]

45. Waithaka, J. Maasai Mara-An ecosystem under siege: An African case study on the societal dimension of rangeland conservation. Afr. J. Range Forage Sci. 2004, 21, 79-88. [CrossRef]

46. Robertshaw, P. Early Pastoralists of South-Western Kenya; British Institute in Eastern Africa: Nairobi, Kenya, 1990.

47. Macal, C.M.; North, M.J. Tutorial on agent-based modelling and simulation. J. Simul. 2010, 4, 151-162. [CrossRef]

48. Rounsevell, M.D.; Robinson, D.T.; Murray-Rust, D. From actors to agents in socio-ecological systems models. Philos. Trans. R. Soc. Lond. B Boil. Sci. 2012, 367, 259-269. [CrossRef] [PubMed]

49. Moritz, M.; Buffington, A.; Yoak, A.J.; Hamilton, I.M.; Garabed, R. No Magic Number: An Examination of the Herd-Size Threshold in Pastoral Systems Using Agent-Based Modeling. Hum. Ecol. 2017, 45, 525-532. [CrossRef]

50. Bert, F.E.; Rovere, S.L.; Macal, C.M.; North, M.J.; Podestá, G.P. Lessons from a comprehensive validation of an agent based-model: The experience of the Pampas Model of Argentinean agricultural systems. Ecol. Model. 2014, 273, 284-298. [CrossRef] 
51. Matthews, R.B.; Bakam, I. A combined agent-based and biophysical modelling approach to address GHG mitigation policy issues. In Proceedings of the MODSIM International Congress on Modelling and Simulation, Christchurch, New Zealand, 10-13 December 2007.

52. Mialhe, F.; Becu, N.; Gunnell, Y. An agent-based model for analyzing land use dynamics in response to farmer behaviour and environmental change in the Pampanga delta (Philippines). Agric. Ecosyst. Environ. 2012, 161, 55-69. [CrossRef]

53. Filatova, T.; Verburg, P.H.; Parker, D.C.; Stannard, C.A. Spatial agent-based models for socio-ecological systems: Challenges and prospects. Environ. Model. Softw. 2013, 45, 1-7. [CrossRef]

54. Iwamura, T.; Lambin, E.F.; Silvius, K.M.; Luzar, J.B.; Fragoso, J.M.V. Agent-based modeling of hunting and subsistence agriculture on indigenous lands: Understanding interactions between social and ecological systems. Environ. Model. Softw. 2014, 58, 109-127. [CrossRef]

55. Matthews, R.B.; Gilbert, N.G.; Roach, A.; Polhill, J.G.; Gotts, N.M. Agent-based land-use models: A review of applications. Landsc. Ecol. 2007, 22, 1447-1459. [CrossRef]

56. Smith, B.; Prentice, I.C.; Sykes, M.T. Representation of vegetation dynamics in the modelling of terrestrial ecosystems: Comparing two contrasting approaches within European climate space. Glob. Ecol. Biogeogr. 2001, 10, 621-637. [CrossRef]

57. Smith, B.; Wårlind, D.; Arneth, A.; Hickler, T.; Leadley, P.; Siltberg, J.; Zaehle, S. Implications of incorporating $\mathrm{N}$ cycling and $\mathrm{N}$ limitations on primary production in an individual-based dynamic vegetation model. Biogeosciences 2014, 11, 2027-2054. [CrossRef]

58. Lindeskog, M.; Arneth, A.; Bondeau, A.; Waha, K.; Seaquist, J.; Olin, S.; Smith, B. Implications of accounting for land use in simulations of ecosystem services and carbon cycling in Africa. Earth Syst. Dyn. Discuss. 2013, 4, 235-278. [CrossRef]

59. Pachzelt, A.; Rammig, A.; Higgins, S.; Hickler, T. Coupling a physiological grazer population model with a generalized model for vegetation dynamics. Ecol. Model. 2013, 263, 92-102. [CrossRef]

60. Ahlström, A.; Xia, J.; Arneth, A.; Luo, Y.; Smith, B. Importance of vegetation dynamics for future terrestrial carbon cycling. Environ. Res. Lett. 2015, 10. [CrossRef]

61. Jönsson, A.M.; Lagergren, F.; Smith, B. Forest management facing climate change-An ecosystem model analysis of adaptation strategies. Mitig. Adapt. Strateg. Glob. Chang. 2013, 20, 201-220. [CrossRef]

62. Wu, Z.; Ahlström, A.; Smith, B.; Ardö, J.; Eklundh, L.; Fensholt, R.; Lehsten, V. Climate data induced uncertainty in model-based estimations of terrestrial primary productivity. Environ. Res. Lett. 2017, 12. [CrossRef]

63. Krause, A.; Pugh, T.A.M.; Bayer, A.D.; Doelman, J.C.; Humpenöder, F.; Anthoni, P.; Olin, S.; Bodirsky, B.L.; Popp, A.; Stehfest, E.; et al. Global consequences of afforestation and bioenergy cultivation on ecosystem service indicators. Biogeosciences 2017, 14, 4829-4850. [CrossRef]

64. Hely, C.; Bremond, L.; Alleaume, S.; Smith, B.; Sykes, M.T.; Guiot, J. Sensitivity of African biomes to changes in the precipitation regime. Glob. Ecol. Biogeogr. 2006, 15, 258-270. [CrossRef]

65. Fer, I.; Tietjen, B.; Jeltsch, F. High-resolution modelling closes the gap between data and model simulations for Mid-Holocene and present-day biomes of East Africa. Palaeogeogr. Palaeoclimatol. Palaeoecol. 2016, 444, 144-151. [CrossRef]

66. Ostrom, E. A General Framework for Analyzing Sustainability of Social-Ecological Systems. Science 2009, 325, 419-422. [CrossRef] [PubMed]

67. Wilensky, U. Center for Connected Learning and Computer-Based Modeling, NetLogo (and NetLogo User Manual). Available online: http://ccl.northwestern.edu/netlogo (accessed on 11 April 2018).

68. Grimm, V.; Berger, U.; DeAngelis, D.L.; Polhill, J.G.; Giske, J.; Railsback, S.F. The ODD protocol: A review and first update. Ecol. Model. 2010, 221, 2760-2768. [CrossRef]

69. Grimm, V.; Berger, U.; Bastiansen, F.; Eliassen, S.; Ginot, V.; Giske, J.; Goss-Custard, J.; Grand, T.; Heinz, S.K.; Huse, G.; et al. A standard protocol for describing individual-based and agent-based models. Ecol. Model. 2006, 198, 115-126. [CrossRef]

70. Polhill, G.J.; Parker, D.; Brown, D.G.; Grimm, V. Using the ODD Protocol for Describing Three Agent-Based Social Simulation Models of Land-Use Change. Available online: http://jasss.soc.surrey.ac.uk/11/2/3.html (accessed on 11 April 2018). 
71. BurnSilver, S.B.; Worden, J.; Boone, R.B. Processes of Fragmentation in the Amboseli Ecosystem, Southern Kajiado District, Kenya. In Fragmentation in Semi-Arid and Arid Landscapes; Springer: Dordrecht, The Netherlands, 2008; pp. 225-253.

72. De Leeuw, P.N.; Tothill, J.C. The Concept of Rangeland Carrying Capacity in Sub-Saharan Africa: Myth or Reality; Overseas Development Institute, Pastoral Development Network London: London, UK, 1990.

73. Nkedianye, D.; Radeny, M.; Kristjanson, P.; Herrero, M. Assessing Returns to Land and Changing Livelihood Strategies in Kitengela. In Staying Maasai? Springer: New York, NY, USA, 2009; Volume 5, pp. 115-149.

74. Kenya National Bureau of Statistics, K. Kenya Demographic and Health Survey 2008-2009; Kenya National Bureau of Statistics: Nairobi, Kenya, 2010.

75. Amboseli Ecosystem Stakeholders. Amboseli Ecosystem Management Plan (2008-2018). Available online: http:/ /www.amboseliecosystemtrust.org/uploads/3/7/4/8/3748244/amboseli_ecosystem_final_ plan-jan_2009.pdf (accessed on 11 April 2018).

76. Osano, P.M.; Leal Filho, W.; Said, M.Y.; de Leeuw, J.; Moiko, S.S.; Ole Kaelo, D.; Schomers, S.; Birner, R.; Ogutu, J.O. Pastoralism and ecosystem-based adaptation in Kenyan Masailand. Int. J. Clim. Chang. Strateg. Manag. 2013, 5, 198-214. [CrossRef]

77. Kibet, S.; Nyangito, M.; MacOpiyo, L.; Kenfack, D. Tracing innovation pathways in the management of natural and social capital on Laikipia Maasai Group Ranches, Kenya. Pastoralism 2016, 6, 16. [CrossRef]

78. McCabe, J.; Smith, N.; Leslie, P.; Telligman, A. Livelihood diversification through migration among a pastoral people: Contrasting case studies of Maasai in northern Tanzania. Hum. Org. 2014, 73, 389-400. [CrossRef]

79. Grimm, V.; Revilla, E.; Berger, U.; Jeltsch, F.; Mooij, W.M.; Railsback, S.F.; Thulke, H.-H.; Weiner, J.; Wiegand, T.; DeAngelis, D.L. Pattern-Oriented Modeling of Agent-Based Complex Systems: Lessons from Ecology. Science 2005, 310, 987-991. [CrossRef] [PubMed]

80. Climate Research Unit (CRU) University of East Anglia. CRU Time Series (CRUTS) High Resolution Gridded Datasets. Available online: https://crudata.uea.ac.uk/cru/data/hrg/ (accessed on 11 April 2018).

81. Bodin, P.; Olin, S.; Pugh, T.A.M.; Arneth, A. Accounting for interannual variability in agricultural intensification: The potential of crop selection in Sub-Saharan Africa. Agric. Syst. 2016, 148, 159-168. [CrossRef]

82. Bulte, E.H.; Boone, R.B.; Stringer, R.; Thornton, P.K. Elephants or onions? Paying for nature in Amboseli, Kenya. Environ. Dev. Econ. 2008, 13, 395-414. [CrossRef]

83. Thornton, P.K.; BurnSilver, S.B.; Boone, R.B.; Galvin, K.A. Modelling the impacts of group ranch subdivision on agro-pastoral households in Kajiado, Kenya. Agric. Syst. 2006, 87, 331-356. [CrossRef]

84. Rasmussen, L.V.; Rasmussen, K.; Reenberg, A.; Proud, S. A system dynamics approach to land use changes in agro-pastoral systems on the desert margins of Sahel. Agric. Syst. 2012, 107, 56-64. [CrossRef]

85. Sundstrom, S.; Tynon, J.F.; Western, D. Rangeland Privatization and the Maasai Experience: Social Capital and the Implications for Traditional Resource Management in Southern Kenya. Soc. Nat. Resour. 2012, 25, 483-498. [CrossRef]

86. Zinsstag, J.; Bonfoh, B.; Zinsstag, G.; Crump, L.; Alfaroukh, I.O.; Abakar, M.F.; Kasymbekov, J.; Baljinnyam, Z.; Liechti, K.; Seid, M.A.; et al. A vision for the future of pastoralism. Rev. Sci. Tech. 2016, 35, 693-699. [CrossRef] [PubMed]

87. Kirkbride, M.; Grahn, R. Survival of the fittest: Pastoralism and climate change in East Africa. Oxfam Policy Pract. Agric. Food Land 2008, 8, 174-220.

88. Galvin, K.A. Transitions: Pastoralists Living with Change. Annu. Rev. Anthropol. 2009, 38, 185-198. [CrossRef]

89. Martin, R.; Müller, B.; Linstädter, A.; Frank, K. How much climate change can pastoral livelihoods tolerate? Modelling rangeland use and evaluating risk. Glob. Environ. Chang. 2014, 24, 183-192. [CrossRef]

90. Pricope, N.G.; Husak, G.; Lopez-Carr, D.; Funk, C.; Michaelsen, J. The climate-population nexus in the East African Horn: Emerging degradation trends in rangeland and pastoral livelihood zones. Glob. Environ. Chang. 2013, 23, 1525-1541. [CrossRef]

91. Martin, R.; Linstädter, A.; Frank, K.; Müller, B. Livelihood security in face of drought-Assessing the vulnerability of pastoral households. Environ. Model. Softw. 2016, 75, 414-423. [CrossRef]

92. Lamprey, R.H.; Reid, R.S. Expansion of human settlement in Kenya's Maasai Mara: What future for pastoralism and wildlife? J. Biogeogr. 2004, 31, 997-1032. [CrossRef] 
93. Ogutu, J.O.; Piepho, H.P.; Dublin, H.T.; Bhola, N.; Reid, R.S. Dynamics of Mara-Serengeti ungulates in relation to land use changes. J. Zool. 2009, 278, 1-14. [CrossRef]

94. Basupi, L.V.; Quinn, C.H.; Dougill, A.J. Historical perspectives on pastoralism and land tenure transformation in Ngamiland, Botswana: What are the policy and institutional lessons? Pastoralism 2017, 7. [CrossRef]

95. Dong, S.; Wen, L.; Liu, S.; Zhang, X.; Lassoie, J.P.; Yi, S.; Li, X.; Li, J.; Li, Y. Vulnerability of Worldwide Pastoralism to Global Changes and Interdisciplinary Strategies for Sustainable Pastoralism. Ecol. Soc. 2011, 16, 85-99. [CrossRef]

96. Seno, S.K.; Shaw, W.W. Land Tenure Policies, Maasai Traditions, and Wildlife Conservation in Kenya. Soc. Nat. Resour. 2002, 15, 79-88. [CrossRef]

97. Gadd, M.E. Conservation outside of parks: Attitudes of local people in Laikipia, Kenya. Environ. Conserv. 2005, 32, 50-63. [CrossRef]

98. Wishitemi, B.E.L.; Momanyi, S.O.; Ombati, B.G.; Okello, M.M. The link between poverty, environment and ecotourism development in areas adjacent to Maasai Mara and Amboseli protected areas, Kenya. Tour. Manag. Perspect. 2015, 16, 306-317. [CrossRef]

99. Ogutu, J.O.; Kuloba, B.; Piepho, H.P.; Kanga, E. Wildlife Population Dynamics in Human-Dominated Landscapes under Community-Based Conservation: The Example of Nakuru Wildlife Conservancy, Kenya. PLoS ONE 2017, 12, e0169730. [CrossRef] [PubMed]

100. Jandreau, C.; Berkes, F. Continuity and change within the social-ecological and political landscape of the Maasai Mara, Kenya. Pastoralism 2016, 6. [CrossRef]

101. Vuorio, V.; Muchiru, A.; Reid, R.S.; Ogutu, J.O. How pastoralism changes savanna vegetation: Impact of old pastoral settlements on plant diversity and abundance in south-western Kenya. Biodivers. Conserv. 2014, 23, 3219-3240. [CrossRef]

102. Boone, R.B.; Lesorogol, C.K. Modeling Coupled Human-Natural Systems of Pastoralism in East Africa. In Building Resilience of Human-Natural Systems of Pastoralism in the Developing World; Springer: Dordrecht, The Netherlands, 2016; pp. 251-280.

103. Thompson, M.; Homewood, K. Entrepreneurs, elites, and exclusion in Maasailand: Trends in wildlife conservation and pastoralist development. Hum. Ecol. 2002, 30, 107-138. [CrossRef]

104. Groom, R.J.; Western, D. Impact of Land Subdivision and Sedentarization on Wildlife in Kenya's Southern Rangelands. Rangel. Ecol. Manag. 2013, 66, 1-9. [CrossRef]

105. Lee, J.-S.; Filatova, T.; Ligmann-Zielinska, A.; Hassani-Mahmooei, B.; Stonedahl, F.; Lorscheid, I.; Voinov, A.; Polhill, G.; Sun, Z.; Parker, D.C. The Complexities of Agent-Based Modeling Output Analysis. J. Artif. Soc. Soc. Simul. 2015, 18. [CrossRef]

106. Ward, J.A.; Evans, A.J.; Malleson, N.S. Dynamic calibration of agent-based models using data assimilation. R. Soc. Open Sci. 2016, 3. [CrossRef] [PubMed]

107. Platts, P.J.; Omeny, P.A.; Marchant, R. AFRICLIM: High-resolution climate projections for ecological applications in Africa. Afr. J. Ecol. 2014, 53, 103-108. [CrossRef]

108. Anderson, D.M.; Bollig, M. Resilience and collapse: Histories, ecologies, conflicts and identities in the Baringo-Bogoria basin, Kenya. J. East. Afr. Stud. 2016, 10, 1-20. [CrossRef]

109. Okello, M.M.; Buthmann, E.; Mapinu, B.; Kahi, H.C. Community Opinions on Wildlife, Resource Use and Livelihood Competition in Kimana Group Ranch Near Amboseli, Kenya. Open Conserv. Biol. J. 2011, 5, 1-12. [CrossRef]

110. Water Resources and Energy Management International. Mara River Basin Monograph, Mara River Basin Transboundary Integrated Water Resources Management and Development Project; Final Technical Report; Water Resources and Energy Management International Inc.: Atlanta, GA, USA, 2008.

111. Okello, M.M.; D'Amour, D.E. Agricultural expansion within Kimana electric fences and implications for natural resource conservation around Amboseli National Park, Kenya. J. Arid Environ. 2008, 72, 2179-2192. [CrossRef]

(C) 2018 by the authors. Licensee MDPI, Basel, Switzerland. This article is an open access article distributed under the terms and conditions of the Creative Commons Attribution (CC BY) license (http:/ / creativecommons.org/licenses/by/4.0/). 


\title{
Chiefs in a Democracy: A Case Study of the 'New' Systems of Regulating Firewood Harvesting in Post-Apartheid South Africa
}

\author{
Sarah J. Findlay * and Wayne C. Twine \\ School of Animal, Plant and Environmental Sciences, University of the Witwatersrand, Private Bag 3 Wits, \\ Johannesburg 2050, South Africa; wayne.twine@wits.ac.za \\ * Correspondence findlaysj@gmail.com; Tel.: +27-83-969-2084
}

Received: 5 January 2018; Accepted: 7 March 2018; Published: 12 March 2018

\begin{abstract}
Much of the international commons literature reveals a decreased functioning of local traditional institutions that regulate natural resource harvesting. In South Africa, it is believed that the creation of new democratic structures at the end of Apartheid has contributed significantly to the deterioration in traditional resource regulation and this in turn has led to the extensive resource degradation seen in parts of the country. Many of these assertions, though, remain anecdotal in nature. Given the high reliance by rural households on natural resources, and the serious negative implications that over-use has on livelihood security, understanding how well or poorly such commons are regulated is key to ensuring the sustainability of such resource-dependent populations. The aim of this study was therefore to examine systems of resource governance, focusing specifically on firewood, and to determine the roles of traditional and democratically elected community leaders in six rural villages spanning two chieftaincies in Bushbuckridge, South Africa. In each study village, five local leaders were interviewed and five community focus groups were conducted. Results indicate that most parties still regard the Chief as the ultimate authority for regulating firewood harvesting. However, overall firewood management appears weak, at best, across the region. Although some authors attribute this to community confusion over the roles of local leaders in a new democracy, we provide evidence that other socio-political factors, including political expediency, may be driving the increasingly relaxed implementation of these firewood management systems. With resource dependence remaining a vital contributor to livelihood security across the developing world and with many rural communities facing increasing strain under local resource depletion, these findings shed new light on the complex social dynamics underlying the widely reported weakening of traditional institutions in South Africa. In so doing, it offers insights into local firewood governance that can be used to combat these challenges and thereby reduce regional social and ecological vulnerability being experienced in communal landscapes across the region.
\end{abstract}

Keywords: institution; natural resources; firewood; South Africa; traditional authorities; governance systems

\section{Introduction}

Hardin's provocative 'Tragedy of the Commons' publication (1968) initiated the contemporary debate on common property resource management across the globe. He asserted that all resources that fell under communal property rights would invariably become overused (Hardin, 1968 [1]). While 'tragedies' of this nature have indeed occurred worldwide, an equally extensive body of research resists these purely pessimistic outlooks and reveals that resource degradation is not an inevitable outcome of communal resource harvesting (Ostrom et al., 1999, Poteete and Ostrom 2004, Hartter and Ryan 2010 [2-4]). Examples from across the globe demonstrate that common property systems are 
not necessarily synonymous with circumstances of 'open access' (see Ostrom et al., 1999 [2]) and that successful collective action and effective resource management can indeed be achieved in multiple contexts. With millions of households directly and indirectly dependent on natural resources for everyday needs, there is a critical need to explore strategies that not only have the potential to enhance the livelihoods of those that extract them, but also that improve the landscapes from which they are extracted.

Within this scholarship, institutions have been repeatedly identified as a key factor in the success or failure of natural resource management (Ostrom 1990, Wells 1998, Acheson 2006 [5-7]). Institutions are described as the formal and informal structures or principles that guide human-environment relations and that shape perceptions, activities and behaviors associated with resource harvesting (Goetz 1995, Folke et al., $1996[8,9])$. Formal institutions, for example, can be used to manage community's access to resources either by specifying how the land can be used (Belcher et al., 2005 [10]) or by enforcing resource-focused laws (Barrett et al., 2005, Cocks et al., 2008 [11,12]). These regulations influence harvesting decisions by incentivizing (or disincentivizing) certain behaviors, often through the prospect of punishment for disobedience. In this way, institutions regulate the ways in which resource users interact with their resources and they should therefore be central to the enquiry into individual and regional natural resource consumption (Seidman 1992 [13]). Following this, governance can be described as the relationships between processes and structures that define power dynamics in a specific context and the mechanisms by which decision-making takes place (Graham et al., 2003 [14]). Therefore, and for the purposes of this paper, institutions refer specifically to the institutional actors, including individuals and entities as the key players, as well as the rules, laws and governance arrangements they implement (Wells 1998 [6]).

Importantly, institutions are not static inert features of a system (Kepe and Scoones 1999, Adger $2000[15,16])$. Rather, institutions evolve, adapt and respond to context-specific internal and external drivers of change (Ostrom et al., 1999, Kepe and Scoones 1999, Potts et al., 2016 [2,15,17]). Here, changes to the broader social, cultural, economic and political landscape can impact on the effectiveness of institutions to moderate use (see Nkhata et al., 2017, Le Tourneau and Beaufort, $2017[18,19])$. Indeed, failure of societies to innovate new forms of governance in response to new stresses may mean that previously effective systems of resource control become ineffectual against the new conditions of resource extraction and could lead to over-use. Differences between historical rules and new local contexts therefore often lead to weak regulation as the incentives to obey such laws no longer outweigh the pressures residents face (Dietz et al., 2003, Ostrom and Nagendra, 2006, Ormsby, 2013 [20-22]). Institutions therefore need to adapt to novel threats and absorb such system shifts to ensure ongoing sustainable management (Ostrom et al., 1999, Adger 2000, Nkhata et al., 2017, Armitage $2005[2,16,18,23])$.

Much research conducted worldwide, however, demonstrates the poor capacities of institutions to adapt to change and the consequences are generally some degree of resource degradation (Kepe and Scoones 1999, Nkhata et al., 2017, Armitage 2005, Frost et al., 2007 [15,18,23,24]). This, in turn, has the potential to directly undermine the livelihood security of those dependent on such natural resources for their everyday needs. Specifically, in the developing world, interacting pressures such as modernization and political revolutions (including colonization and political independence) have been shown to greatly weaken historically effective systems of resource regulation. For example, Brown and Lassoie (2010) found in Cameroon that the installation of local modern institutions, resulting from a new democratic national political order, had diluted the importance of cultural beliefs in younger generations and had also blurred the legitimacy and authority of traditional leaders in the eyes of local communities. This contributed to a diminished adherence to traditional rituals associated with resource harvesting and ultimately led to the deterioration of the local resource base (Brown and Lassoie 2010 [25]). The institutions that previously governed resource use therefore failed to adequately adapt to and buffer against the external forces of cultural and political change and this ultimately produced a de facto open access resource system. Here, the opportunity to significantly improve 
local socio-economic and landscape conditions through sustainable community forestry programs was curtailed by ineffective institutional structures (Brown and Lassoie 2010 [25]). Case studies that describe similar instances of erosion in customary resource systems and their impact on local livelihoods are widespread in the literature including examples from Zimbabwe (Frost et al., 2007, Mukamuri et al., 2003 [24,26]), Malawi (Kayambazinthu et al., 2003 [27]), Tanzania (Wilfred et al., 2007 [28]) and India (Ormsby, 2013 [22]).

South Africa is no exception to this general observation where changes in the political landscape, even at a national level, have impacted on local resource control and these changes have been linked to a growing number of reports describing the increasingly unsustainable use of natural resources, including firewood (e.g., Andrew et al., 2003, Shackleton and Stickler, 2015, Thondhlana et al., 2015 [29-31]). Even though it is accepted that institutional, and specifically traditional, management in natural resource use systems has decreased across the country (see Kirkland et al., 2007, Twine et al., 2003, [32,33]), most commentary in published South African literature has been cursory about this change rather than explicit. Despite large volumes of work describing key features of natural resource use, including their contributions to local livelihoods (see following section, Shackleton and Shackleton, 2004 [34]) and the numbers, types and volumes of species extracted (Shackleton and Stickler 2015, Dovie et al., 2003, Shackleton and Shackleton, 2000, Nott and Thondhlana, 2017, [30,35-37] ), few studies (see Kepe and Scoones, 1999, Kirkland et al., 2007; Twine et al., 2003, [15,32,33]) have specifically examined natural resource institutions and the impacts of socio-political changes thereon in regions of South Africa. In order to close this knowledge gap, this paper therefore sets out to explore the current state of natural resource management, the actors involved and the degree of institutional functioning, specifically regarding firewood, in six villages of the resource-dependent region of Bushbuckridge, South Africa. Given the centrality of firewood as an essential energy source to millions of households in the country, the management of such resource harvesting is therefore fundamental to sustaining the livelihoods of these resource-dependent populations. Here, understanding how institutions have been shaped, changed and complied with by those that devise and observe them can offer important insights into the current and future reality of natural resource governance on the ground (Agrawal 2003 [38]) and these observations may be useful to other regions as they navigate similar economic, cultural and political transitions as those experienced in the communal lands of South Africa.

This paper starts by exploring the South African context in terms of both natural resource use and historical socio-political change. We then examine our case study region of Bushbuckridge where we look at the current systems of firewood regulation as a whole and attempt to establish the degree of institutional functioning in firewood management, as perceived by local residents. This is achieved by examining different stakeholders' perspectives on the roles and responsibilities of local institutions (e.g., traditional authorities, village community development forums, municipalities and community residents) in the regulation of firewood. These views were also used to determine why such institutional functioning is thought to exist (the drivers) and what could be done to improve such systems. The paper then ends by providing a summary of what was seen and describes the implications of these findings on resource use and livelihood security in the region.

\subsection{Resource Use in South African Communal Lands}

Although resource use characterized South African indigenous populations for centuries (von Maltitz and Shackleton, 2004 [39]), Apartheid-era policies saw the large-scale relocation of black populations onto small tracts of land known as Bantustans and this resulted in the majority of the South African populace effectively occupying only $13 \%$ of rural land. The establishment of these 'homelands' resulted in high population densities, households with limited access to other forms of livelihood capital, and often occurred in regions where climatic conditions were not particularly conducive to subsistence agriculture (Shackleton, 2004 [40]). While these policies were critical political mechanisms to control black citizens, this forced influx of relocated households dramatically increased 
the number of households harvesting and consuming local environmental produce to survive, and this substantially intensified the resource use pressures on those small parcels of land (Shackleton, 2004 [40]). This dependence on resources continues today where many rural communities in South Africa continue to rely heavily on environmental resources for physical, financial and social security (Shackleton and Shackleton, 2004 [34]).

A key example is firewood, where research across the country shows that an overwhelming majority of investigated rural households continue to use firewood as their dominant energy source (Shackleton and Stickler 2015, Dovie et al., 2002, Nott and Thondhlana, 2017, Shackleton et al., 2004, Giannecchini et al., 2007, Madubansi and Shackleton, 2007 [30,35,37,41-43]) and this often occurs despite household electrification and government-funded free basic electricity allowances (Madubansi and Shackleton, 2007, Matsika et al., 2012 [43,44]). Here, firewood is generally collected free-of-charge from surrounding communal landscapes and is a cheap alternative to electricity. Given the high levels of poverty and lack of alternative livelihood options that often characterize these communities, firewood use is often a critical cost-saving strategy. Firewood is also seen as an important contributor to social and cultural practices, a role that other energy sources cannot fulfill (see White et al., 1997 [45]). From this, Shackleton et al. (2007) [46] expect that rural firewood use will remain unchanged at least into the medium-term as household financial insecurity and preferences will, for the most part, continue to sideline the use of substitute fuels.

Bearing this heavy dependence in mind, and in light of the growing number of households turning to the firewood trade to supplement incomes (Giannecchini et al., 2007 [42]), much research conducted in Bushbuckridge (Mpumalanga Province, South Africa) shows how local firewood availability has decreased in recent times under this intensifying pressure (Giannecchini et al., 2007, Matsika et al., 2012, Twine and Holdo, 2016 [42,44,47]). This has been shown in local environmental changes including decreases in overall tree density (Matsika et al., 2012, Shackleton et al., 2005 [44,48]), higher proportions of mature tree stems being chopped (Shackleton et al., 2005 [48]) and reduced availability of preferred firewood species (Madubansi and Shackleton, 2007 [43]). Changes to the ways in which households acquire firewood also reflect such regional shortages and include households travelling further distances to obtain firewood (Madubansi and Shackleton, 2007 [43]), more households buying firewood rather than self-collecting (Giannecchini et al., 2007, Madubansi and Shackleton, 2007 [42,43]), the harvesting from neighboring village commons (Twine et al., 2003 [33]) and the harvesting of less preferred species and size classes (Matsika et al., 2012 [44]). These studies form part of mounting evidence highlighting the intense resource exploitation of firewood in many rural South African landscapes, specifically in Mpumalanga, and in some cases these have been defined as unsustainable in the long-term (Matsika et al., 2012, Shackleton et al., 2005 [44,48]).

Critically, the consequences of these resource shortages on livelihoods cannot be overlooked. Madubansi and Shackleton (2007) [43] suggest that the increased harvesting times (as noted above) not only increase the opportunity costs associated with firewood collection, but also impact on the allocation of time and labor to other livelihood activities in the household. Furthermore, Brouwer et al. [49] comment that such shifts in the allotted resources to livelihood pursuits may render households further impoverished as fewer labor resources and less time are spent on other potential income-generating activities. These examples therefore show how the impacts of resource degradation extend beyond simply decreasing the volumes of available resources in a particular landscape, but also clearly affect other elements of resource users' livelihood strategies, decisions and well-being. Sustainable resource extraction is therefore fundamental not only to ensuring landscape conservation, but also to reducing socio-economic vulnerability of those dependent on such resources.

Many authors attribute the observed over-harvesting to both burgeoning populations as well as to the fast-eroding systems of local control (Kirkland et al., 2007, Twine et al., 2003, von Maltitz and Shackleton 2004, Giannecchini et al., 2007, Cousins et al., 2007 [32,33,39,44,50]). In terms of the latter, many of these resource-use systems are thought to have transitioned from well-managed communal property to essentially 'open-access' firewood systems (Kirkland et al., 2007, von Maltitz 
and Shackleton 2004, Cousins et al., 2007 [32,39,50]). The following section unpacks in more detail the different factors that are believed to be reducing the effectiveness of local firewood management in many of South Africa's rural communities.

\subsection{Past and Present Institutional Governance of Communal Lands in South Africa}

In the pre-colonial era, natural resource harvesting was regulated by the local traditional authorities, specifically the chiefs and headmen (known locally as Ndunas) (Thornton 2002 [51]). During both the colonial and Apartheid regimes, the then-governments used these same traditional institutions to apply their own set of rules regarding resource use. Therefore, traditional institutions became part of the Apartheid homeland bureaucracy. The implementation of local harvesting systems, based on the guilty paying fines or completing community service for disobeying specific resource rules, controlled, to some extent, resource harvesting in the region (Twine 2005 [52]). This local control, however, has gradually yet noticeably weakened, particularly since the birth of democracy in 1994 (Twine et al., 2003, Cousins et al., 2007, Thornton 2002, Twine 2005 [33,50-52]). This has been attributed to three dominant factors. Firstly, the induction of the new democratic government triggered a change in the perceptions of village residents, particularly among the youth, regarding the authority and power of traditional leaders. The perceived close, often corrupt, ties between traditional leaders and the former Apartheid government bred widespread mistrust and suspicion of tribal leadership both during and after Apartheid (King 2005 [53]). The continuation of tribal institutional rule, despite democracy, has therefore generated pervasive discontent in much of the rural population (King 2005 [53]), and in many ways has led to blatant disrespect for local traditional leaders and their attempts at resource management (Twine et al., 2003 [33]).

Secondly, the new government, upon appointment, reduced the financial resources previously granted to traditional authorities. This reduced the capacity of local leaders to hire patrolmen and thereby police communal areas and this, in turn, has severely impeded their ability to enforce natural resource management rules (Kirkland et al., 2007, Twine 2005 [32,52]). Thirdly, the inauguration of the new government generated confusion regarding the modern function of the hereditary traditional authorities in a new democratic society (Twine et al., 2003, Cousins et al., 2007 [33,50]). Other forms of governance, including provincial officials, local municipalities and village-level governance structures, emerged under the democratic dispensation. Traditional leaders now share authority and responsibility with these newly established institutions, but some research shows that the roles and responsibilities of these separate groups can be undefined, ambiguous and often conflicting (Thondhlana et al., 2015, Kirkland et al., 2007, King 2005, [31,32,53]). These uncertainties and capacity insufficiencies have created an 'institutional vacuum' in the region, where the system of governance has become increasingly unclear and the access to and consumption of natural resources is no longer as strongly moderated (Kirkland et al., 2007, Twine et al., 2003 [32,33]).

Little research has set out to identify how natural resources are actually regulated in post-1994 South Africa or what local leaders themselves deem as their exact function in these systems. Given the wealth of data and insight on socio-ecological systems in Bushbuckridge resulting from sustained long-term research conducted by University of the Witwatersrand and other institutions in the region, Bushbuckridge was identified as a key opportunity for this research. The aim of this study was therefore to explore the current systems of firewood regulation in Bushbuckridge as a whole and to establish the degree to which relevant institutions were carrying out their duties in regulating firewood harvesting, as perceived by local residents. In so doing, the study also sought to investigate some of the key factors affecting the levels of institutional functioning observed. 


\section{Materials and Methods}

\subsection{Study Site}

This study was conducted in six villages spanning two chieftaincies that fall under the Bushbuckridge local municipality in Mpumalanga Province $\left(31^{\circ} 0^{\prime}-31^{\circ} 35^{\prime} \mathrm{E} ; 24^{\circ} 30^{\prime}-25^{\circ} 0^{\prime} \mathrm{S}\right)$, South Africa (see Figure 1). In the Amashangane chieftaincy, the three villages were New Forest A, Merry Pebble Stream (MP Stream) and Arthur Stone and in the Mnisi chieftaincy, the study villages were Cottondale, Burlington and Islington. In order to examine similarities and differences in the firewood regulation systems of different villages, the study villages were purposively selected as they share similar patterns in biophysical and socio-economic conditions, i.e., any differences noted in the regulation systems were unlikely to result from biophysical and socio-economic characteristics.

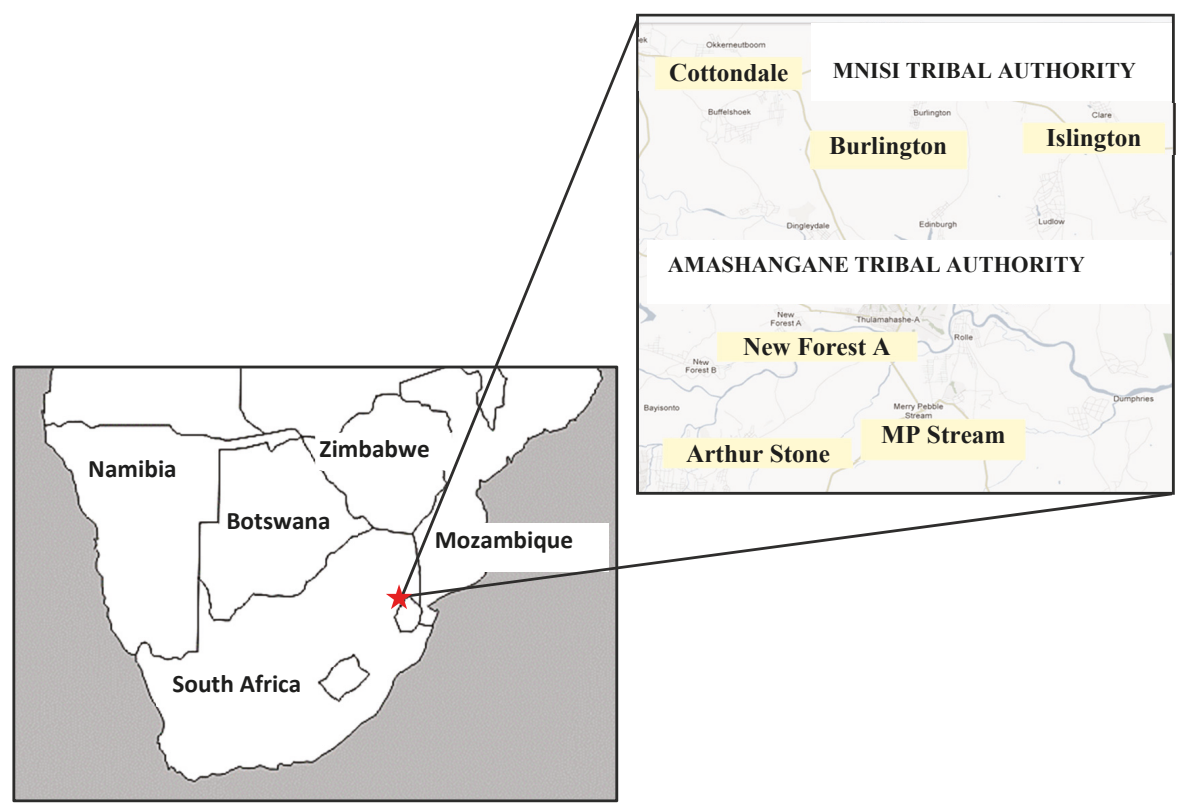

Figure 1. A map of the six study villages in the Bushbuckridge region, South Africa.

\subsection{Biophysical Conditions}

The Bushbuckridge local municipality is situated in the north-eastern portion of Mpumalanga province and is bordered in the east by Kruger National Park. The region is characterized by hot humid summers and mild winters with an annual temperature averaging $22{ }^{\circ} \mathrm{C}$. The mean annual rainfall ranges from $700 \mathrm{~mm}$ to $500 \mathrm{~mm}$, from west to east (Shackleton et al., 1994 [54]). The vegetation type is broadly defined as semi-arid savanna woodland, where species of Combretaceae and Mimosaceae prevail throughout the region (Emanuel et al., 2005 [55]).

\subsection{Socio-Economic Characteristics}

The six villages fall within the boundaries of the former homeland of Gazankulu. Despite the dissolution of the homeland system in 1994, many of these regions, including Bushbuckridge, remain characterized by poor economic development and low employment levels as during Apartheid (Thornton 2002 [51]). Most households rely heavily on migrant labor remittances and government social grants (Kirkland et al., 2007, Shackleton and Shackleton 2000, Thornton 2002 [32,36,51]), 
with subsistence agriculture and natural resource harvesting playing a significant role in supplementing cash-based incomes (Emanuel et al., 2005, Shackleton 2000 [55,56]). Dependence on natural resources, such as firewood, wild fruit, and medicinal plants remains widespread in this region (Ifegbesan et al., 2009 [57]), and these products are generally collected from the communal lands that surround each village settlement and fall under communal tenure.

\subsection{Institutional Context}

The Bushbuckridge local municipality covers roughly $2590 \mathrm{~km}^{2}$ and is one of five local municipalities of the Ehlanzeni district of Mpumalanga Province (Bushbuckridge Local Municipality, 2014, [58]). The municipality is divided into 37 wards and each ward consists of 5-10 villages. Within this region, all communities are governed by dual leadership structures: civic government and Traditional Councils (Thornton, 2002 [51]) that occur at different spatial scales (see Table 1).

Community Development Forums (CDFs) represent the lowest tier of municipal governance and comprise two representatives from each village civic group (Community Based Organization or Civic Association) together with the village Nduna or Headman (a representative of the Chief's Traditional Council) (Cousins et al., 2007 [50]). The next level of governance is the ward council and this consists of delegates from CDFs across different villages as well as a nominated Ward Councilor. These councils present village-level matters to the local municipality and are answerable both to higher-level municipal offices as well as to community-level CDFs (Cousins et al., 2007 [50]).

In terms of traditional leadership, the Chief's jurisdiction generally extends to between ten and 12 villages. In each of these villages, the Headman or Nduna acts on behalf of the Chief. The Ndunas meet regularly to form Traditional Councils that, under the directive of the Chief, discuss issues around development and general village concerns. The Councils also resolve individual or household disputes and try local cases brought before them (von Maltitz and Shackleton 2004, Cousins et al., $2007[39,50])$. The traditional authorities also theoretically regulate the use of natural resources in the village commons.

Table 1. Institutions operating at various spatial scales across the Bushbuckridge study site.

\begin{tabular}{ccc}
\hline Scale & Municipal Government & Traditional Authority \\
\hline Village level & Community Development Forum (CDF) & Nduna \\
Meso level & Ward Councilor, Ward Council & Chief, Traditional Council \\
Municipality level & Local municipal government & \\
\hline
\end{tabular}

\subsection{Data Collection}

Fieldwork, comprising community focus groups and informant interviews, was conducted in September and October 2011. Five focus groups were carried out in each village giving a total of 30 focus groups across the study. These groups were stratified by age (18-30, 30-50, >50) and gender to avoid possible patriarchal biases. Due to the pervasiveness of migrant labor in the area (see Kahn et al., 2012 [59]), economically active men (aged 30-50) were largely absent and were therefore unavailable to participate. Group sizes varied between three and 12 people, with the mean group size being roughly six people. Each focus group was run as a semi-structured group interview and was conducted in the local language of Shangaan via a translator. These discussions, although flexible, aimed to address specific predetermined topics and were designed to elicit information on the following: (1) Why firewood is used and laws about firewood; (2) The implementer of firewood laws; (3) The local firewood permitting system; (4) The roles and responsibilities of different entities; (5) The main challenges in regulating firewood; and (6) Potential solutions to prevent future over-harvesting. The answers recorded were the final consensus answers reached by the group. To supplement general question-and-answer-based information, some Participatory Rural Appraisal techniques were also used. For example, each focus group was asked to rank all the institutions according to their level of 
responsibility in firewood regulation. Each of these institutions was then given a score from nine (9) to one (1) (representing most important institution to least important institution respectively) and these scores were then averaged across all focus groups.

In order to obtain a diversity of perspectives from local leadership on firewood regulation systems, representatives from traditional institutions and democratic structures from each hierarchical level (see Table 1 above) were accessed. In-depth interviews were therefore carried out with the Nduna as well as the chairperson, secretary and another member of the CDF of each village. At the ward level, each of the Ward Councilors as well as Chief Mnisi (from Mnisi Traditional Authority) and the secretary of the Amashangane Traditional Affairs (in lieu of the Chief who was away) were interviewed. Attempts at interviewing municipal or provincial officials were unsuccessful despite extensive enquiry. A total of 30 people were interviewed. The interviews were all conducted in the local language of Shangaan via a translator and were 30-40 min long, depending on the length of responses. In the interviews, the same questions as those in the focus groups were asked and data on perceptions of firewood governance and the institutional roles thereof were gathered. Responses from focus groups and interviews were then categorized and coded to provide numerical data for analysis. These data were then totaled for comparison between villages. In terms of the rank score data, the mean rank score was calculated for each institutional actor combining data from across all villages. Direct quotes from both the focus groups and interviews were also used as supporting data to the quantitative findings. Ethics clearance was obtained from the Wits Non-Medical Human Subjects Ethics Committee (Protocol number: H110913), and permission from each village's Nduna, heads of the CDFs and Chiefs was also obtained prior to data collection.

\section{Results}

\subsection{Governance Regime}

\subsubsection{Perceptions Regarding the Implementer of Local Firewood Laws}

It was unanimous among community members and leaders alike that local laws about harvesting firewood existed. However the specifics of these varied to such an extent that enumeration of responses was unfeasible. That being said, a common law mentioned by most groups was that the cutting of live trees for firewood was strictly prohibited. Most focus groups (22 of 30) and leaders (18 of 30) across both chieftaincies cited the Chief as the primary implementer of local firewood laws. Although other agents in traditional institutions, such as the Nduna and the Chief's police, and non-tribal authorities including nature conservation rangers and various government departments, were also mentioned, these were each only cited once.

\subsubsection{Permission}

Most respondents (all leaders and 29 of 30 focus groups) agreed that permission was required to harvest firewood. While most parties also agreed that the Chief was the only authority who could issue firewood permits, a handful of focus groups (5) and two leaders also indicated that the Nduna could grant permission. Respondents were divided as to who needs to obtain such permission, be it all harvesters or only commercial harvesters. Many respondents (13 focus groups and 23 leaders) also agreed that everyone requires a permit. However, seven groups and two leaders said that it was only commercial harvesters who needed permission because they were collecting much larger firewood loads. Finally, variations in the price of the harvesting permits were also seen across all respondents. Each focus group and leader offered a different value both for the permit and the harvestable amount it allowed. These ranged from 'no payment required', to R5 per single piece of wood to R100 for two or three days of continuous harvesting. Eight focus groups also conceded that they did not actually know the cost of a permit. 


\subsubsection{Roles of Different Leaders}

Each group was asked to identify the roles of different institutions and these were clustered according to the level of responsibility required to carry these out i.e., high, intermediate and none. Every focus group and every leader acknowledged that the Chief's duties in firewood management occurred at the highest tier of responsibility (Tables 2 and 3). The supremacy of the Chief's duties was indicated by the 24 focus groups and 11 leaders that saw him as the 'ultimate authority' in firewood governance (Tables 2 and 3). Descriptions of his role included 'overseer of everything', 'firewood [is] his responsibility' and the 'regulator of the land'. The next two most commonly cited responsibilities were those of fining transgressors and having security that actively patrol the communal lands (Tables 2 and 3). These responsibilities immediately ascribe an upper level of authority to the Chief, who has the power to finalize punishment for lawbreakers and who also has 'lower level' personnel under his command.

Unlike the consistent descriptions of the Chief, discussions about the role of other institutions generated varied responses across all villages. For example, while 18 focus groups stated that the Nduna could fine guilty parties for firewood transgressions, another eleven groups stated outright that he could not (Table 2). Similarly, 12 groups suggested that the Nduna had active security patrolmen, while another four groups said that he had 'no responsibility' in firewood regulation at all (Table 2). The responses about the Nduna's responsibilities were also equally divided between leaders (Table 3).

These differences in perceptions were also seen in the descriptions of the CDF, Civic Association and community members generally. Here, the focus groups consistently suggested that these institutions had 'no responsibility' and only occasionally ascribed duties such as 'reporting illegal harvesters to a higher power' or 'advising not to harvest' (Table 2). In contrast, the leaders more commonly stated that these organizations, and the CDF specifically, could 'report illegal harvesters to a higher authority', could 'advise community members not to harvest' and could 'call meetings' (Table 3). In the same way, while 23 and 25 focus groups stated that the municipal and provincial government, respectively, had 'no responsibility' in firewood management (Table 2), leaders occasionally suggested that these officials did have some intermediate role to play (Table 3). From this, the Chief appears to maintain a high position of prominence in firewood regulation across the region, the Nduna has varied, if not conflicting, responsibilities and the other institutions appear to play a minor, if any, role. 
Land 2018, 7, 35

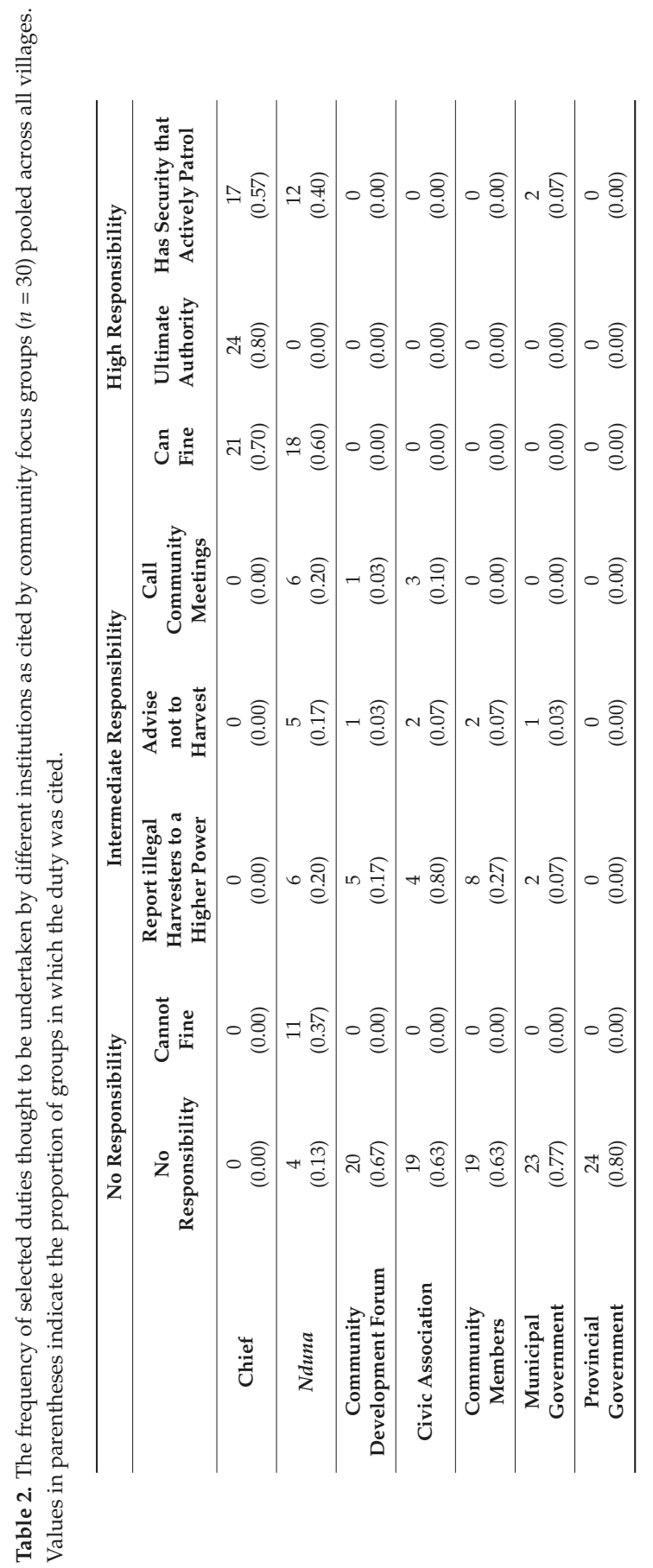




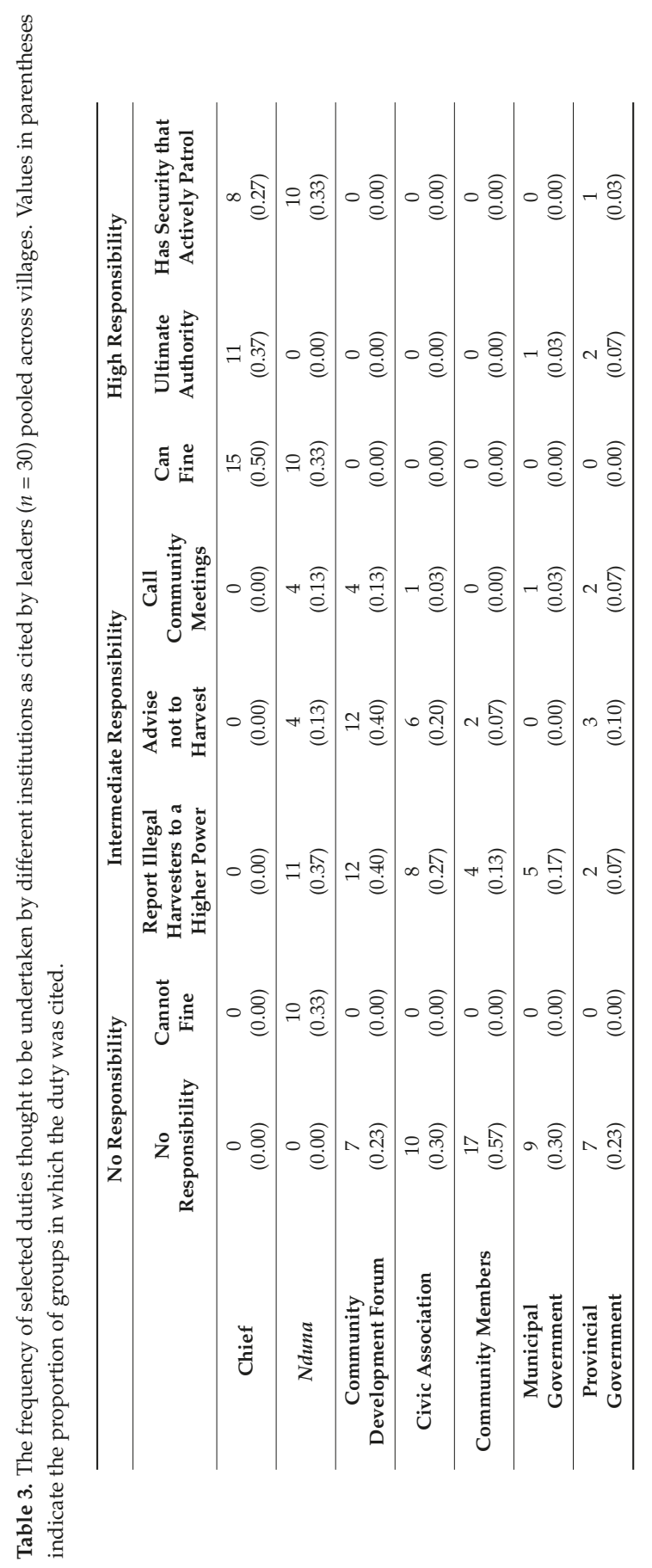




\subsection{Relative Importance of Institutions in Firewood Regulation}

Both the Chief and the Nduna were consistently classed as the two most important authorities in terms of firewood governance across all six villages (Table 4). The Chief was repeatedly assigned a first or second position of importance over all other parties and such high rankings are reflected in the mean scores across villages that range from 8.2 and 9.0 (Table 4). Similarly, the range of the Nduna's scores (1.6-8.0), although more diverse than those of the Chief, still designated him the second most important institution in each village and reinforced the notion, as suggested in some focus group sessions, that he is second-in-command to the Chief. This range of scores also corresponded to differing levels of responsibility the Ndunas are perceived to hold by different groups, as seen in the section above.

Table 4. Mean rank scores of local institutions with regard to their importance in firewood regulation, as perceived by community focus groups $(n=30) .9 .0$ is highest possible rank.

\begin{tabular}{lcc}
\hline \multirow{2}{*}{ Institution } & \multicolumn{2}{c}{ Mean Rank Scores } \\
\cline { 2 - 3 } & Total & Range \\
\hline Chief & 8.5 & $8.0-9.0$ \\
Nduna & 7.0 & $1.6-8.0$ \\
Community members & 2.5 & $1.2-5.0$ \\
Civic Association & 1.9 & $0.0-5.4$ \\
Community Development Forum (CDF) & 1.7 & $0.0-2.6$ \\
Provincial Government & 1.2 & $0.0-2.6$ \\
Municipal Government & 0.9 & $0.0-4.0$ \\
\hline
\end{tabular}

The mean rank scores of the other institutions varied more widely between villages (Table 4) and this could indicate village-level differences in the roles of these institutions, especially Civic Association and community members. Having said that, none of these institutions generated a mean rank score higher than 3, which suggests that despite possible village-level differences, each of these groups is regularly perceived as being lower in relative importance than the Chief and the Nduna.

Ambiguity around the importance of provincial and municipal government in firewood governance was evident in the ranges of scores generated in the focus group discussions (Table 4). Three focus groups maintained that the provincial government was the highest authority as 'all departments fall under the provincial government' and it 'gives the law to the Chief'. In contrast, other focus groups failed to mention the provincial government at all. Similar inconsistencies are noted for the municipal government. These discrepancies in community perceptions may result from difficulties between differentiating 'level' of authority and their importance in actually regulating firewood harvesting. As such, some community groups may have recognized the importance of government bodies in developing legislation and in their 'upper level' governance operations and were therefore highly regarded, while others overlooked the importance of such institutions as their on-the-ground presence or degree of active regulation was scarce or limited.

\subsection{Firewood Regulation Issues}

One of the most important challenges to effective firewood regulation, as noted most frequently by focus groups and second most frequently by leaders, was community members' noncompliance with well-established firewood laws (Figures 2 and 3). Such disregard for the local rules was encapsulated in statements such as 'they [the community] do know the laws but they keep breaking them', 'lots of people break the law' and 'everyone harvests, nobody cares'. This concern was raised almost twice the number of times as the second most cited response (Figure 2). Although some focus groups viewed such disobedience as insubordination where it is just 'human nature to break the rules', a far more common perception was that villagers could not afford to buy permits and were therefore forced 'to harvest [illegally] to survive'. These constraints of poverty and unemployment were also emphasized in suggestions of households relying on firewood as a coping strategy because they are unable to pay for electricity or alternative energy 
sources. This issue, as stated in one focus group, of '[e]veryone harvests. Electricity is expensive' was the most frequently cited challenge by leaders (Figure 3).

Another common issue, raised by both leaders and community members, was that of 'threats to security' as well as 'limited security' (Figures 2 and 3). In the first case, patrolling rangers are beaten, shot, threatened with bewitchment or faced unwarranted aggression by harvesters. As a result, rangers are increasingly reluctant to patrol specific areas and illegal harvesting continues unabated in certain communal lands. In the second case, there are not enough patrolmen available to adequately cover all the communal lands in the area. One focus group highlighted that the Chief only had three security men who had to patrol the entire chieftaincy. This issue was thought to stem from reduced Traditional Council budgets.

An important discrepancy in responses between community members and leaders related to suggestions of dissension between village leaders and their communities, which here refers to issues of bribery, corruption, nepotism and lack of trust as explicitly stated by respondents. Interestingly, while this discord was collectively mentioned nine times in village talks, they were only cited twice in leadership answers (Figures 2 and 3). In contrast, suggestions of the community being 'uneducated' or unknowledgeable about the firewood regulation processes and 'inactive' in issues of firewood were raised by leaders, but were not mentioned by focus groups at all.

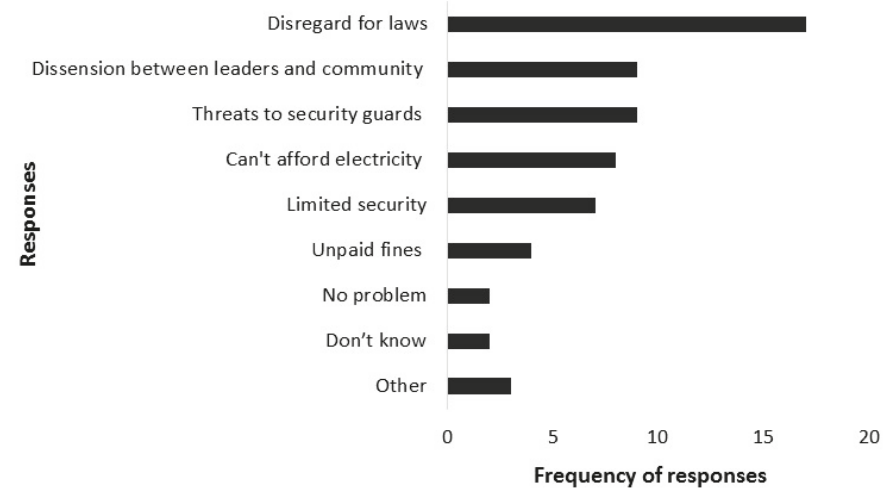

Figure 2. Frequency of firewood governance issues raised in focus groups $(n=30)$ across all villages.

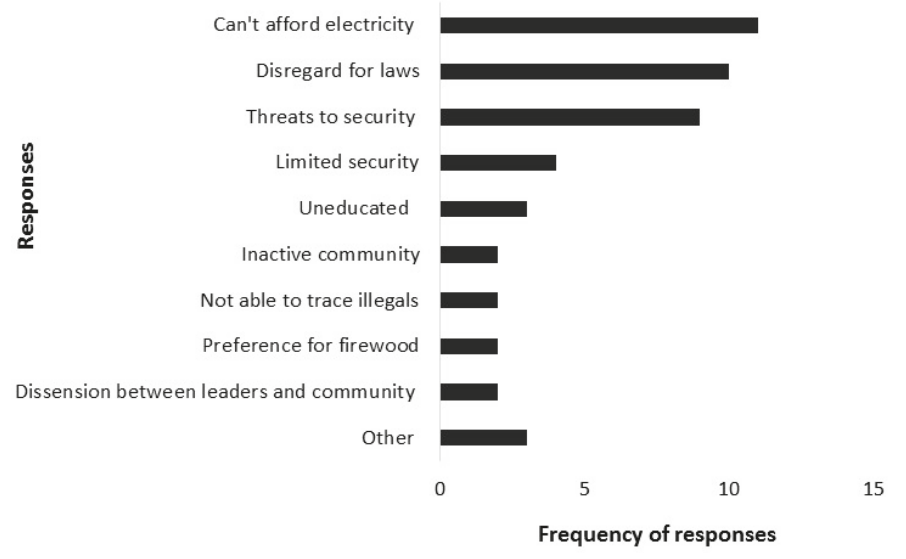

Figure 3. Frequency of firewood governance issues raised by leaders $(n=30)$ across all villages. 


\section{Discussion}

\subsection{Local Firewood Management Systems}

\subsubsection{Importance of Traditional Leaders over Democratic Structures}

Across our research villages, there was little contestation that the Chief, and traditional authorities in general, are the over-riding powers in firewood governance. This perception is evidenced in the consistency of responses across all six villages where the Chief was repeatedly cited as the ultimate authority in firewood regulation, the primary implementer of firewood laws and, in most cases, the most important institution in firewood harvesting management. Although the local Ndunas were also ranked as highly important, perhaps suggesting a second-in-command authority, the differing views of their practical responsibilities produce an unclear picture of their actual role in firewood regulation. These inconsistencies may stem from chieftaincy- and/or village-level differences in the functions of these local level leaders and future work is required to unpack these potential nuances. In contrast, the other governance structures, such as the Community Development Forum $(\mathrm{CDF})$, were consistently considered to either have no responsibility in firewood management or to fall under the directive of one of the traditional leaders. From this, the bulk of responsibility in firewood governance is therefore understood to lie with traditional authorities rather than local democratic institutions. Given the numerous examples throughout the developing world in which traditional leaders remain the primary governors of natural resources (see Brown and Lassoie 2010, Mukamuri et al., 2003, Kayambazinthu et al., 2003, Kajembe et al., 2003 [25-27,60]), this result is unsurprising. Importantly, though, the low prominence of state conservation agencies is of interest and their perceived role in regulating the harvesting of resources should be explored further.

These results suggest that the emergence of modern institutional structures have not had as much impact on the perceived functional roles of traditional authorities in natural resource management as expected. Despite assertions by some that confusion over the roles of different institutions has decreased local firewood regulation (see Kirkland et al., 2007, Twine et al., 2003 [32,33]), the findings here indicate that the roles of traditional leaders and democratic institutions appear separate and quite well-defined in the study villages. Here, traditional institutions remain closely linked to natural resource regulation while democratic groups ( $\mathrm{CDF}$, Civic Associations etc.) are more involved with service delivery and community development issues. This was confirmed by both community residents and leaders across villages. While studies elsewhere show that the establishment of local democratic institutions can create institutional uncertainty between the two groups (Brown and Lassoie 2010, Mukamuri et al., 2003, Kayambazinthu et al., 2003, Clover and Eriksen 2009 [25-27,61]), this tension is unlikely to be the primary contributing factor to the reduced effectiveness of firewood systems seen in these specific villages.

\subsubsection{General Weakening of Institutional Control}

Although the emergence of democratic institutions appears to have had little bearing specifically on the perceptions of traditional leadership in firewood management, three lines of evidence indicate a generalized reduction in firewood regulation across all the study villages. Firstly, no single group or leader described a set of firewood laws that was described by any other group. Many of the laws were only mentioned once and this meant that the laws were too variable to enumerate in this study. While this assortment of laws may point to a complex and extensive system of firewood regulations, it may also suggest that knowledge of firewood laws may be poorly communicated or weakly enforced in these communities. Secondly, although almost all respondents acknowledged that permission was required to harvest firewood and that the Chief was the primary issuer of permits, there was no consensus as to the amount required to pay for the permit or what the permit authorizes the holder to harvest. It is possible that these vague and incongruous responses, evident in both chieftaincies, indicate that very few, if any, households ever actually obtain permits or that leaders 
ever issue them. This could also point to decreased compliance to known firewood regulations around obtaining permission. Finally, and linked to the above, one of the most pressing governance issues, as cited by both community and leader respondents, was villagers' non-compliance with firewood laws. In discussions, this sentiment often referred to the instances of live tree harvesting that, although prohibited, were thought to have intensified in recent times and have been noted elsewhere (Kirkland et al., 2007, Giannecchini et al., 2007 [32,42]). In the words of one community respondent, harvesters overlook established traditional laws "to harvest as they please" and "everybody harvests, nobody cares". These concerns point to the increase in perceived lawlessness with which harvesters, both commercial and domestic, access firewood.

These findings could suggest a widespread reduction in compliance with and enforcement of traditional firewood laws in these study villages and could signify a weakening of local institutional control, as noted in other literature (Kirkland et al., 2007, Twine et al., 2003, Giannecchini et al., 2007 [32,33,42]). Across rural Africa, many studies point to similar levels of insubordination by communities and reflect on the increasingly diluted systems of governance by historically well-respected tribal leaders. Mukamuri et al., 2003 [26], for instance, describe how in some regions of rural Zimbabwe, community members increasingly contravene local harvesting laws by cutting previously sacred trees and these activities undermine the traditional systems of miombo woodland regulation.

These cases above exemplify a cycle of firewood degradation where livewood harvesting, for both domestic and commercial purposes, is both a cause and a symptom of local deadwood scarcity. Although it is recognized that often harvesters have few alternative livelihood options and are left with no choice but to harvest live trees, the continuation of live tree chopping has the possible and indeed high likelihood of further decreasing the natural resource supply and rendering resource-dependent households further impoverished in the areas studied (Kirkland et al., 2007, Twine et al., 2003 [32,33]). This cycle evinces the inter-dependence and inter-connectedness of social systems and the landscapes on which they rely, where changes to one feature ultimately feedback, directly or indirectly, to modify another (Twine, 2005, Liu et al., 2007 [52,62]).

Although it is critical to recognize situations of weakened natural resource management, it is often even more important to identify and understand what factors have led to those governance changes in order to develop suitable interventions that promote sustainable management, and thereby reduce poverty and improve livelihoods (Kepe and Scoones, 1999, Potts et al., 2016 [15,17]). As such, the following section delves into the possible drivers of the weakened institutional functioning described above.

\subsection{Drivers of Weakening Traditional Resource Control in Bushbuckridge}

\subsubsection{Poverty-Driven Use}

A common theme throughout this study was that of poverty-driven firewood use. Leaders, more so than community members, cited this as one of the biggest firewood governance issues, where households, out of poverty, were left with no choice but to continue harvesting both live and deadwood. It was emphasized by leaders here that firewood dependence was a last resort for community members and that livewood harvesting, although proscribed, stems from desperation, necessity and poverty, rather than from malevolence. Some leaders gave the impression that they found themselves in a "catch-22" situation, where although acknowledging that livewood harvesting was illegal, saw residents having no other option but to harvest livewood in a firewood-scarce and poverty-stricken environment. Given these perceptions, we argue that some leaders may be consciously choosing to overlook the illegal harvesting that has intensified across the landscape. While the decision of local leaders to turn a 'blind eye' may stem from acts of political expediency (see below), Mukamuri et al., 2003 [26] note that local leaders in certain regions of rural Zimbabwe, despite having the capacity and authority to detain firewood transgressors, are consciously choosing not to because they believe illegal harvesters are doing so out of livelihood destitution. In this 
study, such empathy and consequent leniency may therefore be an important feature of the observed deterioration of local control.

\subsubsection{Political Self-Interest}

Although poverty-driven use may be an important factor influencing leaders' degree of law enforcement, another reason could be more closely related to that of leaders maintaining their social standing in the community. In these villages, although this was never specifically stated by respondents, political self-interest may be at play in the easing of firewood regulations. For instance, von Maltitz and Shackleton 2004 [39] describe how in other areas of rural South Africa, traditional leaders are no longer enforcing local regulations as strictly or chastising lawbreakers as regularly out of fear of losing local votes to democratically-elected councilors. Here, competition for local support with newly emerging institutions has prompted tribal leaders to be more lenient on community transgressors, leading to an increasingly relaxed governance system (von Maltitz and Shackleton 2004 [39]). In our study region, although there appears to be no overt competition between the different leadership groups on issues of natural resource regulation (see Section 4.1.1. above), politicking in the form of firewood leniency may be one mechanism by which some traditional authorities are attempting to regain a degree of local legitimacy and to win back standing in their communities. This may be particularly true given the weaknesses in their institutional credibility and trust in the eyes of those they are meant to govern (see Section 4.2 .3 below).

\subsubsection{Decreased Trust in Local Institutions}

A key issue raised in discussions was that of discord and dissension between community members and their leaders. That is, the perceived bribery, corruption and nepotism exhibited by some of the village and regional leaders had created a sense of distrust between them and the communities they intend to rule. Concerns over intensified commercial harvesting, the perceived lawlessness with which some residents harvest as well as increasing threats of violence towards patrolmen may also be indicative of these strained relations.

Trust between stakeholder parties has been identified as a critical factor in effective natural resource management (Vaske et al., 2007, Stern 2008a [63,64]) and distrust for leadership has been shown to fuel non-compliance with regulations and stimulate open defiance of authority in systems across the globe (Brown and Lassoie 2010, Kayambazinthu et al., 2003, Thondhlana et al., 2015, Stern 2008a, Stern 2008b, Oyono 2009 [25,27,31,64-66]).

Following this, the impact of reduced social trust and the weakened legitimacy of traditional leaders should not be underestimated in the deterioration of resource regulation and in the increasing powerlessness of traditional authorities to regulate in these villages. It is this cycle of reduced authority, increased disobedience and associated institutional collapse that some authors consider the basis for the 'open access' nature of communal land systems observed in other parts of Africa (Thondhlana et al., 2015, Jones 1999, Luoga et al., 2005 [31,67,68]).

\subsubsection{Decreased Financial Capacity of Governance Structures}

Finally, our results confirm much of other South African literature (see Kirkland et al., 2007, Twine 2005 [32,52]) that speaks of the explicit links between weakening traditional resource control and decreased financial support from government. Here, the ineffectiveness of traditional leaders to implement resource laws was highlighted in various ways, including how authorities do not have enough security to patrol the communal lands and that they cannot trace illegal harvesters. These issues speak to capacity insufficiencies where, even in contexts where leaders may seek to enforce laws, budgetary constraints mean that they are largely incapable of maintaining previous firewood governance systems. In a similar study, Twine et al., 2003 [33] note that traditional authorities themselves asserted that one of the main factors impeding their implementation of resource laws was reduced government funding. 


\section{Conclusions}

With rural poverty and natural resource dependence remaining widespread in South Africa, there is an indisputable need to implement strategies and reforms that seek to improve landscape function and advance livelihood opportunities in such resource-dependent areas. While the results of this study add support to the notions of weakening local governance and their impact on firewood availability in Bushbuckridge specifically, the insights gained have broader applicability to other common property systems. The first of these is that enduring institutions do not necessarily translate into effective institutions. In this system, the institutions involved in natural resource management remain firmly in place, however, they have failed to account for the social, political, economic and environmental changes that currently shape the mechanisms by which natural resources are being used. This oversight has meant that regulations and the institutions meant to enforce them are fixed in historical policies that are no longer appropriate to deal with the new stresses and pressures both within and on the system. This weakened capacity to deal address new forces, such as the reduced resource base, has meant that other changes have evolved in their place, including decreased obedience to laws by residents. What we need in order to combat landscape degradation and livelihood vulnerability, such as already appears in Bushbuckridge but also elsewhere, is to increase the capacity of such institutions to adapt and evolve to changing circumstances.

Secondly, the findings from this study shed new light on the complexity of factors that drive the effectiveness, or indeed the ineffectiveness, of institutions in carrying out their functions. Where previously it was widely accepted that traditional authorities in Bushbuckridge could not enforce resource harvesting laws because of certain exogenous factors, such as their reduced financial capacity, here we see a multiplicity of factors that contribute, individually and in combination, to the weakening of local resource control. Importantly, these new insights into the specific drivers of regional governance were achieved only by coupling community and leader perspectives. The inclusion of these new understandings helped unpack more fully the complexities of local issues and can also be used in the development of more effective interventions. Here, for example, simply increasing Traditional Council budgets or providing more patrolmen does not address the tangled network of factors resulting in the illegal harvesting seen above. Rather the multi-dimensional nature of such resource-use systems calls for the development of policy and programs that engage with such complexity and offer solutions that are holistic and multi-pronged in approach (Nkhata et al., 2012, [69]). We therefore argue that future work should seek to engage as many stakeholders as possible where a diversity of views, perspectives and experiences add more fully to understanding the nuances in such systems that other more singular-focused research may overlook.

Finally, three of the four major drivers of weakened institutions in this case were based on the relationships between the leaders (regulatory institutions) and their communities. Some leaders may have chosen to withhold enforcement on penalties for reasons of compassion and/or political self-interest. Likewise, communities' perceptions of their leaders, both from current practices (e.g., bribery and nepotism) and historical affiliations, impacted on communities' attitudes towards and compliance with firewood regulations. We would argue that these findings point to the underestimated role of personal motivations, beliefs and relationships in shaping institutional effectiveness in resource use systems. Here, without understanding the relationships between the different entities, we fail to acknowledge how successful natural resource governance can be achieved in any landscape (de Castro, 2016 [70]). From this, future studies of both resource use systems and socio-ecological systems in general should focus on the relationships between resource users and their regulatory institutions from a more personal perspective to not only more fully understand the drivers of specific degrees of functioning but also to develop more effective strategies for future resource use regulation. 
Acknowledgments: Funding for fieldwork expenses was provided by the University of the Witwatersrand.

Author Contributions: Sarah Findlay and Wayne Twine conceived and designed the study. Sarah Findlay carried out the data collection and analysis, wrote the first draft of the paper, and did the bulk of the revisions. Wayne Twine contributed to the revisions and critical reviews of the various drafts of the paper.

Conflicts of Interest: The authors declare no conflict of interest.

\section{References}

1. Hardin, G. Tragedy of the Commons. Science 1968, 162, 1243-1248. [CrossRef] [PubMed]

2. Ostrom, E.; Burger, J.; Field, C.B.; Norgaard, R.B.; Policansky, D. Revisiting the Commons: Local Lessons, Global Challenges. Science 1999, 284, 278-282. [CrossRef] [PubMed]

3. Poteete, A.R.; Ostrom, E. Heterogeneity, Group Size and Collective Action: The Role of Institutions in Forest Management. Dev. Chang. 2004, 35, 435-461. [CrossRef]

4. Hartter, J.; Ryan, S.J. Top-down or Bottom-up? Decentralization, Natural Resource Management and Usufruct Rights in the Forests and Wetlands of Western Uganda. Land Use Policy 2010, 27, 815-826. [CrossRef]

5. Ostrom, E. Governing the Commons; Cambridge University Press: Cambridge, UK, 1990; p. 294.

6. Wells, M. Institutions and Incentives for Conservation. Biodivers. Conserv. 1998, 7, 815-835. [CrossRef]

7. Acheson, J.M. Institutional Failure in Resource Management. Annu. Rev. Anthropol. 2006, 35, 117-134. [CrossRef]

8. Goetz, A.M. Institutionalizating Women's Interests and Accountability to Women in Development. IDS Bull. 1995, 26, 1-10. [CrossRef]

9. Folke, C.; Holling, C.S.; Perrings, C. Biological Diversity, Ecosystems, and the Human Scale. Ecol. Appl. 1996, 6, 1018-1024. [CrossRef]

10. Belcher, B.; Ruiz-Perez, M.; Achdiawan, R.I. Global Patterns and Trends in the Use and Management of Commercial NTFPs: Implications for Livelihoods and Conservation. World Dev. 2005, 33, 1435-1452. [CrossRef]

11. Barrett, C.B.; Lee, D.R.; McPeak, J.G. Institutional Arrangements for Rural Poverty Reduction and Resource Conservation. World Dev. 2005, 33, 193-197. [CrossRef]

12. Cocks, M.; Bangay, L.; Shackleton, C.M.; Wiersum, K.F. "Rich Man Poor Man"-Inter-Household and Community Factors Influencing the Use of Wild Plant Resources amongst Rural Households in South Africa. Int. J. Sustain. Dev. World Ecol. 2008, 15, 198-210. [CrossRef]

13. Seidman, R.B. State, Law and Agricultural Institutions: A Theoretical Framework. In Transforming Southern African Agriculture; Seidman, A., Mwanza, K., Simelane, N., Weiner, D., Eds.; Africa World Press: Trenton, NJ, USA, 1992; pp. 19-30.

14. Graham, J.; Amos, B.; Plumptre, T. Governance Principles for Protected Areas in the 21st Century; A Discussion Paper; Ottawa Institute on Governance, Parks Canada and the Canadian International Development Agency: Ottawa, ON, Canada, 2003; p. 50.

15. Kepe, T.; Scoones, I. Creating Grasslands: Social Institutions and Environmental Change in Mkambati Area, South Africa. Hum. Ecol. 1999, 27, 29-53. [CrossRef]

16. Adger, W.N. Social and Ecological Resilience: Are They Related? Prog. Hum. Geogr. 2000, 24, 347-364. [CrossRef]

17. Potts, R.; Vella, K.; Dale, A.; Sipe, N. Evaluating Governance Arrangements and Decision Making for Natural Resource Management Planning: An Empirical Application of the Governance Systems Analysis Framework. Soc. Nat. Resour. 2016, 29, 1325-1341. [CrossRef]

18. Nkhata, B.A.; Breen, C.; Hay, D.; Wilkinson, M. Property Rights, Institutional Regime Shifts and the Provision of Freshwater Ecosystem Services on the Pongola River Floodplain, South Africa. Int. J. Commons 2017, 11, 97-118. [CrossRef]

19. Le Tourneau, F.M.; Beaufort, B. Exploring the Boundaries between Individual and Collective Land Use Management in a CPR System: The PAE Chico Mendes (Acre, Brazil). Int. J. Commons 2017, 11, 70-96. [CrossRef]

20. Dietz, T.; Ostrom, E.; Stern, P.C. The Struggle to Govern the Commons. Science 2003, 302, 1907-1912. [CrossRef] [PubMed] 
21. Ostrom, E.; Nagendra, H. Insights on Linking Forests, Trees, and People from the Air, on the Ground, and in the Laboratory. Proc. Natl. Acad. Sci. USA 2006, 103, 19224-19231. [CrossRef] [PubMed]

22. Ormsby, A. Analysis of Local Attitudes toward the Sacred Groves of Meghalaya and Karnataka, India. Conserv. Soc. 2013, 11, 187-197. [CrossRef]

23. Armitage, D. Adaptive Capacity and Community-Based Natural Resource Management. Environ. Manag. 2005, 35, 703-715. [CrossRef] [PubMed]

24. Frost, P.; Campbell, B.; Luckert, M.; Mutamba, M.; Mandondo, A.; Kozanayi, W. In Search of Improved Rural Livelihoods in Semi-Arid Regions through Local Management of Natural Resources: Lessons from Case Studies in Zimbabwe. World Dev. 2007, 35, 1961-1974. [CrossRef]

25. Brown, H.C.P.; Lassoie, J.P. Institutional Choice and Local Legitimacy in Community-Based Forest Management: Lessons from Cameroon. Environ. Conserv. 2010, 37, 261-269. [CrossRef]

26. Mukamuri, B.B.; Campbell, B.M.; Kowero, G. Local Organisations and Natural Resource Management in the Face of Economic Hardships: A Case Study from Zimbabwe. In Policies and Governance Structures in Woodlands of Southern Africa; Kowero, G., Campbell, B.M., Sumaila, U.R., Eds.; Center for International Forestry Research: Bogor, Indonesia, 2003; pp. 28-43.

27. Kayambazinthu, D.; Matose, F.; Kajembe, G.; Nemarundwe, N. Institutional Arrangements Governing Natural Resource Management of the Miombo Woodland. In Policies and Governance Structures in Woodlands of Southern Africa; Kowero, G., Campbell, B.M., Sumaila, U.R., Eds.; Center for International Forestry Research: Bogor, Indonesia, 2003; pp. 45-64.

28. Wilfred, P.; Madoffe, S.S.; Luoga, E.J. Roles of Institutions in Biodiversity Conservation in Northern Uluguru Mountains, Morogoro, Tanzania: The Villagers' Perspective. Discov. Innov. 2007, 19, 15-24.

29. Andrew, M.; Ainslie, A.; Shackleton, C. Land Use and Livelihoods; Evaluating Land and Agrarian Reform in South Africa Occasional Paper Series; 8; Institute for Poverty, Land and Agrarian Studies: Cape Town, South Africa, 2003.

30. Shackleton, C.M.; Stickler, M.M. Local Wood Demand, Land Cover Change and the State of Albany Thicket on an Urban Commonage in the Eastern Cape, South Africa. Environ. Manag. 2015, 55, 411-422.

31. Gladman, T.; Shackleton, S.; Blignaut, J. Local Institutions, Actors, and Natural Resource Governance in Kgalagadi Transfrontier Park and Surrounds, South Africa. Land Use Policy 2015, 47, 121-129.

32. Kirkland, T.; Hunter, L.M.; Twine, W. "The Bush Is No More": Insights on Institutional Change and Natural Resource Availability in Rural South Africa. Soc. Nat. Resour. 2007, 20, 337-350. [CrossRef] [PubMed]

33. Twine, W.C.; Moshe, D.; Siphugu, V. Harvesting of Communal Resources by "Outsiders” in Rural South Africa: A Case of Xenophobia or a Real Threat to Sustainability? Int. J. Sustain. Dev. World Ecol. 2003, 10, 263-274. [CrossRef]

34. Shackleton, C.M.; Shackleton, S.E. The Importance of Non-Timber Forest Products in Rural Livelihood Security and as Safety Nets: A Review of Evidence from South Africa. S. Afr. J. Sci. 2004, 100, 658-664.

35. Dovie, D.B.K.; Shackleton, C.M.; Witkowski, T.F. Direct-Use Values of Woodland Resources Consumed and Traded in a South African Village. Int. J. Sustain. Dev. World Ecol. 2002, 9, 269-283. [CrossRef]

36. Shackleton, C.M.; Shackleton, S.E. Direct Use Values of Savanna Resources Harvested from Communal Savannas in the Bushbuckridge Lowveld, South Africa. J. Trop. For. Prod. 2000, 61, 28-47.

37. Nott, M.; Thondhlana, G. Fuelwood Preferences, Use and Availability in the \# Khomani San Resettlement Farms, Southern Kalahari, South Africa. For. Trees Livelihoods 2017, 26, 156-169.

38. Agrawal, A. Sustainable Governance of Common-Pool Resources: Context, Methods, and Politics. Annu. Rev. Anthropol. 2003, 32, 243-262. [CrossRef]

39. Von Maltitz, G.P.; Shackleton, S.E. Use and Management of Forests and Woodlands in South Africa: Stakeholders, Institutions and Processes from Past to Present. In Indigenous Forests and Woodlands in South Africa: Policy, People and Practice; Lawes, M.J., Eeley, H.A.C., Shackleton, C.M., Geach, B.G.S., Eds.; University of KwaZulu-Natal Press: Scottsville, NY, USA, 2004; pp. 109-135.

40. Shackleton, C.M. Assessment of the Livelihoods Importance of Forestry, Forests and Forest Products in South Africa; Unpublished Report Developed for Department of Water Affairs and Forestry and DFID: Grahamstown, South Africa, 2004. 
41. Shackleton, C.; Grundy, I.M.; Williams, A. Use of South Africa's Woodlands for Energy and Construction. In Indigenous Forests and Woodlands in South Africa: Policy, People and Practice; Lawes, M.J., Eeley, H.A.C., Shackleton, C.M., Geach, B.G., Eds.; University of KwaZulu-Natal Press: Scottsville, NY, USA, 2004; pp. 337-363.

42. Giannecchini, M.; Twine, W.; Vogel, C. Land-Cover Change and Human-environment Interactions in a Rural Cultural Landscape in South Africa. Geogr. J. 2007, 173, 26-42. [CrossRef]

43. Madubansi, M.; Shackleton, C.M.Ã. Changes in Fuelwood Use and Selection Following Electrification in the Bushbuckridge Lowveld, South Africa. J. Environ. Manag. 2007, 83, 416-426. [CrossRef] [PubMed]

44. Matsika, R.; Erasmus, B.F.N.; Twine, W.C.A. Tale of Two Villages: Assessing the Dynamics of Fuelwood Supply in Communal Landscapes in South Africa. Environ. Conserv. 2012, 1, 1-13. [CrossRef]

45. White, C.; Bank, L.; Jones, S. Restricted Electricity Use among Poor Urban Households. Dev. S. Afr. 1997, 14, 413-423. [CrossRef]

46. Shackleton, C.M.; Buiten, E.; Annecke, W.; Banks, D.; Bester, J.; Everson, T.; Fabricius, C.; Ham, C.; Kees, M.; Modise, M.; et al. Exploring the Options for Fuelwood Policies to Support Poverty Alleviation Policies: Evolving Dimensions in South Africa. For. Trees Livelihoods 2007, 17, 269-292. [CrossRef]

47. Twine, W.C.; Holdo, R.M. Fuelwood Sustainability Revisited: Integrating Size Structure and Resprouting into a Spatially Realistic Fuelshed Model. J. Appl. Ecol. 2016, 53, 1766-1776. [CrossRef]

48. Shackleton, C.M.; Guthrie, G.; Main, R. Estimating the Potential Role of Commercial over-Harvesting in Resource Viability: A Case Study of Five Useful Tree Species in South Africa. Land Degrad. Dev. 2005, 16, 273-286. [CrossRef]

49. Brouwer, I.D.; Hoorweg, J.C.; van Liere, M.J. When Households Run out of Fuel: Responses of Rural Households to Decreasing Fuelwood Availability, Ntcheu District, Malawi. World Dev. 1997, 25, 255-266. [CrossRef]

50. Cousins, T.; Pollard, S.; Toit, D. Legislation in Relation to Land, Water and Natural Resource Governance in Communal Land in South Africa; Working Report for the Craigieburn Wetlands Governance Project: Acornhoek, South Africa, 2007.

51. Thornton, R. Environment and Land in Bushbuckridge, South Africa. In Human Rights and the Environment: Conflicts and Norms in a Globalizing World; Zarsky, L., Ed.; Earthscan: London, UK, 2002; pp. 219-240.

52. Twine, W.C. Socio-Economic Transitions Influence Vegetation Change in the Communal Rangelands of the South African Lowveld. Afr. J. Range Forage Sci. 2005, 22, 93-99. [CrossRef]

53. King, B.H. Spaces of Change: Tribal Authorities in the Former KaNgwane Homeland, South Africa. Area 2005, 37, 64-72. [CrossRef]

54. Shackleton, C.; Griffin, N.J.; Banks, J.M.; Mavrandomis, J.M.; Shackleton, S.E. Community Structure and Species Composition along a Disturbed Gradient in a Communally Managed South African Savanna. Vegetio 1994, 115, 157-167.

55. Emanuel, P.L.; Shackleton, C.M.; Baxter, J.S. Modelling the Sustainable Harvest of Sclerocarya Birrea Subsp. Caffra Fruits in the South African Lowveld. For. Ecol. Manag. 2005, 214, 91-103. [CrossRef]

56. Shackleton, C.M. Comparison of Plant Diversity in Protected and Communal Lands in the Bushbuckridge Lowveld Savanna, South Africa. Biol. Conserv. 2000, 94, 273-285. [CrossRef]

57. Ifegbesan, A.; Pendlebury, S.; Annegarn, H. Forest People, Two Countries and One Continent: What Empirical Connections? Int. Res. Geogr. Environ. Educ. 2009, 18, 45-56. [CrossRef]

58. Bushbuckridge Local Municipality. Integrated Development Plan 2014-2016: Final IDP Document; Bushbuckridge Local Municipality: Bushbuckridge, South Africa, 2014; p. 228.

59. Kahn, K.; Collinson, M.A.; Gómez-Olivé, F.X.; Mokoena, O.; Twine, R.; Mee, P.; Afolabi, S.A.; Clark, B.D.; Kabudula, C.W.; Khosa, A.; et al. Profile: Agincourt Health and Socio-Demographic Surveillance System. Int. J. Epidemiol. 2012, 41, 988-1001. [CrossRef] [PubMed]

60. Kajembe, G.C.; Luoga, E.J.; Kijazi, M.S.; Mwaipopo, C.S. The Role of Traditional Institutions in the Conservation of Forest Resources in East Usambara, Tanzania. Int. J. Sustain. Dev. World Ecol. 2003, 10, 101-107. [CrossRef]

61. Clover, J.; Eriksen, S. The Effects of Land Tenure Change on Sustainability: Human Security and Environmental Change in Southern African Savannas. Environ. Sci. Policy 2009, 12, 53-70. [CrossRef] 
62. Liu, J.; Dietz, T.; Carpenter, S.R.; Alberti, M.; Folke, C.; Moran, E.; Pell, A.N.; Deadman, P.; Kratz, T.; Lubchenco, J.; et al. Complexity of Coupled Human and Natural Systems. Science 2007, 317, 1513-1516. [CrossRef] [PubMed]

63. Vaske, J.J.; Absher, J.D.; Bright, A.D. Salient Value Similarity, Social Trust and Attitudes toward Wildland Fire Management Strategies. Hum. Ecol. Rev. 2007, 14, 223-232.

64. Stern, M.J. The Power of Trust: Toward a Theory of Local Opposition to Neighboring Protected Areas. Soc. Nat. Resour. 2008, 21, 859-875. [CrossRef]

65. Stern, M.J. Coercion, Voluntary Compliance and Protest: The Role of Trust and Legitimacy in Combating Local Opposition to Protected Areas. Environ. Conserv. 2008, 35, 200-210. [CrossRef]

66. Oyono, P.R. New Niches of Community Rights to Forests in Cameroon: Tenure Reform, Decentralization Category or Something Else? Int. J. Soc. For. 2009, 2, 1-23.

67. Jones, B.T.B. Community Management of Natural Resources in Nambia; Issue Paper No. 90; Earthscan: London, UK, 1999.

68. Luoga, E.J.; Witkowski, E.T.F.; Balkwill, K. Land Cover and Use Changes in Relation to the Institutional Framework and Tenure of Land and Resources in Eastern Tanzania Miombo Woodlands. Environ. Dev. Sustain. 2005, 7, 71-93. [CrossRef]

69. Nkhata, B.A.; Mosimane, A.; Downsborough, L.; Breen, C.; Roux, D.J. A Typology of Benefit Sharing Arrangements for the Governance of Social-Ecological Systems in Developing Countries. Ecol. Soc. 2012, 17, 293-303. [CrossRef]

70. De Castro, F. Local Politics of Floodplain Tenure in the Amazon. Int. J. Commons 2016, 10, 1-20.

(C) 2018 by the authors. Licensee MDPI, Basel, Switzerland. This article is an open access article distributed under the terms and conditions of the Creative Commons Attribution (CC BY) license (http:/ / creativecommons.org/licenses/by/4.0/). 
Article

\title{
Assessing Climate Smart Agriculture and Its Determinants of Practice in Ghana: A Case of the Cocoa Production System
}

\author{
Felix Akrofi-Atitianti ${ }^{1,2, *}$, Chinwe Ifejika Speranza ${ }^{1,2,3}$, Louis Bockel ${ }^{4}$ and Richard Asare ${ }^{5}$ \\ 1 Institute of Geography, University of Bonn, Meckenheimer Allee 166, 53115 Bonn, Germany; \\ chinwe.ifejika.speranza@giub.unibe.ch \\ 2 Institute for Environment and Human Security, United Nations University, Platz der Vereinten Nationen 1, \\ 53113 Bonn, Germany \\ 3 Institute of Geography, University of Bern, Hallerstrasse 12, 3012 Bern, Switzerland \\ 4 Food and Agriculture Organization of the United Nations, Viale delle Terme di Caracalla, 00153 Rome, Italy; \\ louis.bockel@fao.org \\ 5 International Institute of Tropical Agriculture, PMB L56, Legon, Ghana; r.asare@cgiar.org \\ * Correspondence: felix_akrofi@yahoo.com; Tel.: +49-1737861062
}

Received: 5 January 2018; Accepted: 27 February 2018; Published: 4 March 2018

\begin{abstract}
Agriculture in Africa is not only exposed to climate change impacts but is also a source of greenhouse gases (GHGs). While GHG emissions in Africa are relatively minimal in global dimensions, agriculture in the continent constitutes a major source of GHG emissions. In Ghana, agricultural emissions are accelerating, mainly due to ensuing deforestation of which smallholder cocoa farming is largely associated. The sector is also bedevilled by soil degradation, pests, diseases and poor yields coupled with poor agronomic practices. Climate Smart Agriculture (CSA) thus offers a way to reduce the sector's GHG emissions and to adapt the sector to the adverse impacts of climate change. This study assesses the potential of CSA vis-à-vis conventional cocoa systems to enhance production, mitigate and/or remove GHG emissions and build resilience, in addition to understanding key determinants influencing CSA practices. Using a mixed methods approach, data was collected in Ghana's Juabeso and Atwima Mponua districts through semi-structured household questionnaires administered to 80 household heads of cocoa farms, two focus group discussions and expert interviews. A farm budget analysis of productivity and economic performance for both scenarios show that CSA practitioners had a $29 \%$ higher income per ha compared to the conventional farmers. Estimations using the FAO Ex-Ante Carbon-Balance Tool (EX-ACT) indicate CSA practices preserve forest resources without which the effect on carbon balance as presented by conventional farming would remain a source of GHG emissions. Farm tenure, age of farmers, location of farm, residential status and access to extension services were the main determining factors influencing CSA practices among cocoa farmers. An in-depth understanding of these indicators can help identify ways to strengthen CSA strategies in the cocoa sector and their contributions to climate change mitigation and resilience.
\end{abstract}

Keywords: climate smart agriculture; resilience; carbon balance; cocoa; mitigation; Ghana; Ex-ACT; agroforestry

\section{Introduction}

Agriculture is the primary source of livelihood in many African countries, employing more than $60 \%$ of the population and often the largest contributor to Gross Domestic Product [1,2].

Yet the sector faces various challenges including market system failures and trade barriers, unstable and ineffective socio-economic policies, poor information, infrastructural and financial 
accessibility, increasing population pressure and resources scarcity, unsustainable agronomic practices and environmental degradation [3,4]. These challenges are further compounded by the effects of climate variability and change as the sector is mainly rain-fed and climate dependent [2,5]. Thus, agriculture in Africa remains one of the most vulnerable sectors to climate variability and change.

Yet African agriculture is not only exposed to climate change impacts but can also be a source of greenhouse gases [6]. Although in global dimensions, GHG emissions in Africa are relatively minimal, a key concern is that major parts of these emissions emanate from the agriculture sectors with high growth rates [7]. For instance, between 1990 and 2014 annual agricultural emissions from Africa increased by $46.4 \%$ from 569.3 to 833.6 Megatonnes of Carbon dioxide equivalents (Mt CO2e) making up nearly $16 \%$ of global agricultural emissions over the period [7]. As many African economies like Ghana expand, it is crucial to initiate measures to reduce emissions from the agricultural sector while adapting the sector to the impacts of climate change.

Ghana's agriculture is the second largest contributor to total national GHG emissions, constituting approximately 38\%, only after the energy sector's $41 \%$ [8]. Moreover, agricultural emissions in Ghana are growing at a faster rate, considering trends between 1990 and 2006, of $44.2 \%$ as opposed to a $39 \%$ growth rate of energy sector emissions [8]. Although cocoa production is the most important economic activity in Ghana's agriculture sector, it is associated with significant contributions to national agricultural GHG emissions $[9,10]$. The expansion of cocoa cultivation into the high forest zones in the 1990s in order to increase national production levels has resulted in biodiversity loss, massive forest degradation and associated GHG emissions [11,12].

Furthermore, the Ghanaian cocoa landscape is plagued with ecological problems such as declining soil fertility, high incidence of pests and diseases and high exposure to droughts and temperature extremes, coupled with poor agronomic practices and inadequate farm maintenance by characteristically aged farmers [13,14]. Yields are estimated to be $350 \mathrm{~kg} / \mathrm{ha}$ on average and are far lower than other major producing countries like Cote d'Ivoire with an average yield of $800 \mathrm{~kg} / \mathrm{ha}$ and Malaysia's $1700 \mathrm{~kg} / \mathrm{ha}$ [15]. Consequently, livelihood conditions of many of the approximately 800,000 smallholder cocoa farmers [16] have deteriorated over the decades with lower returns from cocoa farming leaving them impoverished [17].

Despite high commitments to meeting its objectives, the state-owned Ghana Cocoa Board (COCOBOD) charged with nationwide sustainability of the sub-cocoa sector, is yet to achieve necessary synergies between emerging socio-economic and environmental trade-offs such as increasing productivity/income vis-à-vis reducing extensive cultivation and deforestation. To address the challenges of adapting the cocoa sector to climate change and reducing the sector's emissions, Climate Smart Agriculture (CSA) is increasingly being promoted especially for cocoa production in Ghana $[10,18,19]$. CSA integrates economic, social and environmental dimensions of sustainable development to build on three main pillars as follows: (1) sustainably increasing agricultural productivity and incomes; (2) adapting and building resilience to climate change and; (3) reducing and/or removing greenhouse gases emissions relative to conventional practices [4]. Hence, the World Bank programme to reduce emission from deforestation and forest degradation (REDD+) is strongly focused on cocoa and expected to drive sustainability in the sector post $2016[10,20]$. However, a majority of the predominant smallholder cocoa farmers still employ conventional methods of production [10,21]. Antwi-Agyei et al. (2013) [22] attribute this situation to the limited understanding of the barriers to effective implementation of adaptation strategies faced by farm households across sub-Saharan Africa.

Furthermore, knowledge on the extent to which existing agricultural practices are climate smart in terms of increasing productivity/income and building resilience does not exist. There is thus a need to identify factors that contribute to livelihood resilience, which has been characterized to encompass buffer capacity (as portrayed by livelihood capitals and their dynamics) and actors' capacity to self-organise and to learn [23]. There is also no information on the conditions and factors that influence climate-smart cocoa practices. Thus, we aim to analyse the potential of cocoa farming systems to 
maintain or enhance cocoa production, reduce and/or remove GHG emissions and build resilience. Further, we aim to identify and analyse the factors that influence CSA practices from the individual and household as well as the institutional and policy perspectives. We therefore seek to answer the following questions: What is the level of increase in productivity, farm income and GHG balance due to CSA practices compared to conventional cocoa production? What factors influence CSA practices in cocoa farming systems in Ghana?

\section{Materials and Methods}

\subsection{The Study Area}

The cocoa landscapes of Juabeso and Atwima Mponua districts in the Western and Ashanti regions respectively (Figure 1) were selected for this study. These sites were considered suitable primarily because of the predominance of smallholder cocoa farming households, engaging in either 'business-as-usual' or improved cocoa farming systems based on scientific recommendations. The area also embodies successful implementation of major voluntary standards and certification schemes in Ghana including Rainforest Alliance (RA) and UTZ certified (an abbreviation for "Utz Kapeh": 'Good Coffee' in the Mayan Quiché language; global certification program for sustainable coffee, cocoa and tea production) [24]. While conventional farming systems are common in each district, the presence of the Rainforest Alliance certified Climate Cocoa Project in Juabeso and Organic Cocoa Project in the Atwima Mponua Districts represent essential classifications that allowed the study to explore and compare different dimensions to adoption and practices of CSA, as well as determinant factors in different locations.

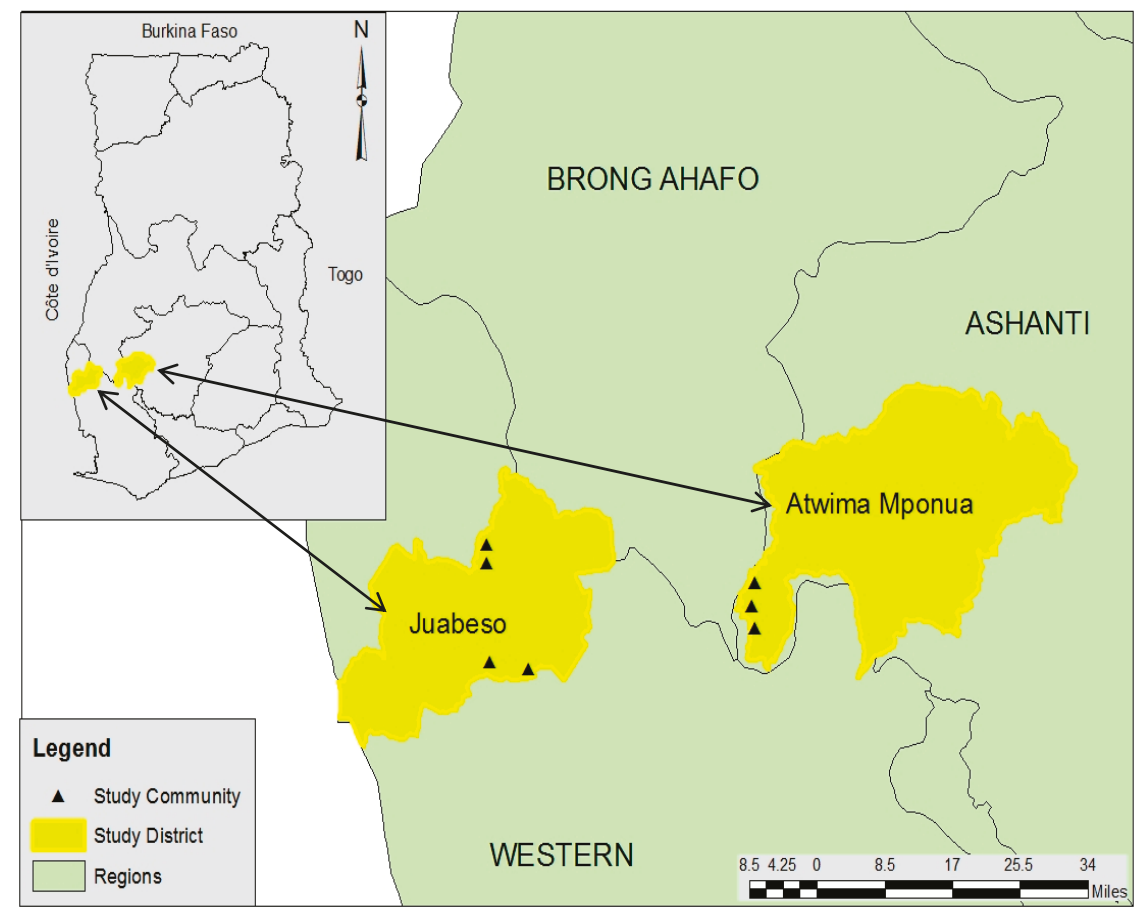

Figure 1. Map of the Study Area (Source: Authors (2015)). The Juabeso district is in the Western Region of Ghana while the Atwima Mponua district is located in the Ashanti Region. The characteristics of both regions are displayed in Table 1. 
Table 1. Profile of the study area districts.

\begin{tabular}{|c|c|c|c|}
\hline Feature & Juabeso District & Atwima Mponua District & Source \\
\hline $\begin{array}{l}\text { CSA/Agroecology } \\
\text { intervention }\end{array}$ & RA Climate Cocoa Project & $\begin{array}{l}\text { Agro Eco Louis Bolk Institute } \\
\text { Organic Cocoa Project }\end{array}$ & \\
\hline $\begin{array}{l}\text { Study Area } \\
\text { Study Location }\end{array}$ & $\begin{array}{c}1924 \mathrm{~km}^{2} \\
2^{\circ} 40^{\prime} \mathrm{W} ; 3^{\circ} 15^{\prime} \mathrm{W} \& 6^{\circ} 06^{\prime} \mathrm{N} ; 7^{\circ} 00^{\prime} \mathrm{N}\end{array}$ & $\begin{array}{c}1883.2 \mathrm{~km}^{2} \\
2^{\circ} 00^{\prime} \mathrm{W} ; 2^{\circ} 32^{\prime} \mathrm{W} \& 6^{\circ} 32^{\prime} \mathrm{N} ; 6^{\circ} 75^{\prime} \mathrm{N}\end{array}$ & {$[9,25,26]$} \\
\hline Capital & Juabeso & Nyinahin & {$[9,27,28]$} \\
\hline Climatic Zone & Wet Semi-Equatorial & Wet Semi-Equatorial & {$[9,29]$} \\
\hline Temperature & $25.5^{\circ} \mathrm{C}-30.0^{\circ} \mathrm{C}$ & $27.0^{\circ} \mathrm{C}-31.0^{\circ} \mathrm{C}$ & {$[9,28]$} \\
\hline Rainfall & $\begin{array}{l}\text { May-June: } 1250 \mathrm{~mm} \\
\text { September-October: } 2000 \mathrm{~mm}\end{array}$ & $\begin{array}{l}\text { March-July: } 1250 \mathrm{~mm} \\
\text { August-November: } 1850 \mathrm{~mm}\end{array}$ & {$[9,26,28]$} \\
\hline Relative Humidity & $70-90 \%$ & $75 \%$ (Average) & [28] \\
\hline Vegetation & Moist semi-deciduous Forests & Moist semi-deciduous Forests & {$[9,28]$} \\
\hline Population (Density) & $58,435(42.7)$ & $119,180(63.0)$ & {$[26,27]$} \\
\hline Population Growth Rate & $3.5 \%$ per annum & $3.6 \%$ per annum & {$[9,24]$} \\
\hline Gender (Sex Ratio) & Male (50.9\%); Female (49.1\%) & Male (51.3\%); Female ( $48.7 \%)$ & {$[26,27]$} \\
\hline Main Economic Activity & $\begin{array}{l}\text { Agriculture (engaged in by } 76 \% \text { of } \\
\text { economically active population) }\end{array}$ & $\begin{array}{l}\text { Agriculture (engaged in by } 66 \% \text { of } \\
\text { economically active population) }\end{array}$ & {$[25,26]$} \\
\hline Forest Reserves & Krokosua Hills; Bia National Park & Asenanyo; Tano Ofin & {$[9,25]$} \\
\hline
\end{tabular}

The study area is composed of a rural population of which growth rates reflect high immigration mainly by migrant cocoa farmers who are estimated to own about $70 \%$ of cocoa farms in the districts $[9,24]$. The Juabeso district is host to the Krokosua Hills forest reserve, which is one of the remaining forest patches surrounded by vast areas of low or no shade cocoa farms with negative implications for biodiversity and ecosystem services [9]. Similarly, encroachment also threatens the forest reserves in Atwima Mponua district, which cover over half of the land area making it one of the biggest forest reserves in Ghana [30].

Recognised as very productive, Juabeso district is a hub of recent cocoa expansion, illegal logging and associated encroachment into protected areas $[9,29]$. Bush fires are frequent in the dry seasons resulting from the activities of farmers practicing slash and burn, as well as from hunting and palm wine tapping activities [25]. With annual deforestation rate of $2.2 \%$ compared to a $2 \%$ per annum national rate, land, forest, wildlife and water resources remain under threat of degradation [31].

\subsection{Data Collection}

Data for the study was collected using a mixed methods approach. Semi-structured household questionnaires were administered to 80 household heads of cocoa farms to elicit information on household characteristics and farm management in the two study areas. In addition, two Focus Group Discussions (FGDs), each targeting cocoa farmers in the respective districts were conducted to explore perceptions about climate change and cocoa production as well as factors influencing adoption of CSA practices. The FGDs helped to verify and build consensus on conflicting data. Lastly, interviews with selected experts provided further data on the study area. These various sources also served to triangulate collected data.

In each study area, two categories of cocoa farmers were identified, namely, farmers practicing conventional models of cultivation and those engaged in CSA/Agroecology as illustrated in Table 2 below. CSA/Agroecology farming systems were selected from the cocoa certification projects by the RA or AgroEco Louis Bolk Institute. Following this stratification, 20 farmers were selected under each of the categories in each location of the study. Four communities were randomly selected in each location. These included Anasu, Pasoro, Gyereso and Wurubegu in the Atwima Mponua District and Cashiekrom, Komeamaa, Breman and Addaekrom in the Juabeso district, from which 
five respondents under each stratum of conventional and CSA/Agroecology farming categories were respectively selected.

Table 2. Characteristics of CSA/Agroecology juxtaposed Conventional Practices in Ghana.

\begin{tabular}{|c|c|c|}
\hline Activities/Practices & $\begin{array}{l}\text { CSA/Agroecology (Recommended } \\
\text { Improved Systems) }\end{array}$ & $\begin{array}{c}\text { Conventional Farming } \\
\text { (Business-As-Usual Systems) }\end{array}$ \\
\hline Land Preparation & $\begin{array}{l}\text { Leaving cleared weeds and biomass to mulch on } \\
\text { prepared lands (locally known as proka) }\end{array}$ & $\begin{array}{l}\text { Burning of entire land for cocoa } \\
\text { cultivation }\end{array}$ \\
\hline Planting Material & Hybrid cocoa seedlings from certified source & $\begin{array}{l}\text { Amazon, Mixed hybrid-Amazon and } \\
\text { Amelonado varieties }\end{array}$ \\
\hline Planting Methods & $\begin{array}{l}\text { Grafting, Lining and Pegging seedlings at } \\
\qquad 3 \mathrm{~m} \times 3 \mathrm{~m} \text { spacing }\end{array}$ & $\begin{array}{l}\text { Randomly planting cocoa beans } \\
\text { "Planting at Stake" }\end{array}$ \\
\hline Fertilizer Application & $\begin{array}{c}371 \mathrm{~kg} / \mathrm{ha} \text { of } 0-18-23 \mathrm{NPK} \text { to mature cocoa on } \\
\text { previously cultivated land }\end{array}$ & $\begin{array}{l}\text { No fertilizer/Lesser quantities per } \\
\text { hectare in varying compositions }\end{array}$ \\
\hline Pesticide Application & $\begin{array}{l}\text { If needed, apply fungicide to control black pod } \\
\text { and other fungal diseases and insecticide at four } \\
\text { times (August, September, October, December) } \\
\text { per year to control mirids (Akate) }\end{array}$ & $\begin{array}{c}\text { No pesticide application or application } \\
\text { between 1-2 times per year at irregular } \\
\text { time periods }\end{array}$ \\
\hline Shade Tree Planting & 12-18 matured trees per hectare & $\begin{array}{l}\text { No shade trees/lesser numbers per } \\
\text { hectare }\end{array}$ \\
\hline Weeding Regimes & 4-6 times per year for young cocoa, as necessary & No weeding $/<4$ times yearly \\
\hline Pruning Practices & $\begin{array}{l}\text { Prune to remove epiphytes and deadwood and to } \\
\text { improve aeration }\end{array}$ & No pruning \\
\hline Production strategy & Cocoa intensification approaches & Extensive practices \\
\hline
\end{tabular}

Asare (2014) outlines the following justification by experts and practitioners for recommended CSA/Agroecology practices over conventional practices: During land preparation, leaving cleared weeds to mulch increases soil organic carbon via decomposition and improves soil fertility, avoiding emissions associated with burning in the context of conventional practices. Planting hybrid seedlings increases yield as well as disease resistance, while applying recommended fertilizer regime not only significantly increases yield but also increases root and shoot growth of cocoa causing enhancement of soil carbon stocks. Applying pesticides four times per year, if needed, helps control black pod, other fungal diseases and pests affecting cocoa. Grafting, lining and pegging seedlings at a three square meter spacing reduces intra cocoa competition associated with planting at stake and enhances yield. Allowing natural regeneration and planting shade trees lead to modest carbon sequestration, while planting cocoa under forest-tree or shade produces no emissions from clearing. Weeding regimes reduce competition for soil nutrients, enhances carbon sequestration from cocoa and shade growth. Pruning practices improve cocoa growth and reduces incidence of pest and diseases thereby ensuring healthy cocoa and greater resilience. Cocoa intensification as production strategy ensures higher resource efficiency, climate adaptation and mitigation co-benefits in contrast to extensive practices.

One community representing each study district was selected for a Focus Group Discussion. Anansu and Komeamaa communities were selected in Atwima Mponua and Juabeso districts respectively. In each case, the groups were limited to a randomly selected sample of 10 participants to enable effective facilitation.

We interviewed one targeted expert each from the International Institute of Tropical Agriculture (IITA), Rainforest Alliance (RA) and Nature Conservation Research Centre (NCRC). These institutions were considered due to their technical know-how on the theme of this paper and also due to convenience and resource constraints. 


\subsection{Data Analysis}

Statistical software (SPSS and STATA) were used to analyse quantitative data on productivity, income and factors framing CSA practices. Qualitative data from focus group discussions and expert interviews were analysed using content analysis. The FAO Ex-Ante Carbon Balance Tool (EX-ACT) was used to estimate climate change mitigation potentials of the two farming systems.

\subsubsection{Farm Budget Analysis}

A farm budget analysis was carried out for both conventional and CSA/Agroecology farming categories. This was to assess respective levels of productivity in average yield per hectare (ha) and economic performance through average income per hectare expressed in Ghana Cedis per hectare (GHS/ha). To realise this, income indicators such as Gross Output Value and Total Production Cost were calculated and set in the function below.

$$
\text { Income }(\mathrm{I})=\text { Gross Output Value }(\mathrm{GOV})-\text { Total Production Cost }(\mathrm{TPC})
$$

The GOV is defined as the total value of cocoa and associated intercrops harvested per hectare over the 2014/2015 farming season. For the purpose of this study, fixed costs were held as a constant factor and TPCs were therefore limited to total variable costs incurred during the same season consisting of variables such as costs for labour (both hired and permanent), pesticides and herbicides, farm maintenance (pruning, weeding etc.), harvesting (pod plucking and breaking), post-harvest (drying and bagging) and transportation.

\subsubsection{Estimation of Greenhouse Gases as Part of Natural Capital}

The FAO Ex-Ante Carbon-Balance Tool (EX-ACT) was used for the estimation of GHGs emission and/or sequestration from farming systems (conventional and CSA/Agroecology). The EX-ACT is a land-based accounting system for measuring the impact of agriculture, forestry and other land use on carbon $(\mathrm{C})$ stocks, stock changes per unit land and methane $\left(\mathrm{CH}_{4}\right)$ and Nitrogen oxide $\left(\mathrm{N}_{2} \mathrm{O}\right)$ emissions expressed in tonnes per hectare of carbon dioxide equivalent $\left(\mathrm{t} \mathrm{CO}_{2}\right.$-eq/ha) [32]. The difference between two scenarios; with or without project interventions, which in the study's context is considered as with or without CSA/Agroecology intervention, defines the C balance, which is the main output of the tool.

\subsubsection{Logistic Regression for Identifying Factors Framing CSA/Agroecology Practices}

A binomial logistic regression was used to identify factors framing CSA/Agroecology practices among cocoa farmers in the study area. The logistic model was estimated using the following equation:

$$
\begin{gathered}
Y_{i}=\beta_{0}+\beta_{1}(\text { Education })+\beta_{2}(\text { Farm Tenure })+\beta_{3}(\text { Farm Size })+\beta_{4}(\text { FarmerAge })+ \\
\beta_{5}(\text { FarmerAge Squared })+\beta_{6}(\text { Number of Farms })+\beta_{7}(\text { Dependency Ratio })+ \\
\beta_{8}(\text { Gender })+\beta_{9}(\text { Location })+\beta_{10}(\text { Residence Status })+\beta_{11}(\text { Extension Service })+ \\
\beta_{12}(\text { Credit })+\beta_{13}(\text { Nonfarm Economic Activities })+\beta_{14}(\text { CocoaAge })+\varepsilon_{i},
\end{gathered}
$$

where $Y_{i}$ is the dependent variable measured as a dummy, 1 if farmer practiced CSA/Agroecology, 0 if farmer practiced conventional farming; $\beta_{0}$ is the constant term; $\beta_{1}$ to $\beta_{14}$ represent the coefficients of the explanatory variables; and $\varepsilon_{\mathrm{i}}$ the error term. In relation to the following a priori expectations as presented in Table 3, the coefficients were estimated using STATA software [33]. 
Table 3. A Priori Expectations for Explanatory Variables.

\begin{tabular}{|c|c|c|c|c|}
\hline $\begin{array}{l}\text { Explanatory } \\
\text { Variables }\end{array}$ & Description & Measurement & $\begin{array}{l}\text { Expectation: } \\
\text { CSA Practice }\end{array}$ & $\begin{array}{l}\text { Supporting } \\
\text { Literature }\end{array}$ \\
\hline Education & Education level of farmer & $\begin{array}{c}1=\text { no education, } 2 \text { = Basic education, } \\
3=\text { Secondary } / \text { Tertiary education }\end{array}$ & + & {$[21,34]$} \\
\hline Farmer Age & Age of farmer & Years & + & {$[21,33,35]$} \\
\hline $\begin{array}{l}\text { Square of } \\
\text { Farmer Age }\end{array}$ & Age of farmer squared & Square of the age farmer & - & [21] \\
\hline Farm Size & Farm size & Hectares & - & {$[21,33]$} \\
\hline Farm Tenure & Farm ownership and rights & $\begin{array}{c}0=\text { own farm, } 1=\text { family farm }, \\
2=\text { sharecropper } 3=\text { Tenant }\end{array}$ & + & {$[16,36,37]$} \\
\hline Dependency Ratio & $\begin{array}{l}\text { Ratio of economic inactive \& } \\
\text { active household members }\end{array}$ & Ratio of dependency & - & \\
\hline Gender & Gender of farmer & Dummy: $0=$ female, $1=$ male & + & [33] \\
\hline Location & Location of the study area & $\begin{aligned} \text { Dummy: } 0 & =\text { Atwima Mponua, } \\
1 & =\text { Juabeso }\end{aligned}$ & - & \\
\hline Residential Status & Farmer residential status & $\begin{array}{l}\text { Dummy: } 1=\text { Yes, if farmer is native to } \\
\text { farming community, } 0=\text { if Not }\end{array}$ & - & [38] \\
\hline Extension Service & Extension services access & $\begin{array}{l}\text { Dummy: } 1=\text { Yes, if farmer received } \\
\text { extension visits last year, } 0=\text { if Not }\end{array}$ & + & {$[16,34,36]$} \\
\hline Credit & Access to credit & $\begin{array}{c}\text { Dummy: } 1=\text { Yes, if farmer had access } \\
\text { to credit, } 0=\text { if Not }\end{array}$ & + & [21] \\
\hline $\begin{array}{c}\text { Non-farm } \\
\text { Economic Activity }\end{array}$ & $\begin{array}{c}\text { Farmer engagement in } \\
\text { off-farm economic activities }\end{array}$ & Dummy: $0=$ No, $1=$ Yes & + & [33] \\
\hline Cocoa Age & Age of cocoa trees on farm & Years & - & [21] \\
\hline
\end{tabular}

\subsubsection{Content Analysis}

Qualitative data that was collected in focus group discussions and expert interviews were analysed via content analysis. Voice recordings obtained via these processes were transcribed and manually synthesised to retrieve information to complement the quantitative data.

\section{Results}

\subsection{Demographic and Socio-Economic Characteristics of Household Respondents}

Demographic and socio-economic characteristics considered include age, gender, education, household size, farm tenure, number of farms and size, among others (Table 4). The age of respondents ranged from 24 to 75 years with a mean of 45 and modal age of 40 years, whereas $63 \%$ of respondents were male. On average, farming experience (number of years engaged in cocoa farming) was about 18 years. Table 4 shows a similar distribution of farmers with primary education while those with secondary education are more among the CSA/agroecology farmers.

The average number of persons per household is 8 persons. About $72 \%$ of respondents employ both household and hired labour. Average farm size cultivated is 2.7 ha with conventional farming having the largest farm size ( 8 ha) in the range. With respect to farm tenure, $69 \%$ of the farmers own their farms while $20 \%$ managed family farms and $11 \%$ operated as share croppers under equal share of proceeds (abunum) agreements. However, $60 \%$ of farmers interviewed had access to only one cocoa farm and $29 \%$ operated 2 different cocoa farms while $11 \%$ operated 3 to 4 cocoa farms. In general, $59 \%$ of the respondents were members of farmer organizations but only $23 \%$ of conventional farmers belonged to a farmer organization compared to $95 \%$ of farmers in CSA/Agroecology with membership in at least one farmer organization. Furthermore, $64 \%$ of respondents who had access to extension 
services in the previous farming season $(2014 / 2015)$ comprised $90 \%$ and $38 \%$ of CSA and conventional farmers respectively.

Further, only $10 \%$ and $13 \%$ of respective farmers under conventional and CSA/Agroecology categories had access to farm credits, which made up $11 \%$ of respondents who obtained access to credit. Despite the government's support with free cocoa fertilizer distribution and free pests and disease control exercises, $71 \%$ of respondents claimed no access to farm inputs in the previous $(2014 / 2015)$ farming season. Only $15 \%$ of conventional farmers had access to pesticides and fertilizer compared to $43 \%$ CSA/Agroecology farmers.

Table 4. Characteristics of Cocoa Farming Household Respondents.

\begin{tabular}{|c|c|c|c|c|c|c|}
\hline \multirow{2}{*}{ Variable } & \multicolumn{2}{|c|}{ Conventional } & \multicolumn{2}{|c|}{ CSA/Agroecology } & \multicolumn{2}{|c|}{ Total } \\
\hline & $(\mathrm{N}=40)$ & $\%$ & $(\mathrm{~N}=40)$ & $\%$ & $(\mathrm{~N}=80)$ & $\%$ \\
\hline \multicolumn{7}{|l|}{ Gender } \\
\hline Female & 18 & 45 & 12 & 30 & 30 & 38 \\
\hline Male & 22 & 55 & 28 & 70 & 50 & 63 \\
\hline \multicolumn{7}{|l|}{ Formal education } \\
\hline None & 10 & 25 & 3 & 8 & 13 & 16 \\
\hline Basic/Primary & 21 & 53 & 20 & 50 & 41 & 51 \\
\hline Secondary/Tertiary & 9 & 23 & 17 & 43 & 26 & 33 \\
\hline \multicolumn{7}{|l|}{ Residential Status } \\
\hline Native & 25 & 62 & 18 & 45 & 43 & 54 \\
\hline Settler & 15 & 38 & 22 & 55 & 37 & 46 \\
\hline \multicolumn{7}{|l|}{ Tenure } \\
\hline Own Farm & 24 & 60 & 31 & 77 & 55 & 69 \\
\hline Family Farm & 11 & 28 & 5 & 13 & 16 & 20 \\
\hline Share Cropper & 5 & 13 & 4 & 10 & 9 & 11 \\
\hline \multicolumn{7}{|l|}{ Number of Cocoa Farms } \\
\hline One & 25 & 63 & 23 & 58 & 48 & 60 \\
\hline Two & 9 & 23 & 14 & 35 & 23 & 29 \\
\hline Three-Four & 6 & 15 & 3 & 8 & 9 & 11 \\
\hline \multicolumn{7}{|c|}{ Member of Farmer Organisations } \\
\hline No & 31 & 78 & 2 & 5 & 33 & 41 \\
\hline Yes & 9 & 23 & 38 & 95 & 47 & 59 \\
\hline \multicolumn{7}{|c|}{ Access to Extension Services } \\
\hline No & 25 & 63 & 4 & 10 & 29 & 36 \\
\hline Yes & 15 & 38 & 36 & 90 & 51 & 64 \\
\hline \multicolumn{7}{|c|}{ Livelihoods Diversified (off-farm) } \\
\hline No & 25 & 63 & 27 & 68 & 52 & 65 \\
\hline Yes & 15 & 38 & 13 & 33 & 28 & 35 \\
\hline \multicolumn{7}{|l|}{ Access to Credits } \\
\hline No & 36 & 90 & 35 & 88 & 71 & 89 \\
\hline Yes & 4 & 10 & 5 & 13 & 9 & 11 \\
\hline \multicolumn{7}{|l|}{ Access to Inputs } \\
\hline No & 33 & 85 & 23 & 58 & 56 & 71 \\
\hline Yes & 6 & 15 & 17 & 43 & 23 & 29 \\
\hline
\end{tabular}

Source: Field Data (2015).

\subsection{Assessing Productivity, Income and Resilience as Dimensions of CSA/Agroecology}

\subsubsection{Farm Production Input and Costs}

Farm investments in inputs and other costs incurred for cocoa production in the 2014/2015 farming season links to the value of assets at the disposal of cocoa farmers. Cocoa production costs per hectare (Table 5) ranged from GHS 65 (USD 17) in the conventional category to GHS 1962 (USD 516) in 
CSA/Agroecology with an overall mean of GHS 715 (US \$188). Averages of total production costs (without fixed costs) per hectare for Conventional and CSA/Agroecology practices were GHS 621 (USD 163) and GHS 920 (USD 242) respectively. Labour constituted the largest cost component in both categories representing $42 \%$ and $51 \%$ of total cost respectively.

Table 5. Share of Average Cocoa Production Costs in Ghana Cedis per Hectare (GHS/Ha).

\begin{tabular}{ccccc}
\hline \multirow{2}{*}{ cost Items/Activities } & \multicolumn{2}{c}{ Conventional Farming } & \multicolumn{2}{c}{ CSA/Agroecology } \\
\cline { 2 - 5 } & Mean & SD (\%) & Mean & SD (\%) \\
\hline Weeding & 83 & $70.3(13)$ & 150 & $91.4(16)$ \\
\hline Pruning & 21 & $20.18(3)$ & 45 & $28.4(5)$ \\
\hline Organic Fertilizer/Compost & 186 & $(30)$ & 169 & $49.4(18)$ \\
\hline Chemical Fertilizer & 94 & $170.1(15)$ & 190 & $249.4(21)$ \\
\hline Fuel & 14 & $12.1(2)$ & 20 & $13.7(2)$ \\
\hline Herbicides & 6 & $9.9(1)$ & 0 & $0.0(0)$ \\
\hline Herbicide Application & 7 & $11.5(1)$ & 0 & $0.0(0)$ \\
\hline Pesticides & 60 & $57.9(10)$ & 70 & $101.6(8)$ \\
\hline Pesticide Application & 27 & $15.3(4)$ & 67 & $48.5(7)$ \\
\hline Harvest & 60 & $48.56(10)$ & 114 & $55.19(12)$ \\
\hline Pod Breaking & 26 & $12.6(4)$ & 46 & $13.2(5)$ \\
\hline Drying/Bagging/Transporting & 37 & $27.3(6)$ & 49 & $17.2(5)$ \\
\hline Cost of Labour & 260 & $169.4(42)$ & 471 & $168.0(51)$ \\
\hline Total Production Cost & 622 & $350.6(100)$ & 921 & $386.2(100)$ \\
\hline Source: Field Data (2015) ${ }^{*}$ USD 1.00 GHS 3.80. &
\end{tabular}

\subsubsection{Farm Productivity of Cocoa}

A total average yield of $432 \mathrm{~kg} / \mathrm{ha}$ was achieved for the entire study area. Average yield per hectare for the whole study area was $37 \%$ higher in CSA/agroecology $(500 \mathrm{~kg} / \mathrm{ha}$ ) than in conventional farming $(363 \mathrm{~kg} / \mathrm{ha})$. We use the difference between CSA/Agroecology and conventional cocoa yields as an indicator of resilience. The performance of CSA/agroecology in Juabeso and Atwima Mponua indicates $50 \%$ and $22 \%$ improvements in productivity and by extension improvements in resilience compared to respective cases of conventional cocoa. In CSA/Agroecology, yields in both Juabeso and Atwima Mponua were $594 \mathrm{~kg} / \mathrm{ha}$ and $406 \mathrm{~kg} / \mathrm{ha}$ respectively. Conventional cocoa yields in Juabeso and Atwima Mponua were $394 \mathrm{~kg} / \mathrm{ha}$ and $332 \mathrm{~kg} /$ ha respectively. Independent sample $t$-test of yields showed a significant difference between yields from CSA/Agroecology and conventional farming $(t(78)=-3933, p=0.000)$, with yields from CSA/Agroecology being higher than yields from conventional farming.

\subsubsection{Value of Produced Cocoa}

With reference to the producer price of cocoa as set by Ghana's cocoa governing institution (COCOBOD) for the 2014/2015 farming season of GHS 5.47 (USD 1.4) for $1 \mathrm{~kg}$ (Ministry of Finance 2014) and additional $3.5 \%$ premium paid for organic cocoa beans, the value of cocoa output per hectare ranged from GHS 1050 (USD 276) to GHS 6394 (USD 1683) with a mean of GHS 2382 (UD \$627). Farmers practicing CSA/Agroecology produced higher output per hectare with an average value of GHS 2786 (USD 733) compared to GHS 1978 (UD \$521) for conventional cocoa. 


\subsubsection{Farm Income from Cocoa and Non-Cocoa Farm Production}

Considering farm productivity and value of output, respondents in the study generally made profits for the 2014/2015 farming season, indicating improvement in their buffer capacity (resilience) with results (Table 6) showing an average income per hectare of GHS 1726 (USD 454). With farm sizes averaging 2.7 hectares, farmer income from cocoa production for the season ranged from GHS 658.40 (UD \$173) to GHS 5865 (USD 1543) per hectare. CSA/Agroecology farmers earned higher incomes with a mean of GHS 1983 (USD 522) per hectare, 29\% above that of conventional farmers' (GHS 1470 (UD \$387)).

Table 6. Average Farm Size in Hectares and Income Indicators in Ghana Cedis per Hectare (GHS/Ha).

\begin{tabular}{|c|c|c|c|c|}
\hline Farming Systems & Farm Size & Gross Output Value (GOV) & Total Production Cost (TPC) & Income \\
\hline Conventional (Atwima. Mponua) & 2.62 & 1862.57 & 436.41 & 1487.95 \\
\hline CSA/Agroecology (Atwima Mponua) & 2.88 & 2276.93 & 680.52 & 1669.76 \\
\hline Total & 2.69 & 2382.04 & 715.11 & 1726.62 \\
\hline
\end{tabular}

Source: Field Data (2015).

With these mean income values for CSA/Agroecology and conventional farming categories associated with a standard deviation of 871.3 and 516.3 respectively, results of the independent sample $t$-test showed a statistically significant effect, $t(62.9)=-3.334, p=0.002$. Thus, income levels from cocoa were statistically higher among farmers practicing CSA/Agroecology than among farmers practicing conventional farming.

Furthermore, an assessment of diversity in household income shows that the average on-farm income from non-cocoa related farm activities was 11\% higher in CSA/Agroecology (GHS 930) compared to conventional farming (GHS 840). For instance, intercropping annual food crops on cocoa farms is a common practice in both farming systems. However, CSA/Agroecology had a higher diversity of 3 crops on average in contrast to 2 crops in the conventional cocoa farms. Animal rearing (e.g., grass-cutter; Greater cane-rat: Thryonomys swinderianus), bee keeping and economic trees on-farm such as citrus and avocado, augmented household income and hence contribute to their economic resilience. Although statistically not significant $(t(47)=-0.280, p=0.781)$, non-cocoa farm income levels were higher among farmers practicing CSA/Agroecology than among farmers practicing conventional farming.

\subsection{Assessing Climate Change Mitigation and Resilience as Dimensions of CSA/Agroecology}

\subsubsection{Land Use Change}

Both conventional (87.5\%) and CSA/Agroecology ( $80 \%)$ cocoa farmers in the study area cultivated cocoa mainly by slashing and burning secondary forests (Deforestation by fire). Figures 2 and 3 show the results from the carbon balance analysis of conventional and CSA/Agroecology cocoa production. While deforestation affected 133 hectares of forests via conventional farming systems in Juabeso, 111 hectares of forest were affected by CSA/Agroecology interventions. Consequently, the study estimated emissions of 64,493 $\mathrm{tCO}_{2}$-eq (2150 $\mathrm{tCO}_{2}$-eq yearly) with CSA/Agroecology interventions and $76,876 \mathrm{tCO}_{2}$-eq ( $2563 \mathrm{tCO}_{2}$-eq yearly) with conventional practices over a 30-year period ex-ante. For this period, a carbon sink of $12,383 \mathrm{tCO}_{2}$-eq (413 $\mathrm{tCO}_{2}$-eq yearly) is estimated from avoided deforestation as a result of CSA interventions (Figure 2). 


\begin{tabular}{|c|c|c|c|c|c|c|c|c|c|c|c|}
\hline \multirow{2}{*}{$\begin{array}{r}\text { Project Name } \\
\text { Continent }\end{array}$} & \multicolumn{2}{|c|}{ CSAAgroecology Juabeso } & Climate & \multicolumn{3}{|c|}{ Tropical (Moist) } & \multicolumn{3}{|c|}{ Duration of the Project (Years) } & \multicolumn{2}{|l|}{30} \\
\hline & Africa & \multicolumn{2}{|c|}{ Dominant Regional Soil Type } & \multicolumn{3}{|l|}{ LAC Soils } & & \multicolumn{2}{|c|}{ Total area (ha) } & \multicolumn{2}{|l|}{142.36} \\
\hline \multirow{4}{*}{$\begin{array}{c}\text { Components of the } \\
\text { project }\end{array}$} & \multicolumn{2}{|c|}{ Gross fluxes } & \multirow{4}{*}{ Balance } & \multicolumn{3}{|c|}{ Share per GHG of the Balance } & \multirow{4}{*}{$\mathrm{N}_{2} \mathrm{O}$} & \multirow{4}{*}{$\mathrm{CH}_{4}$} & \multicolumn{2}{|c|}{ Result per year } & \multirow{4}{*}{ Balance } \\
\hline & CSA & Conventional & & \multirow{2}{*}{\multicolumn{3}{|c|}{$\mathrm{CO}_{2}$}} & & & \multirow[t]{3}{*}{ Without } & \multirow[t]{3}{*}{ With } & \\
\hline & All GHG in & tCO2eq & & & & & & & & & \\
\hline & Positive $=\mathbf{s}$ & source / negative & & Biomass & Soil & Other & & & & & \\
\hline \multicolumn{12}{|l|}{ Land use changes } \\
\hline Deforestation & 76,876 & 64,493 & $-12,383$ & $-11,972$ & 0 & & -124 & -286 & 2,563 & 2,150 & -413 \\
\hline Afforestation & $-2,913$ & $-8,648$ & $-5,735$ & $-5,735$ & 0 & & 0 & 0 & -97 & -288 & -191 \\
\hline Other LUC & 0 & 0 & 0 & 0 & 0 & & 0 & 0 & 0 & 0 & 0 \\
\hline \multicolumn{12}{|l|}{ Agriculture } \\
\hline Annual & 0 & 0 & 0 & 0 & 0 & & 0 & 0 & 0 & 0 & 0 \\
\hline Perennial & $-36,152$ & $-30,267$ & 5,885 & 5,508 & 377 & & 0 & 0 & $-1,205$ & $-1,009$ & 196 \\
\hline Rice & 0 & 0 & 0 & 0 & 0 & & 0 & 0 & 0 & 0 & 0 \\
\hline \multicolumn{12}{|l|}{ Grassland \& Livestocks } \\
\hline Grassland & 0 & 0 & 0 & 0 & 0 & & 0 & 0 & 0 & 0 & 0 \\
\hline Livestocks & 0 & 0 & 0 & & & & 0 & 0 & 0 & 0 & 0 \\
\hline Degradation \& Management & 0 & 0 & 0 & 0 & 0 & & 0 & 0 & 0 & 0 & 0 \\
\hline Inputs \& Investments & 396 & 760 & 365 & & & 280 & 84 & & 13 & 25 & 12 \\
\hline Total & 38,206 & 26,339 & $-11,867$ & $-12,199$ & 377 & 280 & -40 & -286 & 1,274 & 878 & -396 \\
\hline Per hectare & 268 & 185 & -83 & -83.7 & 2.6 & 2.0 & -0.3 & -2.0 & & & \\
\hline Per hectare per year & 8.9 & 6.2 & -2.8 & -2.8 & 0.1 & 0.1 & 0.0 & -0.1 & 8.9 & 6.2 & -2.8 \\
\hline
\end{tabular}

Figure 2. EX-ACT results showing fluxes per relevant component in cocoa farm projects in Juabeso Source: Field Data (2015).

\begin{tabular}{|c|c|c|c|c|c|c|c|c|c|c|c|}
\hline \multirow{2}{*}{\begin{tabular}{|r|} 
Project Name \\
Continent
\end{tabular}} & \multicolumn{2}{|c|}{ CSAVAgrecology Atwima M } & Climate & \multicolumn{3}{|c|}{ Tropical (Moist) } & \multicolumn{3}{|c|}{ Duration of the Project (Years) } & \multicolumn{2}{|l|}{30} \\
\hline & Africa & \multicolumn{2}{|c|}{ Dominant Regional Soil Type } & \multicolumn{3}{|l|}{ LAC Soils } & & \multicolumn{2}{|c|}{ Total area (ha) } & 156.1 & \\
\hline \multirow{4}{*}{$\begin{array}{l}\text { Components of the } \\
\text { project }\end{array}$} & \multicolumn{2}{|l|}{ Gross fluxes } & & \multirow{2}{*}{\multicolumn{3}{|c|}{ Share per GHG of the Balance }} & & & \multicolumn{2}{|c|}{ Result per year } & \multirow{4}{*}{ Balance } \\
\hline & CSA & Conventional & Balance & & & & & & Without & With & \\
\hline & All GHG in & tcO2eq & & $\mathrm{CO}_{2}$ & & & $\mathrm{~N}_{2} \mathrm{O}$ & $\mathrm{CH}_{4}$ & & & \\
\hline & Positive $=\mathrm{s}$ & source $/$ negative $=$ & $=$ sink & Biomass & Soil & Other & & & & & \\
\hline \multicolumn{12}{|l|}{ Land use changes } \\
\hline Deforestation & 84,710 & 63,648 & $-21,062$ & $-20,364$ & 0 & & -211 & 487 & 2,824 & 2,122 & -702 \\
\hline Afforestation & $-2,822$ & $-8,830$ & $-6,008$ & $-6,008$ & 0 & & 0 & 0 & -94 & -294 & -200 \\
\hline Other LUC & 0 & 0 & 0 & 0 & 0 & & 0 & 0 & 0 & 0 & 0 \\
\hline \multicolumn{12}{|l|}{ Agriculture } \\
\hline Annual & 0 & 0 & 0 & 0 & 0 & & 0 & 0 & 0 & 0 & 0 \\
\hline Perennial & $-39,831$ & $-29,871$ & 9,960 & 9,369 & 590 & & 0 & 0 & $-1,328$ & -996 & 332 \\
\hline Rice & 0 & 0 & 0 & 0 & 0 & & 0 & 0 & 0 & 0 & 0 \\
\hline \multicolumn{12}{|l|}{ Grassland \& Livestocks } \\
\hline Grassland & 0 & 0 & 0 & 0 & 0 & & 0 & 0 & 0 & 0 & 0 \\
\hline Livestocks & 0 & 0 & 0 & & & & 0 & 0 & 0 & 0 & 0 \\
\hline Degradation \& Management & 0 & 0 & 0 & 0 & 0 & & 0 & 0 & 0 & 0 & 0 \\
\hline Inputs \& Investments & 90 & 65 & -26 & & & -15 & -11 & & 3 & 2 & -1 \\
\hline Total & 42,148 & 25,012 & $-17,136$ & $-17,003$ & 590 & -15 & -222 & -487 & 1,405 & 834 & -571 \\
\hline Per hectare & 270 & 160 & -110 & -109.0 & 3.8 & -0.1 & -1.4 & -3.1 & & & \\
\hline Per hectare per year & 9.0 & 5.3 & -3.7 & -3.6 & 0.1 & 0.0 & 0.0 & -0.1 & 9.0 & 5.3 & -3.7 \\
\hline
\end{tabular}

Figure 3. EX-ACT results showing fluxes per relevant component in cocoa farm projects in Atwima Mponua. Source: Field Data (2015).

Similarly, results from Atwima Mponua indicate 110 and 146 hectares of deforested area with and without CSA/Agroecology interventions respectively. Over a 30-year ex-ante period of consideration, these results indicate future emissions of $63,648 \mathrm{tCO}_{2}$-eq $\left(2122 \mathrm{tCO}_{2}\right.$-eq yearly) with and $84,710 \mathrm{tCO}_{2}$-eq (2824 $\mathrm{tCO}_{2}$-eq yearly) without CSA/Agroecology (Figure 3). The estimated balance of $21,062 \mathrm{tCO}_{2}$-eq (702 $\mathrm{tCO}_{2}$-eq yearly) represents a carbon sink from avoided deforestation (Figure 3). Thus, CSA/Agroecology practices preserve forest resources (natural capital) without which the effect on carbon balance as presented by conventional farming would remain a source of GHG emissions.

Furthermore, in Juabeso (Figure 2), afforestation activities of planting shade trees as engendered in CSA/Agroecology was higher with an average of 11 trees per hectare, in contrast to results shown from conventional practices with 5 trees per hectare. Consequently, CSA/Agroecology was responsible for an estimated sequestration of $8648 \mathrm{tCO}$-eq compared to only $2913 \mathrm{tCO}$-eq resulting from the fewer 
trees planted in conventional systems. Hence a carbon balance reflected a sink of $5735 \mathrm{tCO}$-eq over a 30 year period (191 tCO2-eq yearly), resulting from improvement via CSA/agroecology interventions beyond the conventional or business as usual practices. Similarly, over the same period in Atwima Mponua (Figure 3), a sink carbon balance of $6008 \mathrm{tCO}_{2}$-eq (200 $\mathrm{tCO}_{2}$-eq yearly) was estimated from afforestation activities. CSA/Agroecology was responsible for sequestration of $8830 \mathrm{tCO}_{2}$-eq compared to only $2822 \mathrm{tCO}_{2}$-eq by conventional or business as usual practices.

\subsubsection{Crop Production and Farm Input}

The study also analysed crop systems and farm inputs under CSA/Agroecology and Conventional systems, using the EX-ACT, to further understand associated GHG mitigation potentials. As a perennial crop, the production of cocoa in Juabeso over a 30 year period of analysis generally sequestered an estimated 36,152 $\mathrm{tCO}_{2}$ eq in conventional systems compared to 30,267 $\mathrm{tCO}_{2} \mathrm{eq}$ in CSA/Agroecology (Figure 2). Due to expansive production with closely spaced cocoa trees, typical in conventional farming systems, more cocoa trees were cultivated per hectare and hence the higher carbon sequestration estimates associated with growing the perennial crop compared to CSA/Agroecology. The same situation held true in Atwima Mponua, where over a 30 year period of analysis, cocoa cultivation generally accounted for an estimated sequestration of $39,831 \mathrm{tCO}_{2} \mathrm{eq}$ in conventional systems compared to $29,871 \mathrm{tCO}_{2}$ eq in CSA/Agroecology (Figure 3).

Despite the resulting emission source balance of $5885 \mathrm{tCO}_{2} \mathrm{eq}\left(196 \mathrm{tCO}_{2}\right.$ eq yearly) and $9960 \mathrm{tCO}_{2} \mathrm{eq}$ (332 $\mathrm{tCO}_{2}$ eq yearly), linked to the intervention of CSA/Agroecology practices in Juabeso and Atwima Mponua respectively, its overall mitigation impact is yet greater considering benefits from avoided deforestation and afforestation practices as explained above.

Emissions from farm investments and inputs such as application of fertilizer, pesticides, spraying and fuel use were higher at $760 \mathrm{tCO}_{2} \mathrm{eq}\left(25 \mathrm{tCO}_{2}\right.$ eq yearly) with practices under $\mathrm{CSA} /$ Agroecology compared to $396 \mathrm{tCO}_{2} \mathrm{eq}\left(13 \mathrm{tCO}_{2}\right.$ eq yearly) in conventional systems at Juabeso. This is justified from the observation that cocoa farms under CSA/Agroecology were more intensified with relatively higher inputs, compared to those in the conventional systems. In the case of Atwima Mponua, a sink balance of $26 \mathrm{tCO}_{2} \mathrm{eq}\left(1 \mathrm{tCO}_{2}\right.$ eq yearly) is projected and accounted for by a carbon source of $90 \mathrm{tCO}_{2}$ eq ( $3 \mathrm{tCO}_{2}$ eq yearly) due to farm input under conventional systems and $65 \mathrm{tCO}_{2} \mathrm{eq}$ ( $2 \mathrm{tCO}_{2}$ eq yearly) from farm input approaches under CSA/Agroecology. This was due to lower or no input organic farming practices, typical with CSA/Agroecology systems in that part of the study area.

\subsection{Assessing Farmer Self-Organisation as a Dimension of Livelihood Resilience}

Though CSA/Agroecology groups were historically formed by external project organizations (Rainforest Alliance and Agro-Eco Louis Bolk Institute), these groups have thrived over time through institutions created by farmers themselves.

Farmers indicated in the focus group discussions that they introduced their own rules and regulations, ways of enforcements and related punitive measures such as fines for non-compliance to these introduced organizational rules by members. These local institutions also worked to improve knowledge and skills of members and access to their rights and entitlements mainly through their own initiatives. Through fellow members whom they had selected and promoted with the groups resources as lead farmers, they interact with stakeholders at various levels and information and skills acquired through this process is shared within the groups. Further $90 \%$ of CSA/Agroecology farmers compared to only $38 \%$ of Conventional farmers had access to extension and advisory services; and $45 \%$ of CSA/Agroecology farmers compared to $15 \%$ of conventional farmers had access to government's free improved planting materials.

The integration of CSA/Agroecology farmers, into their respective farmer organizations is also driven by trust. Thus, farmers who are believed to be trustworthy and could trust others, worked together to enhance their livelihood. $25 \%$ of farmers who were not members of any farmer organization identified mistrust in others as an important reason, while $25 \%$ were refused admission 
into their desired groups. Through such processes, CSA/Agroecology farmers in different instances collectively organized assets at their disposal to support enhancements of their livelihoods such as through buying spraying machines, training lead farmers and maintaining demonstration farms.

These interrelations between farmers' abilities (buffer capacities), in terms of ownership of livelihood capitals and exercise of necessary utility rights, highlight the contribution of farmer self-organization to livelihood resilience. Majority of CSA/Agroecology cocoa farmers (95\%) rather than conventional farmers ( $23 \%$ ) however, have willingly become group members in order to secure their livelihoods.

\subsection{Assessing Farmer Capacity for Learning as a Dimension of Livelihood Resilience}

Results from the FGDs indicated that farmers were generally aware of what constituted threats (mainly high temperatures and rainfall variability) and opportunities to their livelihoods. However, transfer of new ideas and technology is challenged mostly in conventional farming due to limited interaction among conventional farmers and key stakeholders. In contrast, CSA/Agroecology farmers demonstrated commitment to learning through creation and use of existing group-managed demonstration farms for experimentations and transfer of knowledge and technology. They also engaged visiting extension officers and their lead farmers acquired training from relevant agencies.

Based on previous experiences with unfavourable tree tenure, CSA/Agroecology farmer groups have engaged with the officials of the Forestry Commission of Ghana to register trees they have planted on-farm to protect their ownership and rights. However, conventional farmers have not exercised such agency to take advantage of this collaboration but are rather demotivated to plant trees on their farms due to illegal logging by chainsaw operators without appropriate compensation to the conventional farmers. In addition, analysis of selected farm management practices (Figure 4), underscored that CSA systems indicated higher commitments for learning, by following and implementing recommended best practices better than in conventional systems, although this strategy may be tied to the conditions set by the organizations for CSA/Agroecology farmers to access farm inputs.

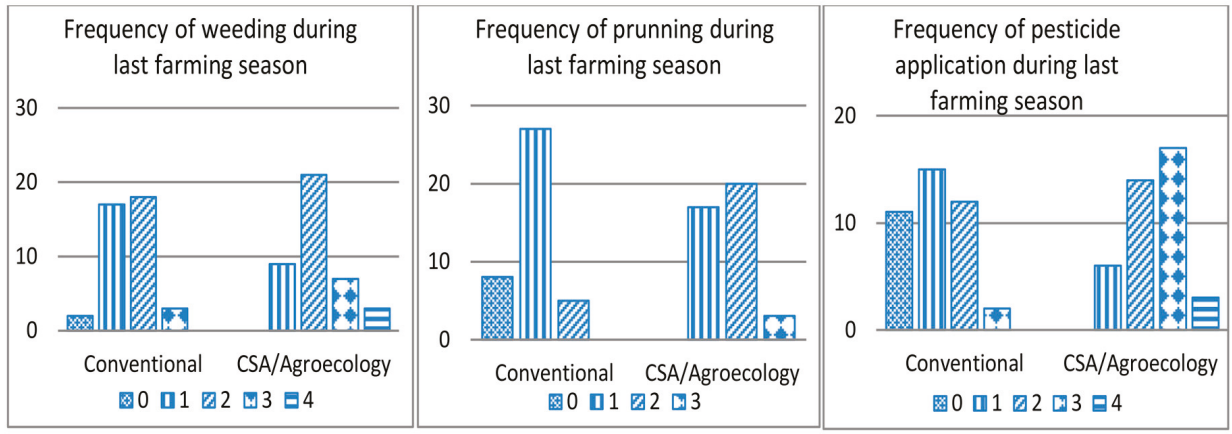

Figure 4. Frequency of selected farm management practices per farming systems. Source: Field Data (2015).

Despite a general awareness of climate risks on cocoa production, livelihoods diversification was moderately undertaken in each of the farming systems. While CSA/Agroecology systems showed more diversity on-farm in terms of non-cocoa crops and forest/shade tree cover, conventional systems were averagely more diversified with respect to non-farm economic activities

\subsection{Factors Affecting Practice of CSA/Agroecology}

Results of the logistic regression model to identify the factors affecting CSA/Agroecology practices are presented in Table 7. Using the specifications with the dependent variable measured as 1 if farmer practiced CSA/Agroecology and 0 if farmer practiced conventional farming, a maximum likelihood 
procedure was used to estimate the parameters. The co-efficient of determination, Pseudo $\mathrm{R}^{2}$ of 0.446 , indicate that about $44.6 \%$ of variation in the practice of CSA/Agroecology could be explained by the explanatory variables. The model is statistically significant at $1 \%$.

Table 7. Estimations of regression models for framing factors of CSA/Agroecology practice.

\begin{tabular}{|c|c|c|c|c|c|c|}
\hline \multirow[b]{2}{*}{ Variables } & \multicolumn{3}{|c|}{ Logit Estimation } & \multicolumn{3}{|c|}{ Probit Estimation } \\
\hline & Co-Efficient & $\begin{array}{l}\text { Standard } \\
\text { Error }\end{array}$ & $\begin{array}{c}\text { Marginal } \\
\text { Effects }\end{array}$ & Co-Efficient & $\begin{array}{l}\text { Standard } \\
\text { Error }\end{array}$ & $\begin{array}{c}\text { Marginal } \\
\text { Effects }\end{array}$ \\
\hline \multicolumn{7}{|l|}{ Reference Group (RG): Education } \\
\hline Education (Basic) & 1.147 & 1.051 & 0.271 & 0.654 & 0.622 & 0.249 \\
\hline Education (Secondary/Tertiary) & 0.915 & 1.156 & 0.223 & 0.552 & 0.675 & 0.216 \\
\hline \multicolumn{7}{|l|}{ RG: Farm Tenure (own farm) } \\
\hline Farm Tenure (family Farm) & $-2.004^{* *}$ & 1.016 & -0.391 & $-1.152 * *$ & 0.585 & -0.377 \\
\hline Farm Tenure (share croppers) & $-2.655^{* *}$ & 1.288 & -0.427 & $-1.459^{* *}$ & 0.731 & -0.412 \\
\hline Age & $0.472 *$ & 0.271 & 0.115 & $0.260 *$ & 0.157 & 0.101 \\
\hline Square of Age & $-0.006 *$ & 0.003 & -0.001 & $-0.003 *$ & 0.002 & -0.001 \\
\hline No of Farms & -0.691 & 0.645 & -0.168 & -0.323 & 0.365 & -0.126 \\
\hline Dependency Ratio & 0.004 & 0.006 & 0.001 & 0.002 & 0.003 & 0.001 \\
\hline Gender & -0.315 & 0.866 & -0.077 & -0.285 & 0.496 & -0.111 \\
\hline District & $1.598 *$ & 0.887 & -0.371 & $0.938 *$ & 0.511 & 0.353 \\
\hline Residential Status & $1.659^{* *}$ & 0.826 & 0.386 & $0.895^{* *}$ & 0.444 & 0.339 \\
\hline Access Extension Service & $4.295^{* * *}$ & 1.037 & 0.728 & $2.491^{* * *}$ & 0.566 & 0.716 \\
\hline Access to Credit & 0.431 & 1.283 & 0.107 & 0.239 & 0.735 & 0.095 \\
\hline Off-farm Economic Activity & -1.041 & 0.703 & -0.253 & -0.616 & 0.409 & -0.239 \\
\hline Cocoa Age & -0.051 & 0.051 & -0.012 & -0.03 & 0.03 & -0.012 \\
\hline Constant & $-11.375 *$ & 5.919 & & $-6.310^{*}$ & 3.416 & \\
\hline \multicolumn{7}{|l|}{ Model Diagnostics } \\
\hline Observations & 80 & & & 80 & & \\
\hline Pseudo $R^{2}$ & 0.446 & & & 0.445 & & \\
\hline Prob $>$ Chi2 & $1.49 \times 10^{-5}$ & & & $1.51 \times 10^{-5}$ & & \\
\hline
\end{tabular}

Farm tenure, age of farmer, location (district), residential status and access to extension services were the main determining factors influencing CSA/Agroecology practices. Farm Tenure was statistically significant at 5\% indicating that farmers who owned their farms were $39 \%$ more likely to adopt CSA/Agroecology practices than those who managed family farms and $43 \%$ more likely to practice CSA than share croppers. While age of farmer was positively significant at $10 \%$, results showed non-linearity in the variable as the square of farmer age was negatively significant at $10 \%$. Thus, farmers are more likely to practice CSA / Agroecology with increase in their age but this tendency of CSA practice eventually drops with further age increase.

Location has an influence on the practice of CSA/Agroecology. 'District' as a variable was significant at $10 \%$, showing a $37 \%$ likelihood of CSA/Agroecology practice in Juabeso more than in Atwima Mponua District. However, with residential status remaining positively significant at $5 \%$, native farmers are $39 \%$ less likely to practice CSA / Agroecology than settlers. Further, access to extension services has a positive significant effect at $1 \%$ on the practice of CSA/Agroecology in cocoa production. It is $73 \%$ likely that increasing farmer access to extension services increases farmer adoption of CSA/Agroecology practices. Nevertheless, farmer level of education, household dependency ratio and access to credit were positively related to CSA/Agroecology but were not statistically significant.

\section{Discussion}

\subsection{Contributions of CSA/Agroecology to Productivity and Income}

The results indicate higher income in CSA agroecology systems. The average yield for conventional systems ( $363 \mathrm{~kg} / \mathrm{ha}$ ) identified in this study is validated by the national average of $350-400 \mathrm{~kg} / \mathrm{ha}[15,35]$, mainly reflecting the conventional cocoa production practiced by most farmers 
in Ghana. The relatively higher yields ( $501 \mathrm{~kg} / \mathrm{ha}$ ) attributed to CSA/Agroecology, is confirmed by Aidoo and Fromm (2015) [39], who reported similar results for farmers engaged in certification for implementing more sustainable practices in the Ashanti Region of Ghana.

CSA/Agroecology farmers also had higher financial capital as evidenced in their average incomes ( $29 \%$ more) and hence increased their purchasing power as observed in their average farm investments (32\% more) compared to conventional farmers. Incremental financial capital can buffer livelihood risks (such as poor soil fertility, pests and diseases, etc.), since farmers are more capable to finance their strategies (such as fertilizer application, spraying pesticides, etc.) to reduce or cope with the risks, which is a crucial dimension of livelihood resilience [40].

Through intercropping of diverse non-cocoa crops (particularly food crops), respective CSA/ Agroecology households invariably have access to food and are additionally provided with income ( $10 \%$ more than conventional) mainly due to higher cropping intensities and diversities. Such farm households earn additional incomes directly from the sale of food products including plantain, yams, fruits, honey, vegetables etc., and indirectly from monies saved that would have been otherwise used to buy food [41]. Furthermore, through agroforestry practices that increase carbon stocks on-farm and hence reduce GHG emissions, CSA/Agroecology provides a potential opportunity for additional household incomes from carbon credits through the result-based national REDD+ programme [42]. However, this potential raises questions on equity concerning how farmers would be fairly rewarded from carbon credits and other related benefits for achieving mitigation benefits. This is because there is not yet clarity on key issues around the development of a fair and transparent benefit sharing scheme and carbon rights definition, land and tree tenure and gender mainstreaming mechanisms are still outstanding, which have dominated the REDD+ implementation discourse [41].

While CSA/Agroecology contributed to increased yields and incomes which in turn build resilience of farmers' livelihoods through improved food security (also from higher variety and output of food crops) and enhanced buffer capacity [39], the study also considers the hypothetical diminishing of this buffer capacity given the susceptibility of cocoa to reduction in rainfall particularly during the dry season and increased temperatures which have worsened due to increase climate variability and change [16]. The following further places the discussions in this context to highlight the potential of CSA/Agroecology to mitigate such climatic risks and adapt to associated impacts.

\subsection{Contributions of CSA/Agroecology to Climate Change Mitigation}

Although farmers clear fell and burn secondary forests to plant cocoa crops before the adoption of recommended practices, the emission effect was lower with the intervention of CSA/Agroecology. This is explained by the effect of avoided deforestation for the purposes of farm expansions as CSA/Agroecology farmers were rather shifting to intensification practices. Unlike conventional farmers who typically employ low input and aim to increase yields by expanding the area of land cultivated and hence further deforest secondary or virgin forests [9], CSA farmers rather intensify input investment in relatively smaller areas of land to increase productivity thereby saving carbon stock in forest, which would have otherwise been burnt.

According to Cambell et al. (2014) the approach of sustainable intensification is an essential means of adapting to climate change, also resulting in lower emissions per unit of output and is highly complementary with CSA [43]. Gockowski and Sonwa (2011) further observed in their study of rural livelihoods in the Guinea rain forest of West Africa that this strategy not only mitigate deforestation and carbon emissions but also biodiversity loss and enhance poverty alleviation and rural development [44], all of which are essential ingredients for strengthening adaptive capacities against and building resilience to climate variability and change.

\subsection{Contributions of CSA/Agroecology to Farmer Social Capital and Learning}

Increase in income among CSA/Agroecology farmers was inextricably linked to their respective higher value in social capital (increase in other assets due to membership or participation in social 
networks; labour support from group members and income gained through membership in groups) and vice versa. This also influenced their higher capacities for learning via institutionalising group processes and their ability to further mobilise more resources to protect their livelihoods as a collective. To protect and enhance their livelihoods, CSA/Agroecology farmers actively self-organised and integrated into farmer based groups such that they subject themselves to rules and regulation, offer themselves to trust and be trusted and pulling resources together as well as remaining open to information and new ideas for the achievement of livelihood outcomes. Hence enhancement in not only their buffer capacities but also their social capital and capacity for learning as dimensions of resilience [39] This is further supported by Mohammed et al.'s (2013) [45] observation of a positive relationship between social capital and access to credit.

CSA/Agroecology farmers have also generally demonstrated agency through resources at their disposal including increased economic power from higher incomes and political influences through the functioning group dynamics. These represented the foundation on which they engaged with the officials of the Forestry Commission of Ghana and which was instrumental in protecting their interest in established tree tenure for example. Asare (2014) argues that making the shift to a sustainable and climate resilient cocoa landscape will require significant changes, including extensive coordination and collaboration between key stakeholders, many of which have traditionally not collaborated, like the Cocoa Board and the Forestry Commission [10]. These forms of cooperation have implicitly been initiated by CSA practices.

\subsection{Conditions and Processes Framing Practice of CSA/Agroecology}

\subsubsection{Land and Farm Tenure}

In accordance to the a priori expectations of the study, farm tenure influenced the practice of CSA/Agroecology in the study area showing that farmers are more likely to invest time and resources on their own farms than on farms where ownership right is insecure [16,35]. Secure land tenure thus has a significant effect on agricultural production and the ways in which rural livelihoods are sustained. According to Acheampong et al. (2014) [35], the security and quality of land tenure rights directly affect how respective resources are used and managed.

Linking this situation to resilience, up-scaling the practice of CSA in the study areas will require the processes of land and farm right acquisition to foster farmers with greater security in terms of ownership and rights to use (entitlement). Freudenberger (1994) [46] argues that local land and farm tenure system in Ghana is complex, adaptive and evolves over time in response to changing ecological and socio-economic conditions. Given that this is a product of the interaction of customary laws as guaranteed by government statute [47], local and public institutions are crucial as they influence options and strategies available to farmers to sustain their livelihoods. Therefore, institutional reforms must create conducive environments that reduce farmers' risk associated with accessibility of farmlands. Short term interests acquired by migrant farmers in lands or in farms as well as the resources on them should therefore be ensured by capitalising on Customary Land Secretariat systems to enhance enabling contractual agreements between them and their respective land or farm owners [44].

\subsubsection{Age of Farmer}

According to the results, the adoption and practice of CSA/Agroecology grew with increase in farmers' age but only up to a threshold beyond which adoption of CSA/Agroecology practices declined as farmers grew older. Farmers also tend to reduce farm investments as well as the propensity to experiment or employ new technologies as they grow older. Knowler and Bradshaw (2007), Aneani et al. (2012), Obuobisa-Darko (2015) $[21,33,34]$ indicated that older cocoa farmers in Ghana are more resistant to shift from traditional practices to improved ones as they are risk averse.

However, it needs to be considered that younger farmers are less likely to have the necessary endowments in livelihood assets or capitals compared to older farmers. Thus, access to natural 
capital (farmlands), financial capital (credit, bank loans), human capital (farm experience, know-how), social capital (household control, trust) and physical capital (access to technologies) are more likely to be limited among younger farmers than older ones. These have implications for the extent of practice of CSA/Agroecology among younger farmers despite their will to change considering that Mumuni and Oladele (2016) [48] observed young farmers are more likely to develop entrepreneurial abilities than aged ones. To overcome these barriers, institutions and policies governing the sector need to not only target CSA / Agroecology technologies among young farmers but also enhance their capacities to improve their relatively weak buffer capacities and livelihood resilience [39,49].

\subsubsection{Location (District) of Farmer}

The location of farmers also influenced their tendency to practice CSA/Agroecology with farmers in Juabeso District being more engaged in CSA/Agroecology systems than those of Atwima Mponua. This can be explained by the status of Juabeso district as part of the Western Region, which is recognised as the cocoa hub of the country and produces more than half of the country's cocoa [9]. This comparative advantage could also be linked to government and private sector interventions to support cocoa farmers through fertilizer distribution, free cocoa farm spraying exercises, extension and technical support services and other important facilities, skewed towards the Juabeso district. Thus, significant variations in socio-economic and ecological contexts can explain the success of CSA/Agroecology interventions.

\subsubsection{Residential Status of Farmer}

Farmers' residential status was identified to be a significantly influential factor determining farmers' capacity to practice CSA/Agroecology in Ghana. Contrary to a priori expectations, the results showed that native farmers rather have lower tendencies to practice CSA/Agroecology than migrant farmers. This contradicts other findings $[37,50]$ that associate unsustainable land management practices with migrant farmers because of their short-term insecure land access and interests in faster and higher returns, than natives with more secured interest and as such greater incentive to sustainably preserve the quality of land.

Van der Geest (2011) [51] also challenged findings attributing unsustainable land management practices to Dagara migrants in Ghana's Brong Ahafo Region. Given that migrant farmers in Ghana have mostly been displaced by environmental change [49], their experiences and awareness of previous threats are likely to define their capacity for learning in their new locations to build livelihood resilience. According to Marney et al. (2014) [49], migration of farmers in Ghana is mostly an adaptation strategy and in the process migrants expand their social networks with stronger ties through which they access information, while deploying social-ecological memory as potential agents of innovation and adaptation. Thus, there is a need to revise unpopular perceptions that associate migrant farmers with growing forest degradation in Ghana, while enabling their adaptation as they have potentials to be agents of change through innovation, technological transfer and adoption. In cases of environmentally induced migration, recognition should be given to migrant farmers in Ghana's climate change adaptation policies to provide them with adaptation opportunities and rights, similar to non-migrant farmers.

\subsubsection{Farmer Access to Extension Services}

It is expected that increased access to extension services by farmers will correspondingly increase CSA/Agroecology adoption and practice [34,36]. Anim-Kwapong and Frimpong (2010) [16] argued in this relation that cocoa farmers in Ghana are quite conservative and as such require very effective extension systems to motivate them adopt innovations and new technologies. Yet the processes of extension in Ghana have not been effective mainly due to financial constraints [36]. This condition also produces risks in adaptation to climate change.

However, with institutional bottlenecks, processes of agricultural extension initiated out of the agency of farmers to build their own capacities as evidenced by the CSA/Agroecology farmer groups 
should be encouraged. Collaborations between farmers and responsible institutions for extension service delivery would be instrumental in closing this gap. For instance, involving farmers in extension delivery through the concept of "Lead Farmers" where selected farmers from farmer groups are equipped with extension delivery skills in order to train and educate their colleagues would be a vital strategy towards reducing livelihood risks under current conditions among cocoa farmers in Ghana.

\section{Conclusions}

This study has shown that average farm productivity and average income is significantly higher among farmers practicing CSA/Agroecology, who also incur higher farm investment costs required to meet recommended practices, than conventional cocoa farmers. Premiums additionally paid to cocoa CSA/Agroecology farmers for undertaking these recommended practices under certification schemes also augmented their incomes, in addition to income from non-cocoa farm production. The relatively high income is linked to enhancements in other livelihood capitals and hence increased ownership of livelihood assets and utility rights such as in land tenure for example. With enhanced buffer capacity and resilience, farmers practicing CSA/Agroecology also indicated better self-organisation with higher capacity for learning in an inter-linked fashion, contributing more to livelihood resilience than in conventional farming systems. Further, the study highlights that trade-offs may exist between practicing CSA / Agroecology cocoa production and diversification of farmer livelihoods as a climate change adaptation strategy.

The estimations of carbon balance due to land-use change, crop production and farm input use, using the EX-ACT tool varied with different production systems. While farm input intensification practices of CSA/Agroecology have negative implications for climate mitigation, CSA/Agroecology practices, overall have positive impacts on GHG mitigation without which cocoa landscapes would be a source of emission. The contributions of CSA to climate mitigation however showed no direct impact on farmers' livelihood resilience. The study however found that the institutional processes of obtaining land or farm ownership and rights (land/farm tenure system) in Ghana, age of farmers, geographical location of farmers (district), farmers' residential status and their access to agricultural extension services were the main factors influencing the practice of CSA/Agroecology in the study area and by extension resilience to climate change impacts on cocoa production.

While the study assessed resilience with selected proxy indicators, the analysis hints that a comprehensive resilience profile of cocoa production systems integrating all relevant indicators and related proxies under each of the three components of resilience (buffer capacity, self-organization and capacity for learning) should be further studied. This also means re-examining the concept of CSA that captures resilience as one of its components. It is also instrumental to research existing trade-offs that exist with practice of CSA by cocoa farmers and to assess the extent to which they can be minimised.

Acknowledgments: We acknowledge Rebecca Ashley Asare (Nature Conservation Research Centre), Christian Mensah (Rainforest Alliance) and Sander Muilerman (International Institute for Tropical Agriculture) for their invaluable insights. We also appreciate the support of Anthony Adom and Abraham Yelley of Rainforest Alliance, as well as Israel Kuadzi and Selasse Gidiglo of Agro Eco-Louis Bolk Institute. "This work was implemented as part of the CGIAR Research Program on Climate Change, Agriculture and Food Security (CCAFS), which is carried out with support from CGIAR Fund Donors and through bilateral funding agreements. For details please visit https:/ / ccafs.cgiar.org/donors. The views expressed in this document cannot be taken to reflect the official opinions of these organizations."

Author Contributions: F.A.-A. conceived and designed the research; performed literature review, managed the field data collection processes; analysed the data; and wrote the paper. C.I.S. designed and shaped the research as well as analysing supporting literature, writing and reviewing the paper to finalize it. L.B. contributed to the research design and provided the Ex-Ante Carbon Balance Tool as well as supporting the estimation and analysis of Greenhouse Gas Emission resulting from farming activities. R.A. contributed to the research design and the data collection tools and processes, as well as reviewing the paper.

Conflicts of Interest: The authors declare no conflict of interest. 


\section{References}

1. Branca, G.; Tennigkeit, T.; Mann, W.; Lipper, L. Identifying Opportunities for Climate Smart Agriculture Investment in Africa; Food and Agriculture Organisation of the United Nations (FAO): Rome, Italy, 2013.

2. Williams, T.O.; Mul, M.; Cofie, O.; Kinyangi, J.; Zougmore, R.; Wamukoya, G.; Nyasimi, M.; Mapfumo, P.; Speranza, C.I.; Amwata, D.; et al. Climate Smart Agriculture in the African Context-Background Paper. In Proceedings of the Feeding Africa Conference-Unlocking Africa's Agricultural Potentials for Transformation to Scale, Dakar, Senegal, 21-23 October 2015.

3. Vermeulen, S.J.; Campbell, B.M.; Ingram, J.S.I. Climate Change and Food Systems. Annu. Rev. Environ. Resour. 2012, 37, 195-222. [CrossRef]

4. FAO. Climate Smart Agriculture Sourcebook; Food and Agriculture Organisation (FAO): Rome, Italy, 2015.

5. IPCC. Climate change 2014: Mitigation of Climate Change. In Intergovernmental Panel on Climate Change; Fifth Assessment Report; Cambridge University Press: Cambridge, UK, 2014.

6. Harvey, C.; Chacon, M.; Donatti, C.; Garen, E.; Lee, H.; Andrade, A.; Bede, A.L.; Brown, D.; Calle, A.; Chara, J.; et al. Climate-Smart Landscapes: Opportunities and Challenges for Integrating Adaptation and Mitigation in Tropical Agriculture. Conserv. Lett. 2013, 7, 77-90. [CrossRef]

7. FAOSTATS-Food and Agriculture Organisation of the United Nations, Statistics Division. Emissions: Agriculture. Available online: http:/ / www.fao.org/faostat/en/\#compare (accessed on 31 August 2017).

8. EPA. National Greenhouse Gas Inventory Report for 1990-2006; Environmental Protection Agency: Accra, Ghana, 2013.

9. Gockowski, J.; Robiglio, V.; Muilerman, S.; Agyema, N.F. Agricultural Intensification as a Strategy for Climate Mitigation in Ghana: An Evaluative Study of the COCOBOD High Tech Programmes, Rural Incomes and Forest Resources Bia (Juabeso) District of Ghana; International Institute for Tropical Agriculture (IITA): Accra, Ghana, 2011.

10. Asare, R.A. Understanding and Defining Climate-Smart Cocoa: Extensions, Inputs, Yields and Farming Practices; Natural Conservation Research Center-Forest Trends: Accra, Ghana, 2014.

11. Gockowski, J.; Sonwa, D. Biodiversity and Smallholder Cocoa Production Systems in West Africa; International Institute for Tropical Agriculture (IITA): Accra, Ghana, 2008.

12. Mohammed, A.; Robinson, J.; Midmore, D.; Verhoef, A. Carbon Storage in Ghanaian Cocoa Ecosystems; Springer: London, UK, 2016.

13. Dormon, E.; Huis, A.V.; Leeuwis, C.; Obeng-Ofori, D.; Sakyi-Dawson, O. Causes of Low Productivity of Cocoa in Ghana; Farmers' Perspective and Insight From Research and the Socio-Political Establishment. NJAS Wagening. J. Life Sci. 2004, 52, 237-259. [CrossRef]

14. Onyeiwu, S.; Pallant, E.; Hanlon, M. Sustainable and Unsustainable Agriculture in Ghana and Nigeria: 1960-2009. Ecosyst. Sustain. Dev. 2011, 3, 211-222.

15. Danso-Abbeam, G.; Aidoo, R.; Agyemang, K.O.; Ohene-Yankyera, K. Technical Efficiency in Ghana's Cocoa Industry: Evidence From Bibiani-Anhwiaso-Bekwai District. J. Dev. Agric. Econ. 2012, 4, 287-294.

16. Anim-Kwapong, G.J.; Frimpong, E.B. Vulnerability and Adaptation Assessment under the Netherlands Climate Change Studies Assistance Programme Phase 2 (NCCSAP2) Vulnerability of Agriculture to Climate Change-Impact of Climate Change on Cocoa Production; Cocoa Research Institute of Ghana: New Tafo Akim, Ghana, 2006.

17. Godfrey, M. Cocoa and Food Security. 2011. Available online: http://cocoasustainability.com/2011/11/ cocoa-and-food-security/ (accessed on 19 May 2016).

18. Zougmoré, R. Climate Smart Agriculture Integrated into Decision-Making in Ghana. 2014. Available online: https://ccafs.cgiar.org/blog/climate-smart-agriculture-integrated-decision-makingghana\#.VuAuAPnnVyN (accessed on 20 December 2015).

19. Amlalo, D.S.; Oppong-Boadi, K.Y. Ghana's Third National Communication Report to the UNFCCC: 2015 Climate Change Report; Environmental Protection Agency: Accra, Ghana, 2015. 
20. Hutchins, A.; Tamargo, A.; Bailey, C.; Kim, Y. Assessment of Climate Change Impacts on Cocoa Production and Approaches to Adaptation and Mitigation: A Contextual View of Ghana and Costa Rica. 2015. Available online: https: / / elliott.gwu.edu/sites/elliott.gwu.edu/files/World\%20Cocoa\%20Foundation.pdf (accessed on 20 December 2015).

21. Aneani, F.; Anchirinah, V.M.; Owusu-Ansah, F.; Asamoah, M. Adoption of Some Cocoa Production Technologies by Cocoa Farmers in Ghana. Sustain. Agric. Res. 2012, 1, 103-117. [CrossRef]

22. Antwi-Agyei, P.; Dougill, A.J.; Stringer, L.C. Barriers to Climate Change Adaptation in Sub-Sahara Africa: Evidence from Northeast Ghana and Systematic Literature Review. Clim. Dev. 2014, 7, 297-309. [CrossRef]

23. Ifejika Speranza, C.; Wiesmann, U.; Risk, S. An Indicator Framework for Assessing Livelihood Resilience in the Contexst of Social-Ecological Dynamics. Glob. Environ. Chang. 2014, 28, 109-119. [CrossRef]

24. Addae-Boadu, S.; Aikins, S.; Alhassan, A.S. The Cocoa Certification Program and Its Effect on Sustainable Cocoa Production in Ghana: A Case Study in Upper Denkyira West District. J. Environ. Earth Sci. 2014, 7, 108-116.

25. Atwima Mponua District Assembly. The Composite Budget of the Atwima Mponua District Assembly for the 2012 Fiscal Year. 2012. Available online: http:/ / www.mofep.gov.gh/sites/default/files/budget/ Atwima\%20Mponua.pdf (accessed on 14 January 2016).

26. Ghanadistricts.com. Ashanti: Atwima Mponua \& Western: Juabeso. 2006. Available online: http:// ghanadistricts.com/districts/?news\&r=5\&_=136 (accessed on 16 January 2016).

27. Ghana Statistical Service. 2010 Population and Housing Census: Juaboso District; Ghana Statistical Service: Accra, Ghana, 2014.

28. Ghana Statistical Service. 2010 Population and Housing Census: Atwima Mponua District; Ghana Statistical Service: Accra, Ghana, 2013.

29. Juaboso District Assembly. District Information. 2012. Available online: http://juaboso.ghanadistricts.gov. gh/ ?arrow=dnf\&_=136\&r=5\&rlv=location (accessed on 14 January 2016).

30. ITTO. Enrichment of Young Forest Plantations with Selected NTFPs for Livelihood Improvement and Support of Forest Fringe Communities in Atwima Mponua District, Ghana; International Tropical Timber Organization (IITO): Yokohama, Japan, 2013.

31. GoG. 2015 Juaboso District Composite Budget and Economic Statement. Government of Ghana, 2015. Available online: http://www.mofep.gov.gh/sites/default/files/budget/2015/Composite/WR/Juaboso. pdf (accessed on 14 January 2016).

32. Bernoux, M.; Branca, G.; Carro, A.; Lipper, L.; Smith, G.; Bockel, L. Ex-Ante Greenhouse Gas Balance of Agriculture and Forestry Development Programs. Sci. Agricola 2010, 67, 31-40. [CrossRef]

33. StataCorp. Stata Statistical Software: Release 13; StataCorp LP.: College Station, TX, USA, 2013.

34. Knowler, D.; Bradshaw, B. Farmers' Adoption of Conservation Agriculture: A Review and Synthesis of Recent Research. Food Policy 2007, 32, 25-48. [CrossRef]

35. Obuobisa-Darko, E. Credit Access and Adoption of Cocoa Research Innovations in Ghana. Res. Humanit. Soc. Sci. 2015, 5, 16-29.

36. Acheampong, E.; Dawoe, E.; Bosu, P.; Asante, W. Moving forward with REDD+ in Ghana: Shade Systems, Crown Cover, Carbon Stocks and Socio-Economic Dynamics of Smallholder Cocoa Agroforestry Systems; SNV World: Accra, Ghana, 2014.

37. Aseidu-Darko, E. Agricultural Extension Delivery in Ghana: A Case Study of Factors Affecting it in Ashanti, Eastern and Northern Regions of Ghana. J. Agric. Ext. Rural Dev. 2013, 5, 37-41.

38. Antwi-Agyei, P.; Dougill, A.J.; Stringer, L.C. Impacts of Land Tenure Arrangements on the Adaptive Capacity of Marginalized Groups: The case of Ghana's Ejura Sekyedumase and Bongo Districts. Land Use Policy 2015, 49, 203-212. [CrossRef]

39. Aidoo, R.; Fromm, I. Willingness to Adopt Certifications and Sustainable Production Methods among Small-Scale Cocoa Farmers in the Ashanti Region of Ghana. J. Sustain. Dev. 2015, 8, 33-43. [CrossRef]

40. Ifejika Speranza, C. Buffer Capacity: Capturing a Dimension of Resilience to Climate Change in African Smallholder Agriculture. Reg. Environ. Chang. 2013, 13, 521-535. [CrossRef]

41. Djokoto, J.; Afari-Sefa, V.; Addo-Quaye, A. Vegetable Diversification in Cocoa-Based Farming Systems in Ghana. Agric. Food Secur. 2017, 6. [CrossRef]

42. Foli, E.; Dumenu, W. Background Paper for Ghana's REDD+ Benefit Sharing Dialogue; The Forest Dialogue: Elmina, Ghana, 2013. 
43. Campbell, B.; Thornton, P.; Zougmoreé, R.; van Asten, P.; Lipper, L. Sustainable Intensification: What is the Role of Climate Smart Agriculture? Curr. Opin. Environ. Sustain. 2014, 8, 39-43. [CrossRef]

44. Gockowski, J.; Sonwa, D. Cocoa Intensification Scenarios and their Predicted Impacts on $\mathrm{CO}_{2}$ Emissions, Biodiversity, Conservation and Rural Livelihoods in Guinea rain forest of West Africa. Environ. Manag. 2011, 8, 307-321. [CrossRef] [PubMed]

45. Freudenberger, K.S. Tree and Land Tenure: Rapid Appraisal Tools; Food and Agriculture Organisation (FAO): Rome, Italy, 1994.

46. Larbi, W.O. Tenure Transformation and Land Valorisation Processes at the Urban Periphery of Ghana. In Proceeding of the International Conference on Land Tenure in the Developing World with a Focus on Southern Africa, University of Cape Town, Cape Town, South Africa, 27-29 January 1998; pp. 27-29.

47. Mumuni, E.; Oladele, O.I. Access to Livelihood Capitals and Propensity for Entrepreneurship amongst Rice Farmers in Ghana. Agric. Food Secur. 2016, 5. [CrossRef]

48. ILO. Research to Identify Practical Measures to Enhance Productivity in Cocoa Growing Communities in Ghana; International Labour Organization (ILO): Geneva, Switzerland, 2013.

49. UNDP. Environmental Sustainability and Policy for Cocoa Production in Ghana; United Nations Development Programme (UNDP): Nairobi, Kenya, 2012.

50. Van der Geest, K. The Dagara Farmer at Home and Away: Migration, Environment and Development in Ghana; African Studies Centre: Leiden, Netherlands, 2011.

51. Marney, I.E.; Anglaaere, L.N.; Akoto, D.S.; Dawoe, E. Migrant Farmers as Information Brokers: Agroecosystems Management in the Transition Zone of Ghana. Ecol. Soc. 2014, 19, 56.

(c) 2018 by the authors. Licensee MDPI, Basel, Switzerland. This article is an open access article distributed under the terms and conditions of the Creative Commons Attribution (CC BY) license (http:/ / creativecommons.org/licenses/by/4.0/). 
Article

\title{
Adoption of Small-Scale Irrigation Farming as a Climate-Smart Agriculture Practice and Its Influence on Household Income in the Chinyanja Triangle, Southern Africa
}

\author{
Nelson Mango ${ }^{1, *}$, Clifton Makate ${ }^{1}$, Lulseged Tamene ${ }^{2}$, Powell Mponela ${ }^{2}$ and Gift Ndengu ${ }^{2}$ \\ 1 International Centre for Tropical Agriculture (CIAT), P.O. Box MP 228 Mt. Pleasant, Harare, Zimbabwe; \\ ruumakate@gmail.com \\ 2 International Centre for Tropical Agriculture (CIAT), c/o Chitedze Agricultural Research Station, \\ P.O. Box 158 Lilongwe, Malawi; lt.desta@cgiar.org (L.T.); powellmponel@gmail.com (P.M.); \\ g.ndengu@cgiar.org (G.N.) \\ * Correspondence: nelsonmango16@gmail.com; Tel.: +254-722270913
}

Received: 31 January 2018; Accepted: 10 April 2018; Published: 14 April 2018

\begin{abstract}
This article is concerned with the adoption of small-scale irrigation farming as a climate-smart agriculture practice and its influence on household income in the Chinyanja Triangle. Chinyanja Triangle is a region that is increasingly experiencing mid-season dry spells and an increase in occurrence of drought, which is attributed largely to climate variability and change. This poses high agricultural production risks, which aggravate poverty and food insecurity. For this region, adoption of small-scale irrigation farming as a climate-smart agriculture practice is very important. Through a binary logistic and ordinary least squares regression, this article determines factors that influence the adoption of small-scale irrigation farming as a climate-smart agriculture practice and its influence on income among smallholder farmers. The results show that off-farm employment, access to irrigation equipment, access to reliable water sources and awareness of water conservation practices, such as rainwater harvesting, have a significant influence on the adoption of small-scale irrigation farming. On the other hand, the farmer's age, distance travelled to the nearest market and nature of employment negatively influence the adoption of small-scale irrigation farming decisions. Ordinary least squares regression results showed that the adoption of small-scale irrigation farming as a climate-smart agriculture practice has a significant positive influence on agricultural income. We therefore conclude that to empower smallholder farmers to respond quickly to climate variability and change, practices that will enhance the adoption of small-scale irrigation farming in the Chinyanja Triangle are critical, as this will significantly affect agricultural income. In terms of policy, we recommend that the governments of Zambia, Malawi and Mozambique, which cover the Chinyanja Triangle, formulate policies that will enhance the adoption of sustainable small scale-irrigation farming as a climate-smart agriculture practice. This will go a long way in mitigating the adverse effects that accompany climate variability and change in the region.
\end{abstract}

Keywords: climate-smart agriculture; adoption; small-scale irrigation farming; household income; Chinyanja Triangle; Southern Africa

\section{Introduction}

The rural poor in Sub-Saharan Africa (SSA) earn their livelihoods mostly from climate-sensitive rainfed agriculture. Their production is typically limited to a 3-6-month rainy season and crops grown are mainly staple cereal crops meant to sustain their livelihoods [1]. However, the yields from these crops are subject to weather-driven fluctuations and are generally low. Dependence of 
smallholder farmers in SSA on such climate sensitive, seasonal staple production systems often leads them into multiple-scale poverty traps [2]. Additionally, this often makes economies in the region (SSA) vulnerable to climatic variability and change [3-5].

It therefore requires that African governments assist the smallholder farming sector to transform and adapt to the various challenges it faces, including climate variability and change. Gaining access to relevant climate-smart technologies and other sustainable productivity-improving practices that will enable them to increase farm productivity, achieve climate resilience, improve food security, nutrition, and income and achieve other developmental goals is therefore key [6,7]. Climate-smart agriculture may be defined as an approach for transforming and reorienting agricultural development under the new realities of climate change [8]. The most commonly used definition is provided by the Food and Agricultural Organisation of the United Nations (FAO), which defines climate-smart agriculture as "agriculture that sustainably increases productivity, enhances resilience (adaptation), reduces/removes greenhouse gases (mitigation) where possible, and enhances achievement of national food security and development goals". In this definition, the principal goal of climate-smart agriculture is identified as food security and development [8,9], while productivity, adaptation, and mitigation are identified as the three interlinked pillars necessary for achieving this goal.

Adopting improved land and water management practices amongst other sustainable technologies can assist smallholder farmers in SSA to achieve the aforementioned goals [6-9]. Some of these technologies may include improved water management in agriculture through the adoption of small-scale irrigation, use of improved crop varieties, fertilizers and other innovative practices more suited to their local conditions. Of interest is the adoption of small-scale irrigation, which currently does not play a significant role in African agriculture, especially as compared to other regions such as Asia and Latin America [10]. Statistics show that irrigated land in Africa as the proportion to cultivated land is only about $6 \%$ for Africa compared to $14 \%$ for Latin America and 37\% for Asia [11,12].

In the Southern African region where this study was conducted, agricultural practice can be grouped into three categories: small-scale farmers, emerging farmers and large-scale farmers. When defining farming practice, the land size alone is not adequate for classifying whether a farmer is a small-scale or a large-scale farmer. Classification should also be based on the general character of the business with labour supply as the principal factor [13]. Small-scale farmers are those who are mainly located in rural areas where agriculture is the main activity to alleviate poverty and they are challenged by a number of constraints to increase productivity [14]. Small-scale farmers differ by individual characteristics: the size of the farm system, proportion of crops sold, household expenditure patterns, distribution of factors of production between food crops and cash crops and off-farm activities. These differences mean that these farmers make different contributions toward their country's economy [15].

Small-scale irrigation is critically important as an innovative practice in smallholder agriculture in Africa [16]. This is because it improves farm productivity [16], farming systems adaptation to climate variability and change and achievement of household food security and national developmental goals. According to Kamwamba-Mtethiwa et al. [16], there is a lot of heterogeneity in what small-scale irrigation farming entails in Africa. It is characterized by the use of simple technologies to access water for irrigation. Burney and Naylor [1] defined water access technology as any method of moving water from its source to where it was previously unavailable. This includes all types of pumps from human powered, rope and treadle pumps to liquid fuel engine-driven systems and solar powered pumps as well as gravity/river diversion methods [17]. In SSA, a wide variety of such technologies has been introduced since the 1990s for small-scale irrigation development [17]. Gravity technology typically involves diverting water flow using open channels without pumping. Motorized systems include engine-driven pumps, while treadle and rope and washer pumps are manual and wind and solar use renewable energy [16]. Previously, most rural farmers in SSA had relied on traditional methods on small plots of land using, for example, shadoof, buckets, watering cans, calabashes or blocking streams [18]. It can also mean total area of land covered by the irrigation practice that is in place. This can be from less than half an acre of land to multi-farmer irrigation projects that 
serve farms larger than 5 ha in size [19]. In SSA, the adoption of small-scale irrigation farming is hugely important for smallholder farmers, especially when one considers that rainfall is highly unreliable and insufficient in many places [6,20]. Drought—especially mid-season—due to low and erratic rainfall poses high uncertainty and agricultural production risks in sub-Saharan Africa [21]. This leads to threats of widespread poverty and food insecurity. Small-scale irrigation is possibly a viable climate-smart agriculture technology to consider in SSA given that the continent has abundant freshwater resources from various lakes and river basins [10] even though their distribution is not even across agro-ecological zones. In addition, small-scale irrigation is an important step towards the intensification of farming systems [22] and in helping farmers ensure against drought risk and transform their farming activities [23,24].

There is limited literature on studies that assess the impacts of adopting small-scale irrigation on people's livelihoods in SSA. The scarcity is even worse if we are to consider studies that have analyzed the livelihood impacts of small-scale irrigation as a potential climate-smart agriculture technology - that is, evaluating the potential of small-scale irrigation to build the resilience of farming systems to climate variability and change. With increased threats from climate variability and change in various parts of the world, including SSA, studies to assess the effectiveness of small-scale irrigation adoption in sustainably increasing productivity and incomes should be a priority. Literature that discusses adoption of small-scale irrigation in general in SSA is available. In these literature, small-scale irrigation was found to improve income and food security in the Ambo district, the Ada Liben district, the Tigray region, the Southern Nations, Nationality and People's Region, and the Oromia region, all in Ethiopia [25-29]. Similarly, in Zimbabwe, Mudima [30] investigated five irrigation schemes for their livelihood impacts. The study shows that the irrigation schemes acted as sources of food security for the participants and their surrounding communities. The main livelihood contributions of the irrigation schemes came through increased productivity, stable production and incomes. In addition, the study found that members of the irrigation schemes never ran out of food supplies compared to their counterparts relying on rainfed agriculture.

In the Southern African region, not much land is under irrigation for both subsistence and commercial agriculture. However, areas with irrigation schemes can be categorized into four groups. First is the bureaucratically managed small-scale scheme in which farming is carried out by the government or its agencies on behalf of the farmers. Second is the community or garden scheme, which is usually very small and is maintained by community users with the main objective of subsistence farming. Community gardens share a similar infrastructure for water supply where small dams are usually used for the water supply. Third are the corporation-financed schemes in which governments provide support from infrastructure down to farm gate while farmers only contribute toward a subsidized water fee and make operational service and management decisions. Lastly are the large estate irrigation schemes that are managed by agents with the objective of maximizing the use of resources through the production of high-value crops, such as tea, coffee, etc. [19,31]. The other significant group of small-scale farmers is the independent irrigators. They have a private water supply, such as their own borehole, and their primary objective is to make a living out of farming where it is usually considered as an additional source of income. Independent irrigators are usually not being supported through funds but use their own or family capital accumulated over time. Moreover, there is a lack of support for specialized technical advice on cropping and irrigation management, which reduces their overall productivity. According to Delgado [32], independent irrigators can be differentiated on the basis that they buy their own inputs and sell produce independently wherever they choose. In this study, we focus on the independent irrigators as they form the majority in the study site.

In Zambia, Malawi and Mozambique where the study area falls, small-scale irrigation generally relies on residual moisture and it is practised along stream banks. Smallholder farmers benefit from either government established smallholder schemes operated by the governments or from self-help schemes run by the farmers. In some cases, they are supported by non-governmental organizations (NGOs). These schemes receive little or no formal technical support in design, operation 
and maintenance. In addition to schemes, other informal un-documented irrigation practices such as the use of buckets, watering cans and hosepipes have been in place for several decades. The areas being irrigated range from as small as $100-200 \mathrm{~m}^{2}$ with traditional approaches to $1000-2500 \mathrm{~m}^{2}$ and up to 50 ha when organized as a smallholder scheme [33-35]. See Table 1 for coverage of areas of irrigation land in Zambia, Malawi and Mozambique.

Table 1. The cultivated, potential irrigable and actual areas under irrigation in Malawi, Mozambique and Zambia.

\begin{tabular}{cccc}
\hline Country & $\begin{array}{c}\text { Cultivated Area } \\
\text { (ha) }\end{array}$ & $\begin{array}{c}\text { Total Potential Irrigable Area } \\
\text { (ha) }\end{array}$ & $\begin{array}{c}\text { Total Irrigated Area } \\
\text { (ha) }\end{array}$ \\
\hline Malawi & $2,440,000$ & $480,000\left(100,000^{\mathrm{b}}\right)$ & 60,000 \\
Mozambique & $4,435,000$ & $3,072,000$ & $200,000^{\mathrm{c}}$ \\
Zambia & $5,289,000$ & $2,750,000$ & 156,000 \\
\hline
\end{tabular}

Source: FAO [33-35]. ${ }^{a}$ Based on water availability and soil irrigability; ${ }^{\mathrm{b}}$ small-scale farms; ${ }^{\mathrm{c}}$ Northern Mozambique.

The main crops grown include vegetables, rice, bananas and some local varieties of sugarcane. In 2005, the irrigation water use efficiency on smallholder farms was around $25-50 \%$ due to higher loss experienced in surface irrigation. There have been improvements in irrigation as the sector is gradually being transformed from subsistence-oriented to high value marketed crops. Since smallholder agriculture is not capital intensive, it is promoted as an adaptation strategy for the recurrent droughts that are attributed to climate variability and change in the region. Most of the streams in the region are seasonal with torrential flows during the short wet season of 3-4 months. The greater part of the year has low flows. The ground and large river/lake basin water are considerable but has not been tapped for irrigation use. The main challenge in developing small-scale irrigation has been the insufficient institutional capacity at both national and local levels [36].

With regard to the views above, this article aims to analyze the adoption of small-scale irrigation as a climate-smart agriculture practice in the Chinyanja Triangle, southern Africa, and assess its contribution to people's livelihoods. More specifically, the article aims to identify factors that influence smallholder farmers' decisions to adopt small-scale irrigation and assess the influence of adoption on household incomes. Policy options for targeting out and upscaling small-scale irrigation adoption for effective adaptation to climate variability and change in the region are therefore proposed.

\section{Research Methods}

\subsection{Study Area Context and Sites}

The study was conducted in the Chinyanja Triangle and covered Furancungo (14.90 S; $33.61 \mathrm{E})$ in Tete Province of Mozambique, Budula-Siliya (13.71 S; 31.96 E) in Zambia's eastern province, as well as Linthipe (14.17 S; $34.12 \mathrm{E}$ ) and Nsipe (14.87 S; $34.75 \mathrm{E}$ ) in the central and southern regions of Malawi (Figure 1). The common denominator in this region is the inhabitants' mother tongue, Chichewa. This region forms a triangular shape. Culturally, the majority of people in the region share the same beliefs. It is hypothesized that they would share similar approaches to resource management, especially in terms of the land on which they depend for their livelihoods and the adoption of certain agricultural practices [37]. According to the characterization by scholars from the Consultative Group for International Agricultural Research (CGIAR) [38], 37.9\% of the area in the Chinyanja Triangle is under shrub cover, which is classified as closed-open deciduous trees. Tree cover occupies $31 \%$ of the study area. Cultivated and managed areas make up $24 \%$ of the area and water bodies occupy $4 \%$. Herbaceous species cover $2.04 \%$ of the site and bare, artificial and associated areas take up less than $1 \%$. The study sites are dominated by maize as the staple food crop, mixed with legumes and groundnuts. 


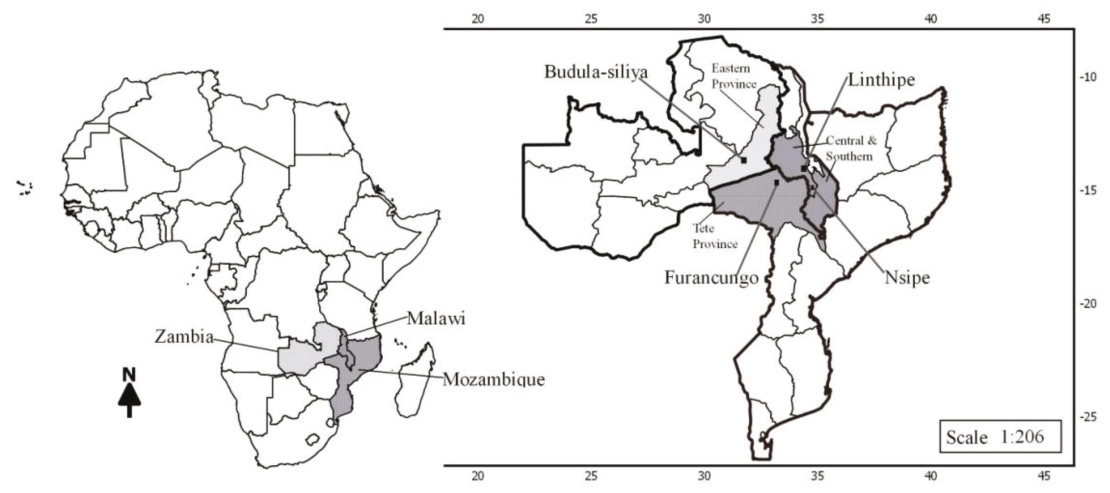

Figure 1. Map showing the location of the Chinyanja Triangle and research sites. The numbers on the map are the latitude and longitude of the specific research locations in degrees.

In terms of irrigation and water management, farming in the Chinyanja Triangle is mainly rainfed. This is despite the abundance of water resources within its catchment area, mainly from the Zambezi River Basin [37]. Irrigated agriculture contributes to less than $10 \%$ of the produce [39]. The general trends in the region show that climate variability and change pose a great risk to agriculture productivity. The unpredictable climate of the Chinyanja Triangle means that the risk of crop loss in rainfed agriculture exceeds 50\% and can reach up to $75 \%$ in the drier southeastern zones of the triangle, including most parts of Tete Province of Central Mozambique [37-39]. On the other hand, the western and northern parts of the triangle have conditions that are more conducive for rainfed agriculture where the probability of good harvests during the wet season is 70-95\% [40].

Irrigation development is considered as a strategy for poor small-scale farmers to get out of poverty by shifting towards market-oriented agriculture [39]. Higher-value crops are grown in the valley bottoms mainly under irrigation or the dambo (wetland valley bottom) system. This is done as a response to climate variability and change in the region. In the dambo system, crops use residual moisture along with some supplementary irrigation to ensure adequate water supply during the growing period. Farmers also practice spate irrigation, furrow irrigation and, in a few cases, motorized pumps to deliver water to fields. The relatively higher-income and middle-income farmers are commonly the ones using motorized pumps while the low-income farmers use predominantly furrow irrigation or manual treadle pumps to transfer water from small springs [37].

The food crops commonly grown under irrigation include maize, rice, sweet potatoes, Irish potatoes, beans, leafy vegetables, tomatoes and onions. This is also where most farmers use external inputs (fertilizers and pesticides), particularly for growing cash crops such as tobacco and cotton. Most farmers have agricultural land to grow food crops and a few cash crops but not everyone has a garden area because of limited access to irrigation water. Malawi's renewable water resource is estimated to be $17.28 \mathrm{~km}^{3} \mathrm{yr}^{-1}$ of which about $16.14 \mathrm{~km}^{3} \mathrm{yr}^{-1}$ is produced internally, drained from the rivers within the country [40]. About $91 \%$ of the country is within the Zambezi River Basin, over $90 \%$ formed by the Shire Basin. According to FAO [33-35] and the Department of Irrigation in Malawi, the estimated irrigation potential in the country is about 480,000 ha while only 63,000 ha have been fully developed, of which $77 \%$ is used by commercial estates whilst only $23 \%$ is used by smallholders [40,41] who produce mainly cereals (mostly rice and maize) and horticultural crops. Among those parcels that are irrigated, $62 \%$ use watering cans, $14 \%$ use flooding, $11 \%$ are gravity-fed and $6 \%$ use treadle pumps [42]. Peters [41] estimated that about 11,500 ha of the small-scale irrigation are under farmer-run self-help irrigation schemes while 3,200 ha are under government-run irrigation schemes. The irrigated area in estates is used for export- or high-value crops such as sugarcane (45\%), tea (44\%) and coffee (11\%) [43]. Moreover, about 62,000 ha of land is estimated to be used for traditional wetland cultivation using 
residue moisture, mainly during the dry seasons as the areas are waterlogged and inaccessible during the rainy season. There is no formal classification of smallholder irrigation schemes in Malawi but they are informally classified as farmer-run self-help schemes or government-run irrigation schemes. The latter schemes commonly target smallholder farmers but are managed and rehabilitated, where necessary, by the government, commonly using donor funding. Because there was limited participation in the design, construction and management of the irrigation schemes, government-run irrigation schemes managed by settlers and smallholders are underperforming and are the least diversified in terms of market opportunities. Their landholdings are also small, even by Malawi standards, each being between 0.1 and 0.3 ha [43] — too small to support substantial livelihoods.

Zambia has a huge irrigation potential, estimated to be about 2.75 Mha of land [40], with a large portion of it being in the Chinyanja Triangle. However, the total area currently under irrigation is estimated to be only about $10 \%$ of the potential and is mostly practised by large- and medium-scale farmers using surface water irrigation [44]. Only 15,000 ha of land is estimated to be irrigated with motor pumps although the region holds a high groundwater potential that could be exploited by increasing access to motor pumps. Most of the smallholder-irrigation schemes produce food crops, such as rice, maize and horticultural crops, but they are usually underperforming due to poor infrastructure, inadequate water supply, and inefficient use of the available water [43]. The high rainfall from December to March commonly saturates the soil and creates seasonally waterlogged low-lying dambos. There is potential for developing and expanding small reservoirs in the region for multiple uses, namely drinking for livestock, fishery, household irrigation and other domestic uses [44].

Mozambique has more than 100 river basins. Most of the rivers have highly seasonal, torrential flow regimes with high flow for 3-4 months and low flow for the remainder of the year, corresponding to the distinct wet and dry seasons [39]. Among these, the Zambezi River Basin is the most important in Mozambique [37]. It accounts for about $50 \%$ of the surface water resources of the country and about $80 \%$ of its hydropower potential, including the Cahora Bassa Dam [40], the second largest dam in Africa. The main source of water for irrigation in Mozambique is surface water. Irrigation in Mozambique is in its infancy despite being a downstream country with large seasonal flows of the region's big rivers, including the Limpopo and the Zambezi. The irrigation potential is estimated to be above 3 Mha but only a small part of it is being developed, primarily for the large-scale production of sugarcane, rice and vegetables in the downstream, central and southern provinces. Tete Province, which is within the Chinyanja Triangle, has limited surface water flow except in districts at higher altitudes (e.g., Angonia) [37]. Small-scale irrigation is very much limited to surface water irrigation for producing tobacco, vegetables and a few rice fields. Mozambique could expand its provision of water to smallholder farmers, particularly in the Chinyanja Triangle, to mitigate the potential effects of recurrent drought. With the increasing market opportunities in Tete and its surroundings, thanks to the expanding mining sector, small-scale irrigation could help farmers produce high-value agricultural products, access regional markets and improve their capacity to respond to emerging demands and climatic shocks [37]. Vegetables, fruits, dairy and small ruminant production seem to be feasible entry points. In terms of irrigation technology, motor pumps could play an important role in the near future in that landscape in getting water to farmers' fields although the governments in the three countries are promoting the use of treadle pumps because of the low maintenance requirements and operational costs.

In general, there is an increasing trend to use water for multiple purposes in the entire Chinyanja Triangle socio-technical landscape, particularly in Malawi through integrating fishponds into farming practices, drinking for livestock, irrigation farming and household use. Those farmers who have adopted aquaculture have doubled their household income and increased household food production by about $150 \%$ [45]. This compensates for crop losses due to climate change and variability. The adoption of fishponds has been growing in number by about $25 \% \mathrm{yr}^{-1}$ since 2000 and is being increasingly practised in the region, particularly in the lower Zambezi River Basin [45]. Governments have also acknowledged the challenge of promoting this practice in areas where the total rainfall amount is low and access to the Zambezi River or its tributaries is limited [37]. However, increased 
integration of fishponds into farming systems along with the increasing demand for irrigation water has created a fierce local competition among and between communities [37]. Expansion of small-scale irrigation systems coupled with ineffective institutions for water governance for multiple demands has led to frequent water shortages and local conflicts among communities.

\subsection{Sampling Methods, Data Collection and Data Source}

\section{Sampling and Data Collection}

Sampling units for this study were drawn using the multistage spatially stratified random sampling design of the Land Degradation Surveillance Framework [46]. Four sites, as described in Section 2.1, were used to make up the sample data. There were 16 clusters within each site. For the Africa Rising sites, the two mother trials (established during the 2012/13 growing season) were used as centre clusters with the other 14 clusters randomly spread around them. Each cluster covered an area of $2 \mathrm{~km}^{2}$ with 10 randomly located sampling plots from where a Land Condition Survey (LCS) was conducted. For each cluster, five farmers who owned odd numbered plots (1, 3, 5, 7 and 9) were considered for a socioeconomic questionnaire. The socioeconomic data were collected from owners of the plots sampled during the LCS, thereby geo-referencing farmers to their sampled plots and not their place of residence. Plot owners were identified during the LCS by locals from the nearest village. The household survey was conducted to collect primary household socioeconomic data using structured questionnaires. Collected data included the socio-demographic and economic characteristics of the households, land characteristics and integrated soil fertility management (ISFM) technology usage, livestock ownership and species, as well as irrigation and water harvesting technology practices. Extension service personnel, agriculture research officers and trained enumerators collected data between December 2012 and June 2013. Data on different livestock species were further converted into standard livestock units (LUs) using nutritional and feed requirement factors for sub-Saharan Africa $[47,48]$.

Data were collected from 312 households. In this context, a household was defined as a group of people who normally live together and eat their meals in the same dwelling [49]. The data obtained were used to estimate the binary logistic and ordinary least squares (OLS) regression models. For the purposes of this study, the heads of the selected households, whether male or female, were implicitly assumed to be the sole decision-makers in the adoption of irrigation farming decisions. Household heads were therefore selected to respond to the structured questionnaire. Predictor variables of adoption were selected from the broad range of the household's socioeconomic aspects, including demographics, farming activities, institutions, processes of adoption and asset endowment.

\subsection{Data Analysis}

In this article, both descriptive and econometric data analysis methods were used. Where land holdings are fixed, the allocation of land into crop type and the adoption of small-scale irrigation farming are possibly endogenous. The adoption decision of small-scale irrigation farming as a climate-smart agriculture practice and associated technologies is distinct, as a farmer can decide to adopt or not adopt, in which case the smallholder farmer faces a dichotomous decision problem to adopt or not adopt irrigation farming. In this context, smallholder irrigation farming adopters practised irrigation farming at the time of the survey, while the rest were taken as non-adopters. In this study, irrigation farming was mainly practised in the forms of spate, furrow and surface water irrigation with a few farmers using manual and or motorized treadle pumps as discussed in the previous sections. A smallholder farmer was considered an adopter of small-scale irrigation if he/she was practising at least one of the aforementioned irrigation types as a response to climate variability and change in the region. On the other hand, those farmers who did not practise any of the irrigation farming methods were considered as non-adopters. Similar definitions of adopters and non-adopters have been used by other writers [50]. In the OLS-based impact analysis, only farmers who had practised irrigation farming for at least one season were considered as adopters. The econometric models for adoption 
and the model on the effect of the adoption of small-scale irrigation farming on income are specified in the section below.

Modelling the Adoption of Small-Scale Irrigation Farming as a Climate-Smart Agriculture Practice

The general assumption was that there is a desire to maximize the expected utility of adopting new technologies such as small-scale irrigation farming given the persistent drought in the region [22,51]. Although the utility-maximizing objective of individual smallholder farmers everywhere might be the same, the specific characteristics that influence their technology adoption decisions are far from uniform. The farmers' responses to the adoption of small-scale irrigation farming as a climate-smart agriculture practice were assumed to be consistent with utility maximization. Binary logistic regression is a common statistical procedure in which the probability of a dichotomous outcome (adoption or non-adoption) is related to a set of explanatory variables and has been widely applied in adoption studies [48,50,52-61]. In this research, smallholder farmers' adoption of small-scale irrigation farming as an adaptation strategy to climate change was based on an assumed underlying utility function. According to this model, the farmer will adopt small-scale irrigation farming if the utility obtained from small-scale irrigation farming exceeds that of non-adoption. Considering the probability of an event = Prob ( $\mathrm{Y}=1$ if the smallholder farmer adopted and 0 otherwise), the smallholder farmer's behaviour towards irrigation farming is described as an indirect utility that is derived from the adoption of small-scale irrigation farming, which is a linear function of $k$ explanatory variables $(\mathrm{X})$ expressed as:

$$
\mathrm{Z}_{\mathrm{i}}=\beta_{0}+\sum_{i=1}^{n} \beta_{i} X_{k i},
$$

where $\beta_{0}$ is the intercept term and $\beta_{1}, \beta_{2}, \beta_{3}, \ldots, \beta_{i}$ are the coefficients associated with each of the $k$ explanatory variables $\left(X_{1}, X_{2}, X_{3}, \ldots, X_{k i}\right)$. The $X$ vector of variables (including socioeconomic, farming, institutional factors and other household-specific characteristics that influence the individual farmer's decision whether to adopt or not) explains the adoption of irrigation farming by the smallholder farmer, i.e., it explains the likelihood of the adoption of irrigation farming by the individual $\left(i_{\text {th }}\right)$ farmer (see Table 2 ).

Considering $P_{i}=\frac{e^{z i}}{1+e^{z i}}$, where $P_{\mathrm{i}}$ denotes the probability of the $i$ th farmer's adoption decision and $\left(1-P_{i}\right)$ is the probability of non-adoption, the odds of adoption $(\mathrm{Y}=1)$ versus the odds of non-adoption $(Y=0)$ can be defined as the ratio of the probability that a farmer adopts $\left(P_{i}\right)$ to the probability of non-adoption $\left(1-P_{i}\right)$, namely odds $=P_{i} /\left(1-P_{i}\right)$ [62]. By taking the natural logarithms, one gets the prediction equation for the individual farmer:

$$
\operatorname{Ln}\left(\frac{P_{i}}{1-P_{i}}\right)=\beta_{0}+\sum_{i=1}^{n} \beta_{i} X_{k i}=Z_{i}
$$

where $\mathrm{Z}_{\mathrm{i}}$ is referred to as the odds ratio in favour of the adoption of irrigation farming.

\subsection{Variable Selection and Hypothesis on Adoption Decisions Model}

Table 2 gives a full description of the dependent variable, explanatory variables and initial hypotheses of selected predictor variables on adoption decisions. Previous studies on the adoption of agricultural technologies, such as the determinants of micro-irrigation adoption [63-65], economic theory on adoption and the researchers' own perceptions of the socioeconomic setting of the study locations guided the selection of variables and their expected signs [49,51-61]. The study therefore considered the characteristics of the household head and the household itself including gender, age, household size, education, off-farm employment and occupation. The household's access to various assets such as extension and agricultural credit, reliable water reservoirs, irrigation equipment (such as manual and motorized pumps) and land was determined. Other explanatory variables included the distance to the nearest markets and knowledge of conservation practices. It is important to note that 
access to irrigation equipment (manual and or motorized pumps) also acted as a proxy for general access to resources (affluent farmers).

Table 2. Description of the variables specified in the binary logistic model of adoption.

\begin{tabular}{|c|c|c|c|c|}
\hline Variable Acronym & Description & Measurement & $\begin{array}{l}\text { Posited } \\
\text { Sign }\end{array}$ & Supporting References \\
\hline \multicolumn{5}{|l|}{ Dependent variable } \\
\hline Irrigation farming & $\begin{array}{l}\text { Whether farmer adopted } \\
\text { irrigation farming or not }\end{array}$ & Dummy ( 1 if yes, 0 if no) & + & {$[19,20,44,45,51,53,63,64]$} \\
\hline \multicolumn{5}{|l|}{$\begin{array}{l}\text { Explanatory } \\
\text { variables }\end{array}$} \\
\hline Gender & $\begin{array}{l}\text { Gender of household } \\
\text { head }\end{array}$ & $\begin{array}{c}\text { Dummy ( } 1 \text { if male, } 0 \text { if } \\
\text { female) }\end{array}$ & + & {$[19,20,44,45,52,54,64]$} \\
\hline Age & Age of household head & Years & - & {$[44,45,51,54,64,66-69]$} \\
\hline Household size & Household size & Numbers & + & {$[19,20,44,45,51,54,64]$} \\
\hline Education & $\begin{array}{l}\text { Educational background } \\
\text { of the household head }\end{array}$ & $\begin{array}{l}\text { Number of years of } \\
\text { formal education }\end{array}$ & + & {$[19,20,44,45,51,54,64]$} \\
\hline Extension & $\begin{array}{l}\text { Access to agricultural } \\
\text { extension services }\end{array}$ & Dummy ( 1 if yes, 0 if no) & + & {$[19,20,44,45,51,54,64]$} \\
\hline Occupation & $\begin{array}{l}\text { Nature of the main } \\
\text { occupation of the } \\
\text { household head }\end{array}$ & $\begin{array}{l}1 \text { if farming, } 2 \text { if formal } \\
\text { employment, } 3 \text { if } \\
\text { small-scale business, } 4 \text { if } \\
\text { casual labour, and } 5 \text { if } \\
\text { skilled labour }\end{array}$ & $+/-$ & {$[19,20,44,45,51,54,64]$} \\
\hline $\begin{array}{l}\text { Off-farm } \\
\text { employment }\end{array}$ & $\begin{array}{l}\text { Members of the } \\
\text { household with off-farm } \\
\text { employment }\end{array}$ & Numbers & - & {$[19,20,44,45,51,54,64,70-72]$} \\
\hline Credit access & Access to credit & Dummy ( 1 if yes, 0 if no) & + & {$[19,20,44,45,51,54,64]$} \\
\hline $\begin{array}{l}\text { Irrigation } \\
\text { equipment }\end{array}$ & $\begin{array}{l}\text { Household's access to } \\
\text { irrigation equipment }\end{array}$ & Dummy ( 1 if yes, 0 if no) & + & {$[19,20,44,45,51,54,64]$} \\
\hline $\begin{array}{l}\text { Reliable water } \\
\text { source }\end{array}$ & $\begin{array}{l}\text { Access to a reliable water } \\
\text { source that can be used } \\
\text { for irrigation purposes }\end{array}$ & Dummy ( 1 if yes, 0 if no) & + & {$[52,54,66]$} \\
\hline $\begin{array}{c}\text { Awareness of } \\
\text { conservation } \\
\text { practices }\end{array}$ & $\begin{array}{l}\text { Awareness of some of } \\
\text { the water conservation } \\
\text { practices, such as } \\
\text { rainwater harvesting }\end{array}$ & Dummy ( 1 if yes, 0 if no) & + & {$[40,43,45,52,54,66]$} \\
\hline $\begin{array}{l}\text { Distance to market } \\
\text { (square root) }\end{array}$ & $\begin{array}{l}\text { Distance to the nearest } \\
\text { market (square root) }\end{array}$ & Kilometres & - & {$[37,42,52,54,66]$} \\
\hline $\begin{array}{l}\text { Land size } \\
\text { cultivated }\end{array}$ & $\begin{array}{l}\text { Size of land available } \\
\text { for cultivation }\end{array}$ & Hectares & $+/-$ & {$[19,22,36,47,52,54,66]$} \\
\hline
\end{tabular}

\subsubsection{Validity of the Binary Logistic Model}

Coefficients of the binary logistic model were estimated by the maximum likelihood method using STATA 12 software. The results of the binary logistic model are given in Table 4 . The number of observations used in the model is 312 . Prob $>$ Chi $2=0.000$ and a pseudo $R^{2}$ of $42.2 \%$ shows that the model is valid and the model estimates fit very well with the data at an acceptable level.

\subsubsection{Modelling Effect of the Adoption of Irrigation Farming on Income}

The continuous dependent variable is agricultural income. As such, the OLS regression model can be used without a doubt. Getacher et al. [50] have also used the approach to estimate the effect of irrigation technology adoption on total agricultural income. To estimate the effect of the adoption of 
irrigation farming on household agricultural income, a multiple OLS regression model was used that is specified as follows:

$$
Y_{i}=\beta_{0}+X_{1 i} \beta_{1}+X_{2 i} \beta_{2}+\cdots \ldots \ldots+X_{k i} \beta_{k}+p_{i} \beta_{k+1}+\varepsilon_{i}
$$

where $Y_{i}=$ agricultural income; $X_{k i}$ is a vector of the household's socioeconomic characteristics and other farm-specific characteristics. These characteristics include livestock units (LUs), contact with agricultural extension and labour; $p_{i}$ denotes the adoption of small-scale irrigation farming status for a farmer; a dummy variable is specified as 1 for adopters and 0 for non-adopters; and $\varepsilon_{i}$ is the error term, which is assumed to be normally distributed with a mean of 0 and unit (constant) variance.

Table 3 shows the explanatory variables used in the OLS regression model with their specifications.

Table 3. Description of the variables specified in the ordinary least squares (OLS) regression model.

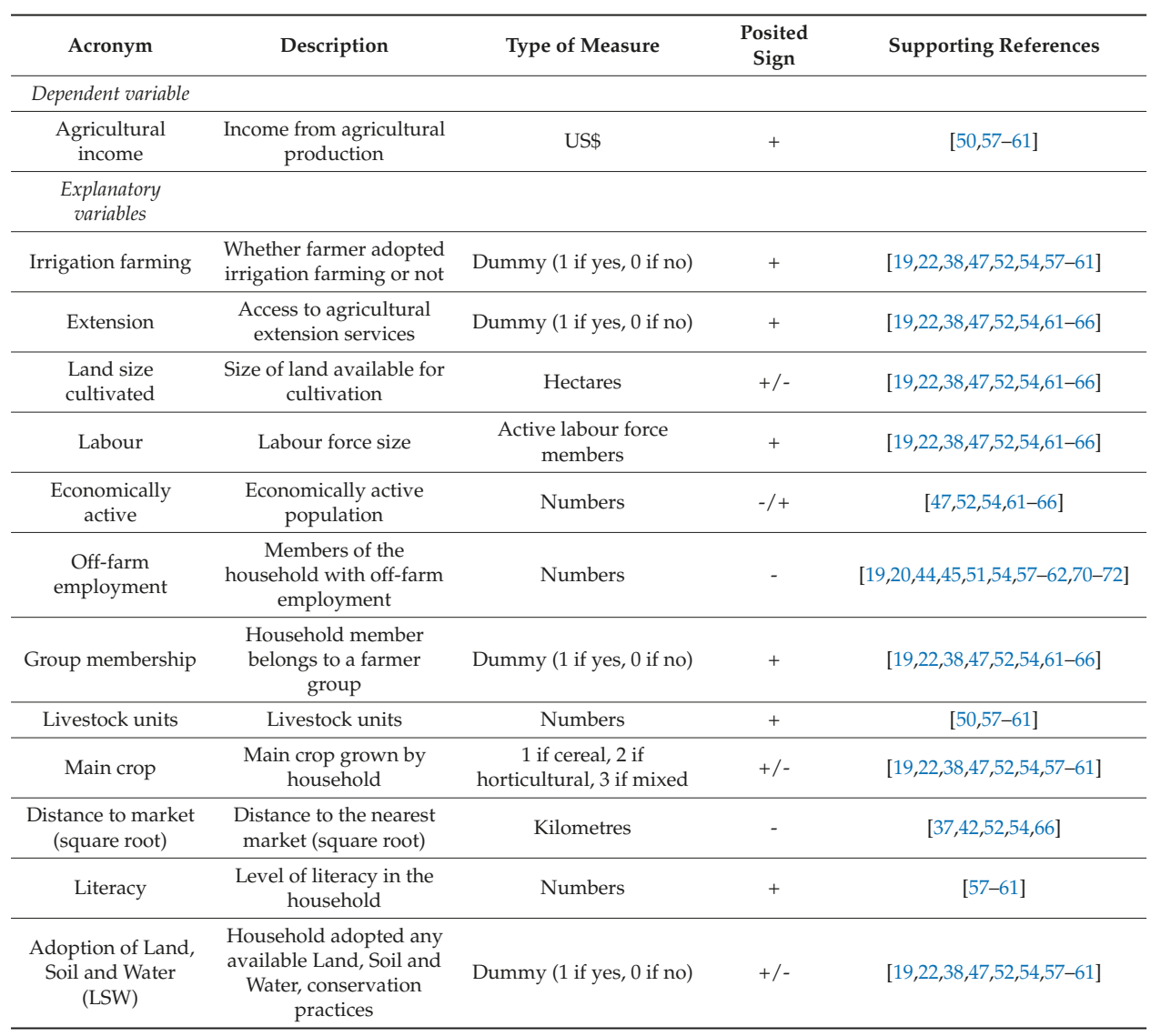

\subsubsection{Descriptive Statistics of Variables Used in the Two Econometric Models}

The statistics of the variables specified in the two empirical models (the adoption of irrigation farming model and the income model), as shown in Tables 2 and 3, are given in Table 4. The table shows summary statistics on the profile of enumerated smallholder farmers. 
Table 4. Statistics of variables used in the econometric models.

\begin{tabular}{ccccc}
\hline Variable & $\begin{array}{c}\text { Mean } \\
n=\mathbf{3 1 2}\end{array}$ & $\begin{array}{c}\text { Standard } \\
\text { Deviation } n=\mathbf{3 1 2}\end{array}$ & $\begin{array}{c}\text { Minimum } \\
n=\mathbf{3 1 2}\end{array}$ & $\begin{array}{c}\text { Maximum } \\
\boldsymbol{n} \mathbf{3 1 2}\end{array}$ \\
\hline Age & 46.589 & 15.308 & 20 & 90 \\
Household size & 5.837 & 2.379 & 1 & 15 \\
Education & 5.045 & 3.637 & 0 & 17 \\
Extension & 0.692 & 0.462 & 0 & 1 \\
Occupation & 1.311 & 0.909 & 1 & 5 \\
Off-farm employment & 0.776 & 1.354 & 0 & 8 \\
Credit access & 0.237 & 0.426 & 0 & 1 \\
Irrigation equipment & 0.333 & 0.472 & 0 & 1 \\
Reliable water source & 0.487 & 0.501 & 0 & 1 \\
Awareness of conservation practices & 0.792 & 0.407 & 0 & 1 \\
Distance to market & 30.142 & 21.135 & 0.3 & 95 \\
Distance to market (square root) & 5.133 & 1.951 & 0.55 & 9.75 \\
Land size cultivated & 6.126 & 7.041 & 0.3 & 41 \\
Labour & 3.288 & 1.807 & 0 & 12 \\
Economically active & 2.824 & 1.754 & 0 & 10 \\
Off-farm employment & 0.776 & 1.354 & 0 & 8 \\
Group membership & 0.340 & 0.474 & 0 & 1 \\
Livestock units & 1.457 & 4.093 & 1 & 60 \\
Main crop & 1.154 & 1.109 & 0 & 14 \\
Literacy & 2.458 & 1.970 & 0 & 11 \\
Adoption of LSW & 0.712 & 0.454 & 0 & 1 \\
Irrigation farming & 0.471 & 0.50 & & 1 \\
\hline
\end{tabular}

\section{Results and Discussion}

\subsection{Results of the Model and Discussion}

Table 5 reports the coefficients (B), standard errors of the coefficients (S.E), odds ratios and the $p$-values. Odds ratios show the predicted change in odds for a unit increase in the corresponding explanatory variable. Expressed in terms of variables used in the model, the logistic regression equation is:

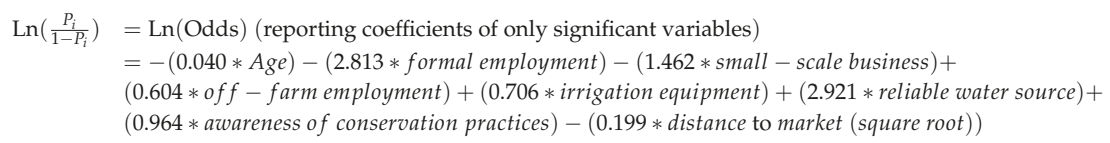

These estimates provide information on the relationship between the significant explanatory variables and their influence on the adoption of irrigation farming as a climate-smart agriculture practice within the study area, where the dependent variable is on the logit scale.

The results of the logit model (Table 5) show that among the hypothesized explanatory variables only eight significantly influenced the adoption of irrigation farming. Age, formal employment, small-scale business, off-farm employment, irrigation equipment, reliable water sources, awareness of conservation measures and distance to the nearest market were the significant variables in the binary logistic model. Contrary to the hypothesis, gender, household size, education, extension, casual labour, skilled labour, credit access and land size cultivated did not significantly influence the adoption of small-scale irrigation farming.

Age had a negative impact on the adoption of small-scale irrigation farming, which suggests that the odds of adoption are higher among younger farmers than among older farmers. Specifically, the results show that a one-year increase in the farmer's age reduced the odds of adoption by about $4 \%$ ( 1 to 0.96 ). The average age of 46 for a population with a life expectancy of 40 shows that most farmers are ageing. As farmers get older, despite their accumulated experience in farming, they tend 
to lose energy, have short planning horizons and become more risk averse and therefore adopting new irrigation practices may be difficult for them. This result was expected and is consistent with other scientists' findings [66-69]. Moreover, small-scale irrigation farming is time and labour intensive. The proper management of irrigable crops (especially fruit and vegetables) also requires storage and transportation facilities, as well as market availability and access to the market, which act as an adoption barrier to the older farmers.

Table 5. Parameter estimates of the binary logistic regression model for factors influencing the adoption of irrigation in the Chinyanja Triangle.

\begin{tabular}{|c|c|c|c|c|}
\hline Variable & B & (S.E) & Odds Ratio & ( $p$-Value) \\
\hline Gender & 0.543 & 0.452 & 1.721 & 0.229 \\
\hline Age ${ }^{* * *}$ & -0.040 & 0.012 & 0.961 & $0.001^{* * *}$ \\
\hline Household size & 0.046 & 0.074 & 1.047 & 0.537 \\
\hline Education & 0.011 & 0.05 & 1.011 & 0.830 \\
\hline Extension & -0.482 & 0.383 & 0.618 & 0.208 \\
\hline \multicolumn{5}{|l|}{ Occupation } \\
\hline formal employment $* * *$ & -2.813 & 0.983 & 0.060 & $0.004^{* * *}$ \\
\hline Small-scale business * & -1.462 & 0.794 & 0.232 & $0.066^{*}$ \\
\hline Casual labour & -1.554 & 1.653 & 0.211 & 0.347 \\
\hline Skilled labour & -1.099 & 0.924 & 0.333 & 0.234 \\
\hline Off-farm employment ${ }^{* * *}$ & 0.604 & 0.179 & 1.829 & $0.001^{* * *}$ \\
\hline Credit access & -0.171 & 0.414 & 0.843 & 0.680 \\
\hline Irrigation equipment ${ }^{* *}$ & 0.706 & 0.358 & 2.027 & $0.049^{* *}$ \\
\hline Reliable water source $* * *$ & 2.921 & 0.367 & 18.564 & $0.000 * * *$ \\
\hline Awareness of conservation practices ${ }^{* *}$ & 0.964 & 0.471 & 2.623 & $0.041 * *$ \\
\hline Distance to market (square root) ${ }^{*}$ & -0.199 & 0.104 & 0.819 & $0.055^{*}$ \\
\hline Land size cultivated & 0.006 & 0.023 & 1.006 & 0.811 \\
\hline constant & -0.381 & 0.925 & 0.683 & 0.680 \\
\hline
\end{tabular}

The household head's occupation was another variable that was thought to influence the adoption of small-scale irrigation farming. In terms of the sub-categories of the nature of employment, formal employment and small-scale business were found to have a significant negative impact on the adoption of small-scale irrigation farming. The odds of adoption were found to decrease if the household head's main occupation was either formal employment or involvement in a small-scale business. A probable explanation is that for households with formal employment and those involved in small-scale businesses, time will be the major limiting factor when it comes to focusing on agricultural activities. Household heads will tend to focus more on their work and small businesses and, as a result, the adoption of small-scale irrigation farming becomes more difficult. This finding agrees with that of Abera [70] who argued that irrigation is generally a labour- and time-intensive endeavour and that households usually find it difficult to synchronize small-scale irrigation farming with other off-farm activities.

In addition, the number of household members with off-farm employment was found to significantly influence the adoption of small-scale irrigation farming. The predicted change in the adoption of small-scale irrigation farming was found to be 1.83 for an increase in membership of the household by one with off-farm employment. This could probably be because if some members of the household are involved in off-farm activities, they play a supportive role in agricultural practices, especially by providing an alternative source of agricultural financing. Therefore, an increase in household members with off-farm employment increases the chances of adoption because of its supportive role. This result is consistent with that of Namara et al. [71] who concluded that off-farm employment activities improve income for the farmer and that income can be used to complement agricultural activities. However, the result was not as expected but was still acceptable as the empirical 
studies by Herath and Takeya [72] noted the role of off-farm income in the adoption of agricultural practices as unclear and a contested terrain.

As expected, access to irrigation equipment influenced the adoption of small-scale irrigation farming positively and significantly at a $5 \%$ level. The odds of adoption were found to be 2.03 times greater for farmers with access to irrigation equipment compared to those without access. Access to irrigation equipment necessitates the adoption of small-scale irrigation farming. Moreover, access to a reliable water source that can be used for irrigation also influenced the adoption of small-scale irrigation farming as expected. The odds of adoption were 18.6 times greater for farmers with access to reliable water sources-such as for farmers whose fields neighboured rivers and small water channels-compared to farmers without reliable water access. The results thus highlight the importance of the necessary irrigation equipment and reliable water sources (i.e., proximity to a perennial water source such as river or dam) in setting up successful small-scale irrigation farming systems. Based on the binary logistic model, access to irrigation equipment and a reliable water source are vital for any farmer to try small-scale irrigation farming.

Awareness of water conservation practices such as rainwater harvesting was also selected as an explanatory variable to explain variability in the adoption of small-scale irrigation farming. Results show that awareness of water conservation practices within the study sites had a positive and significant influence on the adoption of small-scale irrigation farming. The odds of the adoption of small-scale irrigation farming were found to be 2.62 times greater for farmers who were aware of water conservation methods practiced within the study sites compared to those who were not aware of such methods. This could be because the farmers who were aware of water conservation practices were more likely to adopt such practices. This necessitates the adoption of small-scale irrigation farming, since earlier results indicate that access to reliable water sources positively influenced the adoption of irrigation farming. Besides, farmers who had installed rainwater harvesting technologies, such as water tanks, would divert more of their time to adopt small-scale irrigation practices in riparian areas instead of going to fetch water for domestic use.

The distance travelled to access the nearest market was another variable that was thought to influence the adoption of small-scale irrigation farming. The results show that the distance travelled to access input and/or output markets had a significant negative influence on the adoption of irrigation farming. Odds of adoption decreased by about $18 \%$ with a one-kilometre increase in distance to the nearest input or output market for the farmer. This might be explained by the fact that most smallholder farmers now appreciate the role of markets in their farming activities. As a result, access to markets influences their farming intensification decisions. Farmers closer to input markets are motivated to adopt small-scale irrigation farming as a climate-smart agriculture practice since they realize that their production will be improved and they can easily sell the surplus at nearby markets. For farmers who travel long distances to access output markets, the situation might be very different. As much as they realize the importance of the adoption of small-scale irrigation farming in raising agricultural output, they may be discouraged to adopt the practice when they plan to sell their surpluses because long distances come with additional marketing costs, which they cannot afford.

Overall, the results point to important behavioural, market, institutional, organizational, social and economic factors that influence the adoption of small-scale irrigation farming as a climate-smart agriculture technology in the Chinyanja Triangle. Such factors can be a crucial input to scaling up of small-scale agriculture within the Chinyanja Triangle for greater, positive livelihood impacts on the society.

\subsection{Impact of the Adoption of Small-Scale Irrigation Farming on Income}

The adoption of small-scale irrigation farming was hypothesized to positively influence smallholder farmers' agricultural income. In the OLS-based impact analysis, the dependent variable was agricultural income. The adoption of small-scale irrigation farming was selected as an independent variable to explain the variations in agricultural income. The results of the analysis are shown in Table 6. 
Table 6. Impact of the adoption of irrigation farming on agricultural income: OLS results.

\begin{tabular}{cccc}
\hline Square Root of Agriculture Income & Coefficient & Standard Error & $p$-Value \\
\hline Irrigation farming ** & 2.052 & 0.940 & $0.030^{* *}$ \\
Extension & 1.70 & 0.972 & $0.081^{*}$ \\
Land size cultivated & 0.097 & 0.067 & 0.147 \\
Labour ** & 0.645 & 0.318 & $0.043^{* *}$ \\
Economically active & -0.371 & 0.315 & 0.240 \\
Off-farm employment & -0.173 & 0.373 & 0.643 \\
Group membership & 0.620 & 0.989 & 0.531 \\
Livestock units & -0.087 & 0.116 & 0.452 \\
Main crop * & 0.747 & 0.399 & $0.062^{*}$ \\
Distance to market (square root)* & 0.423 & 0.256 & $0.099 *$ \\
Literacy & 0.036 & 0.264 & 0.893 \\
Adoption of LSW ** & -2.247 & 1.004 & $0.026^{* *}$ \\
_constant** & 5.979 & 1.780 & $0.001^{* * *}$ \\
\hline
\end{tabular}

${ }^{* * *}=1 \%$ level of significance, ${ }^{* *}=5 \%$ level of significance, ${ }^{*}=10 \%$ level of significance.

As expected, the results confirm that the adoption of small-scale irrigation farming as a climate-smart agriculture practice within the Chinyanja Triangle explains the variation in agricultural income. The adoption of small-scale irrigation farming was found to have a significant positive impact (at a $5 \%$ level) on agricultural income. This could be because farmers who use small-scale irrigation farming can intensify and diversify their agricultural activities, which increases their production. This was confirmed by Singh et al. [73] and Hussain et al. [74] in their studies on the adoption of small-scale irrigation farming to be effective in reducing poverty due to improved productivity and greater returns from farming. Increased production will lead to increased income from agriculture (through the sale of surpluses), all things being equal. This is also influenced by market access, which is a driver or an incentive to stay engaged in farming. With small-scale irrigation, farmers can produce off-season as they can supplement their crops with water in the case of mid-season dry spells or shortages. In other words, small-scale irrigation farming reduces climate risks, improves crop production and reduces agricultural production's overdependence on rainfall $[50,75]$. This is also consistent with literature that ascertained the positive impacts of small-scale irrigation in developing areas on livelihood outcomes such as yield and income [27-29], poverty reduction [25], and food security $[19,26]$. These findings are also confirmed by studies in India by Chambers [76] who found that reliable and adequate irrigation increases employment opportunities and income, which ultimately contributes to food security. The result also bears important implications for climate change adaptation in smallholder agriculture within the Chinyanja Triangle. Small-scale irrigation is therefore a vital technology that can help reduce crop production risks posed by variable climate in the area and this can ultimately lead to more climate resilient livelihoods within the area. Related, Kumar [77] also confirmed the positive effects of small-scale irrigation in boosting India's food production and generating surpluses that can be used as a drought buffer.

Factors such as access to extension, labour, crops grown, distance to the nearest market, and the adoption of land, soil and water conservation practices also had a significant influence on agricultural income.

\section{Conclusions, Implications and Policy Recommendations}

This study was undertaken to improve our understanding of how efforts to promote the adoption of small-scale irrigation farming as a climate-smart agriculture practice can influence the income of smallholder farmers in the Chinyanja Triangle. Several useful conclusions that provide insight into pathways to increase smallholder farmers' adoption of small-scale irrigation farming in the study area and improve agricultural income have emerged from this research. 
First, the results indicate that promoting small-scale irrigation farming as a climate-smart agriculture practice for adoption by smallholder farmers should consider the farmer's age, main occupation, off-farm employment status, access to and availability of micro-irrigation equipment, water source reliability, awareness of certain water conservation measures and distance to the nearest markets. Failure to consider these socioeconomic aspects may lead to inappropriate results when aiming for higher rates of adoption of small-scale irrigation farming as a climate-smart agriculture practice in the study area. For example, the rehabilitation of reliable water sources will be an important move that can positively impact the adoption of small-scale irrigation farming. In addition, assisting farmers to access intermediary irrigation farming technologies and equipment will also enhance adoption. Raising farmers' awareness of water conservation practices, such as rainwater harvesting methods and techniques, through extension or any other means will be critical for improving the uptake of small-scale irrigation farming. Increased adoption of small reservoirs in the Chinyanja Triangle could be an important investment in the region to improve access to water, sustain multiple uses, support soil and water conservation, drought proofing and supplementary irrigation during dry spells. The overall trajectory in the high rainfall areas of the Chinyanja Triangle is to promote small-scale irrigation and to integrate irrigation into the social and economic context of the entire landscape.

Secondly, the results suggest that succeeding in enhancing the adoption of small-scale irrigation farming as a climate-smart agriculture practice through careful consideration of the socioeconomic aspects and other farm-specific attributes will enhance farmers' income. This is an important finding since the main motivation for urging farmers to adopt this technology is their welfare. Enhancing the adoption of small-scale irrigation farming within the Chinyanja Triangle will be a great step towards improving farmers' agricultural income and combating climate variability and change. This is supported by studies from India that show that adopting small-scale irrigation farming creates employment opportunities both on and off the farm that transforms into improved livelihoods and quality of life in the countryside [26,74,78].

Although our study makes a notable contribution to the adoption and impact of small-scale irrigation in smallholder farming, it is not without limitations. We relied on cross-sectional household level data, which in itself is associated with limitations (cf. [79]). It is therefore plausible that dynamics of irrigation farming adoption and impacts could be slightly biased due to the cross-sectional nature of our data. In light of this potential weakness, reliance on longitudinal data sets in future studies may give outcomes that are more robust. Other limitations noted in the study include insufficient institutional capacity both at the central and local levels. These were found to be the major constraint hampering the development of the small-scale irrigation subsector as a climate variability and change adaptation strategy. The institutions dealing specifically with irrigated agriculture are severely constrained by insufficiently qualified human resources and an inadequate budget (cf. [37]). A point of concern for the development of irrigation as a whole is the lack of flexibility of the legal and political framework concerning access to and use of land and water.

In view of the above, we recommend that the three governments (Zambia, Malawi and Mozambique) that cover the Chinyanja Triangle formulate national and regional policies on small-scale irrigation farming that will ensure that farmers do not suffer total loss of their agricultural produce due to climate variability and change. Currently, such policies in the three countries are wanting as they are not enforced and farmers and extension agents are left to confront the effects of climate variability and change on their own. Given that climate variability and change is increasingly becoming a reality in Africa, climate-smart agriculture practices such as small-scale irrigation farming need to be given emphasis.

Acknowledgments: The authors would like to acknowledge the financial assistance received from the Dryland Systems Consultative Research Programme (CRP1.1) that was used in carrying out this study. The authors would also like to acknowledge the support of Janine Smit Editorial Services that helped with language editing and proofreading of this article. We thank all the enumerators for good work in data collection and most importantly to farmers who patiently gave us their time and responded to our questions. 
Author Contributions: L.T., N.M., P.M. and G.N. conceived and designed the study; P.M. and G.N. conducted fieldwork; C.M., analyzed the data; N.M., and C.M., wrote the paper; L.T., P.M. and G.N. revised and reviewed the paper.

Conflicts of Interest: The authors declare no conflict of interest.

\section{References}

1. Burney, J.A.; Naylor, R.L. Smallholder Irrigation as a Poverty Alleviation Tool in Sub-Saharan Africa. World Dev. 2012, 40, 110-123. [CrossRef]

2. Barrett, C.B.; Swallow, B.M. Fractal poverty traps. World Dev. 2006, 34, 1-15. [CrossRef]

3. Barnichon, R.; Peiris, S.J. Sources of inflation in sub-Saharan Africa. J. Afr. Econ. 2008, 17, 729-746. [CrossRef]

4. Conway, G.; Waage, J.; Delaney, S. Science and Innovation for Development; UK Collaborative on Development Sciences (UKCDS): London, UK, 2010.

5. Davies, M.; Guenther, B.; Leavy, J.; Mitchell, T.; Tanner, T. Climate change adaptation, disaster risk reduction and social protection: Complementary roles in agriculture and rural growth? IDS Work. Pap. 2009, 1-37. [CrossRef]

6. FAO. Sourcebook on Climate Smart Agriculture, Forestry and Fisheries; Food and Agriculture Organization: Rome, Italy, 2013.

7. SciDev.Net African Smallholder Farmers Need Tech to Spur Food Security. 2014 . Available online: https:/ / www.scidev.net/sub-saharan-africa/agriculture/news/african-smallholders-need-techsto-spur-food-security.html (accessed on 12 March 2018).

8. Lipper, L.; Thornton, P.; Campbell, B.M.; Baedeker, T.; Braimoh, A.; Bwalya, M.; Caron, P.; Cattaneo, A.; Garrity, D.; Henry, K.; et al. Climate-smart agriculture for food security. Nat. Clim. Chang. 2014, 4, 1068-1072. [CrossRef]

9. FAO. Climate-Smart Agriculture: Sourcebook; Food and Agriculture Organization of the United Nations: Rome, Italy, 2013.

10. You, L.; Ringler, C.; Wood-Sichra, U.; Robertson, R.; Wood, S.; Zhu, T.; Nelson, G.; Guo, Z.; Sun, Y. What is the irrigation potential for Africa? A combined biophysical and socioeconomic approach. Food Policy 2011, 36, 770-782. [CrossRef]

11. AQUASTAT; Food and Agriculture Organization (FAO): Rome, Italy, 2009.

12. NEPAD; AU. Sustainable Land and Water Management. In The CAADP Pillar 1 Framework; New Partnership for African Development and African Union: Midrand, South Africa, 2009.

13. Carver, T.N. Large-Scale and Small-Scale Farming. Am. Stat. Assoc. 1911, 12, 488-489. [CrossRef]

14. Kirsten, J.F.; Van Zyl, J. Defining small-scale farmers in the South African context. Agrekon 1998, 37, 551-562. [CrossRef]

15. Machingura, C. An Analysis of Factors That Can Be Used to Identify Successful Smallholder Farmers: A Case Study of Mbhashe and Ngqushwa. Master's Thesis, Department of Agricultural Economics and Extension, University of Fort Hare, Alice, South Africa, 2007.

16. Kamwamba-Mtethiwa, J.; Weatherhead, K.; Knox, J. Assessing Performance of Small-Scale Pumped Irrigation Systems in Sub-Saharan Africa: Evidence from a Systematic Review. Irrig. Drain. 2016, 65, 308-318. [CrossRef]

17. Namara, R.E.; Gebregziabher, G.; Giordano, M.; De Fraiture, C. Small pumps and poor farmers in Sub-Saharan Africa: an assessment of current extent of use and poverty outreach. Water Intern. 2013, 38, 827-839. [CrossRef]

18. Baba, K.M. Irrigation development strategies in sub-Saharan Africa: A comparative study of traditional and modern irrigation systems in Bauchi State of Nigeria. Agric. Ecosyst. Environ. 1993, 45, 47-58. [CrossRef]

19. Bembridge, T. Guidelines for Rehabilitation of Small-Scale Farmer Irrigation Schemes in South Africa; WRC Report 891/1/00; Water Research Commission: Pretoria, South Africa, 2000.

20. You, L.Z. Irrigation investment needs in sub-Saharan Africa. In A Report Produced for the World Bank by the Environment and Production Technology Division; International Food Policy Research Institute (IFPRI): Washington, DC, USA, 2008. 
21. Archer, E.; Mukhala, E.; Walker, S.; Dilley, M.; Masamvu, K. Sustaining agricultural production and food security in Southern Africa: An improved role for climate prediction? Clim. Chang. 2007, 83, 287-300. [CrossRef]

22. Bekele, W.; Drake, L. Soil and water conservation decision behaviour of subsistence farmers in the Eastern Highlands of Ethiopia: A case study of the Hunde-Lafto area. Ecol. Econ. 2003, 46, 437-451. [CrossRef]

23. Balcha, Y. Prospects of Transforming Subsistence Agriculture into Sustainable Livelihoods. A Case Study of the Ribb Sub-Catchment, Ethiopia. Master's Thesis, Uppsala University, Uppsala, Sweden, 2013.

24. Fan, S.; Brzeska, J.; Keyzer, M.; Halsema, A. From Subsistence to Profit: Transforming Smallholder Farms; IFPRI: Food Policy Report; International Food Policy Research Institute (IFPRI): Washington, DC, USA, 2013.

25. Bacha, D.; Namara, R.; Bogale, A.; Tesfaye, A. Impact of small-scale irrigation on household poverty: Empirical evidence from the Ambo district in Ethiopia. Irrig. Drain. 2011, 60, 1-10. [CrossRef]

26. Tesfaye, A.; Bogale, A.; Namara, R.E.; Bacha, D. The impact of small-scale irrigation on household food security: The case of Filtino and Godino irrigation schemes in Ethiopia. Irrig. Drain. Syst. 2008, 22, 145-158. [CrossRef]

27. Woldeab, T. Irrigation Practices, State Intervention and Farmers Life-Worlds in Drought-Prone Tigray. Ph.D. Thesis, Wageningen University, Wageningen, The Netherlands, 2003.

28. Gebrehaweria, G.; Regassa, E.N.; Stein, H. Poverty reduction with irrigation investment: An empirical case study from Tigray, Ethiopia. Agric. Water Manag. 2009, 96, 1837-1843.

29. IFAD Special Country Program Phase II. Interim Evaluation; International Fund for Agricultural Development: Addis Ababa, Ethiopia, 2005.

30. Mudima, K. Socioeconomic Impact of Smallholder Irrigation Development in Zimbabwe: A Case Study of Five Successful Irrigation Schemes. In Private Irrigation in Sub Saharan Africa; Sally, H., Abernethy, C.L., Eds.; IWMI: Colombo, Sri Lanka, 2002.

31. Perret, S. Water policies and smallholding irrigation schemes in South Africa: A history and new institutional challenges. Water Policy 2002, 4, 283-300. [CrossRef]

32. Delgado, C.L. Sources of growth in smallholder agriculture integration of smallholders with processors in Sub-Saharan Africa: The role of vertical and marketers of high value-added items. Agrekon 1999, 38, 165-189. [CrossRef]

33. Food and Agricultural Organization of the United Nations (FAO) AQUASTAT. 2005a. Available online: http://www.fao.org/nr/water/aquastat/countries_regions/ZMB/index.stm (accessed on 12 March 2018).

34. Food and Agricultural Organization of the United Nations (FAO) AQUASTAT. 2005b. Available online: http://www.fao.org/nr/water/aquastat/countries_regions/MOZ/ (accessed on 12 March 2018).

35. Food and Agricultural Organization of the United Nations (FAO) AQUASTAT. 2005c. Available online: http://www.fao.org/nr/water/aquastat/countries_regions/MWI/ (accessed on 12 March 2018).

36. You, L.Z. Africa Infrastructure Country Diagnostic: Irrigation Investment Needs in Sub-Saharan Africa; Background Paper 9; World Bank: Washington, DC, USA, 2008.

37. Amede, T.; Desta, L.T.; Harris, D.; Kizito, F.; Xueliang, C. The Chinyanja Triangle in the Zambezi River Basin, Southern Africa: Status of, and Prospects for, Agriculture, Natural Resources Management and Rural Development. WLE Research for Development (R4D) Learning Series 1. 2014. Available online: http:/ /www. iwmi.cgiar.org/Publications/wle/r4d/wle_research_for_development-learning_series-1.pdf (accessed on 28 November 2017).

38. CGIAR Characterization of Areas Targeted for Sustainable Intensification. 2013. Available online: http: //drylandsystems.cgiar.org/content/characterization-areas-targeted-sustainable-intensification (accessed on 28 December 2017).

39. Food and Agriculture Organization of the United Nations (FAO). Irrigation potential in Africa: A basin approach. In FAO Land and Water Bulletin; FAO: Rome, Italy, 1997; Volume 4, ISBN 92-5-103966-6. Available online: http:/ / www.fao.org/docrep/w4347e/w4347e00.htm\#Contents (accessed on 14 March 2018).

40. Food and Agriculture Organization of the United Nations (FAO). AQUASTAT. Malawi, Zambia and Mozambique. 2006. Available online: http://www.fao.org/nr/water/aquastat/countries_regions/malawi/ index.stm (accessed on 5 March 2018).

41. Peters, P.E. Informal Irrigation in Lake Chilwa Basin: Stream-Bank and Wetland Gardens'; Final Research Report under BASIS-CRSP; University of Wisconsin-Madison: Madison, WI, USA, 2004. 
42. National Statistical Office. National Census of Agricultural and Livestock 2006/2007; Main Report; NSO: Zomba, Malawi, 2010; Available online: http:/ / www.nsomalawi.mw/images/stories/data_on_line/agriculture/ NACAL/Nacal\%20Report.pdf (accessed on 7 March 2018).

43. Malawi Ministry of Agriculture and Food Security (MoAFS). Malawi Agricultural Sector-Wide Approach. In A prioritized and Harmonized Agricultural Development Agenda, 2011-2015; MoAFS: Lilongwe, Malawi, 2011.

44. Evans, A.E.V.; Giordano, M.; Clayton, T. (Eds.) Investing in Agricultural Water Management to Benefit Smallholder Farmers in Zambia; AgWater Solutions Project Country Synthesis Report; IWMI Working Paper 150; International Water Management Institute (IWMI): Colombo, Sri Lanka, 2012; 37p. [CrossRef]

45. Worldfish. Sustainable Water Usage in the Chinyanja Triangle. 2013. Available online: http://www. worldfishcentre.org/our-research/ongoing (accessed on 6 April 2013).

46. Vågen, T.; Winowiecki, L.; Desta, L.; Tondoh, J. The Land Degradation Surveillance Framework Field Guide; World Agroforestry Centre (ICRAF): Nairobi, Kenya, 2010.

47. Chilonda, P.; Otte, J. Indicators to monitor trends in livestock production at national, regional and international levels. Livest. Res. Rural Dev. 2006, 18, 117. Available online: http:/ /www.lrrd.org/lrrd18/8/ chil18117.htm (accessed on 28 November 2017).

48. Eurostat. The EU in the World 2013: A Statistical Portrait; European Union: Luxembourg, 2013.

49. Chianu, J.N.; Tsujii, H. Determinants of farmers' decision to adopt or not adopt inorganic fertilizer in the savannas of northern Nigeria. Nutr. Cycl. Agroecosyst. 2004, 70, 293-301. Available online: https: / / link.springer.com/article/10.1007/s10705-005-0715-7 (accessed on 28 November 2017). [CrossRef]

50. Getacher, T.; Mesfin, A.; Gebre-Egziabher, G. Adoption and impacts of an irrigation technology: Evidence from household-level data in Tigray, Northern Ethiopia. Univ. J. Agric. Res. 2014, 1, 30-34.

51. Asfaw, A.; Admassie, A. The role of education on the adoption of chemical fertilizer under different socioeconomic environments in Ethiopia. Agric. Econ. 2004, 30, 215-228. [CrossRef]

52. Mulugeta, E.; Belay, K.; Legesse, D. Determinants of adoption of physical soil conservation measures in central highlands of Ethiopia: The case of three districts of North Shewa Zone. Agrekon 2001, 40, 313-335. [CrossRef]

53. Adesina, A.A.; Chianu, J. Determinants of farmers' adoption and adaptation of alley farming technology in Nigeria. Agrofor. Syst. 2002, 55, 99-112. [CrossRef]

54. Somda, J.; Nianogo, A.J.; Nassa, S.; Sanou, S. Soil fertility management and socioeconomic factors in crop livestock systems in Burkina Faso: A case study of siting technology. Ecol. Econ. 2002, 43, 175-183. [CrossRef]

55. Knowler, D.; Bradshaw, B. Farmers' adoption of conservation agriculture: A review and synthesis of recent research. Food Policy 2007, 32, 25-48. [CrossRef]

56. Kassie, M.; Zikhali, P.; Manjur, K.; Edwards, S. Adoption of organic farming technologies: Evidence from semi-arid regions of Ethiopia. Nat. Resour. Forum 2009, 33, 189-198. [CrossRef]

57. Woodhouse, P.; Veldwisch, G.J.; Venot, J.P.; Brockington, D.; Komakech, H.; Manjichi, A. African farmer-led irrigation development: re-framing agricultural policy and investment? J. Peasant Stud. 2016, 44, 213-233. [CrossRef]

58. Shah, T.; Verma, S.; Pavelic, P. Understanding smallholder irrigation in Sub-Saharan Africa: results of a sample survey from nine countries. Water Intern. 2013, 38, 809-826. [CrossRef]

59. Serrano, V.M.B.L.; Carter, R.C. Small Scale Irrigation in Angola: Potential and Promise. Outlook Agric. 1991, 20, 3-175. [CrossRef]

60. Kimmage, K.; Adams, W.M. Small-scale farmer-managed irrigation in Northern Nigeria. Geoforum 1990, 4, 4-443. [CrossRef]

61. Carter, R.C. The development of small-scale irrigation in sub-Saharan Africa. J. Theor. Soc. Psychol. 1989, 9, 543-555. [CrossRef]

62. Long, J.S. Regression Models for Categorical and Limited Dependent Variables; Advanced Quantitative Techniques in the Social Sciences Number 7; Sage Publications: Thousand Oaks, CA, USA, 1997.

63. Caswell, M.F.; Zilberman, D. The choices of irrigation technologies in California. Am. J. Agric. Econ. 1985, 67, 224-234. [CrossRef]

64. Shrestha, R.B.; Gopalakrishnan, C. Adoption and diffusion of drip irrigation technology: An econometric analysis. Econ. Dev. Cult. Chang. 1993, 41, 407-418. [CrossRef]

65. Skaggs, R.K. Predicting drip irrigation use and adoption in a desert region. Agric. Water Manag. 2001, 51, 125-142. [CrossRef] 
66. Sureshwaran, S.; Londhe, S.R.; Frazier, P. A logit model for evaluating farmer participation in soil conservation programs: Slopping agricultural land technology on upland farms in the Philippines. J. Sustain. Agric. 1996, 7, 57-69. [CrossRef]

67. Yohannes, G.M. The effects of conservation on production in the Andit Tid Area, Ethiopia. In Soil Conservation for Survival; Kebede, T., Hurni, H., Eds.; Iowa State University Press: Iowa City, IA, USA, 1992.

68. Shiferaw, B.; Holden, S.T. Resource degradation and adoption of land conservation technologies in the Ethiopian highlands: A case study in Andit Tid, North Shewa. Agric. Econ. 1998, 18, 233-247. [CrossRef]

69. Sidibe, M. Farm-level adoption of soil and water conservation techniques in northern Burkina Faso. Agric. Water Manag. 2005, 71, 211-224. [CrossRef]

70. Abera, B.D. Factors Influencing the Adoption of Soil Conservation Practices in Northwestern Ethiopia; Discussion Paper, No. 37; University of Goettingen: Goettingen, Germany, 2003.

71. Namara, R.E.; Upadhyay, B.; Nagar, R.K. Adoption and Impacts of Micro-Irrigation Technologies: Empirical Results from Selected Localities of Maharashtra and Gujarat States of India; Research Report 93; International Water Management Institute: Colombo, Sri Lanka, 2005.

72. Herath, P.H.M.U.; Takeya, H. Factors determining intercropping by rubber smallholders in Sri Lanka: A logit analysis. Agric. Econ. 2003, 29, 159-168. [CrossRef]

73. Singh, B.; Singh, B.N.; Singh, A. Effect of mulch and irrigation on yield of Indian mustard on dry terraces in Alfisols. Indian J. Agric. Sci. 1996, 60, 477-479.

74. Hussain, I.; Namara, R.E.; Madar, S. Water for Food Security for the Poor; A Collection of Thematic Papers; Asian Development Bank: Mandaluyong, Philippines, 2004.

75. Diao, X.; Hazell, P.; Thurlow, J. The role of agriculture in African development. World Dev. 2010, 38, 1375-1383. [CrossRef]

76. Chambers, R. Irrigation against rural poverty. In Socioeconomic Dimension and Irrigation; R.K., Gujar, Ed.; Printwell: Gujarat, India, 1994.

77. Kumar, D. Food Security and Sustainable Agriculture in India: The Water Management Challenge; Working Paper; International Water Management Institute: Colombo, Sri Lanka, 2003.

78. Hussain, I.; Hanjra, M.A. Irrigation and poverty alleviation: Review of the empirical evidence. Irrig. Drain. 2004, 53, 1-15. [CrossRef]

79. Rowe, J.W.; Andres, R.; Tobin, J.D.; Norris, A.H.; Shock, N.W. The effect of age on creatinine clearance in men: A cross-sectional and longitudinal study. J. Gerontol. 1976, 31, 155-163. [CrossRef] [PubMed] 
Article

\title{
Expansion of Commercial Sugarcane Cultivation among Smallholder Farmers in Uganda: Implications for Household Food Security
}

\author{
Edward N. Mwavu ${ }^{1, *}$, Vettes K. Kalema ${ }^{2}$, Fred Bateganya ${ }^{3}$, Patrick Byakagaba ${ }^{1}$, \\ Daniel Waiswa ${ }^{1}$, Thomas Enuru ${ }^{1}$ and Michael S. Mbogga ${ }^{1}$
}

1 School of Forestry, Environmental and Geographical Sciences, Makerere University, P.O. Box 7062, Kampala, Uganda; Byakagaba@caes.mak.ac.ug (P.B.); daniel.waiswa@gmail.com (D.W.); tenuru@caes.mak.ac.ug (T.E.); mbogga@caes.mak.ac.ug (M.S.M.)

2 Kachwekano Zonal Agricultural Research and Development Institute, P.O. Box 421, Kabale, Uganda; vetteskalema@gmail.com

3 College of Humanities and Social Sciences, Makerere University, P.O. Box 7062, Kampala, Uganda; frebat2011@gmail.com

* Correspondence: emwavu@caes.mak.ac.ug or edward.mwavu@gmail.com; Tel.: +256-772-510-831

Received: 31 January 2018; Accepted: 5 June 2018; Published: 11 June 2018

\begin{abstract}
Understanding the impact of commercial agriculture in the face of global change is critical to support strategies that ensure food security and alleviate poverty among households. We assessed the contribution of commercial sugarcane cultivation to household-level food security among smallholder farmers in Busoga sub-region, eastern Uganda. Land use changes are motivated by quick commercial gains rather than sustained food production; a situation that influences food security. The majority of households cultivate few crop varieties, lack adequate and nutritious foods, and have inadequate income to purchase food to meet their needs. Inadequacy of food within some commercial sugarcane-cultivating households suggests that generating income does not necessarily increase food security. To cope with food insecurity, households offer labour in exchange for food, borrow food, ration food, and at times steal. This is exacerbated by increasing food crop failures, large family sizes, trade in food items, and declining availability of food and land for food production. Commercial sugarcane cultivation is the main driver of food insecurity but given its perceived economic benefits, future sugarcane plantations expansion in the region is probably inevitable. Therefore, future policy should be designed to provide triple-win strategies (i.e., food security, poverty alleviation, and climate change adaptation) that provide sustainable livelihoods.
\end{abstract}

Keywords: poverty alleviation; sustainable livelihoods; climate change; commercial agriculture

\section{Introduction}

Understanding the impact of commercial agriculture in the face of increasing human population and climate change in a rural landscape is critical for biodiversity sustainability and meeting the needs of households whose livelihoods (i.e., food, medicine, and income) are mainly dependent on natural resources. In many sub-Saharan African countries, subsistence agriculture (i.e., crop, tree, livestock, and fisheries production) is not only a vital source of food but also the prevalent way of life. However, in these countries with mainly agrarian economies, subsistence agriculture is increasingly being replaced by commercial agriculture as national governments push to increase the contribution of the agriculture sector to the national Gross Domestic Product (GDP) [1-3]. By 2016, the contribution of the agricultural sector ranged between 3\% (for Botswana and South Africa) and more than 50\% (for Chad) [3]. For Uganda, the contribution of the agriculture to the GDP was about 
$25.8 \%$ [4]. With increasing interest in agriculture as an income earner, commercial firms and households in tropical Africa and Asia countries have adopted commercial agriculture leading to expansive lands of monocultures (incl. oil palms, sugarcane, tobacco, and sunflower) in historically forested and subsistence-oriented agriculture production systems, but with mixed results. For sub-Saharan Africa, the total value of agricultural output has grown markedly over the past decade; however, it remains the most food insecure region in the world [3]. According to Binswanger \& von Braun [5], the optimistic view is that normally, technology and commercialization stimulates agricultural growth, improves employment opportunities, and expands food supply that are all central to the alleviation of poverty. In the tropical Asian countries (e.g., Malaysia, Indonesia, Sumatra, and Papua New Guinea), oil palm cultivation is reported to be profitable, offering wealth and development, but it also threatens traditional livelihoods and biodiversity [6-10].

In Uganda, recent times have witnessed the central government encouraging farmers to invest in commercial agricultural enterprises as one of the efforts for poverty alleviation and wealth creation. In areas close to sugarcane-processing industries in Uganda (e.g., Kinyara Sugar Works Ltd., Masindi, Mayuge Sugar Ltd., Mayuge, Kaliro Sugar Ltd., Kaliro, and Kakira Sugar Works Ltd., Jinja), sugarcane cultivation has been highly preferred relative to other more traditional crops (e.g., coffee, cotton) as well as plantation forests, as it is perceived to be more profitable and economically valuable [11]. As commercialization of sugarcane and other non-food crops cultivation increases in importance to rural households, the value of productive land and incentives to increase yields continue to escalate, resulting in further loss of natural vegetation, and a reduction of land available for food crop cultivation [12]. This reduction of land for food crops is of major concern, as producing more food for a growing population in the coming decades, while at the same time combating poverty and hunger and coping with the impacts of climate change is the major challenge facing agriculture in Africa. It is important to note that food production is dependent among other factors on environmental (including large-scale changes in land use, biogeochemical cycles, climate and biodiversity) and economic conditions $[13,14]$. This might also have crucial consequences for food security and nutrition for rural populations, where high human population growth and poverty reduction are of great concern. In Uganda, like in many African countries, food insecurity amongst poor households remains a serious problem, contributing to poor health, problems with learning in school, and lack of socio-economic development [15]. Indeed, regional and seasonal food insecurity and varying degrees of malnutrition within the general population are among the development challenges faced by Uganda [3]. Food security may be defined as a situation that exists when all people always have physical, social and economic access to sufficient, safe and nutritious, and is acceptable within the given culture food to meet dietary needs and food preferences for an active and healthy life $[13,16-18]$. It also includes obtaining foods without resorting to emergency food supplies, scavenging, stealing, or similar coping strategies [17].

Some studies (e.g., $[19,20]$ ) elsewhere suggest that commercial agriculture, especially oil palm and sugarcane growing, increases household income, thus indirectly addressing food security. Other studies (e.g., $[9,10,21])$, however, have found that cash cropping undermines food and livelihood security particularly for smallholder farmers. In spite of the increased commercial sugarcane cultivation in various regions of Uganda ostensibly resulting in improved household incomes and road infrastructure, its impacts on rural household food security are not clearly known. Yet a clear understanding of the area-specific factors that influence household-level food security and nutrition in rural commercial agricultural landscapes is fundamental if we are to achieve food security. Such an understanding may support strategies/policies for ensuring food security among households as they practice commercial agriculture to alleviate poverty. The fight to eliminate hunger at the household level and reach the other UN Sustainable Development Goals (SDGs) targets in sub-Saharan Africa will be won or lost in the rural areas where most the poor and hungry people live.

In this study, we assessed the contribution of commercial sugarcane cultivation to household-level food security within the commercial sugarcane cultivation landscape of Mayuge and Jinja Districts, 
in Busoga sub-region, Eastern Uganda. In this regard, we attempted to address the following questions: (i) does engaging in commercial sugarcane growing increase or undermine household-level food security; (ii) what are the levels of food security, food insecurity, and hunger among the households in the sugarcane cultivating villages; (iii) apart from sugarcane cultivation, what other social-economic activities do households participate in; and lastly (iv) wat strategies do households use to cope with food insecurity? We also sought to understand the changes in land-use/cover types over a decade (i.e., between 2000 and 2016) with major interest in commercial sugarcane plantations coverage.

\section{Materials and Methods}

\subsection{Description of the Study Area}

The study was conducted in the sugarcane out-grower villages of Jinja and Mayuge Districts within a radius of $21 \mathrm{~km}$ from the Kakira Sugar Works Limited (KSWL) factory, Jinja, Uganda (Figure 1). This is an area where most of the registered out-growers for KSWL are located and therefore areas of small and large-scale commercial sugarcane cultivation. Agriculture is the main land use activity and source of income for the local population in most parts of Jinja and Mayuge Districts. With the falling prices for cotton and coffee in these districts, commercial sugarcane growing is increasing in importance as a cash crop. However, recent vulnerability assessment indicates that changes in climate will alter crop phenology, as well as increasing the incidence of crop pests and diseases, especially because of higher temperatures [22]. Climate projections for most of Uganda also indicate higher temperatures-about 5\% increase in precipitation in most areas, with increasing spatial and season variability.

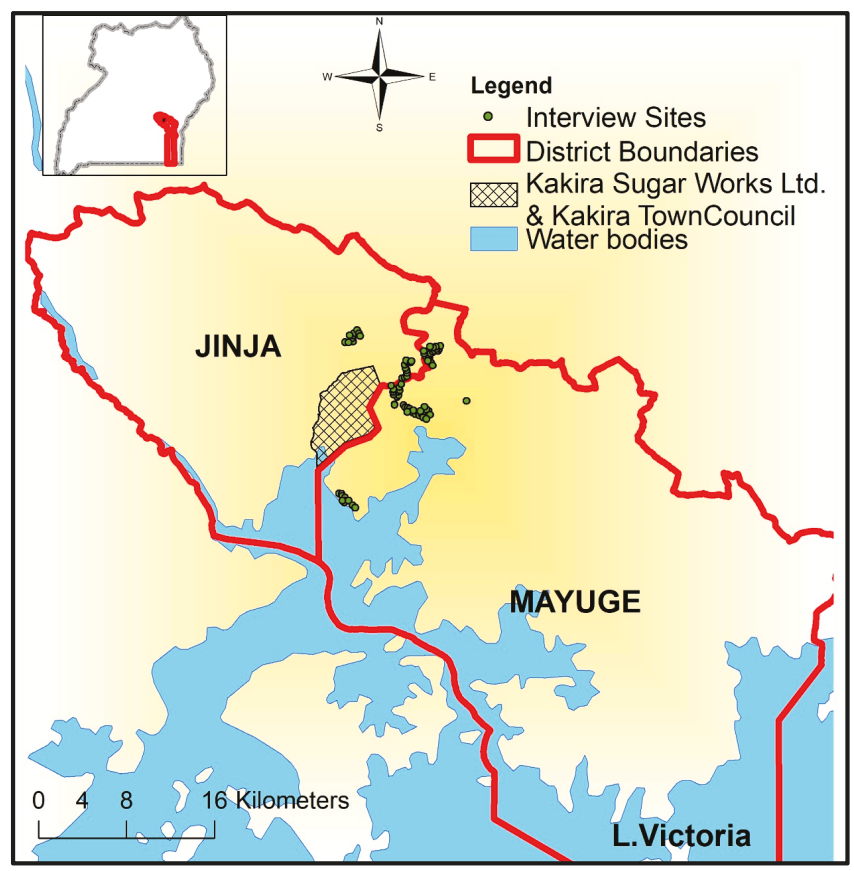

Figure 1. A location map of the study area showing the 120 interview sites $(\bullet)$ within a radius of 21 $\mathrm{km}$ from Kakira Sugar Works Limited, Jinja in the commercial sugarcane growing villages of Jinja and Mayuge District, Eastern Uganda. 


\subsection{Methods}

\subsubsection{Study Design and Data Collection}

The study applied an exploratory research design in which face-to-face questionnaire interviews with households/respondents were applied in data collection. Households/respondents were randomly selected from 10 villages, each village contributing at least 10 households. The ten villages were derived from a population of 89 villages based on a sample size calculation using a $95 \%$ confidence level and a $20 \%$ Margin of Error. To be eligible for the study, a household had to have at least one adult resident who grows sugarcane or has lived in the area for more than 10 years but not necessarily growing sugarcanes. The questionnaire interviews were conducted on an individual basis to minimize peer influence [23]. In total 208 respondents were interviewed. The questions covered in the questionnaire focused on: (i) general household characteristics such as gender, age group, ownership of land, level of education and main source; (ii) household incomes; (iii) organization membership; (iv) crops cultivated for cash income and food; (v) decision making on crops planted; (vi) adequacy of food provisioning; (vii) observed trends in food production and availability; and (viii) quality and variety of food available to households. In addition, time series Landsat imagery (2003 and 2016) were obtained from United State Geological Surveys (USGS) database to aid in assessing the changes in sugarcane coverage in the study area.

\subsubsection{Data Analysis}

Quantitative data was entered into an Epi Info database and exported to an SPSS dataset for analysis. Themes related to the study objectives were identified and formed the codes to be used in the analysis. Data were analysed using descriptive and inferential statistics generated in SPSS 17.0 [24]. Summary statistics, for example the mean, frequency, percentages, and totals were generated to show the number of households, which responded to each variable of interest. The relationship between dependent variable (i.e., vulnerability to food insecurity) and the independent variables (i.e., socio-economic and demographic characteristics of households among other categorical variables) was determined using a Pearson's Chi-square $\left(\chi^{2}\right)$ statistics at $5 \%$ level of significance. The time series Landsat imagery (2003 and 2016) were subjected to image pre-processing and supervised classification procedures in ENVI software to determine the changes in sugarcane coverage in the study area over the time.

\section{Results}

\subsection{Description of Respondents}

The majority $(72.6 \%$ ) of respondents were males (Table 1 ), which is not surprising, given that in the study area the patriarchy social system dominates. This has implications for the ownership of / or access to productive assets in the agriculture sector amongst other economic activities. The decisions on what type of plants/crops to be cultivated on the land and the acreage to be cultivated for a crop, even for the type of food security crops, is mainly made by males. This is likely to negatively affect household food security since males are mainly interested in crops that earning money. It was also observed that a majority ( $91 \%$ ) of the respondents were below the age of 60 years, and most (59.3\%) of them were members to sugarcane out-growers' group. This suggests that they have a high interest in sugarcane cultivation and a need to organize themselves for better outcomes. Over $78 \%$ of the respondents were smallholder farmers, and for most $(78.4 \%)$ of them, it was their major source of income. Very few households earn their income from salaries/wages $(6.7 \%)$ and trade $(9.1 \%)$. This dependence on smallholder agriculture that is rain-fed for food and income makes them more vulnerable to impacts of climate variability and change. The majority $(73.5 \%)$ of the households reported their annual income to be not more than USD275, which may on average be less than USD 1 per day. Although $54.8 \%$ of the households reported to rear livestock, they mostly owned one or two goats or cows. 
And those who kept it, did it mainly for trade (66.4\%), breeding (17.7\%), and consumption (13.3\%) among other reasons.

As for education, $84.5 \%$ of the respondents had attained at least some level of education (Table 1). Of these, $51.2 \%$ attained primary education and $31.9 \%$ had advanced to secondary school level education. However, the percentage of those who had advanced beyond secondary school level (i.e., university, tertiary, institute etc.) was relatively low, and they had also not gained training in any other specialties (e.g., agriculture). The household heads' low educational attainment and their lack of training in other specialties narrows their possibility of depending on other sources of livelihoods that requires higher education qualification, hence keeping them majorly in subsistence rain-fed agriculture.

Table 1. General household characteristics based on results from questionnaire interviews with respondents $(n=208)$ from Mayuge and Jinja Districts. 1USD = 3640UGX (Uganda Shillings).

\begin{tabular}{|c|c|}
\hline Household/Respondent Characteristics & Percentage Respondents \\
\hline \multicolumn{2}{|l|}{ 1. Gender } \\
\hline Female & 72.6 \\
\hline Male & 27.4 \\
\hline \multicolumn{2}{|l|}{ 2. Age group } \\
\hline$\leq 20$ & 4.2 \\
\hline $21-40$ & 45.0 \\
\hline $41-60$ & 41.8 \\
\hline 61 and above & 9.0 \\
\hline \multicolumn{2}{|l|}{ 3. Level of Education } \\
\hline None & 15.5 \\
\hline Primary Incomplete & 33.8 \\
\hline Primary Completed & 17.4 \\
\hline Secondary (Lower) & 30.0 \\
\hline Secondary (Upper) & 1.9 \\
\hline Post-Secondary & 1.4 \\
\hline \multicolumn{2}{|l|}{ 4. Membership to sugarcane out-growers' group } \\
\hline Household head is a Member & 59.3 \\
\hline Household head is a Non-Member & 40.7 \\
\hline \multicolumn{2}{|l|}{ 5. Occupation of household head } \\
\hline Smallholder Farmer & 78.8 \\
\hline Trader/Business Man/Woman & 7.7 \\
\hline Salary/Wage Earner & 5.3 \\
\hline Fishing & 2.9 \\
\hline None & 0.5 \\
\hline Other & 4.8 \\
\hline \multicolumn{2}{|l|}{ 6. Main source of income } \\
\hline Smallholder Farming & 78.4 \\
\hline Trade & 9.1 \\
\hline Salary/Wages & 6.7 \\
\hline Fishing & 1.4 \\
\hline Other & 4.3 \\
\hline \multicolumn{2}{|l|}{ 7. Mean annual household income (USD) } \\
\hline$<27.5$ & 14.5 \\
\hline $27.6-137.4$ & 31.9 \\
\hline $137.5-275$ & 27.1 \\
\hline$>275$ & 26.6 \\
\hline
\end{tabular}




\subsection{Dynamics of Sugarcane Plantation Coverage in Mayuge District}

Commercial sugarcane covered an area of 14,995 hectares in 2003 and 53,518 hectares in 2016 (Figure 2). This shows an increase in commercial sugarcane plantation coverage by $256.9 \%$ between 2003 and 2016. The land taken up for sugarcane growing replaces other land use/cover types and arable land, which includes land previously used for food crop cultivation, wetlands, forests and grasslands, as this was majorly a subsistence agriculture landscape.
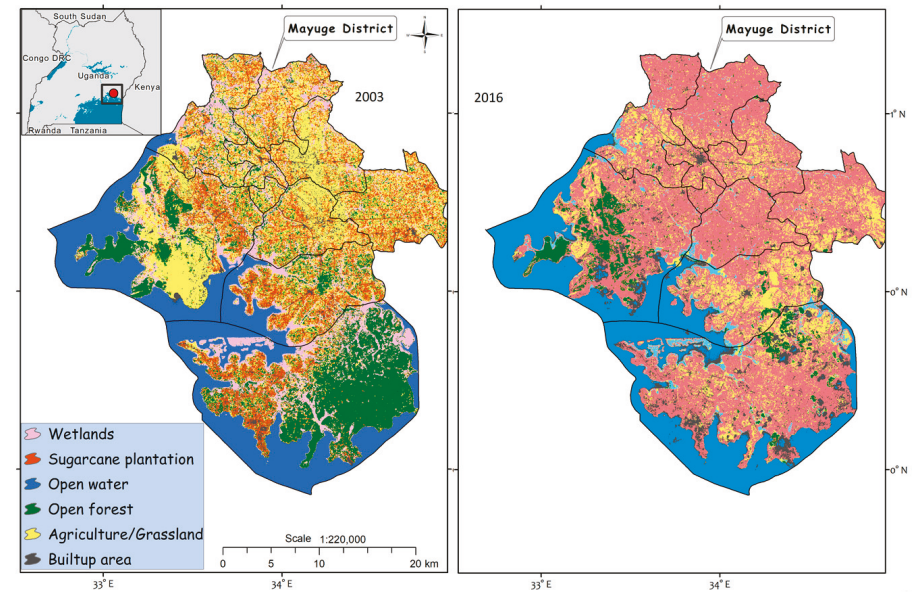

Figure 2. Land use/cover changes in Mayuge District between 2003 and 2016.

\subsection{Food Security, Insecurity and Hunger among Households}

Most (87\%) of the respondents (181 out of 208) reported that most of the households in Mayuge (95 out of 110) and Jinja (86 out 98) districts did not have adequate and nutritious food to meet their family needs in the last 12 months prior to the study. Among the respondents, there were sugarcane cultivators and those who were not but had rented out their land to other individuals for sugarcane cultivation Even among the commercial sugarcane cultivators, only 3 in every 10 households reported having access to adequate food. This is further compounded by the fact that there are few varieties of food crops cultivated by households, and the households do not have enough money to supplement what they grow.

Households were also found to not always have enough food and of the quality and/or variety needed to eat, with households with large family sizes and children the most vulnerable. The major reasons for this situation were low household financial capacity ( $92.4 \%)$, limited arable land available for food crop cultivation $(89.4 \%)$, poor farming practices and unreliable weather conditions resulting in low crop yields (88.3\%), and pest and diseases damage to food crops (87.1\%) (Figure 3). In spite of a lack of enough food to eat, some households go ahead and sell the little food harvested to earn an income for use in meeting other household needs. To these families, food crops also serve as a short-term source of income, yet usually the food harvests are very low. Food crops usually take a short time to mature, while the maturity cycle for major sugarcane varieties in the tropics is 12-20 months [25]. In the study area, households that participated in the study were found not to have the right quality or variety of food they need. This is majorly attributed to households having few varieties of food crops cultivated in their usually small home gardens and a lack of enough money to purchase food to supplement what they grow (Figure 3). The commonly grown crops and are the major sources of food for every household are maize (Zea mays L.), cassava (Manihot esculenta Crantz.), sweet potaoes (Ipomea batatas (L.) Lam), and beans (Phaseolus vulgaris L.). These are mainly starchy foods, while most of the 
previously cultivated nutritious foods like cowpeas, Bambara nuts, soya beans, and simsim have been lost from agricultural systems. Poor farming practices, low soil fertility, and pests and diseases inhibit proper cultivation, as most of the crops are sensitive to such conditions, limiting farmers to a few varieties that are resilient. Other reasons for households not always having the right quality or variety of food they want include lack of enough time for cooking, absence of quality foods in the nearby local shops, and not enough firewood for cooking. Indeed, most of the traditional sources of fuelwood (e.g., forests, and woodlands) have been replaced by sugarcane plantations, making it difficult to get fuelwood to cook the three meals required in a day; foods like beans require a lot of biomass energy.

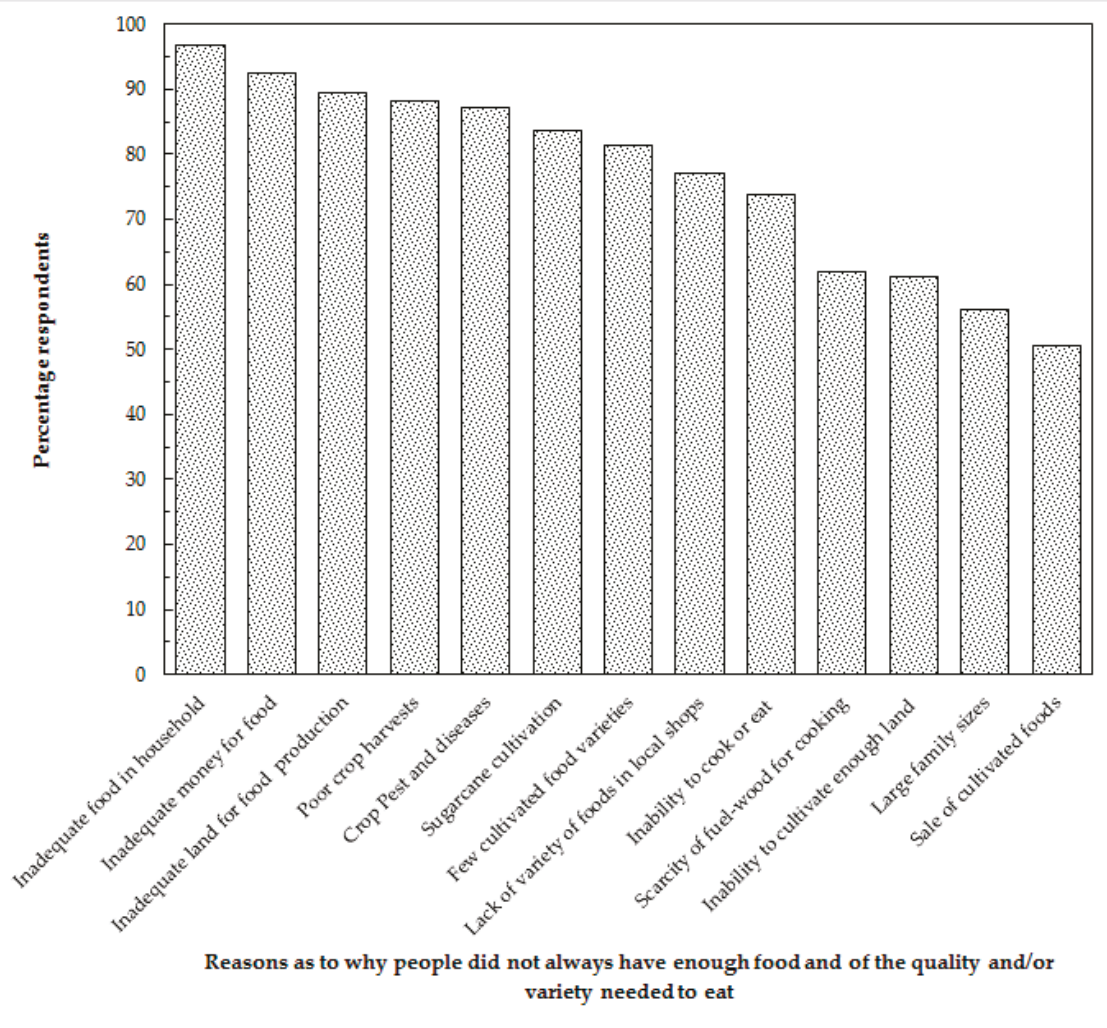

Figure 3. Reasons cited as to why people did not always have enough food and of the quality and/or variety to eat in the surveyed households in areas of commercial sugarcane cultivation of Mayuge and Jinja Districts, Eastern Uganda $(n=208)$.

These results point to a food insecurity situation within the commercial sugarcane cultivation areas. The main causes of this food insecurity situation were reported to also include sugarcane cultivation, poor soils, poor farming practices, sale of all food harvests, and prevalence of crop pest and diseases (Figure 3). Nearly 21 in every 25 households (i.e., $84 \%$ ) reported commercial sugarcane cultivation as the main source of food insecurity in the area. Furthermore, out of the 64 households that were engaged in commercial sugarcane cultivation, most of them (78.1\%) cited sugarcane cultivation as the main cause of food insecurity in the community.

Faced with the challenge of food insecurity, households employ various coping strategies that include offering labor in exchange for food $(30.8 \%)$, borrowing food $(9.1 \%)$, rationing of food $(7.2 \%)$, 
and at times stealing from their neighbors. This food insecurity situation in the study area has been exacerbated by increasing trends in crop failures, family sizes, trade in food items in the villages (Figure 3), as well as declining food availability, land available for crop cultivation, and livestock numbers (Figure 4).

\subsection{Perceived Trends in Relation to Food Production and Availability}

In the 5-10 years prior to the study, a decrease in land availability for crop cultivation, food availability and livestock numbers (Figure 4) was observed. The declining land availability result here corroborates the results of the land use/cover change analysis results (Figure 2) that show that increasing land for sugarcane cultivation has over the years taken over the arable for food crop production and other natural ecosystems. On the other hand, family sizes, trade in food, and food crop failures are reported to have increased. The combination of increased food crop failures, family sizes, and the decreased land available for food crop cultivation heightens the food insecurity situation in the study area. Most of the households now depend on their home gardens as the main source of food and nutrition. However, the sizes of these home gardens continue to shrink as some of them, and where they are located, is increasingly converted into the assumedly lucrative commercial sugarcane plantations.

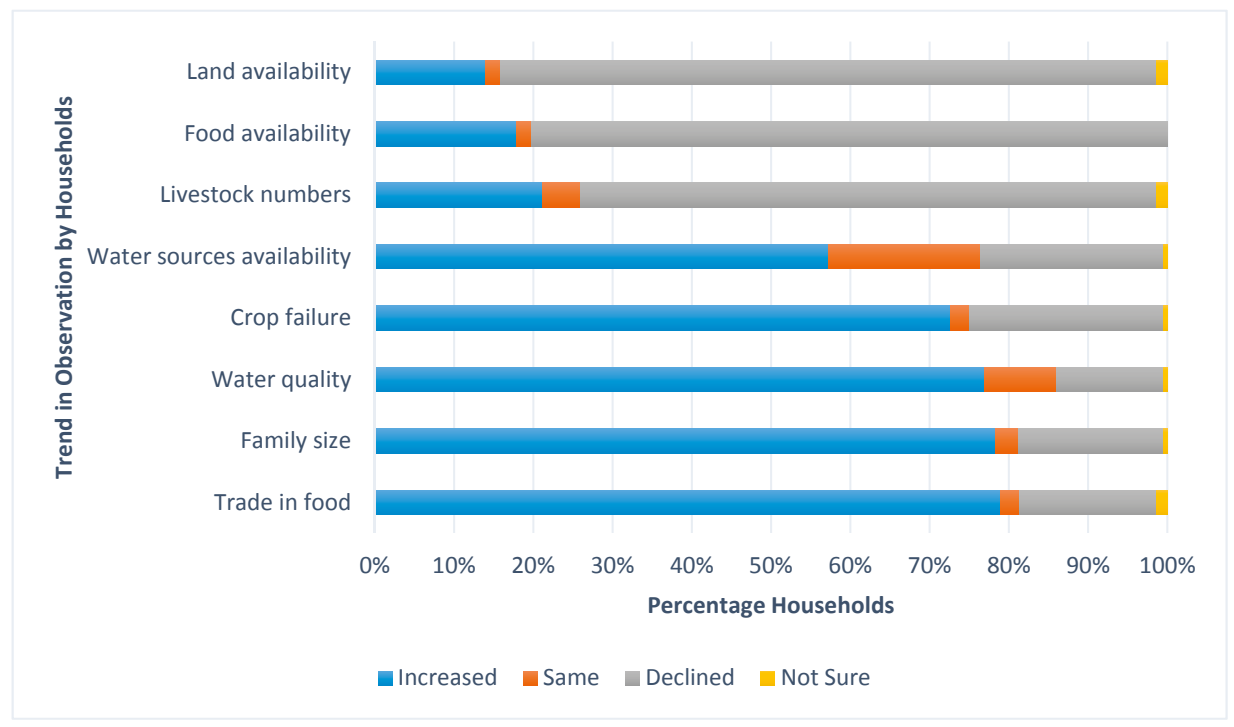

Figure 4. Perceived trends observed in 5-10 years prior to the study year in relation to food production and availability in the commercial sugarcane cultivation areas of Mayuge and Jinja Districts, Eastern Uganda.

\subsection{Relationship between Household Characteristics and Likelihood of Being Food Insecure}

Our results reveal that there is a relationship between household characteristics and their likelihood of being food insecure. Most (i.e., 62.5\%) of the male-headed households and those (68.0\%) that owned land were found to be the most food insecure. Food insecurity among the households was significantly related to status of access to land $\left(\chi^{2}=4.8, \mathrm{df}=1, p=0.028\right)$, land size owned $\left(\chi^{2}=10.75, \mathrm{df}=3, p=0.013\right)$, and size of land under sugarcane cultivation $\left(\chi^{2}=4.72, \mathrm{df}=1, p=0.03\right)$ (Table 2). This suggests that households with more land under sugarcane cultivation are more likely to have less land under food crop cultivation and therefore more food insecure. Hence, the gender of the 
household head and land variables appear to be a key factor in the food security puzzle in the study area. Some of the households with land lease it out for a period of eight years to other individuals with the capacity to cultivate sugarcanes on a commercial scale, leaving them with very small or no land at all to cultivate food crops. Meanwhile, those who cultivate sugarcanes do not always have enough money to sustain them through an 18-month period when the sugarcanes can be mature enough to be harvested and marketed. Yet, many of the sugarcane cultivators do not have multiple plantations of different ages to ensure that they will always have one to harvest throughout the year.

Table 2. Relationship between household characteristics and their likelihood of being food insecure $(n=208)$.

\begin{tabular}{ccc}
\hline \multirow{2}{*}{ Household Characteristic } & \multicolumn{2}{c}{ Food Insecure } \\
\cline { 2 - 3 } & No. of HH (\%) & $\chi^{2}, \mathbf{d f}, p$ \\
\hline Gender & - & \\
Level of education of household head & $143(68.8)$ & \\
Main occupation of household head & $52(35.3)$ & \\
Participate in farmer groups & - & $4.8,1,0.028$ \\
Decision making & - & $10.75,3,0.013$ \\
Status of access to land & - & $4.72,1,0.03$ \\
Land size & - & $9.11,4,0.058$ \\
Land under sugarcane cultivation & - & \\
Land under food crop cultivation &
\end{tabular}

No. of HH (\%) = Number of households (Percentage).

\section{Discussion}

\subsection{Food Security Situation and Coping Strategies among Households}

The three interrelated elements that are essential to achieving food security in each community are food availability (sufficient quantities available for consumption), food access (adequate resources to obtain appropriate foods for a nutritious diet), and food utilization (a diet providing sufficient energy and essential nutrients [11,26]. Results of the present study reveal that the people in this commercial sugarcane growing region are food insecure, as they do not always have both the physical and economic access to sufficient food to meet their dietary needs for a productive and healthy life [13,26,27]. In their study in the same region Mwavu et al. [12] found that a majority of the households rely on subsistence crop agriculture and agrobiodiversity of home gardens as their main source of food and income. Similarly, for most of oil palm smallholders in Papua New Guinea, living on land settlement schemes, garden food production, whether for domestic consumption or for sale at local markets, is a fundamental component of their livelihood strategies [10]. However, the home gardens in the Busoga sub-region are also increasingly experiencing the loss of important and nutritious food crops like cowpeas, soya beans, aerial yams, and Bambara groundnuts [12] from agricultural systems. Thus, in the study area, subsistence food crop agriculture is increasingly under threat, yet according to research by Baiphethi \& Jacobs [28] it can play an important role in reducing the vulnerability of rural and urban food insecure households and improving livelihoods.

Some of the households in the present study had to cope with food insecurity by resorting to offering labor in exchange for food, borrowing food, rationing of food, and at times stealing from their neighbors. However, to be food secure, households must obtain food without resorting to emergency food supplies, scavenging, stealing, or similar coping strategies to meet their dietary needs and food preferences for an active healthy life [17]. In this area, children are the most likely to be affected by food shortage in the household and the community. Similarly, among the migrant and seasonal Latino farmworkers, households with children were reported to have a significantly higher prevalence of food insecurity than those without children [29]. 
Male-headed households and those with very small land areas under food crop cultivation were found to be the most food insecure, although they are assumed to have high income than women. This is not surprising given the evidence from other parts of Africa (e.g., Rwanda), Asia, Latin America, which has shown that women's income has greater positive effect on food security than men's income [30]. This was not expected, considering that owning land would give one an opportunity to grow food crops. But most land owners who are mostly men utilize their land for sugarcane production or rent it out to other individuals with the cash to cultivate sugarcanes, thus reducing arable land for food production. In the present circumstances in the study area, of reduced land available for food crop, there is also increasingly little opportunity to implement improved agroforestry systems, yet they have the potential to reduce the vulnerability of smallholder farmers and help them adapt to changing conditions [31]. One of the adaptation options of the food cropping system in the study area would be to alter the timing and location of the cropping activities [32]. However, this is also increasingly becoming hard since most of the households do not have alternative land for relocation or fallowing. Furthermore, households lack diversified incomes with little or no integration with other farming activities such as livestock rearing given the lack of land for agro-pastoral livestock systems.

\subsection{Commercial Agriculture and Its Implications for Food Security among Households}

While largescale commercial agriculture has succeeded in feeding the world, it has in the process also contributed to deforestation, loss of wetlands, soil erosion, biodiversity losses, and increased carbon emissions in many countries [9,33]. The expansion of sugarcane plantations is cited as presently the major source of food insecurity in the Busoga sub-region. Similarly, in Swaziland, sugarcane out-growers particularly the poorer ones were unable to meet their food requirements after converting all their land to rain-fed sugarcane [34]. The widespread conversion of wetland, forest, and arable crop land areas, leading to a commercial sugarcane plantation land matrix in the Busoga sub-region, is resulting in the loss of biodiversity; yet, biodiversity is fundamental to agricultural production and food security $[12,35]$. Loss of forest in the area has serious implications for household food security, since forests represent an important repository of food and other resources that can play a key role in contributing to food security, especially if integrated into complex systems that are managed for multiple benefits [36]. Moreover, these land-use/cover changes are driven largely by the increasing demand for more land to alleviate poverty and enhance the human and social welfare at household and community levels [37], and not necessarily food security. Given their limited alternative sources of income, smallholder farmers in these rural areas are often more involved in the cultivation of crops that can earn them an income than just food. Yet, the income from sugarcane cultivation comes once every 18 months, the average time required for sugarcane to reach a marketable age or maturity. Thus, this often compromises the sustainable management of their agro-diversity as well as food production, consequently exposing them to food insecurity and malnutrition. Expansion of commercial sugarcane cultivation is making it hard for these households to maintain an intact and interconnected ecosystem —one that will help them adjust to changing environmental conditions and continue to provide services [38], thereby reducing vulnerability to the impacts of climate change.

In the study area, the landscape is increasingly being fragmented with sugarcane plantations forming the land matrix. This is resulting in the loss of natural resources (incl. forests, wetlands and grazing lands), that are linked to household livelihood security and are also underlying factors for vulnerability to both climatic and non-climatic impacts [39]. The forest and wetland ecosystems that are being lost have been reported to play an important role in adaptation to the impact of climate change [40]. They are considered as "safety-nets", in that people draw on available natural resources to meet emergency shortfalls and to keep them from being worse off in times of need [41,42], particularly when agricultural crops fail because of climatic events [30]. The systematic loss of wetlands and natural forest patches in these rural areas is driving the already poor natural resources dependent households into deeper poverty, food insecurity, and malnutrition. Our findings corroborate the findings of the report of the National Household Survey 2016/2017 [43], where about $42.1 \%$ of the population in this 
region live below the poverty line. Although sugarcane cultivation is increasing income, it is only for a small percentage of households that are out-growers, and not the majority who just lease out their land for an eight-year period with a one-time pay off. For the lessor, the income is usually small and is spent within a short period of time to solve immediate household needs (e.g., pay school fees for children, medical bills, clothing, etc.); yet, they do not have any other consistent source of income. Moreover, the cycle of hunger in Uganda, like in any other sub-Saharan African country, begins and ends with poverty-the inability to grow or purchase food causes malnutrition and poor health, which in turn leads to the inability to earn income and deeper poverty. The poverty levels pose a major threat to household food security, since income is a critical determinant of a household's ability to obtain food [30], particularly in absence of sustainable own-production of quality food. Furthermore, given that these smallholder farmers often depend on local and their own rain-fed agricultural production, climate change will have negative effects on the food systems [44], reducing their access to adequate food. Projected changes in climate point to increasing moisture stress especially during the growing season, which calls for agriculture to rely on other ecosystem services like from forests or wetlands to remain resilient. A recent vulnerability assessment conducted in Uganda suggests that changes in climate will alter crop phenology, as well as increase the incidence of crop pests and diseases, especially because of higher temperatures [22].

\subsection{Perceived Trends in Food Inadequacy and Its Causes}

Most of the respondents indicated that they did not have adequate food, both in quantity and quality. This was mainly due to low incomes and limited arable land for crop production. Apart from smallholder agriculture-their main source of food and income-many households lacked other viable employment and economic activities to build their financial base to meet their livelihood needs. The sugarcane cultivation is an 18-month cycle, meaning that an individual or household with one plantation will have to wait for that period before gaining income; yet, they will be various household needs to meet. Thus, such a household will borrow in anticipation that it will refund when it sells its sugarcane produce. Hence, by the time such an individual sells the sugarcane, the income will have already been spent keeping him/her financially constrained. Further, according to a U.S. policy, food insecurity and hunger results from financial constraints and not voluntary restrictions in food intake [29]. Similarly, in our study, lack of money (i.e., financial constraint) to buy food to supplement what households grow is reported as one of the reasons why people do not always have the right quality or variety of food they need. Trend analysis also revealed that food and land availability, and livestock numbers had reduced in the last 10 years. This confirms other studies (e.g., [45]) that have found that commercial agriculture of non-food crops can negatively affect food security. It should also be noted that households' vulnerability to climate change impacts and food insecurity tends to increase as cash crops displace the traditional safety nets (e.g., forests) [41] and food crops in the farming systems, and household consumption of own-produced staple foods is reduced [46]. This is unlike a research by Kennedy \& Cogill [47] who reported that household food security is not jeopardized by commercial sugarcane growing. Indeed, sugarcane is a crop associated with significant positive and/or negative environmental and socio-economic impacts. It has been argued that moving up from the individual out-growers level and their households there are trade-offs between national food security, health of local communities, quantity and quality of water for other uses, disruption of biodiversity and other land related ecosystem services and the expansion of the sugar industry on the other hand [48]. To make way for commercial sugarcane plantation establishment, households lose their lands that had previously been used for food crop production, fuelwood provision, or livestock grazing. Although commercial sugarcane cultivation provides local jobs, they are mainly seasonal casual laborer jobs with little income for those involved. The casualization and seasonal employment with laborers being repeatedly hired on short-term (seasonally) absolve employers of the responsibility of providing benefits, such as pension contributions, health and social services, and employment security [48]. In the region, there is also a trade-off between commercial sugarcane benefits and the 
drawback (i.e., amount of atmospheric pollutants) that ensues from the off-cuts removal from the fields through burning [49-51].

The lack of enough food among the households calls for a significant increase in the productivity of subsistence agriculture to ensure long-term food security [28]. Yet, producing enough food for the growing population like in the study area, where soil fertility and many of the farmers lack the capacity to intensify agriculture, might require opening more land for cultivation. However, this is no-longer tenable, given that most of the land in the area is being taken up for commercial sugarcane cultivation that has an assured market ensuring income to the out-growers, seasonal casual labour employment to the unskilled local communities, and tax revenues to both the local and central governments.

\section{Conclusions}

Commercial sugarcane cultivation, although contributing to increased household income, does not necessarily increase food security among households in the Busoga sub-region, since even some of the households practicing commercial sugarcane cultivation were found to be food insecure. The fact that such households' practicing of commercial sugarcane cultivation compromises the ability to meet their own food needs places food security as a major consideration in commercial agricultural projects. These findings seem to support the conventional "wisdom" that the transition to commercial agriculture causes a deterioration in household-level food security. However, our results do not support the optimistic view that normally technology and commercialization stimulate agricultural growth, improve employment opportunities, and expand food supply—all central to the alleviation of poverty [9].

There is unsustainable expansion of sugarcane plantations in the study area, causing loss of traditional safety-nets (i.e., forest and wetland ecosystem services) and leaving many poor households without land for food crop cultivation and adequate livelihoods, making them more vulnerable to the future impacts of climate change. Hence, there are trade-offs between future expansions of sugarcane cultivation for economic benefits, and the quest for food security, water resources, environmental conservation, and provisioning of ecosystems goods and services. While acknowledging the serious environmental implications of sugarcane plantation expansion, and additionally the livelihood consequences of such impacts, future expansion is probably inevitable. If natural ecosystems in the study area were to be well managed, they could provide a wide range of local ecosystem services that reduce societies' vulnerability to climate change [52], thereby helping them to adapt both to current climate hazards and to future climate change [53]. Thus, it is important to put in place strategies that allow ecologically and socially sustainable sugarcane cultivation to maximize its development benefits, while minimizing the negative social and environmental impacts. It may be necessary to enact and enforce regulations for agro-ecological zoning and land use plans to ensure a balance between the competing commercial sugarcane and food crop cultivation. Governments should consider promoting distributional equity in areas where sugarcane is commercially grown through initiatives such as providing agricultural incentives from taxes generated from sugar companies to enhancing food production per unit area among the local communities. It will also be important for future studies to integrate the nexus between commercial sugarcane cultivation, natural resource governance, and other livelihood components of smallholder farmers to promote future sustainability.

Author Contributions: E.N.M., V.K.K., F.B. and D.W. conceptualized the original research idea, participated in data correction and analysis, and write-up of the draft manuscript. P.B., T.E. and M.S.M. actively participated in data correction and analysis, and write-up of the draft manuscript.

Acknowledgments: This study was funded in part by the Carnegie Corporation of New York and Makerere University, through the Next Generation of African Academics Project.

Conflicts of Interest: We the authors declare no conflict of interest. 


\section{References}

1. Vink, N. Commercializing agriculture in Africa: Economic, social and environmental impacts. Afr. J. Agric. Resour. Econ. 2013, 9, 1-17.

2. World Bank. Fact Sheet: The World Bank and Agriculture in Africa. 2013. Available online: http:/ / web.worldbank.org/WBSITE/EXTERNAL/COUNTRIES/AFRICAEXT/0, contentMDK: 21935583 pagePK:146736 piPK:146830 theSitePK:258644,00.html (accessed on 22 March 2013).

3. OECD/FAO. Agriculture in Sub-Saharan Africa: Prospects and Challenges for the Next Decade. In OECD-FAO Agricultural Outlook 2016-2025; OECD Publishing: Paris, France, 2016; pp. 59-95.

4. The WorldBank Group. Agriculture, Value Added (\% of GDP). Available online: https:/ / data.worldbank. org/indicator/NV.AGR.TOTL.ZS (accessed on 18 April 2018).

5. Binswanger, H.P.; von Braun, J. Technological change and commercialisation in agriculture: The effect on the poor. World Bank Res. Observ. 1991, 6, 57-80. [CrossRef]

6. Clay, J. Palm Oil. In World Agriculture and Environment: A Commodity-by-Commodity Guide to Impacts and Practices; Island Press: Washington, DC, USA, 2004; pp. 203-235.

7. Zen, Z.; Barlow, C.; Gondowarsito, R. Oil palm in Indonesian socio-economic improvement: A review of options. Oil Palm Ind. Econ. J. 2006, 6, 18-29.

8. Sheil, D.; Casson, A.; Meifaard, E.; van Nordwijk, M.; Gaskell, J.; Sunderland-Groves, J.; Wertz, K.; Kanninen, M. The Impacts and Opportunities of Oil Palm in South East Asia: What do We Know and What Do We Need to Know; Occasional Paper No. 51; CIFOR: Bogor, Indonesia, 2009.

9. Nesadurai, H.E.S. Food security, the palm oil-land conflict nexus, and sustainability: A governance role for a private multi-stakeholder regime like the RSPO? Pac. Rev. 2013, 26, 505-529. [CrossRef]

10. Koczberski, G.; Curry, G.N.; Bue, V. Oil palm, food security and adaptation among smallholder households in Papua New Guinea. Asia Pac. Viewp. 2012, 53, 288-299. [CrossRef]

11. Mwavu, E.N.; Witkowski, E.T.F. Land-use and cover changes around Budongo Forest Reserve, NW Uganda: Implications for sustainability of the forest/woodland. Land Degrad. Dev. 2010, 19, 606-622. [CrossRef]

12. Mwavu, E.N.; Ariango, E.; Ssegawa, P.; Kalema, V.N.; Bateganya, F.; Waiswa, D.; Byakagaba, P. Agrobiodiversity of homegardens in a commercial sugarcane cultivation land matrix in Uganda. Int. J. Biodivers. Sci. Ecosyst. Serv. Manag. 2016, 12, 191-201. [CrossRef]

13. FAO. State of Food Insecurity 2009; Food and Agriculture Organization: Rome, Italy, 2009.

14. Liverman, D.; Kapadia, K. Food systems and the global environment: An overview. In Food Security and Global Environmental Change; Ingram, J., Ericksen, P., Liverman, D., Eds.; Earthscan: Washington, DC, USA, 2010.

15. Kung'u, J.B. Food security in Africa: The challenges of researchers in the 21st century. In Advances in Integrated Soil Fertility Management in Sub-Saharan Africa: Challenges and Opportunities; Bationo, A., Boaz, W., Job, K., Joseph, K., Eds.; Springer: Dordrecht, The Netherlands, 2007; pp. 105-113.

16. Latham, M. Human Nutrition in the Developing World; FAO: Rome, Italy, 1997.

17. IFPRI (International Food Policy Research Institute). Reaching Sustainable Food Security for all by 2020. Getting the Priorities and Responsibilities Right; IFPRI: Washington, DC, USA, 2002.

18. Rosegrant, M.W.; Cline, S.A.; Li, W.; Valmonte-Santos, R. Looking Ahead: Long-Term Prospects for Africa's Agricultural Development and Food Security; IFPRI: Washington, DC, USA, 2005.

19. Kennedy, E.T. The Effects of Sugarcane Production on Food Security, Health, and Nutrition in Kenya: A Longitudinal Analysis; International Food Policy Research Institute: Washington, DC, USA, 1989; Volume 78.

20. Rist, L.; Feintrenie, L.; Levang, P. The livelihood impacts of oil palm: Smallholders in Indonesia. Biodivers. Conserv. 2010, 19, 1009-1024. [CrossRef]

21. Goldemberg, J.; Coelho, S.T.; Guardabassi, P. The sustainability of ethanol production from sugarcane. Energy Policy 2008, 36, 2086-2097. [CrossRef]

22. U.S. Agency for International Development's (USAID). Uganda Vulnerability to Climate Change Assessment Report; United States Agency for International Development: Washington, DC, USA, 2013.

23. Phillips, O.; Gentry, A.H. The useful plants of Tambopata, Peru: 1: Statistical hypothesis test with a new quantitative technique. Econ. Bot. 1993, 47, 15-32. [CrossRef]

24. SPSS Inc. Released 2008. SPSS Statistics for Windows, Version 17.0; SPSS Inc.: Chicago, IL, USA, 2008. 
25. Hagos, H.; Mengistu, L.; Mequanint, Y. Determining optimum harvest age of sugarcane varieties on the newly establishing Sugar Project in the tropical areas of Tendaho, Ethiopia. Adv. Crop Sci. Technol. 2014, 2, 156. [CrossRef]

26. U.S. Agency for International Development's (USAID). Policy Determination of 1992 for Definition of Food Security; United States Agency for International Development: Washington, DC, USA, 1992. Available online: http:/ / www.usaid.gov/policy/ads/200/pd19.pdf (accessed on 17 August 2017).

27. Food and Agriculture Organization (FAO). Declaration on World Food Security; World Food Summit; FAO: Rome, Italy, 1996.

28. Baiphethi, M.N.; Jacobs, P.T. The contribution of subsistence farming to food security in South Africa. Agrekon 2009, 48, 459-482. [CrossRef]

29. Quandt, S.A.; Arcury, T.A.; Early, J.; Tapia, J.; Davis, J.D. Household food security among migrant and seasonal Latino farmworkers in North Carolina. Public Health Rep. 2004, 119, 568-576. [CrossRef] [PubMed]

30. Quisumbing, A.R.; Brown, L.R.; Feldstein, H.S.; Haddad, L.; Penã, C. Women: The Key to Food Security; Food Policy Report; The International Food Policy Research Institute: Washington, DC, USA, 1995.

31. Verchot, L.V.; Van Noordwijk, M.; Kandji, S.; Tomich, T.; Ong, C.; Albrecht, A.; Mackensen, J.; Bantilan, C.; Anupama, K.V.; Palm, C. Climate change: Linking adaptation and mitigation through agroforestry. Mitig. Adapt. Strat. Glob. Chang. 2007, 12, 901-918. [CrossRef]

32. Howden, S.M.; Soussana, J.-F.; Tubiello, F.N.; Chhetri, N.; Dunlop, M.; Meinke, H. Adapting agriculture to climate change. Proc. Natl. Acad. Sci. USA 2007, 104, 19691-19696. [CrossRef] [PubMed]

33. Millennium Ecosystem Assessment (MEA). Ecosystems and Human Well-Being: Synthesis; Island Press: Washington, DC, USA, 2005.

34. Terry, A.; Ryder, M. Improving food security in Swaziland: the transition from subsistence to communally managed cash cropping. Nat. Resour. Forum 2007, 31, 263-272. [CrossRef]

35. Thrupp, L.A. Linking agricultural biodiversity and food security: The valuable role of agrobiodiversity for sustainable agriculture. Int. Aff. 2000, 76, 265-281. [CrossRef] [PubMed]

36. Sunderland, T.C.H. Food security: Why is biodiversity important? Int. For. Rev. 2011, 13, 265-274. [CrossRef]

37. Maitima, J.M.; Gumbo, D.J. Land Use in Sub-Saharan Africa. In Global Change Processes and Impact in Africa: A Synthesis; Otter, L., Olago, D.O., Niang, L., Eds.; East African Educational Publishers: Nairoib, Kenya, 2007; pp. 109-130. Available online: https://cgspace.cgiar.org/bitstream/handle/10568/3016/Land\%20\%20Use\% 20Chapter\%20Proofs\%20pd.pdf? sequence=1\&isAllowed =y (accessed on 20 February 2018).

38. Jarvis, A.; Lau, C.; Cook, S.; Wollenberg, E.; Hansen, J.; Bonilla, O.; Challinor, A. An integrated adaptation and mitigation framework for developing agricultural research: Synergies and trade-offs. Exp. Agric. 2011, 47, 185-203. [CrossRef]

39. Adger, N. Vulnerability. Glob. Environ. Chang. 2006, 16, 268-281. [CrossRef]

40. Locatelli, B.; Evans, V.; Wardell, A.; Andrade, A.; Vignola, R. Forests and climate change in Latin America: Linking adaptation and mitigation. Forests 2011, 2, 431-450. [CrossRef]

41. Belcher, B.M. Forest product markets, forests and poverty alleviation. Int. For. Rev. 2005, 7, 82-89.

42. Nkem, J.; Kalame, F.B.; Idinoba, M.; Somorin, O.A.; Ndoye, O.; Awono, A. Shaping forest safety nets with markets: Adaptation to climate change under changing roles of tropical forests in Congo Basin. Environ. Sci. Policy 2010, 13, 498-508. [CrossRef]

43. Uganda Bureau of Statistics (UBOS). Uganda National Household Survey 2016/17; UBOS: Kampala, Uganda, 2007.

44. Wheeler, T.; von Braun, J. Climate change impacts on global food security. Science 2013, 341, 508-513. [CrossRef] [PubMed]

45. Sparovek, G.; Barretto, A.; Berndes, G.; Martins, S.; Maule, R. Environmental, land-use and economic implications of Brazilian sugarcane expansion 1996-2006. Mitig. Adapt. Strateg. Glob. Chang. 2009, 14, 285-298. [CrossRef]

46. Immink, M.D.C.; Alarcon, J.A. Household income, food availability, and commercial crop production by smallholder farmers in western highlands of Guatemala. Econ. Dev. Cult. Chang. 1996, 41, 319-342.

47. Kennedy, E.; Cogill, B. The commercialization of agriculture and household-level food security: The case of southwestern Kenya. World Dev. 1988, 16, 1075-1081. [CrossRef] 
48. Hess, T.M.; Sumberg, J.; Biggs, T.; Georgescu, M.; Haro-Monteagudo, D.; Jewitt, G.; Ozdogan, M.; Marshall, M.; Thenkabail, P.; Daccache, A.; et al. A sweet deal? Sugarcane, water and agricultural transformation in Sub-Saharan Africa. Glob. Environ. Chang. 2016, 39, 181-194. [CrossRef]

49. Hassuani, S.J.; Leal, MR.; de Carvalho Macedo, I. Biomass Power Generation, Sugarcane Bagasse and Trash, 1st ed.; Report PNUD-Programa das Nações Undas Para O Desenvolvimento CTC-Centro de Technologia Canavieira: Piracreaba, Brazil, 2005.

50. Pankhurst, C. Should Sugarcane Trash be Used as Biofuel for Cogeneration of Left in the Field for its Long-Term Benefits to the Soil Health and Crop Productivity; A Report Prepared for the Sugar Yield Decline Venture; Sugar Research \& Development Corporation (SRDC): Queensland, Australia, 2005.

51. Watson, H.K.; Garland, G.G.; Purchase, B.; Dercas, N.; Griffee, P.; Johnson, F.X. Bioenergy for Sustainable Development and Global Competitiveness: The Case of Sugar Cane in Southern Africa, Thematic Report 1-Agriculture; CARENSA/SEI Special Report Series; SEI: Stockholm, Sweden, 2008.

52. Vignola, R.; Locatelli, B.; Martinez, C.; Imbach, P. Ecosystem-based adaptation to climate change: What role for policy-makers, society and scientists? Mitigat. Adapt. Strat. Glob. Chang. 2009, 14, 691-696. [CrossRef]

53. Turner, W.R.; Oppenheimer, M.; Wilcove, D.S. A force to fight global warming. Nature 2009, 428, $278-279$. [CrossRef] [PubMed]

(C) 2018 by the authors. Licensee MDPI, Basel, Switzerland. This article is an open access article distributed under the terms and conditions of the Creative Commons Attribution (CC BY) license (http:/ / creativecommons.org/licenses/by/4.0/). 


\title{
Article \\ Livelihoods on the Edge without a Safety Net: The Case of Smallholder Crop Farming in North-Central Namibia
}

\author{
Dian Spear* and Angela Chappel \\ African Climate \& Development Initiative, 6th floor Geological Sciences Building, University Avenue South, \\ University of Cape Town, Rondebosch, Cape Town 7700, South Africa; chappelangela@gmail.com \\ * Correspondence: dian.spear@uct.ac.za; Tel.: +27-21-6502838
}

Received: 24 May 2018; Accepted: 15 June 2018; Published: 21 June 2018

\begin{abstract}
Semi-arid Namibia is marginal for agricultural production. Low soil fertility combined with low and variable rainfall restrict the livelihoods of smallholder farmers who often struggle to produce enough food. Although historically, communities have adopted a number of coping mechanisms, climate change threatens to further reduce agricultural production. There are many additional options available to smallholder farmers to adapt to climate change, but they are not necessarily adopting these measures despite having noticed increasing temperatures and declining rainfall. Semi-structured interviews were conducted in three villages in Onesi constituency to examine what agricultural practices smallholder crop farmers use, perception of changes in their yields, their perspective on future yields and whether they are planning on changing their agricultural practices. The results suggest that to sustain the livelihoods of rural communities in north-central Namibia, support is needed from local and regional authorities, as well as traditional and religious leaders to assist with enhancing access to information, enabling information sharing on adaptation options, and increasing awareness on climate change, its impacts and what can be done about it. In addition to this, implementation of the adaptation action also requires demonstration sites and building capacity to enable the development of self-help groups.
\end{abstract}

Keywords: vulnerability; culture; religion; agency; adaptation; perceptions; climate change; dependency

\section{Introduction}

Semi-arid environments are becoming increasingly harsh for smallholder farmers. This means that providing a livelihood is becoming even more difficult. By their nature, semi-arid lands are difficult to eke out a living in. They are remote, infertile, have limited services and have variable climates, although they are generally hot and dry $[1,2]$ This makes surviving on agriculture difficult. However, communities in these environments have managed in the past by adopting different coping mechanisms. North-central Namibia is no exception. In this marginal environment, agriculture has persisted by people adopting ways of coping with uncertain rainfall. One of the traditional Ovambo farming practices is the use of indigenous land units with different elevation and soil characteristics to plant different crops under different climatic conditions [3].

More recently, a number of other mechanisms have been used by some farmers to sustain their livelihoods. These include: (i) diversifying livelihoods to off-farm activities [3,4]; (ii) growing drought-resistant crop varieties such as early maturing Okashana millet with a three-month growing season [5]; (iii) keeping heat-resistant breeds of livestock [6]; (iv) adjusting planting of crops by delaying, using a combination of early and late planting, and/or planting multiple times within a season $[7,8](\mathrm{v})$ soil and water conservation through conservation tillage, ripping, ridging, farrowing, crop rotation, intercropping and the use of manure [6]; (vi) supplemental feeding, watering and 
moving to access alternative water and grazing resources for livestock $[3,6]$ and sometimes selling livestock [3]; (vii) storing mahang $u$ [3] and getting food from friends and neighbours [3]; (viii) receiving remittances from family members living in urban areas [4]; and (ix) relying on pension grants from the government [3,9]. However, in drylands although remote communities can be well equipped to cope with climate variability and change, they are often marginalized, chronically disadvantaged, and can battle to secure resources to respond to changes in climate [10].

Despite the different measures available to cope with variable climates, not all farmers can or do apply these measures, e.g., there is limited crop and livelihood diversification [3] and many of the existing crops and livestock are susceptible to drought, heat stress and disease. Livestock owners also often don't sell livestock when there is impending drought [11] and crops and livestock losses are most often not insured [12]. As a consequence of this reliance on rain-fed crops and livestock for livelihoods, and a lack of alternatives, these communities are sensitive to climate variability and change $[3,11]$. In addition, as food insecurity is getting worse, some coping measures, such as the sharing of food, are becoming less prominent [3].

Inherent poverty, marginalization and inequality [13], degraded natural resources [14], limited availability of fertile land, [6] and limited grazing $[3,6,14]$ combined with unreliable crop yields, mean that many households face food insecurity, which is most pronounced during drought periods [11]. Droughts are already becoming more frequent and intense and this trend is expected to worsen in the future. Significant increases in temperature have been observed in Namibia over the past century [15], and there has been a decrease in average annual rainfall [16] with higher variability in rainfall and more droughts since 1970 [17], but also frequent floods [18]. Of concern is that trends of increased temperatures and reduced rainfall are expected to continue in north-central Namibia $[7,19,20]$ and as such, agricultural productivity is expected to decrease [21].

Although smallholder farmers have already noticed reductions in rainfall and increases in temperature [9] and have experienced severe droughts that have led to major crop and livestock losses, they are not necessarily changing their agricultural practices $[7,22]$. This qualitative study uses three villages in Onesi constituency in the Omusati region of Namibia as a case study to examine: (i) the agricultural practices that smallholder crop farmers use; (ii) the perceptions of these farmers of changes in their yields; (iii) their perceptions about the future and what their planned responses are; and (iv) barriers to the adoption of new agricultural practices.

\section{Materials and Methods}

The study was conducted in three villages in the Onesi constituency in Omusati region in semi-arid north-central Namibia. 31 structured interviews were conducted across the villages: Okathitukeengombe $(n=10)$, Omaenene $(n=11)$ and Oshihau $(n=10)$, by Angela Chappel (AC) between 4 and 15 July 2017. The secretary of the Uukolonkadhi traditional authority set up a meeting with each village headman who granted permission for interviews to be conducted in their respective villages. The headmen also identified a few initial interviewees, after which snowball sampling was used to locate others. The sample was $68 \%$ female compared to $55 \%$ female in the 2011 census for Onesi constituency [23]. The mean age of the sample was 56; $55 \%$ of interviewees were between 26 and 59 and $45 \%$ were over 60 years old. In the 2011 census, the equivalent figures would be $83 \%$ in the age group of 15 to 59 and $17 \%$ in the age group [23]. Although the sample was largely aged and female, these were the people who were home and looking after the crops. In this paper, quotes are given from 17 of the farmers (10 females and 7 males).

A translator assisted in asking farmers, in the local language of Oshiwambo, about their agricultural practices, whether they think their yields have changed over time, whether they think there will be future changes in their yields, if they are worried about their future food supply, what changes they have made or plan to make to their farming practices and what prevents them from making these changes. During the interviews, the translator loosely translated each answer given by the respondent. This allowed AC to understand the essence of the interview and to ask further questions where 
necessary for clarification. Interviews were recorded using a Dictaphone and after the interviews, $\mathrm{AC}$ and the translator listened to the recordings and transcribed each interview into English so that all information was captured, and quotes could be recorded word for word. The interview data was then coded for different themes taking note of relevant quotes. The identity of the interviewees was also coded. As some of the data on barriers to adopting agricultural practices is published elsewhere, [24] summary information is presented in the results for barriers to adopting new practices.

\section{Results}

\subsection{Livelihoods in the Study Area}

During interviews with the 31 respondents (ten men and 22 women) it was noted that generally when a family owned livestock, men were responsible for the livestock and women were responsible for crop production. If the family did not own livestock, crop production responsibilities tended to be shared. In terms of the use of crop yields, 20 respondents used their crops for subsistence only and 11 sold certain of their crops or homemade sorghum beer when they had adequately supplied their own family and had an excess of yields. Mahang $u$ (pearl millet) $(n=30)$, cowpeas $(n=30)$, and sorghum $(n=27)$ were the most commonly grown crops. Other crops that are grown included maize, watermelon, Bambara nuts, cooking melons, ground nuts, pumpkins, and oilseed melons. In addition to these crops, some families had fruit trees either around their homestead or in the fields with their crops. The fruit trees grown across the study site are lemon, mango, marula, guava, palm, and custard apple.

\subsection{Smallholder Farmer Perceptions of Past Changes}

Most crop farmers in this study mentioned that the soil quality of their fields and their crop yields have declined over time. One farmer explained that their "family has been living here for more than 50 years and the texture of the soil is changing, and nutrients are decreasing" (FK28). Another farmer said, "When I first came here, I used to get much better yields" (FM82). The most commonly stated reason for observed changes in yields was that rainfall in the area has decreased: "It has also changed because of rain, because sometimes you will plough your field and sow seeds, but the rain won't come or when it comes it is just not enough for the crops, and this results in dry land which leads to poor yield" (MM73). Next most mentioned was the depletion of nutrients from the soil due to overuse followed by soil erosion. A farmer mentioned that "the land lost nutrients because the rain washed it away" (FS89). The weather was also blamed for low yields: "Last year was hotter and drier than this year, so we received less yield than this year" (MK30). Crickets were also held responsible by five farmers. One farmer explained that "the crickets came this year and decreased the yield" (FS48). Two people also mentioned that their soil is nutrient poor because they do not have livestock: "The nutrients are depleted because we keep using the same land every year and we don't have livestock to put manure on the land" (FK70). A lack of animals, after them having died in the drought, was also linked to poor yields by them not being available for ploughing and having to use a tractor instead. One farmer said: "Now we use a tractor, but I believe the tractor brings bad soil to the top and puts the good soil deep into the ground" (MM60).

\subsection{Farming Approaches That Have Been Applied by Smallholder Crop Farmers}

Many farmers still use indigenous land units and plant different crops in different portions of land; they also intercrop some of the crops and rotate some. One farmer mentioned they "look at the soil structure and nutrients and plant different crops in different portions" (FS45) and another that they "grow each crop in a different portion and change them every year" (FK62). However, different farmers intercrop different crops. One famer mentioned "Bambara nuts and sorghum have their own portion" (MK30), another that they "intercrop sorghum, mahangu, oilseed melons and cooking 
melons" (MK30); yet another said that "different portions for maize, Bambara, sorghum; other crops are intercropped" (FK70).

Farmers also move crops between land units if they don't do well during periods of climatic variability. One farmer explained that, "when the sorghum doesn't do well we put mahangu and watermelon, then move the sorghum to grow somewhere else" (FK40). Another said, "where we put mahangu, if it doesn't do well, the next year we plant it somewhere else and plant Bambara nuts there" (FK26). The use of drought resistant varieties is also common. One farmer mentioned, "I have changed the mahangu I usually grow (Ongonga) to Kangara and Okashana \#2. Ongonga takes long to mature, so it requires the rain to start early but now rain starts very late, while Kangara and Okashana mature faster, if the rain comes late, we will be able to get a better yield" (MM72). However, different varieties are used in wet years. Another farmer said that, "when there is too much rainfall I change the variety from Okashana \#2 to Kangara. When there is too much rainfall Kangara is better because it can withstand the water better and Okashana falls. But the problem is that Kangara does not mature fast enough so this year while we were waiting for it to grow the crickets came and killed the crops" (FS40). Another response to changes in yields by many farmers is the application of manure. One farmer explained, "We apply the manure from the livestock to replace the nutrients" (MM68).

Despite some of the approaches mentioned above, some farmers were of the opinion that they have not changed any of their farming approaches, despite having noticed declines in their yields. One famer mentioned, “We have not changed any crops or techniques. We don't have animals to put manure on the land" (FS89). However, another farmer said, "I have never changed the farming practices or crops because I don't know any other ways" (FK85).

\subsection{Smallholder Perceptions of the Future and Their Planned Responses}

In general, the smallholder farmers do not perceive reduced yields in the future. Many $(n=11)$ farmers mention that their yields depend on rain but don't seem to have any opinion of rainfall trends in the future. One farmer indicated, "If it rains we will get a good yield, if it doesn't rain the yield will be bad" (FK37). Quite a few farmers ( $n=5$ ) thought their yields would improve in future because of crop rotation or applying manure. One farmer thought "yields might get better in the future because even this year was better than last year, and this might continue if we keep rotating crops" (FK26). Another was of the opinion that "the yield will get better because we put manure everywhere, if it rains the soil quality will improve and we will get better yields" (FS45). However, 12 farmers mentioned an expected decline in yields for a number of different reasons. Some thought their yields would decline because of low soil fertility. One farmer thought that "the yield will be less in the future because the nutrients will keep being depleted and the soil will get worse" (FK70). Another perspective was that crickets would reduce yields. One farmer thought "the yields will get worse because of the crickets" (FS40). A few farmers did not know, and a few were of the opinion that only God knew. One farmer explained, "We don't know how the crop yield will change in future, because we haven't been receiving good rainfall in the past but when it came this year, it was too much again that it ended up flooding our fields killing our crops. So, if anybody says she/he thinks the yield will be high or low in future that person must be lying, no one can predict the future, only God knows" (MM73). Only one farmer mentioned that because of climate change there might be reduced yields in the future. This young farmer explained that, "according to climate change if there is too much rain or not enough rain the yields will be poor. I can't predict what will happen, but I think that there will probably be less rain" (FK28).

Some farmers perceived that they would still be able to provide for themselves in the future using the same approaches as now. One farmer thought that "with crop rotation we will get a good enough yield to supply food for our family. New variety Okashana \#2 will also help us-we will get this from Ministry of Agriculture" (MK75). Others didn't what know what will happen in the future or trusted in God to provide for the future. The minority opinion was that there would not be enough food in the future. One man mentioned: “I don't think we will have enough food for the family in the future 
because having bad land with no nutrients and poor rainfall is going to lead to poor yields and not enough food" (FK78).

Twenty-four of the farmers were worried about food security in the future. Some said that they were worried because they were not sure it would rain, others were worried because the land was not very fertile, and some were not worried because they had faith in God. One farmer mentioned: "I am very worried. The land has poor nutrients which is bad for growing crops. We can't predict rainfall anymore and we don't know when it will come. In the past we used to predict rainfall. Now even if you predict rain you will be surprised that you don't get rain" (FK78). However, seven farmers we not worried about the future. This was predominantly attributed to faith that God will provide sufficient rain or that the government will provide assistance. One farmer's perspective was that he was "not worried because we don't know what God has in store for us. He is the creator, he will provide" (MS42). The same farmer also expected that the government would provide food for them if they were going hungry: "There is no other method that I can use in my field because we don't have enough water. Maybe I will get enough food for my family but if I don't, the government will assist us" (MS42). Another mentioned, "We are even thinking that the government should help us with projects that will give us food" (MM72). Although many of the farmers perceived that their crop output would in fact decrease in the future, bar one, all respondents said that they would continue farming in the same way without adaptation. Only one farmer (MM68) was preparing for the future and he had recently attended a workshop on adaptation. When asked specifically about climate change, 16 respondents stated that they had heard about climate change either on the radio, by word of mouth, or from school. Most of the respondents believed that climate change would cause decreased rainfall in the future.

\subsection{Barriers to Changing Farming Practices}

Most farmers said they would continue to farm their crops in the same way as now. Many mentioned tradition as a reason for this. One farmer mentioned that "we are used to farming in the same way" (FK70). Another farmer mentioned that they do not have another option. Whereas others mentioned they might try something else if they had information on it. One farmer said, "we just have to continue farming the same way because we don't have any other information on the other methods that we could possibly use, and our animals have died of drought we will continue using tractors" (MM72). When asked specifically whether farmers would adopt new practices, they expressed willingness to do so but there were barriers to doing so. The most commonly mentioned barrier was lack of information on new or alternative farming practices followed by a belief that current approaches are the only or best way. Other popular responses were that farmers feared new approaches would not work or that they did not have enough water. Other than this money, equipment, time, labour and old age were mentioned as reasons.

\section{Discussion}

Perceptions of vulnerability and future risk play an important role in adaptation to climate change $[25,26]$ and action to respond is shaped by belief systems, personal experiences and perceived responsibility of the problem $[25,27,28]$. In this study, climate change did not specifically come up as a contributing factor to reducing yields nor did farmers express a perception of worsening droughts. Although climatic change may be difficult for farmers to detect amidst the climatic variability that is characteristic of drylands $[29,30]$ this result perhaps also reflects on a lack of awareness about climate change. Despite the likelihood that yields are going to decline in the future because of the expected effects of climate change [21], the smallholder farmers that were interviewed did not reflect this in their responses. The factors that were mentioned as affecting yields were those that would be expected for agriculture: rain, soil fertility, the weather, crickets, and the availability of livestock for ploughing and providing manure. However, the tendency for farmers to have a stronger memory of more recent events e.g., crickets and short-term trends should also be taken into consideration [31]. 
Although some farmers are worried about soil fertility and are uncertain about having enough rain in the future, the findings of this study suggest that many smallholder farmers in north-central Namibia may not be aware of how vulnerable they are to climate change. As such, they are not necessarily expecting changing conditions in future and are not planning for this by changing their approach to securing food for their families. The coping mechanisms that were mentioned as being already used by farmers were the use of land units, intercropping, and crop rotation, but farmers did not consider that as changing their practices and did not plan to change practices despite reductions in yields. These findings are in concordance with other studies that have also suggested that if farmers are not aware that they are vulnerable to the effects of climate change they will be less likely to respond e.g., in rural communities in Brazil [32].

It is expected that if farmers perceive the effects of climate change to be imminent they will take action to adapt [33]. Fortunately, there are examples of where this is so e.g., in Tanzania where farmers perceived increasing temperatures and decreasing rainfall, they changed to drought-resistant crops and increased the area under cultivation to make up for declining yields [34]. Similarly, farmers in Kenya that noticed similar trends in temperature and rainfall started mulching and planting early maturing crops [35]. In Kenya, there are also examples of farmers adopting new approaches, e.g., rice farming, after perceiving the land as being degraded [36]. However, farmers do not always respond to perceived changes. For example, a study in South Africa showed that $95 \%$ of farmers perceived changes in temperature and $97 \%$ perceived changes in rainfall, yet $62 \%$ of the farmers did not adapt in any way to these changes [37]. Similarly, although farmers perceive changes in north-central Namibia, they are not necessarily changing their agricultural practices.

Some farmers in north-central Namibia are not worried about the future because they believe that God will provide or that the government will assist them if they do not have enough food. Others are not willing to change because of traditional norms. In north-central Namibia, culture is a central component of Oshiwambo people's lives and farming traditions [22]. This is very important to take into consideration here as it can act as a barrier to adaptation when those who prescribe to it are bound to cultural practices that have been passed down over many generations and are unwilling to deviate from what is known and trusted $[27,38]$. Such cognitive and normative social barriers to climate change adaptation are widely recognised [39-41]. Mindsets influenced by traditional norms, religious beliefs and dependence on government, make smallholder farmers more vulnerable to impending climate change and are important to consider because the perception of risk is more important than calculated estimations of risk in determining response behaviour [27]. Farmers are also less likely to adopt climate smart agricultural practices if they are skeptical about climate change [38] and they are likely to be less aware and have a limited understanding of climate change if they have a low level of education $[30,31]$.

A number of factors have likely led to high vulnerability and low levels of agency that are currently seen in north-central Namibia. A history of colonial dispossession, market-driven economic policies, and gender inequality has led to chronic poverty, marginalization and inequality in the country [13]. In addition, there is a culture of expectancy of the government to do something. The government has been providing social grants including state pensions as well as drought relief and people are very reliant on this. This situation of government assistance reducing adaptive capacity is also seen in other remote drylands in Botswana and Australia and is considered potentially maladaptive [10]. However, it should be recognised that some form of social protection is needed to keep people out of extreme poverty and food insecurity. In Namibia, drought relief could be maladaptive in that it is encouraging the continuation of existing activities, creating dependency and reducing the use of coping mechanisms and further innovation. Importantly, Namibians could learn lessons from other countries where innovative agricultural practices have been used to combat the effects of climate change. For example, in Ghana, many farmers say that they are not concerned by environmental change because they innovate using methods such as zai pits and trash lines, intercropping, use of manure, and tied-ridges [42]. 
Despite there being a number of different possible coping mechanisms and adaptation options that could be employed, many of these are not used in north-central Namibia. There are a number of reasons for this. Some of the barriers to action, such as lack of information, traditional norms, religious beliefs (the expectation that God will provide) and a reliance on government, influence perceptions and others impede the implementation of adaptation interventions e.g., lack of water, money, equipment, time, labour and old age [24].

The problem of limited information on adaptation solutions is frequently cited as the main barrier to the adoption of new agricultural practices in Namibia [22,43], and elsewhere e.g., South Africa [37]. Scientific information is crucial in helping smallholder farmers e.g., to establish early warning systems and change the time of planting [44]; insufficient information is a problem not only at the farmer level, but also with extension officers and higher levels of authority $[7,45,46]$. It has been previously noted that there is limited awareness about climate change and its impacts, in addition to a lack of knowledge about solutions [7,45]. Part of the problem is that climate change information and technical advice is not being interpreted and communicated to policy makers, practitioners and farmers to assist with decision making [45-47]. In addition, many farmers don't have access to extension services in north-central Namibia $[43,48]$

The provision of information and enhanced knowledge through education, training, and communication is a vital component of changing behaviour and initiating action [49]. Therefore, to sustain the livelihoods of rural communities in north-central Namibia support is needed from local and regional authorities, as well as traditional and religious leaders to assist with enhancing access to information, enabling information sharing on adaptation options, and increasing awareness on climate change, its impacts and what can be done about it. In addition, the implementation of adaptation action also requires beneficial interventions such as demonstration sites and building capacity to enable the development of self-help groups.

It is important that information is framed appropriately to take into consideration local traditional and religious beliefs and that it is communicated by someone that is trusted by the community [24, 38,50]. Therefore, it is important to work with community leaders that are informed about climate change, its impacts and what can be done about it so that they are able to share information that is context relevant [50]. In north-central Namibia, radio is an important avenue for communicating this information as most households have radios [46].

Although having information is useful, it has been found that more action happens (e.g., investment in research and training of extension services) when actors see the benefits of an intervention e.g., agroforestry improving food security in Zambia [51]. Some farmers will only adopt new practices after witnessing success by others, even when they are aware of the benefits e.g., of compost [52]. Both demonstration sites [46] and working with champions [24] are an opportunity for communities to observe effective practices e.g., the demonstration of planting pits near a busy road in Burkina Faso [53].

Having enough labour is also often vital to enable the adoption of some labour-intensive practices and can be achieved through self-help groups [54-56], in which farmers organise themselves to take turns working on each other's farms e.g., in Ethiopia [56]. These can also strengthen social networks, which are important in the uptake of soil and water conservation practices as an essential means of sharing information, brainstorming ideas and as an informal source of credit [37,57]. Rural development policies that promote the formation of formal or informal farmer associations can strengthen this form of farmer-to-farmer interaction $[55,58]$.

\section{Conclusions}

This study indicates that the lack of understanding of future risks posed by climate change is problematic. If smallholder farmers do not perceive that they are vulnerable or becoming more vulnerable, they have less motivation to change. Having said this, another study [3] indicated that farmers in focus groups in Omusati region, mentioned concern over being able to continue farming if there was an increase in dry years. However, there are many other reasons they might not change as 
evidenced through the findings. It is not merely a case of a lack of access to finances [7], limited access to technologies such as drought resistant seed [59] or the time, labour and effort required. Local norms, customs and beliefs influence adaptation to climate change by influencing conceptual understanding of the reason for hazards as well as whether people decide to make changes to minimize current and future risks $[25,28]$. This study shows both how traditional norms and religious beliefs are preventing people from making changes, thereby making them more vulnerable to climate change. But it is not only the intent to continue with traditional farming practices and faith that God will provide that make these communities vulnerable. Another reason why smallholder farmers do not necessarily do anything to change their practices is the expectation that the government will do something to help. All of these ways of thinking prevent action by these smallholder farmers.

For communities in these drylands to sustain livelihoods in these areas, they need to adopt more climate-smart agricultural practices and they need access to alternative livelihoods. Part of the solution is building the adaptive capacity of these communities so that they can help themselves. In other developing countries, often where there isn't as much state support, there is a stronger presence of self-help groups, self-mobilisation self-organisation, and innovation [60] e.g., women's self-help groups in India [61]. The attitude of waiting for God or the government to resolve the situation isn't useful when it is expected that conditions are going to get much worse and food security will decrease. Although there are limited resources in villages in north-central Namibia, a change in perspective would help in bringing forth action. It is hoped that traditional leaders and religious leaders can play a role in changing some of these perspectives.

Although suggestions are being made here on how to increase the adaptive capacity of rural farmers in northern Namibia, it cannot be said that the government does not have some measures in place. There are some government agricultural projects in existence. One of these is the FAO (Food and Agriculture Organisation) and EU (European Union) funded MAWF (Ministry of Agriculture, Water and Forestry) Learning and Information Sharing for Agriculture SMS (Short Message Service) line, where farmers can communicate with extension officers [62]. It would be beneficial if this innovative platform for information sharing could be further promoted e.g., through radio [46]. However, it would also be beneficial for smallholder farmers to have more access to extension services, especially where there is no radio and cellular phone network. These communities need agricultural support, but they also need training and access to markets to enable them to diversify their livelihoods outside of agriculture.

Author Contributions: D.S. and A.C. conceptualized the study, A.C. collected and analysed the data under the supervision of D.S. and D.S. wrote the manuscript based on A.C.'s thesis.

Funding: This research was funded by International Development Research Centre grant number 107640-001 and Department of Science and Technology, Republic of South Africa grant number 0123/2014.

Acknowledgments: Efaishe Kavela is thanked for translating. This work was carried out under the Adaptation at Scale in Semi-Arid Regions project (ASSAR). ASSAR is one of four research programmes funded under the Collaborative Adaptation Research Initiative in Africa and Asia (CARIAA), with financial support from the UK Government's Department for International Development (DfID) and the International Development Research Centre (IDRC), Canada. The views expressed in this work are those of the creators and do not necessarily represent those of DfID and IDRC or its Board of Governors. This work was also funded by the South African Department of Science and Technology.

Conflicts of Interest: The authors declare no conflict of interest.

\section{References}

1. Reynolds, J.F.; Smith, D.M.S.; Lambin, E.F.; Turner, B.L.; Mortimore, M.; Batterbury, S.P.; Downing, T.E.; Dowlatabadi, H.; Fernández, R.J.; Herrick, J.E.; et al. Global desertification: Building a science for dryland development. Science 2007, 316, 847-851. [CrossRef] [PubMed]

2. Sietz, D.; Ludeke, M.K.B.; Walther, C. Categorisation of typical vulnerability patterns in global drylands. Glob. Environ. Chang. 2011, 21, 431-440. [CrossRef] 
3. Newsham, A.J.; Thomas, D. Agricultural Adaptation, Local Knowledge and Livelihood Diversification in North-Central Namibia; Research Technical Report; Tyndall Climate Change Research Centre: Norwich, UK, 2009; pp. 1-48.

4. Angula, M. Gender and Climate Change: Namibia Case Study; Heinrich Boell Foundation: Cape Town, South Africa, 2010; p. 45.

5. Uno, D. Farmer's selection of local and improved pearl millet varieties in Ovamboland, Northern Namibia. Afr. Study Monogr. 2005, 30, 107-117.

6. Kuvare, U.; Maharero, T.; Kamupingene, G. Research on Farming Systems Change to Enable Adaptation to Climate Change; University of Namibia for the Ministry of Environment and Tourism and the United Nations Development Program Namibia: Windhoek, Namibia, 2008; p. 103.

7. Dirkx, E.; Hager, C.; Tadross, M.; Bethune, S.; Curtis, B. Climate Change Vulnerability and Adaptation Assessment: Namibia; Desert Research Foundation of Namibia and Climate Systems Analysis Group for the Ministry of Environment and Tourism: Windhoek, Namibia, 2008; p. 149.

8. Government of the Republic of Namibia. Third National Communication to the United Nations Framework Convention on Climate Change; Ministry of Environment and Tourism: Windhoek, Namibia, 2015; p. 173.

9. Angula, M.N.; Kaundjua, M.B. The changing climate and human vulnerability in north-central Namibia. Jamba J. Disaster Risk Stud. 2016, 8, 1-7. [CrossRef]

10. Maru, Y.T.; Smith, M.S.; Sparrow, A.; Pinho, P.F.; Dube, O.P. A linked vulnerability and resilience framework for adaptation pathways in remote disadvantaged communities. Glob. Environ. Chang. 2014, 28, 337-350. [CrossRef]

11. Muhangi, P.; Acidri, J. North Central Namibia Upland Cereal and Livestock Zone, Upland Cereal and Non-Farm Income Zone: Baseline Livelihood Profiles; Livelihoods Assessment Main Report; Office of the Prime Minister-Directorate Emergency Management: Windhoek, Namibia, 2008; p. 32.

12. Zeidler, J.; Kandjinga, L.; David, A. Study on the Effects of Climate Change in the Cuvelai Etosha Basin and Possible Adaptation Measures; Integrated Environmental Consultants Namibia: Windhoek, Namibia, 2010; p. 34.

13. Jauch, H.; Edwards, L.; Cupido, B. Inequality in Namibia. In Tearing Us Apart: Inequalities in Southern Africa; Jauch, H., Muchena, D., Eds.; Open Society for Southern Africa: Johannesburg, South Africa, 2011; pp. 181-255.

14. Klintenberg, P.; Seely, M.; Christiansson, C. Local and national perceptions of environmental change in central Northern Namibia: Do they correspond? J. Arid Environ. 2007, 69, 506-525. [CrossRef]

15. Hulme, M.; Doherty, R.; Ngara, T.; New, M.; Lister, D. African climate change: 1900-2100. Clim. Res. 2001, 17, 145-168. [CrossRef]

16. Hutchinson, P. Notes on the Namibia Volumetric Annual Rainfall; Namibia Meteorological Services: Windhoek, Namibia, 1998.

17. Intergovernmental Panel on Climate Change (IPCC). Climate Change 2007: Impacts, Adaptation and Vulnerability; Summary for Policymakers. Working Group II Contribution to the Intergovernmental Panel on Climate Change Fourth Assessment Report; Cambridge University Press: Cambridge, UK, 2007; p. 44.

18. Gilau, A.M.; Dayo, F.B.; Abraham, L.Z.; Mundia, L. Drought and Flood Risk Assessment Tool for Gender Specific Decision-Making; Summary Report; Triple "E" Systems Inc, USA for Africa Adaptation Project-Namibia. Republic of Namibia: Windhoek, Namibia, 2011; pp. 1-30.

19. Davis, C.L. Climate Risk and Vulnerability: A Handbook for Southern Africa; Council for Scientific and Industrial Research: Pretoria, South Africa, 2011; p. 92.

20. Department of Environmental Affairs. Long-Term Adaptation Scenarios Flagship Research Programme for South Africa (LTAS) Phase 1. Climate Trends and Scenarios for South Africa Technical Report (no. 1 of 6). Pretoria, South Africa. 2013. Available online: https://www.environment.gov.za/sites/default/files/docs/ climate_trends_bookV3.pdf (accessed on 20 June 2018).

21. Intergovernmental Panel on Climate Change. Climate Change 2014: Impacts, Adaptation, and Vulnerability, Part A: Global and Sectoral Aspects; Contribution of Working Group II to the Fifth Assessment Report; Cambridge University Press: Cambridge, UK, 2014; p. 1132.

22. Von Hase, F. Facilitating Conservation Agriculture in Namibia through Understanding Farmers' Planned Behaviour and Decision Making; Swedish University of Agricultural Sciences: Upsalla, Sweden, 2013; p. 62.

23. Namibia Statistics Agency Namibia 2011: Population and Housing Census Main Report; Namibia Statistics Agency: Windhoek, Namibia, 2011; p. 212. 
24. Davies, J.; Spear, D.; Chappel, A.; Joshi, N.; Togarepi, C.; Kunamwene, I. Considering religion and tradition in Climate Smart Agriculture: Insights from Namibia. In The Climate-Smart Agriculture Papers: Investigating the Business of a Productive, Resilient and Low Emission Future; Rosenstock, T., Nowak, A., Girvetz, E., Eds.; Springer International Publishing: Basel, Switzerland, in press.

25. Schipper, E.L.F. Religion as an integral part of determining and reducing climate change and disaster risk: An agenda for research. In Climate Change: The Social Science Perspective; Voss, M., Ed.; VS-Verlag: Wiesbaden, Germany, 2010; pp. 377-392. ISBN 978-3-531-15925-6.

26. Balama, C.; Augustino, S.; Eriksen, S.; Makonda, F. Forest adjacent households' voices on their perceptions and adaptation strategies to climate change in Kilombero District, Tanzania. SpringerPlus 2016, 5, 792. [CrossRef] [PubMed]

27. Becken, S.; Lama, A.; Espiner, S. The cultural context of climate change impacts: Perceptions among community members in the Annapurna Conservation Area, Nepal. Environ. Dev. 2013, 8, 22-37. [CrossRef]

28. Thomalla, F.; Smith, R.; Schipper, L. Cultural aspects of risk to environmental changes and hazards: A review of perspectives. In Disasters' Impact on Livelihood and Cultural Survival: Losses, Opportunities, and Mitigation; Companion, M., Ed.; CRC Press: Boca Raton, FL, USA, 2015; pp. 3-18.

29. Slegers, M.F.W. "If only it would rain": Farmers' perceptions of rainfall and drought in semi-arid central Tanzania. J. Arid Environ. 2008, 72, 2106-2123. [CrossRef]

30. Gbetibouo, G.A. Understanding Farmers' Perceptions and Adaptations to Climate Change and Variability: The Case of the Limpopo Basin, South Africa; Environment and Production Technology Division Discussion Paper 00849; International Food Policy Research Institute: Washington, DC, USA, 2009; p. 52.

31. Muller, C.; Shackleton, S. Perceptions of climate change and barriers to adaptation amongst commonage and commercial livestock farmers in the semi-arid Eastern Cape Karoo. Afr. J. Range Forage Sci. 2014, 31, 1-12. [CrossRef]

32. Da Silva-Rosa, T.; Bonatti, M.; Vanini, A.; Zuffo, C. Vulnerability and climate change perceptions: A case study in Brazilian biomes. Environ. Pollut. 2014, 3, 82-96. [CrossRef]

33. Alam, G.M.M.; Alam, K.; Mushtaq, S. Climate change perceptions and local adaptation strategies of hazard-prone rural households in Bangladesh. Clim. Risk Manag. 2017, 17, 52-63. [CrossRef]

34. Mongi, H.; Majule, A.E.; Lyimo, J.G. Vulnerability and adaptation of rainfed agriculture to climate change and variability in semi-arid Tanzania. Afr. J. Environ. Sci. Technol. 2010, 4, 371-381. Available online: http://www.academicjournals.org/AJEST.

35. Ogalleh, S.A.; Vogl, C.R.; Eitzinger, J.; Hauser, M. Local perceptions and responses to climate change and variability: The case of Laikipia District, Kenya. Sustainability 2012, 4, 3302-3325. [CrossRef]

36. Gicheru, M. Barriers and Enablers to Uptake and Implementation of System of Rice Intensification: A Case Study of Mwea Irrigation Scheme in Kenya. Master's Thesis, University of Cape Town, Cape Town, South Africa, 2016. Available online: http:/ / hdl.handle.net/11427/23716 (accessed on 20 June 2018).

37. Bryan, E.; Deressa, T.T.; Gbetibouo, G.A.; Ringler, C. Adaptation to climate change in Ethiopia and South Africa: Options and constraints. Environ. Sci. Policy 2009, 12, 413-426. [CrossRef]

38. Gruère, G.; Wreford, A. Overcoming Barriers to the Adoption of Climate-Friendly Practices in Agriculture; OECD Food, Agriculture and Fisheries Papers, No. 101; OECD Publishing: Paris, France, 2017; p. 40.

39. Adger, W.N.; Dessai, S.; Goulden, M.; Hulme, M.; Lorenzoni, I.; Nelson, D.R.; Naess, L.; Wolf, J.; Wreford, A. Are there social limits to adaptation to climate change? Clim. Chang. 2009, 93, 335-354. [CrossRef]

40. Biesbroek, G.R.; Klostermann, J.E.M.; Termeer, C.J.A.M.; Kabat, P. On the nature of barriers to climate change adaptation. Reg. Environ. Chang. 2013, 13, 1119-1129. [CrossRef]

41. Shackleton, S.; Ziervogel, G.; Sallu, S.; Gill, T.; Tschakert, P. Why is socially-just climate change adaptation in sub-Saharan Africa so challenging? A review of barriers identified from empirical cases. WIREs Clim. Chang. 2015, 6, 321-344. [CrossRef]

42. Nyantakyi-Frimpong, H.; Bezner-Kerr, R. The relative importance of climate change in the context of multiple stressors in semi-arid Ghana. Glob. Environ. Chang. 2015, 32, 40-56. [CrossRef]

43. Paulus, N.N. Factors Affecting Subsistence Farmers' Adoption of Sustainable Land Management Practices in Oshikoto Region, Namibia; United Nations University Land Restoration Training Programme: Reykjavik, Iceland, 2015.

44. Antwi-Agyei, P.; Dougill, A.J.; Stringer, L.C. Barriers to climate change adaptation: Evidence from northeast Ghana in the context of a systematic literature review. Clim. Dev. 2015, 7, 297-309. [CrossRef] 
45. Ministry of Environment and Tourism. Namibia Second National Communication on Climate Change to the United Nations Framework Convention on Climate Change; Ministry of Environment and Tourism: Windhoek, Namibia, 2011; p. 125.

46. Thomas, B. An assessment of the role of research and extension services for small-scale crop farmers in North-Central Namibia. J. Agric. Biodivers. Res. 2012, 1, 122-126. Available online: http://www. onlineresearchjournals.org/JABR (accessed on 20 June 2018).

47. David, A.; Braby, J.; Zeidler, J.; Kandjinga, L.; Ndokosho, J. Building adaptive capacity in rural Namibia: Community information toolkits on climate change. Int. J. Clim. Chang. Strateg. Manag. 2013, 5, $215-229$. [CrossRef]

48. Jona, C.N.; Terblanche, S.E. Farmers' perception on contact frequency, adequacy, relevance and quality of agriculture support services in Oshikoto region in Namibia. S. Afr. J. Agric. Ext. 2015, 43, 107-121.

49. Michie, S.; van Stralen, M.M.; West, R. The behaviour change wheel: A new method for characterizing and designing behaviour change interventions. Implement. Sci. 2011, 6, 42. Available online: http://www. implementationscience.com/content/6/1/42 (accessed on 20 June 2018). [CrossRef] [PubMed]

50. Nyasimi, M.; Kimeli, P.; Sayula, G.; Radeny, M.; Kinyangi, J.; Mungai, C. Adoption and Dissemination Pathways for Climate-Smart Agriculture Technologies and Practices for Climate-Resilient Livelihoods in Lushoto, Northeast Tanzania. Climate 2017, 5, 63. [CrossRef]

51. Garrity, D.P.; Akinnifesi, F.K.; Ajayi, O.C.; Weldesemayat, S.G.; Mowo, J.G.; Kalinganire, A.; Larwanou, M.; Bayala, J. Evergreen Agriculture: A robust approach to sustainable food security in Africa. Food Secur. 2010, 2, 197-214. [CrossRef]

52. Ouédraogo, E.; Mando, A.; Zombré, N.P. Use of compost to improve soil properties and crop productivity under low input agricultural system in West Africa. Agric. Ecosyst. Environ. 2001, 84, 259-266. [CrossRef]

53. Danjuma, M.N.; Mohammed, S. Zai Pits System: A catalyst for restoration in the dry lands. J. Agric. Vet. Sci. 2015, 8, 1-4. [CrossRef]

54. Critchley, W.; Graham, O. Looking after Our Land: Soil and Water Conservation in Dryland Africa; Oxfam Publishing: London, UK, 1991; p. 88.

55. Nkegbe, P.K.; Shankar, B.; Ceddia, G. Smallholder adoption of soil and water conservation practices in northern Ghana. In Proceedings of the EAAE 2011 Congress: Change and Uncertainty Challenges for Agriculture, Food and Natural Resources, Zurich, Switzerland, 30 August-2 September 2011; p. 13.

56. Sidibé, A. Farm-level adoption of soil and water conservation techniques in northern Burkina Faso. Agric. Water Manag. 2005, 71, 211-224. [CrossRef]

57. Sietz, D.; Van Dijk, H. Land-based adaptation to global change: What drives soil and water conservation in western Africa? Glob. Environ. Chang. 2015, 33, 131-141. [CrossRef]

58. Nganga, S.K.; van Wijk, M.T.; Rufino, M.C.; Giller, K.E. Adaptation of agriculture to climate change in Ethiopia. Reg. Environ. Chang. 2016, 16, 2317-2330. [CrossRef]

59. Office of the Prime Minister-Directorate Emergency Management. Namibia Rural Food and Livelihood Security Vulnerability Assessment and Analysis Report 2014/2015; Government of the Republic of Namibia: Windhoek, Namibia, 2014; p. 23.

60. Adger, W.N. Social capital, collective action, and adaptation to climate change. Econ. Geogr. 2003, 79, 387-404. [CrossRef]

61. Reddy, C.S.; Manak, S. 2005 Self-Help Groups: A Keystone of Microfinance in India-Women Empowerment and Social Security; Mahila Abhivruddhi Society: Hyderabad, India.

62. Ministry of Agriculture, Water and Forestry, Learning and Information Sharing for Agriculture. Available online: http:/ / www.lisa.com.na/admin/ (accessed on 22 May 2018).

(C) 2018 by the authors. Licensee MDPI, Basel, Switzerland. This article is an open access article distributed under the terms and conditions of the Creative Commons Attribution (CC BY) license (http:/ / creativecommons.org/licenses/by/4.0/). 
Article

\title{
A Slipping Hold? Farm Dweller Precarity in South Africa's Changing Agrarian Economy and Climate
}

\author{
Donna Hornby ${ }^{1, *}$, Adrian $\mathrm{Nel}^{2}$, Samuel Chademana ${ }^{3}$ and Nompilo Khanyile ${ }^{4}$ \\ 1 Institute for Poverty, Land and Agrarian Studies, University of the Western Cape, \\ 7535 Western Cape, South Africa \\ 2 Adrian Nel: University of KwaZulu-Natal, Pietermaritzburg, 3201 KwaZulu-Natal, South Africa; \\ Nela@ukzn.ac.za \\ 3 Samuel Chademana: Groundwork, 3201 Pietermaritzburg, South Africa; samuel@groundwork.org.za \\ 4 Nompilo Khanyile: Association for Rural Advancement, 3201 Pietermaritzburg, South Africa; \\ thandilindo@gmail.com \\ * Correspondence: donnahornby@gmail.com; Tel.: +27-072-538-1708
}

Received: 7 February 2018; Accepted: 12 March 2018; Published: 23 March 2018

\begin{abstract}
The paper investigates whether farm dwellers in the KwaZulu-Natal (KZN) province of South Africa are subject to a "double exposure": vulnerable both to the impacts of post-apartheid agrarian dynamics and to the risks of climate change. The evidence is drawn from a 2017 survey that was undertaken by the Association for Rural Advancement (AFRA), which is a land rights Non-Governmental Organization (NGO), of 843 farm dweller households. Data on the current living conditions and livelihoods was collected on $15.3 \%$ of the farm dweller population in the area. The paper demonstrates that farm dwellers are a fragmented, agricultural precariat subject to push and pull drivers of mobility that leave them with a precarious hold on rural farm dwellings. The key provocation is that we need to be attentive to whether the hold farm dwellers have over land and livelihoods is slipping further as a result of instability in the agrarian economy? This instability arises from agriculture's arguably maladaptive response to the intersection of structural agrarian change and climate risk in post-apartheid South Africa. While the outcomes will only be apparent in time, the risks are real, and the paper concludes with a call for agrarian policy pathways that are both more adaptive and achieve social justice objectives.
\end{abstract}

Keywords: agrarian dynamics; climate change; farm dwellers; livelihoods; precariat; vulnerability; South Africa

\section{Introduction}

What place is there for farm dwellers in South Africa's changing agrarian and climate context? The uncertainty over this issue is what we intend to engage in this paper. Some things are more certain, however. Three key features of South Africa's agrarian economy 24 years into democracy are the persistence of a racially skewed distribution and structure of land ownership with most rural people living on state land under traditional authorities and accessing land through (neo-) customary processes (Hornby et al., 2017 [1]); concentration, centralisation, and integration of agricultural capital creating a globally competitive but highly capital intensive and labour shedding agro-food regime (Greenberg, 2015 [2]); and, the ongoing evictions of farm dwellers from commercial farms despite tenure reform laws, with totals exceeding evictions from a decade prior to 1994 and greater than the number of beneficiaries of land reform policies (Wegerif et al., 2005 [3]).

The politics of land reform remain contested while consensus on agrarian solutions is elusive. AgriSA, the national agricultural union representing commercial farmers, claims that the government's target to redistribute 30\% of white owned farmland has been achieved (AgriSA, 2017 [4]). However, methodological 
critiques (Hall and Cousins 2017 [5]) show that the real figure is closer to 8\% (Aliber and Cousins 2013 [6]) and growing populist demands for land expropriation without compensation indicate widespread discontent with the land ownership distribution. Debates on agrarian futures revolve around the possibility of expanding rural household use of small plots to generate food and income (Aliber and Cousins 2013, Hall, 2009a [6,7]), while others (Sender and Johnstone 2009, Hein, $2011[8,9]$ ) suggest that the dominance of large scale farmers and agro-food conglomerates (or 'Big Food') (Igumbor et al., 2012 [10]) eviscerate the space for small farm strategies. O'Laughlin et al. [11] argue that "Land reform can therefore be seen as simultaneously both central and marginal (or 'necessary but not sufficient') to meeting South Africa's crisis of employment, livelihood and social reproduction ..."

This poses serious challenges for South Africa's attempt to use agrarian reform to confront rising unemployment, persistent structural inequality, and growing poverty and hunger ${ }^{1}$, particularly for farm dwellers, the focus of this paper. Moreover these challenges are exacerbated in the context of emerging climate change risks. Global warming is widely acknowledged as one of the greatest environmental, social, and economic threats to sustainable development in the world this century (Agrawala and Frankhauser 2008, Stern 2008, United Nations Intergovernmental Panel on Climate Change (IPCC) 2014, Ziervogel and Taylor 2008, Anbumozhi 2009, Kaijage 2011, Turpie and Visser 2012 [12-18]). In South Africa, the mean annual temperatures have increased by at least 1.5 times the observed global average of $0.65^{\circ} \mathrm{C}$ over the past five decades and extreme rainfall events have increased in frequency (Ziervogel 2014 [19]). Both the United Nations Intergovernmental Panel on Climate Change (IPCC) and South Africa's own localized and downscaled assessment models project warming of about $3-6{ }^{\circ} \mathrm{C}$ by 2081-2100 (IPCC 2014, Department of Environmental Affairs and Tourism (DEAT) 2004 [14,20]). Despite the parallels, there is a disconnect in the literature with agrarian political economists tending to neglect climate as a factor of change, while the climate change literature disregards how these changes will intersect with the social dynamics underlying agrarian change. Yet, climate change could deepen and exacerbate pre-existing historical and current vulnerabilities of the approximately 2 million (Stats SA 2011 [21]) already vulnerable farm dwellers across the country.

This paper thus investigates the degree to which farm dwellers, their land tenure and livelihoods are subject to a "double exposure" (O'Brien and Leichenko 2000 [22]); vulnerable to the impacts of post-apartheid agrarian dynamics and change while their land-based livelihoods are vulnerable to climate change as are the commercial farm enterprises on which their wage labour and residential rights depend. The study is innovative in providing extensive data on frequently neglected rural dwellers, namely those who live on commercial farms that they do not own, and in drawing attention to their double exposure to a combination of agrarian and climate changes, the livelihood vulnerabilities that are created, and the particular politics that this generates on farms.

The paper demonstrates that farm dwellers are a "fragmented" (Bernstein, 2010:110 [23]) agricultural "precariat" (Standing, 2011 [24]) that are subject to centrifugal (push) and centripetal (pull) drivers of mobility that leave them with a precarious hold on rural farm dwellings. The key provocation of this paper is that we need to be attentive to whether the hold farm dwellers have over land and livelihoods is slipping further as a result of instability in the agrarian economy ${ }^{2}$ ? This instability, we suggest, arises from agriculture's arguably maladaptive response to the intersection of structural and climate change in post-apartheid South Africa. While outcomes will only be apparent in time, we suggest the risks are real, and the paper concludes with a call for more research, and for agrarian policy pathways that are both more adaptive and achieve social justice objectives.

1 Food prices in 2016 recorded the highest level of inflation at 11.6\% (Province of KwaZulu-Natal, 2017: 14 [25]) while agricultural production in the KwaZulu-Natal recorded a sixth consecutive contraction in 2016 due to a severe multi-year drought (ibid, 20).

2 StatsSA (2016 [26]) records a 25.2\% decline in "agricultural households" in KwaZulu-Natal between 2011 and 2016, the highest rate of decline nationally, and followed by North West with $21.6 \%$. 


\section{Capital, Climate and the Agricultural Precariat}

The contested discourse of a new geological era, in the form of the Anthropocene-in which anthropogenic climate change is acknowledged to have fundamentally altered our climate system (Clark 2015, Morton $2014[27,28]$ ) — provides an entry point for a number of issues that re pertinent to this paper; namely the interconnections between climate, capital and socio-ecological change. Moore 2017 [29] argues that there is a fundamental Human/Nature dualism at the centre of the Anthropocene discourse, which "obscures our vistas of power, production and profit in the web of life". Instead of the Anthropocene discourse, which begins with Nature as analytically distinct to a homogenous and abstracted notion of Society, Moore, amongst others (Klein 2014 [30]) proposes the Capitalocene as a way for understanding the conditions for co-production in the planetary 'web of life', and how capitalism has revolutionised the "co-production of historical natures" (ibid: 599).

Indirectly substantiating this argument, $\mathrm{O}^{\prime}$ Brien and Leichenko 2000 [22] consider processes of globalisation together with climate change arguing that "on-going processes of economic globalization are modifying or exacerbating existing vulnerabilities to climate change" (ibid, 221).

Most directly, the connection between highly capitalised, commercial agriculture and climate change is one of cause and effect: on one extreme commercial agricultural systems are energy-intensive and fossil-fuel based, and thus contribute to greenhouse gas emissions. Estimates posit that agriculture and the food system as a whole accounts for between $8.2 \%$ (Takle and Hofstrand 2008 [31]) to $29 \%$ (Vermeulin et al., 2012 [32]) of global greenhouse gas emissions, thus further accelerating climate change (Hewitson et al., 2005 [33]). Moreover, some scholars (Weiss 2013, Van Der Ploeg et al., 2015 McMichael and Schneider 2011 and Schneider and McMichael 2010 [34-37]) contend that the shift towards a highly capitalised, mono-culture form of agriculture has constituted a form of maladaptation to ongoing climate change and associated shifting agro-ecological conditions. Grain production (specifically maize in Southern Africa and rice in Asia) faces particular adaptation threats due to sensitivity to small temperature increases (IAASTD, 2009:287 [38]), with small farmers most at risk (ibid). Maladaptation, according to the IPCC (2014 [14]), is 'an adaptation that does not succeed in reducing vulnerability but increases it instead' ${ }^{3}$

Yet Moore's argument is further nuanced regarding accumulation dynamics, where he situates the capitalist revolution in the co-production of historical natures in the four "cheaps" of Nature-labour 4 , food, energy, and raw materials- that have sustained capitalism's expansion and that are now drawing to an end. The launch of the green revolution in the 1960s, along with the intensive investment that accompanied it, was based on the extensive farming of monocultures and supported by a boom in the agrochemical sector and fossil fuel based mechanization (Capra, 2015 [39]). While the new technologies supported an exponential growth in agricultural production and increased food supply for a growing world population (Bernstein 2010 [23]), the assumptions were that the climate would remain stable and both fossil fuels and water supply would always be abundant and affordable (Capra 2015 [39]). However, the mounting evidence of climate change and food price volatility (Holt-Giménez a \& Altieri 2013, Van Der Ploeg 2013 [40,41]) have shown the limits of these assumptions. Commercial agriculture is now increasingly faced with prospects of peak fossil fuels, peak fertilizers (Pinock 2010 [42]), falling water tables in some regions, with risks of food shortages, increasing food prices, and increased social instability (Raleigh et al., 2015 [43]), as well as global political pressures to curb agriculture's contributions to greenhouse gas emissions. The spatially uneven distribution of climate change effects (O'Brien and and Leichenko 2000 [22]) has already resulted in periodic declines in crops yields and failures in some regions.

3 There is debate about adaptation as a useful concept, however. See, for instance, Atteridge and Remling (2018 [44]) who suggest that adaptation is redistributing vulnerability rather than reducing it.

4 Cheap labour, according to Moore 2017 [29], was based on the disconnection of indigenous populations from the fold of 'civilized' people: what English colonial administrators referred to as the 'wild' Irish and the Castilians called the 'Naturales' in reference to indigenous Peruvians. 
Of interest with regards to 'cheap' labour in South Africa, the dynamics run somewhat contrary to Moore's assertion of scarcity, with increasing precarity for an oversupplied labour base. O'Laughlin et al., 2013:6 [11]) argue that it was apparent in the 1970s "that the system of migrant labour [in South Africa] had eroded its own conditions of existence". The subsistence 'subsidy' that household farming in the apartheid 'Bantustans' had provided to agricultural and mining wage labour had been undercut by overcrowding as a result of forced removals and consequent declining farm production. However, this particular contradiction created the basis for the subsequent emergence of 'surplus labour' as people continued to migrate out of rural areas and the need for labour in mining and manufacturing declined. As a result, "cheap labour was no longer scarce and securing it no longer required systematic state intervention" (ibid). Furthermore, the growing surplus of labour over the past 40 years have "narrowed the range of employment-based entitlements, cut flows of remittances between rural and urban areas, and heightened competition for jobs and access to services" (ibid).

The effect of this surplus labour boom alongside the capitalist restructuring of agrarian social relations have been far reaching for rural farm dwellers and labourers. Ewert and Du Toit 2005: [45] use the idea of a "double divide" to characterise the changes in the agrarian structure that have take place over the past four decades. On the side of capital are farmers "able to profit from the opportunities offered by international expansion and those who are not"; and, on the side of labour is a growing gap "between 'core' workers and those thrown out by casualization and externalization". While there is no reference to what happens to the dynamics internal to the double divide in the context of climate change, an effect of the double divide has been the growth of a "rural lumpenproleteriat, often residing in rural, peri-urban or metropolitan shantytowns" (ibid: 317).

Perhaps more accurately, the position of farm dwellers in the face of these trajectories can be described as something of a rural agricultural precariat. Standing 2011 [24] argues that the fragmentation of the labour market accompanying globalisation has created a new social class of people who are 'habituated' to precariousness characterised as flexible, insecure and intermittent employment as well as "uncertain access to housing and public resources". While the idea that the 'precariat' constitutes a specific social class has been thoroughly critiqued for disregarding the (geographically varied) logic of class domination under capitalism (see Breman 2013, Bernado 2016, Munk 2013 [46-48]), further theorisation has linked employment precariousness (or "wageless existence" for Denning, 2010 [49]; 'footloose labour' for Breman, 1996 [50]) to eroded conditions of social reproduction (Hart 2014, Bernstein 2004: 205-6, Bernstein 2003: 210 [51-53]). Tania Li (2010: 67 [54]), in her essay 'To Make Live or Let Die', argues that the deepening condition of precariousness is the result of a new round of enclosures, leading to the dispossession of large numbers of rural people from land combined with "the low absorption of their labour, which is 'surplus' to the requirements of capital accumulation". It is in this sense that we find the term 'precariat' a useful conceptual lens to engage with changing social relations on farms in the rural midlands of KwaZulu-Natal (KZN) province, to which we presently turn. Firstly, however, we set out the KZN context of capitalist agrarian transformation in South Africa over the past decades.

\section{Study Method}

The evidence is drawn from a 2017 survey that was undertaken by the Association for Rural Advancement (AFRA), a land rights NGO that works with farm dwellers in the Umgungundlovu District of the KwaZulu-Natal (KZN) province. The Umgungundlovu District, which is located in the midlands area of KwaZulu-Natal (the country's second most densely populated province), is one of 11 municipal districts that are located on the east coast of South Africa, inland from the port city of Durban. The District has a population of just over a million inhabitants, $61 \%$ of whom are located in the Msunduzi Local Municipality in the vicinity of the city of Pietermaritzburg (Stats SA, 2017 [55]). The commercial farm areas are dominantly sugar, forestry and beef with some poultry and diary. The farm dweller population is estimated to be just under 41,000 people. 
The survey was undertaken as part of AFRA's Pathways Project, whose objective is to find pathways for farm dwellers out of poverty. ${ }^{5}$ The purpose of the survey was three-fold: firstly, to collect base-line data on farm dweller households in the district in order to update information on the living and livelihood conditions of farm dwellers across the district; secondly, to provide data that could be used in longitudinal studies to assess changes to the living and livelihood conditions of farm dwellers; and thirdly, to provide a GPS location of the interviewed farm dweller households and summary data on rights to land and services as a record of evidence to be used to adjudicate any arising future disputes over rights.

Surveys on farms in South Africa are not politically neutral processes of data collection. The research was planned to be undertaken together with land owners in a single municipal area, but after landowner structures subsequently withdrew their co-operation, AFRA changed the scope to a sample of farm dweller households across the District in order to ensure access to a representative sample. The access to farm dwellers then had to be negotiated through other structures, which included elected councilors, community development workers, and farm dweller structures. This may have created some bias in the sample in that the farms more likely to be known to these structures are those where farm dwellers have reported problems of some kind, but these problems also constitute the rationale for researching farm dwellers in the first place. A further dimension shaping the sample was that some land owners prevented the researchers from accessing farms and in one case threatened to bring trespassing charges.

The sampling method under these conditions was essentially opportunistic and the robustness of the data depended on the percentage of farm dweller households sampled. ${ }^{6}$ The survey was conducted with 843 farm dweller households, which collected data on 6478 individual men, women, and children, living on 83 farms, and thus comprises an estimated $15.8 \%$ of the farm dweller population in the District. Data was collected on both individuals ${ }^{7}$ and households ${ }^{8}$, and analysed accordingly. The instrument was piloted repeatedly and amendments to the instrument were made on the basis of research assistants' experience of administering the survey.

The survey was loaded onto a tablet, and interviews were undertaken by six research assistants over a six month period, with a subsequent two months for checking and correcting errors. ${ }^{9}$ Data analysis was undertaken in excel and made available on a limited access website as information was being updated. Cross-tabulations were run across variables where possible relationships had been identified through literature or through focus sessions with farm dwellers and AFRA field staff. In terms of ethics, AFRA was concerned that the collected data not be used by landowners or government to further erode land and service rights of farm dwellers. The permission of respondents to be interviewed was thus obtained in every case, and the respondents assured that the data linked explicitly to their names would not be released without their consent.

5 The pathways include a number of strategies for settling land rights and the providing municipal services and state housing through multi-stakeholder processes, including with land owners, and different spheres of municipal, provincial, and national government (see https://afra.co.za/current-focus-areas/).

6 The total number of farm dweller households in the District was calculated from Stats SA (2013 [56]) data which showed that in $20115.28 \%$ of South Africa's population lived in designated "Farm Areas", and of this population, 76.1\% lived on commercial farms (see Visser and Ferrer, 2015: 8 [57]). Although the census data is old, there is no up to date data that can be used to calculate the farm dweller population. AFRA thus used these percentages to calculate the population of farm dwellers living on commercial farms as: 5.28/100 × 76.1/100 $\times 1,017,763$, which amounted to 40,895 individuals.

7 Data collected on individual members of household included educational levels, gender and age, permission to be on the farm, residence on the farm, income levels and sources of income.

8 The data collected on households included household composition, age and gender characteristics, length of time resident on farms, use of land for livestock production and cultivation, access to basic needs and services (specifically water, energy, and housing), succession in relation to housing and perception of relationship to farmer, and whether the municipality provided services to farm dwellers.

9 The captured data was uploaded daily and verified and accepted by the research team leader twice a week. Errors or missing data were sent back to research assistants on a weekly basis during data collection, and then again in the seventh and eighth months when preliminary analysis and data cleaning were being undertaken. 


\section{Structural Change and Labour Vulnerability in South Africa's Agrarian Economy}

The structure of South Africa's agricultural economy is the outcome of history, its persistent effects into the present, and of changes occuring in the democratic period (Ledger, 2016 [58]). Bernstein (1998: 1 [59]) states that "land and production, poverty and power, are key coordinates of the terrain of the agrarian question and of prospects of agrarian reform" in South Africa. These "coordinates" are often characterised as a dualism ${ }^{10}$, with poverty, overcrowding, and subsistence agriculture in the apartheid-constructed former 'Bantustans' existing alongside the vast, highly capitalised, mainly white-owned commercial farms. An often-neglected dualism is the persistence of "divisions and stark contrasts within commercial farms ... [which] exemplify the twin processes of accumulation and underdevelopment, featuring extreme poverty (among farm workers and dwellers) in the midst of substantial agrarian wealth in large-scale capitalist agriculture" (Hall et al., 2013: 48 [60]).

Beyond its apartheid history, what accounts for these changes? Answers are complex, and include policy changes in the early 1990s resulting in de-regulation (Marais 2011: 124 [9]), the dismantling of apartheid agricultural marketing boards and monopolies and the withdrawal of government subsidies (Hall $2009 \mathrm{~b}$ [61]), and the reduction of tariffs on agricultural imports that exceeded with the requirements in 1994 of the General Agreement on Trade and Tariffs (GATT) (Ledger 2016 [58]). Nicholson (2001 [62]) shows that tariffs on agricultural, forestry, and fishing imports were set at $41.2 \%$ but had been reduced to $2.2 \%$ by 1998 . The changes meant that South African farmers were, over a very short period, expected to compete on global markets, and in this "moment of globalisation" (Bernstein 2003:203 [53]) were subjected to conditions of extreme competition and an "export or die" (Andrade 2017 [63]) dynamic. There was a need to adhere to and pay the costs for stringent quality requirements imposed by these markets (Reardon et al., 2003 [64]), with little support from the South African state and despite continued subsidies provided to farmers in Europe and the United States (Visser, 2016 [65]). These new conditions and disciplines have made it difficult for emerging small farmers to gain a secure foothold (Ledger 2016 [58]).

Capitalist agriculture's response to the changes has varied. Sections of agrarian capital supported and lobbied for the changes in the early 1990s in order to open up their access to global markets (Bernstein 1996 [66]) resulting, amongst others, in expansions of sugar milling corporates and their commercial models into Africa (Dubb 2016 [67]) and forestry corporates into Europe and the United States. Others used the opportunities to assert local market dominance, with the rise in 'Big Food' dominating the food and beverage sectors (Igumbor et al, 2012 [10]), the emerging dominance of a small number of retailers and supermarkets (Reardon et al., 2003 [64]), the squeezing out of small growers from the agro-food system (Weatherspoon and Reardon 2003 [71], and increased expenditure of rural households on food purchases (D'Haese and Van Huylenbroeck 2005 [72]). However, many agro-corporates and commercial farmers have not survived the new 'disciplines' of competition and have gone out of business (Visser 2016 [65]), as is evidenced in the declining number of farming units; in KZN the number of commercial farm units declined rapidly from 6080 in 1993 to 3574 units in 2007. Accompanying this decline is the growth in the mean size of farms from 668 ha in 2003 to 808 ha in 2006 (Stats SA 2013: 6 [56]).

Genis (2015 [73]) summarises responses to changes in conditions for agricultural production as follows. Firstly, an expansion and consolidation of production and landholdings, which resulted in increased concentration in agriculture. Secondly a large degree of centralisation, with vertical integration into up and downstream value chains. This is less apparent at farm level and most apparent in the agrochemical and seed sector (e.g., Monsanto, Bayer) although the concentration

10 The notion of a dualism in the agricultural economy is highly contested, with some theorists arguing that the underdevelopment of the peripheral former TBVC states is the result of capitalist development in the centre (see, for instance, Du Toit 2004 [68]; Cousins 2005 [69]; Legassick and Wolpe, 1976 [70]). As O'Laughlin et al (2010:5 [11]) put it: “the highly 'dualistic' but unified economic structure was articulated with and dependent on the bifurcated colonial polity". 
at farm level is probably a response to centralisation beyond the farm-gate. Thirdly, increased labour productivity, through the systematic application of labour technologies in work processes and mechanization. These changes have enabled shifts to smaller, more skilled farm labour, with low skill or seasonal work being undertaken by contracted labour. This reorganisation of labour has particular pertinence for this paper because it also threatens to snap the connection between farm labour and access to land (Hall et al., 2013 [60]). Finally, increased production efficiency through the use of high-yielding plant varieties and production practices, e.g., conservation agriculture, moisture conservation, and pruning practices.

\section{KwaZulu-Natal}

KwaZulu-Natal's agricultural structure reflects key features of the national structures, specifically, racially skewed land ownership, a decline in contribution to GDP, and a decline in the number of farming units with an associated increase in the size of farms; together with a restructuring of labour, which has included an overall decline in jobs and a shift to contract and seasonal work.

In terms of its contemporary land dispensation and agrarian patterns, the KwaZulu-Natal Agricultural Union (KwaNalu) claims that $46.29 \%$ of land in the province is black owned, while only $15.6 \%$ is white owned (with about $35.8 \%$ of the province's land ownership unknown) (De Lange 2017; Groenewald $2015[74,75])$. These statistics include nearly half of the province's land that is owned by the Ingonyama Trust Board, which is a public entity. To describe the tenure in these areas as black ownership is misleading and inaccurate. By contrast, the audit of state owned land undertaken by the Department of Rural Development and Land reform (2013: 9 [76]) suggests that 50\% of the province is state owned, while $46 \%$ is privately owned, with only $4 \%$ unaccounted for. The report does not provide a racial or urban/rural breakdown but does indicate a shift from individual private ownership to corporate ownership of rural land, and reflects some ownership changes as a result of transfer through land reform. However, accurate data on the exact racial and class composition of land ownership in the province and the mechanisms accounting for changes do not exist.

The contribution of agriculture to KZN's Gross Domestic Product (GDP) has declined from 4.4\% in 2004 to $2.1 \%$ in 2014 (TIPS 2016: 3 [77]), though with a slight increase to 2.3\% by 2017 (TIPS 2017 [78]). Despite this decline, agriculture is nevertheless more important to the provincial economy than agriculture generally is to the national GDP. Employment in agriculture in the province has fluctuated: 150,000 jobs in 2008, down to a 100,000 in 2011, and up to 148,000 in 2015 (ibid).

The dominant agricultural commodities in KwaZulu-Natal are forestry, sugar, poultry and beef production. Forestry uses 5.5\% of KZN's total land (exceeded only by Mpumalanga Province at $6.3 \%$ ). Although a relatively low user relative to $12.7 \%$ used for arable production, $58.3 \%$ for grazing, and $15.1 \%$ used for nature conservation (Godsmark 2013 [79]), forestry in KwaZulu-Natal makes up a significant proportion of the national forestry hectorage, expanding from $36.8 \%$ in 1979/80 to 39.9\% in 2015/6. While forestry's contribution to national agricultural GDP has risen from about 4 to $10 \%$ (although declining from just above to below $1 \%$ of national GDP), its contribution to manufacturing GDP through processing has declined from approximately 6 to $5 \%$. This drop has been associated with the halving of employment in the KZN wood and paper industry from approximately 34,000 jobs to 15,000 between 2010 and 2015, the most rapid decline in provincial manufacturing industries over this period (TIPS 2016: 4 [77]). The drop-off in manufacturing employment could be explained by the diversification and globalisation strategies of the SAPPI and MONDI forestry corporates, while Mondi has also shifted to a longer term strategy of leasing rather than owning land subject to land reform (SAPPI 2016 [80]).

Sugar is the provinces second most important agricultural revenue earner after forestry, generating $\mathrm{R} 2,3$ bln in 2007, followed by broilers (R1,7 bln) and beef farming (R1,4 bln) (Stats SA 2007: 11 [81]). KwaZulu-Natal accounts for 90\% of the country's sugar production (Thornhill et al., 2009 [82]). The Department of Agriculture, Forest and Fisheries (DAFF) (2016 [83]) reports that 318,865 ha (4.8\%) of agricultural land in the province is under sugarcane plantations, a decrease of about $24 \%$ from the 2006/07 season, which stood at 419,465 ha (6.3\%). Most sugar in the province is grown under dryland 
conditions (SASA 2017 [84]), and hence is vulnerable to climate variability. The sector experienced a decline in employment that was associated with a decline in output per hectare over the last two decades due to a combination of factors, including rising input prices, volatile global sugar prices, drought, and its impact on yields and quality of production, the withdrawal of state subsidies since the 1990s (EDTEA 2017 [85]), the perceived risks of land reform (Cronje 2015 [86]) and rising labour costs (Visser 2016 [65]).

The poultry industry (which has a high concentration of broiler chicken production in the Umgungundlovu District between Cato Ridge and Pietermaritzburg) took a large knock after a trade dispute saw European goods flood the market (Meyer and Davids 2017 [87]). As the largest agricultural sub-sector in the country, poultry contributes $16.5 \%$ of the gross value of agricultural production, and is the cheapest and most consumed animal protein source (DAFF, 2016 [83]; Davids and Meyer 2017 [88]), whereas beef contributed $11.9 \%$ and sugar $3.2 \%$ of the total value of agricultural revenue nationally in 2015. KwaZulu-Natal has the highest percentage of agricultural households that were engaged in poultry production $(27.5 \%)^{11}$ and vegetable production $(30.3 \%)$, while the percentage of agricultural households that were engaged in cattle production $(24.5 \%)$ is second to the Eastern Cape (Stats SA, 2013 [56]).

In terms of climate risk, Thornhill et al., (2009 [82]) note that KwaZulu-Natal has been subject to extreme weather episodes at regular intervals over the last 100 to 150 years, and while there are data gaps that make it difficult to identify trends with surety, these events are likely a part of a continuum of events whose frequency and severity will increase in the future. The impacts of these events will be made more severe by the degradation of natural abatement systems, such as floodplains, wetlands, forested valleys, and coastal dunes. Discussion of further climate impacts are the subject for the penultimate section, and we now proceed to discuss the survey data on farm dwellers in KZN.

\section{Farm Dwellers in KZN as a Rural Precariat}

According to the 2011 Census [21], 3.7\% of South Africa's population lives on commercial farms that they do not own, and yet little is known about the living conditions of farm dwellers. Farm dwellers are a distinct category of rural dweller, and while there are overlaps with farm workers, to collapse them into a single sociological category blurs important differences between them. Farm dwellers in this study, following AFRA's definition (2017 [89]), include four categories: waged farm workers who have long histories of living on the farm together with their families; waged farm workers who have recently come to live on the farm with their families and have no homes elsewhere; migrant farm workers who have homes elsewhere (often in other countries) but visit them infrequently; and finally, families with nobody working on the farm, but who have lived many generations on the farm and have no homes elsewhere. ${ }^{12}$

The 2017 AFRA survey of 838 farm dweller households ${ }^{13}$ living on 83 farms across the Umgungundlovu District in KwaZulu-Natal found that the mean size of farm dweller households is 7.2 members, with $55.8 \%$ with six or more members, a significantly higher number than the 3.5 members per household national mean (Wittenberg et al, 2017: 1299 [90]). 35\% of household members are

11 Despite the importance of poultry production to the province, none of the farms surveyed in the AFRA data produced poultry. The majority of interviews took place on farms producing sugar cane (39\%) followed by beef cattle (23\%) and forestry plantations $(22 \%)$.

12 These categories are different from legal categories that include farm occupiers (in terms of the Extension of Security of Tenure Act 62 of 1997) who have rights of occupation linked to employment, farm workers (in terms of the Agricultural Sector, farm workers (Basic Conditions of Employment Act, 75 of 1997 and Agricultural Labour Act 66 of 1995) who may not be resident on the farm, and labour tenants (Land Reform Labour Tenants Act 1996) who have access to land for residence and farming in return for the provision of labour.

13 The definition of household is an important sociological concept as it is key to much demographic research. There are, however, a number of debated definitions (see, for instance, Amoateng 2007 [91]). In this paper, we follow the definition used by Wittenberg et al., (2017 [90]), of the household as both a social entity (as in family) and residential unit. The social entity allows investigation of family members who are absent but who consider the residential space to be 'home', while the physical residence is the site for service delivery, including housing, electricity, water, and sanitation. These aspects of farm dweller existence are all covered in the AFRA survey. 
younger than 18 years, $52.1 \%$ are female and the remainder male, with slightly more men between the ages of $18-35(50.9 \%)$ than women of the same age.

Farm dwellers secure incomes from multiple sources, including wage work on farms and off farms, social grants, remittances and own enterprises. However, rising unemployment and labour casualisation on farms (identified above) combined with declining work opportunities in rural and urban secondary and tertiary sectors, declining access to land for farming and high numbers without access to social grants means that farm dwellers, and particularly young men, struggle to secure the conditions for their social reproduction. The combination of these factors create the conditions for the identified politics. Drawing from the data and supporting literature, the following sub-sections cover the precarity, mobility, and politics of holding on related to farm dwellers.

\subsection{Precarity}

Two-thirds of farm dwellers $(66.5 \%)$ over the age of 18 have no income at all. This means that they are unemployed, receive no social grants, and are involved in no enterprises or activities that generate income. Of those farm dweller households in our sample that do have an income from work, social grants or own enterprises or combinations thereof, there are significant differences in mean amounts, with a minimum of $\mathrm{R}^{14}$, a maximum of $\mathrm{R} 95,840$, the mean in the first quartile $\mathrm{R} 2600$, in the second quartile R4000, and in the third quartile R6600. As household sizes average 7.2 members, this means that members of households in the first quartile have a mean allocation of R361 per member per month, those in the second quartile a mean allocation of R555 per member per month and those in the third quartile R917 per member per month.

Our data thus suggests that farm dwellers may be worse off than previously indicated. ${ }^{15}$ Furthermore, $75 \%$ of members in farm dweller households in our sample receive less than the upper-bound poverty line (of R992 per person per month) in 2015 prices (Stats SA, 2017 [55]). Stats SA (2017) reports that $55.5 \%$ of South Africans were poor in 2015 , and that this rising poverty is concentrated among children, black Africans, females, people living in the Eastern Cape and Limpopo, and those with low educational levels. Our data shows that, by Stats SA's definition, farm dwellers are one of the poorest, albeit socially differentiated, social categories in the country, and that their poverty levels and the inequalities may be obscured in national data sets. The reason for this possibly lies in nuances revealed by distinctions in the data between individual and household incomes, primary income sources and combined income sources and temporary, seasonal, and contract employment along with unemployment.

Farm labour (combining permanent, temporary, and seasonal labour) ${ }^{16}$ constitutes half $(49.9 \%)$ of the primary income sources of individual farm dwellers that have an income when those who have no income are excluded from the analysis. Wage labour is thus a very important source of income. This is not significantly different from $51.1 \%$ of permanent farm labour reported in Visser and Ferrer (2015: ii). However, the figure drops to $38.9 \%$ when labour (of unspecified duration) only on the farm on which the farm dweller is resident is taken into account, as opposed to work on another farm in the

14 This was found in the case of two elderly men living alone, and who were supported with food by other farm dwellers. They both died during the data collection process.

15 According to Visser and Ferrer drawing mainly on national databases (2015:10 [57]), the 2013 work status of people living on farms showed $4.8 \%$ unemployed, $2.5 \%$ discouraged work seekers and $19.9 \%$ not economically active. National unemployment figures currently stand at $27 \%$ when only active job seekers are counted and around $37 \%$ when discouraged work seekers are included (Stats SA 2017 [55]).

16 These distinctions fluctuate over time (Bhorat et al., 2014 [92]) while the extent of casualisation is difficult to gauge because researchers use different definitions of temporary, including blurring differences between seasonal, contract and regular work (Visser 2016 [65]). Our data combines temporary and contract work understood as intermittent work with short-term contracts for specific employers. Seasonal and permanent work are separate categories, with seasonal implying short-term but seasonally regular work often for a specific task (e.g., cane cutting, planting, felling and transportation in forest plantations) and permanent meaning on-going work for the same employer, on either a full day basis or part of a day. 
area. Furthermore, of those individual farm dwellers whose primary ${ }^{17}$ income is from farm labour, our data shows $79.5 \%$ are permanent workers, followed by temporary or contract workers $(18.9 \%)$ with very few people stating seasonal work $(1.6 \%)$ as their primary income source ${ }^{18}$. Notwithstanding methodological and analytical differences in the studies, this is significantly less than the work of limited or unspecified duration of $48.9 \%$, as reported by Visser and Ferrer (2015:21 [57]) and Hall et al., (2013:53 [60]), and when factoring in those farm dwellers over the age of 18 who have no incomes at all, then full-time permanent employment on the farm on which they reside is the primary income source for just over $10 \%$ of farm dwellers.

Relatedly, incomes and their differentials also appear to have a bearing on how farm dwellers view their relationship with farmers (something that has a bearing on the 'politics of holding on' section to follow). Where the distribution of the total primary income of households is relatively equal, households are more likely to rank the relationship with the farmer as good (see Table 1). Indeed, even where a high percentage of household incomes fall into the fourth quartile of highest incomes, this distribution does not improve the ranking of relationship with the farmer.

Table 1. Household Primary Income Distribution V Relationship to Farmer.

\begin{tabular}{cccc}
\hline & Good & Average & Poor \\
\hline Quartile 4 & $24.3 \%$ & $32.6 \%$ & $19.8 \%$ \\
Quartile 3 & $22.8 \%$ & $20.1 \%$ & $29.5 \%$ \\
Quartile 2 & $25.9 \%$ & $26.4 \%$ & $19.8 \%$ \\
Quartile 1 & $26.9 \%$ & $20.8 \%$ & $30.9 \%$ \\
Total no HH & 193 & 288 & 288 \\
\hline
\end{tabular}

The worst relationship ranking is where most of the households fall into the first income quartile, and this indicates a significant, simmering politics of discontent surrounding farm dweller precariousness and fragmentation.

Other primary sources of income for individual farm dwellers (excluding those in the sample who have no income) are child grants and government old age pensions (15.9\% and $13.4 \%$ respectively) and off farm income (13.8\%). While primary income sources reveal an important component of farm dweller incomes, the diversification and combination of incomes shows the increasing importance of multiple income sources to farm dweller livelihood strategies (see also Cousins (2013 [94]). More than half of farm dweller households $(60.6 \%)$ have more than one income source, in a range of 0 to 12 , while only $38.1 \%$ of households have a single income. The most frequently stated secondary income source is child grants (15.3\%), and the most frequent combination is mainly permanent full-time farm work as the primary income supported by child grants. Reversals are also apparent, for example, government old age pensions the primary income source supported by part-time work on the farm. Other secondary income sources include other social grants (child foster grants, disability grants), own businesses, second part-time jobs in addition to a primary job, and remittances. While work-social grant livelihood combinations may avoid the precariousness of intermittent contracted work, very few farm dwellers secure this combination of livelihood strategy or the alternative income source from contracted and seasonal work opportunities ${ }^{19}$.

We thus suggest that declining permanent employment (in agriculture and industry) and modes of labour casualisation of farm labour that exclude farm dwellers, together with uneven access to social

17 Primary income refers to the income that generates the highest amount of cash in a month.

18 This is possibly because labour contractors, who increasingly supply seasonal workers to forestry plantations (see Khosa, 2000 [93]) and sugar cane farms, do not employ farm dwellers but secure labour from off-farm locations.

19 With the increase in labour brokers, labour contractors and sub-contractors (see Khosa 2000 [93] for the forestry sector), it is possible that farm dwellers are sidelined as a source of labour in preference to other sources of labour. However, this would require investigation. 
grants, small (agricultural and other) businesses are resulting in social differentiation among farm dwellers with associated fragmentation. Farm dwellers are, in other words, a poor but diversified and socially differentiated precariat, whose best chance of survival is multiple, combined incomes strategies, alongside mobilities, which the next sub-section indicates.

\subsection{Mobility}

The social dynamics underlying mobility can be analysed in terms of centrifugal or push factors (moving from a central zone to another periphery, i.e., from the farm dwelling to town) and the converse centripetal forces (attractive qualities operating at destination peripheries that attract individuals to them (Colby, 1933 [95]) or pull factors back to the farms. The data indicates that farm dweller mobility falls into three distinct types: eviction, constructive eviction, and voluntary migration. In the latter case, migration involves both movements off the farm, as well as movements back to the farm.

Regarding prospective evictions, $7.1 \%$ of individual farm dwellers ${ }^{20}$ have had permission to reside on the farm withdrawn, with $76 \%$ of these taking place after 2005 . This is the first step hat a farmer is obliged to take in order to secure an explicit, or legal eviction. ${ }^{21}$ The reasons given by land owners for withdrawing permission vary (as Table 2 below shows), although in most cases farm dwellers said farmers simply said farm dwellers should make their homes somewhere else.

Table 2. Reasons for farmer withdrawing permission vs. Age category.

\begin{tabular}{ccccccc}
\hline & $\begin{array}{c}\text { Make a Home } \\
\text { Elsewhere }\end{array}$ & $\begin{array}{c}\text { Person Working } \\
\text { Elsewhere }\end{array}$ & $\begin{array}{c}\text { Misdemeanor } \\
\text { Committed }\end{array}$ & No Reason & Other & Total \\
\hline Younger than 18 & 30 & 0 & 2 & 3 & 6 & 41 \\
18-35 years & 59 & 4 & 4 & 26 & 8 & 101 \\
36-60 years & 37 & 10 & 4 & 25 & 10 & 86 \\
Older than 60 & 8 & 0 & 0 & 3 & 4 & 15 \\
Total & 134 & 14 & 10 & 57 & 28 & 243 \\
\hline
\end{tabular}

Despite having their permission to be on the farm withdrawn, not all of the affected farm dwellers have moved off the farm. As Table 3 below shows, of those whose permission to be on the farm has been withdrawn over half (53\%) stay home most nights. Perhaps more striking than the impending potential evictions is that of the many individuals who said that they have the farmer's permission to be on the farm, nearly a third (31\%) do not stay at home most nights, suggesting that more farm dwellers are leaving farms, at least temporarily, for reasons other than an explicit eviction.

Table 3. Permission to stay on the farm vs Stays home most nights.

\begin{tabular}{cccc}
\hline & $\begin{array}{c}\text { Permission to Stay on } \\
\text { the Farm Withdrawn }\end{array}$ & $\begin{array}{c}\text { Has Permission to } \\
\text { Stay on the Farm }\end{array}$ & Total \\
\hline Stays home most nights & 178 & 3045 & 3223 \\
Not home most nights & 135 & 1063 & 1198 \\
Total & 313 & 4108 & 4421 \\
\hline
\end{tabular}

Evictions can also take a 'constructive' form. Legal, explicit eviction procedures, which require a court order, alternative accommodation and reporting to the Department of Rural Development and Land Reform and the local municipality, can be onerous and expensive for the landowner (AFRA, 2017 [89]).

20 The data on withdrawn permission was collected for all people over the age of 18 rather than at household level because young adults have reported to AFRA that they are particularly vulnerable to eviction.

21 In terms of the Extension of Security of Tenure Act (ESTA, 1997), explicit evictions involve legal processes in which landowners withdraws the farm dwellers' right to occupy the land, for reasons that include termination of labour, violations of farm rules by the farm dweller, or the landowner's intention to make productive use of the land occupied by the farm. 
As a result, some farmers pressure farm dwellers to vacate on-farm residences. Constructive evictions thus refer to processes whereby the landowner puts pressure on the farm dweller with the intention of pushing him or her to decide to abandon the property. They can take many forms that are designed to compel farm dwellers to 'decide' to leave the farm, including acts of omission (withdrawing access to basic needs such as water or energy resources), or more explicit acts of commission (fencing in the household and depriving children of access to roads needed to get to schools (Reilly, 2014 [96]), or refusing occupiers permission to renovate their houses, even at their own cost and in an effort to create habitable living environments for their families that secure human dignity ${ }^{22}$ ).

Omission of services is a common impetus for constructive evictions, and this is reflected in the relationship between farmers and farm dwellers. Table 4 shows that the higher the number of households that have access to a bundle of goods (including access to electricity, water and toilet, the presence of family graves on the farm, and the right to have visitors), the higher the probability that farm dwellers will rank their relationship with the farmer as good. Similarly, if a higher number of farm dwellers do not have access to the bundle of goods, then the relationship is ranked as poor. We assume that a poor relationships with farmers are more likely to result in conditions giving rise to constructive evictions, than where relationships are good. However, the relationship to farmer trends suggested by access to a bundle of services, while present, is not strong. ${ }^{23}$

Table 4. Relationship to farmer V Access to bundle of goods.

\begin{tabular}{lccccccccc}
\hline \multicolumn{1}{c}{ Relationship to Farmer } & \multicolumn{2}{c}{ Good } & \multicolumn{2}{c}{ Average } & \multicolumn{2}{c}{ Poor } & \multicolumn{2}{c}{ Total HH } \\
\hline Access to service: & Yes & No & Yes & No & Yes & No & Yes & No \\
1. Electricity & 134 & 59 & 167 & 121 & 109 & 179 & 410 & 359 \\
2. Water & 178 & 14 & 263 & 25 & 249 & 39 & 690 & 78 \\
3. Toilet & 126 & 66 & 191 & 96 & 121 & 167 & 438 & 329 \\
4. Have graves & 88 & 105 & 121 & 167 & 173 & 115 & 382 & 387 \\
5. Allowed visitors & 186 & 7 & 259 & 28 & 248 & 40 & 693 & 75 \\
TOTAL & 712 & 251 & 1001 & 437 & 900 & 540 & 2613 & 1228 \\
As \% & 73.9 & 26.1 & 69.6 & 30.4 & 62.5 & 37.5 & 68 & 32 \\
\hline
\end{tabular}

Evictions, constructive or explicit, are not the only reason farm dwellers leave farms, as centrifugal forces are at play. Of the $31 \%$ of adult farm dwellers who have the landowner's permission to live on the farm but do not stay on the farm most nights, nearly half (41.6\%) left because they have found work elsewhere, followed by a third (32.1\%) who went to live with relatives living elsewhere, sometimes in order to provide support to those relatives. It is also possible that while some respondents stated that various household members had gone to live with other relatives, they had in fact been told by the farmer that they should leave the farm. ${ }^{24}$ As Table 5 below shows, there is a gendered dimension to this centrifugal mobility, with more men (61.6\%) than women $(38.8 \%)$ leaving for reasons of finding work elsewhere, while many more women left the farm for reasons of marriage ( $86.3 \%$ compared to $13.7 \%$ of men) or to live with families elsewhere $(57.4 \%$ of women compared with $48.6 \%$ of men). Finding work elsewhere was the most frequently given reason given by men for leaving the farm

22 In the Constitutional Court case (Daniels v Scribante and Another 2017 ZACC 13, five judges ordered that the farm dweller, Daniels, be allowed to effect renovations to her home at her own cost. They argued that "there can be no true security of tenure under conditions devoid of human dignity", and that to fail to grant permission to renovate could inadvertently facilitate an illegal eviction because the living conditions are "intolerable".

23 Just over a quarter of households who rank their relationship to the farmer as good do not have access to a bundle of services, while nearly two-thirds of farm dwellers who rank the relationship with the farmer as poor do have access to a bundle of services. In some respects, this indicates a methodological difficulty in researching the conditions that give rise to constructive evictions, as pressures exerted by land owners on farm dwellers to leave the farm can take many forms and different actions may be interpreted differently by farm dwellers and farmers.

24 This interpretation, which emerged in discussion with AFRA staff, was not canvassed in the survey, however 
$(61.6 \%)$, whereas going to live with relatives was the most frequent reason women had for leaving the farm $(32.1 \%)$.

Table 5. Gender of farm dwellers with permission to be on the farm who have left.

\begin{tabular}{ccccc}
\hline & Male/Female Breakdown & \multicolumn{2}{c}{ Breakdown of Samples by Gender } \\
\hline Reasons for leaving the farm & Females & Male & Female sample & Male sample \\
Found work elsewhere & $38.3 \%$ & $61.6 \%$ & $173(31 \%)$ & $278(52.8 \%)$ \\
Left to live with relatives elsewhere & $57.4 \%$ & $48.6 \%$ & $179(32.1 \%)$ & $169(32.1 \%)$ \\
To continue education & $46.6 \%$ & $53.4 \%$ & $48(8.6 \%)$ & $55(10.4 \%)$ \\
To get married & $86.3 \%$ & $13.7 \%$ & $157(28.2 \%)$ & $25(4.7 \%)$ \\
Total (of 1084) & $52 \%$ & $48 \%$ & $557(100 \%)$ & $527(100 \%)$ \\
\hline
\end{tabular}

There is also a significant gender-generational nexus to those that are leaving farms for the purpose of working elsewhere. More than half (58\%) are young men that are below the age of 35 . This is probably due to a combination of factors, including that young adult men do not have social grants to reduce their income vulnerability and that women are more likely than men to be expected to undertake family duties where there is a need for support and care.

Centripetal forces also operate to draw farm dwellers back to the farm in migration patterns that are often described as circulatory. A perhaps surprising feature of the data is the high preponderance of young adults who are on the farm. As Figure 1 below shows, 71\% of young adults between the ages of 18 and 35 stay at home most nights. Although most of the people leaving farms for work elsewhere are young men in this age group, the size of this age group on farms together with the high proportion who have no income from any source suggests that this is the most vulnerable sub-group in the agricultural precariat, and that residence on farms is the best of their a very limited range of options for living.

Anecdotal evidence from AFRA (Sithole, 2017 [97]) suggests that this growing population of younger adults, many of whom are better educated than their parents and who have a better understanding of their legal rights, is a source of friction on farms. Whereas, older generations tend to adhere to the farm rules, younger adults are more willing to confront farmers around what they view as unreasonable actions. In a particular case in the Umgungundlovu District, the farmer locked the gate and prevented a farm dweller household from admitting visitors who had arrived by car to attend a ceremonial family function. The younger adults eventually cut the lock, which resulted in a confrontation with the farmer, who had a firearm, and his wife. The conflict was recorded on phone video and sent to AFRA. Strikingly, the farmer asserted his right to lock the gate on the basis that "This farm is mine. I have a title deed", to which the young farm dwellers in the dispute responded: "This is our home. This is where we live". We turn now to consider further these centripetal forces of that pull farm dweller back to homes on farms, or the politics of holding on to the land. 


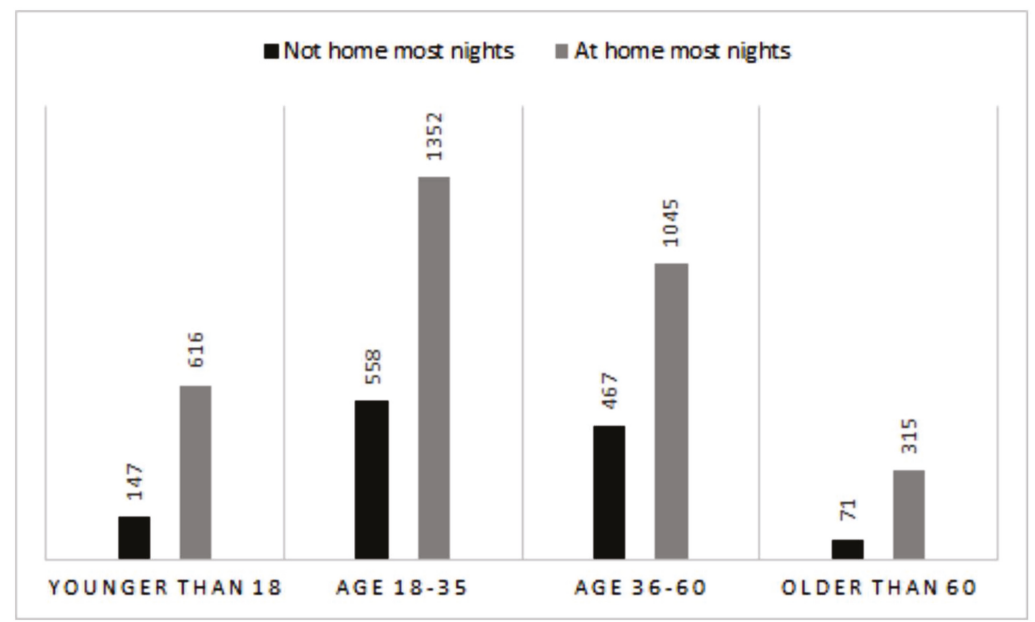

Figure 1. Age Category of Adult Farm Dwellers Home Most Nights.

\subsection{The Politics of Holding on to the Land}

A significant number of households, and in particular, young adult members of households, remain on farms, despite difficult and worsening living conditions, which contradicts the processes of "rural hollowing" (Liu et al., 2010 [98]) that an over-simplified analysis of the push-pull migratory trends would suggest. Farms are neighborhoods that constitute the foundations of well-being and identity of those who grow up on them (AFRA, 2005 [99]). Together with deep connections to graves and the recreation of these links through ongoing burial practices, "[1] and ties people to their histories" (Greenberg, 2015: 975 [2]), and this is an important centripetal force to take note of. Our data shows that farm dwellers assert 'home' as a place that belongs to them, based on histories to specific land that are re-enacted through ceremonies in the present, along with entitled remuneration for a life of labour.

Dynamics of belonging are multi-faceted. Despite restricted financial resources, Mosoetsa (2011 [100]), in a study of home, shows that familial solidarity is not compromised in settlements on the periphery of cities in KwaZulu-Natal, and is expressed as "eating from one pot". The reference to food as an anchor for the farm dweller family is also supported by the data, which indicates that $69 \%$ of households cultivate gardens on the farm and $44 \%$ own some livestock. ${ }^{25}$ History and length of occupation on the farm also play a role, as Figure 2 below shows. Nearly $70 \%$ of households $(69.6 \%)$ arrived on the farm where they live before 1994, with $59 \%$ of those stating that the family had either always lived on the farm, or that one or both of their father and grandfather had been born on the farm. There is a key correspondence between when a household came to live on a farm and who they believe will take over the home on the death of the household head.

The majority of respondents who came to live on the farm before 1994 said family would take over the house on the death of the head of house, whereas most of the respondents who came to live on the farm after 1994 stated that the farmer would take over the house. The reasons given by those who say a family member will take over the house include that they have always lived in the house and that they have no house elsewhere. A life of labour without adequate remuneration was also a justification. As one respondent stated: "My husband worked on this farm all his life and when he died, there was no pension. So I took this house to be his pension".

25 Visser and Ferrer (2015 [57]), however, have disputed the emphasis NGOs place on farm dwellers' security of tenure and argue that labour conditions and housing constitute the key concerns of farm workers. 


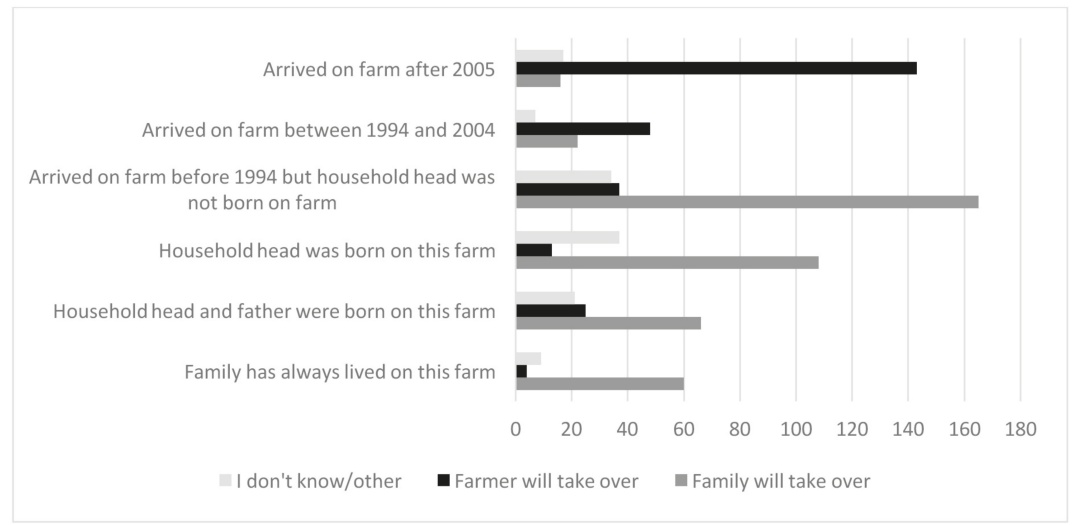

Figure 2. What will happen to the house V When the family came to this farm.

There are ties between family and home in the data. $82.2 \%$ of farm dwellers who live in single room houses believe that the farmer will take over the house, whereas $78.7 \%$ of those who live in houses with five rooms or more said that family would take over the house, with only $0.06 \%$ stating that the farmer would take over. This corresponds with the presence of family on the farm as single-room quarters invariably $(77 \%)$ have two or fewer occupants in them, whereas $87 \%$ of houses with more than five rooms are occupied by households with six or more family members. Households that have lived on the farm since before 1994 thus tend to be bigger and have more rooms, suggesting that these are homes for families.

While length of residence and presence of family is important to a notion of home, belonging is forged through keeping the link between identity and place alive in the present. This can be seen in the data on graves. Just over half of farm dweller households (422) have graves on the farm where they live. Hornby (2015 [101]) shows that ceremonial practices on farms in KwaZulu-Natal around the deceased are drawn-out, extended affairs that are located in specific homestead spaces and involve animal slaughter, communication with ancestors, and participation of extended family and community. The entanglement of graves, land, family, and community possibly explains why burials hold such potential for conflict between farmers and farm dwellers. Of the 99 households that are no longer allowed to bury on the farm, $46.6 \%$ judged their relationship with the farmer as 'poor' and only $6 \%$ said they had a 'good' relationship $(60 \%$ of households that assessed their relationship with the farmer as being 'poor' have graves on the farm). This suggests not so much a process of constructive eviction as a process of constricting the space and normative activities that underpin 'home' for farm dwellers. This constriction of home-life could result in farm dwellers either abandoning homes on farms or defending homes on farms in order to secure the ceremonial and other social reproductive activities necessary for making homes.

Tying this together with unemployment figures and the on-farm household demographics that are shown above, the conclusion is that a large number of residences on farms are not housing for farm workers, but homes for families who have lived on the farm for 24 years and longer. These individuals expect that their homes will remain theirs into the future, and who continue to construct 'home' through ceremonial activities such as burials. However, this conclusion is contrary both to farm tenure legislation as well as the conclusions drawn by Visser and Ferrer (2015 [57]). ${ }^{26}$ While we do not dispute Visser and Ferrer's conclusion that that "[e]xtending on-farm tenure security and protection from

26 As noted above, the ESTA closely links farm wage work with on-farm residence, placing the tenure of the farm dweller at risk if their employment is terminated (see AFRA, 2017 [89]). Visser and Ferrer (2015: 85 [57]) argue further that the state 
eviction is no longer the single, biggest need of farm workers" (ibid: v1) and that farm workers are an increasingly diverse group with a range of livelihood and tenure needs, our argument is that the farm is nevertheless "home" for a significant proportion of rural dwellers, many of whom do not secure their primary income from farm work.

We thus propose that farm dwellers are asserting a politics of home, of belonging to the land, as a counter response to what Barchiesi (2011 [102]) argues is the disciplining effects of the normative nexus of employment and citizenship that underpins South Africa's "precarious liberation". Unable to secure regular or 'decent' employment in the 'new' South Africa, some farm dwellers hang on to 'home' as a silent expression of a 'subaltern politics' (Spivak 1998 [103]). This politics arises from national and global drivers of agrarian change, but it also stands in tension to them. ${ }^{27}$ Moreover this subaltern politics constitutes the social force, together with increasingly constrained livelihood options, which could potentially activate a local politics that focuses on farm dweller precarity. With an understanding of structural changes in the agrarian sector and their relation to farm dweller's distributed precarity and 'holding on' to land, we turn to consider the second component of the 'double burden' related to climate change risks and their implications for farm dwellers.

\section{A Slipping Hold? The Risk of a Double Exposure for Farm Dwellers}

Climatic changes that were observed in the province over the past 50 years include general warming (Hewitson et al. 2005; Schulze 2005, CSAG 2017 [33,104,105]), with weather stations along the coast reporting temperature increases of over $2{ }^{\circ} \mathrm{C} /$ century, more than twice the global rate of temperature increase (CSAG 2017 [105]). Hewitson et al., 2005, amongst other climate change studies (including Schulze 2005 [104]; CSAG 2017 [105]) identify the KwaZulu-Natal Midlands as one of three climate change hotspots in South Africa. This is because the warming already observed and the projected changes in climate have expected impacts on people, ecosystems and economies.

The important derived trends projected into the future (CSAG 2017, Zierwogel 2014 [19,105]) for the purposes of this article are: firstly, an increase in the annual maximum mean temperatures, particularly over the KwaZulu-Natal Midlands and the north-eastern parts of the province; secondly, an increase in heat units in the summer months across the province; thirdly, an increase in heat units in the winter months along the coast and inland to the Pietermaritzburg area, and finally, an increase in the annual means of minimum temperatures. The projected result of warming is changes in weather patterns with expected increases and variability in the amounts of precipitation coupled with changes in seasonality. These are likely to be accompanied by a corresponding increase in the intensity of extreme events such as floods, tropical cyclones, storm surges, heat waves and droughts. While statistically there exists no clear evidence of substantial changes in annual precipitation totals, seasonal total rainfall or daily rainfall extremes there is consensus that there is a general wetting trend over $K Z \mathrm{~N}$, a phenomenon supported by modelling data in the $2017 \mathrm{draft}$ of the Third National Communication Report to the United Nations Framework. Convention on Climate Change (UNFCCC). The localized analysis of the extended Long Term Adaptation Scenarios (LTAS) data set for 1960-2015 indicates significant positive trends in annual rainfall in the south of KZN and negative trends in the north (CSAG, 2017 [105]).

With these changes in mind, O'Brien's notion of double exposure is useful in approaching both the risk that farm dwellers will be affected by climate change at the household level at the same time as they are affected by a changing agrarian political economy, and that climate change and agrarian change may interact to amplify farm dweller vulnerability. According to McDowell et al., (2010 [106]),

focus on litigation to prevent evictions is "misplaced" because movement off farms is the "inevitable" result of agricultural "modernisation" and tenure security without a livelihood is "not sufficient".

27 Greenberg (2015 [2]) argues that these ties to the land and the conflict skewed ownership will produce constitutes a political imperative for land reform while the potential of agrarian reform to create small scale farming as an alternative to wage employment is an economic imperative for land reform. 
there are a variety of ways to understand and apply the concept of vulnerability, from a principally biophysical focus on climatic exposures to the concept of "social vulnerability" that exists, regardless of climatic conditions (Adger and Kelly 1999 [107], Kelly and Adger 2000 [108]). Erratic rainfall constitutes a significant biophysical risk to food security for those approximately $69 \%$ of farm dwellers in the sample supplementing their diets with home gardens. There are likely to be increased public health risks for those approximately $30 \%$ of residents with poor service access-especially to water borne diseases when faced with poor sanitation and water sources. Vulnerability studies assessing the level of risk should an extreme weather event occur indicate that KwaZulu-Natal has the highest human vulnerability to climatic events (Jansen Van Vuuren cited in Thornhill et al, 2009: 51 [82]). The province's high level of human-climate vulnerability is closely associated with the high poverty levels and population densities coupled by high levels of land degradation (ibid).

While taking full cognizance of the importance of considering biophysical exposures, including extremes, such as flooding and drought, scholars (Adger and Kelly 1999 [107] Kelly and Adger 2000 [108] and Turner et al., 2003 [109]) posit that a focus solely on external stressors is insufficient in explaining how a population is exposed, its sensitivity, and its adaptive capacity (Fussel and Klein 2006 [110]). Low level social and economic conditions of a population, such as the precariat within the farm dweller sample, render it vulnerable, even in the absence of actual climatic events. In fact, McDowell et al., (2010 [106]) go as far as to say that the ability of a population to deal with biophysical exposures is a function of its social vulnerability. The sample can be interpreted as fitting with her framework of social determinants of individual vulnerability. These include low social status, lack of access to resources such as land (with farm dwellers lowest on the priority list for land restitution and redistribution (Hall et al., 2013 [60]), and a lack of diversity of income sources (high levels of no income combined with dependency on farm wage income and child grants). A lack of stable off-farm income for young adults in cities in a context of high unemployment also limit alternative - or multiple-livelihood strategies. Therefore, the on-going precarity of farm dweller livelihoods is the foundation for future climatic shocks because it increases their sensitivity to climate events and lowers their adaptive capacity.

A second set of dynamics relates to the implications for farm dwellers of climate change impacts at farm or regional/national scales, as well as those implications of mitigation or adaptation strategies on the part of farmers and government. The awareness and evidence base of these factors is nascent. Officially, however, the Department of Environmental Affairs and Tourism (DEA, 2013 [111]) has identified agriculture as a sector highly vulnerable to climate change, and expects to see a reduction of $3.5 \%$ to $4.3 \%$, respectively, in total average maize and wheat yields for the median impact scenario by 2050 , with impacts on food production, agricultural livelihoods, and food security of a magnitude to be of national policy concern (DEA, 2013 [111]). Studies that were conducted by Turpie and Visser (2013 [65]) project costs to farmers of climate change to be R694 billion rand by 2080 (although KwaZulu-Natal is less severe than other provinces). This is likely to exacerbate the winners and drop-outs from commercial agriculture that were identified by Ewert and Du Toit (2007 [45]) above, entrenching and deepening farmers' responses identified by Genis (2015 [73]), including labour shedding. The climate trends highlighted above, and in particular recent extreme weather events such as drought and floods, have already started having a bearing on the day-to-day decision-making processes of farmers. Hewitson et al. (2005 [33]) and Schulze (2005 [104]) suggest that these events are affecting farmers' selection of cultivars, irrigation regimes, fertilizer, and pesticide applications, as well as number of farm employees, although Genis (2015 [73]) attributes these decisions to increased competition. An incidence of the knock on effects for the employment in KZN of labour reductions was evident in the sugar cane industry, where, largely in response to the 2016/17 drought, saw a decline of $14.1 \%$ in total number of workers on cane farms as compared with the previous year (Canegrowers 2017: 20 [84]). ${ }^{28}$

28 A survey the Canegrowers' Association undertook of large scale canegrowers in 2015/6 indicated that inflation adjusted revenue was $11 \%$ lower than the previous season, attributed to drought, and that growers may have reduced staff or hours as a cost-saving 
Such impacts beg the question of what is to be done. Mitigation strategies that were identified by DEA include building more sustainable production, enabling farmers to access more formal markets and finance, and incentivising carbon sequestration and climate smart agriculture (DEA, 2013 [111]). ${ }^{29}$ While the adoption of 'biological' farming practices (such as drip irrigation and zero till cultivation) are championed and have their place, purely technological approaches lack analytical integration of how vulnerability is either mitigated or exacerbated by the structural changes of the past 35 years, which largely entailed consolidation and expansion. Expansion of production can be a climate-mitigating strategy depending on the commodity produced. ${ }^{30}$ For example, goats in bush encroached communal areas may serve to control bush encroachment where it is beginning to displace grasslands (Alcock 2017 [112]). However, the expansion of plantations-for example, sugar and timber-is also likely to put pressure on diminishing ground water resources and increase crop yield vulnerability to intermittent drought, increased temperatures, and climate change induced crop diseases. In parts of the Umgungundlovu District, the plantation expansions of the global corporate, Mondi, have brought it into conflict with farm dwellers that are resident on the land it leases around eviction threats, diminished access to services, land for small farm production (Ziqubu 2017 [113]), and reduced opportunities for waged employment and contracting (Khosa 2000 [93]).

In relation to this, climate justice, food and agroecology activists (amongst others, Holt-Giménez and Altieri (2013 [40]) and Van Der Ploeg et al., 2015 [35]) argue that the expansion of land-holdings in response to competition (CF Genis 2015 [73]) and the increase of monoculture plantations in agriculture, create food security and climate related risks, and constrain adaptive responses to technological innovation and bioengineering. Their contention, fitting with O'Brien and Leichenko (2000 [22]), is that the social impacts of environmental distress are unevenly distributed across space and social groups, and that, in line with McDowell et al., 2010 [106], such strategies are in themselves maladaptive as they increase the vulnerability of other systems, sectors, or social groups (McDowell et al., 2010 [106]).

Such perspectives emphasise the need for a politics that enhances food and livelihood security at the household level for farm dwellers. Yet, the current land reform dispensation and agrarian trajectory that benefits elites rather than the rural poor (Hall and Kepe 2017 [116]) seems to preclude this eventuality. In this context, the land question remains a central and politically contested issue, and in particular, whether there is place for farm dwellers to own commercial farms? The shift in redistribution policy focus away from poor people who need land for multiple purposes, together with the government's failure to develop a comprehensive tenure reform policy (Hornby et al., 2017 [1]), has meant that farm dwellers are no longer a policy priority for commercial farmland acquisition. Indeed, their tenure appears to have become more insecure with an escalation of evictions during post-Apartheid South Africa (Mntungwa 2014 [117]; Wegerif et al., 2010 [3]).

\section{Conclusions}

This paper set out that intersections between climate change risk, capital, and precarity are playing out at a farm-dweller household level in Kwazulu-Natal. Initially, we set out how structural change in the agricultural sector has created a diversified agricultural precariat. Farm dwellers are primarily a group of wageless, income-less adults, whose lives are precarious in that high levels of unemployment co-exist with declining permanent farm work and extremely limited and intermittent

measure in response to the drought. Wage costs per ton of cane attributed to seasonal workers constitute $18.8 \%$ of the total wage bill, suggesting a significant proportion of low skill workers are seasonal (Canegrowers 2017 [84]).

29 Deressa et al (2005 [114]) for instance found that irrigation was ineffective as a KZN adaptation strategy for sugarcane, and that adaptation strategies should focus special attention on technologies and management regimes that will enhance sugarcane tolerance to warmer temperatures during winter and especially the harvesting phases.

30 Vertical integration can be an adaptive responses in terms of enhancing employment, particularly into downstream value-adding processes in the timber sector (National Planning Commission (NPC) 2011 [115]). Khosa (2000 [93]) also shows that there are opportunities in forestry for small contractors and sub-contractors. However, agro-processing can also be a major contributor to water and air pollution, as well as major user of water and fuel inputs. 
seasonal and contract work. Furthermore, farm dwellers are evidence of labour fragmentation, in that those who do have incomes secure them from multiple sources in a variety of combinations, with signs of emerging social differentiation being indicated in uneven distributions of income at both individual and household levels. Income precariousness is compounded by insecure tenure in the form of explicit and constructive evictions. This results in often circular migration to towns, where an absence of employment opportunities pushes people back home and generates a politics of holding on to home on the farms. Here, the concept of land as lived home space occupied by farm dwellers co-exists with the farm as landed property that is owned by the farmer. We see this as the expression of a subaltern politics that constitutes part of the social forces that activate 'land' as a politics of place and home and not simply as a site of production.

While in the main we demonstrate, based on our study sample, that this hold is tenuous, an additional concern in the context of this special issue is whether climate change exacerbates or the further causes the hold to slip? While there is as yet little evidence in the literature for claiming climate change impacts on agriculture in KZN or farm labour, and given that attribution is difficult in complex agrarian contexts, we suggest that the need to take into account climate related risks to an already precarious population is compelling. Here, we attempted to substantiate that the risk of a double burden for a rural farm dweller precariat is substantial. The structural trends in post-apartheid South Africa, which is characterised by a concentration on the part of capitalist agriculture, and a land reform dispensation that does not take into account farm dwellers, might be construed to constrain responses to climate change that could mitigate farm dweller vulnerability.

In contrast to these risks and vulnerabilities, we advocate an enabling politics and an agrarian plan that explicitly aims to mitigate this precarity and vulnerability, and beyond to create positive trajectories for change. $\mathrm{Li}$ (2015: 80 [54]) hints at this kind of progressive biopolitics, envisioning that "In a democratic system, and within the container of the nation state, tensions between productivity and protection may be worked out by means of the ballot and are embedded in laws that define entitlements and-just as important-a sense of entitlement that is not easy to eradicate". Agrarian reform that puts farm dwellers at its centre is precisely such a legal entitlement arising from within the democratic system and that 'works out' some of the tensions between productivity and protection. Ferguson (2015 [118]) agrees that land reform is important for this reason. South Africa's property clause in the Constitution gives effect to this. The Constitution protects rights to property. This is often interpreted as protection of rights to ownership, whereas land reform laws (especially ESTA and the labour tenants legislation) make clear that rights of occupation are a form of statutory property right. A transfer of such farm dweller rights to land could be undertaken with compensation only for the difference between the full bundle of ownership rights and these rights of occupation. Equal land distribution has a potential to provide vulnerable communities a platform to actively exercise their agro-economic activities. Therefore, secure land rights in conjunction with micro-scale farmer supporter, has the potential to bring about greater justice and equity (Greenberg, 2015 [2]), and, we argue, greater livelihood resilience.

In concert with Ewert and Du Toit (2005 [45]), we argue that a broader approach to pro-poor policies and citizen empowerment is necessary to address the problems on farms. The question is whether the social conditions identified, in particular the fragmentation of farm dwellers as a result of diversified income and income strategies, create the conditions for a politics to pursue the interests of farm dwellers? We argue that these conditions are emerging, in that an increasing number of young farm dwellers constitute the precariat on farms, and this constituency both understands its rights and is more likely to assert them. Furthermore, the circulatory migration pattern means they are potentially connected with the urban precariat in shack settlements and inner city abandoned buildings, thus creating the potential for alliances around a disruptive politics. Whether climate change will lend further impetus to this politics, or exacerbate and engender a 'slipping hold' will be key for rural farm dweller futures. 
Acknowledgments: The European Union made funding available to the Association for Rural Advancement (AFRA) for the data collection and analysis, amongst other project aspects. No funding is available for journal article publication.

Author Contributions: Donna Hornby developed the research design and survey instrument in consultation with AFRA staff and managed the field research team. She undertook data analysis with support from the Bureau for Food and Agricultural Policy (BFAP) from the University of Pretoria, South Africa. She was the primary author, responsible for the sections on agrarian change and dynamics and the research findings. Adrian Nel helped develop the argument and was the primary editor of the text. Samuel Chadamana provided the written material on climate change. Nompilo Khanyile was a research assistant and wrote the sections on the applicable laws and mobility theory.

Conflicts of Interest: Donna Hornby and Nompilo Khanyile were employed by the Association for Rural Advancement (AFRA) for the duration of the research. Adrian Nel and Samuel Chademana declare no conflict of interest. The European Union, as the founding sponsor, had no role in the design of the study; in the collection, analyses, or interpretation of data; in the writing of the manuscript, and in the decision to publish the results.

\section{References}

1. Hornby, D.; Kingwell, R.; Royston, L.; Cousins, B. Untitled: Securing Land Tenure in Urban and Rural South Africa; UKZN Press: Pietermaritzburg, South Africa, 2017.

2. Greenberg, S. Agrarian Reform and South Africa's Agro-Food System. J. Peasant Stud. 2015, 42, 957-979. [CrossRef]

3. Wegerif, M.; Russell, B.; Grundling, I. Still Searching for Security: The Reality of Farm Dwellers Evictions in South Africa; Nkuzi Development Association: Johannesburg, South Africa, 2005.

4. AGRI, SA. Land Audit: A Transactions Approach; AGRI SA: Johannesburg, South Africa, 2017.

5. Cousins, B.; Hall, R. SA still struggling to 'give back the land'. The Citizen, 13 November 2017.

6. Aliber, M.; Cousins, B. Livelihoods after Land Reform in South Africa. J. Agrar. Chang. 2013, 13, $140-165$. [CrossRef]

7. Hall, R. Land reform for what? Land use, production and livelihoods. In Another Countryside: Policy Options for Land and Agrarian Reform in South Africa; Hall, R., Ed.; Institute for Poverty, Land and Agrarian Studies, University of the Western Cape: Cape Town, South Africa, 2009; pp. 23-62.

8. Sender, J.; Johnston, D. Searching for a Weapon of Mass Production in Rural Africa: Unconvincing Arguments for Land Reform. J. Agrar. Chang. 2004, 4, 142-164. [CrossRef]

9. Hein, M. South Africa Pushed to the Limit: The Political Economy of Change; Zed Books: London, UK; New York, NY, USA, 2011.

10. Igumbor, E.U.; Sanders, D.; Puoane, T.R.; Tsolekile, L.; Schwarz, C.; Purdy, C.; Swart, R.; Durão, S.; Hawkes, C. "Big Food", the Consumer Food Environment, Health, and the Policy Response in South Africa. PLoS Med. 2012, 9, e1001253. [CrossRef] [PubMed]

11. O'Laughlin, B.; Bernstein, H.; Cousins, B.; Peters, P. Introduction: Agrarian Change, Rural Poverty and Land Reform in South Africa since 1994. J. Agrar. Chang. 2013, 13, 1-15. [CrossRef]

12. Agrawala, S.; Frankhauser, S. (Eds.) Economic Aspects of Adaptation to Climate Change: Costs, Benefits and Policy Instruments; Organization for Economic Co-operation and Development: Paris, France, 2008.

13. Stern Review: The Economics of Climate Change: Executive Summary, 2006; Her Majesty's Treasury: London, UK, 2008. Available online: http://www.hm-treasury.gov.uk/media/8AC/F7/ExecutiveSummary. pdf (accessed on 3 October 2017).

14. Intergovernmental Panel on Climate Change (IPCC). Climate Change 2014: Impacts, Adaptation, and Vulnerability. Part B: Regional Aspects. Working Group II Contribution to the Fifth Assessment Report of the Intergovernmental Panel on Climate Change; Cambridge University Press: Cambridge, UK, 2014.

15. Ziervogel, G.; Taylor, A. Feeling Stressed: Integrating Climate Adaptation with Other Priorities in South Africa. Environ. Sci. Policy Sustain. Dev. 2008, 50, 32-41. [CrossRef]

16. Anbumozhi, V. Mainstreaming Climate Change Adaptation into Developmental Planning. Discussion Paper Presented at the ADBI Regional Workshop on Mainstreaming Climate Change Adaptation into Developmental Planning. DEAT (2004). A National Climate Change Response Strategy for South Africa; Department of Environmental Affairs and Tourism (DEAT): Pretoria, South Africa, 2009.

17. Kaijage, H.R. A basis for climate change adaptation in Africa: burdens ahead and policy options. Int. J. Clim. Chang. Strateg. Manag. 2011, 4, 152-160. [CrossRef] 
18. Turpie, J.; Visser, M. The Impact of Climate Change on South Africa's Rural Areas (Chapter 4 of Financial and Fiscal Commission: Submission for the 2013/14 Division of Revenue); Financial and Fiscal Commission: Midrand, South Africa, 2012.

19. Ziervogel, G.; New, M.; Archer van Garderen, E.; Midgley, G.; Taylor, A.; Hamann, R.; Stuart-Hill, S.; Myers, J.; Warburton, M. Climate change impacts and adaptation in South Africa. WIREs Clim Chang. 2014, 5, 605-620. [CrossRef]

20. Department of Environmental Affairs and Tourism (DEAT). A National Climate Change Response Strategy for South Africa; Department of Environmental Affairs and Tourism (DEAT): Pretoria, South Africa, 2004.

21. Stats SA. 2011. Census 2011. Government of South Africa. Available online: https:/ /www.statssa.gov.za/ publications /P03014/P030142011.pdf (accessed on 3 December 2017).

22. O'Brien, K.; Leichenko, R. Double exposure: Assessing the impacts of climate change within the context of economic globalization. Glob. Environ. Chang. 2000, 10, 221-232. [CrossRef]

23. Bernstein, H. Class Dynamics of Agrarian Change; Agrarian Change and Peasant Studies Series; Fernwood Publishing: Black Point, NS, Canada, 2010.

24. Standing, G. The Precariat: The New Dangerous Class; Bloomsbury Academic: New York, NY, USA; London, UK, 2011.

25. Treasury, P. Provincial Economic Review and Outlook: 2016-2017; Provincial Government Budget Office: Pietermaritzburg, South Africa, 2017.

26. Statistics South Africa (Stats SA). Community Survey; Government of South Africa: Pretoria, South Africa, 2016.

27. Clark, T. Ecocriticism on the Edge: The Anthropocene as a Threshold Concept; Bloomsbury Publishing: London, UK, 2015.

28. Morton, T. How I Learned to Stop Worrying and Love the Term Anthropocene. Camb. J. Postcolonial Lit. Inquiry 2014, 1, 257-264. [CrossRef]

29. Moore, J.W. The Capitalocene, Part I: On the nature and origins of our ecological crisis. J. Peasant Stud. 2017, 44, 594-630. [CrossRef]

30. Klein, N. This Changes Everything: Capitalism vs. The Climate; Simon and Schuster: New York, NY, USA, 2014.

31. Takle, E.; Hofstrand, D. Global Warming-Impact of Climate Change on Global Agriculture; Ag Decision Maker Newsletter-lib.dr.iastate.edu; Iowa State University: Ames, IA, USA, 2015.

32. Vermeulen, S.J.; Campbell, B.M.; Ingram, J.S. Climate Change and Food Systems. Annu. Rev. Environ. Resour. 2012, 37, 195-222. Available online: http:/ / www.annualreviews.org/doi/full/10.1146/annurev-environ020411-130608 (accessed on 28 November 2017). [CrossRef]

33. Hewitson, B.C.; Tadros, M.; Jack, C. Historical Precipitation Trends over Southern Africa: A Climatology Perspective. In Climate Change and Water Resources in South Africa: Studies on Scenarios, Impacts, Vulnerabilities and Adaptation; RSA, WRC Report 1430/1/05; Schulze, R.E., Ed.; Water Research Commission: Pretoria, South Africa, 2005.

34. Weis, T. The Ecological Hoofprint: The Global Burden of Industrial Livestock; Zed Books: London, UK; New York, NY, USA, 2013.

35. Van der Ploeg, J.D.; Franco, J.C.; Borras, S.M., Jr. Land concentration and land grabbing in Europe: A preliminary analysis. Can. J. Dev. Stud. 2015, 36, 147-162. [CrossRef]

36. McMichael, P.; Schneider, M. Food Security Politics and the Millennium Development Goals. Third World Q. 2011, 32, 119-139. [CrossRef] [PubMed]

37. Schneider, M.; McMichael, P. Deepening, and repairing, the metabolic rift. J. Peasant Stud. 2010, 37. [CrossRef] [PubMed]

38. IAASTD. Synthesis Report: Agriculture at a Crossroads: International Assessment of Agricultural Science and Technology for Development; Island Press: Washington, DC, USA, 2009.

39. Capra, F. Industrial Agriculture, Agroecology and Climate Change. Centre for Ecoliteracy. 2015. Available online: https: //www.ecoliteracy.org/article/industrial-agriculture-agroecology-and-climate-change\# (accessed on 3 December 2017).

40. Holt-Giménez, E.; Altieri, M.A. Agroecology, Food Sovereignty, and the New Green Revolution. Agroecol. Sustain. Food Syst. 2013, 37, 90-102.

41. Van der Ploeg, J.D. Peasants and the Art of Farming: A Chayanovian Manifesto; Agrarian Change and Peasant Studies Series 2; Fernwood: Winnipeg, MB, Canada, 2013.

42. Pinock, S. Peak Phosphorus Fuels Food Fears. ABC Science. 5 August 2010. Available online: http:/ / www.abc. net.au/science/articles/2010/08/05/2973513.htm (accessed on 2 December 2017). 
43. Raleigh, C.; Jin, C.H.; Kniveton, D. The devil is in the details: An investigation of the relationships between conflict, food price and climate across Africa. Glob. Environ. Chang. 2015, 32, 187-199. [CrossRef] [PubMed]

44. Atteridge, A.; Remling, E. Is adaptation reducing vulnerability or redistributing it? WIREs Clim. Chang. 2018, 9. [CrossRef]

45. Ewert, J.; du Toit, A. A Deepening Divide in the Countryside: Restructuring and Rural Livelihoods in the South African Wine Industry. J. S. Afr. Stud. 2005, 31, 315-332. [CrossRef]

46. Breman, J. A Bogus Concept? New Left Rev. 2013, 84, 130-138.

47. Bernado, F. The impossibility of precarity. Radic. Philos. 2016, 198, 7-14.

48. Munk, R. The Precariat: A view from the South. Third World Q. 2013, 34, 747-762. [CrossRef]

49. Denning, M. Wageless Life. New Left Rev. 2010, 66, 79-97.

50. Breman, J. Footloose Labour: Working in India's Informal Economy; Cambridge University Press: Cambridge, UK, 1996.

51. Hart, G. Rethinking the South African Crisis: Nationalism, Populism, Hegemony; University of Georgia Press: Athens, GA, USA, 2014.

52. Bernstein, H. 'Changing before Our Very Eyes': Agrarian Questions and the Politics of Land in Capitalism Today. J. Agrar. Chang. 2004, 4, 190-225. [CrossRef]

53. Bernstein, H. Land Reform in Southern Africa in World-Historical Perspective. Rev. Afr. Political Econ. 2003, 30, 203-226. [CrossRef]

54. Li, T.M. To Make Live or Let Die? Rural Dispossession and the Protection of Surplus Populations. Antipode 2010, 41, 66-93. [CrossRef]

55. Statistics South Africa (Stats SA). Poverty Trends in South Africa. Government of South Africa. 2017. Available online: www.statssa.gov.za/?p=10334 (accessed on 25 November 2017).

56. Statistics South Africa (Stats SA). Annual Report; Government of South Africa: Pretoria, South Africa, 2013.

57. Visser, M.; Ferrer, S. Farm Workers' Living and Working Conditions in South Africa: Key Trends, Emergent Issues, and Underlying and Structural Problems; International Labour Organisation: Pretoria, South Africa, 2015.

58. Ledger, T. An Empty Plate: Why We Are Losing the Battle for Our Food System, Why It Matters and How We can Win It Back; Jacana Media: Johannesburg, South Africa, 2016.

59. Bernstein, H. Social change in the South African countryside? Land and production, poverty and power. J. Peasant Stud. 1998, 25, 1-32. [CrossRef]

60. Hall, R.; Wisborg, P.; Shirinda, S.; Zamchiya, P. Farm workers and farm dwellers in Limpopo Province, South Africa. J. Agrar. Chang. 2013, 13, 47-70. [CrossRef]

61. Hall, R. Dynamics in the commercial farming sector. In Another Countryside: Policy Options for Land and Agrarian Reform in South Africa; Hall, R., Ed.; Institute for Poverty, Land and Agrarian Studies, University of the Western Cape: Cape Town, South Africa, 2009; pp. 121-132.

62. Nicholson, J. Measuring Change: South Africa's Economy since 1994; Trade Union Research Project; University of KwaZulu-Natal: Durban, South Africa, 2001.

63. Andrade, D. 'Export or die': The rise of Brazil as an agribusiness powerhouse. Third World Themat. A TWQ J. 2016, 1, 653-672. [CrossRef]

64. Reardon, T.C.; Timmer, P.; Barrett, C.B.; Berdegué, J. The Rise of Supermarkets in Africa, Asia, and Latin America. Am. J. Agric. Econ. 2003, 85, 1140-1146. [CrossRef]

65. Visser, M. Going Nowhere Fast? Changed Working Conditions on Western Cape Fruit and Wine Farms. A State of Knowledge Review; Working Paper No 41. September 14; Institute for Poverty, Land and Agrarian Studies (PLAAS). University of the Western Cape: Cape Town, South Africa, 2016.

66. Bernstein, H. How White Agriculture (Re)positioned Itself for a "New South Africa". Crit. Sociol. 1996, 22, 9-36. [CrossRef]

67. Dubb, A. Interrogating the Logic of Accumulation in the Sugar Sector in Southern Africa. J. S. Afr. Stud. 2017, 43, 471-499. [CrossRef]

68. Du Toit, A. Forgotten by the Highway: Globalisation, Adverse Incorporation and Chronic Poverty in a Commercial Farming District of South Africa; Chronic Poverty Research Centre Working Paper No. 49; Institute for Poverty, Land and Agrarian Studies, University of Western Cape: Cape Town, South Africa, 2004.

69. Cousins, B. Agrarian reform and the "two economies": transforming South Africa's countryside. In The Land Question in South Africa: The Challenge of Transformation and Redistribution; Ntsebeza, L., Hall, R., Eds.; HSRC Press: Pretoria, South Africa, 2005; pp. 220-245. 
70. Legassick, M.; Wolpe, H. The Bantustans and Capital Accumulation in South Africa. Rev. Afr. Political Econ. 1976, 3, 87-107. [CrossRef]

71. Weatherspoon, D.D.; Reardon, T. The Rise of Supermarkets in Africa: Implications for Agrifood Systems and the Rural Poor. Dev. Policy Rev. 2003, 21, 333-355. [CrossRef]

72. D'Haese, M.; Van Huylenbroeck, G. The rise of supermarkets and changing expenditure patterns of poor rural households case study in the Transkei area, South Africa. Food Policy 2005, 30, 97-113. [CrossRef]

73. Genis, A. Accumulation and Differentiation: Dynamics of Change in the Large-Scale Commercial Farming Sector of South Africa. Unpublished Ph.D. Thesis, University of the Western Cape, Cape Town, South Africa, 2015.

74. De Lange, J. Who Owns SA's Land? News24. 29 October 2017. Available online: https:/ / www.news24.com/ SouthAfrica/News/who-owns-sas-land-20171028 (accessed on 5 December 2017).

75. Groenewald, Y. Who Owns the Land? City Press. 3 May 2015. Available online: http:/ / city-press.news24. com/News/Who-owns-the-land-Ownership-by-numbers-20150503 (accessed on 5 December 2017).

76. South Africa Department of Rural Development and Land Reform (DRDLR). 2013; State Land Audit Booklet. Available online: www.ruraldevelopment.gov.za/phocadownload/.../land\%20audit\%20booklet. pdf (accessed on 28 November 2017).

77. TIPS. The Real Economy Bulletin: Provincial Review 2016: KZN. Available online: https://www.tips.org.za/ publications / the-real-economy-bulletinon (accessed on 15 December 2017).

78. TIPS, 2017. The Real Economy Bulletin: Third Quarter 2017. Available online: https://www.tips.org.za/ publications/the-real-economy-bulletin/item/3402-the-real-economy-bulletin-third-quarter-2017 (accessed on 16 December 2017).

79. Godsmark, R. Forestry Facts and Figures; Forestry South Africa: Johannesburg, South Africa, 2013.

80. SAPPI. SAPPI Corporate Factsheet, 1936-2016. Available online: https://www.sappi.com/global-businesssegments (accessed on 5 January 2018).

81. Statistics South Africa (Stats SA). Community Survey. Government of South Africa. 2007. Available online: http:/ / www.statssa.gov.za/?page_id=3914 (accessed on 16 August 2017).

82. Thornhill, M.; Green-Govendor, J.; Khoza, B. A Status Quo Analysis on the Impacts of Climate Change in KwaZulu-Natal; Report to the Department of Agriculture and Environmental Affairs, Provincial Government, KwaZulu-Natal, South Africa; KwaZulu-Natal Department of Agriculture and Environmental Affairs: Pietermaritzburg, South Africa, 2009.

83. South Africa Department of Agriculture, Forestry and Fisheries (DAFF). 2016. Abstract of Agricultural Statistics 2012. Available online: http://www.daff.gov.za/docs/statsinfo/Abstract_2012.pdf (accessed on 12 December 2017).

84. South African Canegrowers. Review of the Board of Directors 2016-2017. Available online: https:// sacanegrowers.co.za/annual-report-201617/ (accessed on 18 December 2017).

85. Department of Economic Development, Tourism and Environmental Affairs (EDTEA). Provincial Plans Phase Three: Support the Review of Provincial Climate Change Response Strategies and the Development of Action Plans; Prepared for: KwaZulu-Natal Department of Economic Development, Tourism and Environmental Affairs; Climate System Analysis Group (CSAG), African Climate Development Initiative (ACDI), University of Western Cape: Cape Town, South Africa, 2017.

86. Cronje, F. Farmers' Rights must Be Defended. Mail \& Guardian. 2015. Available online: https://mg.co.za/ article/2015-10-15-farmers-rights-must-be-defended (accessed on 30 January 2018).

87. Meyer, F.; Davids, T. The State's Policy Inaction Regarding Poultry Sector Is a Recipe for Disaster. Business Day, April 18. Downloaded on 12 December 2017. Available online: https://www.businesslive.co.za/bd/ opinion/2017-04-18-the-states-policy-inaction-regarding-poultry-sector-is-a-recipe-for-disaster/ (accessed on 3 December 2017).

88. Davids, T.; Meyer, F. Price formation and competitiveness of the South African broiler industry in the global context. Agrekon 2017, 56, 123-138. [CrossRef]

89. Association for Rural Advancement (AFRA). Pathways Out of Poverty: Improving Farm Dwellers' Tenure Security and Access to Housing and Services; AFRA: Pietermaritzburg, South Africa, 2017.

90. Wittenberg, M.; Collinson, M.; Harris, T. Decomposing changes in household measures: Household size and services in South Africa, 1994-2012. Demogr. Res. 2017, 37, 1297-1326. [CrossRef] 
91. Amoateng, A. Towards a conceptual framework for families and households. In Families and Households in Post-Apartheid South Africa: Socio-Demographic Perspectives; Amoateng, A., Heaton, T., Eds.; HSRC Press: Cape Town, South Africa, 2007; pp. 27-42.

92. Bhorat, H.; Kanbur, R.; Stanwix, B. Estimating the impact of minimum wages on employment, wages and non-wage benefits: The Case of Agriculture in South Africa. Am. J. Agric. Econ. 2014, 96, 1402-1419. [CrossRef]

93. Khosa, M. Forestry Contracting in South Africa; Instruments for Sustainable Private Sector Forestry, South Africa Series; International Institute for Environment and Development and CSIR-Environmentek: London, UK; Pretoria, South Africa, 2000.

94. Cousins, B. Smallholder Irrigation Schemes, Agrarian Reform and 'Accumulation from Above and from Below' in South Africa. J. Agrar. Chang. 2013, 13, 116-139. [CrossRef]

95. Colby, C.C. Centrifugal and Centripetal Forces in Urban Geography. Ann. Assoc. Am. Geogr. 1933, 23, 1-20. [CrossRef]

96. Reilly, J. Actual versus Constructive Eviction. 2014. Available online: http:/ /www.thedataadvocate.com/ actual-eviction-vs-constructive-eviction/ (accessed on 17 November 2017).

97. Sithole, S.; Association for Rural Advancement, Pietermaritzburg, South Africa. Personal communication, 2017.

98. Liu, Y.; Liu, Y.; Chen, Y.; Long, H. The process and driving forces of rural hollowing in China under rapid urbanization. J. Geogr. Sci. 2010, 20, 876-888. [CrossRef]

99. Association for Rural Advancement (AFRA). This Is Our Home-It Is Our Land, Our History, Our Right; AFRA: Pietermaritzburg, South Africa, 2005.

100. Mosoetsa, S. Eating from One Pot: The Dynamics of Survival in Poor South African Households; Wits University Press: Johannesburg, South Africa, 2011.

101. Hornby, D. Cattle, Commercialisation and Land Reform: Dynamics of Social Reproduction and Accumulation in Besters, KwaZulu-Natal. Ph.D. Thesis, University of Western Cape, Cape Town, South Africa, 2015.

102. Barchiesi, F. Precarious Liberation: Workers, the State and Contested Social Citizenship in Postapartheid South Africa; UKZN Press: Pietermaritzburg, South Africa, 2011.

103. Spivak, G. Can the Subaltern Speak? Reflections on the History of an Idea; MacMillan: Basingstoke, UK, 1998.

104. Schulze, R.E. (Ed.) Climate Change and Water Resources in South Africa: Studies on Scenarios, Impacts, Vulnerabilities and Adaptation; RSA, WRC Report 1430/1/05; Water Research Commission: Pretoria, South Africa, 2005.

105. Climate System Analysis Group (CSAG). Phase Two: Report on the Update of the 2009 Report "Development of a Status Quo Analysis on the Impacts of Climate Change in KwaZulu-Natal" Report to the Department of Economic Development; Tourism and Environmental Affairs, Provincial Government: KwaZulu-Natal, South Africa, 2017.

106. McDowell, J.Z.; Moe, C.L.; Hess, J.J. Adaptation or Maladaptation: Vulnerability to Competing Economic and Climatic Exposures in the Bolivian Highlands; Emory University, Rollins School of Public Health: Atlanta, GA, USA, 2010.

107. Adger, W.N.; Kelly, P.M. Social Vulnerability to Climate Change and the Architecture of Entitlements. Mitig. Adapt. Strateg. Glob. Chang. 1999, 4, 253-266. [CrossRef]

108. Kelly, P.; Adger, W. Theory and practice in assessing vulnerability to climate change and facilitating adaptation. Clim. Chang. 2000, 47, 325-352. [CrossRef]

109. Turner, B.L., 2nd; Kasperson, R.E.; Matson, P.A.; McCarthy, J.J.; Corell, R.W.; Christensen, L.; Eckley, N.; Kasperson, J.X.; Luers, A.; Martello, M.L.; et al. A framework for vulnerability analysis in sustainability science. Proc. Natl. Acad. Sci. USA 2003, 100, 8074-8079. [CrossRef] [PubMed]

110. Fussel, H.M.; Klein, R.J.T. Climate change vulnerability assessments: An evolution of conceptual thinking. Clim. Chang. 2006, 75, 301-329. [CrossRef]

111. South Africa Department of Economic Affairs (DEA00000). Long-Term Adaptation Scenarios Flagship Research Programme (LTAS) for South Africa; Department of Environmental Affairs: Pretoria, South Africa, 2013.

112. Alcock, R. Drought and Communal Livestock. In Proceedings of the SAEON-NRF Workshop on Drought, Hoedspruit, Limpopo, South Africa, 9 November 2017.

113. Ziqubu, N.; Association for Rural Advancement, Pietermaritzburg, South Africa. Personal communication, 2017.

114. Deressa, T.; Hassan, R.; Poonyth, D. Measuring the impact of climate change on South African agriculture: The case of sugarcane growing regions. Agrekon 2005, 44, 524-542. [CrossRef]

115. National Planning Commission (NPC) 2011. National Development Plan 2030. Government of South Africa, Pretoria. Available online: https:/ / nationalplanningcommission.wordpress.com/the-national-developmentplan/ (accessed on 17 November 2017). 
116. Hall, R.; Kepe, T. Elilte capture and state neglect: New evidence on South Africa's land reform. Rev. Afr. Political Econ. 2017, 44, 122-130. [CrossRef]

117. Mntungwa, D. The Impact of Land Legislation on Farm Dweller Evictions. Unpublished MA Thesis. Wits University. 2014. Available online: http:/ / mobile.wiredspace.wits.ac.za/handle/10539/15305 (accessed on 22 November 2017).

118. Ferguson, J. Give a Man a Fish: Reflections on the New Politics of Distribution; Duke University Press: Durham, NC, USA, 2015.

(C) 2018 by the authors. Licensee MDPI, Basel, Switzerland. This article is an open access article distributed under the terms and conditions of the Creative Commons Attribution (CC BY) license (http:/ / creativecommons.org/licenses/by/4.0/). 
Article

\title{
Tracing Improving Livelihoods in Rural Africa Using Local Measures of Wealth: A Case Study from Central Tanzania, 1991-2016
}

\author{
Wilhelm Östberg ${ }^{1, *}$, Olivia Howland ${ }^{2}$, Joseph Mduma ${ }^{3}$ and Dan Brockington ${ }^{2}$ \\ 1 Department of Human Geography, Stockholm University, SE-106 91 Stockholm, Sweden \\ 2 The Sheffield Institute for International Development (SIID), The University of Sheffield, \\ Sheffield S10 2TN, UK; oliviahowland@googlemail.com (O.H.); d.brockington@sheffield.ac.uk (D.B.) \\ 3 Tanzania Forest Service Agency, Dar es Salaam 40832, Tanzania; mdumajos@gmail.com \\ * Correspondence: wilhelm.ostberg@humangeo.su.se
}

Received: 30 January 2018; Accepted: 27 March 2018; Published: 10 April 2018

\begin{abstract}
We studied livelihood changes and poverty dynamics over a 25-year period in two villages in central Tanzania. The villages were, from the early 1990s and 2000s, strikingly poor with between $50 \%$ and $55 \%$ of families in the poorest wealth groups. 25 years later much has changed: people have become substantially wealthier, with $64 \%$ and $71 \%$ in the middle wealth groups. The new wealth had been generated locally, from farming, particularly of sunflowers as a cash crop. This goes against a conventional view of small-scale farming in Tanzania as being stagnant or unproductive. The area of land farmed per family has increased, almost doubling in one village. People have made money, which they invest in mechanised farming, improved housing, education of their children, livestock, and consumer goods. Improved infrastructure and local entrepreneurs have played key roles in the area's transformation. Locally identified wealth rankings showed that most villagers, those in the middle wealth groups and above, can now support themselves from their land, which is a notable change to a time when $71 \%$ and $82 \%$ in each village respectively depended on casual labour for their survival. This change has come at a cost to the environment. By 2016, the village forests have largely gone and been replaced by farms. Farmers were concerned that the climate was turning drier because of deforestation. Studying the mundane- the material used in roofs, the size of farms, and so on made it possible to trace and understand the radical transition the area has experienced.
\end{abstract}

Keywords: Longitudinal studies; assets; livelihoods; rural entrepreneurs; Tanzania

\section{Introduction}

What does radical, positive change in poor rural societies look like, and how is it achieved? This issue is a bone of contention in Africanist circles, with three contrasting schools of thought at work. There are those who argue that growth is occurring in many African countries with marked positive changes in rural areas (we call these the neoliberal optimists). Others argue that neoliberal capitalism is at best leaving people behind, and at worst wreaking havoc on rural societies as strategies of accumulation by dispossession proliferate (we call these the radical critics). A third school challenges our ability to know anything in rural African contexts with much certainty because the quality of the data is so poor (we call these the data challengers).

Tanzania, where our case study is set, provides a good laboratory to explore these debates. The first school of thought is strongly represented. Most observors accept that Tanzania has experienced strong economic growth (averaging 7\% annually) since the 1990s that was principally generated from mining, tourism, services, construction, and the financial sector [1,2]. The neoliberal optimists herald this as a success of neoliberal reforms, which saw tighter controls on government spending, the withdrawl 
of government attempts to plan and control economies, the sale of parastatals, macroeconomic stability, loosening of financial restrictions, and encouraging foreign investment [3,4]. The fruits of this, these enthusiasts argue, are visible in the reducing levels of basic needs poverty in Tanzania from $34.4 \%$ in 2007 to $28.2 \%$ in $2011 / 12$ and extreme poverty from $11.7 \%$ to $9.7 \%$ in the same period, according to the most recent Household Budget Surveys [5].

These analysts belong to a wider school of enthusiasts for free markets and neoliberal policies which they argue are fundamentally responsible for reducing poverty because they have made economic growth possible [6]. Without growth, they insist, there can be no poverty reduction [7]. Indeed, growth matters far more than redistribution through taxation and social services or social protection payments [8]. Because of the economic growth that is caused by the policies which they advocate, they claim that global poverty has reduced dramatically, driven by transformations in India and China (see Hulme for a review [9]).

At the same time, many of these same observors concede that, amidst this success in Tanzania the agricultural sector in this country appears to be relatively stagnant, showing little sign of growth [3]. Given that $68 \%$ of the population live in rural areas with most working as peasants [10], and $84 \%$ of the country's poor live in the countryside [5], the radical critics argue that the country's rapid economic growth only partly benefits the rural areas $[1,11,12]$. These critics observe that during many years of economic growth up until 2007, poverty lines did not shift particularly noticeably [13]. Even with recent changes and declining poverty, population growth means that the number of Tanzanians living in poverty is larger in 2012 than in 1992, according to World Bank figures [14].

This school is in turn part of a broader critique of what neoliberal capitalism does to poor people, poverty and poor places like Tanzania. Some authors here decry the inequality, dispossession, and social and environmental deprivation that results when firms extract resources from rural places with state violence to support them [15-17]. They point to a growing crescendo of alarm at land grabbing for agriculture [18-20]. Others observe land grabs that are driven by alliances between capitalists and conservationists [21,22] (for a particularly unpleasant example of this in Tanzania see Walsh's work [23]), or by new environmental policies [24]. Others insist that the World Bank's own data are either misconceived, or poorly calculated, or else at face value demonstrate that poverty persists [25]. The costs of living in urban areas are under-estimated meaning that far more people are poor in towns than is recognised [26]. In rural areas, the evidence of poverty is so overwhelming that the correct task for analysts is not to celebrate its reduction but to explain why it persists [27].

Finally, the data challengers question the empirical basis of both sides in this debate. Jerven's already classic study Poor Numbers [28] argues that much of official statistics in African countries are of poor quality, and should not be taken at face value. His work joins a tranche of critiques that question the quality of data to measure large-scale changes in well-being and poverty [29-31]. Ansoms and colleagues found substantial misrepresentation of rural poverty in official statistics in Rwanda when these were confronted with their own qualitatively oriented studies, carried out in 2006-07 and 2011 in six different locations [32]. We can also include in this group critics who contend that some of the alarm raised over land-grabbing is itself based on faulty data and measurements that over-estimate the extent of actual land loss [33].

A different branch of the data challenging debate questions whether the right statistics are being used to measure change. An increasingly important and influential view argues that GDP is anyway the wrong means of measuring progress $[34,35]$ and that income and expenditure are inadequate to capture the experience of poverty [36]. Alwyn Young has used asset data to suggest that there has been such a positive transformation that Africa must have experienced a 'growth miracle', and that poverty dynamics need to pay attention to assets [37]. Young's argument may have been over-extrapolated [38], but the point remains that, as we have argued elsewhere [39,40], the measures of poverty that are used by both the neoliberal optimists and the radical critics rely on poverty lines and baskets of consumption from Household Budget Survey data. This means that they do not include local meanings of wealth 
and poverty that are more concerned with assets. Changes in these measures will not be well captured by such consumption data.

The logic of the data challengers' argument is that national scale figures about changes in poverty may not be good enough to capture local variety and dynamics, either because the numbers are wrong, and / or because they are counting the wrong thing. They will be a poor source of predictions for nature of changes at village level. This raises the possibility that villagers may be richer than the optimists have hoped, or poorer than the radical critics have feared, or even simply not sufficiently well connected to 'national' economies or policies for it to be meaningful to look for prosperity or poverty that results from national fortunes.

The data challengers' arguments are particularly apt for studies of poverty dynamics Tanzania because there are few good data. The normal records to explore poverty dynamics and the mechansims by which GDP changes might affect ordinary people's lives are scarce. Ideally, poverty dynamics are measured using panel data that track the same individuals and families over time, revisiting families every 2-3 years [41-44]. These are only present in Tanzania for Kagera in the 1990s [45], and for the nation as a whole since 2007 when the Living Standards Measurement Survey was started. Alternatively researchers can use longitudinal data, which are less robust than a panel (because the revisits are less frequent), but which nonetheless still track the same individuals, families, or larger communities. Unfortunately these too are rare.

There is therefore a need to look afresh at changes which are occurring in rural parts of Tanzania. We need to understand first what sorts of changes rural villagers aspire to achieve. What do they mean by wealth, prosperity and a good life? Do they think that they are closer to those ideals now than they once were? Do they think that they have become poorer or richer? What data can we use, and should we use, to explore changes in rural areas? Which of the grand narratives just reviewed-the neoliberal optimists and the radical critics are most justified in the light of new data?

In this paper, we address this challenge by exploring the relationship between these national figures and detailed studies of small, rural Tanzanian communities. We draw on data from a longitudinal study set in two villages (Goima and Mirambu) in a geographically peripheral and economically disadvantaged part of central Tanzania. We show how the studied area has gone through a substantial transition, which pleases many villagers, during the last 25 years, and we explore some of the drivers of change. Yet we also argue that these changes can only be cautiously welcomed.

We proceed as follows. First we outline how the study was organised and the broad headline changes. Then, we explain what precisely has changed, and what villagers make of these dynamics in more detail. Then we explore some of the reasons for these changes. Finally, we consider what these changes in Goima and Mirambu might mean for the broader context of Tanzanian economic development.

\section{The Techniques of Longitudinal Research}

This restudy is part of the Long Term Livelihood Change in Tanzania research project which is retrospectively constructing longitudinal profiles of change by revisiting households first visited in the early 1990s-early 2000s [40]. The project has identified 67 villages, which were surveyed by 17 researchers in this time period. Of these, we have revisited 30.

The limitation of this technique is that it is confined to villages that happened to be surveyed in the past. It is not possible systematically to survey the country. We are restricted to places that researchers once found interesting or were able to reach. Its advantage is that if the original researcher is able to take part in the repeat visits, then this adds to the insights that are possible.

This paper presents our findings from two of these revisted villages, Goima and Mirambu, in Chemba district, Dodoma region in central Tanzania (Figure 1). They were first visited by Wilhelm Östberg in the early 1990s as part of his PhD research ([46], and see Materials and Methods). This he undertook with the support of Joseph Mduma, and both he and Mduma took part in the second revisit, 
which took place in 2016. In addition, we are also able to draw on findings of an earlier revisit, 2005, undertaken by a Dutch sociologist Monique Slegers [47].

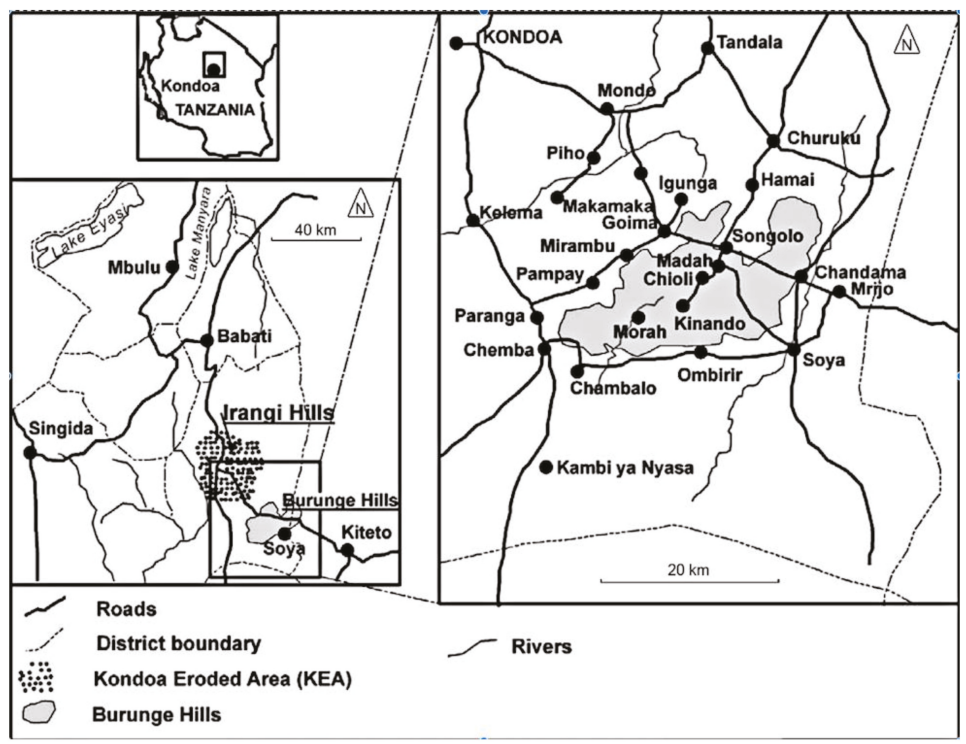

Figure 1. Goima and Mirambu villages on the foot slopes of the Burunge Hills, south-east of Kondoa town, and the Kondoa Eroded Area. Source: Östberg and Slegers 2010.

The technique of retrospective longitudinal survey construction has been used before in the Kageera Health and Development Survey [45]. It is similar to methods which ask respondents to reconstruct change over time from the present-turning survey data 'upside down' as Dercon and Shapira put it ([43], p. 30)—except that it does not rely on those memories for its baseline. The baseline is provided by the first survey. This gives it an advantage, as recall can suffer from rose-tints and inaccuracy, a risk, for all of its insights, in the 'stages of progress' method [48-50]. We rely instead on actual observations that were recorded some twenty years ago.

When we resurvey villages, our methods are deceptively simple (see Materials and Methods). We identify sites that were visited in that time period, and, working with the original researchers where possible, revisit the original families to explore how their circumstances have changed. Our particular focus is to explore the changes in asset control and ownership, as we find that these are central in local meanings of wealth. We combine this with keyinformant interviews and focus groups to talk about the changing meaning of wealth and prosperity. We also take, where village lists allow, profiles of the condition of families that are currently in the village. But note the word 'deceptively' in the first line of this paragraph. Re-identifying families is no easy task, and, on occasion, we find that there has been too much change even to attempt this work.

Fortunately, as Table 1 shows, the levels of attrition are relatively low in this case. Moreover, there is no sign of a tendency in the data for the attrition to affect particular groups. In particular, given that the villages appear to have got richer we have to be clear that this is not due to poorer families who were once present have now just disappeared (through death or migration). Absence of poverty for this reason would not indicate an improvement in well-being. Fortunately this selective attrition is not apparent. As Table 1 shows, there is no trend for higher attrition rates in the poorest groups across both villages: attrition is slightly higher among the poorest in Goima (37\% missing as compared to $31 \%$ from wealth group 2), but lower in Mirambu (only 8\% missing when compared to $19 \%$ in wealth group 2). Nor could we spot any consistent trend in terms of attrition of dual and female headed households 
across both of the villages, with attrition in female headed households being lower than the dual headed households in Goima (29\% as compared to 35\%) and higher in Mirambu (23\% compared to $9 \%$ ).

Table 1. Success rates in recontacting original families.

\begin{tabular}{ccc}
\hline Characteristic & Goima & Mirambu \\
\hline Wealth Group 1 & $100 \%$ & $100 \%$ \\
Wealth Group 2 & $69 \%$ & $81 \%$ \\
Wealth Group 3 & $63 \%$ & $92 \%$ \\
Male Headed & $65 \%$ & $91 \%$ \\
Female Headed & $71 \%$ & $77 \%$
\end{tabular}

Note: We have grouped the 1991/3 categories 2 and 3 into category 2 and categories $4-6$ into category 3 . The $100 \%$ re-contact rate for the richest families is misleading because there are only three families in those cells.

The changing composition of households over time has made some changes to the presence of female-headed households in the follow up in Mirambu alone. In the original survey, 50\% of households in Goima, and 38\% in Mirambu, were female headed. In the revisited group the proportion changes to $47 \%$ and $20 \%$.

However, we can get a deeper picture of the forms of bias that might be at work if we look beneath headline wealth categories to the construction of family units. There is a sadly long history of talking about societies using terms like 'family' or 'household' in problematic ways. These can obscure gender or generational dynamics, or simply fail to mention how a household unit was defined [51,52]. As we have described elsewhere [53], family units are often essential to understand the changes in assets that we explore, but they have to be examined carefully.

For the work of the 1991 survey Östberg and Mduma used village rosters from Goima and Mirambu to construct the sample frame. The basic unit, in the view of the village offices, was a "kaya" (household) which they more specifically defined as a "house". This was made up of people sharing a roof. This definition meant that an aged and/or sickly person sleeping in his/her own house would count as a separate domestic unit, even if he/she on a daily basis was provided with food from relatives, or neighbours. They typically would have only a small piece of land, an aged house of low quality, and they did not own much more than the clothes they wore. In the wealth rankings, people in this category were usually described as "helpless". The advantage with following the local practice of registering them as a separate domestic unit was, from the point of view of our survey, that these cases of poverty were not concealed (they constituted 7\% of the sample). However, for the 2016 re-survey, these units have largely disappeared-they have died. Ours is a record therefore of what happened to the people who have survived the intervening 25 years.

Goima and Mirambu are rather stable social entities, and the households provided a useful unit to record changes of assets, which we use as one dimension to capture the transformation the area has gone through over a period of 25 years. The households afford us with some headline changes and sufficient material to present the arguments in this paper.

But, we must note that there are aspects of this story, taking place within families, which are not told here. This means that the labour implications within the families of the larger farms that we describe are not covered in this paper. Our female informants gave us some inkling as to the value of better water supplies, but we have not provided the sort of rich account which privileges their views. It means that the contests over what sorts of assets (cows, land, farms, houses, education) to invest in, that will have taken place, and currently are taking place, are not described in this paper. They must form the subject of other investigations.

We could go on, but the point is made. We are just beginning to understand the implications of increased investment in assets. Our first task, however, is to describe the nature and the possible causes of the changes that we encountered. This will, we hope, create the space for other richer accounts. Or, to put this differently, we think we can robustly describe in this paper important changes which 
deserve writing up and publishing as they are. We do not pretend for a moment, however, that our household based perspectives are at all complete and we welcome contributions in this area.

\section{Sketching a Changing Scenario}

Goima and Mirambu are located on the lower slopes of the Burunge hills and their surrounding plains in central Tanzania. Before the villagisation campaign of 1973-4, the Burunge people also lived in the interior of the hills. During the villagisation campaign, the people were moved off the hills to settle in the villages surrounding them. As the rigour of the villagisation policy slackened in the 1980s, a number of Burunge began returning to their ancestral lands.

The area has a semi-arid climate with an average (but unpredictable) annual precipitation of below $550 \mathrm{~mm}$. The rain falls entirely between November and May, with no rain being recorded at the nearest guage between June and October [47]. Rivers are ephemeral and it is difficult to find surface water for six to eight months in most years (Figure 2a). In the 1990s, these villages, and indeed the broader region, were marked by their poverty. Agriculture was marginal and precarious, yields poor, and returns slim. Infrastructure was sparse with bad roads, supplies, and transport.

In the early 1990s, an old, battered bus arrived in Goima village from Kondoa town every morning, on its way to Kiteto. In the afternoon, it returned. This was the only public transport on offer. Today, privately operated buses pass frequently with connections to major towns, including Arusha, Babati, Dodoma (the political capital), Tanga, and the metropolis of Dar es Salaam. The road passing through Goima has been widened and provided with a gravel surface, and this encouraged bus companies to open new services. A new road is also planned to take a more south-westerly direction, passing through Mirambu village, and at Chemba, where the district headquarters are, to link up with the major road that is connecting Dodoma with Arusha. The new, tarmacked road will soon also continue to Singida. This means that Goima and Mirambu will be situated along one of the country's major arteries, opening up not only these two villages along the roadside, but the whole region.

The primary court in Goima village is still a dilapidated building made by adobe bricks. In the early 1990s, the open area outside the primary court was the sleepy centre of the village. Peddlers marketed their selection of tomatoes, cassava, dried fish and other produce in the shade of a big Ficus tree, said to have grown from the cattle enclosure of Damasi, the first chief of the Burunge (Figure 2b). These goods the peddlers either carried there, or transported by bicycle.

Today a fleet of motorcycles are parked here, waiting to transport people and goods to various destinations in the area. Motorbikes appeared in Goima in numbers by 2005-6, and a new village centre, with modern buildings, has moved a few hundred metres further east, on land that used to be the primary school's sports field, but that was opened up for commercial development. Here, one also finds a new spacious mosque, and a new secondary school is not far away (Figure 2c,d). 

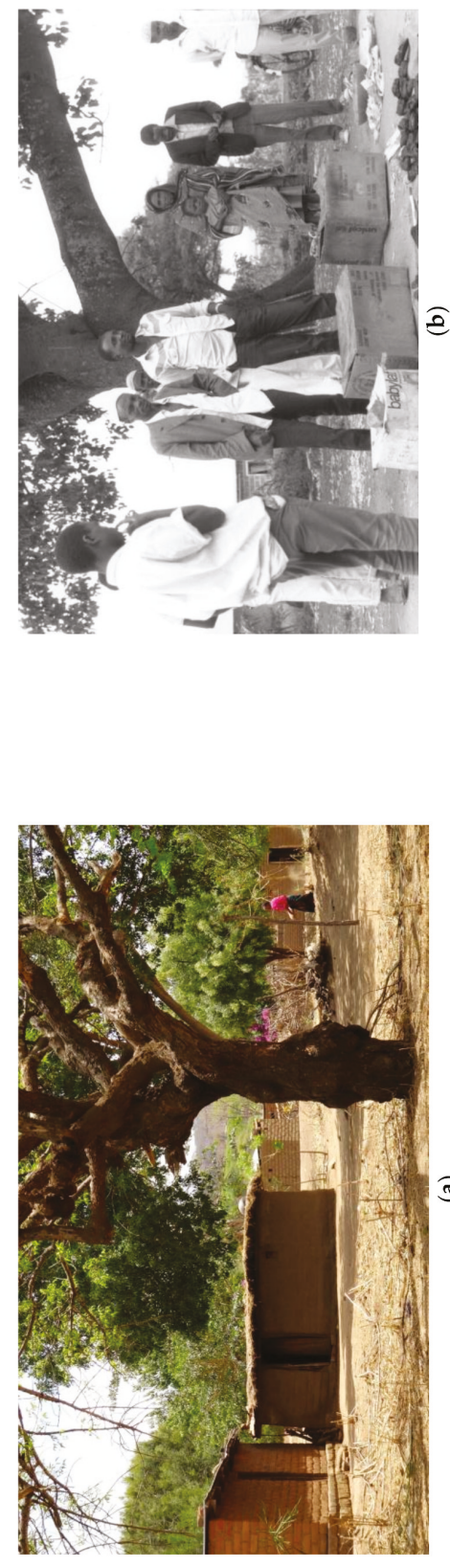

อ
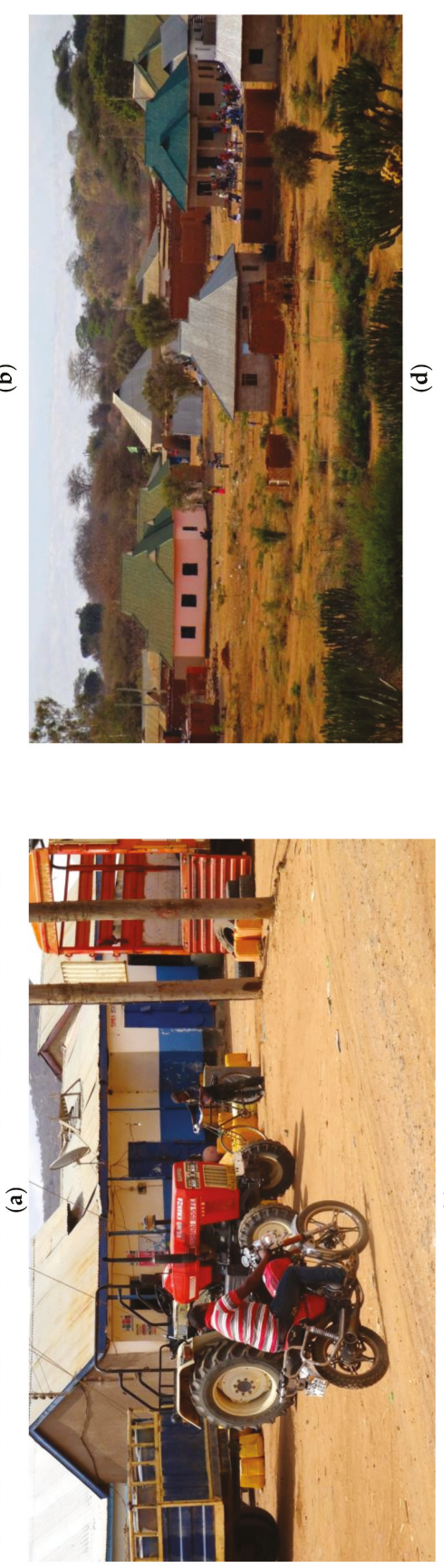

:

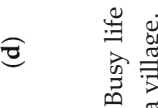

(2)

ลू

$\Rightarrow$

क्ष

灵

๕ี

हुँ

흥

के च्ट

) ฮี

造空

诖

올

之.

Ð

它高

कै छ

궁

돈

อิ

๑ ฐั่

过

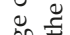

章

5 के

है क्ञ

苛

ङ

ن

总 
Mirambu village is, currently, less obviously changed than Goima in terms of its buildings. It is slightly more off the beaten track, being located some five kilometres from the main Kondoa-Kiteto gravel road, and the road accessing it is small and not well maintained, being better suited to carts than cars or lorries. The village does not look that different from how it was 25 years ago, although there now are more houses, and the farming areas have been expanded considerably (Figure 3a). The primary school has been extended and it is well-maintained. There is a new grinding mill making noise that is close to the village office, which looks just as it did 25 years ago. The 'truly' modern houses in Mirambu are few. In fact, so unusual that they act as village landmarks, with people saying, "you go left at the modern house with the green roof" or "the turning is just past the modern house with the red roof".

In both villages commercial life has expanded dramatically (Table 2). In Goima, shops are almost four times as many as they were 25 years ago. The number of grinding mills and oil presses have more than doubled. There are now seven tractors based in Goima as compared to just one in the early 1990s, and 35 motorcycles when compared to five before, and 128 ploughs. Likewise, Mirambu is today better endowed with facilities when compared to the early 1990s. There are three tractors, three power tillers, and three grinding mills in the village, 28 motorcycles, no less than 106 ploughs (in a village of 672 households), and 25 solar panels.

Table 2. Commerce and Infrastructure Changes.

\begin{tabular}{|c|c|c|c|c|c|c|}
\hline & \multicolumn{3}{|c|}{ Goima } & \multicolumn{3}{|c|}{ Mirambu } \\
\hline & 1992 & 2007 & 2016 & 1992 & 2007 & 2016 \\
\hline Shops & 3 & 8 & 11 & 2 & 4 & 7 \\
\hline Canteens & 8 & 10 & 9 & 2 & 3 & 4 \\
\hline Tractor & 1 & 2 & 7 & 2 & 1 & 3 \\
\hline Power tiller & & & & & & 3 \\
\hline Lorry & & & 2 & & & 1 \\
\hline Car for hire & & & 1 & & & 0 \\
\hline Motorcycles & 5 & 5 & 35 & & & 28 \\
\hline Grinding mill & 2 & 3 & 5 & 1 & & 3 \\
\hline Oil press & & 1 & 3 & & & \\
\hline Spray pumps & & 1 & 3 & & & 2 \\
\hline Hardware & & & 1 & & & \\
\hline Timber sale & & & 1 & & & \\
\hline Motorcycle spares & & & 1 & & & \\
\hline Motor cycle repair & & & 2 & & & 1 \\
\hline Bicycle repair & 1 & 1 & 3 & 2 & 2 & 3 \\
\hline Blacksmith & 2 & 2 & 1 & & & 4 \\
\hline Tailor & 3 & 4 & 11 & & & 8 \\
\hline Carpenter & 2 & 2 & 3 & 3 & 2 & \\
\hline Radio repair & & 1 & 3 & & 2 & \\
\hline Butchery & 2 & & 2 & & & 1 \\
\hline Pharmacy & & & 1 & & & \\
\hline Charging telephones & & & 5 & & & 6 \\
\hline
\end{tabular}

One of the biggest changes to the area is water supply. In the early 1990s, the water situation was desperate. At least one member of most households, often a child, spent hours every day during the long dry season drawing water for household needs from wells that were dug deep into dry riverbeds situated kilometres away from home. Any discussion about farming and livelihoods started and ended with the comment "if only it rains" ([46], p. 31). What can you do when there is not enough water for people, crops, or livestock?

Today, there is a large water body at Adia in a valley that is just west of Goima. In 2016, a large earth wall was constructed leading water from a gully into the area and a shallow lake developed. In November 2016, just before the rainy season, it still contained water. Livestock could be watered 
closer to home instead of taken to distant watering points at Kelema River. People could also get water from wells in the sand fans immediately below the new water reservoir (and prefer to take water from such sites because the sand filters some of the dirt). Furthermore, at the neighbouring village of Jenjeluse, a successful borehole has been installed, and two entrepreneurs ferry water with tractors to Goima, which they sell at a small profit. The changes that access to water has brought to the village cannot be overestimated (Figure $3 b, c$ ). It is for this reason that people have been able to expand livestock herds and take on new building projects.

The water situation has improved also in Mirambu when compared to the early 1990s. A Christian NGO, Compassion, has drilled a borehole for a children's support centre that they have run in the village since 2014 (but it was broken in December 2017 on our return visit). They offer water for households for $100 \mathrm{Tz}$ sh a jerry can (about US\$ 0.05 at the time of writing). The new lake at Adia similarly eases life for the Mirambu livestock keepers.

There has also been considerable population growth. The number of households in Goima grew more than 2.5 times from 1991 to 2016, from 507 to 1350, and in Mirambu, it almost doubled, from 350 to 672. The increase is faster than the annual population increase in the Dodoma region, which was $2.1 \%$ during the last inter-censal period 2002-2012. Both Goima and Mirambu have attracted immigrants, and Goima particularly so, the majority (according to key informants) being from the neighbouring Kondoa highlands.

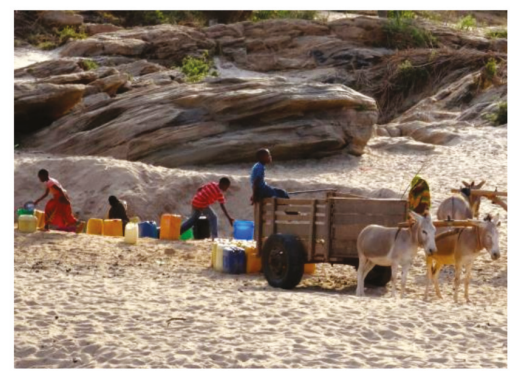

(a)

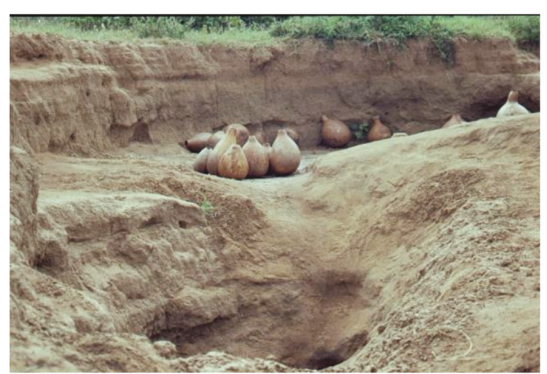

(b)

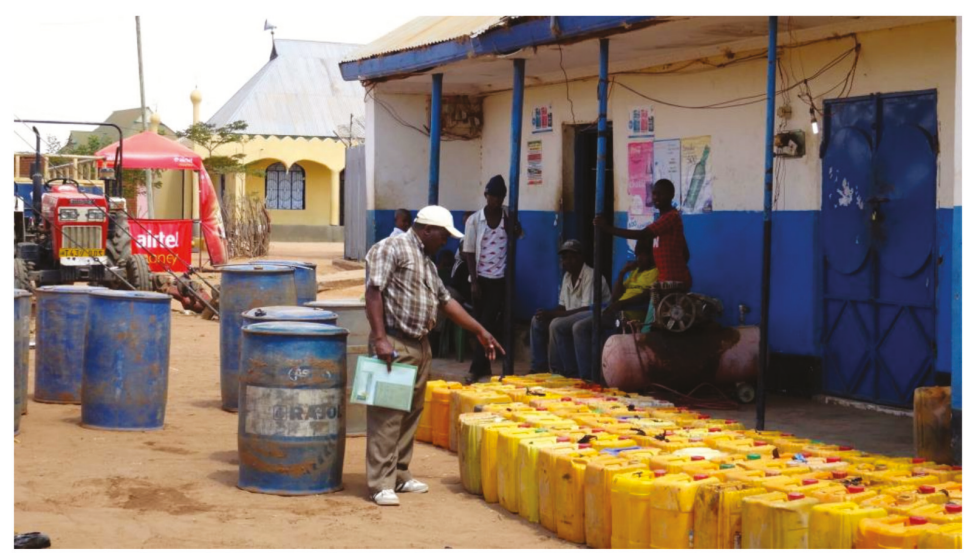

(c)

Figure 3. (a) Drawing water from shallow wells in dry river bed. (b) Gourds lined up to be filled with water from shallow wells dug in a dry river bed, 1991. (c) Household water on sale at Goima village centre, 2016. 


\section{Findings from Revisited Families}

Impressions such as those that we have just described above are notorious for concealing other dynamics. The appearance of new trappings of wealth makes it seem that people as a whole have benefited. However, it is possible that the original inhabitants do not share in the new prosperity. Indeed, worse than that it is possible that earlier residents may have suffered in some way, experiencing displacement or land loss to make way for a new set of economic actors. So, how are the changes described above reflected in the lives of the families who Mduma and Östberg visited in the early 1990s?

Briefly put, it appears that most have prospered, and they are prospering because they are able to farm more. In the early 1990s, farming in Goima and Mirambu was largely undertaken with hand hoes with $64 \%$ and $66 \%$ of land cultivated thus (Table 3). Land was cultivated for a limited period and fallowed to allow fertility to be restored. Many fields looked more like clearings in the forest than a cultivation steppe ([46], pp. 58-66). Families typically owned two or three fields, of which one often was a newly opened field in the Burunge Hills. It was a period of expansion of farm land. In both Goima and Mirambu, the median size of cultivated land was three acres (1.2 ha), while the mean land owned was 6.7 acres (2.7 ha) and eight acres (3.2 ha see Table 4$)$.

Table 3. Mode of cultivation (\%) in Goima and Mirambu villages, 1991/3 (farmers) and 2016 (plots).

\begin{tabular}{ccccc}
\hline & Goima 1991/3 & Goima 2016 & Mirambu 1991/3 & Mirambu 2016 \\
\hline Hand hoes & 64 & 17 & 66 & 31 \\
Ox plough & 18 & 18 & 27 & 25 \\
Tractor & 18 & 65 & 7 & 44 \\
$n$ & 50 & 54 & 45 & 127 \\
\hline \multicolumn{2}{c}{ Note. Goima: $\chi^{2}=29.84, \mathrm{df}=2, p<0.001 ;$ Mirambu: $\chi^{2}=13.07, \mathrm{df}=2, p<0.002}$.
\end{tabular}

Table 4. Land farmed (acres) in Goima and Mirambu villages 1991/3—2016.

\begin{tabular}{ccc}
\hline & Goima & Mirambu \\
\hline Average land farmed 1991/3 & 4 & 3.7 \\
Average land farmed 2016 & 6.5 & 7.4 \\
$n$ & 14 & 26 \\
\hline
\end{tabular}

Note. This table only uses paired families from the original visit and subsequent revisit; excludes 5 outlier families from 1993. Pair Sample test for both villages: $t=-2.279, \mathrm{df}=39, p<0.029$.

By 2016, the mean cultivated area (not the area owned) had increased, in Goima to 6.5 acres (2.6 ha) and in Mirambu to 7.4 (3 ha see Table 4). The extensive land use has been made possible by improved farming technology. The dominance of hand hoes has been replaced by the dominance of tractors in Goima (65\% of farmers ploughed their land with tractors, $44 \%$ in Mirambu). Levels of ox ploughing remain unchanged. Now, only minorities (17\% in Goima and 31\% in Mirambu) cultivate land with hand hoes (Table 3). This growth of farms is clearly visible in the landscape with much more land, on the plains and in the hills, put to use.

The expansion of land used is particularly important because the local definitions of poverty here (and indeed throughout the other 28 villages we have worked in as part of this project) associate poverty not so much with landlessness as with an inability to use land owned properly because the families lack the capital, labour or liquidity to do so. Working land well requires money for ploughing, good seeds, manure, and/or chemical inputs. Poverty is expressed by not being able to use land as well as one might-by not being able to generate an income from assets. Thus, the expansion in land cultivated, being made possible by greater access to tractors, is both likely to be a driver of wealth increase (it increases production and returns) and an expression of that greater wealth.

The farming boom in Goima and Mirambu is not associated with intensified production. In the early 1990s no Goima or Mirambu farmers in our sample used any farm inputs. The picture had not changed by 2016. Only four per cent of the farmers in the Goima and Mirambu samples for the early 
1990 used manure in their fields, and quite sparsely at that. In 2016, five per cent of the Goima farmers used manure, while none in the Mirambu sample did. A district by-law stipulates that manure must be removed from the cattle enclosures and used in the fields. This was rarely enforced at the time of our visit. Villagers cited lack of transport and fear that manure increased pest incidence. Now five per cent of the Goima farmers used improved seeds, but other farm inputs were not used. Neither in Goima, nor in Mirambu, do any shops stock improved seeds. In this respect, Goima and Mirambu are still, in 2016, relatively remote outposts.

Yields of maize are much higher now than in Östberg and Mduma's first survey (Table 5). But the comparision is unreliable as they collected yield data during a particularly dry period when respondents were bemoaning their unproductive farms. Our hypothesis is that there has in fact been little real change in the productivity per unit area, unless it be derived from the different means of land preparation. Tractor ploughing can be more intensive and thorough than hand hoes, especially if performed more than once before sowing.

Table 5. Yield per acre $(\mathrm{kg})$ of different staple crops in the two study sites.

\begin{tabular}{ccccc}
\hline \multirow{2}{*}{ Crop } & \multicolumn{3}{c}{$1991 / 3$} & \multicolumn{2}{c}{2016} \\
\cline { 2 - 5 } & Goima & Mirambu & Goima & Mirambu \\
\hline Maize & 258 & 147 & 556 & 875 \\
Sorghum & 170 & 133 & 480 & 238 \\
\hline
\end{tabular}

Across all villages, yields in maize are significantly different: Mann-Whitney $U=208 ; Z=-2.914 ; p=0.004$. One acre is equivalent to 0.4 hectares.

Cash crops have grown in importance, as has trading. In addition to maize, bulrush millet, finger millet, and sorghum, people also grow sunflower, pigeon peas, green grams, cow peas, pumpkins, water melon, and others. Cash crops became important in the late 1990s, and particularly sunflower has a stable and good market. Village focus groups discussing our findings insisted that the most important cash crop that was driving the new found wealth was sunflowers.

Increased wealth in land is matched by the trends in livestock ownership (Table 6). In the early 1990s, 18\% of families owned livestock in both Goima and Mirambu. By 2016, 32\% of the households in Goima owned cows, and 38\% in Mirambu. There have also been a growth in the incidences of smallstock ownership. These are within bounds of normal statistically significant difference in Mirambu, and just outside these bounds in Goima. Mean herd size for cattle owners has risen substantially to 10.5 in both of the villages, from 2.7 in Goima and 0.6 in Mirambu. More cattle also means more livestock powered goods, such as carts and ploughs, which have increased almost five times (Table 7). In the early 1990s, 23\% of families in Goima had smallstock. This had risen to 39\% in 2016. In Mirambu, smallstock ownership has more than doubled from $23 \%$ of families to $49 \%$. There are signs that the increased wealth in Mirambu has in particular strengthened the cattle economy, while the increased resources in Goima have been used for improved housing, farm expansion, and education.

Table 6. Percentage of Families owning cattle and smallstock, Goima and Mirambu.

\begin{tabular}{ccccc}
\hline & Goima 1991/3 & Goima 2016 & Mirambu 1991/3 & Mirambu 2016 \\
\hline Cattle & 18 & 32 & 18 & 34 \\
Smallstock & 24 & 39 & 18 & 49 \\
$n$ & 51 & 34 & 45 & 41 \\
\hline
\end{tabular}

Note. Goima: $\chi^{2}=4.57, \mathrm{df}=2, p<0.1$; Mirambu: $\chi^{2}=12.4, \mathrm{df}=2, p<0.005$ 
Table 7. Ownership of livestock infrastructure Goima and Mirambu (total number).

\begin{tabular}{ccccc}
\hline & \multicolumn{3}{c}{ Goima } & \multicolumn{2}{c}{ Mirambu } \\
\cline { 2 - 5 } & $\mathbf{2 0 0 7}$ & $\mathbf{2 0 1 6}$ & $\mathbf{2 0 0 7}$ & $\mathbf{2 0 1 6}$ \\
\hline Ox ploughs & 27 & 128 & 23 & 106 \\
Donkey/ox carts & 8 & 24 & 8 & 13 \\
\hline
\end{tabular}

Note: Ploughs and carts were not counted in the first survey.

The consequences of this growing agriculturally-based prosperity are visible in three ways. First in changes to employment practices, second in buildings, and third in commerce. In both villages, casual work (called kibarua in Swahili), which was the affliction and economic mainstay of the early 1990s, has in 2016 been reduced, indeed, the proportion of people that are undertaking it has generally halved (Table 8). Moreover, as we explore below, casual labour now has a different meaning from previous eras. It is not just a sign of poverty, but has also become a strategy of increasing wealth.

Table 8. Casual Work Goima and Mirambu villages (proportion of sample).

\begin{tabular}{ccccc}
\hline & Goima 1991/3 & Goima 2016 & Mirambu 1991/3 & Mirambu 2016 \\
\hline Employing casual labour & 22 & 21 & 15 & 15 \\
Performing casual labour & 76 & 44 & 73 & 39 \\
$n$ & 42 & 34 & 40 & 41 \\
\hline
\end{tabular}

Note. Goima: $\chi^{2}=5.8, \mathrm{df}=1, p<0.02$; Mirambu: $\chi^{2}=16.0, \mathrm{df}=1, p<0.001$.

Asked about what the main changes during the last decades were, people commonly emphasised that they now live in better houses and that all children attend school. Östberg and Mduma did not record housing quality 25 years ago, simply because virtually all the people at that time lived in tembe houses (wattle and daub houses with mud roofs). In 2016, 76\% of people in Goima lived in houses with galvanized metal sheet roofs, which was mentioned in focus groups in both Goima and Mirambu as a key signifier of wealth. In Mirambu, $67 \%$ of interviewees lived in houses with roofs that were covered by metal sheets. This is a clear change to the early 1990s when only the very richest families lived in houses of this type.

It is important to report, however, that while records of assets and farming activity show all these increases, people's own perceptions of their lives are not as positive (Table 9). In Goima and Mirambu, a majority of people ( $56 \%$ and $61 \%$ respectively) thought that life was better before-and this reflects the views of the female headed households who tended to prefer their earlier lives. In some respect, this should not be surprising as many people were recalling the times of their youth when they were healthier and more vigorous. Some people also feel strongly about how the forests in the hills now are gone, and they worry that there is less land that is available for the next generation. Assets provide only a partial insight into the nature of social change in these localities. We provide more of the the details of the changes in Appendix A.

Table 9. Is life better or worse now than at the last survey by village and gender of the domestic unit head.

\begin{tabular}{ccccccc}
\hline & \multicolumn{3}{c}{ Women } & \multicolumn{3}{c}{ Men } \\
\cline { 2 - 7 } & Better Now & No Difference & Better Before & Better Now & No Difference & Better Before \\
\hline Goima & 4 & 1 & 11 & 9 & 1 & 8 \\
Mirambu & 1 & 2 & 5 & 11 & 2 & 20 \\
\hline
\end{tabular}

In the 1990s, in both of the villages, well-off families were those who could feed themselves. The catch-all term that villagers used to rank the households was uwezo (strength, ability), or their nafasi (literally 'space', but here, rather 'possibilities'). Those who were poor were described as people 
who lack strength (hana uwezo). The guiding principle was a household's ability to cultivate the land, rather than the size of the land holding itself. Capacity to plough with oxen or tractors and to hire farm labour meant that a household was regarded as well-off. Note that wealth was not necessarily about owning the oxen (or tractors) per se, rather it focussed on the potential to produce food and to solve problems. The poorest families were those who had to work as farm labourers to meet their daily needs, and in there was also a category of people who were dependent on others to survive ([46], pp. 42-3).

Wealth rankings in 2005 provided findings that were rather similar to the 1990s. More than half of the households struggled to support themselves from their own farms. Day labouring continued to be an important aspect of life in the villages. Farm size had now become more important as a criterion of wealth ([54], pp. 141-2).

In 2016, the number of wealth groups and their definitions were self-determined by participants in a focus group setting. We then assigned households from the village lists to these groups. This exercise highlighted two major changes. First, the significant majority of the families that were currently living in the villages were classified by villagers as being of medium wealth. Poverty (locally defined) is not the dominant experience. There seems to have been an expansion of the middle group, with the poorest categories contracting (Table 10). This is particularly important, as it suggests that the changes of the longitudinal surveys are matched by broader changes in the village as a whole.

This shift matched local perception of some changes. In Mirambu, our informants said that the big change is that many poor households have moved to the category 'ordinary people', and that many now live in sun-dried or baked brick houses, while previously almost all lived in tembe houses. In Goima, they noted that the support of the Tanzanian Social Action Fund (TASAF), which provides financial support to the poorest families, was influential.

Table 10. Changing Wealth Profiles-proportion of families in different wealth classes.

\begin{tabular}{lcccccc}
\hline \multirow{2}{*}{ Wealth Group } & \multicolumn{4}{c}{ Goima } & \multicolumn{3}{c}{ Mirambu } \\
\cline { 2 - 6 } & $\mathbf{1 9 9 3}$ & $\mathbf{2 0 0 5}$ & $\mathbf{2 0 1 6}$ & $\mathbf{1 9 9 3}$ & $\mathbf{2 0 0 5}$ & $\mathbf{2 0 1 6}$ \\
\hline 1 & 2 & 4 & 0.5 & 2 & 8 & 6 \\
2 & 45 & 41 & 64 & 48 & 37 & 71 \\
3 & 53 & 55 & 35 & 50 & 55 & 23 \\
Note. Goima 2005-2016: $\chi^{2}=76.6, \mathrm{df}=2, p<0.001 ;$ Mirambu $2005-2016: \chi^{2}=43.4, \mathrm{df}=2, p<0.001$. \\
Wealth group 3 follows the Mirambu classification in Table 11, which combines categories 3 and 4 of the \\
2016 categories \\
We have grouped categories 2 and 3 of the 1991/3 survey into category 2 of the 2016 survey \\
We have grouped categories 4-6 of the 1991/3 survey into category 3 of the 2016 survey \\
We have grouped categories 4-6 of the 2005 survey into category 3 of the 2016 survey \\
Note that in 2016 Goima is based on the complete village lists and Mirambu from some sub-villages \\
\hline
\end{tabular}

Second, there is considerable shift in the meaning and definition of wealth, as described by our focus groups (Table 11). In the 2016 wealth rankings, uwezo remained the factor upon which wealth is determined, but this now means new things. To be able to afford health care, and to pay for educating one's children, as well as quality of housing, were now factors that our informants in Goima emphasized. Investments, like owning a tractor or a milling machine, were points of reference for the most wealthy. Trading now also appeared as a means for people to better their lives. These all indicate a more diversified economy and improved livelihoods. 
Table 11. Changing Definitions of wealth Goima and Mirambu villages, 1991/3-2016.

\begin{tabular}{|c|c|c|c|c|c|}
\hline $\begin{array}{l}\text { Wealth } \\
\text { Group }\end{array}$ & Goima 1991/3 & Mirambu 1991/3 & $\begin{array}{c}\text { Goima and } \\
\text { Mirambu } 2005\end{array}$ & Goima 2016 & Mirambu 2016 \\
\hline 1 & $\begin{array}{l}\text { The rich, those who } \\
\text { can do anything }\end{array}$ & $\begin{array}{l}\text { The rich. Tractor. } \\
\text { Maize mill. }\end{array}$ & $\begin{array}{l}\text { With resources. } \\
\text { Ploughing. } \\
\text { Employing farm } \\
\text { labour. Livestock. }\end{array}$ & $\begin{array}{c}\text { Children at } \\
\text { university, } \\
\text { car/tractor/lorry/shop, } \\
\text { big land, sell crops } \\
\text { outside, grade cows. } \\
3 \text { meals a day. }\end{array}$ & $\begin{array}{l}\text { Command other people to } \\
\text { work for them } \\
\text { ("veranda farmers"). } \\
\text { Tractor. Bank account. } \\
\text { Livestock. More than } \\
100 \text { acres. Sell crops } \\
\text { outside. Eat well. }\end{array}$ \\
\hline 2 & $\begin{array}{l}\text { Those who have } \\
\text { resources. Can hire } \\
\text { tractor, employ } \\
\text { farm labour. } \\
\text { Salaried people }\end{array}$ & $\begin{array}{l}\text { Those with } \\
\text { resources, better } \\
\text { than average. Hire } \\
\text { tractor and farm } \\
\text { labour. } 8-12 \text { cows + } \\
\text { small stock. }\end{array}$ & $\begin{array}{l}\text { Of average ability. } \\
\text { Can support the } \\
\text { family on their land. } \\
\text { Able to manage } \\
\text { various needs }\end{array}$ & $\begin{array}{c}\text { Modern house, } \\
\text { use hospital, } \\
\text { Bicycle/motorbike, } \\
\text { employ farm labour, } \\
\text { livestock, small shop. } \\
\text { 5-20 acres. } \\
\text { Hire tractor. }\end{array}$ & $\begin{array}{l}\text { Average people. } \\
\text { 5-20 cows. Up to } 20 \text { acres. } \\
\text { Plough with oxen } \\
\text { or tractor. } \\
\text { Children at school. }\end{array}$ \\
\hline 3 & $\begin{array}{l}\text { Average ability. } \\
\text { A few cows and } \\
\text { small stock. Can } \\
\text { afford help with } \\
\text { the farming. } \\
\text { Harvest last } \\
\text { through the year. }\end{array}$ & $\begin{array}{l}\text { Average ability. } \\
\text { A few cows and } \\
\text { small stock. Can } \\
\text { afford help with } \\
\text { the farming. } \\
\text { Harvest last } \\
\text { through the year. }\end{array}$ & & $\begin{array}{l}\text { Children at school, } \\
\text { cannot afford to hire } \\
\text { farm labour, } \\
2-5 \text { cows. } \\
\text { No surplus. }\end{array}$ & $\begin{array}{l}\text { The poor. } 2-5 \text { cows. } \\
1 \text { or } 2 \text { acres of land. } \\
\text { Undertake casual work. } \\
\text { Children not at school. } \\
\text { Eat only once a day. } \\
\text { No medical care. }\end{array}$ \\
\hline 4 & $\begin{array}{l}\text { Poor, managing by } \\
\text { doing casual work. } \\
\text { No margins }\end{array}$ & $\begin{array}{c}\text { Poor but with } \\
\text { ability, must } \\
\text { undertake casual } \\
\text { work. Vulnerable }\end{array}$ & $\begin{array}{l}\text { Poor, but with ability. } \\
\text { Do farm labour. } \\
\text { Almost half the } \\
\text { population. } \\
\text { A vulnerable group. }\end{array}$ & $\begin{array}{l}\text { Poor, "everything is } \\
\text { a problem". } \\
\text { No assets. } \\
\text { Day labouring. } \\
\text { Children not in } \\
\text { school. Looking after } \\
\text { other's livestock. } \\
\text { Dependant on others }\end{array}$ & \\
\hline 5 & $\begin{array}{c}\text { Those who depend } \\
\text { on others }\end{array}$ & Need help & $\begin{array}{l}\text { Needing and } \\
\text { getting assistance }\end{array}$ & & \\
\hline 6 & The helpless & & Destitute. & & $\begin{array}{c}\text { The destitute. Depend on } \\
\text { others. Live in other } \\
\text { people's houses. }\end{array}$ \\
\hline
\end{tabular}

Note. farm size is expressed in acres as this is what Tanzanian farmers use. 1 acre is equivalent to 0.4 hectares.

In Mirambu, the meaning of poverty has changed: the poor are now defined as those who have 'only' a few cattle, and these are put in the same group as those who have none and have to do casual work to keep going. In other words, without things that were once the property of a privileged few, people are currently counted as poor. So, not only are there more wealthy families, but the standards of what it means to be wealthy have risen.

Moreover , the meaning of the activities that defined poverty in the 1990s (casual labour) has changed. In the 1990s, payment was low, often the load of grains that you could carry home after a couple of days' or a week's work. Attendance to the home fields suffered, meaning reduced harvests, in addition to the strain on family life with one or more adults being away from home for long periods. In 2016, the situation was different. We were told that people could undertake casual work not just to 'hunt for food, but (also) to better their lives', as a participant in a focus group in Mirambu formulated it.

\section{Drivers of Change}

What could explain the changes we have described above? We do not have the sample sizes or experimental design to be able to quantify any of the factors that we have discussed. Instead, we present here a qualitative account of the possible factors, drawn from our key informants, interviews and focus groups, as well the academic literature.

First, it is plain that the improved infrastructure and communications networks have made a great difference to the availability of consumer goods and the prices that can be obtained for agricultural products. But, interestingly, our informants were not as concerned about the infrastructure per se as with the mindsets and attitudes of residents. One such change is that there is less alcohol consumption. 
According to both local businessmen and leaders, people used to be away for days, 'following pombe (alcohol). However, they have now come to their senses' (while) 'those who continue with pombe remain poor' (Goima interview, 10 November 2016), and there appears to be less money being spent on local brews than previously. We have no data to test whether this change has happened or not, but if drinking has declined drastically there seem to be two factors responsible: one is a revivalism within the Christian community and the expansion of Islam. The other is that incomes have increased so much that people can afford to improve their houses, pay secondary school fees, buy better clothes, invest in solar panels, motorcycles, televisions, and other consumer durables. Some may be drinking less because there are other things to do with their money.

Another prominent driver of the changes in local eyes is changing attitudes towards farm work. This came up in discussions about rain. In the 1990s people said that if only it rains everything would be fine. But now, some informants objected to that view, as one put it:

'What matters is that you work. Not the rains. That you all the time think that you can do better. People used to be content with cultivating two acres $(0.8 \mathrm{ha})$ growing bulrush millet. Yes, they got food enough to feed the family. But what is that? It was when people turned to commercial crops that things started to change. When they grasped that they could earn money, they also started to work, and not just roam around'.

Some observers suggested that the greater desire for money reflected more social diversity and specifically immigration. Immigrants, we were told, stimulate the community: 'they came and they worked'. They start new activities, and they make use of the land and earn money from farming, in turn motivating others. It also mattered that young people from the area had been working in other places and discovered fresh opportunities: 'then they want progress also for themselves'. When money is available, traders arrive, and people are stimulated to grow commercial crops, and the economy grows.

Another factor has been the role of wealthy entrepreneurs who dominate the booming grain trade in Goima and Mirambu. They have played decisive roles in bringing about the transformation, particularly in Goima village. Their modus operandi involves a mixture of good business knowledge and practices that allow for them to make money out of their neighbours' poverty and poor bargaining position, combined with instances of more philanthropic activity. For example, as many farmers cannot afford to hire a tractor, they ask the entrepreneurs to plough for them and as payment for the service the tractor owner will get access to half the ploughed land for the cultivation season. In this way, the entrepreneurs get access to farmland at a low cost. They also act as an informal bank. People in need of cash ask for a loan, which after the harvest will be repaid in grains at a predetermined price below the market value (up to as much as a third of the price), and the trader increases his margins considerably.

The entrepreneurs have also invested in village infrastructure, and with it have built up their social capital. Two of them ferry in water to Goima village from the government-financed borehole in the neighbouring village of Jenjeluse and sell it at a price that all agree is below the market value of the service. With this service, the two traders have solved the problem of household water in Goima for all who can afford the sum that is charged. One of the traders in 2015 hired a grader to construct a sizeable earth wall to lead water from a gully into the low-lying area at Adia, west of Goima and northeast of Mirambu, as we mentioned in the introduction. The same person also created two smaller dams in the village, which do not contain water year-round, but he plans to extend these so that they will. He furthermore contributed TZS 30 million (c. US\$13,500), according to local hearsay, to the newly built mosque in Goima. Initiatives like these have made the grain traders appreciated in Goima.

Other factors are likely to be at work, but we can only mention their possibility, we do not have the qualitative or quantitative data to examine them. First, many long term observers in Tanzania will recognise that wealth accumulation has been constrained in rural areas of the country due to the fears of jealousy and witchcraft. This, in turn, is sustained by notions of 'limited good', which sees the pursuit of wealth as a zero-sum game [55]. What one person enjoys you cannot. Personal advantage therefore has to be gained at someone else's expense. Fear of retalitation by ones' neighbours constrained wealth 
creation. This is clearly not constraining the wealthier entrepreneurs, and the discourse of jealously is notable for its absence in our most recent fieldwork, especially when compared to previous visits.

Second, crop prices are likely to have played a role in wealth creation. However how they have done so, when and for whom is difficult to disentangle from these data. As several researchers have observed, where most poor farmers in fact purchase more food than they produce then crop price increases must, logically, increase household expenditure and make people poorer [56-58]. Only relatively few farmers who are net food producers will prosper from the higher prices. Thus, it is possible that one of the factors that made people wealthier in these villages was the low food prices when most of the families were net food consumers. However, as they have got richer and started farming more, so more families will become net food producers. At this point. they will benefit from higher food prices. We cannot tell which dynamic is at work-both may work at the same time in that low prices for food crops, and high prices for cash crops will decrease outlays and increase income. Further research is required to understand these dynamics.

\section{Sustaining Beneficial Change}

Members of the local elite, the village officials, teachers, and entrepreneurs, are all optimistic about the future. More and more land is put under the plough and the demands for agricultural products is strong (Figure 4). Goima and Mirambu are booming. However, the entrepreneurs' optimism contrasts with many farmers' fears that their children will face difficulties in accessing land, and that the fertility of the land is reducing. It was plain from our transect walks, field observations, and discussions with villagers that the previous expansion areas in the Burunge hills have now been cleared of trees, and now new land is not so easily available. Signs of soil erosion were evident in many fields. This is in marked contrast to the situation in the early 1990s, when farmers described the Burunge Hills as an endless expanse of land, waiting to be cultivated whenever needs arose. There was a belief that soil would regenerate itself faster than it could be eroded. The forest, with its virgin soils, and re-generating power, was there to guarantee that life goes on ([46], pp. 53-58; 117-120).

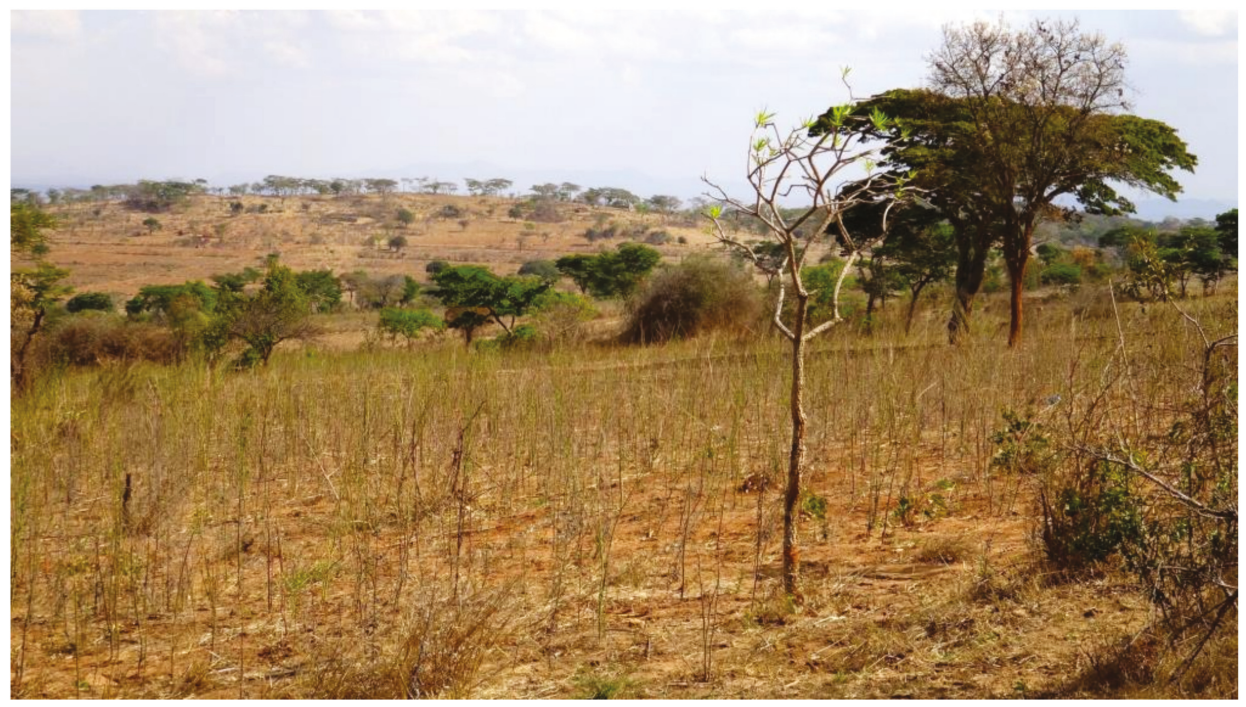

Figure 4. Newly opened fields in the Burunge Hills.

Fifteen years later, by 2005/6, local perceptions of natural resources had notably changed. Many farmers worried about increased drought, which is perceived to be driven by local reductions in 
forest cover. The opinion was shared by rich and poor farmers, men and women. However, the notion was particularly strong among female-headed and younger households, reflecting that female-headed households were less endowed with resources, and therefore, particularly vulnerable, while young farmers had a shorter memory of droughts ([47], p. 258). Rainfall records did not tally with the perceived increased severity of drought, but rather reflected a local interpretation of the diminishing resource base ([47], p. 255).

In 2016, the worry that clearings would result in diminishing rains persists. People argued that rain clouds gather over forests, and with the forests largely gone, the area will no longer attract rains. They felt that they were now facing a changed environment. Over 25 years the attitudes had moved from trusting that nature will provide, to a concern that the area's current farming bonanza may soon be over. The Burunge used to talk of good land as being 'cold', which when over-exploited turns 'hot', describing an environment where rains could be expected to a new situation where rain clouds pass without delivering. They describe the 'hot' land as 'pushing' the rains away.

Since the improved livelihoods that we documented in Goima and Mirambu are based on resource extraction and extensification, the situation is unlikely to be sustainable under current forms of land management. Land rehabilitation, soil conservation, and tree planting were the hallmarks of development policy in the Kondoa area for at least half a century [59-66], but are now history. The institutional set up for land rehabilitation work is no longer there. No government foresters are posted to the study area. There are no tree nurseries. 'There just is no environmental protection any longer. The village environmental committees should be empowered', one informant observed, while admitting that this is unlikely to happen. To sustain the improved living conditions of recent years, and to raise agricultural productivity, the conservation of farm land is essential.

\section{Conclusions}

In some senses, the changes that we have documented here are in accordance with country wide patterns. We have a situation of agricultural activity expanding through increasing the area that is farmed. This is entirely normal. A United States Department of Agriculture report covering 2001-2008 found that 69 per cent of the agricultural growth could be attributed to the expansion of area [67]. Only $17 \%$ of increased agricultural productivity was due to increased use of inputs and technical change ([68], p. 138). One assessment is that in Tanzania 'agricultural productivity has remained stubbornly low' and that the use of agricultural inputs is quite low ([12], p. 64).

But, in other respects, our findings are new and strange. Using local measures of wealth and measures of assets, people here appear to be substantially wealthier. This is contrary to the pessimistic interpretations that saw little return of economic growth to rural people. It is also contrary to perceptions of the agricultural sector as being relatively stagnant and unresponsive to change.

The most striking change since the early 1990s is that most households can now support themselves on their land, and many do this on a substantially improved living standard, while 25 years ago, half the number of households survived only with the help of underpaid day labour. We have described how some differentiation of the economy has indeed taken place, but life in the study area remains firmly anchored in the land. Agriculture is what people live from, and it is their ability to use the land that lies at the core of how people define wealth and well being in Goima and Mirambu today.

Living standards were very low in the early 1990s, by 2005/6 the pattern of social stratification remained similar, while by 2016 many people had moved up the local ladder of progress. If this is sustainable or not will depend on the extent to which farming productivity can be raised, how off-farm income possibilities develop, and how farmers manage their environment.

This finding is important because it suggests that the radical critics may be overlooking important forms of local economic dynamism in their arguments. Indeed, some radical critics already complain that their colleagues' theories are too totalising, and foreclose the possibilities of positive change. Henry Bernstein observes that: 
'the assumption of generalised persistent/'permanent' rural poverty gives no analytical purchase on such questions as: why are some farmers/rural people not poor? Which and why? What are the trends of rural poverty?' ([69] page 173 emphasis in the original).

Our work suggests that by using local measures of wealth, far more dynamism becomes visible. Rural societies in Tanzania, even in its poorest regions, are more varied than the theories of persistent poverty suggest.

However it does not follow from this finding that the neoliberal optimists' exhultation in the success of the country are justified. Not least we should note that neoliberal optimists were concerned about agricultural stagnation and low productivity. In this respect, our findings provide more succour to data challengers than to people who want to celebrate the achievements of economic growth.

It is also important to recall that the changes we have observed may not be as driven by national level change as they might first seem. Local interpretations of the changes emphasise that they are driven from within. The infrastructural change (new roads and transport facilities), like the abundance of land, provides enabling conditions. Similarly, the growth of the Tanzanian economy, with its greater demand for agricultural goods, and its cheaper provision of things, like motorbikes and metal roofing, stimulate growth. But, they are merely that: stimulants. They are not, in themselves, responsible for the improvements we have documented.

Rather, in local parlance, change in these villages derives from the initiative of the villagers themselves. Many emphasize the driving role of locally based entrepreneurs. There is talk of a new ethos of hard work, in a way reverberating with sentiments from the socialist post-independence era. That it is local initiatives, responding to outside opportunities, that transformed Goima and Mirambu, echoes experiences from other places, like Giting village in Hanang District [39], Rukwa Region [70]; from Kagera [71], and from Sibou village in Marakwet County, Kenya [72]. The triggers differ, but what is common is that large-scale outside, technical (green revolution-type) interventions are remarkable for their relative absence. They can cause change [73], but they are not necessary for change to occur. It can be locally driven and incremental.

We do not have the data to test the power of this interpretation, but it is important to note it. Further research that allowed for the researchers to distinguish between exogenous factors such as infrastructure and marketing arrangements, and endogenous factors, such as attitudes to wealth and work, are required.

In a 25-year perspective, the changes are dramatic, as we have reiterated throughout this article. However, when comparing the village to other Tanzania villages, Goima and Mirambu look ordinary. What is so special with a good range of shops, a communication tower, buses, a secondary school, and a new spacious mosque? Well, perhaps little. But, this is our point. For it is precisely this mundane but widespread change that might tell a wider story of improved livelihood conditions in other peripheral parts of rural Tanzania. Goima and Mirambu are, as Tanzanians would put it, 'catching up', and becoming ordinary, whereas just 25 years ago the story was quite different. If Goima and Mirambu are just like any Tanzanian villages, then we need to look at the stories that their mundane asset growth portray in order to get a richer picture of the nature of social and economic change in the country as a whole.

\section{Materials and Methods}

Field data were collected by Mduma and Östberg in Goima and Mirambu villages during the years 1991-94, and reported in a monograph [46]. They made follow-up research visits in 1997, 2006, and 2007. Further background information on the study area and primary data are also available in Slegers \& Östberg [54] and Östberg \& Slegers [47].

The data from the early 1990s derive from participant observation, semi-structured interviewing, transect walks, participatory mapping, wealth and problem rankings, focus group discussions, village asset inventories, reporting back-seminars ([46], pp. 10-14, 6-40, 49-51, 108-111, 221-222), and from surveys that were based on a ten per cent random sample of households in both of the 
villages. The surveys were focused on farming, land management and livelihoods, and they provide the benchmark from which the 2016 situation is evaluated.

The two villages were restudied in November 2016 by Howland, Mduma, and Östberg, together with Cuthbert Mwanyika and Einhart Mwanyika. All of the still existing households from the original study were located with the help of the respective village chairmen and secretary, and were interviewed. When the original informant was no longer available, a close relative (a spouse or a child) was interviewed. In addition to formal interviews and conducting questionnaires with farmers, we arranged focus group meetings, separately with men and women, in both villages (Goima women 9, men 10; Miramu women 7, men 10), and conducted semi-structured interviews with a number of informants from our original study in the early 1990s, with village leaders, subject specialists, entrepreneurs, teachers, shop keepers, religious leaders, traditional specialists, and as many villagers as we found time to engage in conversations during our weeks in the villages. These were combined with and entailed long walks through the landscape in which we assessed forest cover change, from our own observations and in conversation with villagers. The survey work and interviews were conducted in Swahili.

The wealth rankings that were done in 1991 were based on our ten per cent random sample of households. A step-by-step procedure was followed to identify the criteria for wealth that local informants applied, and the number of wealth groups that they used to describe the economic differentiation in the village (the procedure is accounted for in 46, pp. 36-40). The sample households were then ranked by selected well-informed villagers, both in individual exercises and in group sessions. The 2005 and 2016 wealth rankings were likewise based on criteria for wealth that was generated locally. The ranking in 2005 followed the same procedure as in 1991, backed up by the familiarity with the area derived from long-term field work. In 2016, the ranking was done during two focus group sessions in each village.

The data from the original household surveys have been digitalised and anonymised. The 2016 data were digitally recorded in the field using the Open Data Kit app, which allowed for coded version of the questionnaire to be uploaded in app form and then administered using Android devices. These data could then be sent to a central server, to prevent the risk of loss or corruption of data, and later downloaded in an Excel format for ease of analysis. Thus, both the field work in the early 1990s and the one in 2016 used a combination of qualitative and quantitative methods, and utilised the original researchers' familiarity with the area built up progressively over several years.

We then analysed the data to explore what changes had occurred, many of which have been presented in the present paper. Subsequently, we undertook a second visit to the villages to present these findings to villagers and ask them what they made of the changes and why they thought people appeared to have become richer. This took place in February 2018, with two focus groups (Goima women and men mixed, 15 people; Mirambu women 5, men 8), and have been incorporated into the present draft.

Acknowledgments: The authors gratefully acknowledge the support of the DfID ESRC Growth Research Programme (ES/L012413/2) which has funded this research project and of the Research Council of Norway which has supported this work through the Greenmentality project. Östberg gratefully acknowledges support from The Royal Swedish Academy of Letters, History and Antiquities. We are grateful to three reviewers, and to Sheona Shackleton, Hobart Mu and Viola Gao for their comments on earlier drafts, and to the residents of Goima and Mirambu for answering our questions and discussing the findings with us.

Author Contributions: Fieldwork was undertaken by Östberg, Mduma and Howland. The paper was drafted first by Östberg with inputs from Howland and Mduma and further writing and data analysis support from Brockington.

Conflicts of Interest: The authors declare no conflict of interest. 
Appendix A. Short Biographies Introducing Some of the Interviewed Households in Goima and Mirambu Villages

\section{Appendix A.1. Goima Village}

Farmer \#Goima 012 in our sample. In the early 1990s this farmer was in his 40s, a man with a clear plan for his farming. He was doing well at the time, and the family belonged to those who could support themselves on their land. There was no erosion on his land, and they cultivated with ridges. The harvest was more than satisfactory, although less than what they expected in a good year. They counted 53 bags of grains (apart from bulrush millet which he grew but where we did not record the figure) plus beans, cowpeas, pigeon peas, gourds, sweet potatoes, pumpkins, castor. They did not plough, and managed the farm with the help of casual labour.

Today this informant is prospering. He now owns 26 acres (10.5 ha compared to 18 acres7.3 ha-in 1992). He employs casual labour. He owns livestock, and a motorcycle. He has moved closer to the village centre. He has made use of the new possibilities to grow cash crops, and from the profits he has bought land, and built a new house. His children finished primary school, and are now successful farmers. From a solid base, his life has improved further.

\#G073. In 1991 this was a young, recently married family. They had 6 acres (2.4 ha), cultivated with hoes, using ridges, and lived in a modest house. The harvest was adequate at 12 bags of grains plus sunflower, cow peas, pigeon peas, and other "small crops". They started trading animal skins shortly after our visit. The proceeds from that trade helped them to gradually build a house with burnt bricks and an iron sheet roof, and to buy a bicycle. They bought goats and chicken. In 2005, they bought 10 acres ( 4 ha) of land, and they had a herdsman looking after the animals. They have now moved to the centre of the village to develop the skin trade. They have ten cows. Their house is connected to the electricity grid, they have a tv-set, sofa and coffee table.

\#G196. The household was ranked in wealth group 3 (of 6), which means that they were among those who could support themselves on their land. They had 4 acres (1.6 ha) of land, most of it cleared the last two years, and they added one more acre $(0.4 \mathrm{ha})$ in 1993.1 .5 acres $(0.6 \mathrm{ha})$ were cultivated with ridges and the rest flat. They harvested 7 bags of grains (below what they normally expect, but it was a dry year), plus cassava and a wide variety of small crops, including groundnuts and tomatoes. There were considerable problems with soil erosion in the fields. They had 40 beehives and sold both honey, wax and honey beer. They also brewed grain beer for sale. In addition to all this the farmer did woodwork (arrows, handles, etc.) for sale, and the family engaged in petty trade with dagaa (small fish) and salt. They had livestock and ten donkeys helped to bring water from the river some five kilometres away. The cattle enclosure was full of cow dung; i.e., not used in the fields. They lived on land that belonged to the wife's father, and we could not quite make out what animals belonged to him and what to our interviewee.

We returned in 2006, and now the family had doubled the farm size. The erosion problems remained unsolved. There was still no cut-off drain protecting the land, and no other conservation measures either. They hired casual labour (while in 1991 this farmer worked for others) and they received help from work parties. Generally, the economy seemed to have improved. Although they had livestock they did not plough. The manure was not used in the fields. Ten donkeys (!) were used for carrying water from River Dalai. The harvest was modest, and the family depended more on livestock, selling milk, than on farming.

Ten years further on, in 2016, they say life is difficult as the land is not fertile. The farmer now occasionally does casual labour. All the same, in 2014 they built a new house, using their own money, and a contribution from the parents in law, and in 2015 they had bought three goats and four ducks. They had five cows and two donkeys. They say that life was better in the 1990s.

\#G204. In the early 1990s, this farmer was one of Goima's richest persons, owning 32 acres (12.9 ha) of land and a large herd. The family got very good yields in newly cleared land at a distance from the village centre. They harvested 90 bags of grains as well as beans, pigeon peas, cowpeas, 
etc. This, the farmer said, was about half the normal harvest. They used cattle manure in the fields. They ploughed with both tractor and oxen, and used hired labour for the farm work. They also ploughed with oxen for others. The main income came from trading with livestock.

Today the farmer is dead and the sons and their families live on the farm. In 2006 they built a house with burnt bricks, cement floor and roof covered with metal sheets. It is equipped with solar panel. Soil fertility has gone down dramatically, and they continue to transport cow dung to the fields on oxcarts. There are many mouths to feed and they say life is more difficult now. Today they have 18 cows, 20 goats and 7 sheep.

\#G242. When we first met this farmer, she was a middle-aged, recently widowed woman living with her children in the hills above Goima. She was ranked in wealth group 4 (of 6), meaning that people did not think that the family could subsist from only their land. She cultivated 5 acres ( 2 ha), all with ridges, on sloping land, surrounded by forest. She had recently increased with two acres ( $0.8 \mathrm{ha}$ ) to allow two acres ( $0.8 \mathrm{ha}$ ) to stay fallow. She looked after livestock for others, and cultivated with the help of the children. She worked for others now and then, as did her sons. She was, at our first visit, upset because bee-hives had been stolen. "This could never had happened had my husband been alive".

We met her again in 2006. She was growing a wide selection of crops, some for the market but most for home consumption. Her sons were now married and lived with their families on the land. All the land was cultivated, using hoes. A work party had helped with weeding. It was a household in full swing.

Ten years later, 2016, only a grandchild lived with her on the farm. She was still using her old tembe house. She occasionally did casual work. Some of the land has been divided to other grandchildren. The cultivated area was smaller. She was in a phase of the life cycle when life become reduced, and she was not particularly happy to be interviewed while she had on previous occasions been quite helpful.

\#G333. The husband and wife were in their 30s in 1992, with four small children. They had moved five years earlier to the land they cultivated from land close to the village centre. They had been looking for more and better land. They cultivated only half of the 6 acres ( 2.4 ha, with ridges, across the slope) in 1992 because of the poor rains. In 1993 they opened a further two acres (0.8 ha). They had left the land in the village fallow. In the wealth ranking they were regarded as among those who can support themselves on their land, but in the dry year 1992 they harvested very little. To survive they sold goats and did day-labouring. They had 15 beehives, and the husband made bee-hives for sale.

In November 2016, they had recently moved back to the village centre to get closer to schools and services. The house was built by sunburnt bricks, and with a metal sheet roof. They had been successful with the previous move. Most years they reaped good harvests and they bought livestock. In 2013 they sold crops for TZS 300,000 (c. USD 135), which was invested in livestock. They now had ten cows, two donkeys and four goats. They are a modernising family where husband and wife take decisions together. Five children have been through secondary schools. Life has improved, they concluded.

\#G367. In 1991 their land was a clearing in the hills, about an hour and half's walk from the village centre. The farmer was a man in his 60s, who together with his sons and two more families, had returned to the place they had been evicted from during the villagisation campaign of 1974 . Now they had started a small settlement in the forest. It was a calm and pleasant life, and the first two harvests had been good. "If you come here next year, you shall see what we can do here". However, water entered the 3-acre field (1.2 ha), there were rills all over the place and emerging gullies. The 1991 harvest was poor.

We revisited in 1993. The farmer had been sick, and the cultivated area was now reduced. He harvested almost nothing, "no rains". The erosion problem had clearly grown worse. The farmer' solution, he told us, was to "leave for Matui to get new land if things do not improve". In addition to the land, the farmer had 60 beehives but only harvested 7 debe of honey a year. (A debe is a tin container, for kerosene, and re-used to measure and store grains, potatoes and other products. It holds roughly 
13-14 litres or kg. One might think that honey production could be a safe-guard in dry years but also flowers are affected by drought.) He prepared honey beer and sold. He also makes wood products that he sells in Mondo market, about $25 \mathrm{~km}$ away. He and the sons also worked as casual labourers to get food.

In 2016 the farmer was dead and his widow said that without fertilisers, which she could not afford, the land does not produce anything. The house was built by sunburnt bricks and had a grass roof. In 25 years the household had gone from a golden opportunity, on land that had been rested for 20 years, to bad lands.

\#G436. He is one of the farmers who said that life was better in the early 1990s. At the same time, our records tell that at that time his fellow villagers ranked the family in wealth group 4 (of 6), which means that they had to do day-labouring for their food. They experienced considerable problems with soil erosion on the land. They had 12 goats, and the family got extra income from selling local beer. The husband's parents helped with money for ploughing. Things were not that bright in the old days either, we could note.

Now he is divorced since 15 years. His house was destroyed by floods in 2015, and he has built a new house with walls of sticks and adobe and a roof covered with soil. The animals died about ten years ago, and he says he does not have much energy these days. He cultivates 3 of his 5 acres (1.2 ha of 2 ha). It was easier, he commented, when they were two who cooperated, and when the children were still at home. Problems with supporting the family have followed him through his life. The root cause is, we assert, that he never managed to do anything about the soil erosion on the land.

\section{Appendix A.2. Mirambu Village}

Farmer \#M024. This household was ranked in wealth group 4 (of 5) in the early 1990s. The family had sold land, and remained with 7.5 acres ( $3 \mathrm{ha}$ ), of which four were cultivated. One of the fields was on a $4.5 \%$ slope, with serious erosion problems. They harvested only three bags of grains, of which they sold two tins of bulrush millet. Food was finished by October. The four beehives did not produce this year. The husband worked as a casual most of the time. The family sold home-made beer. They received a small quantity of maize as famine relief.

In 2016 the land had been divided between the sons, and they now leased 2 acres ( 0.8 ha) from a neighbour. In 2015 they built a new house, with bricks and iron sheet roof, with the help of two daughters who worked as housemaids elsewhere. Life is better now, they say, as they have a better house, and get help from the children from time to time.

\#M029. In 1992 our informant was an old woman, ranked in the poorest group. She owned 3.5 acres (1.4 ha), had a grandchild staying with her, and got help also from other grand-children to cultivate. This dry year she harvested only a few tins. Food was finished already in July. Her children and neighbours helped her with food. She received famine relief with $4 \mathrm{~kg}$ of maize.

In 2016 an adult son and his family live on the land, and things had improved. The old house had collapsed and they were building a new made of sun-dried bricks with a grass roof, and had eleven goats and two donkeys, bought with money from day-labouring. They ploughed with a donkey instead of using hand-hoes.

\#M044. In 1992 this household was ranked in wealth group 4 (of 5), indicating that the family could not support themselves from their land. The farmer was a woman in her thirties. Her husband lived in a village about $20 \mathrm{~km}$ away. She had 2.5 acres (1 ha), inherited from her maternal grandmother. She harvested two bags of white sorghum, a tin of pigeon peas and very little else. She had chicken and sold eggs. She worked as a casual most of the time. Received a small quantity of maize as famine relief.

In 2016 the informant had died, her house had collapsed, and been replaced with a house built by sun-dried bricks and with a roof covered with metal sheets. Now an adult daughter lives on the land. She works regularly as a day-labourer and gets an extra income from making pots. Life was difficult 25 years ago, and so it is today. 
\#M135. Wealth group 4 (of 5) 25 years ago. Their assets might have implied a better ranking since the family had 5 acres ( 2 ha), 6 cows, 5 goats. The harvest, however, was minimal, and food was finished by September. The husband worked frequently as day-labourer, and they brew beer for sale to get an extra income. Sold two goats to buy grain. They also received $5 \mathrm{~kg}$ maize as famine relief.

In 2016 the farmer was old, both his wives were dead, and he had divided the land among the children, retaining one acre ( 0.4 ha) for himself. In 2015 he built a new house, mud and daube walls and earth-covered roof, with the help of his children. They also gave him food every day. He says life was more enjoyable when he still had cattle. One daughter is a housewife in Dodoma, and the other children are farmers. He survives with the support of the children.

\#M162. In 1991 this farmer was in his mid-thirties. He was ranked in wealth group 4 (of 5), had five children, and lived on 1.5 acres ( 0.6 ha) of land that he had bought. He borrowed land in addition to his own. He harvested two bags of grains and a couple of tins of small crops. He said he would normally get six bags. He was doing casual labour regularly. The family brewed local beer for sale twice a month.

In 2016 the farmer had evacuated his house after it collapsed, and was building a new with mud and daube walls and a roof covered by earth. He still did casual work. He had had livestock at some stage but they died from disease. Erosion problems on the land had grown to the extent that some of the land had been abandoned. Yields are low, and life has not improved, he says, compared to 25 years ago. Receives help from the children.

\section{References}

1. Edwards, S. Toxic Aid: Economic Collapse and Recovery in Tanzania; Oxford University Press: Oxford, UK, 2014.

2. Nord, R.; Sobolev, Y.; Dunn, D.; Hajdenberg, A.; Hobdari, N. Tanzania: The Story of an African Transition; The International Monetary Fund: Washington, DC, USA, 2009.

3. Robinson, D.O.; Gaertner, M.; Papageorgiou, C. Tanzania: Growth Acceleration and Increased Public Spending with Macroeconomic Stability. In Yes Africa Can. Success Stories from a Dynamic Continent; Chuhan-Pole, P., Angwafo, M., Eds.; The World Bank: Washington, DC, USA, 2011.

4. Adam, C.S.; Collier, P.; Ndulu, B. Tanzania: The Path to Prosperity; Oxford University Press: Oxford, UK, 2017.

5. World Bank. Tanzania Mainland Poverty Assessment; World Bank: Washington, DC, USA, 2015.

6. United Nations. The Millenium development Goals Report 2015; United Nations: New York, NY, USA, 2015.

7. Collier, P.; Dercon, S. African Agriculture in 50 Years: Smallholders in a Rapidly Changing World? World Dev. 2014, 63, 92-101. [CrossRef]

8. Atkinson, B. Inequality: What Can Be Done? Harvard University Press: Cambridge, MA, USA, 2015.

9. Hulme, D. Global Poverty: How Global Governance Is Failing the Poor; Routledge: London, UK, 2010.

10. The World Bank. Country Poverty Brief, Tanzania; The World Bank: Washington, DC, USA, 2017.

11. Mashindano, K.; Kayunze, L.; da Corta, F. Maro, Growth without Poverty Reduction in Tanzania-Reasons for the Mismatch in Translating Growth into Poverty Reduction; Beyond the Numbers; Kessy, F., Mashindano, O., Shepherd, A., Scott, L., Eds.; Mkuki na Nyota: Dar es Salaam, Tanzania, 2013.

12. United Nations Development Programme. Tanzania Human Development Report 2014; Economic Transformation for Human Development; Economic and Social Research Foundation Dar es Salaam: Dar es Salaam, Tanzania, 2015.

13. Kessy, F.; Mashindano, O.; Shepherd, A.; Scott, L. Translating Growth Into Poverty Reduction; Beyond the Numbers; Mkuki na Nyota: Dar es Salaam, Tanzania, 2013.

14. McGillivray, M.; Carpenter, D.; Morrisey, O.; Thaarup, J. Swedish Development Cooperation with Tanzania: Has It Helped the Poor? Expertgruppen för Biståndsanalys, Report 2016:10; Elanders Sverige AB: Stockholm, Sweden, 2016.

15. Bracking, S. Money and Power: Great Predators in the Political Economy of Development; Pluto: London, UK, 2009.

16. Bracking, S. The Financialisation of Power: How Financiers Rule Africa; Routledge: London, UK, 2016.

17. Bond, P. Looting Africa: The Economics of Exploitation; Zed Books: London, UK, 2006.

18. Oakland-Institute. Understanding Land Investment Deals in Africa: Country Report: Tanzania; The Oakland Institute: Oakland, CA, USA, 2011. 
19. Theting, H.A.; Brekke, B. Land Investments or Land Grab? A Critical View from Tanzania and Mozambique; Spire: Oslo, Norway, 2010.

20. Wolford, W.; Borras, S.M.J.; Hall, R.; Scoones, I.; White, B. Governing Global Land Deals: The Role of the State in the Rush for Land. Dev. Chang. 2013, 44, 189-210. [CrossRef]

21. Brockington, D.; Duffy, R. Capitalism and Conservation; Wiley: London, UK, 2011.

22. Fairhead, J.; Leach, M.; Scoones, I. Green Grabbing: A new appropriation of nature? J. Peasant Stud. 2012, 39, 237-261. [CrossRef]

23. Walsh, M. The not-so-Great Ruaha and hidden histories of an environmental panic in Tanzania. J. East. Afr. Stud. 2012, 6, 303-335. [CrossRef]

24. Svarstad, H.; Benjaminsen, T.A. Nothing succeeds like success narratives: A case of conservation and development in the time of REDD. J. East. Afr. Stud. 2017, 11, 482-505. [CrossRef]

25. Reddy, S.G.; Pogge, T. How Not to Count the Poor. In Debates on the Measurement of Global Poverty; Anand, S., Segal, P., Stiglitz, J.E., Eds.; Oxford University Press: Oxford, UK, 2010.

26. Mitlin, D.; Satterthwaite, D. Urban Poverty in the Global South; Scale and Nature; Routledge: London, UK, 2013.

27. Boltvinik, J.; Mann, S.A. Introduction. In Peasant Poverty and Persistence in the 21st Century: Theories, Debates, Realities and Policies; Boltvinik, J., Mann, S.A., Eds.; Zed Books: London, UK, 2016.

28. Jerven, M. Poor Numbers: How We Are Misled by African Development Statistics and What to do about It; Cambridge University Press: Cambridge, UK, 2013.

29. Jerven, M. Africa: Why Economists Get It Wrong; ZED: London, UK, 2015.

30. Jerven, M. Economic Growth and Measurement Reconsidered in Botswana, Kenya, Tanzania and Zambia, 1965-1995; Oxford University Press: Oxford, UK, 2014.

31. Jerven, M. Measuring African Development: Past and Present; Routledge: London, UK, 2015.

32. Ansoms, E.; Marijnen, G.; Cioffo, J. Murison, Statistics versus livelihoods: questioning Rwanda's pathway out of poverty. Rev. Afr. Polit. Econ. 2017, 44, 47-65. [CrossRef]

33. Locher, M.; Sulle, E. Challenges and methodological flaws in reporting the global land rush: Observations from Tanzania. J. Peasant Stud. 2014, 41, 569-592. [CrossRef]

34. Fioramonti, L. The World After GDP: Politics, Business and Society in the Post Growth Era; Polity Press: London, UK, 2017.

35. Stiglitz, J.E.; Sen, A.; Fitoussi, J.-P. Mismeasuring Our Lives: Why GDP Doesn't Add Up; The New Press: New York, NY, USA, 2010.

36. Alkire, S.; Foster, J. Understandings and misunderstandings of multidimensional poverty measurement. J. Econ. Inequal. 2011, 9, 289-314. [CrossRef]

37. Young, A. The African Growth Mircale. J. Polit. Econ. 2012, 120, 696-739. [CrossRef]

38. Johnston, D.; Abreu, A. The Asset Debates: How (Not) To Use Asset Indices To Measure Well-Being And The Middle Class In Africa. Afr. Aff. 2016, 115, 399-418. [CrossRef]

39. Brockington, D.; Howland, O.; Loiske, V.-M.; Mnzava, M.; Noe, C. Economic Growth, Rural Assets and Prosperity: Exploring the implications of a twenty year record of asset growth in Tanzania. J. Mod. Afr. Stud. TBC 2018, accepted.

40. Brockington, D.; Howland, O.; Loiske, V.-M.; Mnzava, M.; Noe, C. Assets and Poverty Dynamics: The Methodological Challenges of Constructing Longitudinal Surveys in Tanzania. In Tanzanian Development: A Comparative Perspective; Potts, D., Ed.; Boydell and Brewer: Woodbridge, UK, 2018.

41. Dercon, S.; Gilligan, D.O.; Hoddinott, J.; Woldehanna, T. The Impact of Agricultural Extension and Roads on Poverty and Consumption Growth in Fifteen Ethiopian Villages. Am. J. Agric. Econ. 2009, 91, 1007-1021. [CrossRef]

42. Baulch, B.; Hoddinott, J. Economic mobility and poverty dynamics in developing countries. J. Dev. Stud. 2000, 36, 1-24. [CrossRef]

43. Dercon, S.; Shapiro, J. Moving on, Staying Behind, Getting Lost: Lessons on Poverty Mobility from Longitudinal Data; Global Poverty Research Group: Oxford, UK, 2007.

44. Baulch, B. Why Poverty Persists: Poverty Dynamics in Asia and Africa; Edward Elgar: Cheltenham, UK, 2011.

45. Beegle, K.; De Weerdt, J.; Dercon, S. Migration and Economic Mobility in Tanzania: Evidence from a Tracking Survey. Rev. Econ. Stat. 2011, 93, 1010-1033. [CrossRef]

46. Östberg, W. Land Is Coming Up: The Burunge of Central Tanzania and their Environments; Stockholm Studies in Social Anthropology; Stockholm University: Stockholm, Sweden, 1995. 
47. Östberg, W.; Slegers, M.F.W. Losing faith in the land: changing environmental perceptions in Burunge country, Tanzania. J. East. Afr. Stud. 2010, 4, 247-265. [CrossRef]

48. Krishna, P.; Kristjanson, M.; Radeny, W. Nindo, Escaping poverty and becoming poor in twenty Kenyan villages. J. Hum. Dev. 2004, 5, 211-226. [CrossRef]

49. Krishna, A. Pathways Out of and Into Poverty in 36 Villages of Andhra Pradesh, India. World Dev. 2006, 34, 271-288. [CrossRef]

50. Krishna, A. One Illness Away: Why People Become Poor and How They Escape Poverty; Oxford University Press: Oxford, UK, 2010.

51. Randall, S.; Coast, E. Poverty in African Households: The Limits of Survey and Census Representations. J. Dev. Stud. 2015, 51, 162-177. [CrossRef]

52. Randall, S.; Coast, E.; Leone, T. Cultural constructions of the concept of household in sample surveys. Popul. Stud. 2011, 65, 217-229. [CrossRef] [PubMed]

53. Brockington, D.; Coast, E.; Howland, O.; Mdee, A.; Randall, S. Households, Domestic Units and Assets. Methodological Challenges to Longitudinal Studies of Poverty Dynamics. Unpublished MS, 2018.

54. Slegers, M.F.W.; Östberg, W. The strength of the land and the missing rains. Environmental change in Goima, Tanzania, and farmers' growing concerns. In Exploring Farmers' Perceptions of Drought in Tanzania and Ethiopia; Slegers, M.F.W., Ed.; Wageningen University, Erosion and Soil \& Water Conservation Group: Wageningen, The Netherlands, 2008; pp. 129-150.

55. Foster, G.M. Peasant Society and the Image of Limited Good. Am. Anthropol. 1965, 67, 293-315. [CrossRef]

56. Jayne, T.S.; Mather, D.; Mghenyi, E. Principal Challenges Confronting Smallholder Agriculture in Sub-Saharan Africa. World Dev. 2010, 38, 1384-1398. [CrossRef]

57. Bryngelsson, D.K.; Åhlén, A.; Azar, C.; Persson, U.M. The effect of food-price movements on African households. Int. J. Agric. Res. Gov. Ecol. 2012, 9, 121-146. [CrossRef]

58. Muyanga, M.; Jayne, T.S.; Burke, W.J. Pathways into and out of Poverty: A Study of Rural Household Wealth Dynamics in Kenya. J. Dev. Stud. 2013, 49, 1358-1374. [CrossRef]

59. Christiansson, I.; Kikula, S. Changing Environments: Research on Man-Land interrelations in Semi-Arid Tanzania; Sida, Regional Soil Conservation Unit: Nairobi, Kenya, 1996.

60. Payton, R.W.; Christiansson, C.; Shishira, E.K.; Yanda, P.; Eriksson, M. Landform, Soils and Erosion in the north-eastern Irangi Hills, Kondoa, Tanzania. Geogr. Ann. 1992, 74, 65-79. [CrossRef]

61. Kangalawe, R.Y.M. Changing Land-Use Patterns in the Irangi Hills, Central Tanzania. A Study of Soil Degradation and Adaptive Farming Strategies; Stockholm University, Department of Physical Geography and Quaternary Geology: Stockholm, Sweden, 2001.

62. Mbegu, C.; Mlenge, W.C. Ten Years of HADO, 1973-1983; Ministry of Natural Resources and Tourism, Forestry Division: Dar es Salaam, Tanzania, 1984.

63. Kikula, S.; Mung'ong'o, C.G.; Jengo, R.D. Perspectives of Land Degradation and Conservation in Tanzania: An Annotated Bibliography; Institute of Resource Assessment, University of Dar es Salaam: Dar es Salaam, Tanzania, 1990.

64. Mung'ong'o, G. Social Processes and Ecology in the Kondoa Irangi Hills, Central Tanzania; Meddelanden Series B93; Stockholm University, Department of Human Geography: Stockholm, Sweden, 1995.

65. Mung'ong'o, G.; Kikula, I.S.; Mwalyosi, R.B.B. Geophysical and Socio-Political Dynamics of Environmental Conservation in Kondoa District; Dar es Salam University Press: Dar es Salaam, Tanzania, 1996.

66. Östberg, W. The Kondoa Transformation: Coming to Grips with Soil Erosion in Central Tanzania; Scandinavian Institute of African Studies: Uppsala, Sweden, 1986.

67. Fuglie, K.O.; Rada, N.E. Resources, Policies, and Agricultural Productivity in Sub-Saharan Africa; Economic Research Report Number 145; United States Department of Agriculture: Washington, DC, USA, 2013.

68. International Fund for Agricultural Development. Rural Development Report 2016; Fostering Inclusive Rural Transformation; International Fund for Agricultural Development: Rome, Italy, 2016.

69. Bernstein, H. Agriculture/Industry, Rural/Urban, Peasants/Workers: some reflections on poverty, persistence and change. In Peasant Poverty and Persistence in the 21st Century: Theories, Debates, Realities and Policies; Boltvinik, J., Mann, S.A., Eds.; Zed Books: London, UK, 2016.

70. Brockington, D. The Sesame Seed Cash Injection: Asset Investment and Economic Change in Mtowisa Village, Rukwa Region 2000-2016. Master's Thesis, 2016, unpublished. 
71. De Weerdt, J. Moving out of Poverty in Tanzania: Evidence from Kagera. J. Dev. Stud. 2010, 46, 331-349. [CrossRef]

72. Östberg, W.; Caretta, M.A. Kerio Valley, 1973-2013: A case study of Kenyan smallholder agriculture. Afr. Stud. 2017, 76, 402-422. [CrossRef]

73. Farm Africa. Tanzania Smallholder Sesame Production And Marketing Project Phase II; Final Report; Farm Africa: Dar es Salaam, Tanzania, 2017.

(C) 2018 by the authors. Licensee MDPI, Basel, Switzerland. This article is an open access article distributed under the terms and conditions of the Creative Commons Attribution (CC BY) license (http:/ / creativecommons.org/licenses/by/4.0/). 
Article

\title{
Exploring Long-Term Livelihood and Landscape Change in Two Semi-Arid Sites in Southern Africa: Drivers and Consequences for Social-Ecological Vulnerability
}

\author{
Current Masunungure and Sheona E. Shackleton * \\ Department of Environmental Science, Rhodes University, Grahamstown 6139, South Africa; \\ currentmasunungure@gmail.com \\ * Correspondence: sheona.shackleton@uct.ac.za; Tel.: +27-21-650-4581
}

Received: 22 February 2018; Accepted: 11 April 2018; Published: 16 April 2018

\begin{abstract}
This paper investigates the drivers and dynamics of livelihood and landscape change over a 30-year period in two sites in the communal drylands of Zimbabwe (Marwendo) and South Africa (Tshivuhulani). Of particular interest to us was how access to social protection and a wider range of options may mitigate increased vulnerability under a changing climate. A mixed methods approach (using household surveys, focus group discussions, life history interviews, transect walks and secondary sources of data) was applied to develop human-environment timelines for each study site. Findings indicate that prolonged periods of droughts, unreliable rainfall, changing socioeconomic policies and development-related projects were among the major drivers of both positive and negative change in both villages. Marwendo, in particular, experienced a suite of negative drivers in the last 10 years that increased vulnerability and forced households to diversify into potentially maladaptive activities. In contrast, the expansion in social grants in Tshivhulani provided an important safety net that reduced vulnerability, but also led to a decline in farming and a narrowing of livelihood activities for some households. We demonstrate that rural development initiatives such as electrification and road construction can strengthen local people's capacity to respond to drivers of change, while new methods of farming and diversification of the livelihood portfolio can make them more climate-resilient. However, long-term changes in landscapes and ecosystem services and feedbacks on livelihoods could reverse some of the benefits of development by eroding the natural capital many households still depend on.
\end{abstract}

Keywords: livelihoods; landscape change; drivers; trends; vulnerability

\section{Introduction}

There is a growing sense of urgency to better understand the complex and rapidly changing global realities that the world faces today [1]. Greater risk and uncertainty is fast becoming the norm as our planet undergoes escalating levels of environmental change (e.g., [2]), including climate change, and as globalisation links countries and economic systems in multifarious and often unpredictable ways $[3,4]$. Ongoing and accelerated change in climate, population and migration, environment, land use, and economies often translate into increased risk and vulnerability at the local level, particularly amongst poor natural resource dependent communities [5-7].

In southern Africa, it is well established that contemporary rural society is facing a growing suite of interacting stressors including HIV / AIDS and other health shocks, poverty, food insecurity, weak governance, climate variability and increased extreme events, and land and resource degradation, to name but some [5,8-16]. These changes and stressors combine to exacerbate livelihood asset erosion, 
vulnerability, poverty and food insecurity, and tend to be most amplified in the dryland parts of the region [17-20]. Drylands (arid, semi-arid and dry sub-humid areas) represent highly sensitive systems where precipitation is scarce and typically more or less unpredictable, temperatures are high, humidity is low and soils generally contain small amounts of organic matter [21,22]. These, and other biophysical features, have profound socioeconomic implications, which exacerbate the feedbacks between poverty, environmental decline and long-term vulnerability $[15,23]$. Such biophysical sensitivity is further affected by a lack of capacity in civil society, the private sector and governments to respond appropriately to emerging threats in these areas [24].

Moreover, several commentators have argued that new and incipient risks and threats in these regions are outpacing and superseding any positive development changes that may have strengthened livelihoods and improved the ability of rural people to respond to the negative impacts of change in the past $[15,25]$. Indeed, in dryland regions livelihoods are reported to be deteriorating and poverty deepening [15], while there is mounting evidence that people are turning to potentially unsustainable practices, such as higher levels of natural resources harvesting, in order to cope with the increasingly harsh living conditions they are facing [14,26-28]. Overall, people and ecosystems in the region are said to be becoming increasingly vulnerable, especially to climate change $[17,29,30]$. Given this situation, these local level social-ecological complexities require systematic unpacking in order to identify and promote sustainable pathways and trajectories into the future. In particular, how different economic and policy contexts play out in either blocking or enabling sustainable livelihood responses in these constrained arid and semi-arid environments needs further enquiry, something this paper seeks to do using South African and Zimbabwean case studies.

Many approaches to global environmental change research tend not to include the broader political-economy and development context, nor address historical processes. Vulnerability and adaptation in southern Africa cannot be addressed in isolation of an understanding of broader issues such as historical trends, regional development challenges, drivers of poverty and inequality, problems of political representation, health concerns, land and tenure issues, social welfare systems and people's own concerns and priorities. Current drivers of change are deeply embedded in the past and have profound implications for what is possible in the future [1]. Thus, when facing major environmental change, such as the effects of climate change, developing an in-depth knowledge of past drivers and experiences is of prime importance [31,32]. Furthermore, a holistic picture is needed as poorly coordinated national and regional policies and strategies sometimes reinforce the structural and political factors that contribute to vulnerability and poverty in the first place. To fully understand how different contexts, policies and multiple stressors shape vulnerability and to capture local people's own experiences, local-level, placed-based case studies that link social and ecological change and vulnerability are essential [33]. These studies need to include the 'lived experiences' and narratives of the very people affected by climate change and other stressors. The use of inductive qualitative approaches, such as applied in the human-environmental timeline method $[31,34]$ and life histories, together with quantitative data enable us to describe drivers and processes of change that determine livelihood outcomes and vulnerability in particular local circumstances. We argue that only through understanding how society and ecosystems simultaneously interact and respond to new and exacerbated drivers can we start to address vulnerability and promote sustainability in a changing world. Consequently, more place-based studies that facilitate comparison of the livelihood and vulnerability outcomes resulting from different historical and contemporary drivers, from the national to local scale, are needed in order to inform development and adaptation solutions going forward.

In this paper we use the Millennium Ecosystem Assessment (MEA, [23]) definition of a driver as any factor (natural or human-induced) that can cause a change (direct or indirect) in the structure and/or function of a social-ecological system. Drivers that result in negative outcomes are often referred to as stressors [35] and tend to be ongoing, long-term and persistent [36], as in the case of resource declines, seasonality issues, and temperature increases. Shocks, on the other hand, are generally unpredictable, short term events such as human, crop and livestock disease epidemics; 
natural events such as droughts, and floods; and economic turns such as currency devaluation [37]. To unravel the impacts of different drivers on livelihood outcomes and vulnerability we applied Dorward and colleagues' livelihoods aspiration framework [38] that identifies three dynamic livelihood strategies or trajectories that emerge from change: "hanging in", "stepping up", and "stepping out". We added another category, "losing out", which refers to a situation of increasing vulnerability. Vulnerability is most commonly understood as consisting of exposure to shocks and stressors, the susceptibility to harm from these (sensitivity), and the capacity (or not) to respond and recuperate from such adverse impacts (adaptive capacity) [13]. Here, we draw on a notion of vulnerability that highlights the importance of incorporating both a risk-hazards perspective (that locates vulnerability within external risk) and an entitlements-livelihoods and political ecology perspective (that traces vulnerability to multiple social, political and economic factors at different scales) [39,40]. Place-based vulnerability is thus a function of the starting context in which people find themselves, including their livelihood options and activities and the assets they have to draw on, all embedded within the local institutional context, wider political economy and agro-ecological system, and influenced by historical processes, such as colonisation, and the risks and threats that households face.

Drawing on the above and responding to the research gaps highlighted, in this paper we investigate the drivers and dynamics of livelihood and landscape change over a 30-year period in two rural villages in southern Africa, one in Limpopo Province of South Africa and the other in Manicaland Province of Zimbabwe. The two villages are located in similar semi-arid environments, but vary in terms of socioeconomic policies and conditions. In particular, what stand out are the site differences in relation to access to social protection and welfare, basic service delivery and development opportunities. In South Africa, social grants in the form of old age pensions and child grants are received by large numbers of poor households; these provide a safety net that is not available in Zimbabwe [41]. Furthermore, the post-apartheid period in this country has been characterised by a commitment to improvement in service delivery in many previously neglected areas. Through analysis of how these contextual differences, and the drivers behind them, influence people and landscapes at the local level, we aim to contribute to the growing body of literature on social-ecological change in the region. We are particularly interested in how access to social protection and a wider range of options in South Africa may militate against some of the impacts of new threats and prevent a possible downward spiral of increasing vulnerability or a poverty trap. Such downward trajectories might result from, for example, higher dependency on, and subsequent overuse of, a range of vital ecosystem services that people turn to when livelihood options are limited [14]. The study was thus designed to facilitate examination of the similarities and differences between villages in relation to the national and local socioeconomic and political context, while the construction of coupled human-environmental timelines enabled us to explore the temporal coevolution of drivers, livelihoods and natural resources based on local perspectives and narratives. Specific objectives included to: (1) identify the drivers that have influenced livelihood and landscape change within the two villages; (2) unpack the changes that have taken place; and, lastly (3) interpret what these changes mean for social-ecological vulnerability and future livelihood trajectories in each setting.

\section{Study Sites, Approach and Methods}

\subsection{Study Sites}

The study was conducted in two paired, purposefully selected villages (366 to 645 households), in the drylands of southern Africa, namely Tshivhulani village in Limpopo Province of South Africa (part of the former homeland of Venda; $22^{\circ} 55^{\prime} 46^{\prime \prime}$ S; $30^{\circ} 29^{\prime} 40^{\prime \prime}$ E) and Marwendo village in the Manicaland Province of Zimbabwe (20 $0^{\prime} 28^{\prime \prime}$ S; $32^{\circ} 27^{\prime} 3^{\prime \prime}$ E).

Both study sites fall within the savanna biome, specifically what is commonly referred to as dry woodlands, and receive an average rainfall of between $334-450 \mathrm{~mm}$ per annum, characterised by high variability and mid-season droughts $[42,43]$. The vegetation in Tshivhulani is classified as 
Soutpansberg mountain bushveld [44], and is characteristically heavily impacted by overgrazing, wood-collecting and farming activities. Common trees found include Vachellia (previously Acacia) karoo, Berchemia zeyheri, Combretum molle, and Kirkia acuminata among others. Marwendo lies in agro-ecological Region IV of Zimbabwe [42], a semi-extensive farming region that is characterised by low rainfall and periodical seasonal droughts and severe dry spells. The most extensive vegetation types in the village are open Mopane (Clophospermum mopane) woodland and Acacia-Combretum woodland. Other common species and genera include the baobab (Adansonia digitata) (an important source of fibre and emergency food) and Terminalia spp. The grass cover in the village has been heavily affected by overgrazing and bush encroachment [45].

The villages differ in terms of their socioeconomic characteristics (Table 1), especially with respect to proximity to urban areas, government policies, and access to social protection or welfare. Tshivhulani village is located some $10 \mathrm{~km}$ from the nearest town (Thohoyandou), whereas Marwendo village is located $40 \mathrm{~km}$ from the nearest town (Chipinge). Access to electricity and piped water is more uniform in Tshivhulani than Marwendo. Both sites are characterised by widespread poverty and unemployment [46,47]. In Tshivhulani most households rely on a combination of government social grants (mainly old age pensions and child grants), remittances from migrant workers, home gardening, some livestock production and the collection of firewood and other natural resources (wild fruits, vegetables) for their livelihood [48]. In Marwendo, livelihoods are dominated by cereal production for household consumption, which is the key livelihood activity for the majority of Zimbabwe's rural population [47]. Livestock production, mainly cattle and goats, is also important. The village is located on the edge of the Mutema Highlands [45]. Residents rely heavily on natural resources, such as construction poles, firewood and fencing materials, and food and medicine, obtained from these highlands. Cash and in-kind remittances primarily from South Africa have become an increasingly important source of household income. Due to the significantly high levels of poverty, low levels of economic activity coupled with poor quality of land available, non-farm activities such as seasonal casual work, petty trading and the sale of handicrafts and other local natural resources have become important sources of income.

Table 1. General characteristics of the two study villages.

\begin{tabular}{ccc}
\hline Village Characteristics & Tshivhulani (South Africa) & Marwendo (Zimbabwe) \\
\hline Number of households & 645 & 366 \\
\hline Dominant ethnic composition & Venda & Ndau \\
\hline Water source & Piped water & $\begin{array}{c}\text { River/boreholes for most of village except } \\
\text { township/urban area }\end{array}$ \\
\hline Transportation & Gravel road & Gravel road, close to the main highway \\
\hline Market access & Very easy & Fairly easy \\
\hline Electricity & Yes & Yes/only few households \\
\hline Distance to the nearest town & Less than $10 \mathrm{~km}$ & $40 \mathrm{~km}$ \\
\hline Social grants (monthly) & Yes & No \\
\hline
\end{tabular}

\subsection{Approach and Methods}

The human-environment timelines presented in this paper were developed by drawing on the findings from a mixed-methods approach that included a household survey, focus group discussions, in-depth life history interviews, transect walks and a review of secondary sources. This approach facilitated the triangulation of findings and provided multiple sources of information to construct comprehensive human-environment timelines that are able to highlight the co-evolution of livelihoods and landscapes over time as influenced by major biophysical, socioeconomic, development and policy drivers of change. Furthermore, the insights gained from these various approaches, in particular the qualitative methods, assisted with interpreting the findings presented in the timelines. The timelines 
were constructed to cover the period from 1980 to the present and were divided into three distinct periods: Period 1 (1980s): 1980 to 1989; Period 2 (1990s): 1990 to 1999; and Period 3 (2000s): 2000 to the present. The drivers and changes are described and the outcomes interpreted according to Dorward et al.'s typology in [38].

The bulk of the long-term temporal information was obtained from focus group discussions. One focus group was held in each village with 6-12 participants (based on who arrived on the day) in their 50s and 60s, including both men and women. Members of this age group are viewed as the custodians of considerable knowledge and experience of the past, making it possible to look back at least two generations. The local councillor assisted with finding suitable participants. To determine key chronological events and temporal changes in the village over a 30-year period, participants were asked to recall and generate insights about changes in their villages (both in relation to their livelihoods and the local landscape), the factors behind these changes (drivers) and the outcomes for livelihoods. This was complemented by a ranking exercise that was used to determine the relative importance attached to various livelihood activities and environmental concerns that had been identified by the participants.

Other data used in the human-environmental timeline included findings from the household survey carried out in each village. Some of these results are also tabulated or graphed in this paper to provide additional evidence for the trends indicated in the human-environmental timeline. Structured questionnaires were administered to 80 households in each village. These households were randomly selected using freely downloadable Google Earth software, where random points were generated using the "Cruise tool" [49]. The Cruise functions allow one to enter the number of points required; 80 random points were generated from each map site. These points were then displayed on a Google Earth map, printed out in colour and taken to the field. During fieldwork, the household nearest to the GPS point was selected for the study and, if not available or not willing to take part, the next closest willing household was visited. The questionnaire covered four main themes: (1) household members and structure, income, assets, livestock and farming activities; (2) shocks, long-term stressors and other changes and local responses (including natural resource safety nets); (3) changes in woodland cover and natural resource use and drivers; and (4) future concerns.

Stories obtained from in-depth, life history interviews also provided contextualisation for the timeline. Ten households were selected in each village, targeting the elderly. The interviews were recorded and field notes were taken. The interviews were later transcribed. Respondents were asked to tell their "life stories" in whatever way they felt comfortable and to describe notable events that they believe defined their experiences. To facilitate the storytelling, questions based on the following major themes were used to guide the interview: (1) livelihood changes (general household information, personal narrative of the respondent's life from growing up to present, village's history and any changes that occurred since their arrival, hardships experienced, major causes of hardships); (2) local responses to key changes, shocks and stressors faced (with a particular focus on the role of social protection and use of natural resources); and finally (3) a look into the future (major concerns into the future for the household and the community).

For data on landscape and natural resource change, a transect walk, which involved walking from the village periphery into the surrounding grazing lands, was carried out in each village with 5-10 willing participants (both male and female) recruited from the community. This walk provided an opportunity for direct observation, questioning, discussion and learning about natural resources and biophysical indicators of change and the livelihood impacts of these for villagers. Several aspects related to the use and availability of woodland resources were discussed and recorded. These included the main uses of key woodland products, who uses them (e.g., men, women, children, community outsiders, etc.), any changes in vegetation structure, species, and the relative abundance/scarcity of useful species, changes in the distance and/or time required for collection of woodland products; and changes in land use and cover, including woodland shrinking and/or patchiness and the opening up or abandonment of cultivated areas. Where the transects passed through fields or old fields, various issues relating to arable agriculture were discussed. 
Lastly, secondary data sources including government reports, other published historical or anthropological studies in southern Africa, newspaper articles and non-governmental organisation (NGO) reports were reviewed to gather background information on the historical context as well to triangulate the findings.

\section{Results and Discussion: Coupled Human-Environmental Timelines}

\subsection{Drivers of Change and Trends}

In this section, we highlight the key drivers of change (both positive and negative) identified from the various data sources. For ease of discussion, we classify them into four main categories, namely: (1) climatic drivers and events (perceived changes in rainfall and other weather-related parameters); (2) demographic and socioeconomic drivers and events (changes in socioeconomic and structural policies); (3) local developmental drivers and events (local factors, including NGO projects and provision of new services, that facilitated or detracted from people's ability to make a living); and (4) drivers of natural resource change (changes in land use and cover, natural vegetation and useful species). These various drivers work together to influence ecosystem and human vulnerability and livelihood outcomes. The sections that follow then consider the combined impacts and consequences of these drivers and the subsequent changes in livelihood and landscape vulnerability.

\subsubsection{Climate-Related Events and Drivers}

Given that both villages are located in dryland areas with highly variable climates, it is not surprising that climate, particularly drought, emerged as an important driver of change (Figure 1a,b). Both villages have experienced prolonged periods of drought, on an almost decadal basis, coupled with increasing temperatures since the 1980s. All of the droughts were considered by participants to be severe. In Marwendo (Figure 1aA), participants spoke about the 1992 drought as being the worst in living memory. This drought was said to have been so severe that it resulted in critically low levels of surface water for both domestic use and livestock, and people had to live from hand to mouth. In Tshivhulani (Figure 1bA), the 1992 drought was regarded by the focus group participants as a natural disaster in economic, social and environmental terms that altered the course of their livelihoods, while the 2002 drought was said to have caused severe hunger and dragged people into deep poverty.

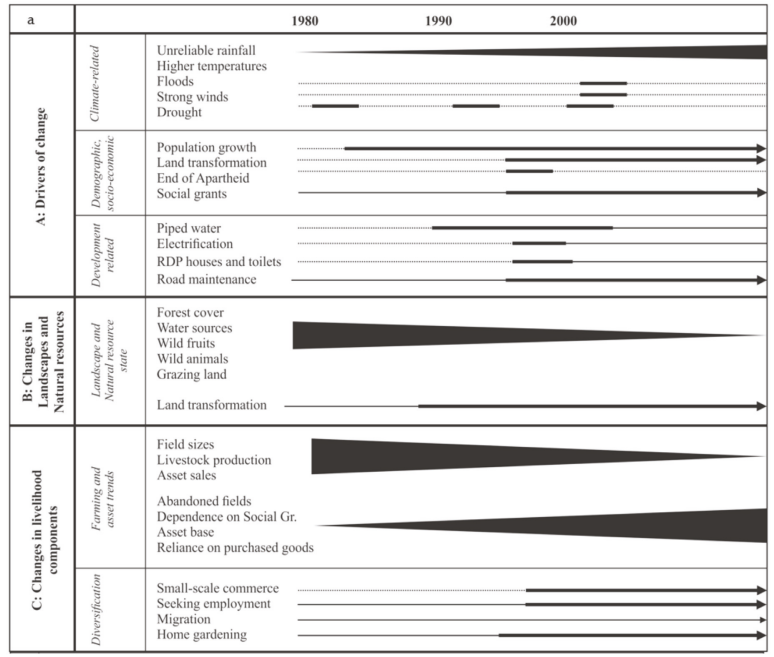

Figure 1. Cont.

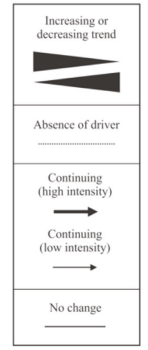




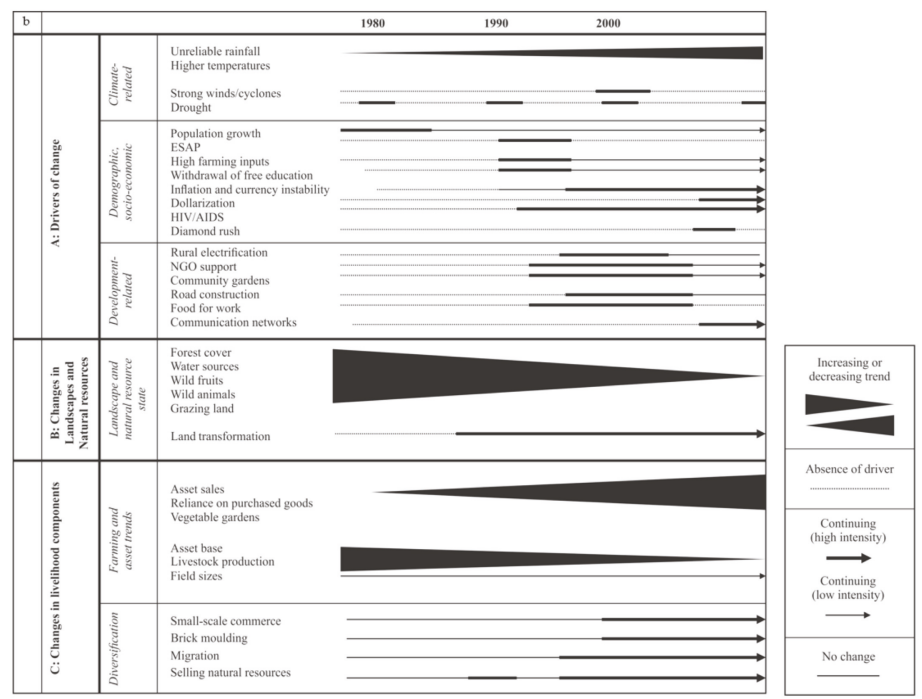

Figure 1. (a) Coupled human-environmental timeline of Tshivhulani village, based on focus group discussions and complemented by transects walks, life history interviews and secondary sources of information. (b) Coupled human-environmental timeline of Marwendo village, based on focus group discussions and complemented by transects walks, life history interviews and secondary sources of information.

Other than droughts and increasing temperature, another climate-related driver mentioned in both villages was greater uncertainty regarding rainfall patterns. The rainy season was described as becoming increasingly unpredictable, and, together with high temperatures, these unfavourable weather conditions were considered to be pushing people into off-farm activities. An increase in strong winds and veld fires, particularly in the early 2000s, were mentioned in Tshivhulani resulting in damage to houses and vegetation. The 2000 flood was also a key event in this village, which resulted in loss of property (collapsed dwellings) and damage to infrastructure such as roads. This was pinpointed to the first two weeks of February 2000, showing that many respondents had clear memories of this event.

\subsubsection{Demographic, Socioeconomic and Policy-Related Events and Drivers}

Events and changes in the demographic, socioeconomic and political spheres also contributed significantly to the changing conditions in the two villages, with the primary drivers being quite different between the two countries.

A key influence on change in both villages in the early 1980s was a peak in the population, and then steady growth following that. In Marwendo, this was said to be the result of an influx of refugees from neighbouring Mozambique. The refugees were fleeing the Matsangaissa anti-communist rebel group, which had sparked war in their country [50]. For some villagers the refugees were welcomed as they provided a relatively cheap source of labour, although after the war many of these Mozambicans returned home. One participant commented:

"I was able to hire one of the refugees (Arushia) ... . I provided him with a place to put his head, food to eat every day ... in return Arushia (the hired refugee) would help me with herding my cattle and farming. By then I had a large herd of cattle before the 1992 drought wiped out all of them ... these friends of ours, 'maputukezi' meaning 'Portuguese refugees', were very obedient and trustworthy and this made it easier for us to live with them like 
family .... After the war in their country, it was sad for me and my family to see him go as he was now part of our family" [Male respondent in Marwendo village].

Most other drivers of change in this category emerged in the 1990s and 2000s, especially the last 10 years, and their impacts continue to be felt. During this period, Marwendo faced mostly negative drivers. One of these was the adoption by the government of Zimbabwe of the Economic Structural Adjustment Programme (ESAP) in the 1990s, designed by the International Monetary Fund (IMF) and World Bank. Smallholder farmers in Marwendo explained that the ESAP resulted in economic turmoil, which saw them becoming less well-off due to rising input costs, higher costs of services (e.g., health care, education), lower output prices and reduced remittances from urban areas as people lost their jobs. The far-reaching impacts of the ESAP have also been written about by several other authors [51-54]. The ESAP saw massive retrenchment of the labour force, particularly in industries and civil service [54]. This had serious negative repercussions on the economy of the country and made rural people worse off, as one participant shared:

"I lost my job after the company I was working for had to retrench workers. I was forced to come back to the village where I started to plough the land. From the day I lost my job, things have never been the same, eating from hand to mouth" [Male participant, Marwendo village].

The above sentiment clearly shows that chronic underemployment and increases in unemployment meant that rural communal areas like Marwendo had to endure much of the strain.

It was during the same period that most participants agreed that HIV / AIDS was becoming a serious concern, furthering the downward spiral of poverty in the village. The HIV / AIDS epidemic hit rural populations hard and peaked in the late 1990s, with major effects on household structure, gender relations and labour. According to Freeny [55], Zimbabwe experienced a huge increase in adult mortality from the mid-1980s to the mid-1990s, essentially due to HIV/AIDS. Most affected households were forced to sell their assets in order to cover medical costs. The South African situation mirrors this.

The decline in health and higher mortality rates was further compounded by policy change, which saw the introduction of school fees for secondary schooling. This presented a major challenge to poor people in the village. This rolling back of government services also included withdrawal of free health care, agricultural extension and veterinary services [56]. The removal of subsidies for seeds and fertilisers, coupled with the healthcare burden, seriously affected farming in the village.

Compounding all of this is the issue of inflation, which peaked in the years 2008 and 2009. People felt desperate, as captured in the following quote:

"It is only left for God to decide the fate of peoples' lives ... It was very hard for me and my family to even buy a loaf of bread 'mari yaisatenga' (meaning 'money could not buy anything') during these difficult times ... the prices of goods and services would change more than three times a day" [Female participant, Marwendo village].

The last 10-15 years have therefore seen a loss of income for investment in productive assets such as livestock, household health, education and household food security for most villagers. We discuss this and the longer-term consequences in the next section.

Another important and more positive economic driver that was noted to have occurred in the late 2000s in Marwendo was the introduction of the United States dollar as the official currency of Zimbabwe in April 2009. Most respondents agreed that this stabilised the prices of goods and services and increased the availability of consumer goods that were in short supply between 2000 and 2008. However, the present chronic shortages of currency have all but reversed the benefits that dollarisation brought.

In contrast to Marwendo, the drivers in this category in Tshivhulani had mainly positive outcomes for villagers. The South African democratic transition in 1994 marked the end of discriminatory 
apartheid policies, and a commitment to amend the injustices of the past. It was generally agreed amongst participants that this led to improvements in basic infrastructure such as water and sanitation systems, electricity lines, roads, housing and other services provided at municipal level (discussed further below). In addition to this, the democratic transition saw the equalisation and increased value of old age pensions, as well as the introduction of child grants (http:/ / millionssaved.cgdev.org/ case-studies/south-africas-child-support-grant). Following this, social grants became an increasingly important part of villagers' income profiles with the availability of cash fostering more livelihood options and providing an important safety net.

\subsubsection{Local Development-Related Events and Drivers}

Local development-related drivers mentioned by focus group participants mainly related to the provision of infrastructure and services, although in Marwendo support by non-governmental organisations was also highlighted. This had benefits for both villages.

The provision of piped potable water (clean and easily accessible) around 1985, by the government to the people in Tshivhulani village was noted as a significant driver of change, as it spared villagers from fetching water from unprotected sources and paved the way for small home gardens for improved nutrition as explained by a female participant:

"We used to wake up very early in the morning to go and fetch water ... but now it is very easy since we have tapped water inside our yard. We even have a small garden where we grow our green vegetables because the water is readily available. Piped water has made our lives easier" [Female participant, Tshivhulani village].

The provision of piped water was also emphasised by participants during the focus group as having relieved drought stress on people, crops in their gardens, and livestock.

Similarly, rural electrification was seen as a significant driver of change in Tshivhulani since 1999 (when the whole village was electrified). Most households were said to now use electricity, as it is faster and cleaner, although the use of firewood is still common. The advent of electricity facilitated the flow of information through radio and television broadcast, and allowed households to diversify their income by engaging in small backyard industries.

More recently the construction of Reconstruction and Development Programme (RDP) houses and toilets has had positive outcomes. Not only did this provide decent accommodation and sanitation for the villagers, but also much-needed employment opportunities as the locals were hired to work as construction workers. Other positive developments included improved road maintenance and thus mobility and access to the nearby town.

Like Tshivhulani, electrification of Marwendo village in 2009 was also a noteworthy positive driver of livelihood change. This came as a result of the government recognising that rural electrification is a major pillar in enhancing socioeconomic development in rural areas. This rural electrification programme mainly targeted growth points; however households close to the gridlines benefited as well. The focus group participants acknowledged an increase in enterprise as a result of electrification, suggesting that such a development can contribute immensely to an increase in rural enterprise opportunities as also shown by Mapoko and Prasad [57] in southwest Zimbabwe in Matebeleland South.

Following the arrival of Non-Governmental Organisation (NGOs) operations during the 2000s, Marwendo witnessed varied development projects and concomitant shifts in local livelihood strategies. Projects included the establishment of a community garden, several nutrition gardens, women's savings clubs and gully reclamation and road construction projects. Thus, external assistance from NGOs acted as a prominent driver of positive change.

The recent advent of mobile network boosters (around 2012) in the village was mentioned to have facilitated communication flow to Marwendo through mobile communication and mobile money transfers, among other services that come with mobile phone networking. Another local 
driver of change was the Chiadzwa Diamond Rush (a period when people migrated to the Chiadzwa diamond mines to engage in illegal diamond mining) in the mid to late 2000s (after discovery in 2006). The diamonds were discovered at Chiadzwa, a communal area located in Marange, Zimbabwe [58], less than $150 \mathrm{~km}$ from Marwendo village. This new activity injected cash into the village economy and resulted in an increase in small-scale commercial activities.

\subsubsection{Drivers of Vegetation and Land Cover Change}

Land transformation was mentioned as the most significant driver of change in village landscapes and natural resources, manifested through establishment of new settlements, deforestation (driven by clearing and fuelwood consumption and sale), overharvesting of natural resources (wild fruits, wild animals, firewood, thatch grass), and brick moulding (only in Marwendo). The bourgeoning of new and unplanned settlements in Tshivhulani was noted as a major driver of landscape change in the village, with $70 \%$ of survey respondents attributing the loss of woodland cover in the village to this driver. In contrast, in Marwendo new settlements (3\%) were only mentioned by a few households. The unplanned expansion of residential areas in Tshivhulani was also said to have resulted in siltation of the river that feeds the village. One participant said:

“The people in our village just settle wherever they want...our 'Bafuwi' (meaning traditional leader) has lost control over the allocation of stands for people to stay. Long time ago it used to be in the hands of the 'Bafuwi', which means that it was organised. Today people have settled themselves near water sources, polluting them and cutting down trees. No wonder we do not have enough water to drink. At this rate, I fear that my grandchildren will not live to see the river flow as it used to. When it rains, all the loose soils are dragged into the river, now it hardly flows throughout the year ... something should be done surely with these new settlements that are erupting all over the village" [72-year-old female respondent in Tshivhulani village].

The increase of brick moulding was said to be having the same impact in Marwendo, while 70\% of respondents in the household survey felt that poor waste management and pollution were a major problem in Tshivhulani (Appendix B).

In both villages, deforestation was indicated as another major contributor to land transformation (60\% of respondents in Marwendo and 56\% in Tshivhulani) (Appendix B) and was associated with decreased availability of woodland goods and the erosion of the ecosystems' capacity to provide ecosystem services, e.g., control of local micro-climate and soil conservation. Transect walks in both villages, revealed that the distance for collection of firewood had increased. In Marwendo, one participant commented:

"We wake up very early before sunrise in search of firewood and only come back in the afternoon. This leaves little time to do other household chores and at the same time is affecting our health" [Female respondent in Marwendo village].

\subsubsection{Linking Drivers and Local Concerns}

Most of the drivers mentioned above relate directly to the areas of concern expressed by villagers. In Marwendo, the major concerns mentioned by survey respondents were persistent unemployment, droughts, hunger, poverty and economic hardships. Respondents in the life history interviews (see Appendix A, Table A1) and the focus groups emphasised economic trends such as inflation and dollarisation, which affected the price of goods and services and the cost of living. Respondents in Marwendo also felt that the current trends in increasing temperature and decreasing precipitation would continue or even increase in the future. Intensified weather extremes, more frequent droughts and dry spells, and more crop failures were anticipated. Consistent with previous results, respondents regularly spoke of the deteriorating natural resource base as a further concern in the village, especially 
as this was linked to current livelihood practices, such as brick moulding, which are undertaken out of desperation given few other choices.

In Tshivhulani, there has been a shift in the main concerns in villagers' lives over the past 30 years. According to focus group discussions and life history interviews, previously food scarcity and poverty were major concerns, whereas now social grants have helped to address these, coupled with the end of the apartheid era. The ability to access a good education and the future of children were now ranked as the major concern for most villagers. A better life with better opportunities was generally hoped for by most of the families, but unemployment was a major concern, as well as truancy and crime (see narratives in Appendix A, Table A2).

\subsection{Changes in Landscapes and Natural Resources}

Several changes in landscapes, the natural resource base and the way in which people utilise ecosystem services were mentioned in the focus group discussions and household survey, primarily as a result of the land transformation drivers mentioned above. These changes are illustrated in section $\mathrm{B}$ of the human-environment timelines (Figure 1a,b). In both villages there was a general consensus by focus group participants that natural resources and woodland products were in a state of decline. In addition, the majority of household survey respondents in both villages also felt that woodland cover, availability of water from natural water sources, species diversity, wild fruits, wild animals and grass cover had decreased (see Appendix B). Increasing soil erosion and loss of soil fertility were also mentioned. Regarding wildlife, elderly participants in the focus group discussions in Marwendo recalled times when there used to be an abundance of small antelope and other small mammals such as scrub hares in the natural woodland close to the village. According to their narrative, all that remains are baboons and monkeys, which are, because of the growing wild food scarcity, increasingly encroaching onto crop fields and the main road that passes through the village. Traditional wild fruits, which used to be abundant, were mentioned to now be scarce and many species that provide fruits were said to have disappeared from local agro-ecological systems. Despite electrification, fuelwood harvesting is still seen as an important livelihood activity and source of energy. Many of these landscape changes impact on livelihoods and even result in livelihood changes, as highlighted below.

\subsection{Livelihood Changes and Trends}

Similar to landscapes, our understanding on how livelihoods are changing as a consequence of the drivers identified was drawn mainly from the focus groups discussions as well as the household survey. From this information we were able to construct the livelihood change portion (C) of each human-environmental timeline (Figure 1a,b). The household survey was particularly useful in relation to trends in livelihoods activities, household physical assets and overall standard of living in the last 5-10 years. Here we consider how drivers work in synchrony to influence what we see in livelihoods today.

\subsubsection{Changes in Livelihood Strategies and Activities}

The highly negative economic and policy drivers in Zimbabwe since 2000 combined with the two recent droughts were viewed to have pushed many villagers in Marwendo to diversify into a range of 'self-reliant' income earning activities. These included the commercialisation of garden produce (tomatoes, vegetables and onions) and woodland products (firewood, wild fruits, baobab fibre goods, and thatch grass), brick moulding, casual labour, and migration in search of employment. Some of these 'new' activities were supported by NGOs and were focused on improving rural livelihoods and adapting to changing climatic conditions. Participants in this village also mentioned they had adopted strategies and practices such as conservation farming, use of small grains and drip-system irrigation in order to continue farming. These technologies have been useful in negotiating livelihoods through the changing climatic conditions and deteriorating crop yields, due primarily to heat and water stress, that participants mentioned. In 2002, an NGO introduced community nutrition gardens and fruit 
tree plantation projects, mainly for women, which led to improved nutrition and substantial income increases through the sale of produce. However, when we visited during the middle of the drought in 2015 little cultivation at all was happening. In addition, development projects also presented opportunities for local residents to be provided with "food-for-work" employment opportunities through road maintenance and gully reclamation projects. Road maintenance and construction was said to have increased accessibility in the village, supporting easier movement of garden produce and facilitating commercial activities in the village.

While, the above adaptations could be consider a positive response to dealing with negative drivers, some of the self-driven diversification activities such as brick moulding have potentially negative feedbacks on key ecosystem services (i.e., water as river banks are mined for clay) increasing both human and ecosystem vulnerability in the long term. The use of baobab fibre for weaving is another example. This activity could affect the health of baobab trees, undermining access to an important emergency food resource (baobab fruit is used for making a maize or small grain porridge substitute during drought). The reversal in free schooling also caused difficulties for many participants in the focus groups who mentioned struggling to pay the fees. This has resulted in withdrawal of children from school, which again has significant long-term consequences for vulnerability and adaptive capacity.

Like the opportunity created by the nearby diamond discovery mentioned above, electrification also opened the door for small enterprises such as welding and retail in both villages:

"It is better in our village with electricity. I started my welding business in the village repairing and making a wide array of things. Since I am no longer much into farming, my welding business has helped me and my family to survive ... My eldest son helps with welding and marketing our products. Since there are not many people involved in this kind of work, everyone in the village comes to us ... For now I continue with welding" [Male participant, Tshivhulani village].

In the above case, diversification of this family's livelihood activities is a strategy that can be considered as both opportunistic and reactive. The respondent's choice to diversify is an example of a coping strategy for dealing with fewer options, especially with the increased risk associated with farming, as well as a response to the opportunities created from having access to electricity. New livelihood strategies and activities are often the product of the interaction between choice and constraint [59] but may emerge through the interaction of different drivers. Despite the positive livelihood outcomes of such commercial activities, some participants mentioned they also brought moral and cultural problems. They mentioned increases in crime, school dropouts and teenage pregnancies. The diamond mine close to Marwendo was said to be particularly problematic in this respect even though it facilitated small enterprise development. In terms of electricity the benefits were also not necessary forthcoming for all. The majority of participants emphasised problems of high costs, slow progress and selective reach to households, and power cuts as some of the negatives associated with the electrification programme.

Migration into neighbouring South Africa in search of jobs was also noted as an important livelihood change in Marwendo and was said to have increased around 2008/9, as at this stage it was mentioned as the most effective way for young men to earn the money needed to get married (i.e., to pay the lobola or bride price).

While there was some livelihood diversification in Tshivhulani, the main changes related to a decline in field-based arable agriculture and to a lesser extent livestock production, and greater reliance on social grants as well an expansion of vegetable gardens. The abandonment of field cultivation is not an unusual finding in the communal areas of South Africa and has been written about in other parts of the country, especially the Eastern Cape (see [16,60-63]). While multiple drivers have been ascribed to this decline, having access to social grants to purchase food means it is no longer essential to farm fields for staple food substances under what is seen as increasingly risky climatic conditions [63-66]. 
The cost of investment as local conditions change and as labour needs increase (due to a decline in free labour and work parties) is also seen to not necessarily be worth the returns [66]. The greater number of vegetable gardens in Tshivhulani reflects a shift from fields to manageable homestead gardens partly due to the availability of piped water. Survey results revealed that a large percentage of respondents $(46 \%)$ have been leaving cultivated land to fallow (Table 2). Focus group discussions reflected similar findings; participants mentioned that although they are still holding on to their fields they are not actively involved in cropping them year in and year out. This was also evident from the transect walks where large areas of unused arable fields were a common feature, especially areas more distant from the village. One participant in the focus group explained:

"We still hold on to my field ... this is our family inheritance . we take pride in the fact that we have a piece of land to our name although we do not crop in it year in and year out ... it still remains our asset ... we have a small garden in our yard where we mainly grow vegetables mainly for consumption. The home gardens are very much easier to maintain as compared to distant fields ... we can easily water and weed them with very little labour required" [Male respondent in Tshivhulani village].

By contrast, most villagers in Marwendo had little choice but to continue with agriculture, and to adapt this by bringing in more small grains (sorghum, pearl millet, finger millet) to minimise the risk of crop loss from drier and hotter conditions and more frequent droughts. The addition of conservation farming and micro-irrigation approaches has also assisted in making cultivation more resilient. It is of note, however, that fewer households in Marwendo (66\%) had access to land than in Tshivulani $(97 \%)$, despite being more dependent on cropping for food security (Table 2). Regarding livestock the results show the reverse; $86 \%$ of respondents in Marwendo owned livestock compared to $31 \%$ in Tshivhulani; this is even in the context of the majority of the respondents in Marwendo believing livestock numbers had declined (Table 2). One respondent explained how he ended up losing most of his livestock:

"As the head of the family and in line with our culture, it's every man's ambition to accumulate wealth through acquiring livestock, especially cattle ... By the late 1980s I had a herd of 19 cattle, but 12 perished during the infamous 1992 drought ... I started again to rebuild my stock using money from my piece jobs. By 2000, I had significantly recovered ... but again the 2002 drought struck and coupled with Foot and Mouth disease my herd was severely affected ... Now I remain with five cattle" [Male respondent in Marwendo village].

The perceived decrease in livestock numbers can be partly explained by the significantly high proportion of survey respondents in Marwendo who confirmed that they had sold livestock in the last five years. The major reasons mentioned included the need for cash income to buy food and pay school fees, and to recover from a shock such as death of a family member, and expensive events, among others. This suggests that in Marwendo, villagers are compelled to sell livestock for cash since it is one of the few options available to them. The quote above illustrates how many villagers are also unable to restock following livestock loss or sale.

As mentioned, in contrast to field cropping, small-scale, intensive vegetable gardening has continued to be important in both sites (some 65\% of households have vegetable gardens) with homesteads being the primary location for these in Tshivhulani, while in Marwendo this includes NGO supported community gardens. However, some barriers to continued growth in gardens were identified. In the focus group discussions and interviews in Marwendo, respondents raised the issue of a recent ban by the Environmental Management Agency (EMA) on cultivating vegetable gardens along natural water sources (i.e., the Tanganda River that flows through the village). This has resulted in abandonment of gardens.

In both villages, there is a sense of an increasing level of vulnerability within farming systems and concerns that in the near future it is likely that further adverse climatic events may lead to further declines in crop and livestock production, ultimately impacting food security. Already in the year of 
the study (which was a drought), people in Marwendo mentioned greater utilisation of wild foods such as baobab fruits to meet local needs. Without improved local natural resource management even these food sources may become increasingly vulnerable through overutilisation and climate impacts in the future.

Table 2. Land use and livestock ownership in the two villages.

\begin{tabular}{ccc}
\hline Variable & Tshivhulani (South Africa) & Marwendo (Zimbabwe) \\
\hline Households having gardens (\%) & 66 & 64 \\
Mean number of gardens/hh & $0.66 \pm 0.053$ & $0.78 \pm 0.087$ \\
Households owning fields (\%) & 97 & 69 \\
Mean number of fields/hh & $0.98 \pm 0.018$ & $0.74 \pm 0.066$ \\
Fallow land left (\%) & 46 & 28 \\
Livestock ownership (\%) & 31 & 86 \\
Mean number of livestock/hh & $2.78 \pm 0.594$ & $8.95 \pm 1.054$ \\
Changes in livestock numbers-yes (\%) & 26 & 72 \\
Decreasing numbers-yes (\%) & 15 & 60 \\
Livestock sales-yes (\%) & 19 & 22 \\
Increasing livestock sales (\%) & 5 & \\
\hline
\end{tabular}

\subsubsection{Changes in Livelihood Assets, Local Self-Sufficiency and Quality of Life}

Household physical asset accumulation and erosion can be a good indicator of livelihood vulnerability and adaptive capacity, as assets are often sold in response to shocks and on-going stressors, while assets purchases are often the result of more disposable household income. Household physical assets can include productive assets such as solar panels, wheelbarrows, farming implements, tools and domestic goods such as televisions, radios, paraffin stoves and furniture. From the survey, we found that the $46 \%$ of households in Tshivhulani indicated that their physical asset base has been increasing over the past 30 years (Table 3). In contrast, almost half of households in Marwendo noted a decrease in their total asset base, due to a combination of factors such as being forced to sell livestock and various goods due to economic hardships, food insecurity, and the need for cash. With respect to the last 5-10 years, which has been a period of greater hardship in Marwendo in particular, we found that $40 \%$ of households in Marwendo mentioned selling physical assets, whereas the corresponding number in Tshivhulani was only $8 \%$. Overall, Marwendo has seen a significant erosion of household and farming assets.

Table 3. Ownership, sale and trends in households' physical assets across the two villages.

\begin{tabular}{|c|c|c|c|}
\hline \multicolumn{2}{|l|}{ Variable } & Tshivhulani & Marwendo \\
\hline \multicolumn{2}{|c|}{ Average number of assets per household } & $5 \pm 0.23$ & $5 \pm 0.42$ \\
\hline \multirow{2}{*}{ Asset purchases in last $5-10$ years (\%) } & Yes & 60 & 47 \\
\hline & No & 40 & 53 \\
\hline \multirow{2}{*}{ Asset sales in last $5-10$ years (\%) } & Yes & 8 & 40 \\
\hline & No & 92 & 60 \\
\hline \multirow{4}{*}{ Reasons for asset sales (\%) } & Food & 100 & 38 \\
\hline & Fees & 0 & 25 \\
\hline & Death/other shocks & 0 & 16 \\
\hline & Expensive events & 0 & 21 \\
\hline \multirow{3}{*}{ Change in assets from childhood (\%) } & Increasing & 46 & 16 \\
\hline & Stay much the same & 46 & 35 \\
\hline & Decreasing & 8 & 49 \\
\hline
\end{tabular}

Given the changes in livelihoods observed, we were interested in whether households are shifting from being largely self-reliant, especially for food, to being more cash dependent and what this means for vulnerability and adaptive capacity. Results from the survey indicate that, in terms of reliance on purchased goods (over the past 10 years), most respondents in both villages agreed that they now rely 
more on purchased goods than crops from their garden/fields for food (Figure 2). This livelihood trend was seen as creating increased hardship in the lives of a majority of households in Marwendo (Figure 2), primarily as a result of scarcity of income and the need for cash leading to asset erosion. One respondent was quoted as saying: "kana usina mari hauna upenyu", which means "if you do not have money you do not have a life". However, mixed responses were observed in Tshivhulani, with $49 \%$ of households agreeing that their lives were made a little easier by relying more on purchased goods due to availability of cash from social grants. Social grants provide a regular source of income pooled within the household and are important to food security as illustrated by the narrative below:

"The whole family survives on a state old age grant from our grandmother whom we stay with ... no-one in the family is employed formally ... the other three grandchildren in the family also receive child support grants ... We normally use this money to buy food and clothes ... If our grandmother were to pass on it will be very difficult for the family to survive because next year one of the grandchildren will be too old to be eligible for the child support grant" [Female respondent in Tshivhulani village].

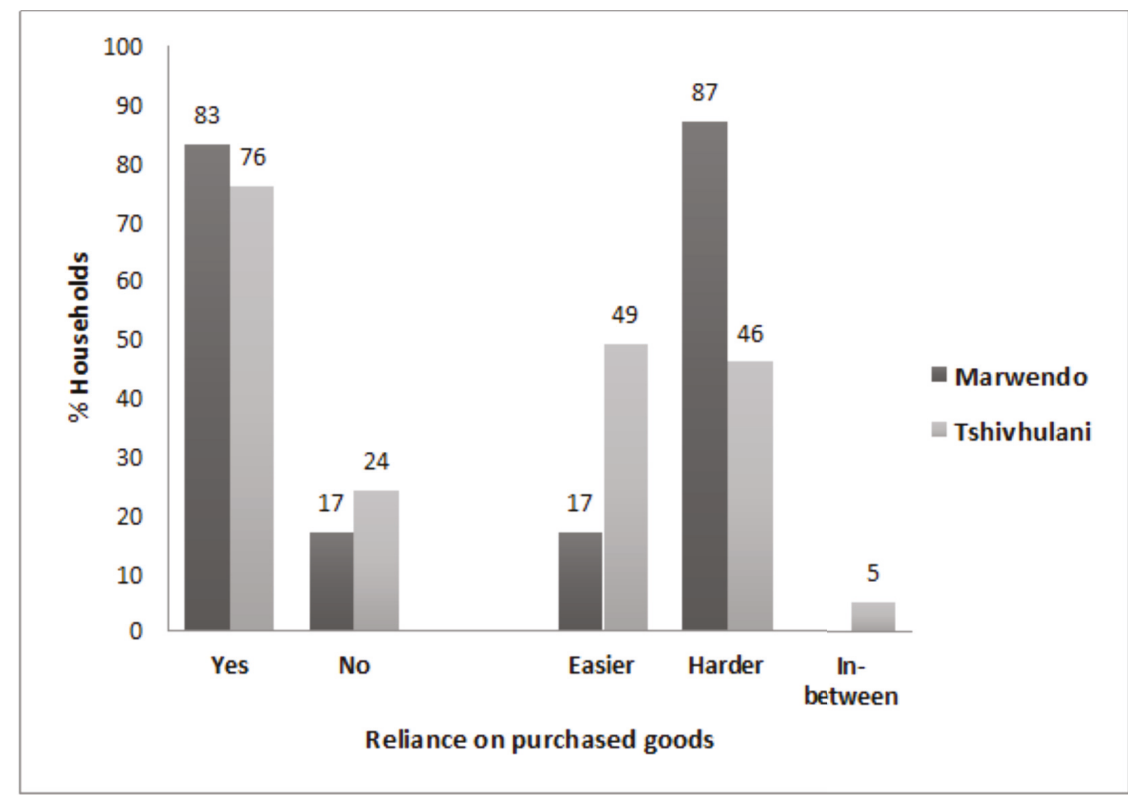

Figure 2. Proportion of households relying more on purchased goods rather than on harvested natural resources/crops from gardens/fields in Marwendo and Tshivhulani village and perceptions of the impact of this change on household livelihoods.

As part of the survey, we asked respondents to reflect on changes in their overall quality of life and how, based on this, they conceived the future. Most respondents in Marwendo (72\%) agreed that their lives were better 30 years ago or during their childhood compared to over the last five years with $86 \%$ saying their lives have worsened due to the multiple negative drivers of change in the past 30 years coupled with the continuous erosion of livelihood assets and the inability to rebuild these. In contrast, in Tshivhulani, $60 \%$ of the respondents said that their lives have become better in the last 5-10 years. This coincides with the increase in social grants, which are described by Shackleton and Luckert [16] as creating a window of opportunity, as well as various developments in the village. Social grants were said to be crucial in contributing to food security and children's education. In addition, 
the infrastructure improvements in the village (electricity, piped water, rural development houses, and road construction) have facilitated access to the town, markets and information, thereby increasing the range of available livelihood options. Studies from elsewhere in the world have also documented how basic rural development can help improve the overall standard of people lives [31,67-69].

Respondents' perspectives on the future were linked to their concerns and their quality of life assessments. Just over half of respondents in Tshivhulani village (55\%) were optimistic regarding their future (Figure 3) reflecting the improved living standards for most people in this village. However, $44 \%$ of households had mixed optimism about their future (unknown-26\%; bleak-18\%). In contrast, $43 \%$ of respondents in Marwendo were very pessimistic about their future and another $34 \%$ of households were unsure of how their future will turn out. Only a few households (14\%) in Marwendo village were positive about their future. Households with a more positive outlook are likely those that have managed to diversify their income sources to include off-farm activities, or those who were receiving remittances from their children or relatives.

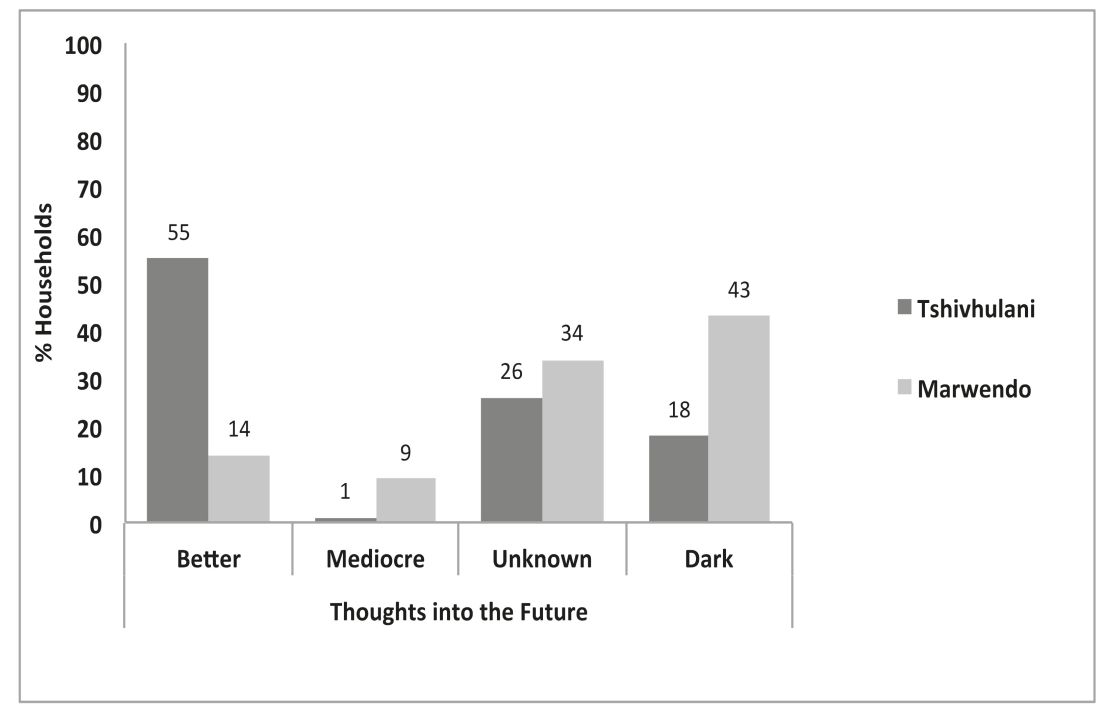

Figure 3. Respondents' perceptions of the future in the two villages.

\subsubsection{Outcomes for Livelihood and Social-Ecological Vulnerability}

The human-environmental timelines constructed for this paper show that considerable changes in livelihoods and landscapes have taken place in Marwendo and Tshivuhlani over the last 30 years, amidst continuity in certain ways of life. These changes are linked to and influenced by the wider political and economic context within which particular drivers operate. The situation is complex, as multiple drivers and changes interact to both create and constrain livelihood options and subsequent ability to respond to changes such as more climate extremes.

Rural development initiatives such as electrification, piped water and road construction, which can be thought as supporting so-called generic adaptation [70], have opened up opportunities as well as countered some of the negative effects of ecosystem service degradation in both villages. Key responses have been new commercial activities and more vegetable gardening. However, the ability to exploit these opportunities is not even, and requires access to cash or credit. Households in Tshivuhlani with access to social grants are much more able to establish alternative livelihood activities when opportunities arise than those in Marwendo. 
In both villages, farming has been affected by climate drivers with responses again differing. In Tshivuhlani, cash from social grants that allow the purchasing of staples has meant that extensive field farming is not essential nor necessarily worth the investment and so it has declined, as is the case for other parts of South Africa [16,62,63]. By contrast, in Marwendo, villagers have had to adopt more climate-resilient approaches to farming as they have few other choices available to meet their basic food needs. The social welfare system in South Africa has thus provided a safety net for people both for their daily living and when faced with shocks, whilst in Marwendo villagers are often faced with no option but to continue to engage in risky farming activities or in potentially maladaptive practices (e.g., woodland product commercialisation, brick moulding or asset sales) to get through difficult times. Thus, in this village, climate-related shocks and socioeconomic hardships have combined to erode the household and community asset base impacting on household adaptive capacity. In the long term this could contribute to spiralling vulnerability as described in Shackleton and Shackleton [14]. That said, one could argue that the development interventions and social protection (food for work) brought by NGOs have helped to counter some of the impacts of negative drivers, although the solutions would need to be scaled up to make a difference in the long term.

If we refer to the well-known typology of livelihood trajectories [38], we could argue that in Tshivuhlani most households are on a "stepping out" (diversification) trajectory, although there is also the danger of becoming too reliant on social grants that may not always be available to households as pensioners pass on and children grow up [16]. In contrast, Marwendo households are either "hanging in" (coping) or potentially entering what we have termed a "losing out" (erosion) trajectory, although small-scale development support by NGOs has helped to offset this to some extent. More social protection, like the food for work opportunities provided by NGOs or state social welfare or drought relief systems, may be needed in Marwendo in the long term to prevent a downward spiral into a poverty trap. Only a minority of households in each site could be viewed as "stepping up" (accumulation), and these are likely to be households that have locally secure employment, and have managed to diversify their income sources to include off-farm activities or are receiving remittances (also see [54]).

Based on some of the current livelihood activities-for example, the commercialisation of natural resources in Marwendo and the over-reliance on social grants in Tshivhulani [71]—we argue that the vulnerability of villagers in both study areas may increase in the future (with Marwendo being worse off). This will result from the impacts on local natural capital in the first case, and a narrowing of livelihood options, flexibility and self-reliance in the latter. The decline in local arable production has possible future consequences as food prices increase with climate change impacts on agriculture globally [16]. This will be further exacerbated by the likely increase in exposure to shocks and stressors of both people and ecosystems, and the current susceptibility of presently pursued livelihoods to both climate extremes and slow onset changes, especially in Marwendo where livelihoods are primarily based on natural resources.

\section{Conclusions and Future Trajectories}

Given that the findings of this study suggest more fragile and vulnerable livelihoods and less healthy ecosystems in the two study sites, and a further lowering of adaptive capacity, especially in Zimbabwe, it is necessary to ask: what is required to move rural communities in these semi-arid regions onto a more sustainable trajectory? The results suggest that this requires attention to both generic and specific adaptive capacity [70] since adaptation to future climate change is highly influenced by the local and national development context, but also by new climate threats and risks. The observed synergies between the coping or adaptive responses to drivers of change, and what can be considered basic development, corroborate the need for 'mainstreaming' adaptation within development planning [31].

Basic service delivery and improved transport, communication and energy infrastructure were found to have positive impacts on livelihoods, for at least some households, in both sites by opening the door for small-scale enterprise development. In Zimbabwe, new climate smart approaches to 
agriculture were proving successful in supporting arable production for some farmers through unfavourable weather periods, while private and communal, mainly irrigated, food gardens were playing a role in enhancing food diversity, nutrition and security in both sites, with this also being an income generating opportunity. These, and other areas of development such as providing access to start-up funding and other forms of credit and developing skills in conservation agriculture and micro-irrigation, could help to broaden local options, support diversification and local self-sufficiency and open-up multiple pathways to sustainability that can cater for the interests and priorities of different types of rural households [72]. Such developments and adaptation strategies need to take into account local contexts, be structured to target poorer households and support economic returns without introducing potential negative ecological consequences [31]. At a policy level, in both sites the issue of education as the entry point to new opportunities, including migration, emerged as an area of concern; in Zimbabwe this was primarily related to the reversal of free education and subsequent costs, while in South Africa it was to the poor state of rural education. Both need to be addressed at a policy level. The findings also suggest that various forms of social protection are of crucial importance in the semi-arid conditions that characterise the villages in this study to prevent increasing vulnerability, especially amongst households that are primarily dependent on natural resources. Such social protection could include free schooling, favourable access to credit, agricultural subsidies, public works programmes, or monetary or in-kind relief to facilitate recovery from drought, amongst others [73]. Certainly, there is some evidence from the South African site that access to social welfare reduced engagement in potentially destructive livelihood activities such as sand mining and brick moulding. The continuing concern regarding the natural resource base and the degradation of ecosystem services such as water provision pointed to the need for improved systems for the management of local landscapes and natural resources to prevent feedbacks on livelihood vulnerability in the future. Apparently, already the traditional leadership is reinstituting controls over baobab harvesting in Marwendo, given the importance of this species in food security. Any natural resource/agro-ecological management approach would also need to consider alternative livelihood options for villagers, as resource exploitation tends to be an option of last resort for many.

Acknowledgments: We acknowledge the South African National Research Foundation (NRF) for an Incentive Funding Grant to S.S. that covered the field costs for this research and a writing retreat to work on the manuscript. C.M. was generously supported through a Master's scholarship awarded by the Beit Trust. We are also grateful to the leaders and residents of Marwendo and Tshivhulani for welcoming C.M. and for supporting the research. We thank the two anonymous reviewers and the special issue editing team for constructive feedback that improved the paper.

Author Contributions: S.E.S. and C.M. conceived and designed the study; C.M. undertook the field work and data analysis under the guidance of S.E.S. as his MSc supervisor; C.M. wrote the paper with support from S.E.S.

Conflicts of Interest: The authors declare no conflict of interest.

\section{Appendix A}

Table A1. Narratives from life histories indicating the general concerns of people in Marwendo village.

\begin{tabular}{c} 
Narratives from Life Histories \\
$\begin{array}{c}\text { "The lack of employment opportunities in our village is a major concern especially for our children who are } \\
\text { in school" }\end{array}$ \\
$\begin{array}{r}\text { "I am worried that my children will not be able to see the Mukamba tree (Afzelia quanzensis) as this has been } \\
\text { seriously overharvested in the village" }\end{array}$ \\
$\begin{array}{c}\text { "The forests are now very far away from the village. This forces us to wake up very early in the morning to go } \\
\text { looking for firewood. The scarcity of firewood is a major concern in the village now as very few houses } \\
\text { have electricity" }\end{array}$ \\
$\begin{array}{c}\text { "We foresee an increased change in the weather patterns, especially with rainfall and temperature. Our river is } \\
\text { never full throughout the year. Most of us fear that it may dry up in the near future ... my greatest concern is } \\
\text { food security for my family" }\end{array}$ \\
\hline "I foresee more frequent droughts hitting our village, worse than the 1992 one. We are most likely to continue \\
to struggle to feed ourselves"
\end{tabular}


Table A2. Narratives from life histories indicating the general concerns of people in Tshivhulani village.

\begin{tabular}{c} 
Narratives from Life Histories \\
"If my children do well in their education, I foresee a better future, as they will be able to take care of me when \\
I am old, as well as their own children" \\
\hline "I am looking forward to a better future for my children and grandchildren" \\
"My main concern is a better life for my children ... I wish my children could live a better life than the one \\
I lived" \\
\hline $\begin{array}{c}\text { "I am unemployed ... I don't want my children to live the way I have lived ... I am concerned about the } \\
\text { future of my children ... they should live a life that is better than mine" }\end{array}$ \\
\hline
\end{tabular}

\section{Appendix B}

Table A3. Perceived drivers of landscape change in Marwendo and Tshivhulani villages (\% of respondents agreeing with each driver).

\begin{tabular}{|c|c|c|c|}
\hline Natural Resource & Drivers of Change & $\begin{array}{c}\text { Marwendo \% } \\
\text { (Zimbabwe) }\end{array}$ & $\begin{array}{c}\text { Tshivhulani \% (South } \\
\text { Africa) }\end{array}$ \\
\hline \multirow{6}{*}{ Forest Cover } & New settlements/stands & 3 & 78 \\
\hline & Deforestation & 60 & 22 \\
\hline & Brick moulding & 4 & - \\
\hline & Hardships/survival & 3 & - \\
\hline & Rainfall variability & 15 & - \\
\hline & Droughts & 15 & - \\
\hline \multirow{7}{*}{ Soil erosion } & New settlements/stands & 1 & 70 \\
\hline & Deforestation & 34 & - \\
\hline & Cultivation & 11 & 30 \\
\hline & Brick moulding & 8 & - \\
\hline & Droughts & 3 & - \\
\hline & Rainfall variability & 4 & - \\
\hline & Floods & 39 & - \\
\hline \multirow{6}{*}{ Water Sources } & $\begin{array}{c}\text { Rubbish } \\
\text { disposal/pollution }\end{array}$ & 3 & 70 \\
\hline & Deforestation & 3 & - \\
\hline & Siltation & 10 & - \\
\hline & Droughts & 14 & - \\
\hline & Rainfall variability & 44 & - \\
\hline & Cultivation & 26 & 30 \\
\hline \multirow{7}{*}{ Forest Diversity } & New settlements/stands & 15 & 23 \\
\hline & Deforestation & 41 & 67 \\
\hline & Fires & 3 & - \\
\hline & Overharvesting & 2 & 10 \\
\hline & Brick moulding & 4 & - \\
\hline & Droughts & 30 & - \\
\hline & Rainfall variability & 5 & - \\
\hline \multirow{7}{*}{ Wild Fruits } & New settlements/stands & 3 & 11 \\
\hline & Deforestation & 18 & 56 \\
\hline & Overharvesting & 31 & 33 \\
\hline & Brick moulding & 11 & - \\
\hline & Hardships/survival & 4 & - \\
\hline & Droughts & 30 & - \\
\hline & Rainfall variability & 3 & - \\
\hline \multirow{5}{*}{ Wild Animals } & New settlements/stands & - & 15 \\
\hline & Deforestation & 5 & 20 \\
\hline & Overharvesting & 62 & 65 \\
\hline & Fires & 3 & - \\
\hline & Droughts & 10 & - \\
\hline \multirow{6}{*}{ Grass Cover } & Deforestation & 8 & 11 \\
\hline & Fires & 37 & 70 \\
\hline & Overharvesting & 5 & 4 \\
\hline & Droughts & 27 & - \\
\hline & Rainfall variability & 23 & - \\
\hline & New settlements/stands & - & 15 \\
\hline
\end{tabular}




\section{References}

1. Hackmann, H.; St. Clair, A.L. Transformative Cornerstones of Social Science Research for Global Change; International Social Science Council (ISSC): Paris, France, 2013; Available online: http://www. worldsocialscience.org/documents/transformative-cornerstones.pdf (accessed on 20 January 2015)Available online: http://www.worldsocialscience.org/documents/transformative-cornerstones.pdf.

2. Rockström, J.; Steffen, W.; Noone, K.; Persson, Å.; Chapin, F.S., III; Lambin, E.; Lenton, T.M.; Scheffer, M.; Folke, C.; Schellnhuber, H.; et al. Planetary boundaries: Exploring the safe operating space for humanity. Ecol. Soc. 2009, 14, 32. Available online: http://www.ecologyandsociety.org/vol14/iss2/art32/ (accessed on 17 November 2017). [CrossRef]

3. Zimmerer, K.S. Agriculture, livelihoods, and globalization: The analysis of new trajectories (and avoidance of just-so stories) of human-environment change and conservation. Agric. Hum. Values 2007, 24, 9-16. [CrossRef]

4. Raworth, K.A. Safe and just space for humanity: Can we live within the doughnut? Nature 2012, 461, 1-26.

5. Reid, P.; Vogel, C. Living and responding to multiple stressors in South Africa-Glimpses from KwaZuluNatal. Glob. Environ. Chang. 2006, 16, 195-206. [CrossRef]

6. Thomas, B.K.; Muradian, R.; de Groot, G.; de Ruijter, A. Resilient and resourceful? A case study on how the poor cope in Kerala, India. J. Asian Afr. Stud. 2010, 45, 29-45. [CrossRef]

7. Fraser, E.D.G.; Dougill, A.J.; Hubacek, K.; Quinn, C.H.; Sendzimir, J.; Termansen, M. Assessing vulnerability to climate change in dryland livelihood systems: Conceptual challenges and interdisciplinary solutions. Ecol. Soc. 2011, 16, 3. [CrossRef]

8. Ziervogel, G.; Taylor, A. Feeling Stressed: Integrating Climate Adaptation with Other Priorities in South Africa. Environment 2008, 50, 32-41. [CrossRef]

9. Drimie, S.; Casale, M. Multiple stressors in Southern Africa: The link between HIV/AIDS, food insecurity, poverty and children's vulnerability now and in the future. AIDS Care 2009, 21, 28-33. [CrossRef] [PubMed]

10. Drimie, S.; Gillespie, S. Adaptation to climate change in Southern Africa: Factoring in AIDS. Environ. Sci. Policy 2010, 13, 778-784. [CrossRef]

11. Sallu, S.M.; Twyman, C.; Thomas, D.S.G. The multidimensional nature of biodiversity and social dynamics and implications for contemporary rural livelihoods in remote Kalahari settlements, Botswana. Afr. J. Ecol. 2009, 47, 110-118. [CrossRef]

12. Sallu, S.M.; Twyman, C.; Stringer, L.C. Resilient or vulnerable livelihoods? Assessing livelihood dynamics and trajectories in rural Botswana. Ecol. Soc. 2010, 15, 3. [CrossRef]

13. O'Brien, K.; Quinlan, T.; Ziervogel, G. Vulnerability interventions in the context of multiple stressors: Lessons from the South Africa Vulnerability Initiative (SAVI). Environ. Sci. Policy 2009, 12, 23-32. [CrossRef]

14. Shackleton, S.E.; Shackleton, C.M. Linking poverty, HIV/AIDS and climate change to human and ecosystem vulnerability in southern Africa: Consequences for livelihoods and sustainable ecosystem management. Int. J. Sustain. Dev. World Ecol. 2012, 19, 275-286. [CrossRef]

15. Olsson, L.; Opondo, M.; Tschakert, P.; Agrawal, A.; Eriksen, S.H.; Ma, S.; Perch, L.N.; Zakieldeen, S.A. Livelihoods and poverty. In Climate Change 2014: Impacts, Adaptation, and Vulnerability. Part A: Global and Sectoral Aspects. Contribution of Working Group II to the Fifth Assessment Report of the Intergovernmental Panel on Climate Change; Field, C.B., Barros, V.R., Dokken, D.J., Mach, K.J., Mastrandrea, M.D., Bilir, T.E., Chatterjee, M., Ebi, K.L., Estrada, Y.O., Genova, R.C., et al., Eds.; Cambridge University Press: Cambridge, UK; New York, NY, USA, 2014; pp. 793-832.

16. Shackleton, S.; Luckert, M. Changing livelihoods and landscapes in the rural Eastern Cape, South Africa: Past Influences and Future Trajectories. Land 2015, 4, 1060-1089. [CrossRef]

17. Leary, N.; Adejuwon, J.; Barros, V.; Batimaa, P.; Biagini, B.; Burton, I.; Chinvanno, S.; Cruz, R.; Dabi, D.; Comarmond, A.; et al. A Stitch in Time: Lessons for Climate Change Adaptation from the AIACC Project. 2007. Available online: http://www.aiaccproject.org/working_papers/working_papers.html (accessed on 15 November 2017).

18. Mbow, C.; Mertz, O.; Diouf, A.; Rasmussen, K.; Reenberg, A. The history of environmental change and adaptation in eastern Saloum-Senegal-Driving forces and perceptions. Glob. Planet. Chang. 2008, 64, 210-221. [CrossRef] 
19. Chidumayo, E.N.; Gumbo, D.J. The Dry Forests and Woodlands of Africa: Managing for Products and Services; Earthscan: London, UK, 2010; Available online: https://www.cifor.org/publications/pdf_files/Books/ BGumbo1001.pdf (accessed on 15 November 2017).

20. Ifejika-Speranza, C.I. Drought coping and adaptation strategies: Understanding adaptations to climate change in agro-pastoral livestock production in Makueni district, Kenya. Eur. J. Dev. Res. 2010, 22, 623-642. [CrossRef]

21. Reynolds, J.F.; Smith, D.M.; Lambin, E.F.; Turner, B.L.; Mortimore, M.; Batterbury, S.P. Global desertification: Building a science for dryland development. Science 2007, 316, 847-851. [CrossRef] [PubMed]

22. African Drought Risk and Development Network (ADDN). A primer on climate change adaptation in the drylands of Africa. In Proceedings of the 3rd African Drought Adaptation Forum, Addis Ababa, Ethiopia, 17-19 September 2008.

23. Millenium Ecosystem Assessment (MEA). Ecosystems and Human Well-Being: Synthesis; Island Press: Washington, DC, USA, 2005.

24. Brown, D.; Chanakira, R.R.; Chatiza, K.; Dhliwayo, M.; Dodman, D.; Masiiwa, M. Climate Change Impacts, Vulnerability and Adaptation in Zimbabwe; IIED Working Paper No.3; IIED: London, UK, 2012.

25. Niang, I.; Ruppel, O.C.; Abdrabo, M.A.; Essel, A.; Lennard, C.; Padgham, G.; Urquhart, P. Africa. In Climate Change 2014: Impacts, Adaptation, and Vulnerability. Part B: Regional Aspects. Contribution of Working Group II to the Fifth Assessment Report of the Intergovernmental Panel on Climate Change; Field, C.B., Barros, V.R., Dokken, D.J., Mach, K.L., Mastrandrea, M.D., Bilir, T.E., Chatterjee, M., Ebi, K.L., Estrada, Y.O., Genova, R.C., et al., Eds.; Cambridge University Press: Cambridge, UK; New York, NY, USA, 2014; pp. 899-943.

26. Brockhaus, M.; Djoudi, H. Adaptation at the Interface of Forest and Ecosystem Goods and Services and Livestock Production Systems in Northern Mali. CIFOR Info Brief No. 19, CIFOR, Bogor, 2008. Available online: http:/ / www.cifor.org/publications/pdf_files/Infobrief/019-infobrief.pdf (accessed on 17 November 2017).

27. Paavola, J. Livelihoods, vulnerability and adaptation to climate change in Morogoro, Tanzania. Environ. Sci. Policy 2008, 11, 642-654. [CrossRef]

28. Gautier, D.; Denis, D.; Locatelli, B. Impact of droughts and response of rural populations in West Africa: A systematic review. WIREs Clim. Chang. 2016, 7, 666-668. [CrossRef]

29. Boko, M.; Niang, I.; Nyong, A.; Vogel, C.; Githeko, A.; Medany, M.; Osman-Elasha, B. Africa. In Climate Change 2007: Impacts, Adaptation and Vulnerability. Contribution of Working Group II to the Fourth Assessment Report of the Intergovernmental Panel on Climate Change; Parry, M.L., Canziani, O.F., Palutikof, J.P., van der Linden, P.J., Hanson, C.E., Eds.; Cambridge University Press: Cambridge, UK, 2007; pp. 433-467.

30. Shackleton, C.M.; Shackleton, S.E.; Gambiza, J.; Nel, E.; Rowntree, K.; Urquhart, P.; Fabricius, C.; Anilsie, A. Linking Ecosystem Services and Poverty Alleviation in the Arid and Semi-Arid Lands of Southern Africa; Nova Publishers: New York, NY, USA, 2010; 267p.

31. Zheng, Y.; Byg, A.; Thorsen, B.J.; Strange, N. A temporal dimension of household vulnerability in three rural communities in Lijiang, China. Hum. Ecol. 2014, 42, 283-295. [CrossRef]

32. Dahlberg, A.C. The importance of environmental history in evaluating the sustainability of NTFP harvesting systems. In Ecological Sustainability for Non-Timber Forest Products: Dynamics and Case Studies of Harvesting; Shackleton, C.M., Ticktin, T., Pandey, A., Eds.; Earthscan: London, UK, 2015.

33. Carpenter, S.; Folke, C.; Norström, A.; Olsson, O.; Schultz, L.; Agarwal, B.; Balvanera, P.; Campbell, B.; Castilla, J.C.; Cramer, W.; et al. Program on ecosystem change and society: An international research strategy for integrated social-ecological systems. Curr. Opin. Environ. Sustain. 2012, 4, 1-5. [CrossRef]

34. Nielsen, J.Ø.; Reenberg, A. Temporality and the problem with singling out climate as a current driver of change in a small West African village. J. Arid Environ. 2010, 74, 464-474. [CrossRef]

35. Nelson, G.C.; Bennett, E.; Berhe, A.A.; Cassman, K.; De Fries, R.S.; Dietz, T. Anthropogenic drivers of ecosystem change: An overview. Ecol. Soc. 2006, 11, 29. [CrossRef]

36. Schroter, D. Our vulnerability to changes in ecosystem services. In Assessing Vulnerability to Global Environmental Change: Making Research Useful for Adaptation Decision Making and Policy; Klein, R.T.J., Patt, A.G., Eds.; Routledge: London, UK, 2008.

37. DfID (Department of International Development, Government of the UK). Sustainable Livelihoods Guidance Sheets. UK DFID, London; 1999. Available online: www.LivelihoodsOrg/info/info_guidancesheetsHtml (accessed on 5 April 2016). 
38. Dorward, A.; Anderson, S.; Bernal, Y.N.; Vera, E.S.; Rushton, J.; Pattison, J. Hanging in, stepping up and stepping out: Livelihood aspirations and strategies of the poor. Dev. Pract. 2009, 19, 240-247. [CrossRef]

39. Turner, B.L.; Kasperson, R.E.; Matson, P.A.; McCarthy, J.J.; Corell, R.W.; Christensen, L. A framework for vulnerability analysis in sustainability science. Proc. Natl. Acad. Sci. USA 2003, 100, 8074-8079. [CrossRef] [PubMed]

40. Ribot, J.C. Vulnerability does not just Fall from the Sky: Toward Multi-scale Pro-poor Climate Policy. In Social Dimensions of Climate Change: Equity and Vulnerability in a Warming World; Mearns, R., Norton, A., Eds.; The World Bank: Washington, DC, USA, 2010. Available online: https:/ / www.researchgate.net/publication/ 284666318_Vulnerability_does_not_fall_from_the_sky_toward_multiscale_pro-poor_climate_policy (accessed on 30 March 2018).

41. Hagen-Zanker, J.; Morgan, J.; Meth, C. South Africa's Cash Social Security Grants: Progress in Increasing Coverage; Overseas Development Institute (ODI): London, UK, 2011. Available online: https: / / www.odi.org/publications / 5479-south-africas-social-security-system-expanding-coverage-grantsand-limiting-increases-inequality (accessed on 17 November 2017).

42. Vincent, V.; Thomas, R.G.; Staples, R.R. An Agricultural Survey of Southern Rhodesia. Part 1. Agro-Ecological Survey; Federation of Rhodesia and Nyasaland: Salisbury, UK, 1960.

43. Schulze, R.E.; Maharaj, M. South African Atlas of Agro-Hydrology and-Climatology; Report No. TT82/96; Water Research Commission: Pretoria, South Africa, 1997.

44. Mucina, L.; Rutherford, M.C. The Vegetation of South Africa, Lesotho and Swaziland. Stretitzia 19; South African National Biodiversity Institute: Pretoria, South Africa, 2006.

45. Maroyi, A. Community attitudes towards the reintroduction programme for the Endangered pepper-bark tree Warburgia salutaris: Implications for plant conservation in south-east Zimbabwe. Oryx 2012, 46, 213-218. [CrossRef]

46. Statistics South Africa. Labour Force Survey March. Statistical Release; Statistics SA: Pretoria, South Africa, 2003.

47. Zim VAC (Zimbabwe Vulnerability Assessment Committee). Rural Livelihoods Assessment. Report, ZimVAC, Harare 2017. Available online: https:/ / reliefweb.int/sites/reliefweb.int/ files/resources/WFP0000019918.pdf (accessed on 17 November 2017).

48. Statistics South Africa. Mid-Year Population Estimates. Statistical Release; Statistics South Africa: Pretoria, South Africa, 2011.

49. Friess, D.A. Using Google Earth for Environmental Research; National University of Singapore: Singapore, 2013; p. 18. Available online: http:/ / www.themangrovelab.com/Google\%20Earth\%20Guide-1.pdf (accessed on 25 February 2018).

50. Fauvet, P. Roots of counter-revolution: The Mozambique national resistance. Rev. Afr. Political Econ. 2007, 11, 108-121. [CrossRef]

51. Scoones, I. Hazards and Opportunities: Farming Livelihoods in Dryland Africa. Lessons from Zimbabwe; Zed Books: London, UK, 1996; 267p.

52. Cavendish, W. Quantitative methods for estimating the economic value of resource use to rural households. In Uncovering the Hidden Harvest Valuation Methods for Woodland and Forest Resources; Luckert, M., Campbell, B., Eds.; Routledge: London, UK, 2001.

53. Campbell, B.M.; Jeffrey, S.; Kozanoayi, W.; Luckert, M.; Mutamba, M.; Zindi, C. Household Livelihoods in Semi-Arid Regions: Options and Constraints; Centre for International Forestry Research (CIFOR): Bogor, Indonesia, 2001; 153p.

54. Mushongah, J.; Scoones, I. Livelihood change in rural Zimbabwe over 20 years. J. Dev. Stud. 2012, 48, 1241-1257. [CrossRef]

55. Feeney, G. The impact of HIV/AIDS on adult mortality in Zimbabwe. Popul. Dev. Rev. 2001, 27, 771-780. [CrossRef]

56. Frost, P.; Campbell, B.; Mutamba, M.; Mandondo, A.; Kozanayi, W. In search of improved rural livelihoods in semi-arid regions through local management of natural resources: Lessons from case studies in Zimbabwe. World Dev. 2007, 35, 1961-1974. [CrossRef]

57. Mapako, M.; Prasad, G. Rural electrification in Zimbabwe reduces poverty by targeting income-generating activities. In Proceedings of the Fifteenth Conference on Domestic Use of Energy, Cape Town, South Africa, 11-12 April 2007; pp. 1-6. 
58. Nyamunda, T.; Mukwambo, P. The State and the Bloody Diamond Rush in Chiadzwa: Unpacking the Contesting Interests in the Development of Illicit Mining and Trading, c. 2006-2009. J. S. Afr. Stud. 2012, 38, 145-166. [CrossRef]

59. Start, D.; Johnson, C. Livelihood Options? The Political Economy of Access, Opportunity and Diversification; Working Paper 233; Overseas Development Institute: London, UK, 2004; Available online: https:/ /www.odi. org/sites/odi.org.uk/files/odi-assets/publications-opinion-files/2470.pdf (accessed on 17 November 2017).

60. Andrew, M.; Fox, R. Undercultivation and intensification in the Transkei: A case study of historical changes in the use of arable land in Nompa, Shixini. Dev. South. Afr. 2004, 21, 687-706. [CrossRef]

61. Hebinck, P.; Monde, N. Production of crops in arable fields and home gardens. In Livelihoods and Landscape: The People of Guquka and Koloni and Their Resources; Hebinck, P., Lent, P.C., Eds.; Brill Academic Publishers: Leiden, The Netherlands; Boston, MA, USA, 2007; pp. 181-221.

62. De la Hey, M.; Beinart, W. Why have South African smallholders largely abandoned arable production in fields? A Case Study. J. South. Afr. Stud. 2017, 43, 1-18. [CrossRef]

63. Shackleton, R.; Shackleton, C.; Shackleton, S.; Gambiza, J. Deagrarianisation and forest succession in abandoned fields in a biodiversity hotspot on the Wild Coast, South Africa. PLoS ONE 2013, 8, e76939. [CrossRef] [PubMed]

64. Kepe, T.; Tessaro, D. Trading-off: Rural food security and land rights in South Africa. Land Use Policy 2014, 36, 267-274. [CrossRef]

65. Trefry, A.; Parkins, J.; Cundill, G. Culture and food security: A case study of homestead food production in South Africa. Food Secur. 2014, 6, 555-565. [CrossRef]

66. Shackleton, S.E.; Hebinck, P. Through the 'thick and thin' of farming on the Wild Coast, Eastern Cape, South Africa. J. Rural Stud. 2018. [CrossRef]

67. Finan, T.J.; Nelson, D.R. Making rain, making roads, making do: Public and private adaptations to drought in Ceará, Northeast Brazil. Clim. Res. 2001, 19, 97-108. [CrossRef]

68. Tschakert, P. Views from the vulnerable: Understanding climatic and other stressors in the Sahel. Glob. Environ. Chang. 2007, 17, 381-396. [CrossRef]

69. Su, Y.; Xu, J.; Wilkes, A.; Lu, J.; Li, Q.; Fu, Y.; Ma, X.; Grumbine, R.E. Coping with climate-induced water stresses through time and space in the mountains of Southwest China. Reg. Environ. Chang. 2012, 12, 855-866. [CrossRef]

70. Eakin, H.C.; Lemos, M.C.; Nelson, D.R. Differentiating capacities as a means to sustainable climate change adaptation. Glob. Environ. Chang. 2014, 27, 1-8. [CrossRef]

71. Quinn, C.H.; Ziervogel, G.; Taylor, A.; Takama, T.; Thomalla, F. Coping with multiple stresses in rural South Africa. Ecol. Soc. 2011, 16, 2. [CrossRef]

72. Leach, M.; Scoones, I.; Stirling, A. Dynamic Sustainabilities: Technology, Environment, Social Justice; Earthscan: London, UK, 2010.

73. Davies, M.; Oswald, K.; Mitchell, T. Climate Change, Disaster Risk Production and Social Protection. Promoting Pro-Poor Growth; Social Protection Organisation for Economic Development and Co-Ordination, OECD: Paris, France, 2009.

(C) 2018 by the authors. Licensee MDPI, Basel, Switzerland. This article is an open access article distributed under the terms and conditions of the Creative Commons Attribution (CC BY) license (http:/ / creativecommons.org/licenses/by/4.0/). 

MDPI

St. Alban-Anlage 66

4052 Basel

Switzerland

Tel. +41 616837734

Fax +41 613028918

www.mdpi.com

Land Editorial Office

E-mail: land@mdpi.com

www.mdpi.com/journal/land

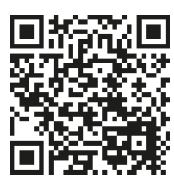



MDPI

St. Alban-Anlage 66

4052 Basel

Switzerland

Tel: +41 616837734

Fax: +41 613028918

www.mdpi.com 